
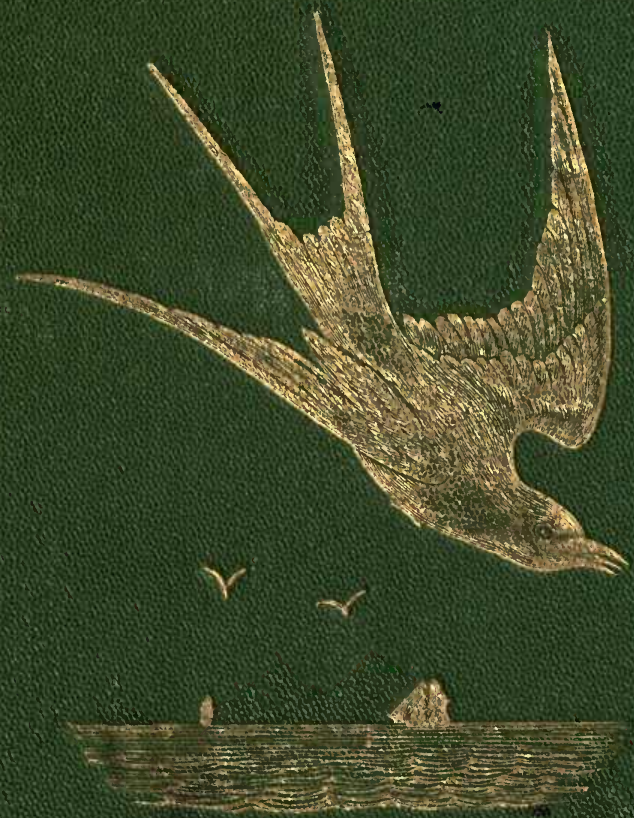


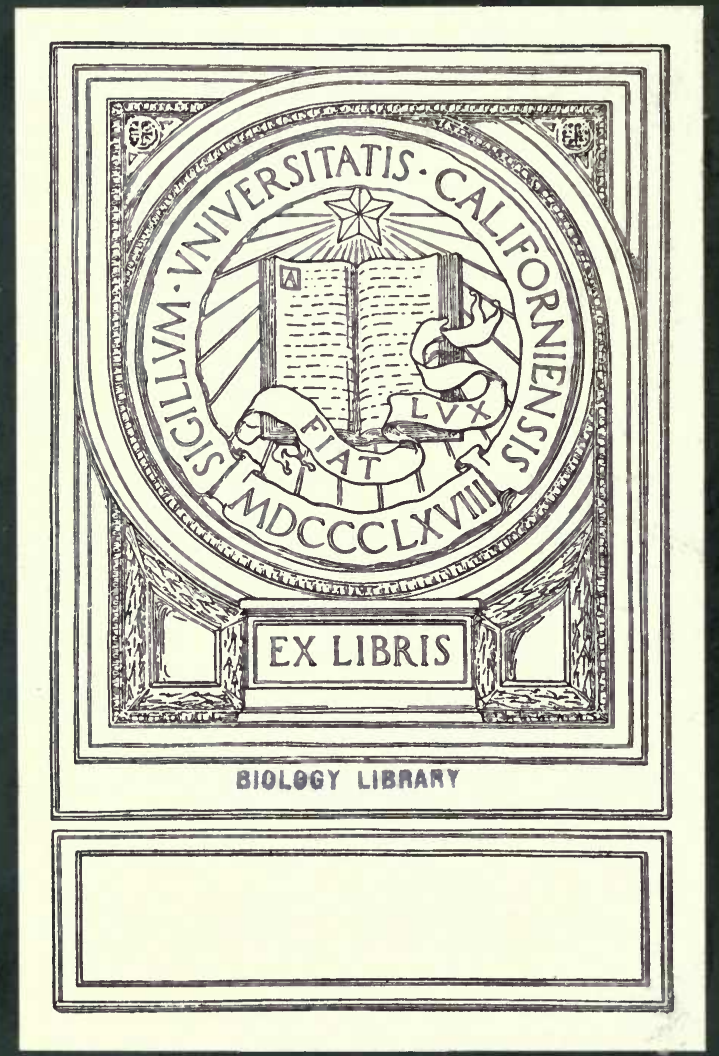




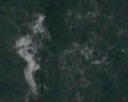

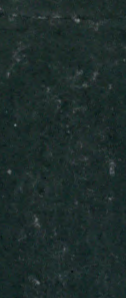

and is
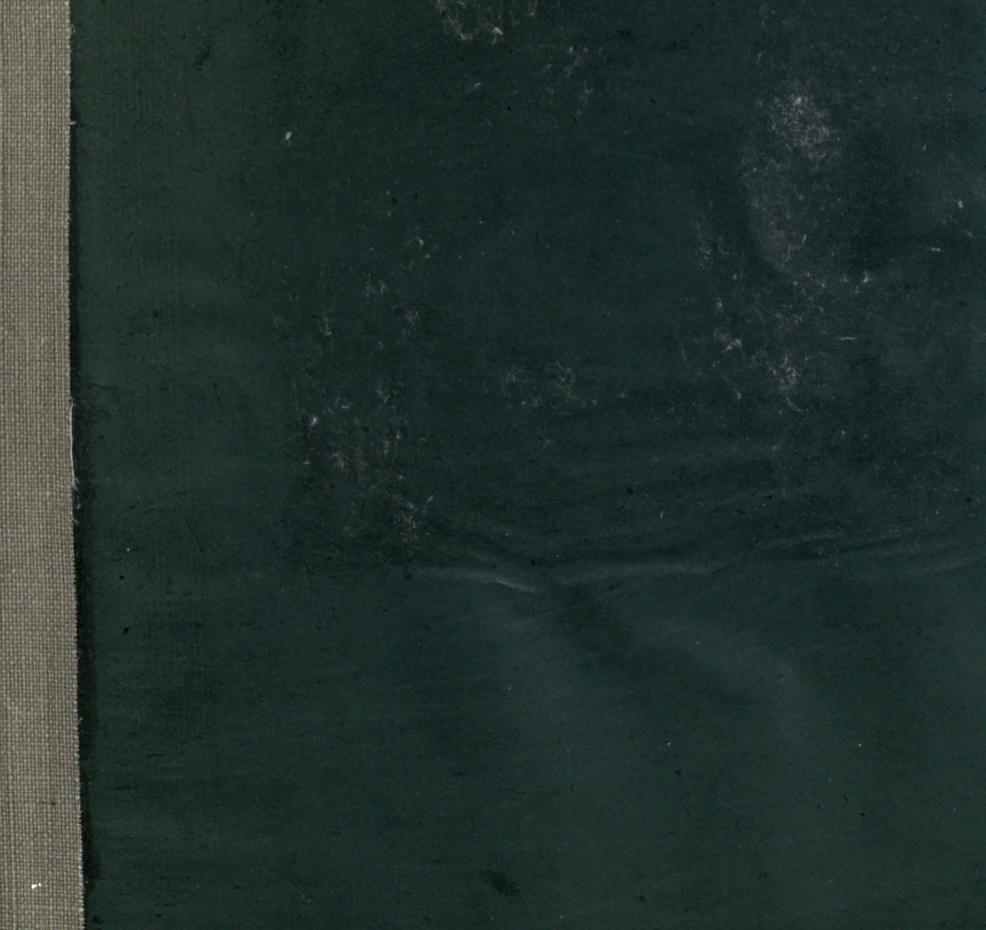

- $x^{2}+x^{3}$ 

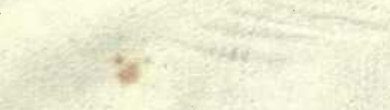

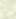
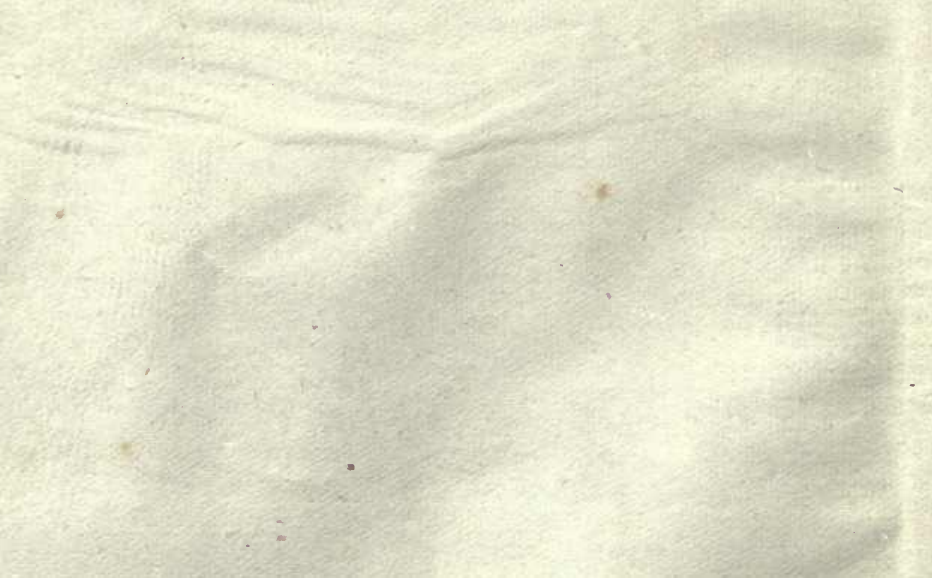
BIRDS OF THE WEST OF SCOTLAND 
"The woodland song, the various vocal quires That harmonize fair Scotia's streamy vales; Their habitations, and their little joys ;

The winged dwellers on the leas, and moors, And mountain cliffs; the woods, the streams themselves, The sweetly rural, and the savage scene,Haunts of the plumy tribes,-be these my theme!" -Grahame. 
$\because 3=$

$3300 \quad 3, \frac{3}{3}$

3000
40,000

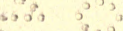

$0^{3}, 0,030$

क्ष

$\therefore \rightarrow 0$

3,3

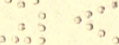

0000000

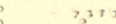

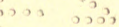

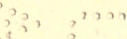

$a^{2}, 3$

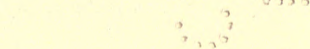



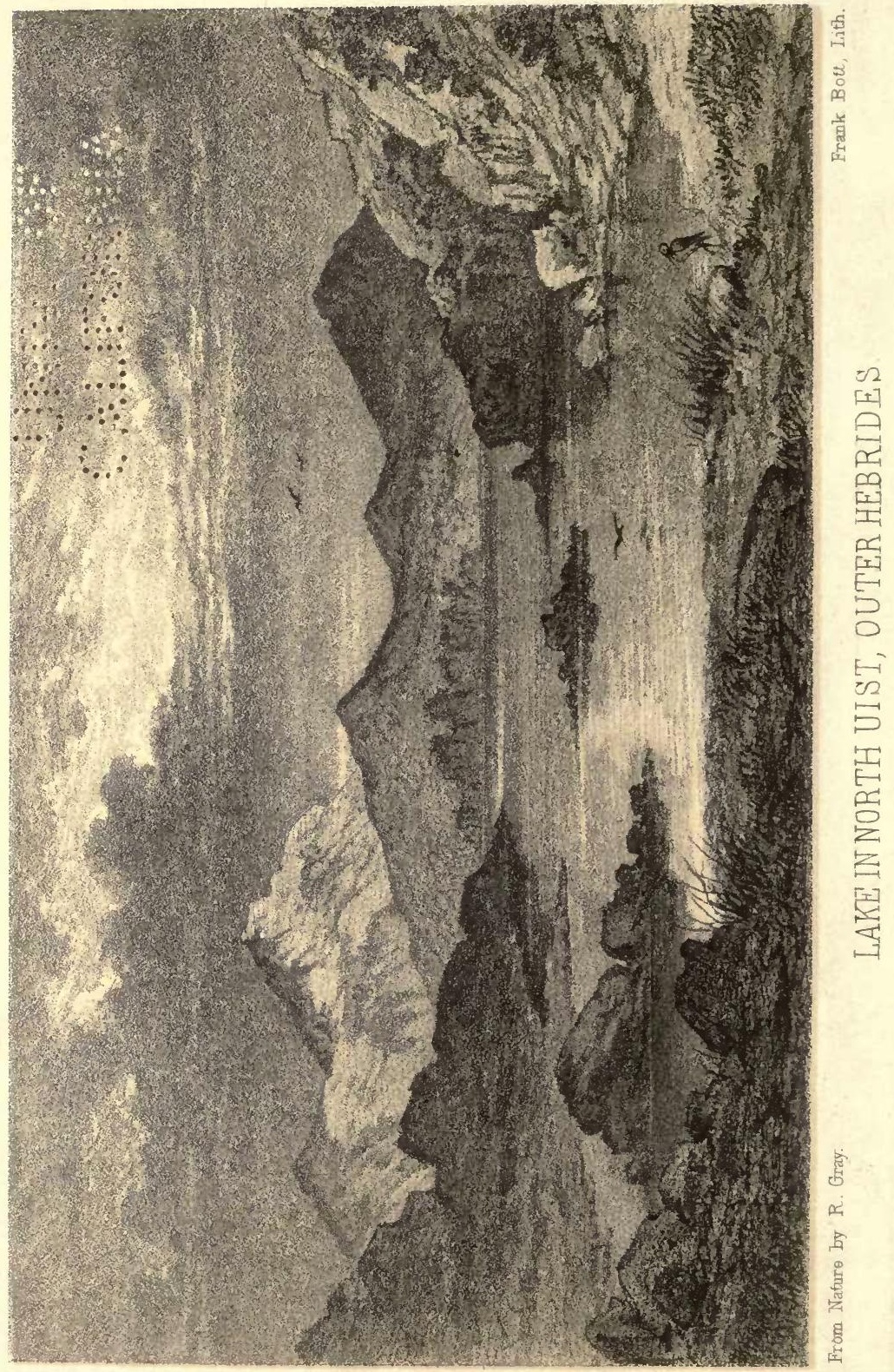

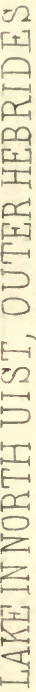


TH E

\section{BIRDS OF THE WEST OF SCOTLAND}

INCLUDING

\section{THE OUTER HEBRIDES}

WITH OCCASIONAL RECORDS OF THF OCCURRENCE OF THE RARER SPECIES THROUGHOUT SCOTTAND GENERALLY?

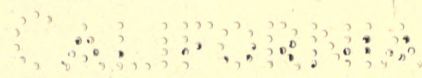

BY

\section{R 0 BERT GRAY}

LATE SECRETARY TO THE NATURAL HISTORY SOCIETY OF GLASGOW ;
MEMBER OF THE BRTTISH ORNTHOLOGISTS' UNION;
CORRESPONDING MEMBER OF THE ACADEMY OF NATURAL SCIENCES OF PHILADĖLPHIA;

AND OF THE DUMFRIESSHIRE AXD GALLOWAY NATURAL HISTORY AND ANTIQUARIAN SOCIETY, ETC., ETC.

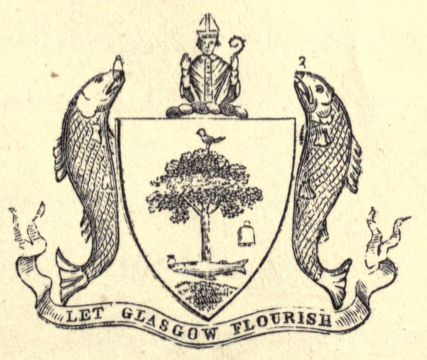

GLASGOW: THOMAS MURRAY \& SON MDCCCLXXI 
QL690
$G 7 G 74$

BIOLOGY

LIBRARY

G

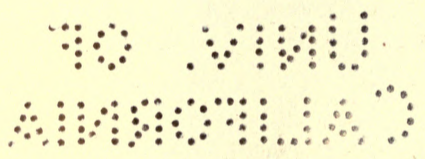

BIOLOGY LIBRARY

GLA S G O W :

PRINTED BY THOMAS MURRAY AND SON, 31 Buchanan Street. 


\section{TO THE RIGHT HONOURABLE}

\section{THE EARL OF HADDINGTON.}

MY LORD,

During the preparation of this Volume on the Birds of Western Scotland, I have had frequent occasion to refer to information communicated to me by your Lordship on the more interesting species frequenting the opposite shores of East Lothian and Berwickshire-a district of country which has revealed many features of significant import to the British ornithologist, and enabled me to form a more accurate estimate of the movements of certain birds than I had previously acquired.

In offering, therefore, to my fellow-naturalists the present Work, containing an account of the bird life of a large and comparatively uninvestigated tract of North Britain, I feel highly gratified in being permitted to dedicate it to your Lordship, as an acknowledgment for the service which has been so courteously rendered.

I have the honour to be,

MY LORD,

Your Lordship's obedt. Servant,

ROBERT GRAY

GLasgow, October, $18 \% 1$. 



\section{P RE FACE.}

SINCE the publication of the respective works of Sir William Jardine, Professor Macgillivray, and $\mathrm{Mr}$ Selby, nothing in a collected form on the Birds of Scotland has been brought under the notice of ornithologists. Many useful and interesting papers have no doubt appeared through various channels, but even the best of these have been restricted within comparatively narrow limits, so that a field, such as that chosen for the title of this volume, may be said to have been hitherto almost unoccupied.

It is now upwards of twenty years since I formed the design of collecting materials for such a work, and during that interval it may safely be said that no exertions have been spared to make these materials serve a useful purpose. I have personally visited nearly every locality mentioned, for the express object of acquiring reliable information, and have made myself practically familiar with the birds whose names are catalogued in these pages. Having, besides, repeatedly traversed the entire coast line of Scotland, as well as rambled over the greater portion of the inland counties and their woodland and moorland solitudes, unusual facilities have been afforded me of renewing my observations on the habits of species, and on the various phases of bird life seen from observatories so varied as our country presents. No part of Great Britain, indeed, is more inviting to the ornithologist than the western mainland of Scotland and its island dependenciestheir mountains and rugged headlands being still frequented by eagles and lordly peregrines; their inland waters and lone sea shores visited by the stately swan; and their peaceful glens and 
brawling rivers enlivened by the presence of many interesting birds long since driven from the meres and sunburnt plains of the south.

In addition to local advantages of this nature, I have had the satisfaction of seeing and examining the greater number of the collections, public and private, in Scotland-a privilege which while it has enabled me to trace the distribution of some of the less common species, gives me an opportunity of estimating the correctness of previous records of their occurrence. Thus the Grey Shrike, Great Spotted Woodpecker, and Shore Lark, formerly represented as rare, are now found to be almost regular winter visitants in considerable numbers, and scattered over a large tract of country, although making their first appearance in the northeastern districts of Scotland; while the Hobby, Wryneck, Tree Sparrow, and some other species formerly looked upon as mere stragglers into Scotland, are now known to occupy breeding stations even in the western counties.

I have also carefully looked into the records of the older Scottish writers, scientific and otherwise, from some of which it is evident that birds recently announced as new to Scotland were long ago found in different localities north of the Tweed. In Don's 'Fauna of Forfarshire,' for example, several species such as the Red-backed Shrike, Nuthatch, etc., are catalogued as having occurred in that county as far back as the beginning of the present centuryrecords which appear to have been entirely overlooked by those writers who have of late years alluded to the distribution of species in the British islands.

In acknowledging how much is due to my numerous friends and correspondents for their valuable co-operation during the progress of this work, I have to express my obligation to Sir William Jardine, Bart., for notices of several rare birds that have occurred in various Scottish localities; to Sir James Matheson, Bart., of Stornoway Castle, for many interesting notes on the birds of Lewis ; to the Earl of Haddington, for very full and carefully prepared lists of the more interesting species frequenting East Lothian and Berwickshire; to Henry J. Elwes, Esq., late 
Captain Scots Fusilier Guards, for several valuable notes on the birds of Islay, Ross-shire, and the Outer Hebrides; and to Henry D. Graham, Esq., for his admirable account of the birds of Iona and Mull. To Captain H. W. Feilden, 4th King's Own Royal Regiment, and J. A. Harvie Brown, Esq. of Dunipace, I am also indebted for many observations of great interest made by themselves in the islands of North Uist, South Uist, and Barra, in the summer of 1870 , as well as for other acts of kindness at a time when their assistance was of most value. Mr Harvie Brown has besides favoured me with a perusal of his numerous journals written in various districts of Scotland, especially the coasts of Stirling and Sutherland; and I have been at the same time under obligations of a like nature to another friend-Edward R. Alston, Esq.-who has furnished me with lists from the Upper Ward of Lanarkshire. Dr J. A. Smith, of Edinburgh, has in the kindest manner allowed me the use of his important notes on many rare birds which have occurred for the most part in the eastern and south-eastern counties; and Professor Dickie, of Aberdeen University, has also taken a kindly interest in procuring me information from those lying to the north. From another resident in Aberdeen-Mr W. C. Angus-I have received very great assistance in forming an estimate of the numbers of migratory birds that make the outlying portion of the north-east of Scotland their halting place, and also for notices and full descriptions of rare visitants that have occurred in that district during the last eight or ten years.

My acknowledgments are also due to Professor Newton of Cambridge; J. H. Gurney, Jun., Esq. of London; R. G. Wardlaw-Ramsay, Esq., 67th Regiment; Dr Dewar of Glasgow; the Rev. Alexander Stewart of Ballachulish; and $\mathrm{Mr}$ J. Hardy of Old Cambus, Berwickshire; to Dr Saxby, late of Unst, Shetland; Mr Reid, formerly resident in Kirkwall, Orkney; and Mr Joseph H. Dunn, Stromness. Through the last named correspondent I have had an opportunity of consulting a copy of Messrs. Baikie and Heddles' Historia Naturalis Orcadensis, with MS. additions by one of the authors to 25th June, 1853. This work, for convenience, has been referred to as the Fauna Orcadensis, and is 
not to be confounded with another work with that title published by Mr Low.

In the preparation of the Gaelic synonymes of the birds I have received every assistance from Messrs. John Macdonald of Buckie, Dugald C. Macdonald, Alexander A. Carmichael, Alexander Macdougall, and other friends connected with the Long Island; and I here take this opportunity of recording my grateful thanks to these friends for all the kindness shewn me while traversing the Outer Hebrides. Without such material aid, indeed, as I was fortunate enough to secure, my researches there might have ended with less satisfactory results.

To my friend Mr William Sinclair my best thanks are due for the bird illustrations which Mr Bott has so faithfully reproduced; and to another friend, Mr. Thomas S. Hutcheson, I am also indebted for many kind services while the book has been in the printer's hands. In the course of my wanderings, proof sheets have, through his careful attention, followed me into the midst of the remotest bird haunts and wildest scenery, and been revised often in the open air during sunshine and storm, with all the elements at hand for consulting the best authorities - the birds themselves.

It remains only to be added that the utmost care has been taken to verify the whole of the information contained in this volume, and that all records of a doubtful nature have been rigidly excluded from it. Although in the experience of almost every naturalist opinions based upon the investigations of many years become more or less modified as observations extend, I hope I may still be allowed to say for myself that during a long course of practical research among the Birds of Scotland, I have been especially guarded in noting only what in after years may freely be subjected to the closest scrutiny.

R. G. 


\section{LIST OF ILLUSTRATIONS.}

I.-Lake in North Uist, Outer Hebrides, Author, - Frontispiece

II.-White-Tailed Eagle, - - - - W. Sinclair, $\quad \begin{array}{r}\text { Page } \\ 9\end{array}$ (Scene, in the Sound of Harris.)

III.-DipPer or Water Ouzel, - - - - Do. $\quad$ - 70

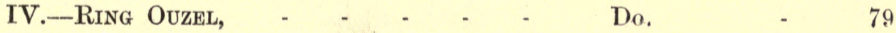

V.-Bohemian Waxwing, - $\quad-\quad-\quad$ Do. $\quad{ }^{107}$

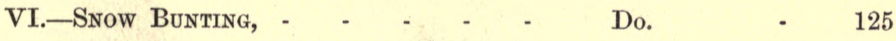

VII.—White-Throated Sparrow, - - $\quad$ - Do. $\quad$ - 138

VIII.-Glengarnock, - - - - - C. N. Woolnoth, W.S.A., 196

IX.-Ptarmigan, - - - - - - W. Sinclair, - 236

X.-Whitberry Point, - - - - J. R. Prentice, - 262 (Dunbar in the Distance.)

XI.-Whimbrel, - - - - - - - W. Sinclair, - 288 (Scene, in the Sound of Harris, Islands of Pabbay and Berneray in the distance.)

XII.-Black-winged Stilt, - $\quad$ - $\quad$ - $\quad$ Do. $\quad 303$

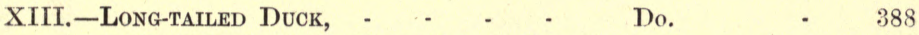

(Scene, Island of Scalpa, Shiant Isles in the distance.)

XIV.-Black-throated Diver and Tufted Ducks, Do. - 414 (Referred to at page 387.)

XV.-View at the Mouth of the Ythan, - James Giles, R.S.A., 466 (Aberdeenshire.) 



\section{BIRDS OF THE WEST OF SCOTLAND.}

RAPTORES.

FA LCONIDA.

\section{THE GOLDEN EAGLE: AQUILA CHRYSAËTOS." ; : ‘, ‘ ? Iolair dhubh.}

There is perhaps no feature in the history of British birds more to be regretted than the gradual disappearance of many species that were once familiar residents. Among these, the Golden Eagle stands pre-eminent as deserving the sympathy of all true naturalists, subjected as it has been to a relentless and continual persecution, which only excites our wonder that the noble bird has so long survived. It is certainly not a false sentiment that urges the ornithologist of our own times to lift up his voice against the destruction of a class of birds whose very presence gives a character to some of the finest scenery in Britain; and every true lover of nature will, I feel sure, join him in the hope that it may not yet be too late to bring back from the verge of extinction the bird that has so long occupied the foremost rank in Scottish ornithology.

As might be expected, the western counties form the only resting place now in the breeding season for this splendid bird. Even there, however, it is by no means certain that the number of eyries will increase, unless the proprietors of the various lands thus frequented unite in determining that eagles are to be spared. That such a feeling already, to some extent, exists is beyond question; but withont the cordial co-operation of all, it is doubtful, looking to the wandering habits of the bird in the autumn and 
winter seasons, whether much good could be accomplished. Not long ago a correspondent wrote to me that a gentleman of his acquaintance, in roaming over his Highland estate, was in the habit of pointing out with a strong feeling of sadness the deserted eyries of the eagles, and looking with something like veneration upon the moth-eaten specimens that had been killed by his sires. May this be the feeling and lament of many such chiefs, and may eagles hereafter be inherited with their mountain home!

On all the Outer Hebrides the Golden Eagle is still a well-known bird, and from Barra Head to the Butt of Lewis various eyries existed in the breeding season of 1867. In the islands of Lewis and Harris they are best known, especially in certain districts distinguished for a grandeur of scenery which the presence of an eagle. is sure to invest with an additional charm. On North

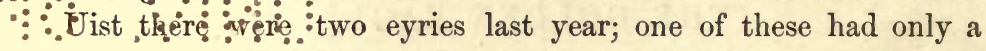
single young bird in.it, and was easily reached, being on a rocky

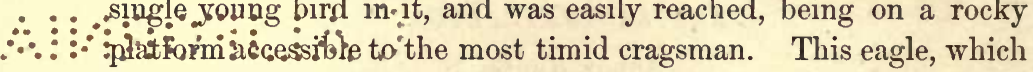
was uncommonly black in the plumage, I had an opportunity of seeing three weeks after it was taken. It was then in the possession of Mr John M'Donald at his residence near the Sound of Harris, and appeared to be thriving well in confinement. On Benbecula, where eagles are frequently seen, there are no eyries; but on the next island-South Uist-there is one every year on Mount Hecla. Mr D. Lamont informed me, when I crossed to the locality with him last year, that he had seen the old birds of this hill coming almost daily from Skye with a young lamb each to their eaglets. The distance is about twenty-five miles. They never, he says, destroy the flocks in South Uist itself; hence the maintenance of their family does not add to the local taxation. But while some of the lairds of Skye might be rejoicing at the sight of the feathered monarch of their own Alps circling above his rocky throne, their shepherds were probably breathing vengeance against the King of Hecla and his mate for their plundering visits. Thus, even within comparatively narrow limits, the bird may well be called the "pride and the pest of the parish!"

Over the whole of the western counties there is but one Gaelic name-Iolair dhubh-given to this bird, signifying Black Eagle; but in no quarter is it more entitled to this appellation than in the outer islands. After examining upwards of a dozen specimens 
bred in the Long Island, I can scarcely resist the conclusion that as a rule these eagles are smaller and darker in colour than those - bred on the mainland. This difference may arise from local causes, such as the paucity of game of all kinds as food, or the persistent storms of the country blowing their natural prey into sheltered recesses, and thus obliging them to fast, perhaps an unusual length of time. A more likely solution of the difference, however, may be founded on the fact alluded to by Mr Cassin, in his "Birds of California and Texas," that the Golden Eagle of some parts of North America is smaller and darker than the European bird; and taking this fact into consideration, these Hebridean eagles may be a race verging on this nearly allied species. This difference in the size of the bird would almost appear to hold good in the egg also, those found in some of the Hebridean eyries, at least, containing very small eggs, very handsomely spotted, and reminding me of the difference between the eggs of the Osprey of America and that of Europe.

Having had fewer opportunities than some other naturalists of examining the eyrie of the Golden Eagle, I turn with pleasure to a highly interesting communication with which I have been favoured by my obliging correspondent, Henry J. Elwes, Esq., late Captain Scots Fusilier Guards, to whom I have had occasion in the course of this volume to refer for other information of equal value and interest :-

"The Golden Eagle usually commences to prepare its nest for eggs about the beginning of April, and selects for that purpose a rock, which, though nearly always in a commanding situation, is nearer the bottom than the top of a mountain. I have been in or near at least a dozen eyries, and not one of them, to the best of my judgment, is more than 1000 feet above the sea, though a beautiful and extended view is obtained from all of them. The rock is generally a good deal broken and clothed with grass, ferns, bushes, and tufts of a plant which I believe is Luzula sylvatica, and which is always found in the lining of the nest. The ledge on which the nest is placed is generally sheltered from above by the overhanging rock, the structure being sometimes composed of a large quantity of sticks, heather, etc., and in other cases very slight indeed. The eggs are laid about the 10th of April, being a little later in the Outer Hebrides than on the mainland. Their number is usually two, very often three, especially with old birds, and 
sometimes only one. When there are three, one is generally addled, and not so well coloured as the other two, and they vary extremely both in size and colour.

"Golden Eagles generally breed year after year in the same place, though they often have two or three eyries near together, especially when the nests are harried frequently. They sit for about twenty-one days, and are very reluctant to leave the nest when it is first discovered, though afterwards they do not sit so hard. I have seen an eagle sit on its nest for some minutes after a double shot was fired within one hundred yards in full view of the bird; but when once they know that the nest is discovered, they are much wilder. As for the stories about people being attacked by eagles when taking their nests, I do not believe them, as I have never seen one come within gunshot of a person at the nest, and I never saw any one who could vouch for a story of this sort on his own knowledge. In a deer forest eagles are of the greatest advantage, and it is a pity that foresters should be allowed to destroy them, as, though they occasionally take a red deer calf, yet, in most cases, the forest is all the better for the loss of the weakest ones, and they confer a great benefit on the deer-stalker by the destruction of the blue hares, which form their favourite food. One of the most interesting sights to a lover of nature is to see an eagle, soon after its young ones have left the nest, teaching them to kill their own prey by dashing amongst a covey of ptarmigan poults, which gives the awkward young eagle a good opportunity of catching one when separated from the old birds. On a sheep farm, where game is scarce, it cannot be denied that eagles do a good deal of harm in the lambing season, but in such cases it is best to take the eggs as soon as laid, which does not cause them to leave the district, though it relieves them of the necessity of providing food for the young ones. I do not think that the Golden Eagle often lays a second time after its nest has been robbed, and although an instance may happen occasionally, it is certainly not the rule.

"On a bright hot day, without much wind, eagles are fond of soaring round and round at a great height above the top of a mountain, more, I think, for exercise than in search of prey, as the hill top itself is sufficiently elevated to command a great extent of country. In this manner they can fly for some time without any perceptible motion of the wings, thongh the tail is often turned from side to side to guide the flight. The points of the primary 
quills are always rather turned up and separated, as is shown in one of Landseer's beautiful pictures, in which an eagle is flying across a loch to a dead stag which has been already discovered by a fox."

Mr Elwes has also informed me that one or two pairs of Golden Eagles regularly inhabit the district of Gairloch in Ross shire and breed there. In a recent letter to myself he says: "I lately saw three nests which had been used in 186t, '65, and '66, by the same pair of birds. The last nest was not at all difficult to get at, as I got within three yards of it without a rope, and could easily have gone into it had I wished. It was placed in a three cornered ledge of rock, overhung by a cliff, a steep gully being within two yards on one side."

Writing from Skye in March, 1867, Capt. I). C. Cameron, of Glenbrittle, obligingly sent me the following note:- " Although there are always two or three eyries of the Sea Eagle on my farm, I only know of the Golden Eagle building above Loch Corruisk. There was a nest there in 1865 . I trapped the female ten miles from the nest, I am sorry to say, and there was no nest there last year. This was the first resumption of the old eyrie after the young were taken by the survey men many years ago, and I was quite delighted to see the birds come back, though I was the innocent cause of the second desertion." Capt. Cameron also states, with a view to show the comparative numbers of the Golden and White-tailed Eagles, that out of sixty-five eagles that he has killed or caused to be killed, only three were of the firstnamed species. He has likewise sent me word that the Golden Eagle has hred for several years past at Barcaldine, near Bonaw, in Argyleshire, and that one of the nests was robbed by a shepherd who trapped one of the birds.

A few months ago a paragraph appeared in some of the Scottish newspapers giving an account of a most extraordinary aerial combat between an eagle of this species and a fox, which happened in Strathmore, Caithness-shire, and was communicated by an eyewitness to the Northern Ensign newspaper in the following letter. Having written to the editor for further information on the subject, I am assured by that gentleman that in every particular the account may be implicitly relied on; the occurrence took place on the hill of Benalskie:-

"The eagle was devouring the carcase of a mountain-hare when 
a fox sprang from a bush of heather and seized the intruder (which had come to rob him of his prey) by the wing. A wellcontested struggle ensued, in which the bird made a desperate attempt to defend itself with its claws, and succeeded in extricating itself from its enemy's grasp, but before it had time to escape Reynard seized it again by the breast, and seemed more determined than ever. The eagle made another attempt to overpower its antagonist, by striking him with its wings, but that would not compel him to quit his hold. At last the eagle succeeded in raising the fox from terra firma, and in a few minutes he was suspended by his own jaws between heaven and earth. Although now placed in an unfavourable position for fighting, his courage did not seem to forsake him, as he firmly kept his hold, and seemed to make several attempts to bring the eagle down; but he soon found the strong wings of the eagle were capable of raising him, and that there was now no way of escape unless the bird should alight somewhere. The eagle made a straight ascent, and rose to a considerable height in the air. The two combatants were still struggling, and in a few minutes a disengagement appeared to have taken place. Reynard, from some cause or other, was obliged to quit his grasp, and was now descending much quicker than he had gone up. In a second or two he was dashed to the earth, where he lay struggling in the agonies of death. The eagle meanwhile made its escape in a southern direction; it appeared weak from exhaustion and loss of blood, but managed, notwithstanding, to hold on its flight until he became obscured in the distance."

Throughout Scotland generally, the Golden Eagle, although looked upon as a rarity, is, from its habit of wandering in the autumn months, frequently seen in lowland districts skimming above woods and fields, but seldom deviating from its line of flight. Sometimes, when pressed by hunger, it comes near enough to be shot; but usually it is wary, even when scanning the ground for prey. A short time ago a friend, when walking in the outskirts of Kirriemuir, in Forfarshire, accompanied by a little terrier, was surprised to see one of these birds stoop suddenly in its flight before him, as if to see whether the dog would make a suitable meal. A glance, however, apparently convinced the bird that an attack in the circumstances would be useless, and as it rose gracefully out of range, it continued its flight northward in a straight 
line, and about the same height from the ground, until it was lost to sight.

"An occasional Golden Eagle," writes my friend Mr Henry D. Graham, "may still be seen pursuing his lofty course over the moors and mountains of Mull and the surrounding islands. A friend, a few years ago, killed one out of a party of seven-a number which would have been thought deeply significant in the days when augury was a fashionable science. In Jura a pair flew close over my head as I sat on the hill side with a friend and a gamekeeper at luncheon. The two birds sailed slowly past without deigning to notice us."

Mr Alexander M'Niven, Shemore, lately told me he had seen an eagle this year in somewhat novel circumstances. He was on the banks of Loch Lomond with a party of friends, when their attention was drawn to a squall sweeping down the loch in their direction. Suddenly it burst upon them in all its fury-the darkened sky having an extraordinary appearance as the hail and rain dashed with a loud hissing noise into the loch. In the very front of this tempest cloud there sailed the majestic bird, turning not its flight, but steadily flying before the blast. The whole of the party saw it, and the species was recognized at once by $\mathrm{Mr}$ M'Niven, who had frequently seen Golden Eagles before near his own residence. Later still, Mr J. A. Harvie Brown, of Dunipace, has sent me his notes taken in Sutherlandshire up to the close of the nesting season of 1869 , in which frequent allusion is made to the flight of this king of birds.

"There are still," writes Mr Brown, "several localities where the Golden Eagle has its eyrie in Sutherlandshire, but of course their numbers have been rapidly on the decrease since Mr Selby visited the county. J. S. assured me that in the short space of three weeks he once killed sixteen adult Golden Eagles and Sea Eagles. I know that one gentleman, who was like ourselves collecting this year in Sutherlandshire, obtained three Golden Eagle's eggs in the north of the county. He bought them from a shepherd who had them in his possession for some time. This does not make it appear that the latest orders will invariably be attended to by shepherds and gamekeepers." While commending this short paragraph to the careful notice of Highland proprietors, I take the opportunity of also drawing their attention to a fact communicated by Mr John Bateson to the Times about a 
year ago, namely, that printed lists are actually in circulation among keepers and shepherds in the county referred to, offering large prices for the eggs of birds of prey, and thus opening up a temptation to these men which no amount of care on the part of their employers is ever able to counteract. Nothing but the strongest censure can be meted out to such collectors as would bribe a man in humble circumstances to procure eggs of the Golden or White-tailed Eagles, Kite, or Osprey, at the price of ten pounds for each specimen.

OBS.-It may here be mentioned that the late Mr Thompson, in his work on the Birds of Ireland, has inserted the following notice in the appendix to the third volume regarding the supposed occurrence of the Spotted Eagle (Aquila noevic) in the island of Skye:-

"Dunvegan Castle, Skye, October, 1850.-It is not improbable that the Spotted Eagle has occurred in this island. On my questioning $\mathrm{Mr}$ Pack (who has been resident here for fourteen years, and eleven of them as gamekeeper) respecting the birds of Skye, he described a spotted eagle-though he had never heard of a species being so called-having been killed by one of the shepherds of the late Mr Macleod, of Orbost, about the year 1840. Soon afterwards, he himself saw another, and subsequently, within a short time, either a second bird or the same individual again. The size he does not accurately remember, though he recollects that it was liker to the Golden than the Sea Eagle; the spotting which he describes would apply correctly to the bird in question. $\mathrm{He}$ and others who saw the individual which was shot considered it quite distinct from the Golden and Sea Eagles, and the Osprey, all of which are found there."

Although this species has never come under my own observation, nor been seen or heard of by any of my correspondents in that part of the country, it is not unlikely that specimens may yet occur, seeing that it has been known to breed and been killed in several instances in Ireland, whence but a short flight would take it to some of the southern and middle districts of the Scottish Hebrides. 


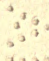

3030
3030

$30 \therefore 8020$

$\because 3:$

300

i) $=0$

$\therefore$ : $33^{3}$

tos a ose

3030

$\begin{array}{lll}30 & 0.030\end{array}$

, e.

${ }_{3} x_{3}$ 


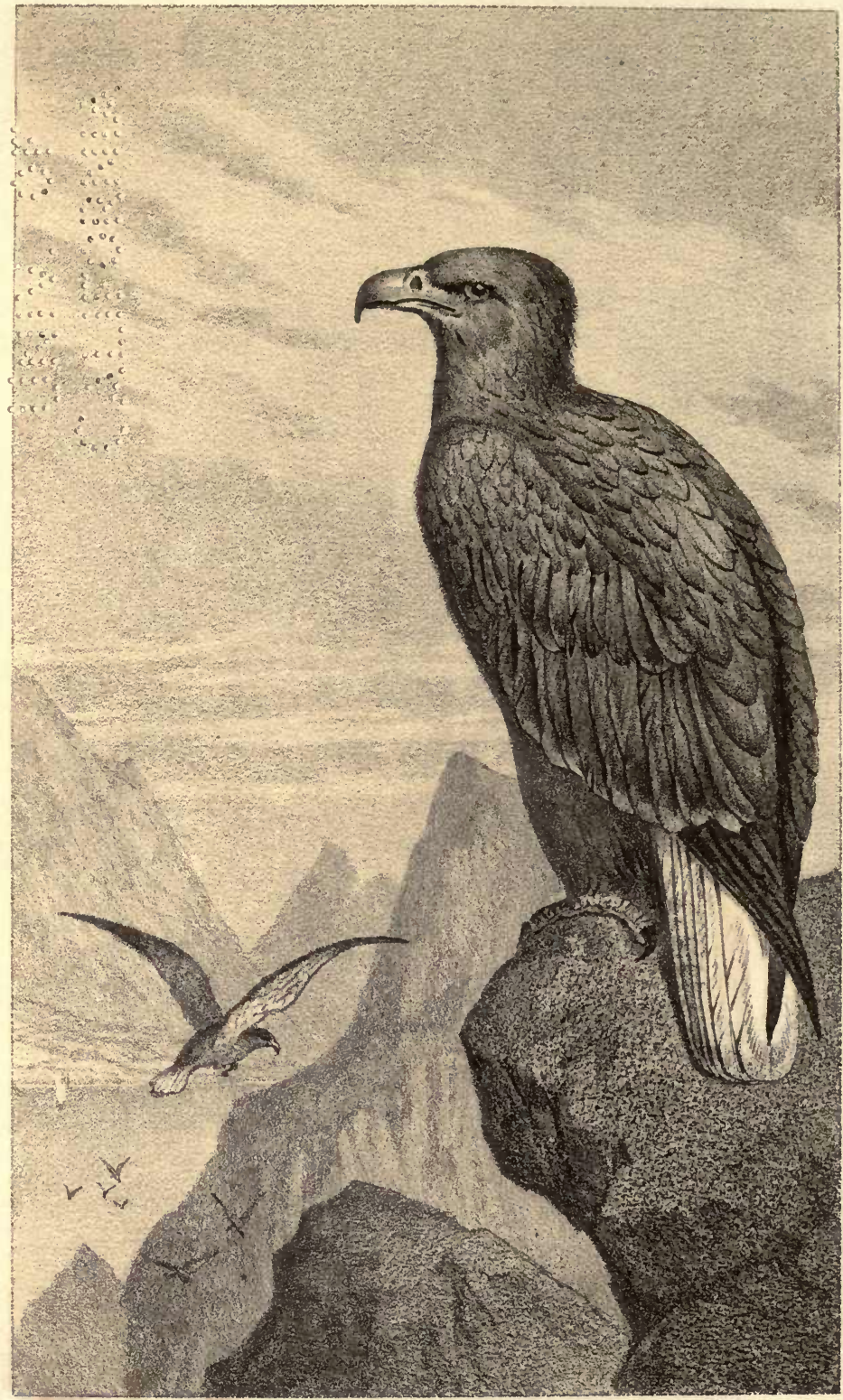

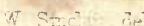

Pr - T T $R$

WHITE-TAILED SEA EAGLE

Haliaëtus Albicilla. 


\section{THE WHITE-TAILED EAGLE.}

IHALIA $\ddot{E} T U S$ A LBICILLA.

\section{Erne. Iolair Bhuidhe. Iolair Riamhach. Ioląir Shuil na Grèin.}

Being a much commoner bird in Scotland than the preceding species, the Sea Eagle has never been at any time in the same danger of extinction. Even in 1867 and 1868 there were numerous eyries in places which have been occupied from time immemorial. Between Loch Brittle and Copnahow Head, in Skye, for example, nine or ten eyries might have been seen, while in several of the smaller groups of isles in the Minch and Gulf of the Hebrides at least a dozen more could be cited. The Isle of Skye, indeed, may be said to be the head quarters of this conspicuous eagle in the west of Scotland-the entire coast line of that magnificent country offering many attractions to a bird of its habits. Nearly all the bold headlands of Skye are frequented by at least one pair of Sea Eagles, and it is at no time a difficult matter to get a sight of them. On one property alone there were recently six breeding places; * and I have been informed by Dr Dewar, that quite recently as many as six old birds of this species assembled together, and were observed soaring in a group above the house of Captain M'Donald, near Bracadale. Two of these birds-probably males--set upon each other, and fought viciously for a considerable time, while the other four soared leisurely round the combatants, uttering their well-known yelping cry, but making no near approach. The battle, during which a quantity of feathers were scattered in the air, continued until the birds reached the ground, when it was found that one of them was so much injured as to be unable to rise; it was therefore knocked on the head by a shepherd who had stood for some time an interested spectator of the novel fight.

\footnotetext{
* It is impossible, however, to conceal the fact that if the present destruction of eagles continues we shall soon have to reckon this species among the extinct families of our "feathered nobility." "During the last nine years," says my friend Dr Dewar, "a keeper in skye has shot fifty-seven eagles on a single estate;" and in a letter addressed to myself in November, 1866, by a keeper resident in the west of Ross-shire, the confession is made that during an experience of twelve years he had shot no less than fifty-two eagles, besides taking numbers of both eggs and young. Captain Cameron of Glenbrittle also informs me that he has now seen as many as sixty-two Sea Eagles killed in Skye. No species of eagle could long survive such persecution.
} 
Thirty years ago the Erne was often observed in the parish of Hamilton, according to the Rev. William Patrick-a good observer in his day; and in several other inland districts in Lanarkshire, Ayrshire, Kirkcudbrightshire, and Wigtownshire, similar records might be given of its past existence. But even at the present time stray specimens are found wandering as far into the Firth of Clyde as Dunoon - the captures in such instances, however, being confined to birds of the year after they have been thrown off by the old ones. Ailsa Craig, formerly a breeding station, is now only visited by a passing vagrant; and in Islay two well-known eyries-one at the Mull of Oe, the other at Bolsa-have for some years been entirely deserted, although stray birds still visit the island.

One of the most picturesque eyries of the Erne on the west coast is perhaps that placed on the breast of one of "Macleod's Maidens," a group of three sharp pointed stacks of rock on the coast of Slkye. Among other breeding stations may be enumerated the Scuir of Eigg, Scalpa, North Uist, Shiant Isles, Wiay, Benbecula, several in Harris, and also in Lewis. The eyrie on the largest island of the Shiant group is perfectly inaccessible; it was referred to by Martin nearly two hundred years ago in his "Description of the Western Islands of Scotland," and has probably been tenanted regularly ever since. On the mainland the breeding localities are much less numerous than in the islands; there are still, however, although I have no wish to see their privacy invaded, a number of frequented eyries in several of the counties stretching from Cape Wrath to the Mull of Galloway. My friend Mr Brown, whose ample and highly interesting manuscript journals have been most generously placed at my service, takes notice of one eyrie in the district of Assynt in Sutherlandshire, and refers to another pair of birds which bred on the island of Handa in 1867, but which were banished from the place by a shepherd destroying the female on her nest. Since this occurrence none have frequented the cliffs there. Shepherds have no doubt cause to look upon eagles as their enemies, as they are occasionally destructive to young lambs; and game preservers have perhaps an equal right to complain of their poaching propensities among grouse and hares. It cannot, however, be denied that the Sea Eagle oftener feasts upon carrion than upon living animals, and that in the most of cases where lambs are actually lifted the offence is to a great extent mitigated by the 
fact of the severe spring weather having previously crippled these poor creatures beyond hope of recovery. So far, indeed, as my own observations have extended, the chief food of this eagle appears to be stranded fish procured in the vicinity of its maritime haunts, dead sheep found on the moors, and occasionally a salmon left by some scared otter-a selection more in keeping with the innocent life of a vulture than the plundering habits usually ascribed to eagles.

The nest of this bird is an immensely large structure, and is built of sticks, bunches of heather, and pieces of turf, varied sometimes by a handful or two of withered seaweed mixed with wool as a sort of lining. The situation varies according to the locality of the bird's haunts. On rocky headlands facing the sea the nest is generally, if not always, placed on an inaccessible platform or rough crevice, the fabric in some instances being more than usually bulky so as to fill up the inequalities before a perfectly flat surface can be attained; while in inland districts it is often built on stunted trees or on the ground, especially where the birds select an islet in a loch which is apparently safe against intrusion. Two or three years ago there was a nest on a rowan tree growing on a small island in Loch-na-Baa, in the north-west of Argyleshire; it was of great bulk, and presented a most extraordinary appearance when viewed from a little distance. MacGillivray mentions having found a Sea Eagle's nest in an island in a Hebridean lake, on a mound of rock not higher than could have been reached with a fishing-rod, and a similar eyrie existed many years ago in an island in Loch Skene in Dumfriesshire.

Of the habits of this eagle in confinement I am unable to say much; indeed, I should prefer the more noble bird, his ally the Golden Eagle, as a subject for the aviary, guilty though he be of clutching pet cats or other domestic prey that venture within his prison bars. The Sea Eagle, however, being more susceptible of kindness, is rather an interesting pet when allowed his liberty, and has been known in a number of instances to tly about in a tamed state. Mr Carmichael, of Lochmaddy, lately communicated to me the following account of one:- "A few years ago, Dr MacGillivray, of Eoligarry, Barra, brother of the late Professor MacGillivray, the well-known ornithologist, had a pet Sea Eagle which was exceedingly interesting. He had a house made for it on the face of a hill about a hundred yarls from his house. Here it 
spent the night, but during the day it was generally abroad with the doctor's two boys. It would come at their call and feed out of their hands, fly about their heads, and follow them whereever they went. I am not sure if ever it went alone in search of prey, but nothing seemed to delight it so much as to get the boys away rabbit hunting. On such occasions it would follow them and hover round their heads, perform the most graceful aerial evolutions, and scream with delight as if it thoroughly understood and enjoyed the expedition; and when an unfortunate rabbit showed itself the eagle would swoop down upon it with amazing rapidity and power. The utmost confidence and attachment seemed to exist between the boys and the bird, till the latter was unfortunately killed by a visitor-a young gentleman from Glasgow -who mistook it for a wild bird, and so shot it, to the great vexation of the entire household, with whom the eagle had been a great favourite." Another instance of the bird's tameness was lately communicated to me by my friend Mr Edward R. Alston, of Glasgow. This specimen was in the possession of a lady some years ago, and was full grown when she got it. "It was allowed full liberty," says Mr Alston, "never attempting to escape nor to injure any one, and coming when called to be fed or caressed. It was particularly fond of fish, but would also eat meat." A third case I have the pleasure of selecting from a mass of highly graphic and interesting notes now before me, penned by one whose correspondence has for nearly twenty years afforded me no ordinary pleasure":- "My friend Mr C. M'Vean has had a tamed Sea Eagle for some years, which is not kept in confinement, but sometimes startles strangers by sweeping past the windows. He says, 'My eagle I named "Roneval," after the lill in South Uist, where he was hatched. He is a male, and a very fine bird. I have had him now for four years, and he has assumed his white tail. $\mathrm{He}$ is allowed to fly about at large, but is not fond of going far, and will always come at the call of the kitchen maid, who feeds him, and

* Henry D. Graham, Esq., who resided a number of years in Iona, and published a meritorious and beautiful work on the antiquities of that interesting island. I cannot sufficiently thank my valued friend for the handsome and disinterested manner in which he has placed his excellent notes on the Birds of Iona and Mull at my disposal. I trust these may yet appear in a separate form, and this feeling will no doubt be shared by those who read the graphic selections I have made use of in these pages. 
for whom he shows the greatest affection.' This personage indeed can manage him even when in most ungovernable tempers. He has a particular aversion to small boys, and will fly at one going near him. The only animal he is afraid of is a pig, and to hear a pig grunt is enough to make him fly off, even if it should not be in sight. A well-dressed friend ventured one day to touch him with the point of his fashionable light umbrella, which so offended 'Roneval's' majesty that he flew at the offending instrument and literally smashed it, breaking the stick and tearing the silk to tatters - the owner gladly escaping in unscathed broadcloth himself at the expense of leaving his pet parupluie a spolia opima in the claws of Jove's irate bird. Usually, however, he is affable enough, and does no more mischief than occasionally killing a hen or two if his own dinner is not served up punctually enough, and this is really great forbearance, considering that he actually lives at large in a poultry yard. This proves how very domestic this monarch of the cliffs may become; for although a short-winged flight would carry him to the illimitable freedom of the neighbouring sea cliffs and mountain tops, he has never been known to 'stop out of nights' more than once or twice during a residence of several years."

In the eastern counties of Scotland this eagle is usually met with in autumn, and almost all the specimens procured from Berwick to Orkney, which I have seen or heard of, were immature birds. At St Abb's Head, in Berwickshire, a solitary eagle is occasionally seen about that season frequenting the precipitous cliffs, which are occupied in summer by large numbers of gulls, razor-bills, and guillemots The stay of these stragglers, sometimes extending over a period of two or three weeks, appears to be regulated by the supply of food, which consists entirely of dead animals procured in the immediate neighbourhood. Fish of various kinds are often thrown up by storms, and at once attract the glaucous and great black-backed gulls, which are constantly prowling along the shores. During the eagle's stay, however, they are compelled to resign all the best fish to his exclusive use, and content themselves with a half-putrid wolf fish (Anarrhichus lupus), or sea devil (Lophius piscatorius), numbers of which are thrown overboard by the fishermen as useless, and in time are stranded on the beach. About twenty miles north of this locality one or two Cinereous Eagles have been obtained in a much quieter, 
though perhaps more dangerous residence-the estuary of the Tyne-where, although an abundant supply of both game birds and wild fowl could have been secured, the same partiality for harmless plunder has characterized their visits Lord Binning, who has for several years closely observed the ornithological features of East Lothian and the neighbouring county of Berwick, informs me that a female bird of this species "was shot at Tyninghame, in December, 1858, by Mr Inglis, gamekeeper. It had been seen for several days in the fir-woods near the shore, and appeared to have lived entirely on fish during that time, as three or four good-sized fish, in various stages of decomposition, were found in its stomach. Though in good condition and plumage, this was evidently not an aged or even adult bird, as shown by the uniform dark colour of the plumage, and the light colour of the bill."

Between East Lothian and the eastern portion of Caithness there are a few occasional resting places for this species, but no permanent haunt until we reach the Orkney and Shetland islands. Formerly, both Golden and White-tailed Eagles were very common, if not abundant, throughout that northern group. Even at the time of Bullock's visit in 1812, their frequent onslanghts on the farm yard apparently caused much anxiety among the inhabitants, who must have appreciated in no small degree the laudable efforts of that early representative of the British collector to reduce their numbers. The following quotation from a curious little book published by Mr Bullock as a guide to his celebrated museum, may not be without interest :-

"The young ones were taken on the 10th of June, 1812, when about three weeks old, from their eyrie on the tremendous cliffs called the West Craigs in the isle of Hoy (one of the Orkneys), the towering rocks of which rise to the perpendicular height of 1200 feet from the sea. About une third of the way of this awful abyss a slender pointed rock projected from the cliff, like the pinnacle of a Gothic building. On the extremity of this is a hollow, searcely of sufficient size for the purpose, these birds had fixed on as a place of security for rearing their young; the situation was such as almost to defy the power of man to molest their habitation; yet with the assistance of a short slender rope made of twisted hogs' bristles, did the adventurous climber or rocksman 'Wooley Thomson' traverse the face of this frightful 
precipice, and for a trifling remuneration brought up the young birds.

"After a fatiguing scramble up the sides of the mountains we arrived at the place from whence we could see the eyrie beneath; the distance was so great that the young eagles appeared no larger than pigeons; after placing us in a secure situation on a projecting edge of the rock that commanded a view of the scene of action, Thomson left us, carrying his rope in his hand, and disappeared for upwards of half an hour; when to our great joy we discovered him creeping on his hands and knees up the spiry fragment on which lay the unfledged eaglets; when knowing he was then in our sight, he knelt at the top, and looking towards us, waved his hat. At this time it was impossible to see the situation he was in without trembling for his safety; the slender point of the rock on which he knelt was at least 800 feet above the surges of the Atlantic, which with unbroken violence were foaming beneath lim. Yet he deliberately took from his pocket a cord, and tying the wings of the young birds, who made some resistance with their bills and talons, he put them into a basket, and began to descend, and in a few minutes the overhanging masses of stone hid him from our view. The old birds were in sight during the transaction, and made no attempt to defend their young; but soaring about a quarter of a mile above, occasionally uttered a short shrill scream, very different from their usual barking noise. Had they attempted a rescue, the situation of the climber would have been extremely dangerous, as the slightest deviation or false step would have precipitated him into eternity - a misfortune that a few years since befel his brother on the same spot when in his company. After waiting in a most painful state of suspense for near an hour [during which interval 'Wooley' can hardly be supposed to have been fortifying himself from a quaich under the overhanging rock], our climber suddenly made his appearance, and laughing, presented his prize." Mr Bullock, who, it is to be hoped, substantially rewarded the pluck of this adventurous fellow, then proceeds to say- "In the isle of Hoy we discovered all the species of British eagles except the Osprey; they are extremely numerous, and are the greatest pest of the poor inhabitants, frequently carrying off their lambs, pigs, and poultry. Near the nest of one we found the remains of several lambs, and the legs of forty-eight fowls were found near another. It is but a few 
years since a person died, who, in his infancy, had been carried off by an eagle, and recovered by his parents. By an ancient law in the Orkneys any person destroying an eagle is entitled to a hen from every farm in the parish in which it occurred."

The following is one of the Acts of Bailiary for executing of justice through the county of Orkney, and is apparently the law spoken of by Mr Bullock: its insertion here may serve at least to interest those who are curious about local enactments :-

$$
\begin{aligned}
& \text { "Act 31.-Anent Slaying of the Earn. } \\
& \text { Apud Kirkwam, } 8^{\text {oo }} \text { die } 9^{\text {bris, }} 1626 .
\end{aligned}
$$

The which day it is statute and ordained by THomas Buchannan, Sherreif-deput of Orknay, with consent of the gentlemen and suitors of Court present for the time. That whatever persone shall slay the earn or eagle shall have of the Baillie of the parochine where it shall happen him to slay the eagle, $8 \mathrm{~d}$. from every reik within the parochine, except from cottars that have no sheep, and 20 shill. from ilk persone for ilk earn's nest it shall happen them to herrie; and they shall present them to the Baillie, and the Baillie shall be holden to present the head of the said Earn at ilk Head Court.

Curia Capitalis vice comitatus de Orkney, tenta apud Kirkwam in insula vocata de Wall house, in templo $\mathrm{S}^{\text {t. }}$ Magni ibidem, per honorabiles viros Magistrum Johannem Dick et Robertum Monteith de Eglishy vice comites deputatos dicti vice comitatus, sexto die mensis Februarii, Anno Domini 1628."

About forty years after this law was passed the Earn would seem to have acquired even a worse habit than that of sheepstealing, as has been narrated in a manuscript written in 1664 by Mathew Mackaile, apothecary at Aberdeen, and preserved in the Advocates' Library, Edinburgh. In making a short extract from this curious account of Orkney, it is perhaps unnecessary to congratulate ourselves that through the diligence of keepers and collectors, we are spared the infliction of seeing a modern perambulator relieved of its occupant. Here is the apothecary's story: "I was very well informed that an eagle did take up a swaddled child a month old, which the mother had laid down until she went to the back of the peat stack at Honton Head, and carried it to Choye, viz., four miles, which being discovered by a 
traveller who heard the lamentations of the mother, four men went presently thither in a boat, and, knowing the eagle's nest, found the child without any prejudice done to it." This of course is an "old narration," but it has the advantage of as much truth on its side as any similar stories that have since appeared.

Although, as we have seen, eagles were abundant in Orkney and Shetland even so late as 1812 , it is now certain that they are all but exterminated. Writing from Stromness, Mr J. H. Dunn, to whom I am indebted for many interesting notices, informs me that no Golden Eagles have bred in Hoy for a number of years, and that the only recent specimen procured there was one shot in 1857 , and supposed at the time to be one of the only pair that had many years previously bred near Radwick; on the west side of Hoy. "Only one pair of Sea Eagles," continues Mr Dunn, "have nested in Hoy for several years back; they are supposed to be very old birds and unproductive. In 1865 their nest was got at, but was found to be empty, and in the year following their nest in another part of the cliffs was also reached, but found to contain one egg, and that an addled one."

Very great differences in size are observable in this speciessome specimens measuring only six feet from tip to tip of the wings, while others are at least one half more. The average stretch of wing may be stated at seven feet and a-half-a measurement which I find to be at all events the average of upwards of thirty specimens which I have of late years examined. The finest British example of the Sea Eagle I have ever seen is one in the collection of Sir James Matheson, Bart., of Stornoway Castle. This magnificent bird, which was killed in the island of Lewis, is distinguished for its great size and lightness of colour, being of a yellowish grey all over. Compared with three or four other Sea Eagles in the same collection, its size, indeed, appears quite extraordinary, and had the specimen been darker in colour it might have readily been mistaken for the Northern Sea Eagle (Haliceetus pelagicus of Pallas) figured in Cassin's " Birds of California and Texas," or some other eagle of mysterious size, several of which are alluded to by that author in his account of the species. Mr Cassin speaks of a "grey eagle of enormous dimensions," which is mentioned by the late Prince Maximilian of Wied in his "Travels in the Interior of North America," and also refers to another almost entirely white, represented by Du Pratz "as inhabiting Louisiana." This Heb- 
ridean eagle, therefore, may be worthy a closer examination, and I commend it in the meantime to the attention of ornithologists who may visit that portion of the outer islands.

Albino varieties of the Sea Eagle have in one or two instances occurred in Scotland. Mr St John has the following note bearing on this subject:- " This year (1848), during the month of September, I saw a freshly-killed Sea Eagle or White-tailed Eagle (Haliaëtus albicilla), whose colour was a fine silvery white, without the slightest admixture of brown. The bird was killed in Sutherland, and I was informed that another eagle had been seen in its company with the same unusual plumage." Mr Brown has also informed me that there is a pure white variety in the museum at Dunrobin Castle.

The figure in the accompanying plate was taken by Mr Sinclair from a fine specimen shot in the Isle of Skye.

\section{THE OSPREY.}

\section{PANDION HALIA ËTUS.}

Iolair uisg.

From being a comparatively common bird, the Osprey is now, with the exception of the kite and goshawk, the rarest of our native species; indeed, it has been stated recently that it is doubtful whether the Osprey now breeds in any part of Britain. Such were my own fears until I had the satisfaction of learning from $\mathrm{Mr}$ Elwes, that there are still (1867) at least three or four breeding stations in Ross-shire, and that these are strictly protected.*

In by-gone years, Ospreys bred on Inch Galbraith on Loch Lomond, and on one of the islets in Lake Menteith; also on Loch Maree, Loch Awe, and other places of a like character; but these localities have been long deserted, although a stray bird may be seen at times hovering in the vicinity of the islets where the nests

* I have since been informed on very good authority of another breeding station in Kirkcudbrightshire; and Mr Brown has also assured me that eggs of the Osprey were taken in Inverness-shire in the breeding season of 1869 , and that the birds laid a second time, and were allowed to hatch their young in safety. I may here repeat what I have elsewhere stated, that the species still nests in Wigtownshire, which is, in all likelihood, the most southernly breeding station at present in Britain. 
were formerly placed. It has of late years, as I am informed, been trapped on Loch Awe, and a pair were noticed two years ago surveying the old site on Inch Galbraith, but they left after a few days' fishing in the neighbourhood. I have good reason for saying that they will be most carefully looked to and preserved, should they again establish themselves there. In 1863, 1864, and 1865 the Osprey must have bred somewhere north of Stirlingshire, as young birds, beautifully spotted, were trapped near Campsie, and sent to a poulterer in Glasgow. These I examined, and found to be in fine feather.

In the first volume of the Ibis, N. S., 1865, it is stated in a letter to the editor by Mr Juhn Roche of Clungunford House, Shropshire, that the Osprey breeds regularly every season at a locality in Inverness-shire, and that Lord Hill had informed him of having received young birds from that quarter for several years. It is gratifying to be able to add that Lord Hill, finding it impossible to rear the birds, has requested that in future they are to be protected.

I have seen this interesting bird fishing in Loch Doon in Ayrshire and Loch Dee in Kirkcudbrightshire, but not of late yearsits appearance in either of these lochs being now extremely. uncertain. Those who practise the "gentle art" will miss their fellow fishers, as no true sportsman who is a lover of nature would grudge them their legitimate prey. Anglers, as a rule, are prond of the companionship of such birds as the Osprey and Water Ouzel, and would as soon think of injuring a fellow-creature as molesting these companions of their solitary hours.

The Osprey is but a rare straggler to the Outer Hebrides--one specimen only having been met with there; it was got on the island of Barra. Mr Elwes informs me that it is of rare occurrence in Islay. There is one preserved in the museum at Islay House.

The most recent instance of the occurrence of this bird in the middle districts of Scotland is one communicated to me by $\mathrm{Mr}$ Brown, in whose collection the specimen has since been placed. It was seen for some time in October, 1868, frequenting Carron Dam, near Falkirk, and extending its flight occasionally up the river in the direction of the village of Larbert. But a marked object like an Osprey was too great a temptation to gun owners living in the neighbourhood of its haunts, and it soon became encircled by a score of enemies. For six days, however, it evaded 
all their attempts upon its life, rising sometimes straight into the air within sight of them all, and wending its flight to a less dangerous part of the river, until one morning, after catching a perch, it alighted upon a board nailed to a pole as a warning to trespassers; then it flew, carrying the fish, to the top of a monumental pillar in the adjoining churchyard, where it forfeited its life. Mr Brown informs me that the poor bird, under a pressure of hunger, no doubt, was seen some days previously making a dash at some fowls in a poultry yard.

It would appear that there are but slender grounds for drawing a distinction between this bird and the Pandion Curolinensis of North America. In speaking of the latter species, the late Mr Cassin, in Professor Baird's work on the "Birds of North America," says:"There are no appreciable specific differences between specimens from all parts of North America, and, we may be allowed to add, very slight between those of this country and of Europe and Asia." Mr J. H. Gurney -an excellent authority-in a communication to the Ibis for 1867 (vol. iii., N. S., p. 465), writes even more conclusively as follows:- "The Norwich Museum possesses an extensive series of Ospreys from various parts of the world; and I have no hesitation in expressing my belief that the species is identical, not only on the coasts of North America and of Europe, but also on those of Africa, Asia, and Australia." To these opinions I may, however, add that so far as I have been able to judge, the eggs of the American bird are invariably much richer in colour than any I have seen taken from the nests of British Ospreys.

A specimen of the Osprey, now before me, was shot near Dunbar a few years ago, and preserved by my friend, Mr W. Sinclair.

\section{THE GREENLAND FALCON.}

\section{FALCO CANDICANS.}

Although a rare bird, the Gyr Falcon, as this species has been called, has frequently been met with in Scotland. It is mentioned by Sir Robert Sibbald in his "Historia Animalium in Scotia," p. 14, forming a section of his "Scotia Illustrata," etc., published in 1684 , and is next referred to by Pennant in the appendix to his "Tour in Scotland," 8vo. edition, 1772, p. 292, where he says:"The Gyr Falcon has been shot in Aberdeenshire. A large white 
hawk-I suppose an unspotted bird of this species-has bred for these last twelve years at Hilleigh Green, near Hackness, four miles from Scarborough." Forty years later it is noticed by Don in his "Forfarshire Fauna," in which, at page 40, the following note occurs:-_" Falco Candicans-Gyr Falcon.-I observed one of this species on the estate of Mr Robertson Scott of Hedderwick, in September, 1810; but I rather think it is rare." These records, with that furnished in Low's "Fauna (Ircadensis," published in 1812, were all that we knew of the bird as a Scottish species until 1835, when a very fine specimen (which I have seen) was shot at Dechmont, in Lanarkshire; but since that year, as ornithologists have increased, instances of its occurrence have been more frequent. These, it may be added, have chiefly happened in the West of Scotland.

In the Outer Hebrides it is seen occasionally. One was shot by Col. Gordon's keeper in South Uist a few years ago, and examined by $\mathrm{Mr}$ Colin $\mathrm{M}$ 'Vean, who made a careful drawing of the bird; another was killed in North Uist by Mr John M'Donald, Newton, in 1860. A very beautiful male, in fine plumage, was shot in Islay by Peter Mackenzie, gamekeeper to Mr Ramsay of Kildalton, in the autumn of 1862, and exhibited at a meeting of the Natural History Society of Glasgow.* It had been seen for some days previously frequenting a glen on Ramsay's property, and made a bold dash at the keeper's dogs one day as they entered its haunts. This offence was the first and last of its kind; the brave bird forgot it was on the wrong side of Iceland. Mr Elwes has informed me that another Gyr Falcon was procured in Islay last year (1867); and I have since learned from Dr Dewar that one was seen in the forest of Black Mount, Argyleshire, about the end of September, 1868, by Mr Peter Robertson, who states that he had several opportunities of observing the bird. It was very fearless, and made repeated swoops at his dogs when out with a shooting party.

In the third volume of MacGillivray's "British Birds," page 738, the following statement occurs respecting this species:-- "Mr Mackinnon informs me that this bird breeds on the main island of

* Since the above was written, I have been informed by Edward C. Newcome, Esq., of Feltwell Hall, Brandon, that he has in his collection an immature male, which was shot by J. Campbell, at Foss, on Loch Tummel, in Perthshire, in the spring of 1862 . 
St Kilda. He states that several pairs occur there; that the young have the upper parts grey all winter, and change to white in summer; that he has been at the nest of one; and that the old birds were so violent in their attacks that he had difficulty in keeping them off with a stick."

Mr J. H. Dunn informs me that a Gyr Falcon was seen frequenting the island of Foula for three or four weeks.

I have in my own collection a very handsome female bird of this species, which was caught near Elgin in the autumn of 1865 . It had previously been wounded, and therefore could offer no resistance to a party of passing workmen, who urged their dog to attack it, and in this way secured the prize.

\section{THE ICELAND FALCON.}

\section{FALCO ISLA NDICUS.}

Between 1835 and 1851 several specimens of this Falcon were shot in Ross-shire, Sutherlandshire, and Inverness-shire; and within the last four years I have satisfied myself that four or five have been shot in the West of Scotland. One was killed by Captain M'Rae on the island of Vallay, Outer Hebrides, in September, 1865. It haunted the farm-yard for some time, and was quite fearless in its attacks among the poultry-killing a great many chickens before meeting its fate. This bird is now in the collection of Dr Dewar of Glasgow. Another, a fine male, had been shot in October of the previous year in North Uist, by Allan M'Lean, gamekeeper there; and a third Hebridean specimen was found washed ashore dead on the west side of the island about the same time, but was not discovered until it had been disfigured by hooded crows. It has likewise occurred on the inner islands, as I have been informed by $\mathrm{Mr}$ Elwes, who writes that "one which was shot in Islay is now in the museum at Islay House."

In September, 1866, another fine Iceland Falcon was caught in a pole trap at Glendaruel, Argyleshire, but unfortunately this bird was lost, the trap not having been looked at for some days after it was sprung. The species, however, was identified beyond a doubt.

Dr Saxby, writing in October, 1865, observes that it is now 
only occasionally seen in winter, although formerly a regular visitor.

Regarding the habits of this bird, Audubon, who figures it in his large work on the "Birds of North America" under the name of Labrador Falcon (see plate 196, and descriptive letterpress in vol. ii., p. 552), remarks that it occasionally alights on the stakes placed on the shore as beacons by the fishermen, sitting not upright but like a tern or skua on the alert for prey, and pouncing on the puffins as they make their appearance at the mouth of their burrows. Its nest is built of sticks, sea-weed, and mosses, and is generally placed on some rocky precipice. In one instance, Audubon found a number of the wings of guillemots, puffins, and willow grouse lying scattered in the vicinity of the nest. The cry is described as being loud, shrill, and piercing like that of a peregrine.

Adult birds of this species have the plumage uniformly of a dark greyish brown with white spots, and the tarsus and toes of a greyish blue. In speaking of the various Falcons to be found in Iceland, Dr Von Troil, in his "Letters" on that country, states that at the time he wrote they were abundant. "There are three sorts," says this author; "they are purchased by the royal falconers, who give fifteen dollars a-piece for the white, ten for those that are darker, and seven for the grey." *

\section{THE PEREGRINE FALCON.}

\section{FALCO PEREGRINUS.}

\section{Sheabhag.}

Although subjected to an extraordinary amount of persecution, this beautiful Falcon maintains a good hold throughout those districts in which it has been well known for centuries, and may still be called a common bird in many districts of western Scotland, ranging from Burrow Head to Cape Wrath. In mountainous and rocky tracts on the inner islands and mainland of Argyle, Inverness, Ross and Sutherland shires, it is found commonly in pairs, each frequenting a radius of about six or eight miles. In Islay, Mull, and Jura, as well as the islands of minor extent, it is about

* "Lettérs on Iceland," etc., by Uno Von Troil, D.D., London, 1780. 
equally distributed, but is much more plentiful in Skye and its outlying stacks of rock, whose precipitous sides afford abundant shelter and protection. It is also comparatively common in the Outer Hebrides, breeding on the higher hills. I have traced it from Barra to Lewis, and have seen it on all the intervening islands. Mr John M'Donald of Newton, North Uist, informs me that he has seen the Peregrine during the breeding season on the Haskeir rocks, between Harris and St Kilda, and on St Kilda itself, where there are several pairs.

As we leave these isolated and almost impregnable fortresses of the Peregrine, and approach the mainland, we find that the ravages of keepers and collectors have of late years greatly thinned its numbers. Among the deserted eyries of the southwestern counties may be mentioned Dumbarton rock, the lesser Cumbrae, Ayr Heads (within the last two years), and at least three or four stations on the cliffs between Girvan and the entrance to Loch Ryan, including that on Knockdolian hill.

There are still many pairs to be found in the vicinity of Ben Lomond and on the mountain ranges stretching from the head of Loch Long both to the north and west. From these districts and other parts of Argyleshire, as well as the island of Arran, considerable numbers of Peregrines are sent in to the Glasgow birdstuffers. In Ayrshire several inland haunts, such as the parish of Straiton, are yet frequented; the same may be said of Wigtownshire, in which county, however, the eyries at Mull of Galloway, Portpatrick, and Burrow Head, are now all but abandoned. I saw at the last-named haunt a handsome pair of birds a year ago, but was sorry to learn that a few weeks after my visit the female was shot while sitting on her nest by a keeper, who, it is hoped, has by this time repented of the cruel act.

It is seldom that this Falcon rears more than three young ones, though as many as five eggs are sometimes laid. In one nest in Skye two years ago there were four young birds. The old fema!e was shot, and a trap was set for her mate, who brought two pigeons and a starling to the nest before he was caught. The prey of the Peregrine is very varied, consisting of game birds, such as young pheasants, partridges, red grouse, and black game, snipe and wild duck, when these can be readily obtained in the vicinity of its ordinary haunts. When located, as is often the case, beside a colony of gulls and guillemots, it contents itself with plun- 
dering the nests of these birds after the young ones are hatched. I have seen many eyries of Peregrines in such situations, as for example the Bass Rock, St Abb's Head, and Troup Head on the east coast; and the Mull of Galloway, Burrow Head, Ailsa Craig, the Shiant Isles, and Barra on the west. The Haskeir Rocks and St Kilda are also instances of their partiality for the companionship of seabirds. In these marine haunts the Falcons prey almost exclusively on birds that can be got on the same ledges, guillemots, razor bills, puffins, kittiwakes, etc. I remember, in one instance, of finding among other things in a nest on a precipitous rocky ledge facing the sea, in the south of Kirkcudbrightshire, the remains of three snipes, and a male cuckoo untouched, his open yellow throat looking as fresh as if he had sung his last note but an hour before. It is not unlikely that the seabird, and consequently rank-tasted, diet may after a time become unpalatable, and oblige the birds to look out for a change at a distance. I recollect on one occasion traversing a distant inland moor and finding an old male fast asleep on the bones and feathers of a red grouse, which he had just killed and eaten. There were several eyries of Peregrines within a few miles of the place, and it was not likely any of these birds would have been so hungry as to commence feeding on its prey where captured, this being generally carried to a distance to be devoured in safety. I therefore conjectured that this bird was a stranger, and, from being probably a resident on some maritime cliff, had wandered from his ordinary beat, and surfeited himself after a long flight. Nor was there any reason to suppose that the prey was too heavy, as I have known a Peregrine carry a blackcock to the Bass Rock-the nearest haunt of that species of game being distant about three miles.

The Peregrine has been accused of striking down birds and leaving them dead, without again touching them, and I believe the charge is to some extent true, though its repetition depends very much upon the kind of prey that happens to cross its flight. No hungry Falcon, for instance, after killing several rooks in succession, would think of letting a good fat woodcock drop out of his clutches; and although an occasional act of mischief cannot be denied, it is not, I think, too much to say that Peregrines as a rule are too generous to imitate man by killing what they do not require. Yet, after all, some of their deeds are bad enough, as 
the following incident taken from one of my note-books will show:-One evening in June, about eight years ago, as I lay crouched behind some rocks on the sea shore near Girvan, watching a small flock of curlews feeding, a Peregrine made its appearance under somewhat unusual circumstances. The occurrence took place about sunset, after the tide had gone back, exposing a rich stretch of open sand, dotted here and there with bits of smooth rock covered with green sea-weed. The sea being smooth, the faint noise it made only added to the eerieness of the twilight hour; and as the sun disappeared behind a bank of fleecy purple clouds on the horizon, the peaked hills of Arran formed as impressive a back ground as could be imagined. In a shallow stretch of water, which a slight ridge of sand had appropriated from the back-going waves, were six or eight curlews I had for some time been watching; some were standing dozing, while others were quietly probing the wet sand for hidden morselsall being without any apparent suspicion of my near presence. There they fed and rested in conscious security until the hues of the sky illumined the place with a peculiar tint, colouring the birds almost into the plumage of the glossy ibis. In the midst of this singular transformation scene, heightened in its effect by the dead stillness pervading all surrounding objects, I observed a sudden alarm among the curlews; in a moment they crouched in terror, uttering a strange but subdued cry, and in another second a shadow passed over me; swift as lightning the head was torn off one of their number, and a Peregrine rose with it, screaming shrilly as if in despair at the neck giving way. Immediately he caught sight of me, the head was dropped almost beside the quivering body as it fell with a slight splash into the pool. Looking round, I saw to my surprise another Falcon-evidently his mate-following in his direction, so without casting one look upon the effects of this sudden tragedy, he joined his comrade, and the two continued their easy flight,- - homeward-bound Falcons, not much caring for the disappointment.*

* On mentioning this occurrence to Dr Dewar, he narrated to me a similar incident that came under his notice in the case of his tame Falcons. He had several merlins on their perches out of doors, and was in the act of teasing a female Peregrine he had just let off by throwing up a lure and suddenly withdrawing it, when, without a moment's warning, down came the angry bird with an impetuous rush past his head, and off went the head of one of the merlins, the executioner meanwhile rising into the air with shrill outcry as if chiding its tormentor. 
In its wanderings along shore the Peregrine is sometimes beset by the larger sea-gulls and other birds, just as I have seen the kestrel and little merlin buffeted by swallows, wagtails, and other small assailants, whose impudent boldness is so often allowed to pass unpunished. Writing from Iona, Mr Graham says:- "It is frequently seen along the coast here hunting for ducks, rock pigeons, and the lesser sea-gulls (if they are not flying over the water), but I never discovered any nesting place, though $I$ have seen the old birds hunting at the time of the year when they might be supposed to have nestlings. The presence of a Peregrine is often announced by an unusual clamour among the hooded crows, who leave their search for shell-fish among the rocks to follow the nobler rogue with their vulgar uproar; and as the word is passed along the beach, the mob increases in numbers and audacity, till the Falcon is fairly rabbled out of their district. A Peregrine who had just struck a red-legged crow was thus assailed, and so distracted by their unusual pertinacity (probably on account of the red-leg being one of their cloth) that I walked up and shot him in mid air, holding his prey in one claw while the other was held ready to give the death blow to any assailant, should he venture within reach of his grip, which they took very good care not to do."

Notwithstanding all that has been said by recent American writers on the distinctions between the European Peregrine and that of the North American continent, I confess that I have never been able to discover any sufficient grounds for their separation. The late Mr Cassin of Philadelphia, in his description of the two birds, which he considers distinct from the Peregrine of the old world, viz., $F$. anutum and $F$. nigricèps, appears to think the former larger than our bird, and the latter the smallest of the three, size alone being apparently his guide. During a long experience, however, among the Peregrines of western Scotland, I have always believed that there could not be a more unreliable test than mere dimensions, some birds, even of the same sex, being almost twice the weight of others. Sir William Jardine gives the following measurements:- "Male nearly 16 inches in length, and $12 \frac{1}{4}$ inches from shoulder to tip of second quill. Female, length about 19 inches; from shoulder to tip of second quill, 14 inches." Yarrell says:- " The whole length of an adult Peregrine Falcon is from 15 to 18 inches, depending on the sex and age of the bird;" while 
Temminck states that the male is 14 or 15 inches, and the female 16 or 21 inches. Swainson and Richardson give the measurements of two birds from Melville peninsula as, male 14, female 18 inches. Mr MacGillivray, whose practical acquaintance with British birds was extensive, states that the male is $16 \frac{1}{2}$ inches, and the female $19 \frac{1}{2}$; but under the head "variations," he says that the males measure from 16 to 18 inches, and females from 18 to 23. Among those I have myself examined, I find the size of both sexes varies very much. Compared with the Hebridean Peregrines, those of the western mainland are in general but pigmies. Two very large female birds are now before me; one was shot in Sutherland in 1869, and forwarded to me by $\mathrm{Mr}$ Brown. In length it is about 21 inches; wing from flexure 15 inches. The other, which was shot in South Uist in March, 1869, and obligingly presented to me by $\mathrm{Mr}$ Alexander Carmichael of Lochmaddy, is the largest Peregrine I have seen. It measures $22 \frac{1}{2}$ inches in length; wing from flexure 16 inches. Some of the Skye Peregrines are very powerful birds - the males in many cases being larger than females from other districts. Mr Brown tells me that he shot a female off the nest in Sutherlandshire on 8th May, 1869, which was no larger than an ordinary-sized male. With such variations in the measurements of British specimens, it is surely rash to conclude that Falco anatum is entitled to rank as a separate species on account of its superior size. The measurements given by Audubon of American birds are, male $17 \frac{1}{2}$ inches in length, female $19 \frac{1}{2}$, while Mr Cassin's are in length from 18 to 20 inches, showing, in fact, dimensions inferior to those of Scottish specimens. As a rule, those taken on the western coasts of Scotland, especially in the isle of Skye and the Outer Hebrides, are much the largest.

In the first volume of Audubon's "Ornithological Biography," the following note occurs at page 88 bearing on the question of unity in the Peregrines of the old and new world, and it is interesting as showing that occasional journeys may be undertaken by these swift fliers from one country to another:--"Once when nearing the coast of England, being then about a hundred and fifty miles distant from it, in the month of July I obtained a pair of these birds which had come on board our vessel and had been shot there. I examined them with care, and found no difference between them and those which I had shot in America." A more 
recent testimony from the pen of J. H. Gurney, Esq.-than whom, perhaps, there can be no better authority-appeared in the "Ibis" for 1867, and is as follows:- "I have for many years made a point of examining, as carefully as I have been able, as many specimens as possible of the Peregrine Falcon from all parts of both hemispheres where that widely-spread species occurs, and I now find myself unable to detect any constant specific difference that may be relied on between the three supposed species, Falco peregrinus, $F$. anatum, and $F$. nigriceps." I may remark that if $\mathrm{Mr}$ Cassin's figure of the last-mentioned bird is correct (see plate xiv. of the Zoology of the "U.S. Naval Expedition in the Southern Hemisphere," vol. ii., Washington, 1855), it exhibits a state of plumage which I have not found in a single Peregrine in this country: the bill is said to be comparatively weaker, but the figure shows an even greater weakness in the claws. Plates, however, are at best subject to fault-finding. Mr Cassin's figure of the northern sea-eagle is not exempt, the drawing being without a hind toe to one of the feet. Falco nigriceps was originally described as a new species by Mr Cassin in his beautiful volume on the "Birds of California and Texas" in 1853.

\section{THE HOBBY.}

\section{FALCO SUBBUTEO.}

Although the Hobby cannot be said to be a common species in Scotland, its occurrence is now so frequent as to excite some surprise that it should have escaped the observation of many previous writers. It is more frequently met with in the eastern counties than in other districts, as, with the exception of the island of Arran, I have not heard of any western locality where specimens have been obtained. A beautiful male was shot there some years ago and examined by myself; and I have been assured by Mr Halliday, one of the Duke of Hamilton's keepers, that he has, in several instances, taken both the bird and its eggs in that island, when assisting the late Dr Martin Barry to make his collection. $\mathrm{Mr}$ Halliday appears to be well acquainted with the merlin, peregrine, and other "hawks" breeding in Arran, and has described to me the plumage of the Hobby so correctly that I have little or no hesitation in recording its occurrence there as a native. 
As far back as the close of last century, the Hobby was included in a very complete and apparently accurate list of birds found in the parish of Luss on the banks of Loch Lomond by the Rev. Mr Stuart, and about twenty years afterwards Mr G. Don, in his "Fauna of Forfarshire"-a very meritorious essay published as an appendix to the Rev. J. Headrick's "View of the Agriculture" of that county-mentions it as "rather rare" in his district. Again, in 1823, a specimen appears to have been shot at Branxholm, near Hawick, as I have been informed by Mr J. Heckford of the Kelso museum; and later still, Mr Tottenham Lee procured two, and saw a third, in 1853 at Glenlee Park, Kirkcudbrightshire, where he at that time resided. The Hobby is also mentioned by the late James Wilson of Woodville, in his "Voyage round the Isles of Scotland," as having been shot in Caithnessa specimen, which he saw, being in the collection of Mr E. S. Sinclair, surgeon, Wick; and in a list of the birds of Caithness, published in the second volume of the Proceedings of the Royal Physical Society of Edinburgh, Mr R. J. Shearer states that a specimen which he saw in the hands of Charles Wilkinson, gamekeeper, was killed at Thrumster, in that county. Dr J. A. Smith, Secretary to the Society just named, has obligingly communicated to me the occurrence of another which was shot near Portobello, Mid-Lothian, in July, 1863, in which year one was obtained at Rothiemay, in Banffshire-its second occurrence in that county, one having been killed about twenty-three years ago near the town of Banff. Mr W. C. Angus of Aberdeen has informed me that in the autumn of the same year an immature specimen was captured at sea off the coast of Aberdeenshire, and sold to Mr Sim, Taxidermist, 20 King Street, who obtained a second specimen, also immature, in the autumn of 1868 , from a person who picked it up dead at Kittybrewster station, near Aberdeen, where it had been killed by the telegraph wires. In addition to these Aberdeenshire records, I have the pleasure of adding a third, communicated to me by Mr Alexander Mitchell, who shot a fine adult male on the 8th June, 1868, at Broadhill, near Aberdeen. The stomach of this specimen, which, with the two in Mr Sim's possession, I have since seen and examined, was crammed with beetles. - Being in full breeding plumage, it was probably a wanderer from Glen Dyea district in the west of the neighbouring county of Kincardine, where, as I have been informed by Mr Brown, who is assured 
of the correctness of his information, the Hobby has for some years been known to breed. I have been informed by Mr George Kirkpatrick that a specimen of the Hobby was shot in June, 1867, on the Rockhall estate, a few miles from Dumfries, and is now in the possession of Mr Hastings, bird stuffer in that town.

Dr Saxby says that this species is very rare in Shetland, and that it seems to occur in autumn only.

\section{THE RED-FOOTED FALCON.}

\section{FALCO RUFIPES.}

I have much pleasure in introducing into the present work a notice of the occurrence of the only specimen of this rare British bird which appears to have been met with in Scotland. It was shot in Aberdeenshire, and is now in the possession of Mr John Ruxton, who has very kindly sent me the following communication:- " An adult female of this rare and beautiful species was shot and given to me by my friend, Mr Andrew Gill, while on a visit at Hill of Fiddes, in the parish of Foveran, and county of Aberdeen, in the last week of May, 1866. The stomach contained beetles, from which I infer that, like many of its congeners, it is not so destructive of game as many preservers imagine."

As this Falcon has not often been captured in Britain, it may not be out of place here to allude to one found near the borders. In a work on the Geology, Botany, and Zoology of the neighbourhood of Alnwick, it is stated, on the authority of $\mathrm{Mr} \mathrm{R}$. C. Embleton, that a female Red-footed Falcon was found at Hauxley in October, 1868.*

\section{THE MERLIN.}

\section{FALCO ESALON.}

Seog.

This interesting and courageous little falcon is very commonly distributed throughout western Scotland, extending to all the Hebrides, including the outer group, or Long Island; and though 
in some of the more carefully watched game preserves it is not so numerous as it was twenty years ago, it cannot be called a scarce species anywhere from Caithness to Wigtownshire. Even in Ayrshire, which is overrun by keepers, it breeds in considerable numbers on the moors, especially in the north eastern quarter of the county, and appears to elude destruction by its great skill in hunting, as well as by the rapidity of its movements, when flushed from its haunts. During autumn and winter it quits the moors entirely, and descends beyond the limits of cultivation, even to the sea-coast, where, by its vigilance and extraordinary activity, it manages to fare well in comparative safety. At this season it also resorts to large towns, taking up, its quarters in church towers and other tall buildings, and passes the entire winter among the housetops, where, in fact, it is much safer than in the open fields. I have seen it oftener than once frequenting slated roofs in the heart of the city of Glasgow, and preying upon the pigeons that are constantly seen dozing for warmth on the chimneys in many of the public streets. In March, 1869, and February, 1870, two male birds which had been captured in the city came into my hands; they were both as black as a chimney sweep, and on dissection, were found to have been preying on pigeons and sparrows. Mr Brown also sent me, in December, 1869, a female Merlin in the same disguised state of plumage, which had evidently been a chimney haunter.

The Merlin is easily tamed, and soon becomes a very interesting pet. A few months ago, Dr Dewar had a beautiful young male in his possession, which was occasionally allowed its liberty in the house. I have seen it come flying into the drawing room, heedless of the glare of gaslight, and make repeated attempts to perch on the polished articles of furniture, or mantel-piece ornaments, occasionally resulting in failures which were highly amusing. Sometimes when settled to its mind, it remained perfectly still, looking exactly like a bronze figure; but when approached or spoken to, for it readily answered to its name "Charlie," it bent forward its neck and became all eagerness, the querulous expression of its beautiful black eye being on these occasions unusually interesting.

When in pursuit of prey, this spirited little bird will rush headlong anywhere, after getting fairly excited, and is rarely baffled in its hunting expeditions, however large the object of chase. It 
will ascend beyond the range of ordinary vision in its endeavours to surmount the Hight of a snipe, or come down like a falling star on a hurrying plover striving to reach some friendly marsh. At other times the chase is persevered in with a courage and determination quite extraordinary in a bird so small, its feats reminding one more of the theftuous acts of a sparrow-hawk than the stoop of the nobler falcon. With the rapidity of an arrow, it will fly along some enclosure, by the hedgerows, seize an object, and glide out of sight, leaving the spectator to marvel at the transaction as at a deed of magic.

On the east of Scotland, where I studied the habits of raptorial birds for many years, I remember some years ago seeing this Falcon capturing snipes very cleverly at the sea shore. At a particular part of the coast near Dunbar, where a rivulet enters the sea, the snipes fed in great numbers at low tide, the ground, which was covered with small brown pebbles, being well adapted for the concealment of birds. With the most punctual regularity, a pair of Merlins used to come as I made my appearance at this place, and hover about till I had raised a brace, which were immediately pounced upon. But after a time the snipes became so terror-stricken that a hundred shots would not frighten them; nor could a single bird be raised, though I saw them occasionally skulking under the stones. I found them more than once, indeed, paralyzed with fear, and so heedless of anything save the hawks, that I was able to pick up one or two and transfer them to my bag while my two friends were flying overhead disappointed of their usual supply, and doubtless in wonder at this sporting novelty. Ultimately, however-for the snipes persisted in frequenting the place, though an unusual one-these birds acquired so much cunning that they ran to conceal themselves under the slimy stones below tide mark, thrusting their bodies, crab-like, into the crevices as soon as the Merlins and I came in sight! At such times their hurry was extremely diverting; and as the facts I narrate extended over a length of time, I could not help being struck with the behaviour of the snipes during the protracted disturbance they were subjected to.

The Merlin makes its nest, as I have observed in various parts of Scotland, in wild tracks of moorland amongst heather, the spot selected being generally near a ravine, or moderate precipice of rock, on the summit and walls of which tufts of heather are 
growing. The nest is composed of small sticks and heather stems, but is without any lining; the eggs are from three to five in number, and, unlike those of the kestrel, are subject to little variety. In a nest in Argyleshire one of the four eggs it contained was almost pure crean-coloured. In the western counties-and I may say in also the eastern, especially in East Lothian-I have observed the bird itself to be tolerably common on the sea coast, where it could satisfy its partiality for shore birds. It seems to prefer sanderlings, dunlins, and snipes, these being oftenest found in its nest, though it be situated on some moor at a considerable distance from the sea. I have seen it also killing larks and wheatears.

I recollect on one occasion finding a Merlin's nest on one of the Haddingtonshire moors, by the side of a ravine filled with great square blocks of grey rock and clumps of feathery birch trees, the banks being decorated with patches of beautiful heather and luxuriant grass. On a little platform near the summit of one of these blocks, which appeared ready to tumble into the glen, the nest was placed beside a tuft of heath, with three fine stalks of foxglove bending slightly forward and gracefully shaking their bells over the heads of the young falcons as they sat waiting an arrival. I was about ten feet above them, peeping over the embankment under a spreading hazel, and well out of sight of the old birds, should they come. They sat like miniature eagles in a line facing the course of the tumbling burn at the bottom of the ravine, and I could discern nothing like an impatient look in any of them. They appeared to be in full feather, and I could not help admiring the four healthy fellows reposing on their picturesque watch-tower, even though it savoured badly of unfinished dinners and the trampled remains of seafaring dotterel. Taking an old letter from my pocket, I tore off several bits, and let them down in a shower on their backs, which had the effect of making each give his neighbour a smart rap on the side of the head, and lift first one foot, then the other, as if the perch were becoming too hot for them. But just as I was about to repeat the infliction, their mother pitched down suddenly beside them with a golden plover in her claws, which she laid down, unconcernedly, as I thought, but in reality relaxing her grasp with a truly inquiring look at so many visitors' cards on the premises. In an instant she looked in all directions, and at once divining nothing good, from my head between her and the sky, she disappeared like a 
thought. I then took a stick and threw it down upon the family, who broke up by fluttering and falling into space till they fairly took wing and glided from me in different directions; so, as they had not touched the plover, I scrambled to the deserted platform and carried it off. It is not likely they would miss it, as I have no doubt that within the next half hour the little rascals were killing their first bird on the adjoining moor.

\section{THE KESTREL.}

\section{FALCO TINNUNCULUS.}

\section{Clamhan ruadh.}

THE Kestrel is by far the commonest bird of prey in the western counties of Scotland, ranking even more numerously than the merlin in its distribution. It is abundant on all the Hebrides, extending to the outer islands and the uninhabited rocks lying between Harris and St Kilda, where it breeds. The nest in these outlying haunts is generally, if not always, built on a rocky platform, the situation resembling the spots usually chosen by the peregrine, and even in cultivated districts I have observed that such a site is oftener chosen than any other. Some eyries which I have seen at a considerable elevation on mountainous tracts were situated in most romantic and picturesque places, oft-times in deep glens and on inaccessible rocks overhanging a.waterfall. Last year I found one about 1800 feet above the sea level, placed at the root of a rowan tree, which grew on the verge of a cliff, over which there poured a beautiful cascade. The nest, which contained five eggs, was a simple hollow among withered ferns, and the bird, in sitting upon it, could see the highland burn making a grand leap of thirty feet into the caldron below. Again, in Inchtavanach, one of the finest islands in that most beautiful of all Scottish lakes-Loch Lomond-there are many nests among the ivy-clad rocks, which are haunted by jackdaws, starlings, and other birds, the whole forming a diversified group, but living in the most perfect harmony, while on almost every steep rock jutting into the lake, from Luss northwards, one or two pairs are constantly to be found in the breeding season.

This elegant and harmless Falcon is easily tamed from the nest. I have often had young birds in my keeping, and found them not 
at all difficult to rear. A few years ago, a pair which were taken near Girvan, fed freely upon small trout, which they seemed to prefer, when supplied with these and small birds at the same time. After getting their liberty, when able to fly, they returned to their cage at night; and during the day-time, if I happened to be fishing in the stream close to the house, they would come and perch on a paling near at hand, and anxiously wait for any small fry that were hooked. Sometimes one of them, tired of waiting, would strike down a linnet and begin eating it on the footpath, but it relinquished its prey at once on being offered a fish.

Mr Graham tells me that he has seen the Kestrel hawking for worms over a newly ploughed field in Argyleshire, alighting to devour one, and then resuming its search, hovering a few yards above the ground very perseveringly.

I am inclined to think that, in some districts at least, the Kestrel is partly nocturnal in its flight, having observed it on the heugh-heads, near Dunbar, about nightfall, snatching at ghostmoths and large beetles as they hovered above some grassy patches near the edge of the cliffs.

I find from Don's Fauna of Forfarshire, that this bird in his day was, not inappropriately, called "Willie whip the wind."

\section{THE GOSHAWK.}

\section{ASTUR PALUMBARIUS.}

As a Scottish species, the Goshawk is now, in common with other conspicuous birds of prey, very rarely met with. In the western districts, it has never indeed come under my observation, either alive or recently captured. I am indebted, however, to my obliging correspondent, the Rev. Alex. Stewart of Ballachulish, for a record of its occurrence in Argyleshire over a period of twenty years. Two were seen by that gentleman thirteen years ago in Glasgow; they were newly stuffed, and had been shot on the Lochbuy estate in Mull. Another was killed in Glenorchy in 1848, and was in the possession of Dr Aldcroft of Oban. A third specimen, a female, was shot in the district of Appin a few years ago, and belonged to the late Captain Sutherland of Invercoe, Glencoe. Mr Stewart also states that he saw a living specimen of the Goshawk in August, 1866, on board the yacht "Chloë," 
the owner, J. Rattray, Esq., having procured it in Orkney a short time previously.

Within a comparatively recent period, I have known the Goshawk to breed in Kirkcudbrightshire, in which district my correspondent, Mr Tottenham Lee, Jun., who was quite familiar with all the British birds of prey, repeatedly saw the birds flying about. Under the observation of that gentleman, a pair of ravens were turned out of their nest by two Goshawks, who appropriated it to their own use, and a second nest, built not far from this locality, was situated in a tree.

In the time of Pennant, this species was a well-known native of the woods of Rothiemurchus, a locality in which it has since repeatedly been obtained. It is likewise included in Don's list of the birds of Forfarshire, without any restrictive remarks, shewing that it had been sufficiently common to take a place among the more familiar species of that county. In later years, however, it must have decreased rapidly, although of occasional occurrence. $\mathrm{Mr}$ Macgillivray mentions in his work on British birds, that $\mathrm{Mr}$ Fenton of Edinburgh saw one which was shot in Forfarshire in 1825 , and I lately examined a very handsome and perfect specimen at Glammis, in the same county, where it was caught, about five years ago, in a pole trap. It had broken the chain, and flown off with the trap at its foot, but the chain becoming entangled in a whin bush, the bird was discovered, and, after a fierce resistance, knocked on the head. The keeper in whose possession this fine bird now is, had previously seen it hunting in the vicinity, and described it to me as a very powerful bird, and much more daring in its attacks than even the peregrine.

Dr Smith of Edinburgh has obligingly sent me word that a young male Goshawk was shot near Tynehead, Mid-Lothian, on the 13th December, 1865, and that he exhibited the specimen at a meeting of the Royal Physical Society.

The most recent instance of the occurrence of the species in any part of Scotland is that of a young bird which was shot near Jedburgh on 12 th November, 1869, and is now in the possession of Lord Minto.

Thirty years ago the Goshawk was a rare species in the parish of Golspie, in Sutherlandshire, but it appears to have maintained its hold in Morayshire after it had become a rarity elsewhere. The late Mr St John, whose notes on the species appear to have 
been written in his journals for 1847, thus speaks of it:- "The Goshawk is now nearly extinct in this country. A few years ago it bred regularly in the forest of Darnaway, and it may still do so. It also breeds in the Glenmore, near Grantown, on the Spey."* Macgillivray states, that upwards of twenty years ago it was occasionally met with on the Grampians; and the Rev. John Lapslie, who was a clever and a discriminating naturalist, mentions in his interesting account of the fauna of Campsie, in Stirlingshire, that about the end of last century it was a native of that district, building its nest in trees in sequestered places.

$\mathrm{Mr}$ Alston has drawn my attention to a curious fact in the history of this bird, in the following communication, from which it would appear to have been a marked species in the south of Scotland six hundred years ago:- "Professor Cosmo Innes states, in his 'Scotland in the Middle Ages,' pp. 129, 130, that when the Avenel family granted Eskdale to the monks of Melrose, they specially reserved the eyries of falcons and tercels. 'Even the trees in which hawks usually built were to be held sacred, and those in which they had built one year were on no account to be felled, till it should be found whether they were about to build there the next year or no.' This charter, Professor Innes kindly informs me, is dated A.D. 1235, and has been printed by the Bannatyne Club (Liber de Melros, vol. i., p. 179). Now, of what species could these birds have been? None of the commoner treebuilding species, as kites, sparrow-hawks, etc., were much valued by the falconer, and it seems to me that the birds thus carefully protected must have been goshawks. If so, we have here distinct evidence that they bred regularly in the south of Scotland in the thirteenth century."

Messrs Baikie and Heddle state that the species is frequently observed in Orkney, and that some apparently remain there during the whole year. In Shetland, however, it appears to be rare, Dr Saxby having in his possession the only specimen known to bave occurred there; it was shot at Scaw, in the winter of 1860.

* Natural History and Sport in Moray, p. 258. 


\section{THE AMERICAN GOSHAWK.}

\section{ASTUR ATRICAPILLUS.}

KNowING the aversion of many ornithologists to admit stragglers into the list of British birds, I have some diffidence in presenting, for the first time, a notice of the occurrence of a species new to this country. It is quite possible, however, that from its general resemblance to the European bird, the American Goshawk may have been hitherto passed over without detection, and may again be found in Scotland. I therefore give it a place in this work, in the expectation that some future observer may be able to note its appearance a second or third time in Britain, and thus place it at least on a level with other species whose occurrence has been recorded at long and uncertain intervals.

In May, 1869, when visiting the town of Brechin, in Forfarshire, I was fortunate in finding a very handsome specimen of this Goshawk in the hands of a bird-stuffer there, who had obtained it a short time previously from a keeper in Perthshire, along with a number of snow-buntings and other birds, shot by him on the flanks of Shechallion, and all recently skinned. The bird was kindly presented to me by its possessor, who looked upon it as a "coarse sort of gled," and hardly worth the trouble of cleaning, as the head had been much stained and the plumage otherwise soiled by the person who skinned it. On proceeding to relax the skin, it was found by the Glasgow stuffer whom I employed to mount the bird, that the brains and eyes had not been removed, nor the flesh from the wing-bones, so that no doubt could be entertained as to its recent occurrence. The total length of the specimen, apparently a female, is $24 \frac{1}{2}$ inches; wing, from shoulder to tip of longest quill, 14 inches; tail, $10 \frac{1}{2}$ inches. The distribution of the markings on the plumage is precisely that detailed by the late Mr Cassin, Prince Bonaparte, and other writers, but the head can scarcely be called black; the hind neck appears, when the feathers are raised, as if spotted with yellowish white, the same semicircular mark appearing on the occiput of a sparrowhawk. The breast and under parts are at first sight grey, but on closer inspection show the faint transverse markings and a thin longitudinal streak in the centre of each feather.

The following concise distinctions are given by Sir William 
Jardine in the third volume of his "Illustrations of Ornithology." "The greatest and most perceptible distinction between the two birds is in the markings of the breast and underparts, and it is so distinct as to be at once perceived. In the American species the under parts are of a uniform pale greyish white, having the quill and centre of each feather black, forming a dark streak. This extends to those in the middle of the belly, after which it is hardly visible; every feather in addition is clouded transversely with irregular bars of grey. In the European bird, the markings are in the shape of two decided transverse dark bars upon each feather, with the shaft of the same colour, but not exceeding its own breadth, each as a whole, having a different appearance."

I have only to add to this description, that a fine European Goshawk now before me, which was shot off the nest by the late $\mathrm{Mr}$ Wheelwright, has each feather on the breast marked with three distinct transverse bars, and that the subject of this notice shows the longitudinal streak on the breast to be almost confined to the shaft of each feather.

Like its European relative, this Goshawk is swift in flight, travelling, when at home, high in the air for long distances, and continuing its journey with a constant beat of the wings, and seldom deviating from its course, unless tempted by some large flock of passing birds. Audubon gives a highly graphic account of its habits in the second volume of his "Ornithological Biography," from which I select the following short extract:"While travelling along the Ohio, I observed several hawks of this species in the train of millions of passenger pigeons. Towards the evening of the same day, I saw one abandoning its course to give chase to a large flock of Crow Blackbirds (Quiscalus versicolor) then crossing the river. The hawk approached them with the swiftness of an arrow, when the blackbirds rushed together so closely, that the flock looked like a dusky ball passing through the air. On reaching the mass, he, with the greatest ease, seized first one, then another, giving each a squeeze with his talons, and suffering it to drop upon the water. In this manner he had procured four or five before the poor birds reached the woods, into which they instantly plunged, when he gave up the chase, swept over the water in graceful curves, and picked up the fruits of his industry, carrying each bird singly to the shore." 


\title{
THE SPARROW-HAWK.
}

\author{
ACCIPITER NISUS.
}

Speir-sheog.

IN the remoter districts of the West of Scotland this daring and destructive bird is not nearly so numerous as the merlin or the kestrel. This scarcity is, of course, attributable to the partiality which the Sparrow-Hawk shows for wooded and cultivated localities, in preferring to bring up its brood where it can have easy access to partridge grounds and farm yards. In such hunting fields it commits great devastation, and is always in such a rapacious hurry that its thefts are not easily observed. A terrified scream from the poultry is all that one hears, and before a minute is past the feathered rascal is devouring his chicken at a safe distance. The male is, generally speaking, the more frequent visitor to farm steadings, small game being more convenient for a bird of his size to carry any distance. The female, however, will dart into a covey of partridges, and carry off a bird with apparent ease. The female Sparrow-Hawk, in fact, would be the game preserver's worst enemy, did it not vary its diet by an occasional wood pigeon, or some such heavy bird of little consequence. When hard pressed by hunger, I have known it come to the vicinity of towns, and carry off any kind of prey that it could conveniently clutch. I remember seeing one make a descent into a back court surrounded with houses, and strike a half grown chicken among a group of common fowls. It fell upon its prey with outspread wings, as if half stunned with the force of its stoop, and in a moment, before it could recover itself, it was attacked by a game cock which was strutting about, and actually held down by the gallant fellow until taken hold of. A still more singular instance of daring in a Sparrow-Hawk occurred at Dingwall, in Ross-shire, in November last. The bird, seeing a caged canary suspended near a window in the house of Mr Grigor, from whom I learned the details, dashed through a pane of glass, broke the cage with the impetus of the same blow, and killed its prey as if the deed had been accomplished without any such obstruction as glass or wires. When apprehended, it was found that the hawk had, some time before, been trapped by one of its 
legs, which was wholly gone from the thigh downwards. I saw both birds about three weeks after the incident happened. Perhaps the hawk was in the habit of frequenting towns and farmsteadings, and had been accustomed to attack objects of easy access; at any rate, it showed great pluck and remaining strength in making such an attack, and committing so much mischief with one foot and a stump.

On the Outer Hebrides this bird is perhaps confined to Lewis and Harris, except in winter, when a few cross the Sound, and range over the other islands in search of prey.

\section{THE KITE.}

\section{MILVUS VULGARIS.}

Clamhan-gobhlach Croman lochaidh.

From being a very common bird in many of the wooded districts of Scotland, the Kite, or salmon-tailed gled, as it is called, has become almost as scarce as the goshawk or the osprey. Generally speaking, its best-known haunts in the West of Scotland have been, during the last ten years, almost entirely deserted, and the bird is now indeed but rarely seen, even as a straggler, in localities where, in 1856-57-58, it remained to breed. I find from my notebooks that three pairs nested in Argyleshire in 1858. One of these pairs had frequented the neighbourhood of Bonaw for some years, but I have not of late been able to trace satisfactorily the existence of the species in that district, which is unfortunately too much in the way of egg-collecting tourists. Two years previously one or two nests were also obtained in Dumbartonshire; an egg in my collection was taken from a nest in Kenmore wood, on the banks of Loch Lomond. The structure remained there until 1864, or the year following, an interesting remnant of the last of the Kites. The materials of which it was built would have almost suggested the idea of the birds having robbed some wandering gaberlunzie of the contents of his wardrobe,-a pair of ragged trousers, worn stockings, and part of an old shirt (the latter flapping on the tree-top like an old worn banner) being among the articles.

The Kite formerly bred also in Stirlingshire, Ayrshire, and the 
island of Arran, but has for many years been banished from these districts. At present it is doubtful if it breeds in more than three counties in Scotland, namely, Inverness, Perth, and Aberdeen. I have recently seen unfledged young from a secluded district in the north of Perthshire, but it is verry doubtful if the birds will maintain their footing there.

In almost every Scottish collection of any consequence, I find more than one specimen of the Kite, a fact which shows the species to have been widely spread. Some of the specimens I have examined are extremely handsome, especially those procured in the counties of Argyle and Inverness, where their prey for the most part must have been lawfully obtained, without the indulgence of plundering raids among poultry.

I have been unable to trace its presence in any part of the Outer Hebrides, but I find that the late Dr Macgillivray, in a communication to the Edinburgh Journal of Natural and Geographical Science, entitled, "An Account of the Outer Hebrides," and published in 1830, remarks that the Kite is very rare in these islands. Mr Elwes informs me, that in Islay it is still seen, but rarely, flying over the island.

OBS.-It may not be out of place here to remark, that in the beginning of the present century, when Don's Fauna of Forfarshire was published, the Black Kite (Falco ater) is recorded by that writer as occurring " on heaths and low hills" in his district. At that time the common Kite was a well-known and even a plentiful species in the county of Forfar, a district of Scotland which, from its great variety of scenery-woods, glens, and mountain ranges - can still boast of many rare birds, and I have little doubt that Don, from his general intelligence and accuracy, was right in his recognition of a second species. In corroboration of what both that writer and Sir Robert Sibbald (who also mentions the black gled (Milvus niger)* as a Scottish species) have left on record, I may observe that Mr John Hancock, of Newcastle-on-Tyne, in a letter to the "Ibis," dated 14th March, 1867, thus alludes to the occurrence of the species in Northumberland, at no great distance from the Scottish borders:- " A fine male example of the black kite (Milous migrans, Bodd. 1783) (Falco ater, Gmel. 1788) came into my possession in a fresh state on the 11th May, 1866. It was

* See his list of Scottish Birds in "Scotia Illustrata," p. 15. 
taken in a trap by Mr J. Fulger, the Duke of Northumberland's gamekeeper, a few days before, in the red deer park at Alnwick. This is, I believe, the first time that this fine rapacious bird has occurred in Britain. The plumage was in very good condition, except on the lower part of the body, where it had sustained some injury from the trap, and agrees with that of mature specimens in my collection, which I received from the Continent some years ago. It proved on dissection to be a male."

According to Mr Tristram (see Ibis, vol. i. N.S., p. 256), this bird, which appears to occur in immense numbers in Palestine, makes a nest quite as unsymmetrical as that of the common Kite. "It is found," says Mr Tristram, "generally in a tree, often in a glen, and is a grotesque, untidy structure, decorated with all sorts of rags and rubbish, apparently to attract observation." * In vol. ii. of the same journal (p. 185), some interesting notes on the species are given by Lord Lilford, who mentions having found in the foundations of one nest three nests of the Spanish sparrow.

Owing to the present scarcity of Kites in our own country, not many opportunities of comparing or carefully examining specimens are now likely to occur. It would be well, however, for collectors, or others who may chance to be favoured with specimens, to scrutinize them, as, if the present work of extermination continues, the one species is about as likely now-a-days to make its appearance as the other.

\section{THE SWALLOW-TAILED KITE.}

\section{NAUCLERUS FURCATUS.}

THIs bird is inserted here as a Scottish species on the authority already given by the late Dr Fleming in his "History of British Animals," and repeated by subsequent writers, for the occurrence of a single specimen at Ballachulish, in Argyleshire, in 1772. In September, 1805, another was caught alive near Hawes in York-

* In speaking of the Egyptian Kite, an allied species found in the Great Sahara, the same author, with characteristic humour, says, "Its nest, the marine-store shop of the desert, is decorated with whatever scraps of burnouses and coloured rags can be collected; and to these are added, on every surrounding branch, the cast-off coats of serpents, large scraps of thin bark, and perhaps a bustard's wing."-Birds of the Sahara, p. 392. 
shire, and kept in confinement by its captor for about a month, after which it escaped, first alighting on a tree at a little distance, and then ascending in a spiral flight to a great height before finally choosing its course. It then went off steadily in a southerly direction, glad, no doubt, to get to some other country where its skin was not of so much consequence. There appears to be no evidence to show that the Swallow-Tailed Kite has ever since been seen in any part of Britain.

The following graphic description of the habits of this bird forms the opening paragraph of Audubon's account of the species:- "The flight of this elegant hawk is singularly beautiful and protracted. It moves through the air with such ease and grace that it is impossible for any individual, who takes the least pleasure in observing the manner of birds, not to be delighted by the sight of it whilst on wing.* Gliding along in easy flappings, it rises in wide circles to an immense height, inclining in various ways its deeply forked tail to assist the direction of its course, dives with the rapidity of lightning, and, suddenly checking itself, reascends, soars away, and is soon out of sight. At other times a flock of these birds, amounting to fifteen or twenty individuals, is seen hovering around the trees. They dive in rapid succession amongst the branches, glancing along the trunks, and seizing in their course the insects and small lizards of which they are in quest. Their motions are astonishingly rapid, and the deep curves which they describe, their sudden doublings and crossings, and the extreme ease with which they seem to cleave the air, excite the admiration of him who views them while thus employed in searching for food."

Wilson, in writing of the species, says:- "I met with these birds in the early part of May at a place called Duck Creek in Tennessee, and found them sailing about in great numbers near Bayo Manchac on the Mississippi, twenty or thirty being within view at the same time. At that season a species of cicada, or locust, swarmed among the woods, making a deafening noise, and I could perceive these hawks frequently snatching them from the trees." Being migratory in its habits, it is seen travelling in great numbers from west to east early in April, and returning to its winter quarters in October. Both Wilson and Audubon speak of these spring and autumn flights as being highly interesting.

* The disappointed captor of the Yorkshire bird may reasonably be exempted from the exaction of this tribute. 
The late Mr Cassin in his "Birds of California and Texas," published in 1865, states that the Swallow-Tailed Hawk is especially abundant in the Southern States; and Dr S. W. Woodhouse, in the account of the birds observed during an expedition down the Zuni and Colorado rivers, mentions that it is common in Texas, and in the Creek and Cherokee nations. "It appears," says that writer, "to have a fondness for frequenting streams; along the Arkansas and its tributaries it was very abundant."* But notwithstanding this abundance, specimens are by no means easily procured.

\section{THE COMMON BUZZARD.}

BUTEO VULGARIS.

\section{An Clamhan.}

To many persons it will seem unwise, I daresay, to call this Buzzard a useful bird in game preserves, yet I cannot but think that if the experiment were made of allowing it to fulfil the ends for which nature designed it, our native game birds would benefit by the trial. So far as my own observations have extended, the Common Buzzard is just the kind of instrument wanted to clear off sickly young birds, which, on arriving at maturity, yield an offspring of a degenerate breed. Of somewhat sluggish habits, it does not care to interfere with strong-winged birds, being content with those that, through wounds or a naturally feeble constitution, are unable to save themselves. In this way strong birds only are left, and a healthy breed ensues. Let any of our proprietors of moors, who are jealous of the daring prowess of eagles and lordly peregrines, act upon this hint, and I will venture to say we should have fewer instances of disease among game birds to chronicle.

Although this Buzzard is still found in some numbers in the Inner Hebrides, where it breeds, I have not been able to trace it to the outer islands. On the whole of the western mainland, however, it is met with sparingly, and appears in some of the lower districts more numerously in autumn than at other seasons, being in this respect somewhat like the next species. It is fre-

\footnotetext{
"See "Report of an Expedition down the Zuni and Colorado Rivers," by Captain L. Sitgreaves. Washington, 1854.
} 
quently trapped in the district of Campsie, where limited numbers seem to linger a week or two during their autumnal wanderings. Of late years I have seen beautifully mottled specimens sent to the poulterers' shops, showing a great diversity of plumage. The species, indeed, appears to be subject to considerable variety, some being very light in colour, and others extremely dark. This diversity occurs in birds apparently of the same age and sex.

\section{THE ROUGH-LEGGED BUZZARD.}

\section{BUTEO LAGOPUS.}

Is not common in the West of Scotland, only a very few examples having come under my observation. But on the east coast it sometimes appears in considerable numbers in autumn, when moving in migratory flocks. At Dunbar, for example, twenty or thirty specimens were obtained by different collectors in 1840-42. I had an opportunity of examining many of these at the time. The species has since that year occurred in the same district, not perhaps so plentifully, but still numerously enough to attract attention. The appearance of the birds is always sudden, and for the most part they are first seen in the moorlands, hunting at times in packs of three or four birds. The late Dr Nelson had three or four in his collection, which were procured near his residence in 1863. Periodically, although not with stated regularity, the Rough-Legged Buzzards appear in larger flights than usual; and $I$ have remarked that in these instances many of the birds are very dark in colour, the entire plumage being of a chocolate brown. I have a very beautifully mottled specimen in my own collection, from Cortachy, in Forfarshire; it was shot by a keeper on the Earl of Airley's estate a few months ago. Within the last two years I have examined a very fine bird of this species that was shot on the banks of the Avon, near Hamilton, in December, 1865, and another-the most beautiful Rough-Legged Buzzard I have ever seen-killed at Bishopbriggs, near Glasgow, in October, 1867.

The Rough-Legged Buzzard is very variable in its markings, scarcely two of the numerous specimens that have come under my notice being alike. The most of the specimens found in East Lothian, especially those belonging to the migratory flocks, are 
dark-coloured, a state of plumage which is accurately given in plate 17, vol. i., of Sir William Jardine's "British Birds."

In January, 1866, a "fine adult specimen"(?) was shot in the island of Raasay, in Orkney.

I believe that some ornithologists now hold the opinion that this bird and the Sancti Johannis of American authors are identical, the latter being that adult stage in which the species has not yet been found in this country. Mr Macgillivray, however, in his "Manual of British Ornithology," (London, 1840), states that "one shot in Dumfriesshire in March, 1840, had a great number of young feathers of a blackish brown colour, and would have been entirely of that tint had the moult been completed."

\section{THE HONEY BUZZARD.}

\section{PERNIS APIVORUS.}

LIKE the preceding species, the Honey Buzzard is found much more frequently in the east of Scotland than in the west. A specimen was shot at Chatelherault, near Hamilton, in the autumn of 1831 , but so far as I can ascertain no other instance of its occurrence can be cited between that year and 1863, when one was trapped at Muirkirk, in Ayrshire, in the month of September. Another-a young male-was shot at the same place about twelve months afterwards, and exhibited at a meeting of the Royal Physical Society of Edinburgh by Dr J. A. Smith, to whom I am indebted for a notice of the circumstance.

In the eastern counties, principally in the autumn season, in localities ranging from Berwick to Shetland, specimens have been procured at intervals since the time of Don, in whose list the species is mentioned. Lord Binning informs me that an adult male in perfect plumage was shot at Tyninghame in East Lothian in May, 1856, and is now in the Earl of Haddington's collection. Three specimens had previously been obtained in the same county, and examined by Mr Archibald Hepburn. In 1862 another was shot by Mr Alexander Henderson at Broxmouth near Dunbar, and about two years afterwards several more were shot on Beil estate in the winter season (January and February, 1864), two of which I saw in the collection of the late Dr Nelson of 
Pitcox. Three or four were shot in Berwickshire in June, 1845, in which county the species again appeared in 1863-64 in one or two instances. Specimens have also occurred in the counties of Roxburgh (at Newton-Don, near Kelso, in May, 1867), Dumfries (on several occasions), Selkirk, Peebles, Fife, Stirling, Ross (at Strathpeffer, near Dingwall, in June, 1863), and Aberdeen. In the last-named county, where this bird has been obtained on perhaps ten or twelve different occasions, the nest has been found at least in two instances; one of these is referred to by Macgillivray, who mentions the occurrence of a nest in the woods of Aberfeldy, on the authority of Mr J. M. Brown; and in the other case both birds were obtained and forwarded to $\mathrm{Mr}$ Wilson, gunmaker, Aberdeen, for preservation. I am indebted to $\mathrm{Mr}$ Angus of that city for the following notice of the circumstance:- " A pair of Honey Buzzards were shot in the woods of Ballogie-the property of Mr Dyce Nicol, M.P.-in 1867; the female was shot in the nest by the forester on the 12th July, her mate having been killed by the gamekeeper about a week previously. The stomachs of both contained bees and honey. The nest was built in a tall fir tree which was difficult to climb, the trunk being smooth and branchless. The structure was about three feet in diameter, very flat, and composed of twigs of various sizes, and covered with grass roots. The eggs, two in number, were about the size of those of a domestic hen, slightly tapered, their colour resembling rosewood, blotched with very dark brown."

The last record I have of the Honey Buzzard is from the same county, where an adult male was shot in August, 1868.

\section{RED-SHOULDERED HAWK.}

\section{BUTEO LINEA TUS.}

A young specimen of this North American bird was shot at Kingussie, in Inverness-shire, on 26th February, 1863, by J. M'Donald, and sold by him, with a lot of common buzzards, to Mr Mansfield, from whom it was purchased by Mr Baker of Cambridge. It is now in the collection of Edward Clough Newcome, Esq. of Feltwell Hall, Brandon, who sent a notice of the occurrence to the editor of the Ibis in September, 1865.

This species-the Buteo lineatus of Gmelin-is now believed to 
be identical with the winter falcon (Faleo hyemalis) of Wilson and Audubon, and other writers, and is said by Mr Cassin to be one of the most abundant of the rapacious birds of the Eastern and Southern States on the Atlantic, and to be restricted to the countries east of the Rocky Mountains. It appears to be much more frequently met with in the adult state of plumage, which varies in a great degree from that of the young bird.

In treating of the habits of Falco hyemalis, Wilson thus sketches its character, which contrasts singularly with the half-indolent life of our British buzzards:-

"This elegant and spirited hawk visits us from the north early in November, and leaves us late in March. He is a dexterous frog-catcher, and, that he may pursue his profession with full effect, takes up his winter residence almost entirely among our meadows and marshes. He sometimes stuffs himself so enormously with these reptiles, that the prominency of his craw makes a large bunch, and he appears to fly with difficulty. I have taken the broken fragments and whole carcasses of ten frogs of different dimensions from the crop of a single individual. Of his genius and other exploits I am unable to say much. He appears to be a fearless and active bird, silent and not very shy. One which I kept for some time, and which was slightly wounded, disdained all attempts made to reconcile him to confinement, and would not suffer a person to approach without being highly irritated, throwing himself backward, and striking with expanded talons with great fury. Though shorter-winged than some of his tribe, yet I have no doubt but with proper care he might be trained to strike nobler game in a bold style and with great effect."

As in the case of some other raptorial birds, this species would appear to breed before attaining maturity. Wilson mentions having shot a female of $F$. lineatus, which is the young of his winter falcon, in a swamp, near Philadelphia, and finding in the ovary several eggs nearly as large as peas.

As this buzzard may occur again in Scotland, a description of the plumage will not be out of place here. The following is taken from Mr Cassin's specific characters, detailed in Professor Baird's work on the Birds of North America.

Adult.-Wing coverts from its flexure to the body fine bright rufous; breast and other lower parts of the body paler orange rufous, many feathers, with transverse bars and spots of white, 
which predominate on the abdomen and under tail coverts. Entire upper parts brown; on the head mixed with rufous, and with white spots on the wing coverts and shorter quills and rump. Quills brownish black, with white spots on their outer webs, and with bars of a lighter shade of brown and of white on their inner webs; tail brownish black, with about five transverse bands of white and tipped with white.

Young.-Entire under parts yellowish white, with longitudinal stripes and oblong spots of dark brown; throat dark brown; upper parts lighter ashy brown, with many partially concealed spots and bars of white; quills dark brown, with wide transverse bars of rufous and white on both webs; tail ashy brown, with numerous bands pale brownish and rufous white; tail beneath silvery white.

Total length, female 21 to 23 inches; wing, 14; tail, 9 inches; male, 18 to 20 inches; wing, 12 ; tail, 8 inches.

\section{THE MARSH HARRIER.}

\section{CIRCUS ARUGINOSUS.}

Nearly all the Scottish specimens of the Marsh Harrier which I have had an opportunity of examining have been birds of the first and second year's plumage. It appears to be of much rarer occurrence in most districts than the hen harrier; and in the Long Island especially, where the nature of the ground is so attractive' to a bird of its habits, it is but very seldom seen, while its congener, the ring-tail, may be called abundant. I have seen it on wing, passing sufficiently close to be recognised, on the island of Benbecula, and Macgillivray mentions having met with it on Harris. It is possible, however, that it may be more common on North and South Uist than my limited observations, especially in the last named island, have led me to believe. The Rev. Alexander Stewart of Ballachulish, author of a series of excellent papers on the Natural History of Nether-Lochaber, published during the last few years in the Inverness Courier, has kindly informed me that the Marsh Harrier is comparatively common in that district, and also in the district of Appin in Argyleshire. He has frequently seen it on wing, and handled at least a dozen specimens shot in his neighbourhood, during the last seven or eight years.

On the east coast of Scotland I am most familiar with this bird 
as an East Lothian species, having examined a number of specimens that were shot in that county. I noticed many years ago its partiality for ducks and pigeons at the Tyne estuary, where a fine specimen formed a marked object for some months before being taken. As the birds on which it was occasionally seen feeding were full grown, they may have been wounded, and thus have fallen an easy prey. I can hardly think any buzzard strong enough to pursue and kill a wild duck of any species. Messrs Baikie and Heddle state that this bird is an occasional visitant in Orkney; and it is likewise known to be a straggler in some parts of Shetland.

\section{THE HEN HARRIER.}

\section{CIRCUS CYANEUS.}

An $t$ eun fionn. Breid-air-toin. Clamhan luch.

THIs is a very common species on all the islands of the Outer Hebridean group, and also throughout the inner islands, Skye, Mull, Islay, Jura, ecc., where it is known by the Gaelic name of Clamhan luch, signifying mouse-hawk. I have seen twelve or fourteen specimens in one day on Benbecula and North Uist, and likewise in South Uist, where its hunting-grounds are of a similar nature. The flight of this bird is peculiarly buoyant, and occasionally very graceful, as it surmounts a hillock or clump of rocks, sweeping down the other side with contemptuous ease. Sometimes, when hungry, it flaps slowly above a grass field, or patch of growing corn, hanging on wing for a second or two before descending somewhat clumsily on its unlucky prey; at other times it sails speedily over the ground, content to stoop at anything which comes in the line of its flight.

This species, in such districts as the chain of outer islands, has the habit of hunting over the same ground for days in succession, appearing regularly at the same hour, and going through its evolutions so methodically, that a specimen can easily be obtained by concealing one's self at a convenient place. I noticed this habit particularly on Benbecula and North Uist, where some grass fields lay near the shore. On Ben Eval I at various times observed several Hen Harriers at a moderate elevation, searching the sides of that conspicuous hill, and, on climbing to the top some time afterwards, I found that numbers of field-mice had their holes near 
the summit, and were sufficiently common to attract the hawks. Looking down from this elevation, one evening in September, about sunset, I could not help feeling amazed at the scene pictured below. There lay the whole of the fragments forming North Uist, scattered like a thousand islets thrown at random into a lake. It was indeed impossible to say whether the land or the water predominated. Near at hand great masses of granite shone through the heath-clad ground, and in the distance the glimmering specks on the dark-brown tracts drew the eye to other vast blocks lying in the moorlands. The evening was exceedingly quiet, and the blue minch separating this strange fragment of the British isles from the mainland looked as calm as a giant asleep. From where I sat I could see the Clamhan luch like a light blue sea-gull skimming the purpled sides of Ben Eval, and gradually nearing the summit. Twenty yards behind came another of a darker hue, not so readily perceived as her mate, but as quick at perceiving; then the two came on abreast, and passed within ten yards, beating the ground like a well-trained couple, and making alternate stoops at the poor mountain mice as they sat at their thresholds.

But as the shadows deepened on the plain, the two birds having apparently satisfied their hunger for the day, steadily yet gracefully descended the golden skirts of this strange mountain, as the last rays of the evening light tinged the glistening granite, till at length they reached the level of heath and water, against which they soon became scarcely discernible. Casting my eyes westward in the direction where I had seen on the previous evening the island of St Kilda, like a blue speck in the distance, I felt sorry, standing as I did where so few persons think of venturing, that I could not describe the singular picture. It was indeed a sight not often enjoyed within the range of the British islands. Bird life was now nowhere visible; in the strange stillness of approaching night the natural surroundings looked as if some unseen hand were withdrawing them from the world.

"A cloud lay cradled near the setting sun;

A gleam of crimson tinged its braided snow;

Long had I watched the glory moving on

O'er the still radiance of the lake below.

Tranquil its spirit seemed, and floated slow!

Even in its very motion there was rest;

While every breath of eve that chanced to blow

Wafted the traveller to the beauteous west." 


\section{MONTAGU'S HARRIER.}

\section{CIRCUS MONTAGUI.}

\section{Clamhan luch.}

ON the western mainland this is certainly the rarest of the Harriers. It is quite possible, however, that from its strong general resemblance to the preceding species it may have been overlooked. Yet, judging from the comparative numbers sent to the eity taxidermists for preservation - no mean criterion-it falls greatly short of the hen harrier-a fact scarcely to be wondered at when we take into account that it is a southern species in its geographical range, inclining eastwards as it recedes from the shores of England. Those I have seen from west country moors were mostly females and young males.

In September, 1867, I observed, as I believed, this species on one or two occasions on the islands of North Uist, Benbecula, and South Uist, where opportunities were afforded me of contrasting the flight of the two together. Montagu's Harrier appeared to me to be a wilder and more impulsive bird, and, from its lightness, to be quicker in its movements-dashing sometimes impetuously to the ground, not heavily, like the common harrier, then rising with a sudden bound to some height, and again pouncing in a straight line on its prey. When flying over a tract of country it may be distinguished, too, by its different flap of wing and general movements, which are more buoyant than those of the shorter winged bird.

The late James Wilson of Woodville, in his "Voyage Round Scotland," mentions having seen a specimen of this bird, which had been shot in Caithness, in the museum of Mr E. S. Sinclair, surgeon in Wick; and I find the species mentioned by the late Charles St John, who states in his "Tour in Sutherland," vol. i., p. 122, that "it breeds near Bonar Bridge, Mr Dunbar having taken the nest and killed the old birds in that district."

In Thompson's "Birds of Ireland" it is stated that a specimen of Montagu's Harrier was obtained near Ballantrae in Ayrshire in 1836. 


\section{THE EAGLE OWL.}

\section{BUBO MAXIMUS.}

Chiefly met with in the Orkney and Shetland islands, where, however, it is of very rare and uncertain occurrence.

The late Patrick Neill, Secretary to the Natural History Society of Edinburgh, has the following note in his "Birds of Orkney," published in 1806:- "In addition to Dr Barry's account (which is extremely meagre), it may be added that the Eagle Owl often attacks rabbits and red grouse, which are abundant in several of the islands. Katugle is the Norwegian name."

Messrs Baikie and Heddle state that this bird, which is the Stock Owl mentioned by Wallace, is "now extremely rare. Low, though he speaks of it, never saw a specimen. Since then, however, one was killed in Sandy, by Mr Strang, in 1830. It is occasionally said to be seen in Raasay, and is believed still to breed in the Hammers of Birsay."

Pennant mentions in his "Tour in Scotland" (8vo. ed., 1772) that a specimen was killed in Fifeshire, but no locality or date is given.

Dr Saxby says it is " now rarely seen in Shetland."

Such were the very scanty notes I had gleaned respecting the occurrence of this splendid Owl in Scotland previous to the receipt of the following interesting notice of its capture in Aberdeenshire, kindly forwarded to me by my correspondent, Mr Angus:-

"Mr John Wilson, Methlick, has just sent me word that on the 2d February, 1866, while out shooting, he saw an Eagle Owl, of which he says:- - It flew very low, keeping close to the ground, rising and falling in beautiful undulations over the uneven surface. I saw it from a considerable distance, and in the grey dawn of the morning thought it was a heron. I could have easily reached the point to which it was flying, but as I did not want a specimen (herons being plentiful in this locality), I let it go. Some doubts, however, having occurred to me at this moment, I made a rush upon the bird, and got near enough to discover my mistake. It did not diverge in the least in its flight at my approach, and I might after all have killed it, but trusted to a better opportunity. After this it was often seen about Haddo House, and always in 
company with a smaller owl.' In the last week of February of the same year an adult female Eagle Owl-no doubt the same birdfound its way to Aberdeen, from Mr Wilson's neighbourhood. It fell into the hands of a wright, who brought it to me for identification. It weighed seven and three quarter pounds. The stomach contained two water rats, nearly whole. The owner would not dispose of the bird, nor would he put it into the hands of a taxidermist to have it properly stuffed. He gave me the body, and I preserved the sternum and made a full description of the plumage. I afterwards saw the Owl in the hands of the lucky fellow, displayed as a curiosity; and in this he succeeded perfectly, as I was forced to confess I had never seen such a fine bird so thoroughly caricatured."

\section{THE SCOPS-EARED OWL.}

\section{SCOPS ALDROVANDI.}

A specimen of this Owl, shot at Morrish, near Golspie, in Sutherlandshire, in May, 1854, was exhibited at a meeting of the Royal Physical Society of Edinburgh in November following, by Dr J. A. Smith of that city; and the late Mr St John has mentioned in his "Tour in Sutherland," vol. i., p. 122, that the species has been found breeding on heaths near the Oykel river. These are the only records of the occurrence of this species in Scotland, but it is possible that the species found by Mr St John was the Short-eared Owl.

It is a somewhat curious feature in the history of the Scopseared Owl, that it lives wholly upon insects. It is, therefore, in temperate countries strictly migratory in its habits, and in France, where it is not uncommon, it is said to come and go with the swallow.

\section{THE LONG-EARED OWL.}

\section{OTUS VULGARIS.}

A MUCH less common bird in western Scotland than the next species, and totally absent from the outer islands. It breeds, however, in Mull and Skye in limited numbers. In the cultivated districts of Dumbartonshire it is tolerably common, and in Ayr- 
shire, Renfrewshire, and Argyleshire woods it is also well known; still as a rule it is more a bird of the eastern counties than of the western. Mr Alston states that it is common in the Upper Ward of Lanarkshire; and in Stirlingshire it is said by $\mathrm{Mr}$ Brown to be one of the commonest species. Yet judging by the numbers sent to the city bird-stuffers, it is seldom met with, compared with other species.

This bird, like the white or barn owl, continues laying and hatching at the same time. Writing from Aberdeenshire, $\mathrm{Mr}$ Angus informs me that he has found both it and the tawny owl commencing to sit as soon as the first egg was laid. "I once," says Mr Angus, "put a tawny owl off its nest three times within an hour; it contained but two eggs. Three days afterwards a lad took four eggs from the nest. I robbed a nest of the Long eared Owl which contained four half-fledged birds and five eggs, most of which were remarkably dirty. Three had been some days sat upon, and two of them were so far advanced that they could hardly be blown."

This species, which is partial to fir plantations, appears to be not uncommon in some of the wooded districts of Ross shire. In Orkney it has occurred in at least two instances; one of which is mentioned in Messrs Baikie and Heddle's work, and the other, as stated in a manuscript note, was obtained at Kirkwall in 1851.

\section{THE SHORT-EARED OWL.}

\section{OTUS BRACHYOTOS.}

REsident all the year in the West of Scotland, north of Ayrshire. I have seen it hawking for prey in dull weather at mid-day over turnip fields, looking probably for field-mice, which in the autumn months become rather numerous in some places. This $\mathrm{Owl}$, indeed, may be looked upon as a useful friend to the farmer in the localities it frequents. In some turnip fields on the east coast, where it likewise breeds in some numbers, I have seen as many as eight or ten birds lodged within the compass of a few acres; and I have also seen them in early morning frequenting the rocky parts of the coast near Dunbar, in East Lothian. I have frequently put up Short-eared Owls from such situations; but whether they had gone there for the purpose of preying upon rats and the 
smaller wading birds, or had alighted during the night after a migratory journey, I am unable to say. Any specimens that I procured were in excellent plumage.

My friend Mr Sinclair has also seen this species in the middle of summer, hawking in daylight alongside a moor at Inverkip Glen, Renfrewshire; and thirty years ago it was a permanent resident as far south as Portpatrick, in Wigtownshire, where it nested regularly.

In the Outer Hebrides the Short eared Owl is very common, breeding in the moors of nearly all the islands. I am most familiar with it, however, as a bird of North Uist and Benbecula, where it has been long well known. Among the inner islands it is resident all the year in Skye, Mull, and Islay.

Mr Angus has sent me word that he has taken the nest, with three eggs, this year (1868) in Aberdeenshire, on the 8th of April. This is the earliest date I have heard of. Sir John Richardson found the eggs ready for being laid on 20th May; Mr Hepburn has seen newly-fledged young ones in East Lothian in the end of July; and Sir William Jardine, who has repeatedly taken the nest in Dumfriesshire, remarks that the young are barely able to fly by the 12th of August.

\section{THE WHITE OR BARN OWL.}

STRIX FLAMMEA.

Cailleach oidhche gheal.

JuDGiNg from the numbers of this beautiful Owl which are sent to the shops of the Glasgow bird-stuffers, it would appear to be one of the commonest "feathered mousers" in the neighbourhood of the city. There is scarcely, indeed, a ruined building of any consequence within a radius of thirty miles of Glasgow, but what is frequented by one or two pairs. Yet it is by no means widely distributed as a Scottish species-some of the more northern counties being totally destitute of the associations which its presence has given rise to. In the western islands, I have been able to trace it only in Mull and Islay; in the former locality it is rather rare, but in the latter it is well known in two districts at least-the woods at Islay House and Port-Askaig-as I have been informed by Mr Elwes. "In Iona," says Mr Graham, "where 
we have a venerable ruined belfrey and $a$ moon, we have no owl to live in the one or mope her melancholy at the other."

In the East of Scotland the White Owl is common enough from Berwickshire to Aberdeeushire, with the exception of perhaps Forfarshire; it is likewise found in many of the midland counties, especially those south of Perthshire. In Banffshire it is rare, but westward it becomes more common, and is by no means rare in Ross-shire. I have been informed by Mr Morrison, gunmaker, Dingwall, that he has had as many as half a-dozen sent to him in the course of a week for preservation. In the woods of East Lothian I have many times been startled by its dismal screechings after dusk. I recollect on one occasion when moth-catching in the Tyne woods in company with my late friend, J. Nelson, Esq., hearing one break out into a piercing solo, which even yet brings that night's work more vividly before me than any mere words could do. We were engaged in brushing a sugary compound on the trunks of the trees to attract the "night-fliers," when the noise suddenly broke the silence of the woods in screams so loud as to startle a group of horses that had been quietly resting for the night, and set them all into a hard gallop across the park. On turning our bull's-eye lantern so as to penetrate, if possible, the gloom of the foliage overhead, we noticed our feathered friend looking down from a branch with a most comical stare, and evidently as much puzzled as we were at the turn affairs had taken. There was no need of a ruined castle or cathedral to enhance the sensation of loneliness we both experienced at the moment; and as we shut off the light and waited for another solo, the dense gloom of the thicket could not have been more irksome.

The Rev. Alexander Stewart of Ballachulish has furnished me with a very amusing account of a pet male bird of this species, which he had brought up from the nest. From a mere puff-ball of white down he had grown into a handsome bird, proud of his sharp claws, which he seemed to make use of with great effect in maintaining his superiority among the feathered gentry of the courtyard. "In the kitchen," says Mr Stewart, " neither cat nor dog dare venture near the hearth when 'Strix,' as we called him, had gravely set himself, standing on one leg, with his back to the fire, for a comfortable nap in the genial warmth, which he seemed always to enjoy vastly. If, while in this state, he chanced to be pushed against, or disturbed in any way, he just opened the corner 
of one eye, blinking in the most comical manner, his way of reconnoitring, and if it turned out to be the cat or dog that had, however unwittingly, roused him from his reverie, he was at him like a flash of lightning. With a pounce, always unerring, he first dug his bill into the cheek or ear of the unlucky intruder, then using the hold thus got as a purchase, he threw himself on his back, and with his claws laid fierce grip of his victim's flank or nose, or about the eyes or forehead-a mode of warfare so fierce and sudden, and so utterly new to the unfortunate assailed, that Strix could in a few seconds always claim a victory as complete and decisive as the Prussians gained at Sadowa, or the Highlanders at Prestonpans. Strix soon became reconciled to the daylight, and flew in and out and about the house and garden at all hours of the day, though the beautiful, round, black piercing eyes were never fully opened but in the twilight. We fed him on fresh fish and such moles and mice as we could procure for him. Strix perfectly knew, not only myself, but all the members of the family, and would come to any of us, when called, with the utmost readiness and goodwill, alighting on such occasions without the rustle of a feather, or the slightest sound from his downy pinions, on the head or shoulders, and greeting us with a gentle scarcely audible murmur, not unlike the cooing of a dove. Our only objection to poor Strix was his habit of frequently repeating a rasping, prolonged half-scream, half-hiss, that evidently gave himself great satisfaction, but which was most vexing to our ears. With this single drawback, however, he was the most amusing, intelligent, agreeable, and affectionate of pets."

But like many other pets, this one met with a violent death. "One day lately," concludes my correspondent, " he was musing in deep reverie in a clump of luxuriant ivy that clothes our garden wall, when a brood of downy ducklings that had only chipped the shell the day before, passed merrily by, under the guardianship of their proud step-mother, a turkey-hen. The owl saw the ducklings, and quickly making up his mind that one of them would be a very good thing by way of lunch, he made a dash at the nearest, but the turkey, alert, and active, and bold in defence of her precious charge, instantly struck at Strix with all her might, and hitting him with her sharp beak right on the head, laid him dead at her feet!" 


\section{THE TAWNY OWL.}

\section{SYRNIUM STRIDULA.}

Cumhachag, Cailleach Oidhche.

BEING for the most part resident in woods, this species is in consequence restricted to districts where the larger plantations have of late years increased so as to afford it, and other birds, the protection which they require. 'The Tawny Owl, indeed, shows so much helplessness and apparent stupidity in the day time that without the privacy and security of dense woods it would fall an easy prey. We find, therefore, that as our forests are spreading there is a corresponding increase in the numbers of this bird, and that although it was known to be a comparatively scarce species throughout Scotland thirty years ago, it has now become a wellknown owl in suitable haunts from Wigtown to the north of Rossshire on the one hand, and from Banffshire to Berwick on the other.

I have met with it frequently in Ayrshire, Argyleshire, and Inverness-shire, and have seen it also in some of the Ross-shire woods, where it breeds. Mr Alston informs me that it is very common in the Upper Ward of Lanarkshire, and Mr Brown states that he has found it breeding regularly in a rocky crevice in Torwood Forest, Stirlingshire. It has even of late years been found on some of the Inner Hebrides-specimens having been met with on Mull and Islay. Mr Elwes has informed me that in the last-named island it has only been seen in the large plantations.

In the eastern counties it breeds in Aberdeenshire, where the nest has been taken several times by Mr Angus. I have myself found the species nesting in the woods near Auchinblae, in the neighbouring county of Kincardine; the nest was a mere hollow in the fork of a large tree about seven feet from the ground, and was lined (accidentally perhaps) with a handful of withered leaves. This owl sometimes lays its eggs in the deserted nest of a rook; indeed, it seems partial to rookeries, as I have repeatedly procured specimens when out "crow shooting" both in Ayrshire and East Lothian.

There is a great variation of plumage in this species, some being of a dark grey, while others are of a bright rust-red colour-this diversity being common to both sexes, and apparently irrespective 
of age. So far as I have observed, the red varieties are more commonly met with in the western counties than in the east or north.

The food of this owl consists entirely of harmless plunder, such as rats, mice, and other small quadrupeds - an occasional young rabbit or small bird, varied by fish, and even earth-worms. In secluded forests at a distance from farm steadings, or other dwellings attractive to rats, I believe it will be found that moles and field-mice constitute its chief prey; and on that account, as well as for its own sake and the associations it calls forth as it croons its nightly serenade, I commend it to the merciful consideration of those who have the power to protect it.

\section{THE SNOWY OWL.}

\section{SURNIA NYCTEA.}

THIs large and handsome bird may almost be regarded as a regular spring visitant to the Outer Hebrides. In the island of Lewis, especially, it is frequently seen and shot, and specimens have also from time to time occurred in Harris, North Uist, and Benbecula. In the last-named island, one was shot in June, 1863, by Mr J. Ferguson, surgeon, at that time resident there. Sir James Matheson has informed me that in the course of a single season, some years ago, several were shot in Lewis. Three or four were observed there in the spring of 1868 , and one of these was shot on the 21st April, by Kenneth Hosack, the keeper at Gress. This bird was seen daily in company with another Snowy Owl, frequenting the farm of Galson, near Ness, for more than two weeks, and the survivor afterwards disappeared for a time, but was seen again at the same farm on the 8th of May. Mr John Munro, the keeper at Marybank Lodge, Stornoway, informs me that a fine specimen was obtained at North Tolsta in the beginning of April, 1867, and adds that the species occurs in the island every spring.

In localities nearer the mainland, the Snowy Owl has been met with in Skye in several instances, in Mull, and in Iona; while on the mainland itself, it has been shot in Caithness (1850); Sutherlandshire (July, 1863); Inverness (Lochness, October, 1868); Ayrshire (Kilmarnock; February, 1863); and Renfrewshire (December, 
1863). Two specimens, both young birds, were obtained in the Clyde in the same year, one near Port-Glasgow, the other at Pollokshields, near the city of Glasgow. One was seen during the months of October and November, 1868, in the neighbourhood of Ben Lomond. It made frequent descents to the low grounds, and appeared to live chiefly upon grouse.

Having examined altogether between twenty and thirty Scottish specimens of this beautiful owl, in the various collections which I have visited, I find that the number of young and old birds is about equal. Those taken on the west coast are probably migrants from Canada. Very large flights have, in fact, been observed by the masters of vessels trading between America and this country. The late Mr Thompson, in his " Birds of Ireland," has given some very striking records of this kind. In one case as many as fifty or sixty Snowy Owls were observed flying about the ship, and alighting on the rigging, the vessel being then about 500 miles from the nearest land. Numbers continued following in its course for about four days, making their appearance among the spars occasionally for rest during the night. Mr Thompson conjectured that these flocks had come from the coast of Labrador, and were migrating to more southern latitudes. Several friends of mine, who have made voyages between the two countries about the close of autumn and beginning of winter, have informed me that a few Snowy Owls are generally met with, at long distances from land, and that, on nearing the coasts of America, the birds are met coming from that country, and are seen pursuing a southeasterly course. It is not unlikely, indeed, that the owls seen by Mr Thompson's informant during four days' sailing did not all belong to one migrating party, but were distinct flocks following their ordinary line of flight.

On the eastern side of Scotland, the numbers that occur there are probably natives of northern Europe, as it is only after severe north-easterly gales that they are met with. Since the beginning of the present century, the species has been a well-known visitant to Orkney and Shetland. In May and June, 1864, several were observed in the island of Unst. Three were shot, and one of these is now in the possession of Dr Saxby. 


\section{THE HAWK OWL.}

\section{SURNIA FUNEREA.}

IN December, 1863, I examined a very fine specimen of this rare British bird, which was shot at Maryhill, near Glasgow, and exhibited at a meeting of the Natural History Society by $\mathrm{Dr}$ Dewar, in whose collection it now remains; it was seen haunting a range of stables for some nights before it was killed. A second specimen was taken in the flesh to the shop of a bird-stuffer in Greenock, about the 20th November, 1868, and is supposed to have been killed at no great distance from that town. It was procured by William Boyd, Esq., who forwarded it to me for exhibition at a meeting of the Natural History Society of Glasgow.

I know of no other instance of the occurrence of this species in any part of Scotland except the Shetland islands, where, according to Dr Saxby, it has been twice observed. The skin of one shot in the north of Unst in 1860, is now in that gentleman's collection.

Regarding the habits of this somewhat interesting species, the late Sir John Richardson has given a very good account in his admirable work on the birds of the northern parts of British America. (See Fauna Bor. Amer., page 92).

\section{TENGMALM'S OWL.}

\section{NOCTUA TENGMALMI.}

THIs Owl-one of the rarer species found in Britain-appears to have been met with in three instances only north of the Tweed; one having been shot by Mr Dunbar in an old ruined factory at Spinningdale, in Sutherlandshire, in May, 1847; another killed at Melsetter, in Orkney, in 1851, as mentioned in a manuscript note in Baikie and Heddle's Fauna Orcadensis, by one of the authors; and the third captured on Cramond island, Firth of Forth, in December, 1860. For a notice of the occurrence of the last-mentioned bird, I am indebted to Dr Smith of Edinburgh, who exhibited the specimen (a female) at a meeting of the Royal Physical Society, on 23d January, 1861. It was caught alive by a man named Lumley, during a severe snow-storm. 
The bird had entered a stable for shelter, and was struck down when attempting to escape, on the door being opened.

Temminck, in his Manuel d'Ornithologie, states that the food of this species consists of moths, beetles, and other insects, and that it also sometimes takes small birds. He does not, however, inform us whether the insects are pursued while in flight.

INSESSORES.

LANIADE.

DENTIROSTRES.

\section{THE GREAT GREY SHRIKE.}

\section{LANIUS EXCUBITOR.}

Throughour the eastern counties of Scotland, the Grey Shrike appears to be a regular winter visitant. In the midland counties it occurs less frequently; while on the west coast, especially of late years, I have not succeeded in tracing its occurrence except at irregular and uncertain intervals. Six or eight examples were taken in the winter of 1865-66 in the counties of Argyle, Renfrew, and Lanark-all of which I had an opportunity of examining.* That particular season, indeed, was somewhat remarkable for the unusual number of this species taken almost everywhere. That these formed part of an extensive migratory flock can scarcely be doubted, as small detached parties were observed keeping company for a short time after their arrival-as many as half-a-dozen having been seen together in one place. In Forfarshire I procured three or four specimens which were shot near Kirriemuir, and the species was also noticed near Crieff, as well as other parts of Perthshire. It has likewise become a well known bird in East Lothian of late years.

It is a somewhat remarkable fact that nearly the whole of the Scottish specimens that have come under my notice have the under parts irregularly barred, or minutely freckled, and have but one spot on the wing, precisely like the figure of $L$. borealis given

* Writirg in 1835, Mr Patrick states that Grey Shrikes were often shot near Hamilton, and that they appeared chiefly in autumn, sometimes attacking the call-birds of the bird-catchers in their cages. They were also seen occasionally thirty years ago in the parish of Dalziel. Last year two or three Shrikes were caught by the Glasgow bird-catchers, with bird-lime, within two or three miles of the city. 
by Swainson in the Fauna Boreali Americana. These birds, of which I have seen at least two dozen, are of both sexes. In two or three instances the specimens have shown the under markings to be nearly obliterated, and may be said to have a strong resemblance to another species figured in the same work-L. excubitoroïdes. I have never, except in one solitary instance, met with what some ornithologists would regard as a male in perfect adult plumage; it was killed near Glammis, in Forfarshire, and is now in my own collection. This specimen is entirely without bars or freckles, and has two conspicuous spots on the wing, besides having the secondaries broadly margined with white. The markings are very clearly defined, and form a striking contrast. If all the other Shrikes I have examined are females and young males, as some of my correspondents have suggested, it is clear that the male in adult plumage is a very rare bird with us.

Swainson, in describing his American excubitoroïdes, founds a specific distinction from the European excubitor in the black patch on the cheek of the former extending in a thin line above the eye, and also meeting over the base of the upper mandible, and in its having a black bill. Professor Baird follows that author in regarding this Shrike as distinct from $L$. excubitor, and points out another feature, namely, the white rump, which none of the others apparently possess. Out of the twenty-four birds I have referred to, eight of which are now before me, scarcely two can be said to be alike; and if a species is to be formed out of differences in the distribution of the black patch on the clieek, markings on the tail feathers, or on the primaries or secondaries, or even on the size of specimens, there is room enough here for the most ardent species maker. So far as I can judge by descriptions, the Shrikes I have seen killed in Scotland present a mixture of the alleged characters of $L$. borealis, ludovicianus, excubitor, and excubitoroïdes, a seeming confusion, however, which might be greatly modified had we the opportunity of comparing. British killed specimens at all seasons of the year. 


\section{THE RED BACKED SHRIKE.}

\section{LANIUS COLLURIO.}

IT is a somewhat singular circumstance in connection with the migratory movements of this species, that in Great Britain its distribution in summer should be confined to the southern half of the island, seeing that it is a well-known visitant to other countries lying much farther north. It is found in Norway, Sweden, Denmark and Russia; and, looking indeed to the fact of its being generally dispersed throughout Europe, it is surprising that our Scottish counties should not regularly be favoured with its presence. Although, however, it has not been regarded by British ornithological writers as a Scottish species, it has extended its flight through the eastern counties in a number of instances. As far back as 1817, a male and female were shot at Caversknowe, near Hawick, and preserved by Mr Heckford, curator of the Kelso museum. The next occurrence $I$ have been able to trace is that of a male specimen, near Peterhead, about the year 1833, as recorded by $\mathrm{Mr}$ Arbuthnot, in the statistical account of that parish. This bird, which I have seen, is still preserved in the local museum there. Another specimen killed in Caithness is mentioned by the late Mr Sinclair, surgeon, Wick, in his catalogue of the birds of that parish, published in the statistical account in 1836. Southwards of these localities this Shrike has been found in Forfarshire, near Montrose (June, 1862); in Fifeshire, near Cupar; a male, which is now in my own collection, having been killed there in the autumn of 1861; and in Haddingtonshire, near Dunbar, where a pair, male and female, were observed haunting a hedgerow during the breeding season of 1856 . The female was shot, and afterwards exhibited by myself at a meeting of the Natural History Society of Glasgow. Three years afterwards, namely, in July, 1859, two specimens were procured at Oxendean, near Dunse, in Berwickshire, as recorded in the proceedings of the Royal Society of Edinburgh, by the Rev. John Duns of Torphichen. To all these examples I may add, that Lord Binning has obligingly informed me, that he saw a male Red Backed Shrike on the farm of Byrewalls, near Gordon, in Berwickshire, in the autumn of 1865; and also that Mr Brown has sent me word of a Sutherlandshire specimen being in the private museum at Dun- 
robin Castle. Last of all, Dr Saxby of Unst, in Shetland, has communicated to me the occurrence of a young male on the 5th October, 1866, and informs me that the specimen, which was shot by himself, is now in his possession. The circumstance of one being obtained so late in the season in such a locality, leads to the conjecture that in travelling southwards from a more northerly habitat, it had been blown out of its course. There is a strong probability, indeed, that nearly all the Scottish examples of the species found north of the Forth are bewildered travellers on their return journey. The Berwickshire and East Lothian pairs, however, may legitimately be reckoned as instances of the Red Backed Shrike extending its summer flight beyond its previously defined range.

OBS.-The Woodchat Shrike (L. Rufus) is included in Don's list of the Birds of Forfarshire, but has never, so far as I am aware, been noticed in Scotland by any subsequent observer.

INSESSORES.

MUSCICAPIDE.

DENTIROSTRES.

\section{THE SPOTTED FLYCATCHER.}

\section{MUSCICAPA GRISOLA.}

THIs quiet inhabitant of woods and gardens is very generally distributed. Of somewhat pensive habits, it is by no means an obtrusive bird, yet it frequently startles the observer strolling near its haunts by its sudden turnings while fluttering after a moth, butterfly, or other insect, the snap of its mandibles being distinctly heard on calm evenings, when few sounds are floating in the air. I have seen a pair so employed as late as ten o'clock P.M., up to which hour they were feeding their young ones. In the autumn months I have likewise observed this Flycatcher perched in apparent innocence on some fruit tree near a bed of dahlias, and snapping up numbers of that beautiful insect, the red-admiral butterfly, cleverly seizing the body lengthwise and dropping the splendid wings, which twirled sadly in their death flight to the ground.

In gardens, the nest of this bird is placed generally in the fork of a fruit tree, and is seldom perfect as a structure-one side, chiefly the front, being thick and bulky, while the back resting against the tree is merely lined with a few hairs. I have found 
the nest picturesquely placed in a rock near Inverkip, Renfrewshire, the little shelf being gracefully overhung with wild flowers. The spot was secluded, and it would have been impossible to detect the nest had the bird not betrayed herself; it was there in 1866 and again in 1868. Mr Alston has informed me that he once observed a nest of the Grey Flycatcher on the ground at the root of a tree. I took a nest three years ago from a tree in a park near my house; it was built of dirty straws, and placed in a fork about fourteen feet from the ground. The outside was covered with black sheep's wool, and on examination I found that there were two black sheep in the park among a number of white ones-the wool of the former having evidently been chosen as a means of better concealment for the nest, which would have been rather conspicuous without the external covering. The structure, when finished, harmonized wonderfully with the colour of the tree.

\section{THE PIED FLYCATCHER.}

\section{MUSCICAPA A TRICAPILLA.}

IN the eastern and midland counties it is not improbable that this Flycatcher will yet be found in limited numbers. It has not up to this time been traced farther west than Stirlingshire, in which county, as I have been informed by $\mathrm{Mr}$ Brown, three examples at least have been met with. It has likewise been taken twice in Aberdeenshire, in 1845 and 1849, and Mr Thomas Edward has sent me word of its occurrence also in Banffshire. The late James Wilson mentions the species in his "Voyage Round Scotland," a specimen, killed in Caithness, having been seen by him in the collection of the late $\mathrm{Mr}$ Sinclair of Wick. In addition to these instances, Dr Smith of Edinburgh has kindly informed me that a male bird of this species was shot by Mr Stevenson in a garden near Dunse, in the first week of June, 1855, and that another male was seen in the same place in June the following year. My friend, Mr W. Sinclair, whose drawings embellish this volume, has also informed me that he saw one in May, 1867, in a garden at Dunbar, where he watched it for some time. I have also the gratification of recording the fact of the Pied Flycatcher breeding in Invernessshire,-Mr E. S. Hargitt of London having obligingly sent me 
word that he has in his collection the eggs taken near Drumnadrochit, in that county, in 1864.

Regarding the occurrence of this species in Aberdeenshire, $\mathrm{Mr}$ Angus has been kind enough to send me the following particulars:- "This beautiful species rarely occurs with us. A specimen in the Aberdeen museum was shot at Hazel Head, in May, 1842, by $\mathrm{Mr}$ Mitchell, who informed me that he saw another in a cherry tree at Arthur Seat. A male was obtained at Brucklay Castle in May, 1849." To these Aberdeenshire records I may add the occurrence of a pair, male and female, near Peterhead, previous to 1835 , in which year Mr Arbuthnot, the founder of the Peterhead museum, where the specimens are still preserved, furnished a list of local birds for publication by the compiler of the statistical account of the parish.

The Stirlingshire specimens already alluded to were observed by $\mathrm{Mr}$ Peter Allan, bird-stuffer, Stirling, who watched a pair at Ballochlean on the 18th June, 1867, and by Mr Thompson, Dunmore, who shot a specimen on the Dunmore estate ten years ago.

Regarding its occurrence in Orkney, Messrs Baikie and Heddle write as follows:- "Often seen in summer. Several were seen in Sanday in October, 1809. A small flock appeared at Elsness on 12th May, 1822, after a gale of north-east wind. One was shot in Sanday, 15th May, 1839. Two killed near Kirkwall in 1844, are now in the Kirkwall museum."

INSESSORES.

MERULIDA.

DENTIROSTRES.

\section{THE COMMON DIPPER.}

\section{CINCLUS AQUATICUS.}

Gobha uisge. Gobha dubh nan allt. Lon uisge.

THE familiar "Water Craw" of Scotland is a bird of wide distribution in almost every county north of the Solway and the Tweed. There is not a river or Highland burn of any consequence but is frequented by several pairs, which may be met with every few miles of its course, from the very fountain-head, where the heath-embedded rocks are crowned with moss and ferns, down a succession of waterfalls and mill-races, to the broad expanse at its 


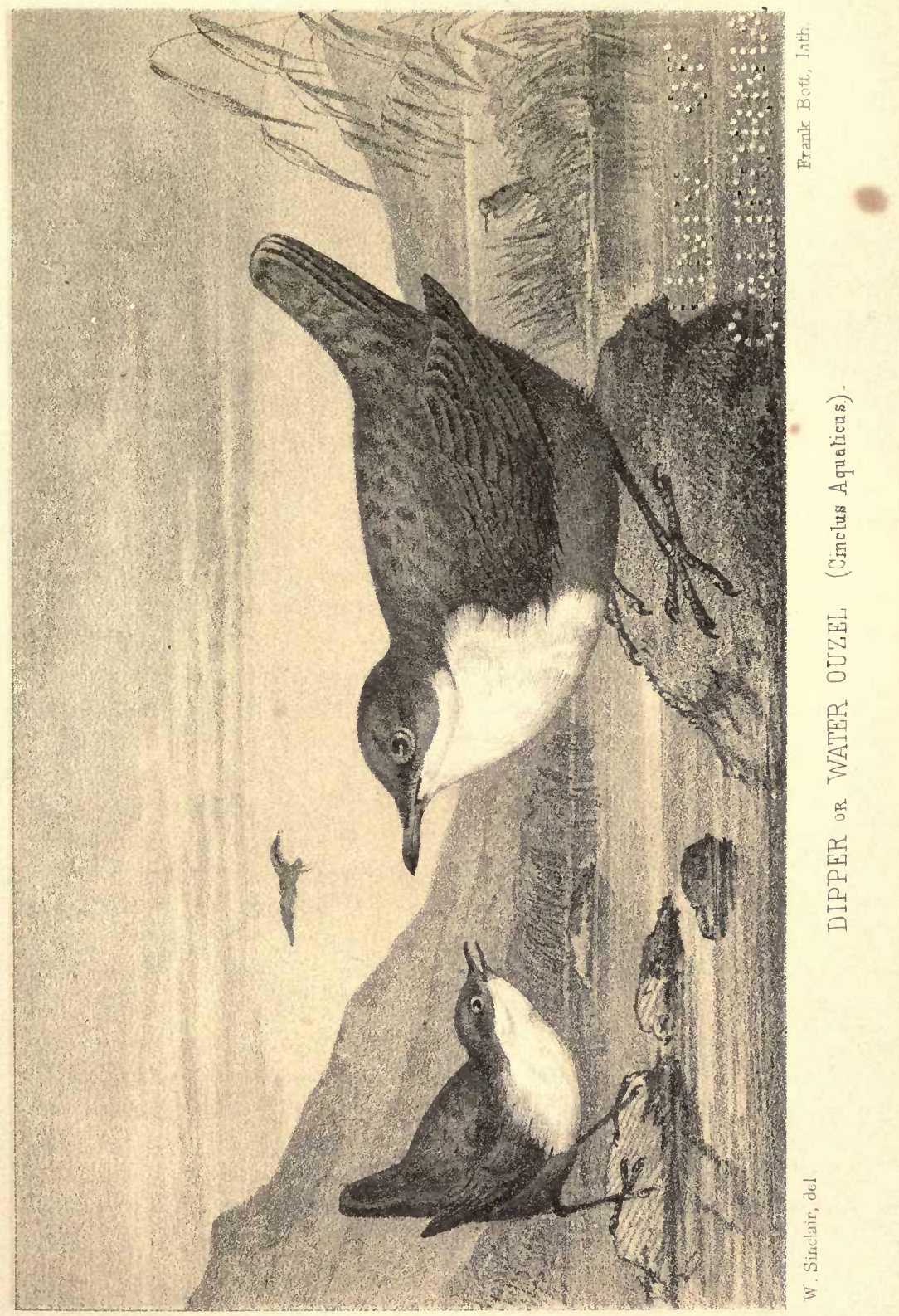




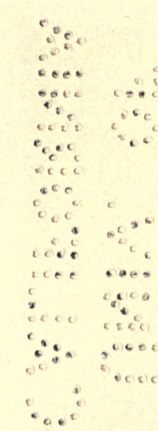


junction with the sea. I have never traversed the banks of any Scottish stream without meeting this bird, and I have seen it repeatedly in rocky gullies worn in the mountain side, far up beyond the line where one expects to find only birds of plunder. In some of the glens on the Loch Lomond mountains, three or four pairs constantly attract the rambler as he traverses their romantic haunts, and their nests are found in sites ranging from the level of the loch itself to the very summit of the chain, whence another streamlet takes its source, and rolls down the other side into the Firth of Clyde. In such districts the site usually chosen is in a niche of rock near a waterfall, or under some rudely constructed bridge; but on the banks of larger streams I have found it placed against the wasted trunks of willow trees, bending over the water, and also in rugged landslips, where a convenient tuft of rough herbage offers both a support and the means of better concealment. In some cases the structure is very skilfully hid, so to speak, by a total disregard of symmetry, the shapeless mass of material being as unlike a nest as possible, and only recognisable when the bird itself betrays the secret. In almost all the nests I have examined, the eggs or young were six in number, the first brood being generally fledged about the last week of April. I found three nests of the Dipper in Shemore Glen, Loch Lomond, last summer; they were all within sound of two or three leaps of water hemmed in by overhanging rocks of a great height, almost meeting at the top, and forming a noisy and gloomy recess such as few birds would make choice of as a nursery. There, in their spray-covered sanctuary, the various broods were reared in safety and dispersed to give additional interest to these beautiful cascades. There, too, in early spring, the male birds may be seen perched on some moss-covered stone, trilling their fine, clear notes, though in a measure lost in the noise of the broken water, tearing and roaring over the rugged rocks. Dippers, indeed, everywhere delight in deep linns and brawling rapids, where their interesting motions never fail to attract the angler and bird student, whose musings suffer not in such feathered company.

In some parts of Scotland this favourite of both poets and naturalists is cruelly shot by keepers and others ignorant of its innocent life, as an enemy to those who practise the "gentle art" on our Highland streams. Writing from the parish of Aberlour in 1836, the Rev. Alex. Wilson takes notice of the Dipper as being 
at that time abundant in the Spey and its tributaries, and also that during the time of spawning it was considered very destructive to the spawn of both trout and salmon. "Formerly," adds Mr Wilson, " any person who succeeded in killing one of these birds was allowed, as a reward, the privilege of fishing in the close season; but for a long time back this has been lost sight of."* Mr Brown informs me that to this day a reward of sixpence a-head is given for Dippers in some parts of Sutherlandshire. I believe it will be admitted by those who have studied the habits of this bird that it feeds almost exclusively on fresh water shells and the larvæ of aquatic insects, and that it is therefore a groundless charge to suppose that it destroys the spawn of fish. Instead of doing harm in this way, it is in fact the angler's best friend by devouring immense quantities of the larvæ of dragonflies and water-beetles-creatures which are known to live to a great extent upon the spawn, and even the newly-hatched fry of both trout and salmon.

The song of the Dipper is extremely pleasing, being heard at all seasons of the year, and, I may add, at all hours of the day. I have stood within a few yards of one at the close of a blustering winter's day, and enjoyed its charming music unobserved. The performer was sitting on a stake jutting from a mill pond in the midst of a cold and cheerless Forfarshire moor, yet he joyously warbled his evening hymn with a fulness which made me forget the surrounding sterility, and imagine that I stood by the fertile banks of the Tyne in East Lothian, where, in boyish admiration, I first listened to the "water pyet's" melodies. On another occasion, also about dusk, when rambling along the margin of the Clyde near Lanark, after the breaking up of a long-enduring frost, I was delighted to hear the familiar voice of a Dipper close at hand, and, on looking round, to find the "sweet singer" perched on a floating block of ice which was somewhat swiftly sailing with the current of the swollen river. Waiting until it had passed me, I had time to observe that his perch was a bit of turf that had become frozen in the block, and that the little sailor seemed hardly conscious of being wafted onwards. The song continued until the tiny iceberg reached a much swifter current, running between two islets in the centre of the river, when the bird, apparently realising

* See New Statistical Account of Banffshire, page 118. 
his change of locality through the walloping motion of the novel craft, sprang with a whirr from his perch, and in another moment was pursuing his rapid flight straight up the stream.

The Dipper is common in the burns of Mull and Islay, and is also met with in the island of Harris, one of the Outer Hebrides, from which locality I have been kindly favoured with a specimen by $\mathrm{Mr}$ Alexander Cameron of Lochmaddy. Mr Elwes has also met with it there.

\section{THE MISSEL THRUSH.}

\section{TURDUS VISCIVORUS.}

DURING the last thirty years there has been a gradual increase of the numbers of this species throughout Scotland. So recently as 1830, it was rather an unusual circumstance to find a Missel Thrush breeding in any locality north of the Tweed. Now, however, it is very common almost everywhere, extending, as I am informed by Mr Brown, to the counties of Sutherland, Ross, and Caithness. At first its breeding haunts were wholly confined to gardens and private avenues, where a variety of tree shrubs afforded it a suitable site; but at the present time the nest is found as often in woods and parks as elsewhere. I have frequently observed the bulky structure placed at some distance from the ground, but always near the main trunk of the tree, or on a strong branch, without much regard to concealment. At other times it may be seen within a few feet of the base, and within reach of prowling animals, which generally manage in such cases to destroy the young ones before they quit the nest.

The materials of which the nest is composed vary greatly. I have many times influenced the birds in their choice by throwing in their way a quantity of wood or paper shavings, moss, or even dried ferns, and have been amused at the readiness with which they took advantage of what had been placed within their reach-handfuls of loose materials being carried away in a few hours, and firmly interwoven by the birds. The nest is much shallower than that of the common thrush, and this makes the bird very easily detected when sitting. As soon as the eggs are hatched, the female becomes very bold in defence of her young, and strikes vigorously at any prowling cat or schoolboy venturing 
near the nest. The male on such occasions is at no great distance, and soon joins his mate, the two making rapid sallies, brushing within a few inches of the offender, and making all the while a harsh, grating noise. I recollect seeing a pair of Missel Thrushes defending their nest against the repeated attacks of two crows, that made a determined assault. The nest was situated in a larch tree, and one of the crows, after making the first attack, flew off to some distance, followed by the disturbed thrush. The second crow then pounced on the defenceless young, and would no doubt have soon destroyed them, had not the other Missel Thrush come to the rescue. Both of the Missel Thrushes then beat off their black assailants, buffetting them with great determination. I was very much interested with the sight, and was glad to see the crows so gallantly repulsed.

About the middle of June the young birds become gregarious, and haunt grass parks, where they pick up snails and other animals, on which they feed. I have seen flocks of twenty or thirty birds collected in this way in various parts of Ayrshire. On being disturbed, they flew at once to the nearest wood, where they had been probably hatched.

Messrs Baikie and Heddle state that this species makes its appearance occasionally in Orkney after strong easterly gales.

\section{THE FIELDFARE.}

\section{TURDUS PILARIS.}

\section{Liatruisg.}

There can be no doubt that the large migratory flocks of Fieldfares which visit Scotland come from the east and north-east. On this account they are first seen in Aberdeenshire and East Lothian. I have often witnessed their arrival in the latter county, having spent many seasons in watching the appearance of our migratory birds. On reaching the coast near Dunbar, for the most part about daybreak, they settle on the Links, and arrange their plumage after their long flight, remaining a few days in the vicinity of the rocks, which they frequent regularly at low tide. Continued frost, especially if accompanied by snow, will afterwards, however, bring them down from the higher ground whither they 
had betaken themselves, and I have observed many hundreds resorting on these occasions to the beach at high water mark, where they appear to pick up small marine animals by digging little holes in the rejectamenta thrown up by the tide. Along this mound, which was covered with a sprinkling of snow, the marks of the Fieldfares had a very curious appearance.

Instances of the Fieldfare breeding in Scotland have been vaguely hinted at by Yarrell in his account of the species, but these appear to want corroboration. Numerous flocks may be seen some seasons as late as May, but these are doubtless birds that have been much farther south, and are now on their return journey. On such occasions, if carefully watched, it will be found that as a large flight passes overhead, the birds, on seeing a suitable field, will wheel round, and, after a short survey, alight, some on the neighbouring fir-trees, where they at once commence pruning their feathers, others on the green sward, across which they hop actively in search of a meal. I have observed hundreds together near Moffat on the 29th of April, and small numbers were seen last year by Dr Dewar, on Loch Awe side, at the foot of Ben Cruachan, in the first week of May.

The Fieldfare is well known on the Outer Hebrides, but does not arrive there until mid-winter; it is chiefly observed in the pasture grounds lying on the west side of North Uist and Benbecula. It is likewise a regular visitor to the Orkneys, a few remaining on these islands all the year, but it has not been known to breed there.

\section{THE SONG THRUSH.}

TURDUS MUSICUS.

Smèorach.

AN abundant species over the whole of Scotland, extending even to the most desolate places.

The Thrush is well known throughout North and South Uist, Benbecula, and Barra by its Gaelic name, Smèorach, and is permanently resident. The nest is found among heath-clad rocks, and in turf walls - trees and shrubs being unknown in these islands. In August and September of this year (1868) I observed numbers of Thrushes in North Uist taking shelter in dry stone dykes, and 
hopping from one crevice to another like disconsolate wrens. I remarked particularly the unusually dark colour of their plumage - the birds being very unlike those brought up in cultivated districts, where gardens, trees, and hedgerows attract this familiar songster and its allies. This species seems more readily to adapt its mode of living to circumstances than any other member of the family. On Ailsa Craig, whence a comparatively short flight would take it to one of the most beautiful and fertile valleys in Scotland, it prefers the society of puffins and razorbills, and makes its habitation among broken masses of rock beside these strange associates. Even at an elevation of six hundred feet on this solitary rock it will remain for months, undismayed by the frequent storms which break upon its lonely haunts. Its nest is sometimes found, too, in the dark caves of Ailsa, whose frowning doorways would deter even hardier birds. In May of the present year two pairs had established themselves in one of these dismal and dripping dwellings, both nests having the usual number of eggs, which were afterwards hatched. Yet even there, in its rocky home, the mavis is not a less interesting or poetical subject than under the "laughing sky" of Northamptonshire, where

"Within a thick and spreading hawthorn bush That overhung a mole-hill large and round,

I heard from morn to morn a merry thrush

Sing hymns of rapture, while I drank the sound

With joy;-and oft, an unintruding guest,

I watched her secret toils from day to day;

How true she warped the moss to form her nest,

And modelled it within with wood and clay.

And by-and-bye, like heath-bells gilt with dew,

There lay her shining eggs as bright as flowers,

Ink-spotted over, shells of green and blue:

And there I witnessed, in the summer hours,

A brood of nature's minstrels chirp and fly,

Glad as the sunshine and the laughing sky."

-John Clare.

Writing of the Thrush in the Hebrides, Mr Elwes says:- "It is extremely common in Lewis and Harris, but not so abundant in Uist. I have often noticed them high up a mountain among the rocks, where there was hardly a bit of heather; and I think they are attracted to these sterile regions by the number of small land shells which are found among the stones." 


\section{THE REDWING.}

\section{TURDUS ILIACUS.}

THIS species of thrush is later in arriving on the west than on the opposite coast of Scotland. On their arrival from Norway and other countries, where they breed, they fly in considerable flocks, remaining, however, only a few days on the sea-coast to recruit, before commencing their inland journey. On the Haddingtonshire coast, I have seen numbers coming in from the sea in company with fieldfares, and settling on the low-lying fields near the beach. At an early hour one morning in the month of October, I recollect seeing quite a swarm of those two species covering the links at Dunbar. They were apparently fatigued, and permitted a very near approach, merely hopping out of the way a little as I walked forward.

In western Scotland, the flocks are not so large, consisting for the most part of a dozen or fifteen birds. These betake themselves to open fields during the daytime, where they feed on grubs and worms, and at nightfall they frequently roost in a group of trees, occupying some exposed situation, unless the weather happens to be very severe, when they are glad to seek the shelter of garden shrubs and bushes. In the memorable frost of 1860-61, great numbers perished during a snow-storm of unusual severity. My friend Dr John Grieve informed me that he had seen at Dunoon, in Argyleshire, twenty or thirty dead Redwings lying huddled together under a laurel bush after the storm had ceased.

The Outer Hebrides are visited also by small flocks of this species, which appears to linger there even longer than it does on the mainland. The late Dr Macgillivray has stated in his work on British Birds, that he has seen specimens on the 25th of May in Harris, the same island on which Mr Bullock had found the Redwing breeding in 1818. This circumstance is mentioned in Fleming's " History of British Animals," the author having been informed by Mr Bullock, in a letter dated 25th April, 1819.

A manuscript note in Mr Dunn's copy of Messrs Baikie and Heddle's work, states that the Redwing breeds in these islands. 


\section{THE BLACKBIRD.}

\section{TURDUS MERULA.}

Lon-dubh.

BLAIR, in his beautiful poem, "the Grave," after describing the pleasures enjoyed by himself and a companion, when wandering heedlessly in some thick wood away from the "vulgar eye," thus introduces the Blackbird and his ally:-

"And sat us down

Upon the sloping cowslip-covered bank Where the pure limpid stream has slid along In grateful eddies through the underwood, Sweet murmuring; methought the shrill-tongued thrush Mended his song of love; the sooty blackbird Mellowed his pipe, and softened every note; The eglantine smelled sweeter, and the rose Assumed a dye more deep; whilst every flower Vied with its fellow plant in luxury Of dress."

But in ushering this fine "negro vocalist" into these pages, I shall not dwell upon his habits in cultivated haunts, these being already familiar to all readers and observers. The life of the merle in the Hebrides has never been associated with verdant woods or beds of roses. There he has no flower-covered lawn or tall poplar tree on which to begin and end the day; he lives but on poor diet, picked from the spray-covered rocks, and sings himself to rest, it may be, on a turf-built wall, or mound of stones in the midst of some desolate moor.

The Blackbird is common at times only in the outer group of islands. On Lewis, although a well-known resident, it is not so numerous as the thrush, but the great improvements near Stornoway will no doubt attract the species more in future, and it may therefore be expected to increase. On Harris it is likewise resident, and also on North Uist, but in very limited numbers; while on Benbecula it is wholly absent in summer, being only a winter visitant. On Iona and Mull it is also a winter bird only; but in some of the other inner islands it is resident. I have found several pairs of Blackbirds on Ailsa Craig; one of these had their nest in a turret hole of the old castle ruins, nearly half way towards the 


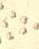

6035

ois s sos

पas? , , ,

$3_{3}^{3} 3^{3}$

$\rightarrow \infty 00$

$3^{3} 3$

3
03

0030 a 370

3 3030

and 0003

a.

$\therefore$ a 3000

$\Rightarrow 30^{3}$

3

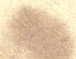




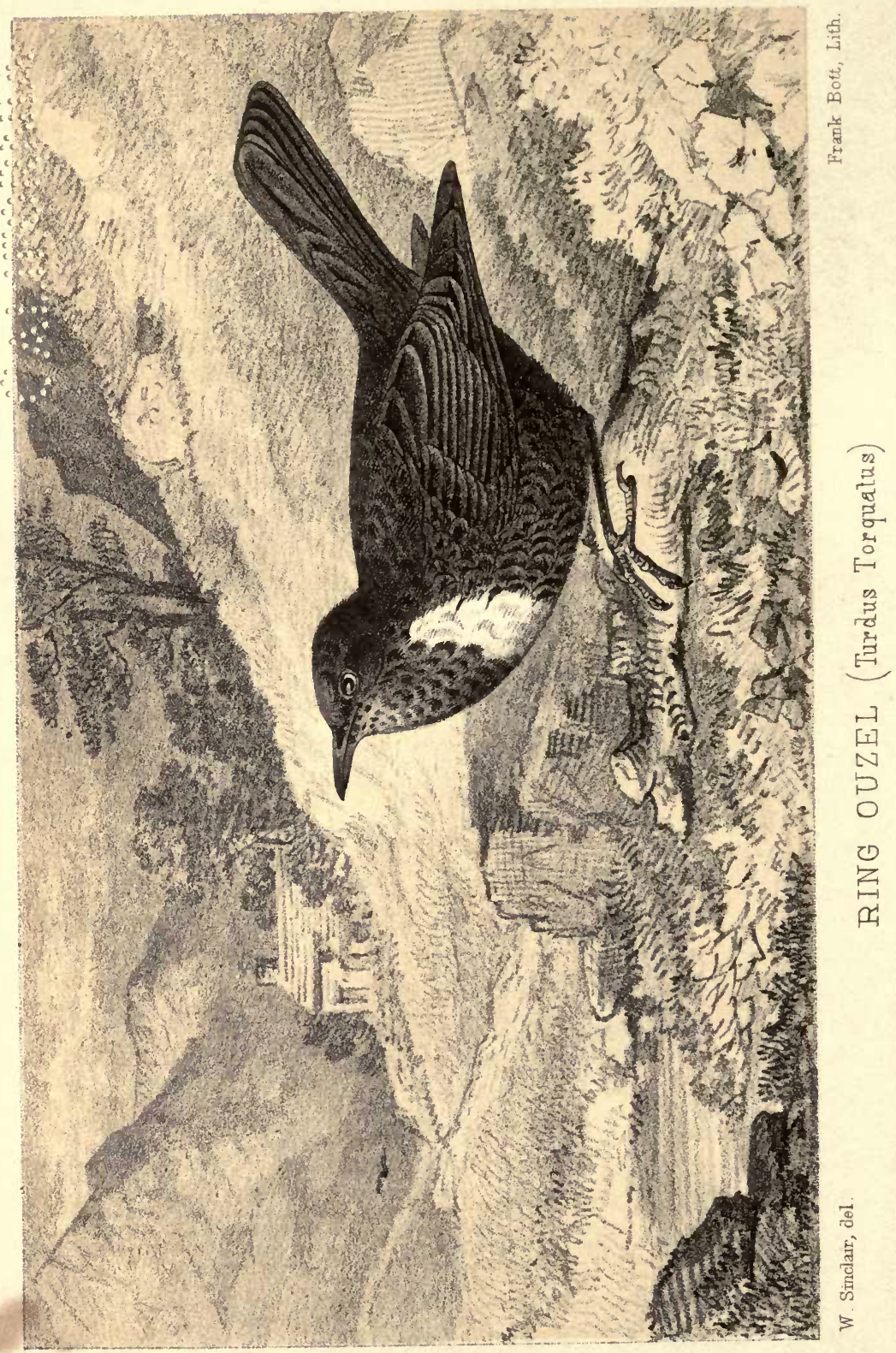


summit of the island. I remember one very hot day in July, hearing a Blackbird sing in a cave there; it had penetrated to the inmost recesses of this dark abode, which must have been a familiar haunt, as on going in to ascertain its extent, I found the bird was able to steer directly out of it, without flitting by side jerks until it regained the entrance.

In some districts of Scotland Blackbirds have of late years multiplied to a great extent; the island of Arran, for example, since the destruction of birds of prey there, has been completely overrun with them.

After the breeding season is over, these birds, in Ayrshire, repair in great numbers to the sea-coast between Girvan and Ballantrae, seeking shelter in hot days under blocks of stone and large flat rocks lying on the beach. On one occasion I turned out eighteen Blackbirds from under a flat rock, resting on broken stones, by poking them with a walking-stick. I have seen sparrowhawks and merlins-apparently aware of this habit-hunting these rocks in vain at mid-day, where the Blackbirds were all concealed, but pertinaciously beating about in the neighbourhood, knowing their quarry to be there, although unable in the meantime to dislodge it.

\section{THE RING OUZEL.}

\section{TURDUS TORQUATUS.}

Dubh chraige.

IN many parts of Ayrshire and Argyleshire, especially wild moorlands where there is a mixture of heath and lichen-covered rocks, the Ring Ouzel is very plentiful in the breeding season. On its arrival in April, it may be seen high up on the mountain sides, perched on some grey boulder, and shifting mysteriously from rock to rock, somewhat in the manner of a wheatear, facing the intruder, and remaining motionless a few seconds, till a nearer approach drives it away. After occupying these haunts about ten days, the male begins his call-notes, which at first are not at all musical; the cry, in fact, is more like the yelping note of a whimbrel, and appears to be exerted only when the bird's haunts are invaded. After the nest is formed, the note of the Ring Ouzel 
gains melody, and has a somewhat wild and bewildering effect on the listener as he stands on the dreary waste of heath.

Numbers of Ring Ouzels breed in Dumbartonshire, Stirlingshire, Ayrshire, Wigtownshire, and a few in the Upper Ward of Lanarkshire. They descend, as the autumn advances, to the lower grounds, where they frequent gardens, and are not in general looked upon as favourites, being then "dingy and tuneless" thieves, devouring cherries and gooseberries with a keen relish, after a six months' experience of their mountain diet. In October they slip away southwards, and leave the West of Scotland at the Mull of Galloway, where young birds occasionally lose their reckoning, and dash themselves against the lantern of the lighthouse.

I have never been able to trace this species on any of the Outer Hebrides, although Mr Yarrell states that Mr Bullock obtained its nest on some of the islands, probably, however, one of the inner group. Mr Elwes informs me that it has been occasionally found in Islay. It is likewise an occasional visitant to Orkney, small flocks having been observed in 1822,1829 , and 1835. Numbers appeared in these islands in October, 1836. These occurrences seem to have escaped Mr Yarrell's notice.

\section{THE GOLDEN ORIOLE.}

\section{ORIOLUS GALBULA.}

The late Dr Fleming mentions, in his " History of British Animals," that he saw a specimen of this bird, which was killed in the island of Arran in 1807; and in the same year another example of the species was taken at Restalrig, near Edinburgh. Besides these instances, mention is made of a third, shot in Berwickshire, in the statistical account of the parish of Cockburnspath, by the Rev. Andrew Baird, who was a very careful and accurate observer. No record of any other Scottish specimen has been made, so far as I know. It may be worth noting here, that a fine Golden Oriole was shot in June of the present year (1868) in the Isle of Man, and taken in the flesh to Mr Hastings, bird stuffer in Dumfries, for preservation.

The habits of so showy and attractive a bird are, of course, not easily studied in a country where the rarer visitors enjoy but a brief existence amid so many watchful collectors. We have, there- 
fore, no opportunity of hearing its richly modulated notes as it sits like a large yellow flower among the green leaves. A friend who has frequently heard it in the forests of Germany lately described it to me as resembling the notes of a flute, changing at times to a querulous, "Ah, how d'ye do?" on hearing approaching footsteps. A different and perhaps less civil construction, however, has been put upon it by a recent contributor to "Chambers' Journal," who remarks that "the song of this splendid bird-a flute-like whistle, with a cadence not unlike speech-sounds ominous to the low German, short of coin; for Hans, drinking before the ale-house door, hears the Oriole sing from the lindens, "Hast du gesopen? so betahl du." "(Hast thou quaffed? then pay)."

INSESSORES.

SYLVIADE.

DENTIROSTRES.

\section{THE HEDGE ACCENTOR.}

\section{ACCENTOR MODULARIS.}

THE familiar hedge-sparrow is everywhere known, from Sutherlandshire to the Mull of Galloway, and on all the Hebrides, except the bleakest islands. On Ailsa Craig even - an isolated refuge, without hedge-rows or any attractive brushwood which make the home of the species unseen in the not far distant valleys of Ayrshireit hops briskly among the broken boulders, and trills its wren-like song among the ungainly guillemots with as much heartiness as if it never knew a more verdant spot. In the dull gloom of one of the numerous caves intersecting that remarkable rock, $I$ have seen the nest of this bird placed in a ledge of rock at the root of a handful of the hart's-tongue fern, the floor of the cave being covered with water, and forming a strange contrast to the site usually selected by the confiding shufflewing near the abodes of men.

From its habit of breeding early in the season, this bird is often robbed of its eggs by wandering schoolboys, who treasure them for their pleasing colour, and in almost all rural districts these young persecutors indulge in the regular habit of prowling along the yet leafless hedgerows, scrubby bushes, or cast-up heaps of winter prunings, where their plunder is only too easy of discovery. 
In our northern climate it is sometimes hard to withhold one's sympathy for this modest little bird, as it sits shivering on the withered sticks among which the nest is placed; frequently, indeed, a sudden change in the weather upsets the teachings of its own instincts by covering its haunts with a carpet of snow, on which it hops in sad wonderment at winter's return, although ready with a cheering note for its sitting mate, the moment the breaking clouds show their silver lining, and the peep of blue sky beyond.

\section{THE REDBREAST.}

\section{ERYTHACA RUBECULA.}

Broinn-dearg.

WHEN the late Mr John Macgillivray wrote his account of the Birds of the Hebrides, he was able to mention but one locality in these islands for this familiar bird, nanely, Rhodil, in Harris. Since that time, however, it has been found in various other places. On the west side of North Uist, it is frequently seen at Paible, and in one or two localities. It is likewise now a common bird in some parts of Lewis, especially in the town of Stornoway and its attractive vicinity, where it may be seen as numerously, perhaps, as in the most fertile districts of Scotland. Drawn thither, no doubt, by the results of the extraordinary improvements that have of late years been effected by the proprietor, Sir James Matheson, it has now become fairly established, and is able to lead a life of pleasure, roaming over the beautifully cultivated grounds of the neighbourhood of the castle, or mounting the height of some Stornoway house-top, whence I have heard the little fellow trilling his morning hymn unseen in the grey dawn.

On all the Inner Hebrides the robin is known as a common bird practising his pugnacious habits, nothing awed by the presence of hawks, or dulled by the absence of other small birds whose society he enjoys in southern haunts. Standing one fine autumnal morning in an old cabbage garden in Mull, where the ground was being turned over, I observed one settling on the limb of a low bush near the gardener at his work. Having espied a worm, he swiftly glided from his perch, lifted his prey without closing his wings, and after alighting on another low twig, de- 
voured what he had got. Cleaning his bill, he chirped a note of satisfaction, jumped down, hopped a few strides, lifted another worm, and disappeared among the bushes, as if he had done something wrong. The hurried movement, however, was very soon explained by his re-appearance in a few seconds, followed by another robin, who at once closed with him in deadly conflict. In the confusion of their movements, of course, I could not tell the one from the other, but I allowed them to settle their battle, which ended in the death of one of the combatants. I could hardly have believed it possible for birds with bills so slender to destroy each other so quickly; they did not fight longer than five minutes.

But although his character for occasional, if not frequent pugnacity cannot be disputed, the Redbreast is in the main a confiding, happy, and contented fellow. Often when other birds are silent and depressed during the tedious weeks of hard weather in early spring, he will mount joyously from his frozen haunts, and, as if

"Proud o' the height of some bit half-lang tree,"

pour out his artless notes so happily, that the listener cannot help wondering at the contentment of the redbreasted philosopher. It must indeed have been the robin of whom a good man lately said-

\footnotetext{
"The bird is your true poet. I have seen him

When the snow wrapped his seeds, and not a crumb

Was in his larder, perch upon a branch,

And sing from his brave heart a song of trust

In Providence, who feeds him though he sows not,

Nor gathers into barns. Whate'er his fears

Or sorrows be, his spirit bears him up.

Cares ne'er o'ermaster him, for 'tis his wont

To stifle them with music. Out of sight

He buries them in the depth of his sweet song,

And gives them a melodious sepulture."
}

I have frequently observed that in the evenings, when the robin sings from a high perch, such as the top of a tree, or the edge of a chimney-can on the house top, one may calculate with certainty on fine weather for next day. 


\section{THE REDSTART.}

\section{PHENICURA RUTICILLA.}

Ceann-dearg.

From its shy and unobtrusive habits, the Redstart, although by no means a rare bird, leads a life of comparative obscurity, and is much seldomer observed by ornithologists than many other species which visit us in fewer numbers. It would almost seem as if it were afraid of its clear contrasting colours proving too great a temptation to the bird-collector, as the male keeps very much out of sight in his ordinary haunts, appearing but for a moment as he darts from the tall hedgerow or ivy-clad wall and hops briskly to the nearest thicket on being observed.

I have not seen this species on any of the Hebrides, but have traced its occurrence in all parts of the western mainland, from Wigtown to Inverness-shire. It visits annually the neighbourhood of Glasgow, and breeds within the city boundaries. Thirty years ago it would appear to have been a much commoner bird in Lanarkshire than it is now. Near Hamilton, according to the Rev. Mr Patrick, it was "exceedingly abundant" in 1835 .

On the east coast it arrives about the same time as the wheatear, perhaps a little later. It is then found near Dunbar, at the seashore, frequenting deserted rabbit-warrens, and flitting among the rocks at low tide; a habit which becomes even more conspicuous after a time when the birds have nested, the male especially being seen perched on a jutting rock watchful and jealous of molestation.

The Redstart is found occasionally in Shetland.

\section{THE BLACK REDSTART.}

PHENICURA TITHYS.

From all I can learn, this species is but a rare straggler in any part of Scotland. Twenty years ago a specimen, said to have been shot in Caithness, was seen by Mr Wilson in the collection of $\mathrm{Mr}$ Sinclair of Wick, and another was obtained at Cullen, in Banffshire, by Mr Thomas Edward, in 1851. A third was shot on 20th December, 1859, at the ruins of the old palace at Kirkwall, in Orkney, by Mr William Reid, now of Pultneytown, Wick, who 
informs me that the bird is still in his collection. These three are the only authentic records of specimens taken in Scotland; but I have been informed by Mr George Kirkpatrick, that in 1858 he found a nest and eggs at Duncow, near Dumfries, which he could not make out to belong to any other than this species. The nest was placed on the ground, on a patch of waste moor, and in structure resembled a yellow hammer's, but was larger; the eggs, five in number, were shining and pure white. The eggs of the Black Redstart are so characteristic, that, when found in a situation like that described, they can hardly be mistaken for those of another species.

\section{THE STONECHAT.}

\section{SAXICOLA RUBICOLA.}

\section{Cloichearan. Clacharan.}

A VERY common species, and in many districts resident all the year, making itself conspicuous by its short, restless flight, and habit of perching upon plants and low bushes, on the topmost stems of which it invariably shows itself when disturbed. Its note resembles the words, "Hey, chuck, chuck," and is more noticeable when the young are hatched than at other seasons. On the coasts of Ayrshire and Wigtownshire, its favourite haunts are sandy fields covered with tall coarse weeds and bramble bushes, among which it lingers through the summer and autumn months. The male is a very pretty bird, looking so dainty in his clean white collar, as he sits calling to the passer-by. Yet there is perhaps no bird in the West of Scotland more suggestive of waste places than the Stonechat. Distributed extensively over all the counties bordering upon the sea, it is often seen frequenting graveyards and other sombre haunts, flitting from stone to stone uttering its clicking or spirit-rapping note, which, in out of the way places especially, is so monotonous and eerie that it begets a feeling which most persons, I daresay, would be disinclined to encourage.

Last autumn, when wandering on the shores of Benbecula, in the Outer Hebrides, one evening towards dusk I happened to draw near the only graveyard on the island, in the centre of which stand the ruins of a Roman Catholic chapel. Hearing the familiar 
clicking of the Clacharan, I looked over the moss-grown wall of boulder stones, and there saw a beautiful male bird of this species on a sculptured urn surmounting one of the few tombstones in this singularly lonely burial-place. Wheeling round on the top of the urn, the little fellow beckoned to me, as I thought, inviting a nearer approach, telling me, however, in very plain bird language, the "gate's shut, shut." I was tempted by the strange look of the inclosure to intrude on the "homes of the dead," and after passing through a rude gap in the wall, I walked up to the spot, and read that a good man lay buried there. The stone, protected by an iron railing, was all but surrounded by desolate weeds; but a deepening glow of purple from the setting sun threw a radiance on the grave none the less impressive as I deciphered the inscription:-

\author{
Sacred to the Memory of \\ NINIAN CLARK, \\ Factor for Colonel Gordon of Cluny's Long Island properties, \\ Who was drowned 4th May, 1843, \\ Aged 38 years. \\ He was much esteemed in life, and deeply lamented in death, \\ by all who knew him. \\ This Tablet is erected by his Beloved and \\ Bereaved Wife.
}

While transcribing these words into my note-book, a large seagull alighted on a turf-covered mound, within a few yards of where I stood, and folded back his neck with the design of remaining there for the night. At this moment the place became invested with a strange solemnity, which made an impression upon me that I can never forget. The sky had become softened into a dark bluish purple, and the fast falling shades brought an unusual sense of loneliness, broken only by the dull sound of the Atlantic breaking on the beach. Sky and sea, indeed, were unlike anything I had ever seen or listened to before. There was no life around save that solitary bird-

" Like an image sitting there

Alone amid the doleful air,

Seeming to tell of some dim union,

Some wild and mystical communion,

Connecting with his parent sea

This lonesome stoneless cemetery." 


\section{THE WHINCHAT.}

\section{SAXICOLA RUBETRA.}

NoT nearly so numerous as the preceding species, though affecting the same haunts by the sea-shore; it, however, approaches nearer to homesteads and farm-yards, being less suggestive as a bird of the waste. It perches more frequently on palings and hedgerows than its congener, and is perhaps quieter and less obtrusive in its habits. As a rule, it is thinly distributed, still it is never absent from places where one would naturally look for it. I have seen it along the shores of Ayrshire, frequenting potato fields, flitting restlessly across the green surface, and perching at times on the plants themselves. Another favourite haunt in the same county is the side of the railway embankment, near Girvan, where I have seen twenty or thirty in the course of a short ramble, hunting in the vicinity of their nests for small beetles which lurked among the clover and grasses growing profusely in the more sheltered cuttings. Sometimes when so engaged, it will neatly perch on a stem of täll grass, and after looking about for a few seconds, resume its hovering and feeding as before. I have often watched this interesting bird feeding its young ones after having left the nest, the family group generally occupying the top rail of some fence conveniently near a good place for insects, where, on warm evenings, they remain for hours perched in a row, each patiently waiting its turn to be fed.

This species is mentioned by the late Mr John Macgillivray, in his list of the Birds of the Outer Hebrides, and it has occasionally been seen in Orkney, although it is not known to breed there. In many Scottish districts it is absent altogether; yet it may be said to range from the border counties to Caithness.

\section{THE WHEATEAR.}

\section{SAXICOLA ANANTHE.}

The appearance of this lively species in the western counties of Scotland is generally unobtrusive, a few pairs only coming at first, until by degrees their accustomed haunts are occupied by the usual numbers. On the eastern shores, however, immense flocks make their appearance suddenly, and occupy for a day or 
two particular localities before dispersing themselves over inland districts. Thus, on Dunbar Links, in the month of March, I have seen them arriving in thousands, and flying before me, in my early morning walks, like bits of sea foam borne by the breeze. The males especially were very beautiful and attractive, from the clearness of their plumage. By-and-by these large flights were broken up into small parties, the distribution of which could be traced by walking inland to some distance on the higher grounds, and watching the restless fellows flitting from hillock to hillock, leaving here and there, as the main body advanced, a few stragglers to people the dry stone dykes of the Lammermoors. I have never seen such arrivals on any of the sea-borders of Western Scotland.

The Wheatear is very abundant in the Outer Hebrides, from Mingaly to the Butt of Lewis, appearing in these islands in early spring, and remaining until late in autumn. There is a very curious superstition prevalent in North and South Uist regarding the bird on its arrival. When seen for the first time in the season, the natives are quite unhappy if it should happen to be perched on a rock or a stone; such a circumstance, as they say, being a sure sign of evil in prospect; but should the bird be seen perched on a bit of turf, it is looked upon as a happy omen. The species is equally common over the whole of the inner group of islands, taking up its abode on many of the uninhabited islets and rocks. It breeds in considerable numbers on Ailsa Craig. In the autumn season certain districts appear to offer temptations for stray birds to prolong their stay, especially some of the higher mountain ranges, whose bleak sides would seem but a poor hunting ground for an insect-feeding bird. I have seen single specimens lingering till October; and on the 11th of that month, in 1866, Dr Dewar informs me that he saw one on the summit of Ben Arnan.

The song of the Wheatear is very pleasing. I have seen males perched on a stone wall begin their warblings with a few modulater notes, accompanied with a pretty motion of their wings, until they fairly burst into joyful utterance and rose into flight, hovering a few feet above the wall, and literally dancing in the air with delight. In hilly districts the nest is chiefly placed in holes of dry stone walls; but on the east coast I have for the most part found it in deserted rabbit-holes, as on Dunbar Links, for example, whence the rabbits are now banished. 


\section{THE GRASSHOPPER WARBLER.}

\section{SALICARIA LOCUSTELLA.}

This very curious bird is apparently more local in its distribution, with the exception, perhaps, of the lesser whitethroat, than any of the other Scottish warblers. It has been traced from the Solway Firth to the Firth of Forth on the east side as a regular visitor, and from Wigtownshire to Loch Lomond on the west. It is also found in some of the midland counties, but I have not been able to trace the migration of the species to a more northern limit than Bonaw, near Oban, Argyleshire. In the Loch Lomond district, it is not uncommon above Tarbet, in a plantation of young larch trees, at an elevation of five or six hundred feet above the level of the loch. The bird is very restless, and is generally heard at nightfall in this plantation, where it at once betrays itself by its peculiar note, which it utters almost without intermission until daybreak. By taking up a favourable position, the observer may usually see the birds come to the outer twigs of a thick bush and wheel round and round, shivering their wings, and making the still air ring with their strangely monotonous concert. I have frequently found young broods dispersed when but half-fledged, from which circumstance I have thought that they quit the nest much earlier than most birds. On such occasions my search for the young warblers was very perplexing, their chirpings coming from all sides with a most bewildering effect.

Mr Oliver Eaton, Kilmarnock, has informed me that this bird has appeared regularly early in May in all the plantations near that town for the last twenty years.

\section{THE SEDGE WARBLER.}

\section{SALICARIA PHRAGMITIS.}

The Sedge Warbler is a very common species in many parts of Scotland, but especially abundant in the western counties extending from the south of Wigtown to the north of Argyle. It is by no means uncommon even in western Inverness and Sutherland. In numbers it appears to rank next to the willow warbler, which enlivens almost every county with its well-known and cheerful song; and throughout the short summer nights, when all other 
birds, save perhaps the skylark, are hushed, it appears to take a pleasure in hurrying over its vigorous batch of notes with as much vivacity as if instigated by the most brilliant sunshine. I have heard this bird singing briskly at all hours of the night in the neighbourhood of Glasgow, especially on the banks of the Kelvin, and on the fringed edges of quarry holes, which are certainly far from inviting to a bird of its lively habits. It is found, perhaps, nowhere more numerously than on the banks of the Water of Girvan, in Ayrshire. Frequently, when fishing on that stream, I have observed one of these warblers threading his way quietly through an alder thicket by the water side, peeping inquisitively at times as he halted a moment on the outside before flying to another bush. Just as he saw he was recognised, he would pour forth a volley of strains not unlike the mild twitterings of a swallow, changing the notes all at once to the pink pink of an angry chaffinch, or the cherk of some impudent cock-sparrow; then he would dart to the summit of the bush, and show off his full powers of mimicry, like a little feathered Merry Andrew, dancing on his pliant perch, and wheeling round so comically that nothing in bird-life could be more diverting. But ordinarily he courts solitude in the thickest shrubs, generally beside some marsh or deep river-pool, remaining in these silent places for many hours without indicating his presence. Occasionally, however, he may be tempted into a musical performance, by the observer throwing a stone into his haunts. At first a low churr is heard, succeeded by chip chow cherry, then off he sets into the drollest imitation of the notes of his every-day associates, at the end of which he jumps to the top of the bush, causing the onlooker to wonder how so slender a little fellow could have furnished an entertainment so varied.

The nest of this species is generally placed in a low bush, within eighteen inches or two feet from the ground. It is somewhat oblong in shape, and the structure is deeper than that of the common whitethroat. Mr Sinclair showed me two nests last summer in a wood near Inverkip, Renfrewshire; they were close to the public road, and were each built in the crowning tuft of an old whin bush. We measured the height of both from the ground, the one being five feet, and the other two inches less. In these cases the tall bushes, having their stems bare to a height of two or three feet, moved freely when rocked by the wind. 
The Sedge Warbler frequents the island of Mull in limited numbers, and will perhaps be found in Skye, especially on the eastern side, where there is but a short separation from the mainland of Inverness; it is also found sparingly in Islay, as I have been informed by Mr Elwes, but is not, so far as I am aware, ever seen in any of the Outer Hebrides.

\section{THE REED WARBLER.}

\section{SALICARIA ARUNDINACEA.}

THIs species, which, in its geographical distribution, appears to be confined to the continent of Europe, is a very rare bird in Scotland. My only authority indeed for introducing it into this volume is my correspondent, Dr Turnbull, of Philadelphia, who has stated in his little work on the "Birds of East Lothian," that it is sometimes seen in that county, and that it has also been seen in the neighbourhood of Bathgate, in Mid-Lothian, where it breeds.

Not having met with this bird in its natural haunts, I must refer to the observations of others. The best account of its habits I have yet read is to be found in Mr Stevenson's admirable volume on the "Birds of Norfolk." "This species," says that very pleasant writer, "like the sedge warbler, is an incessant songster, heard at short intervals throughout the day, except in windy weather, but saving its choicest music for the twilight hours. Its lavish notes are thus associated in my mind with many a calm summer's night on the open broads, the stars shining brightly overhead, and the soft breeze sighing through the rustling reeds, mingled with the hum of insect life on the water. It is at such times that the song of these marsh nightingales is heard to perfection. All is still around save those murmuring sounds that seem to lull to sleep; the barking of the watch-dog has ceased in the distance, and the hoarse croak of the coot or the moorhen harmonizes too well with the scene to startle with its frequent repetition. Presently, as if by magic, the reed-beds on all sides are teeming with melody; now here, now there; first one, then another, and another of the reed-birds pour forth their rich inviting notes, taken up again and again by others, and still, far away in the distance, the same strain comes back upon the breeze, 
till one is lost in wonder at their numbers, so startling to the ear of a stranger, so impossible to be estimated at all during the day."

Mr Stevenson describes a number of the pensile nests of this species taken in a garden near the river-side; one of these was hung in a currant-bush, and had several rich clusters of fruit hanging over it. The structure is generally suspended between three reeds, but sometimes two or four. One mentioned by $\mathrm{Mr}$ Stevenson had even five stems interwoven through the nest.

OBs.-The nightingale (Philomela luscinia) is believed to have been met with in at least two instances north of the Tweed. The first is thus alluded to in Macgillivray's British Birds:- "In a letter with which I am favoured by Mr Robert D. Duncan, is the following notice:- ' The nightingales arrived in Calder wood, in West Lothian, in the early part of the summer of 1826. I cannot remember so far back, but creditable eye and ear-witnesses, on whose testimony implicit reliance may be placed, gave me the information. Before and about midnight, while the full moon shone bright and clear, the superior warble of the male was first heard, which soon attracted a number of admiring individuals, who hastened to the spot, supposing it at first to be a scapecanary. The owner of the wood was extremely anxious to preserve them, thinking, perhaps, that they might propagate; but with all his care and attention, some malicious and selfish individuals attempted to take them with bird-lime, but failing in their efforts, they afterwards shot the male, upon which the female left the wood.'" In this case it is possible that some other bird, such as the sedge warbler, black cap, or garden warbler (although the two latter do not, so far as I am aware, sing at midnight) may have been mistaken for the nightingale, and that the lateness of the hour, not to speak of the "full moon," may have helped the deception. The second instance is given in Turnbull's "Birds of East Lothian," wherein it is stated that the nightingale was heard near Dalmeny Park, Mid-Lothian, in June, 1839.

In the belief that migratory songsters returned to their native haunts in the breeding season, an attempt was made, many years ago, by Sir John Sinclair of Ulbster, Baronet, to introduce nightingales into Caithness-shire, by placing eggs which had been transmitted from the neighbourhood of London, in the nests of robin redbreasts. The foster parents managed satisfactorily to 
bring up the young nightingales, which for some time afterwards were observed flying about in the vicinity of their birthplace. In September, however, in obedience to their migratory instincts, they quitted their northern home, to which they never returned. Perhaps they were right.

\section{THE BLACKCAP WARBLER.}

\section{CURRUCA ATRICAPILLA.}

THIs species, though nowhere numerous, appears to be widely distributed from near Cape Wrath to the shores of the Solway. In the intervening districts, especially those where leafy woods and roadside thickets are sufficiently sheltered for the encouragement of bird-life, the Blackcap is a well-known and welcome summer visitant. Being a bird of comparatively hardy constitution, it does not seem so anxious about leaving us at the end of the season as other migratory warblers, which observe the dates of their arrival and departure with some regularity, and we consequently find it flitting about among the half-withered leaves long after signs of winter have appeared. The lateness of its stay is no doubt owing to the circumstance of its feeding on autumn fruits, such as rowans and elder berries, when insect prey is no longer to be obtained. It has even been observed and procured so late as the 8th of November, in Caithness, the most northerly county in the Scottish mainland. At a meeting of the Royal Physical Society of Edinburgh, held on 22d January, 1862, Dr Smith exhibited two specimens which had been shot near Wick by the late Mr H. Osborne, a male on the 16th October, and a female on the 28 th, respecting which the following notes were contributed by Mr Osborne. After referring to the late stay of the birds in a district so far north in Britain, he thus proceeds:- "With the exception that the male was not in song, both birds were as active and lively as they are described to be in midsummer, and both too were in perfect plumage. I have observed, in cases where the swallow has prolonged its stay with us until far on in the season, that there was an evident lack of that liveliness, vigour, and power of flight displayed, for instance, in the month of June; but no such peculiarity was observable in the Blackcaps. This, for the most part, perhaps, may be owing to the fact that the Blackcap, 
when insect food is scarce, can subsist on the smaller fruits, while the swallow is wholly insectivorous, while under my own observation the Blackcap fed principally on the berries of the mountain ash."

\section{THE GARDEN WARBLER. \\ CURRUCA HORTENSIS.}

According to Mr Selby, the Garden Warbler is found over the greater part of Scotland, but I am disposed to think that it is not commonly distributed. It is, however, very difficult to judge of the comparative numbers of so shy a bird, as it is even less frequently noticed, save by the patient observer, than some other species of greater rarity. In the sheltered and wooded districts of the midland and southern counties, it is one of the most attractive songsters, tuning its loud yet gleeful pipe on the top of some fruit-tree, an hour or two after daybreak, and again about the dusk of the evening. These love notes, however, are not of long continuance, for the bird becomes silent after the young are hatched, unless a second brood is reared, when the same wild yet mellow, blackbird-like song is again for a short time heard.

Mr Sinclair has observed the Garden Warbler at Inverkip, Renfrewshire, where the richly wooded preserves afford it a constant shelter during its summer sojourn. His attention was arrested two or three summers ago by hearing the song of the male in one of the village gardens, and also from the summit of a cluster of trees near the railway station. Being an exceedingly timid creature, it is easily alarmed; even when in full song, it will stop suddenly on hearing the slightest noise or disturbance, and drop at once almost to the ground, where it quickly threads its way out of sight among the bushes or tangled herbage.

Like the preceding species, the Garden Warbler freely partakes of small ripe fruits, such as currants, etc., as a change from its usual insect food.

Dr Saxby mentions that a specimen of this bird was obtained at Baltasound, Shetland, on 30th September, 1861. 


\section{THE COMMON WHITETHROAT.}

\section{CURRUCA CINEREA.}

THE lively Whitethroat, or whishey whey beard, as it is called in many parts of Scotland, is one of the most familiar of our summer visitants. In the western counties it is particularly common, arriving early in May, and frequenting thickets and hedgerows until September. On its arrival, and for some time afterwards, it appears to be much livelier and more obtrusive in its habits than it is later in the season; all day long the male may be seen starting to the outermost twigs, and, with crest erect and puffedout throat, keeping up an earnest but somewhat harsh chattering by way of a song. Occasionally he varies his movements, by rising into the air full of musical intention, and for a while vainly trying to rival other choristers, but these attempts soon subside, and the capering little fellow comes whirling down to the very spot from which he so pretendingly mounted, and skulks at once into the thickest part of the hedge, as if half-ashamed at his failure. I have frequently observed that a pair of Whitethroats will select at the beginning of the season a portion of a hedge in some unfrequented by-road, and remain there until the first brood is hatched, and the young ones able to shift for themselves.

The Whitethroat appears to have occurred once or twice in Orkney and Shetland. Mr Graham informs me that it is found in Iona, and Mr Sinclair has traced it beyond Loch Sunart, in Inverness-shire. It is, so far as I am aware, wholly unknown in the Outer Hebrides.

\section{THE LESSER WHITETHROAT.}

\section{CURRUCA SYLVIELLA.}

The Rev. William Patrick, whose little work on the Indigenous Plants of Lanarkshire, proves him to have been a careful observer, mentions, in the Statistical Account of the Parish of Hamilton, published in 1838, that the Lesser Whitethroat was at that time common near the town of Hamilton. It is now, however, doubtful if the species is common in any part of Scotland. It is sparingly met with in some parts of Ayrshire, Renfrewshire, and Dumbarton, and extends to the middle of Argyleshire, but beyond 
that I have not been able satisfactorily to trace it. On the east coast it is equally local and uncertain in its appearance. Dr Turnbull includes it in his "Birds of East Lothian," as a very rare visitant. In that county it had previously been observed by my friend Archibald Hepburn, Esq., one of the most observant ornithologists Scotland has yet produced. He communicated his notes on the habits of the species, as observed by himself, to Professor Macgillivray, in whose larger work on birds they were published.

Dr Saxby has found the Lesser Whitethroat in Shetland on several occasions, but I have no record of it from counties on the mainland north of the Forth.

This bird is much less demonstrative in its habits than the preceding species, passing a comparatively quiet life in the hedgerows, which it enlivens by its sweet and simple strains. $\mathrm{Mr}$ Hepburn states that in East Lothian it frequents wheat and bean fields, devouring great quantities of aphides, and thus proving itself a useful friend to the farmer. $\mathrm{He}$ has also seen it freely devouring red currants.

No trace of this species has yet been discovered in any of the Inner or Outer Hebrides.

\section{THE WOOD WARBLER.}

\section{SYLVIA SYLVICOLA.}

Although a much less common bird with us than the next species, the Wood Warbler is a familiar and well-known visitant to the woods and thickets of the southern and midland counties, extending to the north of Argyleshire, in all of which districts it breeds. I have myself obtained the nest in the immediate neighbourhood of Glasgow, and it has also been taken by Mr Sinclair in Inverkip Glen, Renfrewshire. Mr William Hamilton informs me that he has found the nest at Minard, on the banks of Upper Loch Fyne, and Mrs Blackburn, in her Book of Drawings of British Birds, mentions having met with the bird on the banks of Loch na Nuagh, in Inverness-shire, which is perhaps the most northern locality for it on the west coast. Mr Hepburn informs me that, in 1847, he found it in considerable numbers about the Falls of Foyers, in the same county. In the eastern counties its distribution is even 
more extended, Mr Edward having found it in Banffshire. $\mathrm{Mr}$ A. G. More states in the "Ibis," that the Duke of Argyle had likewise observed the species at Balmoral. Mr Angus informs me that in Aberdeenshire it is so rare that he has never seen it in any local collection. He has, however, procured several specimens himself in that county; one at Fyvie Castle in 1862, where he took the nest and eggs, and a pair which he shot on the 19th May, 1866, in the pleasure-grounds at Warthill. He has also observed it at Fetteresso, in Glentanner Forest, in the Den of Leggat at Banchory Ternan, and at Parkhouse.

\section{THE WILLOW WARBLER.}

\section{SYLVIA TROCHILUS.}

THE most careless observer, whilst walking in the country about the time the buds are appearing, cannot fail to remark this lively little bird - one of our earliest summer visitants - as it flits briskly on every tree piping its little batch of pleasing notes. In our northern climate it is cheerful indeed to hear the happy song of so delicate a little creature, and see his slender figure threading the intricacies of the half-clad twigs; and as soon as we know that the Willow Warbler has come, we may feel sure that summer is not far distant. There is something almost magical in the suddenness with which our woods and hedgerows become peopled by these early migrants; we pursue our walk over a certain course, and having finished a day's ramble in the certain belief that no warblers have yet visited the long rows of hedges and plantations we have passed, we are surprised next morning to find hundreds darting about among the branches and twigs, making the very tree tops sing with joy. Every ornithologist welcomes the little fellow with as much interest as he does the cuckoo or swallow, and rejoices in its salutation of pent-up notes, which are uttered as if in gladness after a long and somewhat hazardous journey to our shores.

I have found the nest of the Willow Warbler in Shemore Glen, Loch Lomond-side, at a considerable elevation, and placed in the grass among tufts of heather, the structure in these cases being lined with the feathers of black game, grouse, and pheasants. This bird is also found breeding in great numbers in Inverkip 
Glen, Renfrewshire, but not so far above the sea-level. Some of the males on their arrival are very dingy in appearance, contrasting curiously with the sedge warbler, which is then brightest in colour.

From a manuscript note in Baikie and Heddle's work, I find that the species is occasionally found in Orkney. A solitary specimen was taken in 1847, as early as March. With us it seldom appears before the first week of May. I have not been able to trace it on any of the Hebrides.

\section{THE CHIFFCHAFF.}

\section{SYLVIA RUFA.}

ThIs warbler appears to be very local in most parts of Scotland. It is not uncommon in roadside plantations near Glasgow, and a few also visit the district of Loch Lomond. Deeside and Braemar are localities mentioned by the late Dr Macgillivray in his Natural History of Deeside, which was printed by command of the Queen, but in that district it appears to be rare. According to Dr Turnbull, it is also rare in East Lothian. Mr Anderson has procured specimens at Girvan, in Ayrshire; and Mr Brown informs me that it breeds in Dunmore grounds, Stirlingshire, and that he had seen its nest, taken in 1866 by Mr Thompson, who believes that it nests there regularly.

Writing from Aberdeenshire, $\mathrm{Mr}$ Angus states that on the 8th of May, 1865, he received a Chiffchaff, very much destroyed by shot, from Birse, Deeside, and that in May of the year following, he observed this species near Aboyne Castle. He noticed it again in June, 1867, at Ward House. The species has, according to Mr Shearer, been seen for two successive seasons near Wick, in Caithness-shire.

In the Outer Hebrides, the Chiffchaff frequents Rhodil, in Harris, as I have been informed by $\mathrm{Mr}$ Elwes, who procured a specimen there in May, 1868.

A manuscript note in Baikie and Heddle's work mentions the occurrence of a single specimen in Orkney in 1850; and Dr Saxby also includes the species as "rare" in his Shetland lists. One was seen by that excellent observer in 1864, so late as the 21 st of November. 


\section{THE GOLDEN-CRESTED WREN.}

REGULUS CRISTATUS.

In all the older records of Scottish ornithology the various writers seem to agree as to the fact of the gold-crest having been a very scarce bird sixty or seventy years ago. Nor can this be wondered at when it is considered that the numerous fir plantations now beautifying the borders of our lakes and covering our hills with their tall green spires could hardly then have been in existence. But as these have increased in extent, and become the chosen abode of gold-crests during the breeding season, the birds have multiplied greatly, and in many places are now permanently resident. Yet vast flocks appear to leave us in antumn. About the end of September they make their appearance in the Wigtownshire woods in great numbers, and gradually travel southwards till they get to the Mull of Galloway, where they linger until a fitting opportunity occurs for taking their departure. On rough nights about this time, and in the beginning of October, they sometimes come back to that promontory in a bewildered state, and flutter in crowds upon the lantern of the lighthouse. One of the keepers-Mr M'Donald-showed me numbers of them when I was last there, and informed me that it was the commonest visitor they had. Wherever their destination may happen to be, they do not return by the same route; but in the east of Scotland large flights of them make their appearance suddenly in April, and actually swarm in some parts of Haddingtonshire. I have seen them arrive at Dunbar about day-break, and, immediately after reaching the shore, cling to the rocks and walls searching for insects. In such cases they were exceedingly tame after their long and fatiguing flight, and allowed me to get within a few paces. On one occasion I actually covered one with my hat. Having rested an hour or two till the flowing tide obliged them to shift to higher ground, they would then betake themselves to the nearest gardens, where they literally covered the trees.

In autumn similar flights are observable coming from the surrounding country coastwards, and congregating in gardens as before. I recollect seeing a very large flock at this season in 1847. The little creatures took possession of a cabbage plot, and looked more like a swarm of bees than a crowd of birds. On every plant 
there were half-a-dozen or more perched, some busied in looking for insects, others bathing in the rain water which had collected on the broad leaves. I walked through the plot, and with a butterfly net caught ten or twelve specimens. Some of these lived in confinement for a fortnight, and were supplied regularly with insects. They became tame almost immediately, and were allowed the full use of an attic room facing the sea which they had intended crossing. They frequently perched on my hand when held out to them, and were most interesting pets; but a single night's frost killed them all. I have repeatedly since observed this fatal sensitiveness to frost when in a state of captivity, but I cannot learn whether they have naturally a delicate constitution.

I have not traced this diminutive bird to the Outer Hebrides, but I have no doubt it will yet be found in one or other of these islands-especially in Lewis, where the fir plantations near Stornoway must ultimately attract the species. It is frequent in Skye and Islay, and probably in many of the other Inner Hebrides where larches have been freely planted.

\section{THE FIRE-CRESTED WREN.}

\section{REGULUS IGNICA PILLUS.}

VERY little can be said of the fire-crest as a Scottish species. Its occurrence, indeed, in any part of Britain, has chiefly been noted in the southern and eastern counties of England, ranging as far as Durham; and the only specimen killed north of that district is the one referred to in the "Birds of East Lothian," by Dr W. P. Turnbull. It was shot by the author himself in Gladsmuir woods in the summer of 1848 . It appears to be totally unknown in western Scotland.

\section{THE RUBY CROWNED WREN.}

\section{REGULUS CALENDULA.}

IN the summer of 1852 , Dr Dewar of Glasgow shot a specimen of this North American species in Kenmore wood, on the banks of Loch Lomond. The bird was exhibited at a meeting of the Natural History Society of Glasgow, on 27th April, 1858, and identified by me. Dr Dewar stated that he had found it in com- 
pany with a large flock of gold-crests, and that ne had shot a dozen birds altogether before he recognised the difference this one presented. Dr Bree, in his work on the "Birds of Europe," states that the Rev. H. B. Tristram has a ruby crowned kinglet in his possession, which was given to him in the flesh, and which was killed by a Durham pitman in 18.52, in Branspeth woods. This circumstance is in favour of the surmise that a migratory flock of these diminutive birds may have been driven out of their ordinary line of flight, and have come probably through prevalent westerly winds in the direction of Greenland, from the south of which they could travel by stages vic Iceland and the Faroe Islands, etc., to our shores.

Wilson, in his description of the habits of this bird, states that in the autumn they are particularly numerous in some parts of North America, associating with the different species of titmice and golden-crested wrens, and frequenting orchards, feeding upon small black-winged insects which at that season infest apple trees. "I have," he continues, " often regretted the painful necessity one is under of taking away the lives of such inoffensive, useful little creatures, merely to obtain a more perfect knowledge of the species, for they appear so busy, so active and unsuspecting, as to continue searching about the same twig, even after their companions have been shot down beside them. They are more remarkably so in autumn, which may be owing to the great number of young and inexperienced birds which are then among them; and frequently at this season I have stood under the tree, motionless, to observe them, while they gleaned among the low branches, sometimes within a foot or two of my head. They are extremely adroit in catching their prey; have only at times a feeble chirp; visit the tops of the tallest trees, as well as the lowest bushes; and continue generally for a considerable time among the branches of the same tree, darting about from place to place, appearing, when on the top of a high maple, no bigger than humble bees."

I have no doubt this species will yet turn up in some numbers in such places as the dense thickets of fir adorning some of our highland lochs and mountain sides. It is not easy to settle the question unless by wholesale slaughter, which no right-minded naturalist, I think, would wish to see tried. 
IXYESSORES.

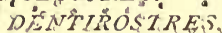

\section{THE GREAT 'TIT.}

\section{PARUS MAJOR.}

THE very remarkable note of this bird, which is extremely loud in spring and early part of summer, has obtained for it the name of "Jacksaw" in many parts of the country; it resembles the noise made by the action of a file upon a saw, and is nttered generally from the height of some tree-top, where the performer jumps about from twig to twig, sharpening his saw with so much energy that one may be readily enough deceived as to the origin of the sound. It rarely happens that two or three of these birds are seen in company. The Great Tit, indeed, differs in this respect from the rest of his clan, and appears to be somewhat unsocial in his habits, travelling for the most part alone, and ranging through woods and gardens without staying above a few seconds in any particular place. All his actions, however, are characterised by a celerity of movement which is always attractive, and as he is invariably well dressed and cheerful in his habits, he may be called a general favourite.

The nest of the Great Tit is often found in stone walls, always at or near the top; also in holes of trees, which in most instances are decayed and easily excavated, so to speak, by the birds themselves. The species, which is permanently resident, appears to be generally distributed, but becomes much less common as we travel north of Argyleshire. It is never seen in any of the outer islands, although from the fact of such a bird as the chiffchaff making its appearance in Harris, we may reasonably look for more than one species of tit. Dr Saxby states that it has been seen in Shetland, although it is of extremely rare occurrence there.

A very unusual charge against this bird is made by Dr Walker (at one time Professor of Natural History in Edinburgh University), in his "Essays on Natural History,"* published in 1808. He states that the ox-eye (Parus major, Linn) "is a notorious beeeater, and has been known to depopulate almost a whole hive." 


\section{THE BLUE TIT.}

\section{PARUS CERULEUS.}

An Snoileuin.

LIKE most of the tits, the "blue cap" is perhaps more conspicuous during the winter months than at any other season. Travelling in merry companies, this species may be seen scouring the leafless trees, hanging at times from the outermost twigs in all sorts of grotesque attitudes, and darting away one after another, as the last of a row has been examined, to some other field of investigation. The cry of the little fellow when so occupied is generally a lively single note; but at other times when not so busy, especially in spring, when these parties break up into smaller groups, the note is suggestive of a light-heartedness which reminds one of opening buds and that pleasant blush of green on the hedgerows which tells of the coming summer. It has been likened to heef birr, as the bird takes breath in the midst of an insect ramble, or chicka chicka chee chee as he darts into a hedge after a short flight. In orchards the blue cap often eats small apples which are left after the gathering of the fruit, and which have become exposed when the trees are bare of leaves; but in the dead of winter it will eat almost anything it can tear with its bill. Beef bones laid outside a window are very attractive, and it is amusing to see the successful way in which so small a creature manages to pick off every morsel of flesh adhering to them.

On two different occasions I have seen nests of this species entombed in trunks of trees that at one time had contained hollows with an external opening, but had been closed by the growth of the bark; one of these contained the remains of eggs, and was thought to have been enclosed for about twenty years; the other had also eggs in it, but contained, besides, the skeleton of their owner and all the quill feathers sufficient for the perfect recognition of the species. There were seven or eight inches of solid wood all round this nest, which had probably been entombed for a period of fifty years.

Strange places are sometimes selected by this little bird for nest building. A friend lately told me of one that had constructed its habitation in a letter box nailed behind a door by the roadside in the country for the convenience of the passing postman. Being made aware of the circumstance, the owner of the box had the 
nest pushed aside to one corner without disturbing the bird, who did not seem at all put about by the daily intrusion of the letters; but like other pets, it had been too good to live, as one unlucky morning the poor bird was found dead in the box, having been crushed by the weight of a newspaper. The result of an inquest in this case would probably have been a verdict that the Tit hall succumbed to the pressure of the Times.

A specimen of this bird-the only Tit yet noticed in Orkneywas procured at Kirkwall in 1845, and Dr Saxby includes it in his list of the birds of Shetland.

\section{THE CRESTED TIT.}

\section{PARUS CRISTATUS.}

THE only breeding places in Scotland for this, perhaps the most local of all the British tits, appear to be confined to the counties of Moray, Ross, and Inverness. Its distribution in winter and spring is somewhat more extended, as specimens have been obtained as far south as Perth. Dr Saxby has informed me that he saw a number of these birds in February frequenting a group of Scotch firs near Edinburgh, about six years ago, and that he also saw two early in April, 1858, in the woods at Blair-Drummond, in Perthshire. In Macgillivray's "British Birds," mention is made of a specimen that was shot in 1838, near Barcaldine House, Argyleshire, the only one I have heard of being found in any of the western counties, except that referred to by Dr Smith (who exhibited the bird) at a meeting of the Royal Physical Society of Edinburgh, held in January, 1857; it had been taken some years previously in the neighbourhood of Dumbarton, in a glen popularly known as Lot's Wife's Glen, so called from an ancient standing stone having suggested a certain incident in Scripture history.

In some seasons this bird is much more plentiful than in others, but it is doubtful if the increase in any particular year can be attributed to a natural extension of its distribution; it probably arises from the arrival of migratory flights from other countries.

Sir William Jardine states, in his " Birds of Great Britain," that Lieutenant Chauner had informed him "that he had several times seen the bird brought fresh into Glasgow, killed in a plantation of 
fir not far distant." I have never, however, been able to trace it in any part of Lanarkshire during the last twenty years.

\section{THE COLE TIT.}

\section{PARUS ATER.}

Cailcheag cheaun dubh.

In the outskirts of Glasgow, especially in the time of winter, the Cole Tit is even more frequently met with than any of its congeners. Wherever there is a patch of fir plantation on the roadside, it may be found in company with gold-crests, flitting silently among the boughs, and diligently ransacking any little cavity in the stems of trees in which it is likely to find insect prey. On Loch Lomond-side, where the species is very abundant, I have seen six or eight at a time clinging to a moss-grown wall, and scattering, with amusing dexterity, the little green tufts under which the insects were concealed. Sometimes one would alight on the ground to pick up what had fallen, and remain there for a time hopping briskly along the footpath, devouring as it went the fragments of what had been dislodged by its companions overhead. It likewise frequents all the wooded islands on the loch, and is sure to make its appearance swinging at the end of some pliant twig, and hailing the presence of a visitor with a lively bir $r-r-r$. Throughout the western counties the Cole Tit is one of the most familiar of the smaller birds, extending to Sutherlandshire; but apart from woods in Mull and Skye, I am not aware of any localities for it in the inner group of islands. It is, of course, unknown in the Outer Hebrides.

\section{THE MARSH TIT.}

\section{PARUS PALUSTRIS.}

Although all our tits are of extremely restless habits, and are therefore found roaming in foraging parties even across districts where they are not usually resident, it does not appear that this species is so widely distributed in Scotland as its allies. Mr Macgillivray mentions that he had never heard of its being found north of Fifeshire, nor can it be said to be a resident in all the counties south 
of that district. It seems, in fact, a very local species, and is less given to shifting about than the Cole Tit or the Blue Tit.

In Mr A. G. More's paper, published in the Ibis, Perthshire, Aberdeenshire, and Inverness-shire are mentioned as counties in which this bird has been found breeding, the most northern breeding haunts being Inverness, so that the range of the species extends considerably beyond the limits formerly assigned to it.

So far as I have observed, the name Marsh Tit has been misapplied, at least a more appropriate one might have been chosen, as the bird does not confine itself to marshes or moist places. Writing from the Upper Ward of Lanarkshire, Mr Alston informs me that, though not so numerous as the preceding species, the Marsh Tit is not uncommon in his neighbourhood, and nests there regularly, frequenting natural birch woods and pine plantations; and I have also been informed by Mr Brown that in autumn he has seen numbers threading their way through the bushes within the policies of his residence at Dunipace, in Stirlingshire.

\section{THE LONG-TAILED TIT.}

\section{PARUS CAUDATUS.}

THIS singularly restless little bird is tolerably common in many parts of the West of Scotland, but is more noticeable in winter, when flying in numbers alongside the bare hedgerows, than in summer, when it betakes itself to the woods. It is, perhaps, nowhere more common than in the neighbourhood of Loch Lomond, where I have seen, I may say, hundreds in the course of a day's walk. In the dead of winter they traverse the hawthorn hedges with amusing quickness, always keeping before the pedestrian, and bounding away in flitting groups, alighting every fifteen or twenty yards, and repeating their movements when approached. I remember one breezy day in October of seeing great numbers at Luss on the march in this way, and of being struck with their curious appearance on wing, apt as they were to have been mistaken for leaves blown off the twigs. Flights like these are occasionally seen in the outskirts of Glasgow. Once or twice I have observed busy companies searching the trees near some of the streets, moving briskly from one tree to another as if they meant to examine hundreds before nightfall. On these occasions they are easily 



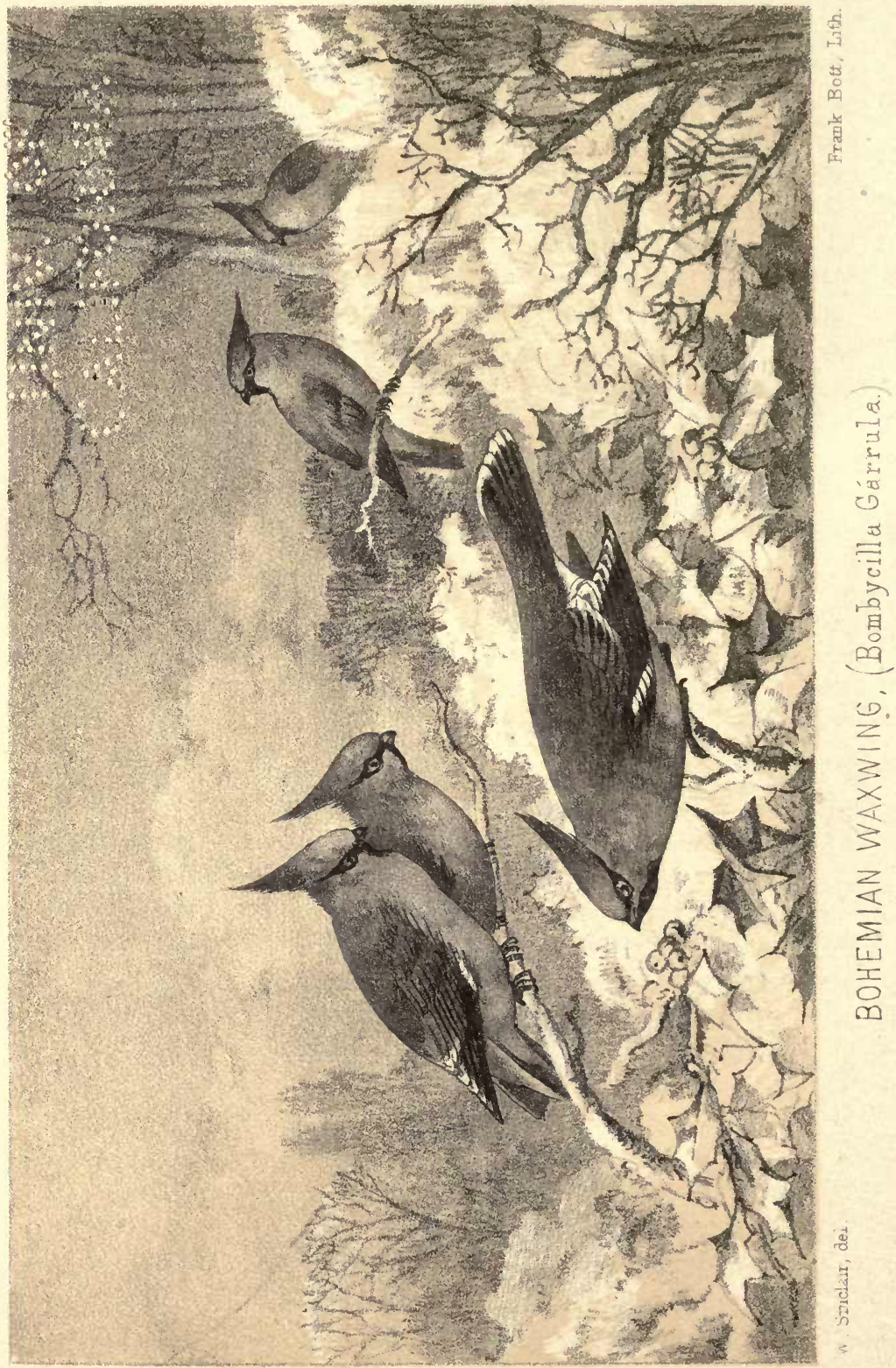


known by their call-note, which is plaintive, yet shrill, and quite in keeping with the slender figure of the bird. It is found also on some of the inner islands, being rather common in Islay, as I have been informed by Mr Elwes, and likewise in some parts of Skye.

The nest of this bird is a very beautiful structure, and is remarkable for the extreme profusion of feathers it contains as a lining. The late Professor Macgillivray had one in his possession which, on being taken down, was found to contain 2379 feathers, belonging chiefly to the pheasant, wood-pigeon, rook, and partridge, and which, when shaken, were sufficient "to fill a hat of moderate phrenological pretensions."

Dr Saxby has met with the Long-Tailed Tit in Shetland, where, however, it is of extremely rare occurrence.

OBS.-It may here not be out of place to state that the BEARDED TIT (Calamophilus biarmicus) is catalogued as a Forfarshire species in Don's fauna and flora of that county, published in 1813, and that a writer in Loudon's Magazine of Natural History, etc., for 1830, states that he saw a specimen at Inchinnan, in Renfrewshire, where the river Gryfe joins the Clyde.

INSESSORES.

AMPELIDAE.

DENTIROSTRES.

\section{THE BOHEMIAN WAXWING.}

\section{BOMBYCILLA GARRULA.}

ThIs lively and beautiful bird may be said to be a frequent winter - visitant to the eastern counties, but in the midland and western counties its appearance is extremely irregular and uncertain. It is recorded by the Rev. W. Patrick, that a vast flock of waxwings appeared in the haughs of Hamilton, in the winter of 1782. Three specimens were shot there in 1830 .

I have not been able to trace the occurrence of this species on any of the Outer Hebrides, but several specimens were seen and shot in the Isle of Skye in 1850. It has likewise been obtained in Argyleshire and Wigtownshire. A specimen which I saw was taken alive at Portpatrick in the winter of 1866 . Early in December of that year, waxwings were observed in various parts of Britain, in large flocks, greatly exceeding those of former years; and from one or two correspondents I learned that these migratory 
flocks had spread themselves over a large tract of country. In the north of England they were observed in the month of November, and I heard of as many as fifty-seven specimens having been killed in a single week in one county alone. On the eastern side of Scotland examples occurred sparingly in nearly all the counties, but in Aberdeenshire and Morayshire, they were seen in flocks of forty or fifty birds. In the western counties, on the other hand, I could not learn of a single instance of the bird's capture; but in midland districts small parties were observed. One of these stray flocks, consisting of five birds, made its appearance near Lanark, in a garden where there were several rowan trees, on the berries of which the birds fed, until by their tameness they attracted the attention of a bird-stuffer, who managed to shoot them all after they had been some days in the neighbourhood. The arrival of these erratic birds in such numbers in the year referred to at once suggested a winter of unusual severity, a surmise which was afterwards abundantly verified, though at the time of their first appearance it was difficult to believe there could be such a thing in prospect, the weather being then remarkably mild.*

In addition to this occurrence of the waxwing, there were numerous records from the eastern counties of England of an extraordinary migration of the grey phalarope to those shoresanother species usually associated with hard winters. Both had come to us even weeks before the storm which their presence predicted, and immense numbers fell victims to the rage for collecting, now unhappily rife among naturalists. In all likelihood they had come from the north-east, and had either already experienced the winters of hard frost and heavy snow which followed in their train, or instinctively quitted their native districts on its approach. The waxwing and phalarope are supposed to breed extensively in Siberia and the north of Asia generally. These great flocks, therefore, had probably travelled along the northern extremity of Lapland and Norway, and down the western side of the latter country, extending their flight across the North Sea to the shores of Britain-a long journey, indeed, but perilous to the poor birds only at its close. I question the fairness of killing these beautiful creatures, coming to us, as they do, for shelter.

* Severe winters are not necessarily connected with the bird's appearance; that just passed-1869-70-memorable for heavy snow-storms, was not heralded, so far as I can learn, by the appearance of a single waxwing. 
Professor Baird, in his account of this species, at page 317 of his work on the Birds of North America, mentions that it is " seen in the United States only in severe winters, except along the great lakes;" but in an appendix to the same work (page 923), the following note occurs:- "Mr Drexler saw 'millions' of this species while in the winter camp of the south pass waggon road party, at the head of Powder River, Nebraska. Every tree for miles was filled with them, the flock rivalling that of the wild pigeon in its size." Such an invasion of our own woods might help to relieve the cacoethes carpendi of British collectors.

OBS.-I was lately informed by Mr Thomas Struthers of Larkhall, that some years ago, when voyaging from Canada to this country, a cedar bird (Bombycilla Carolinensis) flew on board the vessel shortly after it had left the Canadian coast, and continued to abide in the ship, from which it made occasional sallies when the weather permitted, until nearing the coast of Ireland. The bird had become a well-known favourite with the crew and passengers, and usually perched in the rigging or the ornamental work of the figure-head. On sighting Ireland, however, and when about fifteen or twenty miles from land, an outward bound vessel attracted the little feathered passenger as it sped past under a press of canvas, and pluming his crest with eager attention, he quitted the ship my friend was in, with an evident mistrust of the reception he would meet with on British soil, and boarded the stranger, filled with a desire no douht to return to his former haunts in the woods of America.

While this note was passing through the press, I have, by a singular coincidence, been informed by Captain H. W. Feilden, of the 4th King's Own Royal Regiment, that his father, Sir William Feilden of Feniscowles, had in his collection a specimen of this bird which was shot at Cambo, in Fifeshire, in 1841. Sir William, in a recent letter, describes the bird as having been "like a waxwinged chatterer, only less than half the size;" and Captain Feilden, in accounting for its appearance in the east of Scotland, suggests that it may have come to this country via Greenland, Iceland, the Faroes, and Heligoland, and not by ship, or it would probably have been shot in Ireland or the west coast of Scotland. 
INSESSORES.

MOTACILLIDA.

DENTIROSTRES.

\section{THE PIED WAGTAIL.}

MOTACILLA YARRELLII.

Breac-an-t'-sil.

THIS active and sprightly bird is very common in most districts throughout the year, although many hundreds appear to migrate southwards about the close of autumn. That such a movement takes place is evident to any one living near the confluence of any of our larger rivers with the sea, as large numbers which have followed their course from the interior are yearly seen gathered together in the estuaries, where they remain a few days before resuming their journey along the coast-line. Immense numbers of Pied Wagtails are in this way observed travelling down the river Clyde at Glasgow. In September and October I have seen as many as three or four hundred assembled on the timber rafts floating between the two principal bridges spanning the river in the heart of the city. After reaching the sea, they betake themselves to the nearest fields for a day or two, but not far from the beach, where on mild days they pick up a slender living among the mounds of dried sea-weed. The same habit is noticeable on the smaller streams, as, for instance, on the water of Girvan, in Ayrshire, where flocks have been observed regularly for many years past roosting in the alder bushes growing on its banks previous to their final departure. In both localities small parties drop off the main body and remain throughout the winter, those in Glasgow resorting to the farms and villages in the outskirts, where they soon become almost unrecognisable from the soiled state of their plumage through dirt and smoke. I have often stood in wonder looking at as many as half-a-dozen at a time running about the suburban roads, or sitting with downcast tails on barren cinder heaps within sound of a thousand hammers. These dingy specimens living within the city boundaries are not invested with a single white feather, back and breast being precisely of the same hue.

In localities on the mainland lying to the north of the central 
counties the numbers of this species are reduced to the extent of those migrating flocks, leaving comparatively few in some places as winter residents. The Inner Hebrides, indeed, are at that season nearly deserted by the species, while in the outer Islands, including St Kilda, it appears to be strictly migratory, arriving in March and departing about the end of September.

I have observed young broods of Pied Wagtails in full feather by the middle of May. They appear to follow the old birds for some time after leaving the nest, and they then form a very. interesting family group when running along the sunnyside of a bank or wall and getting their first lessons in fly-catching. The Gaelic name of the bird-breac-an-t'-sil—signifies a plaid, and has probably been applied to this wagtail from a resemblance which the contrasting colours of its plumage on the breast bear to that article of apparel when wrapped closely round the upper part of the body, as many Highlanders are in the habit of wearing it.

I suspect that this species is subject to considerable variation in plumage. In a series of about twenty killed at the same season of the year I find remarkable differences even in old birds, some being light grey and some deep black, while others are strongly tinged with yellow on the sides of the head and under parts - a plumage ${ }^{\star}$ hitherto supposed to belong to birds of the first year. These differences are not to the same extent observable in specimens killed in the eastern and central districts of Scotland. It is doubtful, I think, if this bird can be regarded as anything more than a local race of the next species.

\section{THE WHITE WAGTAIL.}

\section{MOTACILLA ALBA.}

IN the winter of 1847 , I observed a single example of this species frequenting a refuse heap in company with three or four pied wagtails on the shore at Dunbar, in East Lothian. On carefully examining the bird, after being shot, I found it presented all the essential characters which are said to distinguish it from the last species. I have at various times since seen very light coloured wagtails on the same coast, and also on the western mainland, but these were probably only varieties of the common bird. Macgillivray mentions having met with this bird several times in the 
south of Scotland. Its haunts, habits, and mode of nesting appear to be precisely the same as those of the pied wagtail.

Dr Saxby states that he saw a pair of White Wagtails at Lerwick in 1854, but is not aware of the occurrence of the species in any other part of Shetland since that year.

\section{THE GREY WAGTAIL.}

MOTACILLA BOARULA.

THIs most elegant and beantiful bird is permanently resident in a number of the western districts of Scotland. I have not yet been able to trace it to the Outer Hebrides, but it is found on some of the inner islands, being not uncommon as a winter visitant in Islay and Skye. On the mainland it ranges from Sutherlandshire to the shores of Wigtownshire, and it is by no means difficult to find at any season of the year. From the Upper Ward of Lanarkshire, Mr Alston writes, that it is even more plentiful in his district than the pied wagtail. "I have observed this species," he adds, "catching flies in the air, and returning to its perch exactly like a common flycatcher." Generally speaking, this wagtail is found frequenting running streams, where it may be seen moving quickly about on the sandy margins; or perching on some little stone in the centre of the brook, from which it makes occasional sallies, turning suddenly in the air with a curious movement of its tail and wings, displaying on these occasions, if the observer be near enough, its beautiful plumage to great advantage. I have at other times observed it on patches of damp meadow, and in marshy hollows at a considerable distance above the sea level, and on several occasions I have seen it on the housetops in the very centre of Glasgow. I recollect seeing a pair, some years ago, on the slates of a house, where they remained two or three hours, examining every likely crevice where insects might be lodged. They scanned almost every slate on the roof with amusing diligence.

The Grey Wagtail is an occasional summer visitant to Orkney, and in Shetland it occurs in August and September, but not in great numbers. 


\title{
THE GREY-HEADED WAGTAIL.
}

\author{
MOTACILLA FLAVA.
}

HAS not yet been observed in any of the western counties. In other parts of Scotland the records of its occurrence are still very meagre. At page 492 of the seventh volume of the Memoirs of the Wernerian Natural History Society, the following remarks occur under the proceedings of 9th January, 1836:- " Sir Patrick Walker then read notices regarding the occurrence, near Edinburgh, of several native birds, generally regarded as extremely rare, particularly the Motacilla neglecta, first remarked by him on the banks of the Water of Leith in 1804 (but referred by him to the Motacilla flava, until he became acquainted with Gould's observations), and often observed since that time." The proceedings of this meeting were inserted in the "Magazine of Zoology and Botany," at pages 110 and 111, and a foot note by the editor states that "this is the second time that $M$. neglecta has been recorded as occurring near Edinburgh; but the birds seem always to have been neglected, and at this time we are not sure that there is a specimen in town."

Dr Saxby writes that this species "has been observed late in autumn" in Shetland, but gives no particular date or locality.

From the strong general resemblance which this rare British bird bears to Ray's wagtail, it may possibly have been overlooked. The habits of the two species, however, are slightly different, the grey-headed wagtail being partial to streams and moist places, while Ray's wagtail chiefly frequents pasture lands and fields of grain at a considerable distance from water. It would be well, therefore, to scrutinize birds of this kind when met with on the banks of streams, etc., so as to make sure that they belong in reality to the common species.*

* While these pages are passing through the press, I have had an opportunity of seeing a specimen of this bird which was shot at Westbarns, near Dunbar, in the beginning of May, 1868. Dr Smith, in drawing my attention to this specimen, has obligingly informed me that the bird, which is now the property of Mr Francis M. Balfour of Whittingham, was exhibited at a meeting of the Royal Physical Society. When first observed, it. was following a plough in search of insects. 


\section{RAY'S WAGTAIL.}

\section{MOTACILLA RAYI.}

IN some parts of Lanarkshire and Ayrshire, the Oatear, or Seed Lady, as this species is called, is very common on its arrival in the month of April. It appears to keep in flocks for a few days before becoming dispersed, and may be then obtained in some numbers by collectors. On the banks of the Clyde, a few miles east of Glasgow, I have seen at this season flights of Oatears enlivening the adjoining fields, and at once attracting notice by the vivacity of their movements. I have remarked also, that their colours were very much brighter than during the summer months; indeed, the strong yellow hue is so conspicuous as to arrest the attention of even unobservant people. Towards the end of April they betake themselves to their old haunts, occupying a tolerably wide tract in the west of Scotland, where they are generally established in pairs at suitable intervals. As the season advances I have observed that, in Ayrshire especially, they go to the sea-shore, frequenting the shingle where any small rivulet enters the sea. They are also seen regularly on the bed of larger streams, especially towards mid-day, at which time I have always been able to find a pair refreshing themselves in the pools. In the outskirts of Glasgow, two or three pairs are found nesting every year, each pair frequenting almost the same spot they had come to occupy twelve months before.

On the east of Scotland the yellow wagtail is distributed in like numbers as far as Forfarshire, and it has occurred several times in Orkney.

INSESSORES.

ANTHIDAE.

DENTIROSTRES.

\section{THE TREE PIPIT.}

\section{ANTHUS ARBOREUS.}

ThE only Scottish district in which I have found this summer pipit in anything like abundance is comprehended within a circle of a few miles around Glasgow. In the neighbourhood of Possil it is very common in the outskirts of woods, especially on its 
arrival in spring, and may be observed perched on the summit of an elm or ash tree, from which it repeatedly ascends to a height of twenty or thirty feet, uttering a series of twitterings, and returning to its perch with almost motionless wing, the descent being slowly performed in a curve. In other parts of western Scotland the species is distributed from Inverness-shire to the Rhinns of Galloway, but is by no means plentiful. I have found it in scattered pairs throughout the summer near Girvan, in Ayrshire, and also in the south of Wigtownshire, where in autumn its numbers increase for about a week or ten days previous to its migratory flight southwards.

On the east coast this pipit seems equally dispersed over the sea-board counties from Berwick to Banffshire, extending its flight occasionally as far as Orkuey. In some of the inland counties I have also observed it, viz., in Dumfries, Stirling, and Roxburgh. $\mathrm{Mr}$ Alston likewise finds it in the Upper Ward of Lanarkshire.

The nest of the Tree Pipit is usually placed on the ground in or near the edge of a wood, and is a somewhat locsely put together structure of soft straws lined with hair. The eggs are extremely variable. Those I lave obtained near Glasgow are very light in colour, but handsomely mottled. Mr Brown tells me that in Stirlingshire, where the species breeds plentifully, he has taken the eggs of all shades, from the common red variety to a grey stone colour, pencilled with delicate lines like those so often seen on the eggs of the sedge warbler. He has also taken others having a strong general resemblance to the eggs of the blackbird.

\section{THE MEADOW PIPIT.}

\section{ANTHUS PRATENSIS.}

Rhiabhag mhonaidh.

THE familiar and lively moss cheeper, as this bird is called in Scotland, is everywhere common, often appearing in places where bird life is scarcely looked for. It is very abundant in North Uist and Benbecula, and indeed over the greater part of the Long Island, extending to the uninhabited rocks and islets far beyond. Even in St Kilda it may be seen frequenting the neighbourhood of the huts of the lonely inhabitants, its feeble notes being at certain seasons of the year almost the only sound breaking the silent 
monotony of their weary life. Although for the most part a bird of the mountain during the time of incubation, I have frequently met with it in glens adorned with a profusion of birch trees and tall breckans, and in the vicinity of old quarries, where its nest is often artfully concealed beneath a tuft of grass. The eggs appear to be subject to great variety, like those of the preceding species. There is even an extraordinary difference in the birds themselves; one being a short dingy bird of an unquiet and restless turn when disturbed, the other very much brighter in colours, larger in body, and silent when put off its nest. The eggs of the first are small and darkly blotched; those of the second are much larger and handsomer, beautifully coloured with clear purple spots very closely grained, such as distinguish some eggs of the tree pipit. When the breeding season is over, and pipits flock to the pastures of the low country, and into stack yards and the vicinity of towns, the same difference of plumage is not so noticeable; the feathers then become abraded and lose their brilliancy, which does not return till the end of autumn or the following spring. I have, however, been struck with the two birds when seen in contrast. It is quite possible that the British pipits, especially those inhabiting the western mountains of Scotland, have not yet been sufficiently studied.

\section{THE PENNSYLVANIAN PIPIT.}

ANTHUS LUDOVICIANUS.

So far back as $1846 \mathrm{I}$ find in my note-books records of this species having been seen by myself at Dunbar in considerable numbers for abont ten days or a fortnight in the winter of that year. They made their appearance suddenly in hard weather, and during their stay on the Links near that town they frequented half frozen pools on the grass, as well as the bed of a small rivulet running from Broxmouth pond, which was filled with broken ice, small patches of water being here and there visible. I could not at the time make out the species, and knew the birds to be strangers: they disappeared as suddenly as they came. A few years later I shot in a garden at Dunbar at least three specimens in the spring time as they silently hovered over a clump of trees, or sallied out from the branches, as I thought, in quest of insects. One of these I had 
stuffed, but the specimen has since been lost; the others were not preserved. I had no doubt whatever as to the species, and wrote to the late Professor Macgillivray, informing him of the captures, without, however, eliciting a reply. I have never again met with this pipit in any district of Scotland.

\section{THE ROCK PIPIT.}

\section{ANTHUS PETROSUS.}

Glais-eun.

I HAVE never missed this familiar bird from the sea shore, either on the eastern or western coasts; it is found at all seasons, and sometimes when all other birds are absent it is the only sign of life visible as it flits constantly from one rock to another. I have never yet seen it away from the coast; it seems to prefer rocks and sea-weed to all other haunts. Even at full tide, when the waters have covered their usual feeding ground, they retire no further than to the nearest creek, where they search for flies among the dry stones, or busy themselves in examining the crevices of rocks high above the action of the waves. The nest is usually placed on rough ground, or rocks almost within reach of the salt spray. I have many times found it in very picturesque situations; one in particular on the lesser Cumbrae was placed above a cave's mouth adorned with a profusion of plants at the root of a tuft of hypericum in full flower. The face of the rock was decked all over with sea-pink and ladies' bedstraw, and in this garden of wild flowers the pair of Rock Pipits had established themselves. They had four fully fledged young ones in the nest, and made a great outcry on their nursery being discovered. The brood, however, could fly perfectly, and got off in safety.

On all the western islands, including the Outer Hebrides, Monach Isles, Haskar Rocks, and St Kilda, this species is equally common, breeding in similar situations, and keeping strictly to the sea margin. 
INSESSORES.

ALAUDIDA.

CONIROSTRES.

\section{THE SHORE LARK.}

\section{ALAUDA ALPESTRIS.}

THough the Shore Lark has been known as a British bird for the last forty years, it appears to have been, with a single exception, entirely unknown as a visitant to our Scottish coasts until 1859. Early in January of that year a small flock made its appearance on the estuary of the Tyne, in Haddingtonshire, and three specimens at least were procured, one of which was exhibited at a meeting of the Royal Physical Society of Edinburgh. I had an opportunity of seeing these birds, shortly after their capture, in the hands of the late Dr Nelson, Pitcox, near Dunbar, who informed me that they were shot by Mr Evans, farmer, at Tynefield. Six years afterwards, namely, in the winter of 1865 , another flock was observed in the estuary of the Eden, near St Andrews, in Fifeshire. Mr Robert Walker of that city has informed me that two specimens were obtained; one of these, having been taken alive in a trap, was kept for some time as a cage-bird, but ultimately made its escape; the other, less fortunate than its neighbour, fell into the hands of a local taxidermist, and is now preserved in the college museum there. I have no doubt that this species is a frequent, if not an annual, visitant to the eastern shores of Scotland, ranging from the Ythan to the Tweed. In January of the present year (1870) similar flights to those already mentioned had apparently visited the same estuaries. On the first of the month a specimen was shot near St Andrews, and was procured by R. G. Wardlaw Ramsay, Jun., Esq., of Whitehill, Lasswade, who saw the bird before it was skinned. Mr Ramsay obligingly forwarded the specimen for exhibition to a meeting of the Natural History Society of Glasgow, and has informed me that when killed the bird was flying in company with snow buntings. Lord Binning informs me that a Shore Lark was shot by a Dunbar fisherman on Tyne Sands, East Lothian, in the end of November, 1869, and is now in the collection of Mr Balfour of Whittingham, and also that there is a specimen in the Mellerstain collection, which was shot on Spittal Sands at Berwick-on-Tweed in 1840. I am therefore indebted to Lord Binning for an opportunity of recording the earliest and, with 
the exception of Mr Ramsay's notice, the latest examples of this species that have been taken on the shores of Scotland.

Sir William Jardine describes this species in the second volume of his British Birds, p. 330, from an American specimen, an example which has been followed by Messrs Macgillivray and Yarrell in their respective works. The late Prince Bonaparte separated that of Europe from the species found in America, but Professor Baird in his work on the birds of that country - a comparatively recent publication-mentions his inability, without specimens at hand, to state the difference between Eremophila cornuta and $E$. alpestris, the latter name being now affixed to the European species. If the difference be really sufficient to constitute a species, it is possible that both may be met with on our Scottish shores. All the specimens that have yet occurred north of the Tweed have been taken on the eastern side of Scotland. Mr Baird alludes to the "great diversity of plumage in the western shore larks, varying with the sex, age, and season." Collectors, therefore, who are fortunate enough to meet with British specimens, should carefully note these particulars, so as to ascertain whether in reality the birds present debateable characters.

According to Audubon, who gives a very interesting account of its habits as observed by himself, the Shore Lark feeds upon "grass seeds, the blossoms of dwarf plants, and insects." It is also "an expert catcher of flies, following insects on wing to a considerable distance, and now and then betaking itself to the sea-shore to search for minute shell-fish or crustacea." There is every likelihood, I think, that the flocks of Shore Larks which have visited Britain of late years have come from Norway. Professor Newton of Cambridge has informed me that in June and July, 1855, he found the species common enough everywhere in that country during the breeding season, and that in particular localities, as, for example, Vadsö in East Finmark, "one can see them at almost any minute." It is somewhat singular that the bird should have so long escaped notice in the British islands, as it is now found in some numbers in districts where its presence had been previously unsuspected. In the county of Norfolk Mr Stevenson has seen in all about twenty-six Shore Larks-a result which shows that particular district to be possessed of careful and discriminating field naturalists. In its summer plumage the species would be easily recognised, but in winter, during which season it 
often associates with other birds, it would require a practised eye to detect it, the striking colours of black and yellow on the head and neck becoming altered in some specimens to a dingy brown. Young birds and females are still more likely to be overlooked, so that it is quite possible the Shore Lark may have been even in Montagu's time an erratic wanderer to our shores. Whatever neglect it may have hitherto experienced, it is not likely that in future the poor bird will be allowed to come and go in peace.

\section{THE SKYLARK.}

\section{ALAUDA ARVENSIS.}

Uiseag.

" Bird of the wilderness,

Blithesome and cumberless."

HAD the Ettrick Shepherd lived in the Outer Hebrides, he might have added a few lines more to his beautiful verses on the Skylark to make the story of its desert life complete. Writing from the inspiration given him by the moors and green mountains of Selkirkshire-the scenes of his many natural pictures-he has left a sketch of the Scottish laverock such as cannot be surpassed. But while singing its praises, he probably never dreamt of its being found in districts sterner in their aspect than the wilderness of heather blooms, over which he bids his

\section{"Musical cherub, soar, singing away!"}

and he would doubtless have gazed with something like surprise had he seen it soaring above the black peat-mosses and sterile tracts of North Uist, where, from a lavverock's height, nothing is seen but a waste of rocks and water. Let any one climb Ben Eval, and survey the eastern portion of the island, where the lark is a well known object in the summer sky, and he cannot fail to wonder where even that little bird can find a spot to dwell upon. A more extraordinary view there is perhaps not to be seen in Britain. Cut into the most extravagantly tortuous shapes, the land and waters are so intermingled, that it seems impossible to believe in the existence of houses, fields, roads, or, indeed, anything of human construction in the whole island. Hundreds 
of far-stretching lakes covered with islets; endless sea-reaches running through deviating channels, even miles inland; islands scattered sea-wards; and giant rocks rearing their bald heads into the clouds, - all form a scene enough to gain for Lochmaddy a reputation for anything but Skylarks. Yet high above this wonderful distribution of rocks, peat, salt and fresh water lochs, unadorned with any of the elements that are supposed to awaken a bird's melody, the Shepherd's favourite sings joyously, and seemingly as much an "emblem of happiness" as when fanning the "snaw-white clouds" over a poet's dwelling.

Besides these outer islands where the species is everywhere common, the Inner Hebrides are likewise frequented by numbers of Skylarks. Mr Graham has written to me recently, with a description of an effect he has often experienced when cruising off the shores of Iona and Mull, where larks are very abundant. After a night's sailing in an open boat, beset by sharp squalls and rapid tides - hearing only the wash of the waves and the distant moan of breakers chafing against a reef-he has made for the entrance of the sound or inlet, and entered calm water just as the first rays of the sun gilded the steep lofty banks, and been gladdened by a burst of bird music coming from opposite shores. Chief among the sweet singers was the lark. "Or, perhaps," says my friend, "the song of this bird is still more remarkable in its effect when on a fine clear morning one is starting off by boat, bound for the distant purple islets which hang upon the dark-blue horizon. As the boat runs along the low coast, skimming over the crisp little waves, the larks spring up one after the other, continuing a succession of merry carols, and when the last point is passed-the boat standing out into deep water, and the land beginning to diminish astern - as long as we can distinguish the white sandy bays and the green mounds beyond them, we still hear the jubilant trilling of many larks filling the air above, although growing fainter and fainter as the sea-breeze now fairly fills the sail, and the boat settles down to her work."

Let us imagine the poet Shelley listening from one of the green mounds of Mull, or one of the dark-brown moors of Benbecula, and seeing the little fellow springing from a green patch in that ancient-looking and sterile plain, his little bosom trembling all over with a store of pent-up melody; and as we ourselves listen with the poet to the gentle trillings of the bird as his wings 
quiver over the spot he has left, and mark his upward flight until he gets fairly into a soaring strain - the air being filled with that torrent of a voice, we can better understand the subject of these lines:-

"Sound of vernal showers

On the twinkling grass,

Rain-awakened flowers,

All that ever was

Joyous, and clear, and fresh thy music doth surpass.

"Better than all measures

Of delightful sound.

Better than all treasures

That in books are found,

Thy skill to poet were, thou scorner of the ground.

"Teach me half the gladness

That thy brain must know,

Such harnonious madness

From my lips would flow,

The world should listen then, as I am listening now."

In some winters -chiefly in severe weather-immense flights of larks make their appearance in the West of Scotland. The most remarkable of these within my recollection occurred near Girvan about eight or nine years ago. Their numbers were incalculable, and for some days they spread themselves over the fields in the vicinity of the town, rising occasionally into the air on being disturbed, and forming a dark cloud of a most singular appearance. In the confusion of their movements the whole body crossed one of the public roads, by the side of which there are several lines of telegraph wires; but the mass of birds was so compact, that none of those in a line with the wires escaped destruction. As soon as the flock passed, dozens were picked up dead or mutilated-portions of wings, torn from the living bird, being even found adhering to the wires.

These extraordinary flocks of laverocks had evidently been migratory, and, as in the case of the common bunting, belonged to more northern districts-perhaps out of Britain altogether. I was particularly struck with the variation in the size of some of the birds. Out of two dozen examined by me, six or seven specimens were not much over half the bulk of the others. Two pairs of them are now before me, and it is strange to find the diffe- 
rence in size so very decided. In every other respect the birds are identical.

I once found an adult bird of this species in a ploughed field in a disabled state, and unable to Hy. My attention was drawn to the spot by the cries of the bird, as another lark-probably its mate of the previous summer-hovered over it with something in its bill. Waiting until it had swallowed the morsel thus brought to it, I went into the field, and, after a fluttering resistance, took it in my hand. To my surprise there was a large ball of clay, about twice the size of a walnut, and worn quite circular in shape, adhering to one of its feet. It had become so hardened that it was not without difficulty I could get the mass removed. I was hopeful the poor creature would then be able to fly; but besides the strained limb, it must have been otherwise injured, as on placing it again on the ground, it merely fluttered to a little distance, where it remained sitting, probably in expectation of another visit from its comrade.

No bird, in any country, has been so often commemorated in song and poetic story as the Skylark. From Shakespeare to the "poet Close," its attributes have been lauded in strains, various in quality, no doubt, but all tending to exalt the celebrated songster into something ethereal. In France the subject is differently treated; at Dieppe, for example, according to an official return, it has been stated that during the winter of 1867-68, 1,255,500 larks were taken into the town, of which 983,700 were consumed there, and 271,800 forwarded to other parts of France. The total commercial value of these amounted to 56,497 francs!

\section{THE WOOD LARK.}

\section{ALAUDA ARBOREA.}

Riabhag-choille.

Though not mentioned as a Scottish species in any of the published works on British birds, except in that of Yarrell, who gives Dumfriesshire as a habitat, the Wood Lark appears from other records to have been long well known in many parishes of the southern and middle districts of Scotland. It is, of course, difficult to ascertain exactly whether in every case these records are to be depended on, but there can be no doubt, I think, of the authenticity of the 
lists given by some observers who are known to have had an accurate knowledge of birds. Thus, it is included in Don's Fauna of Forfarshire, and also in Mr Kinloch's statistical account of the parish of Kirriemuir in the same county, the compilers of both being men of more than ordinary shrewdness and discrimination in matters relating to natural history. The species was likewise observed by the late Dr Landsborough at Stevenston in Ayrshire, and by the minister of Luss in Dumbartonshire, from whose excellent list, published upwards of seventy years ago, I have taken the Gaelic name originally applied to the Wood Lark. Pennant includes it in his 'Caledonian Zoology,' which was prefixed to Lightfoot's 'Flora Scotica,' published in 1777, and the late Dr Fleming, in the short remarks given in his work on British animals, does not speak of it as a bird of restricted distribution. In the county of Caithness it had been found by the late Mr Sinclair, surgeon, Wick, in whose collection a specimen was seen by $\mathrm{Mr}$ James Wilson, who refers to the species in his Voyage Round Scotland, vol. ii., p. 179. Mr Edward informs me that he has procured the species in Banffshire, and it appears to have been oftener than once observed in Aberdeenshire by Mr Angus, who has sent me the following notes on its occurrence there:-

"In the last week of March, 1863, I shot a male Wood Lark in the enclosure at Scotston House.* Being the first time I had heard this pleasing songster, I was particularly struck by its mode of singing. It continued flying in circles, trilling its sweet music without intermission for half-an-hour or longer, except once or twice when it alighted for a moment on the top bar of a wooden fence. I again observed the species one frosty morning in March, 1865 , at the rifle range near the powder magazine. The sun was strong and clear, and the song of the bird was as jubilant as if it had been uttered in the middle of summer." Mr Brown informs me that this bird breeds on the confines of Torwood in Stirlingshire. I have myself seen it on one or two occasions near the Bridge of Allan in the same county, and also in the vicinity of Forres in Morayshire-the only two localities in which I have met with it in Scotland. Mr Thomas M'Ilwraith, now resident in Hamilton, Ontario, C. W., writes to me that he watched a pair of Wood Larks near Ayr in 1853. "The male," says Mr M'Ilwraith,

* Mr Angus has since shown me the specimen. 
$3_{3}^{3}:$

ind

$\therefore \therefore \therefore$

${ }_{3}^{3}, 500$

a...

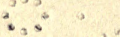

$\therefore 3$

5020
0.002000

$3 \quad 93=0$

कos 3230

$\mathrm{O}_{3}, 000$

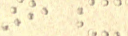

$3_{3,0}$ 


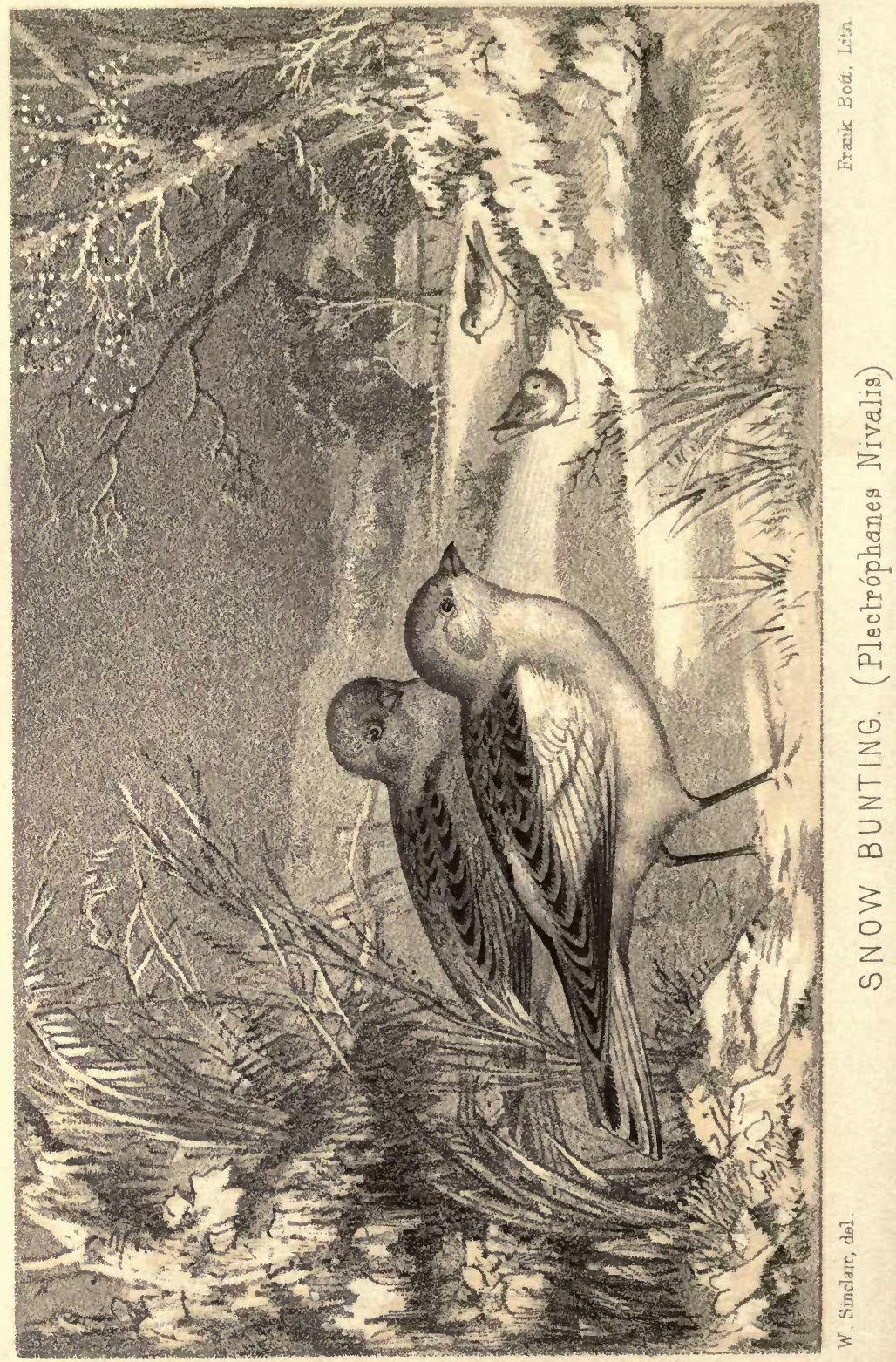


"sang very sweetly, rising from the dead projecting limb of an oak, and, after making a circle, singing as he went, would return again to his starting point, near which, I think, the female was sitting."

The most northern locality for the occurrence of the Wood Lark that I have been able satisfactorily to trace is Orkney, a specimen having been shot in Mr Dunn's garden at Stromness on 20th February, 1844. A manuscript note by one of the authors of the Fauna Orcadensis states that it has occurred in Shetland, but neither date nor locality is given.

INSESSORES.

EMBERIZIDA.

CONIROSTRES.

\section{THE LAPLAND BUNTING.}

\section{PLECTROPHANES LAPPONICA.}

A sPECIMEN of this bunting, shot in Caithness many years ago, is in the collection of the late Mr E. S. Sinclair of Wick. Mr Shearer, in referring to this specimen, states that the species has been found twice in that county, but gives no particulars. (See Proceedings of the Royal Physical Society, Edinburgh, vol. ii., p. 338).

\section{THE SNOW BUNTING.}

\section{PLECTROPHANES NIVALIS.}

Eun an t' sneachdai.

IN the winter season the Snow Bunting may be said to be a very common species over the whole of the western counties, arriving generally in October and taking its departure in April. A few stragglers remain some weeks later, and are occasionally taken on the low grounds in May, but these are exceptional cases. In the Outer Hebrides it is, so far as I can ascertain, strictly migratory, and does not prolong its stay beyond a few weeks in the early part of winter. I have obtained specimens from Benbecula and other islands, chiefly in the month of October. The flocks there are not large, seldom exceeding eighty or an hundred birds; they always come with westerly winds, and pitch upon the low grounds on the 
western side of the Uists and Benbecula, where they are first noticed. These flights are probably migrants from Iceland, none of the Hebridean mountains being of sufficient elevation to detain the species in summer. I cannot learn whether the birds are again seen on their return journey.

Large flocks of Snow Buntings are observed in Ayrshire and Lanarkshire during the months of November and December. These are principally observed on flat pasture lands, where they keep in compact bodies, reminding one of large flights of starlings. In this way they often appear on Glasgow Green, and grounds of a similar character within a few miles of the city; and are also known as regular winter visitants in the neighbourhood of the Campsie Hills, where they attract attention when flying about like drifting clouds along the hill sides.

It is very difficult to establish the fact of this species breeding regularly in Scotland, but that it does so in limited numbers can hardly be doubted. The nest is not easy of discovery; indeed, in many cases it must be almost inaccessible, at least to any one but the most enthusiastic egg collector. Our highest mountain tops, where alone such a treasure as a snow-flake's nest can be found in this country, are but seldom visited, save by wandering shepherds, whose attention is taken up with more important objects than small birds. Many of these men whom I have consulted tell me that they see the Snow Bunting in small parties throughout the year. I have most satisfactory information of this nature from persons who at regular intervals traverse the mountains of Aberdeen, Banff, and Inverness, extending from east to west, including Lochnagar, Ben-na-buird, Ben Avon, Ben-macdhui, Glasmheal, Cairngorm, and Cairntoul. Again, in Ross-shire, Ben Wyvis, Ben Dearig, and an entire group of "Bens" lying to the south and east of Gairloch, are likewise frequented by small flocks in summer. All my informants seem to know the bird perfectly by its Gaelic name, and from some of them I have obtained specimens in summer plumage; but it has been a source of wonder to them how they have never happened to find its nest. The birds are generally met with on the summit of the mountains, where there are large masses of splintered rock lying scattered about in wild confusion, and it is on ground of that nature that the search should be made. Wearied shepherds, however, at the close of a toilsome climb of three or four thousand feet cannot, 
without specific instructions, and the promise of a good reward, be expected to bestow much labour in the acquisition of that kind of game.

In Macgillivray's work mention is made of both old and young Snow Buntings having been seen on the Grampians in the beginning of August, 1830. Various local chroniclers had previously recorded the fact that the species remained in limited numbers to breed, but no instance appears to be cited in which the eggs had been actually obtained. Pennant, in his Caledonian Zoology, states that "a few breed on the summits of the highest mountains, but that the greatest part migrate from the North, appearing first in the Orkneys." In his day, it frequently happened that during their migratory flights, numbers fell wearied into the ships that were passing the Pentland Firth. The same author mentions in his Tour in Scotland, that "snow flecks breed near Invercauld." This information, no doubt, was given entirely on the faith of the birds having been seen, and this is precisely what is understood at the present day, nothing more positive by way of proof having been adduced by any modern observer on the mainland of Scotland.* I have been kindly favoured by $\mathrm{Mr}$ William Hamilton of London with the following extract from one of his journals, proving the presence of the Snow Bunting in Ross-shire about midsummer:- "July 12, 1868.-Went up Scuir Ouran with my brother in the afternoon; weather extremely hot and somewhat hazy. On reaching the top we sat down to enjoy the view, and were surprised to see two pairs of Snow Buntings (old birds), which were very tame, and seemed quite at home among the rough stones with which the top of the mountain is covered. We looked about for their nests, as we had no doubt they were breeding, but were not fortunate enough to find them. In fact, it would be a hopeless task, unless one had time to watch the birds." Scuir Ouran is on the confines of Inverness-shire, and is about 4000 feet in height; it is probably the most westerly resort of this bunting in the summer season.

On the east coast of Scotland I have been much interested in observing this bird along the coast line from Berwickshire to the county of Forfar. In stormy weather I have encountered numbers

* Dr Saxby has, in one instance at least, discovered the nest in the island of Unst in Shetland. 
before daybreak on Dunbar Links, as they were driven by the force of the wind in scattered groups across the line of my path. I have often, indeed, during the prevalence of north-easterly gales, mistaken them in the grey dawn for pieces of foam blown from the water. I recollect being, on one occasion, surrounded by a benighted flock of snow-flakes, several of which struck against my breast as I walked towards the heach, and fell stunned at my feet. They were no doubt migrating parties just reaching the shore. In Forfarshire the winter flocks observed near the coast are evidently made up of both natives and migrants. Two years ago I made an active search in the higher grounds of that county about the end of April, and had the satisfaction of seeing small flocks, and in some places, pairs of the bird nearly in summer plumage, that of the males especially being clearly defined and conspicuous during flight. Numbers are taken at this season to the bird-stuffers of Brechin and Kirriemuir, and are called in these towns " mountain finches." Shepherds and others living near their haunts speak of the birds as constant residents, keeping strictly to the mountains in summer, and approaching the low lying lands in November and December, as the snow becomes deeper. A sudden thaw, however, will cause whole flocks to disappear in one day, and at such times they have repeatedly been traced back to their old haunts on the highest ranges.

\section{THE COMMON BUNTING.}

EMBERIZA MILIARIA.

Gealag-bhuachair.

ON all the western shores the Common Bunting is a familiar bird, being found from the south of Wigtownshire to the north of the Outer Hebrides, and extending westwards to St Kilda. So far as my own notes enable me to judge, it is less local in the west of Scotland than in the east, and is much more numerous in districts near the sea than in inland counties. It is, indeed, nowhere more plentiful than in Argyleshire, Ayrshire, and Wigtownshire, frequenting in these districts dry stone walls enclosing pasture lands and oatfields almost touching the beach. In such places it perches occasionally on a bramble branch or tall stem of ragweed, and runs 
over its monotonous notes, which I have sometimes likened to the jingling of a chain or the sound of breaking glass.

I have seen great numbers of this bird on North Uist and Benbecula, where it is known by the name of 'sparrow;' but even in these islands it is only to be found on the west side, where the lands are flat, and where cultivation extends to the sea shore.

In the east of Scotland, where this bunting cannot be called an abundant species in summer, very large flocks sometimes appear in the winter season. All the specimens shot from these flocks which I have examined appear to be much larger than our native birds, and are better clad-the plumage being thick and rich coloured, very unlike the faded specimens I have met with in the autumn. One of these birds in my own collection is of a rich cream colour, with a few brown spots: it was shot some years ago in Banffshire.

\section{THE BLACK-HEADED BUNTING.}

\section{EMBERIZA SCHENICULUS.}

THIs species appears to be very widely distributed over Scotland. It is found in Shetland occasionally, and is known to have bred in Orkney; it likewise extends to the Outer Hebrides, where a few pairs breed every year. The nest has been taken in North Uist and Harris, and on some of the inner islands it is resident all the year.

On the mainland of western Scotland it is also a permanent resident in many localities, although of restless habits during the winter season, leaving its sedgy haunts for the more substantial attractions of the farm-yard. It is particularly common at Lochwinnoch, frequenting tall hawthorn hedges in the vicinity of the water; and in spring time I have seen parties of thirty or forty of this species frequenting a large patch of marshy ground, forming the old bed of the Fruin, on the banks of Loch Lomond. It breeds there on the banks of ditches, selecting occasionally the sides of deep drains. I have never, indeed, fornd the nest of the Black-headed Bunting away from water, and have always seen it situated on the ground, with the exception of a single instance in North Uist, where the structure was built in a heather bush growing close to the water's edge. 
The Black-headed Bunting frequents the immediate neighbourhood of Glasgow, where I have observed an occasional pair in spring. I have also seen it in mid-winter, flying alongside, and perching on the hedgerows in the outskirts of the city. About the end of April or beginning of May the male bird, which by that time has assumed the full breeding plumage, and is somewhat striking in appearance, may be seen stationed at no great distance from the nest, on some tall weed, hedge, or paling, uttering his tuneless double note, which seldom fails to betray the haunt of the pair. For many years past a very pleasing couple have frequented a small curling pond near the site of the new University. I can always calculate on seeing them there early in May; and never, during their residence, do I miss the morning salutation of the sprightly male as he turns round on his perch to look at the passer-by. These birds seem to get safely off with their brood each year, and sometimes return to rear a second family.

There appears to be a large accession in winter to the numbers of this bunting in the north of Scotland-probably the migratory flocks retiring from Norway and Sweden. These flocks mix with those of the common bunting (E. miliaria), and are commonly met with in the north of Aberdeenshire. From that county, my friend $\mathrm{Mr}$ Thomas Ferguson has obtained numbers of specimens (several of which are now before me) that were shot on the Kinmundy estate, near Peterhead, out of flights which could scarcely have been composed of native birds.

\section{THE YELLOW BUNTING, OR YELLOW HAMMER.}

\section{EMBERIZA CITRINELLA.}

\section{Buidheag bhealaidh.}

The familiar 'Yellow Yite,' or 'Yeldrin,' as it is called in Scotland, is generally distributed in the western counties, being found on nearly all the inner islands, as well as the Outer Hebrides. It is one of the first spring songsters, although its music is of a wearisome and somewhat monotonous quality, being delivered with a lazy kind of drawl, which often strangely contrasts with the pert and hurried performance of the chaffinch. Tannahill, in one of his fine natural pictures, thus notices its dismal ditty:- 
"Beneath the golden gloamin' sky,

The mavis mends her lay;

The redbreast pours his sweetest strain

To charm the lingering day;

While weary yeldrins seem to mourn

Their little nestlings torn,

The merry wren frae den to den

Gaes jinking through the thorn."

I have noticed that in some parts of Ayrshire, where ragweed abounds, the Yellow Hammer is much given to perching upon that plant, the flowers of which closely resemble the colour of its plumage. Its nest is frequently found in grass parks, placed on the ground, and generally under shelter of tufts of ragweed. In the summer of the present year (1869), I observed that this bird was unusually abundant in the county just mentioned, and also in Wigtownshire. The state of the ground probably favoured this partiality - the heat for many weeks having been oppressive, with an entire absence of rain, which often inundates their nests in meadows and other pasture lands near the banks of rivers.

Mr William Sinclair has two bright yellow specimens of this bunting in his possession, which he shot on the island of Gometra some years ago. During their short flights they looked exactly like canaries, the quills being white, and the rest of the plumage of the purest yellow. He had, indeed, some hesitation in shooting them, until he saw their manner of alighting on the ground. As a singular contrast to these extraordinary specimens, I may add that Mr Brown has kindly forwarded to me for inspection a melanoid variety of the bird, which was obtained last year in Kincardineshire. This very curious specimen shows the entire plumage of a dark tint, approaching in some places to black.

The nest of the Yellow Hammer has been found in Orkney.

\section{THE CIRL BUNTING.}

\section{EMBERIZA CIRLUS.}

IN the second volume of the Wernerian Society's Memoirs, p. 658, there is a record of a specimen of the Cirl Bunting having been shot near Edinburgh, and exhibited by Mr James Wilson at a meeting of that Society, held on 3d February, 1816. This instance of the species having been found so far north in Britain 
remained for nearly fifty years the only representative for Scotland, until a second was obtained in Aberdeenshire by $\mathrm{Mr}$ Angus, who has kindly sent me the following communication regarding its occurrence:- "In December, 1863, a friend sent me some small birds which he had kindly taken the trouble to kill for two kestrils which I then kept alive in confinement. He had procured the birds while woodcock shooting near Banchory, and on examining the lot I found a beantiful male Cirl Bunting. It weighed seven drachms and a quarter, and measured seven and a quarter inches in length. Irides brown."

Besides these examples, I may state that when visiting the Kelso Museum in November, 1868, I examined a male bird of this species, which Mr Heckford, the former curator, informed me had been stuffed by him about the year 1840. It was shot at Greenhill, near Yetholm, in Roxburghshire, and brought to him in the flesh.

\section{THE ORTOLAN BUNTING.}

\section{EMBERIZA HORTULANA.}

Alrhough this species is common in the southern parts of Europe during summer, and visits Sweden, Norway, and Denmark in the breeding season, it is very rarely seen in the British Islands. Yarrell mentions but a few instances of its occurrence in England, the most northern locality being the coast of Yorkshire.

Its appearance north of the Tweed appears to have been equally rare and uncertain. The first specimen must have been killed many years ago; it was obtained in the county of Caithness, and is mentioned by Mr Wilson in his Voyage Round Scotland in 1846, but was previously recorded in the Statistical Account of the Parish of Wick, published about ten years earlier. The bird is, I believe, still in the collection of Mr Sinclair, where it was seen by $\mathrm{Mr}$ Wilson.

This would probably have remained the only recorded -Scottish example of the Ortolan, but for the indefatigable diligence of my correspondent, $\mathrm{Mr}$ Angus, who was the means of discovering other two in Aberdeenshire, which are now in his own collection. "In the last week of November, 1863," writes Mr Angus, "I found a pair of Ortolan Buntings in a large quantity of larks 
exposed for sale in Castle Street, Aberdeen, at the weekly market. These I secured for my collection, but the person who sold them to me knew nothing of the species. He offered me my choice of the lot for sixpence, and informed me that they had been captured on the previous day in a turnip field near the sea-side. The birds varied in size, the male being the larger of the two, weighing seven drachms and three quarters, while the female weighed but six drachms and a half. The irides were brown. The birdcatcher stated that they had commenced eating immediately after being caught, and that during their day's confinement they fed constantly."

The Ortolan, when fattened for the table, has long been known as a delicious morsel among French epicures. Its introduction to this country, however, is comparatively a recent event. The first London importer informed the Rev. E. S. Dixon, author of an interesting volume, entitled the "Dovecote and the Aviary," that for some years previous to 1850 , he "used to get them one or two at a time, and then sell them easily at a guinea each. We now, (March, 1850) have them by hundreds, and fat them for the table, but they are of little value, $1 \mathrm{~s} 6 \mathrm{~d}$ each." At a guinea a-piece, therefore, ortolans, each weighing but three ounces, would cost the consumer about $£ 512 \mathrm{~s}$ the $\mathrm{lb}$., and at the reduced rate 8 s the lb. To those who cannot afford even sixpence an ounce for this costly viand, I would recommend Sanderlings, on their first reaching our shores in autumn. They are equally fat, and if properly cooked, will not disappoint any one choosing to make the experiment.

Obs.-The Painted Bunting (Spiza ciris) has occurred once in Scotland, a specimen having been procured in Banffshire, by $\mathrm{Mr}$ Thomas Edward, who informed me of the circumstance about three years ago. Stray examples of this species no doubt reach this country by means of ships crossing the Atlantic. Audubon remarks, in the first volume of his 'Ornithological Biography,' that few vessels in his day left the port of New Orleans during the summer months without taking some painted finches, and that through this means they were probably transported to all parts of Europe. "I have seen them," says Audubon, "offered for sale in London and Paris, with the trifling difference in value in each individual, which converted the sixpence paid for it at New Orleans to three guineas in London." 
INSESSORES.

FRINGILLIDA.

CONIROSTRES.

\section{THE CHAFFINCH.}

\section{FRINGILLA CEELEBS.}

Bricean-beatha.

THE pert and familiar Chaffinch is widely distributed throughout Scotland. It is found in several localities in the Outer Hebrides, especially in the sheltered districts of Harris and Lewis; there are none on the treeless islands. It need not, however, excite surprise should it yet be found frequenting these barren wastes, as it appears to be even a hardier bird than the common sparrow, whose place it frequently takes in out of-the-way bird haunts. I have found it in considerable numbers near lonely farm-steadings in the western moors, and have noticed it as the commonest bird in upland parishes, where other birds of its size do not make a long stay. Mr Elwes informs me that on one occasion he observed a female Chaffinch on the summit of Ben a Chaolais, in the island of Jura, at an elevation of 2500 feet. The bird seemed quite at home, and complained of the intrusion on its haunts-a mass of splintered rocks-with the same quick note that characterizes its impatience when disturbed in an orchard.

In its style of nest-building, this bird varies the structure according to the locality which it happens to frequent. In rural places, away from the dust and smoke prevailing near cities and large towns, the nest is a perfect model in its way for neatness and compactness of form; but in less favourable situations, where the building materials are not so fresh, it is slovenly and untidy. A series of nests before me gives ample proof of this, some being composed entirely of moss closely interwoven; others of lichens laced all over with spiders' webs; whilst those obtained in the outskirts of Glasgow are built of dirty straws, pieces of paper, and bits of blackened moss intermixed, forming as a whole such a cradle as a country shilfa might feel ashamed of. I once took one from a smoke-begrimed hedge within the city boundaries which had, among other odd things adhering to it, three or four postage stamps exhibiting various effigies that a juvenile collector would have prized. 
This bird appears in some instances to thrive well in confinement. I lately saw a beautiful male in Penkill Castle, Ayrshire, which was taken from the nest seventeen years ago. It was then only covered with down, but through careful attention grew to be a strong and healthy bird, and now continues so, making the walls of the room in which its cage is placed ring with its oftrepeated song. Miss Boyd has politely informed me that her favourite has always been fed with great care upon a variety of things, such as meat, fish, seeds, insects, etc., and has never been subjected to any sudden change of temperature-warmth and variety of food being the chief means used to keep the bird in perfect health.

I have noticed in Forfarshire and other counties in the northeast of Scotland, a great acquisition to the numbers of this species in the spring season. About the middle of April this year (1869), every hedgerow was swarming with Chaffinches, all in clear and brilliant plumage. They assembled in groups in the centre of the common highway, to pick up their slender living; and as I drove fifteen or twenty miles of road, I could not help observing their unusual numbers.

The shilfa, as it is called in Scotland, appears in a remarkable degree to be susceptible of kindness. I recollect, when spending a night in the house of a gentleman resident in Forfarshire, being very much interested with the tameness shewn by some Chaffinches as I sauntered in the policies before breakfast. Two birds especially, a male and female, flew down from a large spreading tree near the house, and tried to gain my attention by hopping close to where I stood, and on stooping down and extending my hand, they both eagerly came forward and looked inquisitively into the empty loof in evident disappointment. On speaking to my host about the birds, he informed me that he had induced them so far to set aside their usual timidity, as to come into the breakfastroom on the window being raised, and fly to the table, on which they usually got a bit of cake or some other luxury. This tameness had continued several seasons, and on one occasion the female brought her five newly-fledged young ones to the window, leaving them on the outer ledge until she paid her usual visit to the hospitable board for something to give them.

Sometime ago I was favoured with a communication on this subject from the pen of one whose writings commend themselves 
to every true naturalist. I had learned through a friend that $\mathrm{Mr}$ Aird of Dumfries had tamed several wild birds at liberty to such an extent as to tempt them to come at call, and take crumbs of food out of his hands; and having solicited from that gentleman a note of his experience with small birds, the following account, the substance of which has since appeared in the proceedings of a local society, was obligingly sent to me:- "One severe winter, when I resided in Dumfries, I fed the birds from my parlour window, which overlooked a small garden plot. I noticed in the long-run that the shilfa became the tamest of them all. Since I came to this quiet old dwelling, I have had opportunity of watching the bird more closely. We have had the robin here, who came at call, and sat on the hand in the open air, and ate his fill of crumbs deliberately. Such familiarity in the robin is well known. Not so the tameness to which the shilfa may be brought. In the spring of 1864, a little hen shilfa drew very near my foot for crumbs; and gradually I got her within the door for her breakfast. She built her nest in an Irish yew near the house, and when hatching and eager for food, without loss of time she flew to me in the open air, and seized her crumb from my hand, but would not sit down on it, like Robin. By-and-by she took the bit from my mouth, and followed me closely up and down, flying across my way very near my face, in order to attract attention. Often have I astonished the people passing our gate by calling her down from the tree, and making her take her cake from my lips. Two or three times when I was leaning on a gate a field's breadth from our house she came and sat close down beside me. Once, but only once, as she sat there, she allowed me to touch her with my forefinger. In autumn the general instinct overcame the special familiarity, and she was much away with the flock in the fields-yet, back she came every now and then to our door. Toward the end of autumn, as I was standing by a paling a good way up the slope behind the house, I saw a little bird detach itself from a flock on a high tree and come straight down to me. She took her seat on the paling, quite beside me. This was Tibbie, for so I had named our pet. I offered her crumbs, but she would not take them: she had come to me from pure affection. She made off with a brisk chirrup and rejoined her companions. A hawk must have got her, for we never saw her again. So much for little Tibbie of Mountainhall, and I commend her memory to your special regard. I may add 
that we have other shilfas which fly at the face to attract notice and get crumbs from me on the ground; but Tibbie's wonderful tameness seems to have been a special individuality of temper and character. No such birdie will ever again charm me."

\section{THE MOUNTAIN FINCH OR BRAMBLING.}

\section{FRINGILLA MONTIFRINGILLA.}

THe Brambling is a regular winter visitant to the western mainland, coming occasionally in immense flocks, which do not disperse but keep to their line of flight. These passing companies I have seen in the neighbourhood of the Stirlingshire hills, and $\mathrm{Mr}$ Brown states that he has also seen them there. In January, 1867, a very extraordinary mass of these birds was seen by that gentleman near his residence: it was passing overhead, and proceeding in a north-easterly direction. To give Mr Brown's own words:"The flock took the form of a column, which must have been at least a quarter of a mile in length by some fifteen yards in breadth: it presented a most singular appearance when viewed at some little distance. Every slight alteration in the direction of the flight of the birds in the van was copied by all the members of the flock behind, thus giving to the column the appearance of a great winged serpent as it twisted and undulated onward. They were flying at no great height from the ground."

Like other strictly migratory species, the Brambling arrives during the night, particularly on the east coast, and is often observed shortly after daylight flitting among the rocks or the sea shore, evidently in a somewhat exhausted state after its long flight; at such times it may almost be taken with the hand. It appears at first to betake itself to the higher grounds, but after a time, especially on the approach of snow, it descends to low lying farms, where it becomes a familiar tenant of the stackyard, mixing with chaffinches and yellow hammers. On their first arrival, the plumage of both males and femalesparticularly the latter-is suffused with a mealiness which makes the various markings very indistinct; but as the months wear on the males assume much clearer tints, and are really beautiful birds just before their departure. In other parts of Scotland the Brambling is equally numerous. I have found it plentifully in 
East Lothian and Forfarshire: in the first named county the male is called the "cock o' the north;" in the other both sexes are known as "tartan backs."

Mr Alston writes to me that he skinned a male of this species in the autumn of 1869 , and found its gizzard full of fragments of the kernels of nuts, seemingly hazel. The bird was killed near Glenalmond, in Perthshire.

On the inner islands the Brambling is found but sparingly, some winters passing without a visit from a single bird.

\section{THE WHITE-THROATED SPARROW.}

\section{ZONOTRICHIA ALBICOLLIS.}

A fEMale specimen of this North American bird was shot near the Broadhill, on Aberdeen Links, by Alex. Mitchell, on the 17th August, 1867, and forwarded to me a few weeks afterwards by Mr Angus, to whom Mr Mitchell had presented the bird. In March, 1868, a notice of the occurrence was communicated by $\mathrm{Mr}$ Angus to the Natural History Society of Glasgow, and a full description of the plumage, with other details, was afterwards published in the proceedings of that Society, accompanied by a plate containing two figures, which Mr Sinclair had drawn for this work.

It is quite possible that, from its general resemblance to some of the female buntings, this bird may have hitherto passed unnoticed in the eastern districts of Scotland. Mr Mitchell was attracted, in this instance, to the movements of the bird as it sat perched on a whin-bush jerking its tail, but a less observant eye might have failed to remark the peculiarity. It may be well, therefore, for scientific collectors residing in the north-eastern counties to look out for the species in autumn, when stragglers are likely to arrive on our shores. We know that it is strictly a winter visitant to the Southern States of America, appearing there suddenly in considerable flocks; there is therefore nothing inconsistent in the surmise that straggling parties may in the course of their flight be driven eastwards from Newfoundland to this country.

The two birds which are figured on the plate, when contrasted with ordinary examples shot in spring, present a worn appearance, and are much less vivid in coloration and general markings. Such 


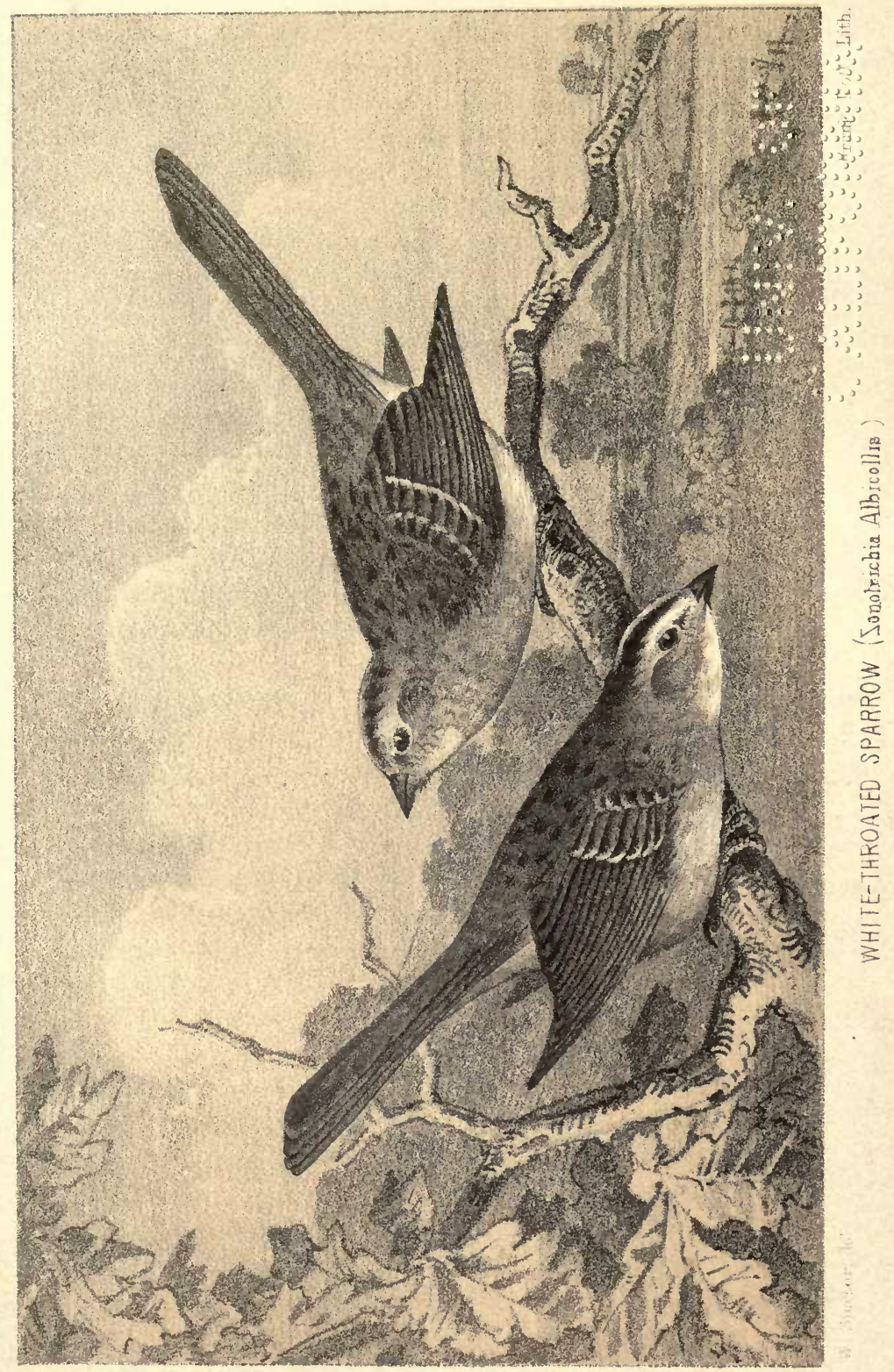




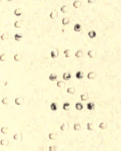


differences no doubt are almost to the same extent noticeable in many of our British birds. The common bunting, for example, in its autumn garb, often looks so lean and faded as to be hardly recognizable when placed alongside a bird of the same species killed in the months of March or April, the whole of the outer layer of feathers, so to speak, being wasted and reduced to little more than half their ordinary breadth. The tail feathers appear to suffer even a greater abrasion, being in some cases much rubbed at the points, and in others, especially with the central feathers, denuded to more than half their length.

Audubon, in his description of the White-throated Sparrow, gives the following pleasing account of its habits:- " This pretty little bird is a visitor of Louisiana and all the southern districts, where it remains only a very short time. Its arrival in Louisiana may be stated to take place in the beginning of November, and its departure in the first days of March. In all the middle States it remains longer. How it comes and how it departs are to me quite unknown. I can only say, that all of a sudden the hedges of the fields bordering on creeks or swampy places, and overgrown with different species of vines, sumach bushes, briars, and the taller kinds of grasses, appear covered with these birds. They form groups, sometimes containing from thirty to fifty individuals, and live together in harmony. They are constantly moving up and down among these recesses, with frequent jerkings of the tail, and uttering a note common to the tribe. From the hedges and thickets they issue one by one in quick succession, and ramble to the distance of eight or ten yards, hopping and scratching in quest of small seeds, and preserving the utmost silence. When the least noise is heard or alarm given, or frequently, as I thought, without any alarm at all, they all fly back to their covert, pushing directly into the very thickest part of it. A moment elapses when they become reassured, and ascending to the highest branches and twigs, open a little concert which, although of short duration, is extremely sweet. There is much plaintive softness in the note. . . At the approach of night they utter a sharper and shriller note, consisting of a single twit, repeated in smart succession by the whole group, and continuing until the first hooting of some owl frightens them into silence. Yet often during fine nights I have heard the little creatures emit here and there a twit as if to answer each other that 'all's well.' " 


\section{THE TREE SPARROW.}

\section{PASSER MONTANUS.}

The first record of the Tree Sparrow as a Scottish species is given by Mr Don, who states that in his day it was found "on the mountains of Angusshire;" the next is mentioned by the late James Wilson, in his Voyage Round Scotland, a specimen, shot in Caithness, having been seen by that ornithologist in the collection of Mr Sinclair, surgeon, Wick. Since that time the Tree Sparrow has been found near that town by $\mathrm{Mr} \mathrm{H}$. Osborne, and also by other observers, in Morayshire, small numbers being known to breed near Elgin;* but the present stronghold of the species north of the Tweed appears to be East Lothian. It was discovered there many years ago by the late John Nelson, Esq., and was first noticed on the farm of Castletown, near North Berwick, where a few pairs breed annually. It was afterwards found at another farm within a few miles distance, and still later at Pitcox, by the late Dr Nelson, who informed me that there were probably from eighty to ninety pairs on his farm. Mr R. Scot, Skirving, has also informed me that a few pairs breed near his residence at Campton, near Drem, in the same county, thus giving the bird a still wider distribution. All these localities are confined within a radius of ten or fifteen miles, and so far as I am aware, the bird has not yet been detected on the higher grounds of Haddingtonshire. I am nearly sure, however, that two pairs at least nested in a tall garden hedge at Dunbar about twenty years ago.

On the west coast it cannot yet with certainty be included in the list of regular visitants; but I have been informed by $\mathrm{Mr}$ Duncan C. Brown of Glasgow, that he has seen the Tree Sparrow at Arrochar, Loch Long, in limited numbers, mixing with the common sparrow, and thus affording him the opportunity of contrasting the two species together.

I have no doubt as to the Tree Sparrow being a much commoner bird in Scotland than has hitherto been supposed, especially in the eastern counties, which, in some particular seasons, are visited by migratory flocks from Scandinavia. A very interesting fact

* It may be mentioned that in a list of birds, evidently prepared with great care, and published in the Statistical Account of the Parish of Edderton, in Ross-shire, the Tree Sparrow is included as a resident species there. 
has been noticed by Mr E. H. Rodd of Penzance of a large flock of these birds having alighted in a Norwegian vessel near the English coast in November, 1860. Mr Rodd informs me that the captain of this merchant ship stated that there were many hundreds in the flock at the time they fell on deck, and that he secured half a dozen of the birds as a memorial of their visit. These were taken to Mr Rodd and identified. The occurrence took place between the Dogger Bank and the Galloper Lighthouse. The birds composing migratory flights like these would probably reassemble in spring, and keep by the coast as they travelled northwards till they reached Aberdeenshire, small numbers being left in the intervening counties, in several of which the species has already been distinguished in the breeding season.

\section{THE HOUSE SPARROW.}

\section{PASSER DOMESTICUS.}

Gealbhan.

Although the common sparrow is a bird of wide distribution and a close follower of man wherever he chooses to settle, it is only within the last thirty-five years that it has ventured across the Minch in Scotland. Two pairs were known to be in the neighbourhood of Stornoway in 1833, but nine years afterwards $\mathrm{Mr}$ Wilson, in noticing this circumstance in his very interesting volume already so often referred to, stated that during his visit to Lewis, he saw none of their descendants, a remark which shows that in 1842 it had been an uncommon bird in the island. Though still restricted to the immediate neighbourhood of the town, it has since that time become very abundant, having increased especially of late years to such an extent as to become a scourge to the farmers. In all other parts of the Outer Hebrides, it is totally unknown, except Barra, where it was observed forty years ago by Mr Macgillivray among the ruins of Kilbar (see Edin. Jour., vol. ii., page 325).

On the inner islands, though nowhere numerous, small colonies are observed frequenting farm steadings, a remark which applies also to the western mainland, from "Sutherland to Argyll; but in some parts of the last named county, where of late years towns of 
considerable size have sprung up as watering places, the sparrow has multiplied in a corresponding degree. Southwards of the Frith of Clyde the species is found still more numerously, but seems to attach itself for the most part to towns and the larger villages. In many of the hill farms of Ayrshire, it is sometimes entirely absent, and is then replaced by the chaffinch and yellow hammer. During the breeding season, which lasts from the commencement of spring until the middle of August, I have observed it in very large communities in the immediate neighbourhood of Glasgow; the most remarkable of these may be seen in an old quarry, about a mile to the north-east of the city, and is certainly one of the most extraordinary congregations of sparrows to be met with. The entire face of the sandstone cliffs, forming three sides of a square, is swarming with the birds; every crevice has been taken advantage of, and is tenanted in some instances by more than one pair-the nests being placed in contact-an arrangement which, judging from the perpetual clamour and onslaught among the occupants, appears to be anything but harmonious. I have also seen noisy companies of sparrows assembled together on the ornamental work of public buildings, and under the eaves of dwelling houses in the principal thoroughfares of the city, where they appear to keep up a loud chattering at all hours of the day, varying their amusements with an occasional fight. I recollect noticing such a colony busily engaged in catching thick-bodied moths (Noctuce) which had been disturbed by their rude behaviour, and been obliged to issue from their retreats into the dazzling glare of daylight. The sparrows made hurried sallies and caught the moths, after many ludicrous turnings in their flight before they accomplished their purpose.

In May of the present year (1870) I was interested in observing a noisy company of sparrows in possession of a part of the ruined masonry of Dunbar Castle, the only isolated fragment of standing wall now left of that once powerful stronghold. About twenty pairs had established themselves for the season in this elevated nursery, exposed to the full blast of the storms that so often beat upon the time-worn pinnacle; but even there the hardy fellows, like the sons of Neptune whose craft they hourly visited in the adjoining harbour, seemed proof against both wind and spray. These seafaring sparrows, as they may justly be called, appeared to subsist on what they could pick up in the castle park or on the 
quay in their vicinity. They remain there, I was informed, all the year round; and with such training it is not to be wondered at that shore-bred birds should make choice of the nearest 'look-out' for a breeding place.

Mr Sinclair has informed me that in June, 1869, he found and examined no fewer than seven sparrow's nests, containing eggs or young, in a pear tree in a garden at Dunbar. The nests were all dome shaped, with a hole at the side.

\section{THE GREENFINCH.}

\section{COCCOTHRAUSTES CHLORIS.}

\section{Glaiseun-darach.}

Permanentruy resident, extending from north to south. In the Outer Hebrides it is found in North Uist and Harris, and probably the whole of the Long Island. It is also a winter visitant to the Orkneys, but does not appear to be so in the Shetlands. A very large flock was driven to the latter islands on 28th October, 1864, in a gale from the north-east, as recorded by $\mathrm{Dr}$ Saxby. I have seen flocks of this bird in the heat of summer frequenting the sea-coast in Ayrshire, and the pebbly beds of some rivers, where they had assembled at mid-day to wash themselves in the little pools.

A very interesting anecdote was lately communicated to me by Mr Sinclair. He was seated in a garden at Dunbar one afternoon in July, in company with a friend under the shade of some elm trees, when their attention was attracted to a female Greenfinch perched upon a twig about six feet from where they sat. It was stretching out its neck and plucking off leaves, passing the stem of each through its bill and dropping it until it found a suitable one, with which it flew to a higher part of the tree. This act being repeated several times, their curiosity became excited, and they watched the bird. A few more leaves were dropped, and again the Greenfinch flew up, when on closer examination they found to their great surprise that it was sticking the leaf into the edge of its nest, which was built on a leafless branch, exposed to the sun, and thus forming a screen for the young fledglings which had been incommoded by the excessive heat. 
The anxious mother of the nurslings had already placed two or three leaves firmly into the structure by the stems, and Mr Sinclair, on comparing them with those the bird had let fall, found them to be much thicker and therefore better suited for the purpose.

A very striking variety of the Greenfinch lately came under my observation; it had the entire plumage of a bright yellow, with the exception of the quill feathers, which were pure white. The specimen was killed near Kilmarnock, and preserved by Mr Oliver Eaton, bird-stuffer there.

\section{THE HAWFINCH.}

\section{COCCOTHRAUSTES VULGARIS.}

I AM not yet able to record this bird as a west of Scotland species. In the southern and eastern counties it has been traced from Dumfriesshire to East Lothian; thence to Aberdeenshire, Banffshire, and Caithness, in all of which counties several specimens have been obtained. It is supposed to be increasing in many parts of England, and future observers may therefore find it frequenting Scottish districts not yet included among its northern habitats.

\section{THE GOLDFINCH.}

\section{CARDUELIS ELEGANS.}

Lasair-choille.

BeING a favourite cage-bird, the Goldfinch is much sought after by those who make it a business to catch these beautiful songsters for the city market. For many winters past I have been surprised at the very large numbers that are sent weekly from Dumfriesshire to Glasgow. Many hundreds must be taken in a season; and as they are despatched in confined boxes, a great many die before reaching the end of their journey. From being a comparatively common bird, therefore, the Goldfinch is, from this cause alone, now rather a scarce species; and, as cultivation extends, the plants, on the seeds of which they feed, are naturally becoming diminished. Their favourite food late in autumn and winter, as 
far as I have observed, is the seed of the common thistle and meadow thistle, and occasionally the ragweed-plants which no prudent husbandman thinks now-a-days of allowing to grow till the seed is perfected. Lanarkshire is yet frequented by small flocks, and even in the vicinity of Glasgow stray birds are occasionally seen by the bird-catchers during severe frosts, when they become an easy prey to these artful trappers. In Renfrewshire, Ayrshire, and some parts of Argyleshire, Goldfinches are still sparingly distributed, being more easily observed, however, in the winter season during the time of snow, when they become conspicuous on their perch on the tops of tall weeds standing above the white surface. Their habits are at these times a very interesting study; yet one cannot help feeling sorry for the poor frozen-out birds, as at best they seem but ill-fitted to stand the rigours of our northern climate. The siskin, although so nearly allied, is a much hardier bird, and will brave even the roughest weather with impunity. Writing in 1813, Don, in his Fauna of Forfarshire, states regarding the Goldfinch, that " this bird has never been plentiful since the hard winter of 1795 , which destroyed many," a recurrence of which disaster appears to have taken place in 1823, as mentioned by Mr Macgillivray. This sensitiveness to cold is doubtless another cause of their gradual disappearance from districts where at one time they were common.

From old parish records I find that in 1794 goldfinches were found in abundance in Ross-shire, especially in the parishes of Kilmuir-Wester and Suddy. Until within these few years past, it was a well-known bird in the vicinity of Dingwall, but the recent rapid advancement in the agriculture of both Strathpeffer and Strath Conon has rooted out many spots which were formerly attractive to the species; hence it is now but seldom seen there. During a residence of some weeks in that beautiful district in 1868-69, I failed to notice it in any of the straths or glens I visited.

The Goldfinch seems to vary greatly in size. A specimen from Ireland, now before me, is $4 \frac{3}{8}$ inches in length; another from Dumfries is 5 inches. The first named has a white throat; both were killed in April, and when placed together, the Irish bird looks as if it must have been, when in the flesh, only half the size and weight of the other. 


\section{THE SISKIN.}

\section{CARDUELIS SPINUS}

THIRTY years ago, this pretty little bird was a well-known winter visitant in some parts of Lanarkshire; but from all I can learn, it is now much less common, or at least not so steady in its times of appearance. In certain seasons it may still be said to be plentiful in the neighbourhood of Glasgow, where, however, the flocks are very soon thinned by the professional bird-catchers. The same may be said of its visits to other counties in the west of Scotland, with the exception perhaps of Argyleshire and Sutherlandshire; in some parts of the last-named county, it appears to be resident all the year. But it is doubtful if the Siskin has yet been recognised on the western side of Sutherland, although Mr St John states in his "Tour" that "it is in almost every wood during spring and summer." Mr Brown has informed me that it is certainly not known in the district of Assynt, but that it breeds plentifully in the woods at Dunrobin Castle. He has likewise found it breeding on the banks of the Dee in Aberdeenshire. As a rule, the nesting localities for the Siskin are situated in the eastern counties of Scotland. Its nest has been taken near Glasgow, in Kirkcudbrightshire, in Perthshire, and in Dumfriesshire-all of which districts are, no doubt, exceptions to that rule; but as the main flocks assemble on the north-eastern counties previous to quitting our shores, it is more natural to find stray parties remaining there, especially should the general outset be delayed by adverse weather. From Berwickshire to Caithness, therefore, the migratory flocks are extremely numerous in some seasons, appearing in the autumn before the foliage has been blown off the trees, and again in March and April, just before leaving. I saw a number of Siskins, evidently mated, in the woods of Altyre, near Forres, in the beginning of May, 1870. In East Lothian, I have met with pairs in June at Dunbar and elsewhere; and I have records of its having bred in that county, and in Fifeshire, Forfarshire, and Kincardineshire. Generally speaking, the flocks are largest in severe winters.

The Siskin does not appear to have occurred in Orkney, but it is a rare winter visitor to Shetland. 


\title{
THE COMMON LINNET.
}

\author{
LINOTA CANNABINA.
}

Gealan-lin.

I Do not know a more pleasing sight to the ornithologist than a group of Common Linnets, collected in the spring time, and sunning themselves on the top of some tree late in the afternoon of a clear day, just as the sun gilds everything with a fine mellow light. At such times, and in calm weather, the notes of these little minstrels are heard at a great distance, and their movements easily observed on their resting place being approached. Some, it may be, are preening their feathers, others sitting with puffed-out plumage, while the minority are warbling a few enjoyable strains, suggestive of a lullaby to sing the whole assemblage to sleep. In a moment every bill is withdrawn from its work of feather dressing, and a tremulous burst of bird music is heard ringing from the branches-such an effect, indeed, as might be brought about by a treeful of tiny bells shaken by a sighing breeze.

In the remoter Hebrides, where there are no trees on which to perch, the linnets make choice of some sheltered bank exposed to the sun's rays, and there they recline towards evening to practise their singing for the coming summer, making the very ground rejoice with them as they utter their harmonious twitterings. The passer-by in his rambles through these bleak solitudes cannot but wonder at the fairy-like notes issuing from the usually dull and stony heath; for although he may notice one or two birds perched on the surrounding rocks, he is not prepared to see so many in the congregation he has disturbed as they suddenly burst into the air before him. The islands of Lewis and Harris are frequented by linnets, and also North Uist and Benbecula. On Lewis, the plantations near Stornoway afford them good shelter; but in the other localities they live entirely among the heather, in which they make their nests. They are also very common over the whole of the inner islands.

I have observed in some parts of Ayrshire that linnets are gregarious to some extent even in the breeding season, both on the sea shore and in the pebbly beds of rivers and smaller streams, which they frequent at certain hours, coming and going together in flocks with apparent regularity. 
In the course of my reading, I have not met with any lines by our poetical writers addressed to this bird in a state of liberty, although in its every-day life it is not a less attractive subject than many of the commoner birds that have been so commemorated. I close, therefore, with a fragment from an address to a dead linnet by a solitary student, whose pen, I venture to think, could, if so directed, have well expressed its habits before it became the

"Friend in hours of lonely thought,

And studious toil through the unresting day."

The lines were sent to me by Mr William Logan of Kilbirnie, himself the author of many amiable verses*:-

\footnotetext{
"The secret bustle of thy frequent meal, Like elfin working mischief, all unseen At bottom of thy cage; thy dipping bill Oft splashing sportive o'er the learned tome, And rousing my 'rapt soul to homelier themes; The tuning twitter, snatch'd and interruptThe timorous essay-low and querulous -

The strain symphonious-and the full burst of song, That made my study walls re-echo sweet The harmonious peal, while all its tattered maps And prints unframed, responsive tremblings gave;All these are past, and joy takes wing with thee."
}

\section{THE MEALY REDPOLE.}

\section{LINOTA CANESCENS.}

Is of irregular and uncertain occurrence only. Some seasons pass without any being seen, while in others they are frequently obtained. The winter of 1863-64 may be noted as one in which this species was comparatively common, numbers having been taken by the bird-catchers even in the neighbourhood of Glasgow. Six specimens were seen in the outskirts of the city in 1861, two of which were caught with bird-lime. The season was a very severe one. Mr Tottenham Lee found several specimens in Kirkcudbrightshire in 1854, and in 1868 Mealy Redpoles were again taken in that county and in Dumfriesshire, and sent to the Glas-

* Died 26th February, 1869. 
gow bird-market. I have seen several specimens that were taken near Forfar, and it has frequently occurred in Midlothian.

Dr Saxby informs me that he shoots these birds in Shetland every winter.

\section{THE LESSER REDPOLE.}

\section{LINOTA LINARIA.}

THis species appears to be more dependent upon woods and thickets of brushwood than either the twite or common linnet, as I have not been able to trace it to those districts where such shelter is absent. It is a visitor to Iona, as I have been informed by $\mathrm{Mr}$ Graham, who has seen it in flocks appearing with the two species just named, and Mr Elwes has added it to his list of Islay birds, a specimen shot in that island being preserved in the museum at Islay House.

On the mainland of Argyleshire the Lesser Redpole is common enough even in summer, and breeds in that county, as well as in Renfrewshire and Dumbartonshire. It also breeds near Glasgow, and is sparingly distributed in other parts of Lanarkshire, especially where birch plantations are numerous. The same remark indeed applies to its occurrence in most Scottish districts. Its habits are very easily studied, as it is exceedingly tame and heedless of observation. I have often stood within a few feet of a small flock perched on thistles or feeding upon the seeds of other plants by the roadside. Its movements are exceedingly active and amusing, and its note wondrously loud for so small a creature.

In Orkney as many as fifty are sometimes seen in a flock.

\section{THE MOUNTAIN LINNET OR TWITE.}

\section{LINOTA MONTIUM.}

Bigean baintighcarna (Uist).

THe stronghold of this lively bird in the west of Scotland is unquestionably the Outer Hebrides. Throughout the whole of the Long Island it is found in very large flocks, and as these pass overhead in the course of their journeys in search of a good feeding ground, the brisk chirrup of the birds may be heard at a con- 
siderable distance. The note of the Twite is much shriller than that of the common linnet, and is readily distinguished even when the two species are together. I have often been much interested in watching numerous companies of twites in North Uist attracted during their flight to a bed of thistles or other plants, on which they would perch after a few restless turns in the air before alighting. They will then permit a very near approach, and never fail to amuse any one taking time to observe their movements. Reared for the most part in bleak and cheerless nurseries, the twites of the Hebrides are hardy and active, and appear to delight as much in a mass of useless growing weeds as do their allies in the leafy groves of the south. Listen to the brisk and encouraging chatter they sustain until they have exhausted the spot of its supplies; a few more piping notes summon the whole flock to order, and away they burst into the air with a shrill but joyous cry, filling the air again with their strange music.

On some parts of the mainland the Twite, although not quite so abundant, is still numerous, extending from north to south. Thus, in Sutherlandshire, it is the prevailing species of linnet, while in many parts of Kirkcudbrightshire it is far from being rare even in the breeding season. In the higher grounds of Lanarkshire it breeds in some numbers, and is still more common in winter. The city bird-fanciers catch occasionally as many as twenty twites in a day. In the east of Scotland the species is much less numerous than in the west; still it is well known in rural districts, where it is called the " heather lintie."

The following notes on this species have been sent to me by $\mathrm{Mr}$ Elwes:- "The Twite does not confine itself to heather when choosing a situation for its nest, but often breeds in a bush or in creepers against a garden wall. It also sometimes makes a nest on the ground under a stone, and during the season of incubation is extremely tame and familiar. The eggs are five or six in number, and I think that two broods are usually hatched in the year, as I have found fresh eggs as late as July. In the summer it is not difficult to distinguish the Twite from the common linnet, which I have never seen in the Long Island, as it has not the ruddy tints in the head and breast which are so conspicuous in the other species.

Mr Brown informs me, that on 17th May, 1870, he took three twites' nests in Mr Macdonald's garden at Newton, North Uist; 
these were built at a height of two or three feet from the ground, in red currant bushes, and contained in two instances four eggs, and in the other five. Mr Brown also took in the same island, a few days later, several other nests, which were placed amongst heather, on the sloping banks fringing the sea-shores and lochsides, these being favourite situations with the bird. The nests were formed of dry grass, lined with sheep's-wool, slightly edged with cow's hair. In one instance he found a mixture of cow'shair, sheep's-wool, and crows' feathers. Another contained a considerable quantity of a small, thin, reddish-coloured root, which was interwoven with the structure outside. In any case the number of eggs did not exceed five, many of them being sat upon about the 20th May.

\section{THE BULLFINCH.}

\section{PYRRHULA VULGARIS.}

Corcan coille. Deargan fraoich.

A Bullfinch away from woods or thick hedges is as much out of his element as a puffin would be in a flower plot; hence when we hear of this beautiful bird being captured in the treeless districts of the north, we naturally think of the perils he has encountered in being driven across the sea against his own instincts. It is, however, but seldom such instances occur; one mentioned by Dr Saxby as having been found in Shetland in October, 1863, and another so far back as 1809 in Orkney, being the only examples recorded of Bullfinches being blown away from their leafy haunts. On the western mainland this species is common from Inverness-shire to the south of Wigtownshire. Mr Sinclair has seen numbers at Loch Sunart, old and young, frequenting birch trees and tangled hedges. In Ayrshire, Dumbartonshire, and Renfrewshire, it breeds in considerable numbers; and $\mathrm{Mr}$ Alston informs me that it appears to be on the increase in Lanarkshire as the county becomes better wooded and enclosed.

When in the town of Banff in May, 1869, Mr Thomas Edward showed me a very interesting variety of this bird; it was pure white, with the exception of the neck and breast, which were suffused with a delicate pink hue, like the blush of a half-blown 
rose. The bird had been obtained in the neighbourhood, and is now preserved in the local museum.

\section{THE PINE GROSBEAK.}

\section{PYRRHULA ENUCLEATOR.}

IN 1769 Pennant observed this species in Aberdeenshire, and refers to the circumstance in the following short notice taken from his "Tour in Scotland," published in 1772, 2d ed., 8vo:- "I saw flying in the forests the greater bullfinch of Mr Edwards; tab. 123, 124-the Loxia enucleator of Linnæus, whose food is the seed of pine cones-a bird common to the north of Europe and America." About twenty years afterwards, Dr Burgess included the Pine Bullfinch in his list of the birds of the parish of Kirkmichael in Dumfriesshire, and it is likewise mentioned in the statistical account of the parish of Eccles in Berwickshire as a rare visitor about thirty-five years ago. In a carefully prepared catalogue of the animals and plants of the Esk Valley in Midlothian, published in 1808, and which bears evidence of having been the work of the late Patrick Neill, Secretary to the Natural History Society of Edinburgh, this species is included, doubtless on good authority.

Don includes this bird in his Fauna of Forfarshire, which was published by the Rev. James Headrick, minister of Dunnichen, in 1813 , and states that it had come in great numbers to the woods of Glamis and Lindertis in company with flocks of the common crossbill, "and totally destroyed the whole larch and fir cones for these two years past."

I can find no reliable record of the Pine Grosbeak having appeared in any part of Scotland since 1833, and it is now extremely doubtful if it ever occurs. There is, indeed, a possibility of the bright coloured males of the common crossbill having been mistaken for this species, especially when males and females are seen on wing together. It is, at all events, a singular circumstance that no recent observer has met with it. Ornithologists would do well to examine carefully any Scottish specimens that may yet come in their way in case the birds should turn out to belong to the American variety, which since Audubon's time has been ranked as a new species. It is catalogued in Professor Baird's work as the Pinicola Canadensis (Cabanis), and its habitat given as "Arctic America, 
south to United States, in severe winters." The following remarks by that author may not be out of place:- "In comparing an American specimen of the Pine Grosbeak ( $P$. enucleator) in the collection of the Philadelphia Academy, I find the former considerably larger (wing $4 \cdot 76$ instead of $4 \cdot 40$ ), the bill much stouter and more bulging at the sides, the tip of the upper mandible much less decurved and less projecting over the lower. The tail feathers are much broaler. The legs are black, the bill dark brown instead of both being horn colour. There is little difference in the character of the red; there is, however, much more white on the wing in very broad and sharply defined pure white external edgings of the quills, especially on the tertials, secondaries, and greater coverts, instead of having these narrower, less conspicuous, and tinged with rose. Without being sure that these differences of the two skins are either constant or characteristic, I think it proper to quote such references only as belong to American specimens."

The flocks seen by Mr Don in 1813 must, I think, have been migratory, and there is nothing inconsistent with what is known of the flights of other species in the surmise that they may have come to this country via Greenland and the Faroes; hence the need of careful examination of specimens that may in future be obtained.

\section{THE COMMON CROSSBILL.}

\section{LOXIA CURVIROSTRA.}

Occurs in some localities in the west of Scotland in great abundance, especially in winter, when they are more easily observed. Large flocks frequently appear in autumn, and are now so well known that they excite but little notice.

The Common Crossbill breeds perhaps more numerously in the central counties than elsewhere. In many parts of Lanarkshire it is found in considerable numbers during the breeding season, especially in the neighbourhood of Douglas. It is also very plentiful in Dalswinton woods, near Dumfries, where many nests have been obtained every year. On the west coast the nest has been several times found in Drummuck woods, near Girvan, where the birds have of late years located themselves. Two nests were obtained there in 1864, as late as May, probably a second brood, and in 
several parts of Dumbartonshire young broods have likewise been observed. The nest of this bird is, however, not easily found.

Throughout Scotland generally this Crossbill is widely distributed, having been taken in every county, although not, as far as I am aware, in any of the outer islands. Wooded districts appear to attract the greatest numbers, but when congregated in very large flocks, they wander restlessly over the country, alighting at times in places hardly suited to their habits. I have observed autumn flights of these curious birds passing the outskirts of the city of Glasgow. In some districts it appears to be resident all the year round.

In Orkney, where great numbers appeared in the winter of 1806-7, the migratory flocks do not occur regularly. I find from a manuscript note, by one of the authors, in Baikie and Heddle's "Fauna," that numbers were observed there in 1849.

The bill of this species appears to vary very much in size; out of a dozen specimens now before me, only three have this feature alike.

\section{THE PARROT CROSSBILL.}

\section{LOXIA PITYOPSITTACUS}

CAN only in the meantime be regarded as an accidental straggler. It is not unreasonable, however, to suppose that it may occur much oftener in Scotland than past records would lead us to believe; and I would recommend Scottish ornithologists especially to renew their observations in northern districts, believing that the large flocks of Crossbills which annually visit us will be found in some cases to include this species. I have a very characteristic specimen of the Parrot Crossbill now before me, which was killed at Wemyss Bay, on the shores of the Firth of Clyde, in the spring of 1862 . It was one of a flock observed by a country lad and his companion, and was knocked down with a stone which one of them was induced to fling at the birds on account of their tameness. Two came into the possession of Sir William Jardine in 1833 ; they were taken in Ross-shire.

The late Mr H. Osborne of Wick mentions in a paper contributed by him to the Royal Physical Society of Edinburgh, 
and published in the proceedings of that Society, vol. ii., p. 341, that a specimen of this Crossbill was found dead near Lyth, in Caithness, and that another specimen-a male-had previously been taken alive in a fishing-boat in which the bird alighted when at sea. The first-named specimen was exhibited at the meeting by Dr Smith, the Society's secretary.

To these instances I may add another, the occurrence of which has been obligingly communicated to me by Edward Hargitt, Esq. of London; it was a female bird, shot near Lochend, Inverness, on 5th December, 1868.

\section{THE EUROPEAN WHITE-WINGED CROSSBILL.}

\section{LOXIA BIFASCIATA (NILSSON).}

I CAN say nothing of this bird from personal observation, nor can I find any recorded Scottish example of the species except that mentioned by Mr Yarrell as having been killed in Roxburghshire by $\mathrm{Mr}$ Jerdon in March, 1845. On referring to the "History of British Birds" by that author, it will be seen that after mentioning the occurrence of the first specimen in Ireland in 1802, he states that "Pennant also mentions in his 'British Zoology' having been told of a second killed in Scotland,"--an obvious misquotation, as there is no notice of the White-winged Crossbill by Pennant himself in the earlier editions of his work. It is first introduced into the edition of 1812 by Dr Latham, who revised, for the editor, the ornithological portion of it. His words are- "The reason of my giving the bird a place here is its having been shot within two miles of Belfast in January, 1802. I had indeed been informed before of the species having been met with in Scotland, but the report came through so uncertain a channel as to forbid my noticing it.-J. L." Pennant died in 1798.

\section{THE AMERICAN WHITE-WINGED CROSSBILL.}

\section{LOXIA LEUCOPTERA (GMELIN).}

IN February, 1841, a specimen of this straggling visitant to Britain was shot near Jedburgh, and eame under the notice of Mr Jerdon, whose name appears in connection with the preceding species; and 
Mr Thomas Edward of Banff has recorded that a large flock appeared near that town in 1859. The birds in this case seemed to be in a state of great exhaustion, many of them being even unable to cling to the trees on which they perched. About twelve or fifteen years ago my friend Dr Dewar, when sailing from America to this country, observed great numbers of this species crossing the Atlantic before a stiff westerly breeze. Many of the flocks alighted on the rigging and deck of the steamer, which, at the time, was about six hundred miles east of the Newfoundland coast. He secured ten or twelve specimens of the bird, and put them in confinement; one or two escaped as the ship approached the Irish coast, and made direct for land; two others flew out of their cage when being conveyed in a cab through the streets of Liverpool, and five birds were sent to myself. These turned out very mischievous pets, breaking everything within their reach. They lived a few months, and were never at rest. Even at night they were perpetually climbing the wires of their cage, and chirming their monotonous, cricket-like notes, reminding one occasionally of a wheel revolving rapidly on an ungreased axle. Two of these birds are now before me, and on placing them beside our common crossbill and parrot crossbill, they seem more likely birds, from their lighter figure, to sustain a continued flight than those of a heavier make.

INSESSORES.

CONIROSTRES.

STURNIDAE.

\section{THE RED-WINGED STARLING.}

\section{AGELAIUS PHENICEUS.}

I HAVE but one instance of the capture of this bird in Scotland to chronicle, namely, a specimen which was shot near Banff in 1866 by H. A. Rannie, Esq. of Greenlaw, corresponding member of the Natural History Society of Glasgow, and sent by him for exhibition to one of the Society's meetings in the same year. It appeared to be a young male. Mr R. Scot Skirving informs me that one of these birds was seen in Haddingtonshire a few years ago, and that he is quite satisfied no mistake had been committed in its identification. 


\title{
THE COMMON STARLING.
}

\author{
STURNUS VULGARIS.
}

Druit.

THIRTy years ago the Starling was comparatively a scarce bird over the whole of the Scottish mainland. So far as I can ascertain, it has been well known in the outer islands as a permanent resident from time immemorial, but in cultivated districts its appearance at any season of the year has been an event so recent as to have excited universal attention. At the present time it is a constant resident in and near large towns, and exists in such numbers as frequently to cause remark among persons usually unobservant of the phenomena of bird life. Within the limits of the city of Glasgow thousands of Starlings live throughout the year, and may be seen almost at any time, with the exception of a few weeks in the dead of winter, perched on the ornamental work of church spires and the roofs of houses, or hurrying overhead in small companies when taking their flights into the outskirts for a change. During summer, numbers may be observed sitting on the chimney-tops uttering their soft and not unmusical chatterings, which they sometimes enliven with an impudent whistle as if inviting attention. These modulated notes appear to be a kind of love song uttered by the male, whose performance is not unfrequently interrupted in the spring time by the strains of some rival minstrel subsiding into a shrill cry of " all serene."

In country districts the Starling seems partial to low-lying grounds or meadows subject to periodical overflow on both east and west coasts. I have observed this partially shewn in our larger estuaries where the brackish water covers a considerable extent of salt marsh at high tide, and leaves a richly spread table for the birds at low ebb. The Starling, indeed, is found in much greater abundance in moist or swampy districts than elsewhere-a habit which is doubtless due to their preference for worms and other soft-bodied animals which are plentiful in such places. I have observed that in counties like Ayrshire and Wigtownshire, which are comparatively well drained, there is a partial migration in autumn. Considerable flocks have been seen by myself and my colleague Mr Anderson flying southwards from Girvan and Ballantrae, and we have been informed that multitudes frequently congregate in 
the vicinity of Portpatrick, from which they are seen setting out about daybreak. Many of these flights are supposed to cross over to Ireland.

The site chosen by this bird for nest-building varies according to the nature of the habitats frequented. Like the jackdaw, it nestles in old towers and castles, ruined mansions, ancient trees, and overhanging sea-cliffs abounding in caves, in which it can share the company of the cormorant and rock dove. I have also found it breeding in holes in new or even unfinished buildings, and in chimneys down as far as the top of a grate, fifteen feet from the mouth of the funnel, where the passage up and down must have been a difficult feat. I remember finding several nests at Dunbar in decayed trees, each of which had a very small opening sufficient certainly to admit of the bird's entry, but not without a squeeze. One of these trees having been blown down during a gale of wind, became soft in the centre, and offered to a pair of Starlings a good opportunity of trying their ingenuity in digging a hole for themselves. They set to work, and I watched them perseveringly until they had finished their excavations. They laboured several days before the hole was large enough to conceal the two birds, as it was necessary for them to carry each particle of wood to a distance, to prevent their employment being discovered; but at the end of the fourth day, a strong breeze prevailed, which blew every chip and fragment far out of sight, over the top of an adjoining wall. The Starlings-for both male and female were engaged-perceiving that the pieces of pith were no sooner exposed at the hole's mouth than they were blown out of their bills with a violent puff, jumped down together as if in concert, and to my great astonishment, after a lapse of some minutes, I observed numberless small pieces of decayed wood issuing from the broken trunk, like smoke coming from a chimney. The birds had vigorously loosened a quantity of pith and shuffled it outside in a twinkling over their backs, as I conjectured, by the aid of their wings, the violence of the wind saving them all farther trouble. On afterwards climbing to the top, I found that they had constructed a chamber large enough to accommodate a bulky nest, which they ultimately built in the hole, the excavation extending to the one side, so as to avoid the risk of water from above. But after some years, as I learned from Mr Sinclair, their nest was flooded during heavy rains, and they left the place. They 
reappeared the following year, and took possession of another hole in an adjoining tree, where they brought up four young ones, which were stung to death by a swarm of bees that happened to settle in the hole. The old birds, after a few days' wailing, disappeared in their sorrow, and did not return.

In the Outer Hebrides, where there are no trees, the Starling breeds under stones on the beach, in turf dykes, and deserted rat holes. In other places I have seen them take possession of holes in rough stone fences in the immediate vicinity of water. On the river Clyde, where the sailing channel is indicated by barrel-shaped beacons, I have found thousands of Starlings roosting at nightfall. By rowing up to one of these hollow perches, and tapping it with an oar, I have been diverted with the screaming uproar which ensued, and the ludicrous celerity with which the birds made their exit by the bunghole. A few years ago I witnessed a curious scene one summer evening at a country church as I sat watching the lengthening shadows of tower and tombstone. The quiet sexton, with whom I had, half-an-hour previously, been in conversation, left off work unobserved, and entered the tower to ring out his nightly chimes. Suddenly the bell began to toll, and in another moment hundreds of screaming Starlings issued from the crevices and the corners of the church and its gilded spire. Shadowy swifts glanced from under the eaves in alarming haste, returning again and again to the tower, and screaming as they passed; pert jackdaws, troubled sparrows, and bewildered pigeons all joined in the general outpouring, until the clamour and disturbance had cleared out the occupants. As soon as the ringing ceased, the birds returned to their holes: in a minute all was hushed; and as the shadows deepened over the trees and surrounding tombs, the great silence which then prevailed seemed to deny the presence of so many creatures of life.

The Starling feeds chiefly upon small land shells and beetles. Any specimens that I have examined of late years had their stomachs filled with minute shells, mostly belonging to the genera Helix and Clausilia. At Dunbar I have noticed that great numbers resort to the dried heaps of seaweed-the cast-up mounds of winter storms-in which they find and feed upon an abundant supply of maggots. I have also seen flocks alight on the rocks and diligently examine the crevices for prey, in procuring which in such situations their wedged-shaped bills seem fitting instruments. In pasture 
lands these flights associate with rooks and jackdaws, feeding with them, and leading the way to another place when disturbed. They are also frequently seen in the company of lapwings, whose movements when on wing they appear to control with diverting accuracy. A dozen Starlings will often lead through the air for miles two or three hundred of these birds.

In sultry weather I have often observed Starlings flying in circles at some height from the ground, and snapping at insects, on which they appeared to prey with great perseverance upwards of an hour at a time. They appear to practise this habit only on very hot days when flies are found in swarms. As a set off to this useful occupation, however, these birds are known to search for and deliberately devour the eggs of birds which breed on the ground, such as larks and yellow hammers. I confess that on first hearing this accusation brought against the Starling I was reluctant to entertain it, but subsequent observation has convinced me that when opportunities offer, the Starling, besides devouring eggs, will not hesitate to prey upon newly hatched birds. I have seen it repeatedly alight on the rough stones of a house to which it clung while it thrust its head and neck into a hole and dragged from it in succession five young sparrows, which it leisurely swallowed on the roof of the house. I have more than once been a witness to such thefts when stationed at a window only a few feet distant from the nest. Similar observations have been made by $\mathrm{Mr}$ John Levack in Cumbrae, some of the attacks of the Starling, witnessed by that gentleman, being indeed even worse than what I have narrated; and bearing such facts in mind, it may not be out of place to suggest that certain limits should be fixed to the protection now afforded to this bird, seeing that its habits bear so close a resemblance to those practised by its relatives of bad repute.

\section{THE ROSE-COLOURED PASTOR.}

\section{PASTOR ROSEUS.}

THIS beautiful bird has occurred in almost every county of Scotland, from Berwickshire to the Orkneys on the east, and from Wigtown to Sutherland on the west; but I have not heard of its occurrence in any of the outer islands. In 1853 a pair-male 
and female-which I examined, were shot in the outskirts of Glasgow, and were presented to the Andersonian Museum by Dr Hugh Colquhoun; and on the 7th August, 1868, I had an opportunity of seeing a male specimen, which had been shot on the previous day by one of Mr Harvey's servants at Hundred-acre farm, within two miles of the city. It was seen flying about with a flock of common starlings. A specimen in my own collection was obtained near Cupar, in Fifeshire, in the autumn of 1863. Specimens have also been obtained in Perthshire, Ross-shire (near Dingwall in several instances), Sutherlandshire, and Caithnessshire. In Aberdeenshire it has occurred frequently. Mr Angus sent me the stomach of one crammed with beetles, which was shot near Aberdeen in June, 1867, and Professor Dickie has obligingly sent me word of another killed about the same time within a few miles of that city.

Mr John Wilson has informed me, through Mr Angus, that in the summer of 1840, the nest of this species was obtained in'a burrow in a sandbank near Methlick, in Aberdeenshire. On the nest being destroyed by some boys, the birds removed to another sandhole about a mile distant, but Mr Wilson does not think they succeeded in rearing a brood.

In the Orkneys it has occurred several times; and Dr Saxby states that he shot two specimens at Balta Sound, in Shetland, one on 10th August, 1860, the other in September, 1863. Both were males.

In referring to the habits of the Rose-coloured Pastor during the breeding season, Messrs Elwes and Buckley, in a contribution to the Ibis for 1870, on The Birds of Turkey (see page 192), write as follows:- "This bird is, in some years, very abundant in Bulgaria, but does not come regularly. It is one of the latest summer visitors to arrive, as the flocks do not make their appearance before the latter end of May, when they at once take up their quarters in a sandpit or bank of earth, and commence nidification. The nests are made at the end of a hole bored in the earth, like a sand martin's, sometimes to a considerable depth. The eggs are like a starling's, but much more glossy, and of a paler blue. Near Milchooa, in the Dobrudscha, we saw the breeding-place of a large colony; and $\mathrm{Mr}$ Barkley informed us that in the summer of 1867 a cutting on the Varna and Rutschuk railway was frequented by two or three hundred of this species." 
The Rev. H. B. Tristram has also the following interesting note on Pastor roseus, in a paper on the ornithology of Palestine, contributed by him to the same journal for 1867:- "The Rosecoloured Pastor is not even a winter visitant, but occasionally appears in vast flocks. It is well known to the natives as the locust-bird, from its habit of preying on that destructive creature, whose flights it generally follows. We found it in 1858 , but not in 1864. It has been known to breed in large colonies in Palestine, but not for many years past. So at Smyrna, numbers of nests were taken in 1858, while, since that year, it has rarely been seen there. The behaviour of the Pastor in Syria reminds us of that of the wax-wing further north, an erratic rather than a migratory bird."

INSESSORES.

CORVIDA.

CONIROSTRES.

\section{THE CHOUGH. \\ FREGILUS GRACULUS. \\ Cathag dhearg-chasach.}

THE history of the Chough as a Scottish bird presents some curious facts which are not unworthy of notice. It appears to have been at no distant date a much commoner bird than it now is, and to have inhabited inland situations from which it has now utterly disappeared. The Chough is mentioned by Don in his Forfarshire list as a resident species in the mountains of Clova, and is likewise referred to by Pennant, who states that he found it "in the farthest parts of Glenlyon and Achmore."* About the same period it appears to have frequented the rocks at the Corra Linn Falls on the Clyde; and twenty years afterwards, namely, in 1794, the Rev. John Lapslie included the species in his list of birds found in the parish of Campsie, in Stirlingshire. This accurate writer states in his report, that the Chough, although a native of the district, was even then becoming scarce, a pair or two only being seen on the whole range of the Campsie Fells. "When we do meet with them," says Mr Lapslie, "it is among the jackdaws, of which there are a considerable number haunting our rocks." The most recent instance of the bird being met with in an inland

\footnotetext{
* Tour in Scotland, 2d Edit. 8vo, 1772.
} 
locality is one which was shot and preserved at Crawfordjohn, in Lanarkshire, in the winter of 1834. In all these localities the Chough has long ago become extinct, and the species is now wholly confined to the sea coast. Yet in many places once distinguished for red-legged crows, it has of late years become very scarce. Thus at Burrow Head and the Mull of Galloway on the southwest coast, Troup Head on the north, and St Abb's Head on the south-east, the bold and precipitous rocks fronting the sea were at one time inhabited by considerable numbers of these birds, while now a few straggling pairs are all that remain; indeed, it may be questioned if a single Chough has been seen at either Troup Head or St Abb's for the last ten or fifteen years. It would almost seem as if some fatality were connected with the Chough in this country, as in nearly all the old and now deserted haunts of the species which I have visited, I can find no apparent cause for its disappearance. That the encroachments of man can have had little or no bearing on the subject is, I think, evident, from the fact of the Chough's haunts being for the most part remote and inaccessible. Other birds-the appropriate residents of these wild and romantic headlands-still maintain their ground, unaffected by such influences as have caused the Chough to disappear. Nor can it be said that in the localities I have enumerated the bird has been the subject of special molestation, unless in this light we recognise the fact that as its numbers have diminished, there has been a corresponding increase of another species-the jackdaw-whose perpetual acts of mischief are no doubt prejudicial to the harmony of a colony of cliff-haunting birds. In almost every district I have visited of late years, jackdaws have increased to an excessive extent; and until some other and more satisfactory explanation be given for the Chough's absence, the increase of the one bird, I suspect, must be looked upon as the cause of the decrease of the other.

The Chough is nowhere so common in Scotland as in the island of Islay, which is still frequented by the same numbers as were known to exist there twenty years ago. I have obtained yearly evidence of this both by observation and the acquisition of specimens. At Bridgend and Port Ellen it is seen in small parties coming close to the village, and frequently approaching the refuse heaps near the dwelling-houses. A very handsome pair now before me were caught a few months ago in a sieve trap. It is 
doubtful if any of their eorvine allies could have been captured so easily. At the Mull of Oe, in the same island, wandering flocks of Choughs are often seen, and I have eggs in my collection from that headland. The following notes, which have been forwarded to me by Mr Elwes, are of interest in connection with this district:- "The Clrough is common nearly over the island, and is one of the most characteristic birds of Islay. It is said to have come first from Colonsay, where they are very numerous, and I think it is rather decreasing in numbers at present, though very seldom molested by the inhabitants. It is seen almost always in pairs throughout the year, or in small companies of two, three, or more pairs, and I believe that this bird, like the raven, pairs for life, for I once shot a pair, that from their general appearance must have been extremely old, the plumage being worn and the beaks and claws unusually long. The Chough roosts every night on the cliffs and rocks near the shore, and in the morning disperses over the cultivated fields in search of food. It frequents grass and seed fields, ploughed land occasionally, and is also seen often about the roads and houses especially in frosty weather. Towards evening they return to their roosting-places, where they hover about the rocks with their broad wings spread, rising and falling in abrupt curves, and constantly uttering their strange and unmistakable cry. They are always restless and uneasy, never remaining long in one spot, but taking short flights and constantly calling. They are easily distinguished by their cry and their very broad wings, the quill feathers of which separate and turn up at the points, more so than almost any bird I know. They are not shy except when pursued, and may be killed without much difficulty when wanted. They breed in the beginning of May, making a large nest of sticks, heath, and wood, generally in a deep crevice of the rock. The eggs are from three to six in number."

Mr Graham informs me that "three pairs at least regularly breed in Iona; two nests are placed in sea-caves, very difficult of access, and the third is on the tower of the cathedral, among those of the jackdaws, with whom the red-legs seem to be on the best of terms, feeding with them abroad, and frequently accompanying them home to their roosting-place. It is the only bird admitted to this privilege-all others, even the lordly peregrine and vagabond hooded crow, being instantly ejected from their sacred altitude without ceremony." 
The Chough is still found on the west coast of Skye, where it breeds in limited numbers. Dr Dewar has three eggs in his collection from that locality, which may be considered its most northern limit. These birds have probably come from Barra, in the Outer Hebrides, where, though now unknown, the species was found about forty years ago by Macgillivray, who states in his account of the Long Island, published in the Edinburgh Jour. of Nat. Geog. Science, vol. ii., p. 323, that it then frequented the southern extremity of the range, but was not met with elsewhere. In like manner, many of the smaller islands within the circle of the inner group have been deserted within the last thirty years. It is no longer known in Tyree, Coll, Rum, or Canna, nor does it now frequent the island of Lismore, or the district of Appin, where flocks existed about the beginning of the present century. It is doubtful if it breeds in Mull or Jura, and it has not bred in Arran for the last seven years. One of the Duke of Hamilton's keepers shot the only pair on that island in 1863, and I have been assured that no Choughs have been seen there since.

On the south coast of Ayrshire* and along the coast line of Wigtownshire, extending to the Mull of Galloway, Burrow Head, and the borders of Kirkcudbrightshire, the Chough, although much reduced in numbers, is still sparingly met with, though in some spots where flocks might have been seen twenty years ago, a solitary pair at most remain. The sable couple may be noticed passing their time at intervals during the winter months, dozing on their high perch outside the mouth of some cave, pleased with the roar of the restless waters below, or perhaps hushed by the dull sound of the cold sea heaving one swelling wave after another into the hollowed chambers of the rock. But in the summer time when their caves are resorted to by other birds such as kestrils, jackdaws, swallows, and cormorants, and while the cliffs themselves are white with snowy gulls and orderly guillemots, the Chough becomes the life of the colony-a light-hearted gossiping fellow, and an elegant dandy among the "craws and kays," soaring lightly in wide circling turns over the busy multitudes, and cheering them all with his lively watchword. Being the only land bird included

* In this county stragglers are occasionally seen as far north as Ballantrae. Mr Anderson informs me that, about forty years ago, it frequented the cliffs at Culzean Castle. A specimen shot there in 1824 is still preserved. 
in the recent Act for the preservation of sea-fowl, it would appear to have excited sympathy in its favour, and the protection it now enjoys may ultimately, it is hoped, restore the declining strength of its numbers in such localities throughout Scotland.

I have been lately favoured, through $\mathrm{Mr}$ David Douglas of Edinburgh, with some very interesting notes on this bird, written by his friend, Mr A. Irvine Robertson, who had many opportunities of remarking the habits of the species in the neighbourhood of Portpatrick, in Wigtownshire. Mr Robertson states that he and his brother have seen as many as six together, but not more, near that village, and that he has also seen them occasionally as far south as Drumore and at the north extremity of Broad sea Bay. "They are most plentiful, however," continues my informant, "within five miles of Portpatrick, on either side of the village. We found five broods on the cliffs to the south, and two to the north, and very probably there were more. One of the nests between Cairngarroch and Port-a-yew, was built in a narrow hole above the centre of the arch at the mouth of a cave. We were told that for many years the birds had built a few yards to the side of the arch, but the Portpatrick boys having managed to reach the nest and rob it, the Choughs, after several vain attempts to rear a brood in the old place, knowingly moved their quarters to the present impregnable position. It is as good a place for watching their habits as one could wish for; the nest is about twenty feet from the ground, and the young ones can be heard distinctly, and when well grown can be seen occasionally looking over the edge and getting fed by the old birds. Another nest found by my brother was placed in a slit in the face of the cliff, about thirty feet from the ground; it contained two eggs, which were taken. In about three weeks a boy from the Port visited the nest and found that the birds had again bred and hatched a pair of young ones; these were, in colour, exactly the same as full grown birds, and had red beaks and legs, though, perhaps, a shade less decided. For a week they throve well and ate worms greedily, but unfortunately at the end of the week he tried them with oatmeal and water-the first dose of which they did not long survive." 


\section{THE RAVEN.}

\section{CORVUS CORAX.}

\section{Fitheach. Biadhtach.}

IN spite of all the persecution to which this well-known bird has been subjected, it is still common on some parts of the mainland, and on both groups of islands extending to the Haskeir rocks and St Kilda. Its proverbial cunning and fitness to withstand the rigours of a variable climate have, doubtless, been the means of its preservation. Up to the present time (1870) it continues breeding at the Mull of Galloway, Ailsa Craig, Island of Arran, Jura, Mull, Islay, Skye, and, it may be added, all the other islands of the Inner Hebrides where there are suitable cliffs for its protection. I have observed it, chiefly in pairs, on the outer chain of islands, where it evades all attempts at its destruction by its activity and vigilance. On Ben Eval, in North Uist, a pair have dwelt for many years, and are observed daily setting out together in the morning and returning in the evening about sunset. During the interval they have been searching nearly the whole of the shores of the Long Island. I watched this pair for ten successive nights returning to their mountain solitudes at the same hour, and, on still evenings, could hear their dull croak long before they came in sight. They flew with strong beats and in a straight line homewards. Mr Lamont of Nunton informs me that ravens occasionally visit farm yards at Benbecula and clutch young chickens: he has shot them in the act. This was chiefly in the evening when the birds had returned hungry and dissatisfied with their day's expedition.

In Macgillivray's work on British Birds, it is stated that as many as two hundred of these birds have been known to assemble in a flock on the island of Pabbay, in the Sound of Harris-a large herd of grampuses which was driven on shore there having been the means of attracting them. Afraid of their prolonged stay, and not liking the company of so many birds of evil repute, the inhabitants resorted to the extraordinary expedient of capturing a few and plucking off all their feathers, except those of the wings and tail, in which plight they were set adrift as scarecrows. The main flock then left in a fright and did not return. In this unusual congregation of Ravens an albino was observed, 
and a pied specimen was noticed some time afterwards in Harris by Macgillivray, who introduced it as a separate species at the close of the third volume of his work under the name of Corvus leucophous-a name originally instituted by Vieillot, but since shown to be without distinctive specific characters. These pied birds occur more frequently in Faroe and Iceland than elsewhere, and have been observed of late years in one or two of the Outer Hebrides. The late Mr J. Wolley makes the following reference to this variety in a paper on the birds of the Faroe islands, read at a meeting of the British Association held at Edinburgh in July, 1850, and afterwards published in Sir William Jardine's "Contributions to Ornithology" for that year:- "Of the Raven I saw the black-and-white variety, which has been called a species under the name of $C$. leucopheus; but two were shown to me alive which came out of the same nest with purely black ones; they were marked irregularly and differently from each other, and had none of the characters of a species." I may here add that I lately examined Mr Macgillivray's specimen of the pied raven, which is labelled in his own handwriting C. leucophoeus, and still preserved in the University Museum, Aberdeen, and that the entire aspect of the bird is opposed to the idea of specific differences, the appearance of the feathers and the light coloured claws and want of symmetry in the white markings proving it to be only a spotted bird which might ultimately have become an albino. It is rather singular that this painstaking naturalist should have allowed himself in this instance to be deceived.

In one of the earliest ornithological papers from Macgillivray's pen, the following remarks on the Raven afford a good insight into the bird's character as a native of the Long Island:--" The Raven is astonishingly common in all parts. It roosts and nestles on high rocks on the sea shore, as well as in the interior, and feeds on carrion of all kinds, fish, poultry, eggs, grain, grass, etc. In autumn the ravens become sub-gregarious, when they make great havoc in some places among the barley. At other times they are commonly seen in pairs, excepting for some weeks after bringing their brood abroad, when the whole family fly about together. I have seen one with patches of white in its plumage, and about fifteen years ago an individual entirely white was seen in the island of Pabbay. When grampuses or other large cetaceous animals are stranded, it is astonishing to see the numbers which 
congregate from all parts. The Raven is the first to find out a dead sheep among the hills. He begins his feast by picking out the eyes, and afterwards the tongue if he can easily get at it; the perinœum is next attacked, and lastly the abdomen, from which he drags out the intestines and devours them. When a horse dies, from thirty to fifty soon gather about him, and continue to make daily visits until the bones are picked. The Raven wages a kind of distant war with the eagle, two of them generally harassing the latter bird when it appears in the neighbourhood of their abode, on which account Ravens are never shot by the islanders during the breeding season. When a Raven has lost his mate during this season, even after the young ones are far advanced, he is observed to procure a stepmother for them with great celerity." *

Over the whole of the district to which this quotation refersnamely, from Barra Head to the Butt of Lewis-these disreputable thieves are still, as they must then have been, looked upon with great dislike; yet to the naturalist the sight of a pair of Ravens hieing to their rocky perch far above the sterile heath, is one not without interest. Frequently when seated on a hill near Lochmaddy, overlooking half of the island of North Uist, I could not help being arrested by the sable couple appearing at first like two dim specks in the evening sky, and, as they gradually neared their destination, holding a hoarse talking with each other, as if chuckling over the mischief they had been doing. Audible at a great distance, this croak of theirs was the only sound I heard for some minutes; but after the birds had passed overhead, and their conversation had died away in the distance, leaving the stillness of this waste of rocks and water more irksome than before, I thought of Macgillivray's impressions when similarly situated, and the somewhat uncomplimentary strain in which he has compared the animate with the inanimate in this most singular group of islands:-

"The character of the Raven accords well with the desolate aspect of the rugged glens of the Hebridean moors. He and the eagle are the fit inhabitants of those grim rocks; the red grouse, the plover, and its page, of those worn and scarred heaths; the ptarmigan of those crags and tempest-beaten summits. The red-throated diver and the merganser, beautiful as they are, fail to give beauty to those

* Edin. Jour. Nat. and Geog. Science, 1830, vol. ii., p. 322. 
pools of dark brown water edged with peat banks, and unadorned with sylvan verdure. Even the water lily, with its splendid white flowers floating in the deep bog, reflects no glory on the surrounding scenery, but selfishly draws all your regard to itself. There, on the rifted crag, let the dark Raven croak to his mate." *

From this suggestion no reasonable reader who has suffered even a fortnight's imprisonment in that strange part of the world will, I am sure, interpose a word of dissent.

\section{THE CARRION CROW.}

\section{CORVUS CORONE.}

As this bird invariably pairs with the next mentioned species in almost every district of western Scotland where the two are found; and as in size, habits, form, and general mode of living the birds are perfectly identical, it is impossible, on examining specimens of either, to say from what parentage they have sprung. From this fact, therefore, it is difficult to believe in the existence of two species in the district of country with which this work is more immediately connected; for, although the fact of the carrion and hooded crows breeding together in isolated cases has long been well known to ornithologists, the habit is so persistent in the middle districts of Argyle, Dumbarton, and some parts of Inverness, that it seems reasonable to regard these counties as the boundary line where the two races unite. $t$ When it is borne in mind, however, that the hooded crow is found at all seasons of the year in great numbers in Egypt and many other countries lying much further south than Britain, and that even in the southern portion of Britain itself the bird is migratory, the question becomes rather a perplexing one. It has even been stated by Mr Edward Blyth, in his notes to an edition of Cuvier's “ Animal Kingdom" (London, 1840), that the black crows which had been observed, by Naumann and other authors, breeding with Corvus cornix and producing fertile offspring, were, in truth, black varieties of the hooded crow! an argument which he had, some

* History of British Birds, vol. i., p. 509.

+ Dr Dewar informs me that he has, on three occasions, met with Carrion Crows paired in the west of Scotland: once at Lochfineside in 1867, and twice in the following year on the banks of Loch Lomond. 
years before, hinted at in the "Field Naturalist" (vol. i., p. 279). Yet, if this surmise be correct, we should expect to find the black variety in a quarter where the hooded crow is the prevailing bird. Throughout the Long Island, or Outer Hebrides, for example, black crows are very rarely seen, and never remain beyond a day or two when they do occur; whereas, the grey crow exists in thousands, and is stationary. The same remark applies to the Inner Hebrides, and also to the Orkney and Shetland Islands. Indeed, it is not known with certainty that the black visitors to these outlying districts are in reality carrion crows: the presumption is that, in many cases, they are rooks out of their usual line of flight, as their arrival appears to depend on the weather and direction of the wind.

The pairing of the two species, if such they really are, seems to have been known to Macgillivray (B. B., iii., 1840), and also to Sir William Jardine (B. B., ii., 1839), who states that he had repeatedly seen them breeding together, the produce being birds of intermediate plumage. Again he says-"In the mule specimens, the grey parts of the back and under parts are indicated by the edges of the feathers being narrowly margined with grey"-a state of plumage which I have not observed in any of the birds of mixed breed which have come under my notice, the offspring from the nest shewing dark specimens of a genuine black, and others with grey markings equally decided. M. Temminck (B. of Eur., 1815) has also the following remarks on this subject- "La corneille noire et la corneille mantèlée s'allient quelquefois; ils produisent des métis qui tiennent de l'une et de l'autre espèce; ceci a lieu dans les contrées méridionales et orientales de l'Europe où la corneille noire est rare; mais on n'en trouve point d'exemple dans les pays où les deux espèces sont communes." In repeating the fact of such unions taking place in countries where the carrion crow is rare, Mr Yarrell (B. B., ii., pp. 84 and 92) assumes that the forlorn birds become mated on the principle that a grey partner is better than nowe at all. To this suggestion I can hardly assent, as I have repeatedly seen two, and even three, carrion crows fighting for possession of a grey-backed one, where the two kinds were flying about in equal numbers. The last encounter of the kind I witnessed happened near Loch Melfort, in Argyleshire. The three birds (two black and one grey) were flying in company across the loch, when one of the former attacked his neighbour 
with great spirit, and caused a loud outcry. Instead of leaving the black combatants to settle their own dispute, the hooded crow, which I took to be a female, turned back on hearing the row, and joined the aggressor in buffeting the poor victim till he was drowned. Similar fights, in which all the combatants were hooded crows, have come under my notice, and I conclude from these exhibitions in the early part of the breeding season, that, unlike their congener, the raven, crows do not pair for life.

Throughout the mainland of Scotland generally, the carrion crow and the hooded crow are found in about the same numbers. In autumn, I have seen very large flocks of both in the north of Banffshire assembled together in the open fields, and examining the heaps of manure that had been laid down previous to the land being ploughed. In September, 1866, I observed upwards of 100 of each in a field near the sea, at Findlater Castle, overlooking the Moray Firth; they were comparatively tame, and allowed me to approach within 20 yards. Having in former years seen similar flocks alighting on the coast at Dunbar, in Haddingtonshire, I conjectured that they were migratory flocks, and had just arrived from the shores of Norway and Sweden. Judging, however, from the comparatively limited numbers that are found breeding in the eastern counties, I suspect that, on the breaking up of these flocks, numbers return to the countries from which they had migrated. I may here remark also, that both of the crows frequenting the shores of eastern Scotland are larger and stronger birds than those met with in the west.

On one occasion, when walking along the banks of Loch Eck, in Argyleshire, I observed a small party of carrion crows in a ryegrass field, busily engaged in catching moths as they clung to the stems of grass. The birds drew up their bodies, and appeared as if wading at some disadvantage, the tall grass obliging them to jurnp occasionally off the ground to reach their prey. This is the only instance I can recollect in which it can be said that their repast was not a work of mischief. 


\section{THE HOODED CROW.}

CORVUS CORNIX.

\section{Feannag.}

Althougr the western mainland of Scotland is frequented by a mixed breed of crows, as has already been said in connection with the preceding species, the grey bird or hooded crow is found in all its purity in the inner group of islands, and also in the Outer Hebrides, including the remoter rocks, and St Kilda. It is there permanently resident, and exists in many places in such numbers as to prove a great nuisance both to the farmer and game preserver. Even with this character, the persecution inflicted upon it does not seem to be injuriously severe, as its ranks have not been diminished in any perceptible degree for the last thirty years. I have often wondered, indeed, how so many ravenous creatures manage to subsist in these islands withont provoking the inhabitants to unite in rooting them out. On the western side of the Long Island, where farming is extensively practised, they are particularly mischievons, their plundering raids among lambs and poultry being distinguished by an amount of wariness and cunning which makes their unwelcome presence a subject of constant annoyance. Away from the coast their perpetual thefts are not less felt. In spring and summer, during the time of breeding, no bird is safe against their attacks-a momentary exposure of the nest and eggs being too great a temptation to the feathered vagabonds. Even the golden and sea eagles frequently lose their eggs by these crows. Mr Brown and Dr Dewar have both told me of instances that have come under their personal notice, where eagles' nests have been robbed of their contents while the owners were absent through disturbance. Dr Dewar states that on the island of Rum this year (April, 1870), three eggs at least were carried off by hooded crows which were seen waiting an opportunity for making a descent on the nest. In one case the eagle had no sooner quitted her eyrie than the crows pounced on the exposed eggs, and would doubtless have succeeded in breaking them had not the male eagle made his appearance and beat them off. Dr Dewar describes the scene as being extremely interesting, the eagle being in a rage at the thieves, one of whom he followed through all the hurried deviations of his 
flight with extraordinary celerity and perseverance, quite unlike the usual stately flight of a large bird of prey; the crow was so buffeted that he uttered several despairing cries as if his punishment was more than enough. Captain Cameron of Glenbrittle has also informed me that he has seen a pair of grey crows rifle a sea eagle's nest, and break and devour the eggs as determinedly as if they were those of some innocent grouse.

In North Uist, Benbecula, and other parts of the Long Island, which may be considered the stronghold of these "foules of reife" in Great Britain, the nests are found in rocks and also on the ground among the heather under shelter of broken boulders, where the rough aspect of the nursery harmonizes with the wild character of the occupants. Occasionally a pair will take up their quarters on the roof of a hut and bring out their young ones unmolested-a proof that to some of the natives at least their habits are a matter of indifference. On the gables of most of the huts there are two crossed sticks projecting from the roof, for the purpose of binding down the bunches of heather with which the huts are thatched, and I have seen as many as six and eight crows roosting on these at a time; hence the perch is called "maidhe feannag," which means literally the crow's stick.

Compared with the hooded crows found in the eastern counties of Scotland, these Hebridean birds have often appeared to me to be smaller and less robust. This difference is not, however, more apparent than that existing between home bred and migratory birds of other species, of which the skylark and the common bunting are familiar examples. In the central districts where the mixed breed occurs, the same inferiority in size is observable; but there are besides other differences almost corroborative of Sir William Jardine's observations on the carrion crow, namely, that in some of the Argyleshire specimens the grey markings do not occupy much more than half the usual space.* At a recent meeting

* On the other hand, hooded crows have been met with in Skye and elsewhere with the wings of a light grey like the back, and have been noticed to occur more frequently in hard winters than at other times. The late Dr Flem. ing (Brit. An., 1828) makes a similar remark in connection with this species, and adds "Female, wanting the grey: Young, like the female." Selby says (IIl. Br. Orn., i., p. 352) that sometimes this bird varies in colour and is found entirely white or black-a remark which he appears to have borrowed from Temminck, whose exact words are as follows: "Varie accidentellement," comme les espéces précédentes (carrion crow); souvent le plumage entièrement blanc, ou presque totalement noirâtre." 
of the Natural History Society of Glasgow a hooded crow from Ardlamont, which is now in the collection of Mr John Gilmour of Glasgow, was exhibited by that gentleman. It had the light space on the back and underparts very much clouded, giving the bird the appearance of a variety of the carrion crow; the pure black lanceolate feathers on the breast were also much more pointed, and in breaking the line of union with the grey parts of the plumage, added much to the handsome appearance of the bird. Other specimens which I have seen shot in the neighbourhood of Loch Lomond had the colours blended to the same extent; but while I record these instances, I may also state that in most cases that have come under my observation the offspring of a hooded and a carrion crow, when mated, do not show any signs of hybridity such as one would expect. Capercailzies and black grouse, for example, produce hybrids which are easily distinguished; while the latter, when paired with the red grouse, has an offspring equally recognisable. The young birds in both cases invariably take after the male parent; but in the case of the crows, the progeny consists of black and grey specimens precisely like both parents.* Sometimes it happens that out of a nest of six, four are black and two grey; in other cases they are all grey but one; in others equally divided. There is no rule as to the sexes, the grey bird being as often the male as the female. In a glen near the banks of Loch Lomond a female hooded crow had her nest, and had commenced laying. Her first mate was a carrion crow, and after the keeper shot him the hen bird went away and returned with a second bird, also black. He, too, was killed a day or two afterwards, but the dauntless widow got another black mate within a few hours, and thus allured a third crow to his doom, for it is needless to say that the watchful keeper was only too glad of the opportunity of shooting the rascal. At length the sitting bird having laid the full complement of eggs, remained at home and brought up her young ones till they could be conveniently killed, after which she herself fell a victim. The keeper, in telling me this episode of crow life, said he was almost sorry when on picking her up he found she had only

* Macgillivray, who must have taken his descriptions of the young from a nest of mules, and probably been deceived by observing only the female near at hand, says they are nearly all black. 
one leg, the other having apparently been taken off in a trap a considerable time before.

In $1867 \mathrm{I}$ had another opportunity of watching a pair of crows that built their nest in Shemore Glen. The male was black and the female grey, and the nest, which was situated in a rowan tree growing on the edge of a deep gorge, was composed of sticks and bones, and lined with heather, straws, and sheep's wool. It contained six eggs; two of these are now before me, and are not distinguishable from those of the hooded crow or carrion crow; four were hatched, but two of the young birds were destroyed when a few days old, leaving two-both grey crows-which were afterwards taken when the old birds were shot. The four birds are now preserved in the Hunterian Museum of the Glasgow University.

During the time the young ones are in the nest this crow must commit serious mischief in localities frequented by game. The quantity of eggs destroyed in a few weeks is indeed remarkable, as any one may observe by searching in the neighbourhood of their breeding place. The cunning creatures seem to avoid betraying themselves, and contrive to leave the marks of their spoil at some distance from the nest. In the instance just noticed the birds had either feasted at a rocky knoll on the other side of the gorge or carried thither the egg shells after having fed their young ones with the contents, the ground being literally covered with the broken fragments of the eggs of grouse, wild duck, and black game, besides the bones of lambs and otber prey. Such a "shell heap" would have roused the ire of the most benevolent ornithologist. Plunder of this kind being obtainable, at least in any quantity, only for a few weeks in spring and early summer, the hooded crow lives for the most part of the year on what it can pick up on the sea shore. Stranded fish, birds, crabs, and various molluses, such as mussels and other bivalves, are its favourite food, and are relished all the more when in a state of decomposition; but when taken alive the crabs and shell-fish being able to resist the crow's beak, are carried to some height into the air and let fall among the rocks-a treatment which enables the ingenious depredator to get at once at the contents. This habit is quite general among hooded crows, and is also practised by the rook when frequenting the coast. In inland situations the hooded crow is occasionally, during severe weather, obliged to resort to a 
vegetable diet. Pennant, in his Tour in Scotland (8vo ed., 1772 , p. 83), mentions that "for want of other food it will eat cranberries and other mountain berries;" and Mrs Blackburn states that it feeds on the berries of the mountain ash.

The following notes, taken from the correspondence of $\mathrm{Mr}$ Graham, give a graphic description of the everyday life of this bird, as observed by that gentleman in the island of Iona, where it is very abundant:- " The black carrion crow is unknown in the western isles so far as my experience goes, but to make up for it we have no end of hoodie crows. The hoodie has got a terrible name, and his best friend could hardly say one word in his favour, supposing he ever had such a thing as a friend, which is improbable. A greedy, cowardly, destructive creature, his appearance is ugly and his voice hateful. But though no doubt ready enough to commit any villainy against eggs, young game, chickens, and even young lambs, yet in these wild districts, where there is not much game to injure, he subsists almost entirely on the bountiful provision afforded by the receding tide, and upon this multiplies exceedingly. Often at feeding time I might string five or six at a shot, as they are too hungry and too impudent to get out of the way. Here you see a grave synod of sombre-hued creatures gathered round a huge stranded fish; there one flies up in the air with a crab which he lets fall in hopes of it breaking on the rock beneath. If he fails in the first attempt, he flies a little higher next time, but he himself always descends so quickly as to alight almost at the same instant as the desired morsel, perhaps lest one of the brethren should put in a claim for it. On the grass above high water mark are one or two favourite rocks where they carry the molluses they have picked up to be cracked and opened at leisure. These favoured spots are marked by perfect mounds of shells and their debris. While all busy searching for food little noise is heard among them, but should a hawk come sailing by he is instantly assailed by all the voices and united strength of the company, which cordially join in driving off the interloper. Sometimes an innocent heron is rudely assailed in this way, and it is very amusing to see her distracted manner as she flounders away on her great wings, shouting and screaming with imbecile rage at her tormentors, who never come to close quarters, and seem to do it out of pure wanton love of mischief.

At night these birds roost among the cliffs, where in summer 
their nests are very abundant, though the birds are not then so numerous; many of those who only sought the shore through winter retire elsewhere to breed. The nests are generally easily accessible, and the birds are very persistent in replacing the eggs if taken, and rebuilding the nest if destroyed. I have tried the experiment of putting bantam's eggs, daubed with indigo, in the place of the crow's own eggs, and have removed the newly-hatched chickens before the foster-mother discovered her mistake. This, of course, implies a good deal of intrusion and watching, which the old bird did not in the least mind; indeed, though the hoodie has plenty of cunning, he has not a particle of shyness or modesty. On one of the first five days of March the hoodie crow may be heard uttering his love-note. He is not a bad-looking fellow then, in his ash-coloured jerkin, with jet black sleeves, hood, and tail. He sits perched on some high rock, basking in the sun, his stomach no doubt well filled, the very picture of a sweet unctuous rogue, and then he emits a call with something of a metallic ring in it which sounds like corrack-corrack, much more jubilant than his usual dull caw. Indeed, the sound is so associated in my mind with a bright sun, a smiling blue sea, and the first burst of spring, that were I a poet I should feel inspired to address an ode to the hoodie crow as the Hebridean herald of spring time. When he utters this vernal note he half opens his wings, and expands his tail after the fashion of the cuckoo. In a word (as love is said to transform the savage), at this moment the hoodie may be almost called a handsome bird. One of our most amusing pets was a hoodie crow whose wing was amputated at the pinion after being shot, and who lived a long time in the garden, where he laboured most assiduously in destroying every kind of grub and vermin; if any one opened the garden gate, he would come forward with a hop, step, and jump, and looking up with one goblin eye which seemed to say, 'Well, what have you brought for poor old hoodie?' he seemed to feel himself as one of the family. The Gaelic name of the bird is Feannag, which means to skin or flay."

The following Morayshire proverb shows that in by-gone times the hooded crow was much commoner in that part of Scotland than it is now:-

"The Guil, the Gordon, and the Hooded Craw,

Were the three worst things Murray ever saw."

The gule is a well-known weed infesting growing crops, and Lord 
Lewis Gordon, who made plundering excursions into Morayshire from the Castle of Rothes, is referred to as the second 'worst thing' in the county. It is now, however, but seldom that 'Murray' ever sees a hooded crow, at least at a time when its presence is really injurious-strychnine and gunpowder having cleared the county of it as a pest; so that if agriculturists are at all diligent in their labours the proverb should now have no foundation in fact.

\section{THE ROOK.}

\section{CORVUS FRUGILEGUS.}

\section{Creumhach Rocus.}

WITHIN a date comparatively recent, this familiar bird has penetrated to, and become permanently established in, places where previously it was only known as an uncertain autumn visitant. $\mathrm{Mr}$ Harvie Brown has sent me word that it is not more than three or four years since the first rookery was set up in west Sutherlandshire; and I have been informed by Mr Binning of Dingwall that in the west of Ross-shire similar colonies were formed at Ullapool and other places in 1864. In the island of Skye there is a large rookery at Dunvegan woods, which is the most westerly breeding station in Scotland for the species. Dr Dewar, who visited Dunvegan in April, 1870, informs me that Rooks have only gone there of late years, and that the trees on which the nests are placed are very small. There can be no doubt that as woods increase the distribution of the Rook in western Scotland will also become extended, though it is certain that this bird is very destructive to the growth of trees, from its habit of breaking off twigs at the nesting season. From this circumstance, proprietors in the western Highlands do not look upon Rooks with much favour, and would rather see them banished from outlying districts in which they have already appeared. Rookeries are now numerous even in the wilder parts of Argyleshire; and in the absence of cultivation, by means of which the ordinary food of the Rook is provided, it is doubtful whether in game-frequented lands the accession of such nurseries can be looked upon as a benefit or an injury. Even in agricultural quarters, the protection or encourgement of Rooks has 
within the last few years been actively called in question. In the county of Haddington, the members of the agricultural club have made an appeal to various proprietors for assistance in keeping down the number of Rooks by destroying the young birds in the rookeries within their policies, and the result has been that thousands of birds have already been destroyed. The same may be said of some other localities where the species has unduly multiplied. Near Tain, in easter Ross, measures have also been taken lately to reduce its numbers.

Many naturalists adhere to the belief that Rooks are innocent of the charges usually brought against their allies the crows, and in this they may be right, as the species has always shown a decided partiality for districts which have been laid under cultivation, and formed settlements in the very centre of game preserves, where Rooks are looked upon as privileged birds, and their nurseries as time-honoured accessories to the park scenery of our country. Rookeries, in fact, are so intimately associated with old mansions and baronial halls, that few proprietors would wish to see them removed. Hence any little thefts which Rooks may commit in the way of taking the eggs of pheasants or partridges appear to merit no greater punishment than a yearly thinning of their numbers in the breeding season. There can be no doubt that these birds are extremely serviceable to the farmer in devouring grubs, slugs, and noxious insects, and I feel sure that their extermination in any particular district would result in a disastrous increase of larvæ and other insect pests, whose ravages cannot be guarded against or watched as in the case of birds. At the same time, it cannot be denied that its near relationship to birds of a bad name has been against the Rook, and that at a time when this country was less cultivated than it now is, its food consisted of articles more in keeping with that connection. We cannot wonder, therefore, if some Rooks of the present day pilfer eggs from the game preserver, or show a partiality for an occasional diet of flesh when it comes in their way. Upwards of four hundred years ago it had apparently a much worse character, if we may judge from the following Act passed in the reign of James II. on 6th March, 1457:-

"Item. Anentis birdes and wilde foules that gainis to eate for the sustentation of man, as pertrickes, plovares, and sik like foules: It is ordained, that na man destroy their nestes, nor their egges, nor zit slaye wild foules in mouting time quhen they may not flie. 
And that all men after their power destroy nestes and egges of birdes and foules of riefe.

"Item. Anent ruikes, crawes, and uther foules of riefe, as eirnes, bissettes, gleddes, mittales, the quhilk destroyis baith cornes and wilde foules, sik as pertrickes, plovares, and utheris. And as to the ruikes and crawes, biggand in orchardes, trees, and uther places: It is seen speedeful that they that sik trees perteinis to, let them to big and destroy them with all their power, and in na waies that their birdes flee awaie. And quhair it is tainted that they big and their birdes flee, and the neste be founden in the trees at Beltane: the trees sall be faulted to the King: bot gif they be redeemed fra him be them that they perteined first, and five shillinges to the Kingis unlaw. And that the said foules of riefe all utterly be destroyed be all maner of men, be all ingine of all maner of crafts that may be founden. For the slauchter of them sall cause great multitude of divers kind of wilde foules for man's sustentation." A similar Act on ruikes biggan in trees had previously been passed (26th May, 1424), and its repetition shows the importance attached to the subject of their alleged depredations. Nearer our own times, having become omnivorous in its tastes, the Rook was considered a subject for fowling, and in a curious old work entitled the "Gentleman's Recreation," published in 1678, I find the following advice:- " How to take Rooks when they pull up the Corn by the Roots: Take some thick Brown paper and divide a sheet into eight parts and make them up like Sugar loaves; then lime the inside of the Paper a very little: (let them be limed three or four days before you set them); then put some Corn in them, and lay three score or more of them up and down the ground; lay them as near as you can under some clod of Earth, and early in the Morning before they come to feed; and then stand at a distance and you will see most excellent sport; for as soon as Rooks, Crows, or Pigeons come to peck out any of the Corn, it will hang upon his head, and he will immediately fly bolt upright so high that he shall soar almost out of sight, and when he is spent, come tumbling down as if he had been shot in the Air." Though the author of this amusing and at the same time interesting volume makes use of the general term "crows," it may fairly be presumed that in trying the experiment himself, he would find hooded crows among the victims.

Macgillivray mentions having found large flocks of Rooks occa- 
sionally in the Outer Hebrides, and various correspondents in the Long Island have informed me that in winter straggling parties come over from the mainland. These are seen on all the islands, from Lewis to Barra, but their visits do not extend beyond one or two days. Writing from Iona, Mr Graham states that the Rook is only a winter visitant to the small isles, though the flocks then remain for some time. "Shepherds assure me," continues $\mathrm{Mr}$ Graham, "that though they come day by day to feed in Iona, they never remain all night, but invariably recross the Sound to roost in Mull, though there are no trees even there within reach. I have continually met them at dusk flying low over the sea towards the rocky shores which bound the south coast of Mull. There are several rookeries on the mainland: one, for instance, at Auchendarroch, near Lochgilphead, and another on the opposite shores of Cowal, the occupants of which often cross over to feed in winter, but never fail to return at night. When belated on the water, wild-fowl shooting, they have passed me streaming home in small parties, flying close above my boat, and have often nearly led me into shooting at them by mistake in the doubtful light."

I have seen large flocks of these birds overtaken by darkness when out on their daily foraging expeditions, on which occasions they were obliged to take up their quarters for the night on hill sides, perching-hundreds at a time-on rocky boulders and stunted trees. It is possible that this habit continued for some months of the year, as the localities in which I have observed it were distant from any extensive wood where the birds could be accommodated.

Curious varieties of the Rook frequently occur. Mr W. Smellie Watson, of Edinburgh, informs me that he has two cream-coloured specimens in his collection, which were shot at Castle-Douglas; and $I$ have now before me two interesting pied varieties from the collection of $\mathrm{Mr}$ Harvie Brown: one of these has the long feathers which cover the nostrils, of a pure white. Both are young birds, and have the legs and claws pied as well as the plumage. 


\section{T H E J A C K D A W.}

\section{CORVUS MONEDULA.}

\section{Cathag. Corrachan (Iona and Mull).}

THE smoke-begrimed "Kays" frequenting the steeples and chimney tops of large cities are certainly not fair representatives of the smart bird one meets with in country places, where the venerable ruins of some of our finest cathedrals afford them a home. Let any one venture within the precincts of these splendid vestiges of former grandeur, and listen to the brisk chatter of the noisy rabble before they pour out of their holes and burst in a cackling stream over the parapet-their voices, as they get to a little distance, sounding like a faint echo from the walls - and he will at once appreciate the effect of such wild behaviour when contrasted with the impudent tameness of city birds. The same noisy companies enliven the bold and romantic headlands which are exposed to the fury of many a sea storm, and salute the adventurous egg-collector with singular vivacity as they dart out of their unseen hiding places. In both localities, widely different in their nature, the species seems to be largely on the increase; on almost every extensive ruin and marine rocky precipice, the numbers have at least become doubled within the last twenty years; and from the ease with which it can issue from its inaccessible retreats into the nearest fields and rob the nests of other birds in a measure unsuspected, and its habit of appropriating the eggs of sea-fowl frequenting the same ledges, it manages to get through its summer life surrounded by luxuries. In winter it joins the clamorous flights of rooks, journeying to distant places in their company, and returning with them at the close of day without attracting attention, save by the lively note it utters as the flock rises into the air. Thus it leads a privileged life, although it is well known as a most destructive and impudent thief, doing more mischief to the game preserver than the kestrel, jay, or magpie-birds which might surely be spared if the Jackdaw is allowed a free pass.

In the very centre of Glasgow Jackdaws reside all the year, nestling in winter by the sides of chimney cans on the housetops for warmth, and in summer frequenting the taller church towers, 
the recesses of which must be filled with the sticks and other rubbish they have used in nest building. In some of these, indeed, the collection of materials is really extraordinary. For weeks at a time the birds seem to labour under a constant mania for carrying twigs and straws into these towers, the top floors of which are literally covered to a depth of some inches. They appear to have no idea of stopping the supply of material until it appears at the mouth of the hole or cavity into which it is dropped. Thus a Jackdaw, especially in wide-mouthed chimneys, will sometimes sit on a nest ten or twelve feet in height.

The site selected by this bird for its nest is very variable-old trees and venerable ruins are favourite places, and the same may be said of church spires and ivy-clad rocks in inland situations. By far the largest colony of Jackdaws I have ever seen is one inhabiting the splendid ruins of Bothwell Castle on the banks of the Clyde. The nests there are placed in holes in the masonry and also among the thick branches of ivy clothing a large portion of the walls. Marine headlands are also well-known nurseries for Jackdaws, the nests being placed in rents and fissures of the rock, and entirely out of the reach of predatory collectors. Pennant, in his Tour in Scotland, states that on the Farne islands he found Jackdaws breeding in rabbit holes.

When these birds have long inhabited a ruin, and become attached to it, they are not easily scared. A very remarkable instance of their confiding tameness occurred some years ago at Penkill Castle, Ayrshire, a most romantic dwelling, which was restored by the proprietor, the late Spencer Boyd, Esq. The Jackdaws had for generations held undisputed possession of the ruins situated on the steep banks of Penwhapple Glen, and overlooking one of the most charming little bits of scenery to be found in the west of Scotland; and when the present beautiful residence was built on the old walls and foundations, the birds remained in the turret holes, which Mr Boyd took the precaution to leave almost untouched. These holes communicated with the interior, and were each fitted with a little door, which, on being opened by visitors, exposed the nests and their contents.

Miss Boyd has obligingly informed me that up to the present time (1869) they still continue to inhabit the tower, and that no one is allowed to disturb them. Jackdaws generally quit a castle when it has been altered or repaired, preferring the crumbling 
ruins to all the grandeur of modern dwellings. But in the Penkill instance they seem to have appreciated the accommodation provided for them, and apparently have taught their offspring to regard the castle and its occupants as a safe refuge and pleasant company.

The following lines, descriptive of their early movements, are from the pen of a gentleman who has a pleasant recollection of their romantic haunts:-

WRITTEN AT PENKILL CASTLE IN SPRING.

This morn at dawn within the temperate clime

Of conscious half-sleep in my chamber high,

I heard the jackdaws murmuring, "Let us fly,

Let's fly;" 'twas near the ploughman's starting time,

And many feeble caws in answer chime

"Hie, hie away, grey heads:" when they had flown,

There was a perfect lull, and I went down

Into deep slumber, beneath dream or rhyme.

But suddenly a louder clamour came,

The little jackdaws, clamouring every one,

The old beaks had returned with worm and fly:

I looked up, and the room was all aflame,

Above the tree tops was the brave young sun,

The lark was up beside him in the sky.

W. B. S.

\section{THE M A G P E.}

\section{PICA CAUDATA.}

Pioghaid.

THIs lively and beautiful bird seems to adhere strictly to the mainland, being seldom found on any of the islands. It is wholly unknown in the Outer Hebrides, but is occasionally seen in Islay and Mull, where, however, it does not breed.

Twenty years ago the Magpie was abundant in the neighbourhood of Glasgow. In my early morning walks, about three miles from the city, I have seen as many as twelve or fourteen hopping on the public road. So recently, indeed, as three years ago, I counted twenty-eight perched on one tree at Scotstown, between Glasgow and Yoker. This was late in the afternoon, in winter time, and the Magpies had apparently assembled there with the intention of remaining over the night, the noise of 
their chattering being very extraordinary. Two years ago a pair of these birds had their nest near Sandyford, and within the city bounds: they were quite familiar in their manners, and made themselves at home, as if in the full knowledge that they were much safer there than in the country. It is a pity that the Magpie is so mischievous and destructive to eggs and young game, as it is really a pleasing object when seen flying alongside a green belt of plantation, or perched on the summit of some tall poplar trying to balance himself by a graceful movement of his ample tail. Its ordinary cry is harsh and grating, not unlike the noise of a policeman's rattle, or an old woman's pattens clattering on the pavement.

Although subjected to the usual amount of persecution among game preservers, the Magpie still maintains its hold in all the wooded districts of Scotland from Wigtown to Sutherlandshire. It is yet very common in some parts of Ayrshire. I lately saw a dozen on a small property near Girvan, the owner of which did not preserve the game, and consequently had no keeper on the ground. Magpies, indeed, soon find out places unfrequented by keepers, although they seldom lose their naturally jealous and distrustful character unless when living in the immediate vicinity of large towns.

Like the carrion or hooded crow, this bird, which I am disposed to think from observation, remains in pairs all the year, appears readily to find a second, third, or even fourth mate when deprived of its companion, by watchful keepers, during the breeding season. Six successive females have been known, in this way, to sit upon the same eggs, one after another having been systematically shot; but I think that no true-minded naturalist would envy any one the possession of a few pheasants and partridges gained through the practice of such inexcusable cruelty.

In some districts of Ayrshire there is still a lingering superstitious rhyme in connection with the Magpie which, I have no doubt, affects to some extent the movements of those who believe in it:-

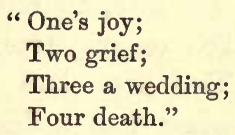

I recollect such a rhyme, or something akin to it, prevailing in 
East Lothian, where I spent my boyhood. Not more than thirty years ago a worthy Dunbar bailie, whose residence was about two miles distant from the town, was in the habit of turning back if he happened to encounter a pair of Magpies on his way either to administer justice or attend divine service!

Varieties of this bird sometimes occur. A very curious instance is mentioned by Macgillivray in his British Birds (vol. i., p. 568), of a specimen having almost the entire plumage, legs and feet, reddish brown. I have myself seen cream-coloured specimens shot in Argyleshire.

\section{THE JAY.}

\section{GARRULUS GLANDARIUS.}

Scriachag-choille.

The very questionable reputation of the handsome Jay has doubtless been the means of thinning its numbers in our wooded preserves. In some districts it is now rare through the persecution of gamekeepers; but in others it appears to maintain its ground in spite of all attempts to destroy it. The Dumbartonshire woods, especially those in the neighbourhood of Loch Lomond, still give shelter to limited numbers; and in many parts of Argyle and Inverness-shires the species is still a conspicuous ornament. I have seen it in pairs in the higher reaches of Shemore glen, Loch Lomond-side, frequenting a thin clump of trees on the hilly slope, about a thousand feet above the sea level.

Mr William Hamilton has informed me that this bird is common in the woods of upper Loch Fyne; and the Rev. Alexander Stewart of Ballachulish has sent me word that it has, of recent years, become rather common in the district of Lochaber, Inverness-shire. " "Ten or twelve years ago," writes Mr Stewart, "there was not a Jay in this part of the country, but within the last three years they have been seen occasionally about Nether Lochaber, and north, as far as Glengarry, along the woods skirting the Caledonian Canal, and about Lochiel's seat of Achnacarry." According to Mr Shearer (see Proc. Royal Physical Soc. of Edin., vol. ii., p. 338), it is found even in Caithness. The species appears to have occurred but once in Shetland.

Being of more retired habits than its congener the magpie, the 
Jay is much less frequently observed. All the noise it makes comes from thick plantations, where one can scarcely catch a glimpse of it; and when two or three are scolding together, they stop at once on hearing the approach of an enemy, and glide quietly through the thicket until they can renew the disturbance in a safer place. I have heard this bird, when in a tuneful mood, give utterance to a subdued and pleasing kind of chatter, but the usual note, or rather scream, of the Jay is perhaps the most discordant sound to be heard in our woods. In the early part of the summer it usually feeds upon insects and worms - a diet which it varies, perhaps oftener than is agreeable, by helping itself to garden produce. Beans, peas, and cherries seem to be more attractive than other seeds or fruits; and when these fail, it partakes freely of acorns and beech nuts. Nor does it scruple to pillage the nests of the smaller birds-eggs and callow young sharing a like fate.

The blue patch on the wing of this bold plunderer is much valued by anglers for dressing artificial flies.

\section{THE NUTCRACKER.}

\section{NUCIFRAGA CARYOCATACTES.}

As a Scottish species I had originally inserted the Nutcracker here on the authority of the late Dr Macgillivray, who states in his work on British Birds that, in addition to the Scottish specimen in the University Museum, Edinburgh, another bird, killed in Scotland, and belonging to Mr Henderson of that city, had served him for a description of the species. A third example is referred to in the statistical account of the parish of Peterhead, the writer of which states that a specimen of the Nutcracker, killed near that town, was in the collection of $\mathrm{Mr}$ Arbuthnot there in $1833 .^{*}$

These records, inexplicit as they appear to be, were all that had been made regarding this bird north of the Tweed, until the occurrence of a specimen in Inverness-shire in October, 1868; it was shot at Invergarry and sent to Inverness, where it was preserved by Mr William M'Leay, Taxidermist, 80 Church Street.

* I visited the Peterhead Museum, which contains Mr Arbuthnot's collection, in May, 1869, but could find no trace of the specimen. 
In a specimen of the Nutcracker now before me, I find the bill very slender at the point, the upper mandible projecting, like a bit of thin horn, over the under one. Authors whom I have consulted seem to agree in saying that the bill is obtuse at the point. Can there be two species, or is the difference merely sexual?* Either bill I should think a very unfit instrument for cracking nuts.

INSESSORES.

PICIDA.

SCANSORES.

\section{THE GREEN WOODPECKER.}

\section{PICUS VIRIDIS.}

\section{Lasair choille.}

Although this woodpecker is a well-known inhabitant of English woods, it is very rarely seen north of the Solway or the Tweed. I have never seen a recently killed specimen, nor can any of my correspondents inform me with certainty of its having been observed of late years in any of the counties of Scotland. $\mathrm{Mr}$ Forrest, gunmaker, Jedburgh, showed me a specimen a few months ago which had been shot near that town about the year 1848; and Mr Angus has sent me word that one was killed near Aberdeen, and that on another occasion in $1868 \mathrm{Mr}$ Hunter of Tillery had seen a single bird in the woods near his residence in the same county. Mr Harvie Brown informs me that there is a Sutherlandshire specimen of this bird in the private museum at Dunrobin Castle.

The green woodpecker is inserted as a Scottish species by Pennant in his Caledonian Zoology, published in 1777, and twenty years later it was included in the old statistical account of Scotland by the minister of Dunkeld in his description of that

\footnotetext{
* Since writing the above, I have learned on consulting Mr Stevenson's highly interesting volume on the "Birds of Norfolk," that a paper on the subject of the supposed specific difference between the Nutcrackers of Central Europe and those of Scandinavia, was read before the Royal Academy of Sciences at Brussels by M. Edm. De Selys-Longchamps, and has since been published, with illustrations, in the Bulletin of the Academy, tom. xi., No. 10. In this paper it is affirmed that the species found in Central Europe has a sharppointed bill, while the Scandinavian Nutcracker has that feature shorter and stouter, "from which peculiarity the specific term of brachyrhyncus had been previously applied to them, in contradistinction to the thin-billed examples (caryocatactes)." P. 282.
} 
parish (1798). It is also mentioned by Don in his Fauna of Forfarshire, published in 1812, and it is not unworthy of note that Fleming, in his History of British Animals, does not restrict the distribution of the Green Woodpecker as a British bird; indeed, his Gaelic name almost proves it to have been, in his day, a familiar Scottish species. I find it inserted, without any qualifying remarks, in a list of the birds of Alnwick, by Mr Tate, Secretary to the Berwickshire Naturalists' Club, which shows that it occurs not far from the borders.

Yarrell, in his second volume of British Birds (3d ed., 1856, p. 143), states that this species is found "over a portion of, if not all, the wooded districts of Scotland,"-a statement which he appears to have borrowed from Selby (Ill. Br. Orn. i., p. 372), and which is certainly a mistake.

According to Messrs Baikie and Heddle, one or two specimens have been taken in Orkney.

\section{GREAT SPOTTED WOODPECKER.}

\section{PICUS MAJOR.}

Snagan-daraich.

THIS woodpecker is known to breed in limited numbers in Banffshire, Aberdeenshire, and a portion of Inverness-shire. I have examined specimens that were shot in these counties during the breeding season of 1867-68. It has been a well-known winter visitant throughout Scotland for the last fifty years, and specimens have been obtained in almost every county. On the east coast it has within the last few years become rather common. Since 1861 very large flocks, chiefly consisting of young birds, have at intervals visited the eastern counties; in almost every case they landed first in Shetland, and afterwards found their way to the mainland, spreading themselves from Banff and Aberdeenshires to the borders of Northumberland. Referring to these unusual flights Dr Saxby says: "This species was unknown in Shetland until September, 1861, when great numbers arrived at Unst with a steady breeze from the south-east. I afterwards heard of them in various parts of Shetland as well as in Orkney. I examined many specimens: the first was an adult male, but all the others were apparently young males of the year." In Sep- 
tember, 1868, the species was plentiful in Sutherlandshire, Rossshire, Morayshire, and Inverness-shire, and I traced its migrations southwards as far as Berwick, through the counties of Aberdeen, Kincardine, Forfar, Fife, and Haddington, having obtained specimens from all these districts. Seven birds are now before me, but only one is a male in perfect plumage, the others being apparently young birds. Other specimens which were offered to me were in bad plumage, as if they had just moulted. In the western counties fewer specimens occurred, though I was able to procure them from Argyleshire, Renfrewshire, Ayrshire, Lanarkshire, and Wigtownshire. In the midland counties it occurred in Perth, Stirling, Dumfries, and Roxburgh. Altogether I examined upwards of sixty specimens, for information regarding which I am indebted to various correspondents, among whom I may mention Lord Binning, ${ }^{*} \mathrm{Mr}$ Angus, Mr Harvie Brown, Mr James Murison, Tillynaught, Banffshire, who presented me with two specimens, and Mr R. Scot-Skirving of Campton, East Lothian.

OBS.- Sir Robert Sibbald, in his "Scotia Illustrata," includes the GraAt Black WOODPECKer (Picus martius) in that section of the work entitled "Historia Animalium in Scotia," p. 15. It may also be here observed that, in the University Museum at Aberdeen, there are two specimens of this bird labelled "Nottingham," in the handwriting of the late Professor Macgillivray, and referred to by that author at page 79 of his general work on British Birds.

In Donovan's British Birds, a figure is given of the THREETOED WoODPECKer (Picus tridactylus) on plate 143, vol. vi., and in the accompanying letterpress it is stated that a specimen of the bird had been "lately shot in the north of Scotland;" upon the authority of which the species was inserted among the migratory visitants to the British Islands. No other specimen appears to have occurred since Donovan's time. His volume is dated 1808.

The Lesser Spotted Woodpecker (Picus minor) is included in Don's Fauna of Forfarshire, and also in Pennant's Caledonian Zoology. Mr Shearer states that it has once been observed in Caithness, and Mr Tate, in his list of Alnwick birds, includes it as a species found on the borders. I have, however, never been able to examine a specimen killed in any part of Scotland.

* Now the Earl of Haddington, his Lordship having succeeded to the title through the lamented death of his father, the tenth Earl, in July, 1870. 


\section{THE WRYNECK.}

\section{YUNX TORQUILLA.}

WITH the exception of a single specimen shot near Hamilton, in 1835, and a notice of one near Glasgow in Yarrell's British Birds, I have not been able, until recently, to trace the occurrence of the Wryneck in any of the western counties. Having read some very pleasant articles on rural objects, written for the Inverness Courier by the Rev. Alexander Stewart, Ballachulish Manse, Fort-William, I was interested to find a notice of the Wryneck having bred in the district of Nether Lochaber, Inverness-shire; and having since communicated with this gentleman, I am enabled here to record the substance of his observations, which prove, in one instance at least, the nesting of the species in Scotland.

"The other day," writes Mr Stewart, "I was so lucky as to stumble on the nest of a bird rarely noticed even as a stray wanderer anywhere north of the Forth, and never before known, so far as I am aware, to breed on the west coast of Scotland. The nest was found in a circular cavity, evidently hollowed out by the bird itself, in the decayed hole of an old rowan tree, and at a height of about seven feet from the ground. The structure consisted mainly of withered grass blades, slightly mixed and interwoven with moss and wool. The eggs were seven in number, and of a shining, marble-like whiteness. I was delighted of course with my discovery, certain that the nest and eggs were those of no ordinary bird of our acquaintance hereabouts; and being determined to know, a little patience and some cunning tactics, to which the naturalist must have frequent recourse, soon put me in possession of an agreeable solution of the mystery by the appearance of the bird itself - a female Wryneck-settling on a neighbouring stump and finally entering her nest. By lying concealed for half an hour or so, I had the satisfaction of being rewarded with a sight of the male-a fine fellow, in full plumage -whose confident hawk-like gi-gligli-gi, thrice-repeated as he settled with a sudden and peculiar jerk on a branch a few feet above the cavity where his mate and her treasure lay hid, clearly showing that he felt quite at home in Lochaber, and rather liked it than otherwise." 
In East Lothian and Fifeshire it has several times occurred, and also in Dumfriesshire and Roxburghshire. I got a beautiful specimen at Dunbar in 1847. Regarding its occurrence in Aberdeenshire, Mr Angus writes: "I received a male specimen of this rare visitor from the neighbourhood of Birse, in July, 1864. Mr Wilson informs me that it has been observed at the Braes of Gight." The most northern locality for its occurrence in the mainland of Scotland is Sutherlandshire; but, as a rule, it is not found north of the Forth.

In Mr Dunn's copy of Messrs Baikie and Heddle's Fauna of Orkney, a manuscript note states that one was got at Melsetter in 1841 , and that in one instance it had been seen before.

INSESSORES.

CERTHIADA.

SCANSORES.

\section{THE COMMON CREEPER.}

CERTHIA FAMILIARIS.

Snaigear. Meanglan. Streapach.

THIs familiar, yet unobtrusive bird-the bark speeler, as it is called in North Britain-is found in limited numbers throughout all the western counties, but is wholly absent from the Outer Hebrides. Nor have I been able to trace it satisfactorily, even as a visitant, to any of the inner islands. It is, however, occasionally found in Orkney. It is very common in woods near Glasgow, and I have frequently seen it in the outskirts of the city in clumps of smoked fir trees-the melancholy remains of woods that have yielded to the invasions of house-building. In the little plantations skirting the public roads in many parts of Renfrewshire I usually find the Creeper in the winter season when the want of foliage betrays the presence of so many of our smaller birds. It is constantly climbing, and, one would think, never at rest. Frequently it is found in company with tits of various species and gold-crests, but only as a fellow insect hunter, as it is always too busy to be classed as a companion. Mouse-like, it scrambles up the trunk or underside of a branch with amusing activity; and after having examined one tree it immediately flies to another, beginning invariably at the base, a few inches above the ground, and ascending spirally till it reaches the top. 
The Creeper is a very timid bird: on a stone being thrown against the trunk of the tree on which it is climbing, or when a heavy blow is struck with a cudgel or other weapon, it will remain quite still as if greatly alarmed until almost laid hold of. It breeds early in the year, often constructing its nest in holes of trees before the branches have thrown out their leaves. Mr Alston tells me that a few years ago a pair of creepers built their nest in a wooden shed which had been erected over a sawpit. The female sat close even when the men were at their noisy work within a yard of the nest: it was placed behind a board leaning against the side of the shed. This board was twice removed by mischievous boys, but still the poor bird sat with a courage worthy of a better success, for her young fell victims to a marauding cat.

Until recently this species was considered identical with that found in North America, and some ornithologists still entertain doubts as to the propriety of separating them. Mr Baird, however, not only gives Certhia Americana as a good species, but indicates another American variety under the name of C. Mexicana (Gloger) of which he says that "additional specimens from the west all show a much longer bill than eastern ones, tending to substantiate the existence of a second (American) species."

The song of the Creeper is somewhat like that of a gold-crest, but less feeble: it is uttered while the bird is busily engaged in foraging for insects. I have never observed it indulging in music when at rest-its notes being but a merry accompaniment to its highly curious movements.

\section{THE WREN.}

\section{TROGLODYTES VULGARIS.}

Dreathann. Dreollan. Dreadhan-Donn.

THIs hardy little bird is everywhere common, inhabiting the most densely wooded glens of the mainland and the barest rocks of the distant islands, alike at home in both haunts, and flitting about with amusing briskness, even in the severest weather. I have heard it singing in places where there were but few elements to attract birds of its size, and none certainly to provoke their 
musical powers. It is common on Ailsa Craig, breeding near the base of the rock among the tufts of coarse vegetation growing near the edge of the rude pathway for some distance round the island. On all the Outer Hebrides it is likewise at home, frequenting heath-clad rocks and the rugged banks of lakes, which it enlivens by its merry movements and clear trilling notes. The nest in such localities is found in the abrupt face of a broken bank or on the naked edge of some deep pool where it is seldom distinguished for neatness, harmonising as it does with the dark coloured heath or black peat moss. Frequently, too, it makes choice of a turf dyke, living in the society of chattering starlings, which are very abundant, and by no means amiable neighbours.

In the cultivated districts of the mainland, the nest of this bird is in many cases a very beautiful structure. In its selection of materials, however, the wren is somewhat capricious, although generally adhering strictly to one substance in building it, and consequently those nests composed of moss or straw are the most compact. I have now before me six different examples; one is wholly built of green moss firmly interwoven, another of beech leaves, a third solely of dried ferns, a fourth of fine white straws, a fifth almost exclusively of slender twigs of the larch, and a sixth entirely of lichens. None of them had any lining of feathers, and all contained eggs. I have often found smaller nests-very neat structures of their kind-in the autumn and winter seasons, chiefly under river banks and edges of rugged landslips or quarries. I imagine these to have been winter retreats; they are very numerous in some places. I have found eight or ten in the course of an hour's walk along the banks of the water of Girvan.

I look upon it as a singular fact in my experience that I have never found more than eight eggs in a wren's nest. It would appear that trustworthy observers, or their correspondents, have taken nests with as many as twelve and fourteen, or even a greater number. None of the numerous nests I have handled could accommodate more than eight or ten young ones; and even with so numerous a family the structures must be well placed to sustain their weight when fledged. Graham, in his "Birds of Scotland," seems to have been a believer in the existence of such wondrous broods, and thus paraphrases the ideas of a much older writer :- 
" But now behold the greatest of this train Of miracles, stupendously minute; The numerous progeny, claimant for food Supplied by two small bills, and feeble wings Of narrow range; supplied-ay, duly fedFed in the dark, and yet not one forgot!"

Nearly two hundred years ago Nicholas Cox-author of a very pleasant and readable treatise on singing birds-wrote as follows under similar impressions :- " This Bird, in my opinion, is a pretty, sweet dapper Songster, being of a nature cheerful; as he is pleasant to the Ear, so he is to the Eye; and when he sings cocks up his Tail, and throws out his Notes with so much alacrity and pleasure that I know not any bird of its bigness more delights the sense of Hearing.

"This bird builds twice a year, about the latter end of April, in shrubs where Ivy grows thick, and sometimes in old Hovels and Barns. They lay a numerous quantity of Eggs, and I can assure you I have seen a Nest containing two and twenty: herein are two things greatly to be wondered at-first, that so small a bird should cover such a great quantity of eggs; secondly, when they have hatched, to feed them all and not to miss one bird, and in the dark also."

In all my ornithological rambles, I have seldom encountered more inviting wren-nooks than are to be found in some parts of Ayrshire and Renfrewshire, where the glens are of sufficient depth and slope to show off to advantage the gushing burn, as it hurries over its rocky bed in a series of waterfalls, or sleeps in summer silence under the green shade of its moss and birch-covered banks. Wilson, during a hard life of mechanical toil, often soothed himself by strolling into such places, where doubtless much of the vivid power of description, which he afterwards displayed in his great work on the Birds of America, was fostered. In the rambles of his leisure hours, it is believed, he wandered inta the glen above Lochwinnoch, and also to the verdant banks of Glengarnock-a view of which I have much pleasure in introducing here through the kind permission of John Knox, Esq., for whom the original picture was painted by Mr C. N. Woolnoth, W.S.A. Here is a likely place to give birth to such a poem as that of Wilson's on the "Disconsolate Wren," the first stanza of which admirably expresses its very features :- 


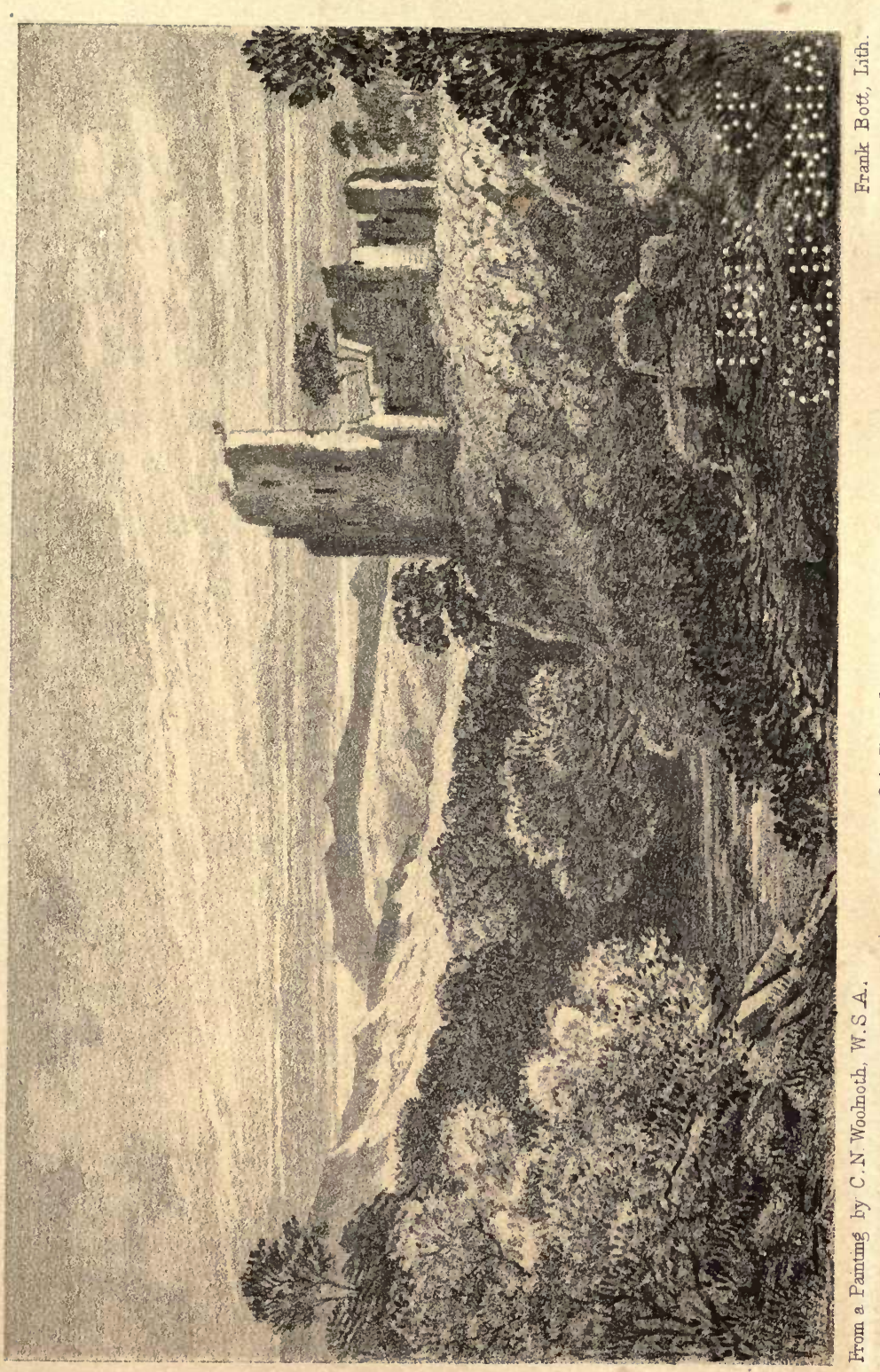

\begin{tabular}{l}
5 \\
0 \\
0 \\
2 \\
4 \\
1 \\
0 \\
7 \\
\hline 1 \\
0
\end{tabular} 

"'The morn was keekin' frae the east,

The lav'rocks shrill, wi' dewy breast,

Were tow'ring past my ken,

Alang a burnie's flow'ry side,

That gurgled on wi' glancin' glide,

I gained a bushy glen;

The circling nets ilk spider weaves

Bent wi' clear dew-drops hung,

A' roun' amang the spreading leaves

The cheery natives sung:

On 'ts journey, the burnie,

Fell dashing down some lins,

White foaming, and roaming

In rage amang the stanes."

There can be no doubt, I think, as to this species being identical with the winter wren of America (T. hyemalis). Mr Baird, who is a competent authority, has declared that the two birds are so much alike that he has not been able to distinguish the one from the other. This author, however, in his "Birds of North America" (see page 369), has remarked that "western specimens of this species appear to be of a darker reddish brown generally than in the eastern, and perhaps a little larger. Northern ones are decidedly largest."

A somewhat interesting observation has been made by Professor Newton in his appendix to Baring Gould's work on Iceland, viz.:that the common wren of that country "is, to some degree, mid-way in appearance between our British form and T. aedon of North America;" and that this Iceland bird, which is the Troglodytes borealis of Herr Fischer of Copenhagen, is easily distinguished from our own familiar species by its much larger bill and feet. These characters are indeed what one might expect to belong to a bird of its habits, permanently resident in a country like Iceland, where its whole life must be spent on the surface of barren wastes, scattered over with rugged boulders, and where a longer bill for extracting insect prey from the cracks and crevices is absolutely needful. The same form is probably found in the Faroe islands, and is thus spoken of by Landt in his description of that outlying group:- "The wren-in Feroese musa brouir-is found everywhere, particularly in the northern islands; for as there are no rats on these islands there are also no cats, which are great enemies to this bird. It is called by the Feroese musa brouir, that is, the mouse's brother, because it is like 
a mouse both in size and colour, and, like the mouse, creeps in through the chinks in their wind houses and feasts on their dried meat. It builds a large compact nest of straw and horses' hair in cavities of the earth, where it lays eight eggs. In a morning before sunrise it sings in a very agreeable manner."

In writing of an American species T. Mexicanus, Mr Baird mentions, on the authority of Dr Heermann, that it is found "occupied in searching for insects between and under the large boulders of rock which, along some portions of the Calaveras river, are there thrown together in confused masses as if by some terrific convulsion of nature."

Taking into account the total absence of trees in some parts of the Outer Hebrides frequented by wrens, I should not be surprised if $T$. borealis should yet be discovered there.

\section{THE HOOPOE.}

\section{UPUPA EPOPS.}

CAN only be regarded as a straggler in any part of Scotland. It has occurred in Berwickshire, Fifeshire, Aberdeenshire, and Banffshire, on the east coast, and I have seen specimens from various other counties, including Sutherlandshire, Perthshire, and Dumfriesshire, but have only three instances to record of its occurrence on the western mainland, namely, a specimen that was shot near PortGlasgow in October, 1863, and exhibited shortly afterwards at a meeting of the Natural History Society of Glasgow; another which was observed in October, 1852, on the property of Blair-Skaith, about six miles from Glasgow, where it remained about ten days; and a third at Tonderghie House, Wigtownshire, in 1862, as I have been informed by H. Stewart, Esq. Mr Yarrell states that it has been killed in Ayrshire, but gives no particular locality. It has likewise occurred in the Hebrides, two specimens having been seen in North Uist in 1859. Mr J. M'Donald, Newton, states that one of these was shot.

The Hoopoe has several times been taken in the Orkney and Shetland islands. In the latter district it occurred in August and September, 1861, and I find it stated in a manuscript note by Dr Baikie that an example of the bird was shot in Orkney in 1852 . 
Dr Saxby reports regarding the Hoopoe in Shetland that it occasionally appears there in autumn.

I am indebted to $\mathrm{Mr}$ Angus for the following records and dates of the occurrence of this bird in Aberdeenshire, in which county it has been found perhaps more numerously than in any other district in Scotland:-

"A male was recently shot by the gamekeeper near the mansion house of Tillery. It was very fat and deep in the moult. The stomach contained worms, centipedes, beetles, and mud. It was seen frequenting ditches, and its long, awl-shaped bill was covered with mud to the base. Mr Sim, 20 King Street, received a specimen for preservation which had completed the moult, and also a male which was killed near the lighthouse two days previously. The contents of their stomach differed but little from those of the Tillery specimen. As a local bird, the Hoopoe was first made known here by Thomas Ligertwood, Esq., who shot a specimen on the links of Belhelvie, near Blairton, in spring, about the year 1826. A specimen in the superb museum in Banchory House was shot at the gardens there in the spring of 1837 or 1838 . In the summer of 1841 a specimen was taken alive at Carnoustie, on the banks of the Deveron. At Tillyhows, another was shot by Mr James Duncan in 1848; and in the spring of $1852 \mathrm{Mr}$ John Henderson received for preservation a specimen that was killed at Kintore in 1852. Another was seen at Haddo House, and described as a bird with two heads. $\mathrm{Mr}$ Mitchell has also stuffed several Hoopoes which were killed in various parts of the county."

To these instances I may add another communicated to me by Mr Angus in a letter dated 12th November, 1868:- "A Hoopoe was shot on 29th September last at Turriff, and sent to Mr Sim for preservation. The stomach contained beetles and grubs."

\section{THE NUTHATCH.}

\section{SITTA EUROPEA.}

I kNow of but two recent instances of the appearance of this bird on the mainland of Scotland, viz.,- - a specimen shot in the summer of 1865 near Hermiston in Haddingtonshire by Mr Muirhead of Salton Middle Mains, and one killed in a garden near Dunse, in 
Berwickshire, in March, 1856. For a notice of the latter I am indebted to Dr J. A. Smith, to whom the bird was sent to exhibit at a meeting of the Royal Physical Society of Edinburgh.

In Don's Fauna of Forfarshire it is stated that the author obtained a specimen of this bird from Tannadice Woods in 1807; and it may also be worth noting that the Rev. Patrick Grant has enumerated the species among the rare birds of the parish of Killin, in Perthshire.

To these records I may add another instance of its occurrence in Scotland, namely, a specimen shot at Bressay in Shetland two years ago (1867), as I have been informed by Mr R. ScotSkirving, who saw the bird. It will doubtless be found to be a more frequent visitor to Scotland than has been hitherto supposed, especially in the Border Counties, where the extending woods may prove an additional attraction to a bird of its habits.

INSESSORES.

CUCULIDAR.

SCANSORES.

\section{THE COMMON CUCKOO.}

\section{CUCULUS CANORUS.}

Cuthag. Cuach.

THIS universal favourite is distributed over the whole of Scotland. From its sylvan aspect and the temptation of its extensive and romantic glens, the west coast is peculiarly attractive to this bird. Shortly after its arrival, especially if the weather be auspicious, every glen and cultivated hollow are filled with its well-known call. In some of the glens near the banks of Loch Lomond as many as ten or fifteen of these lively summer birds may be seen within a short compass uttering their note incessantly. It is also a wellknown visitor to the Outer Hebrides. In the summer of 1867 it was unusually plentiful, especially in Benbecula and the west side of North Uist. Even in the northernmost portion of the Long Island it is usually very common. Sir James Matheson remarks that in the month of May cuckoos are more numerous in Lewis than he has seen anywhere else, "flying about in clusters or groups, and making the air resound with their beautiful note." This notice accords exactly with what I have myself observed in other 
Highland districts, that Cuckoos, on their first arrival especially, keep very much together and give free utterance to their welcome cry, as if joyous at the sight of their old haunts, now clothed with fresh verdure.

Writing from the inner islands, Mr Graham sends the following remarks:- "At the usual time of year the well-known sound of the Cuckoo's cry is heard in all the moorlands, peat mosses, and broken land, half scrub and half rock, the birds usually selecting some slight eminence or knoll, whence they keep calling and reechoing each other's cry, so that such favourite spots often get named after them as Mona-'Chuich, or Cuckoo's moor, Dun-Chuich, Ben-Chuich, or Beann-na-cuaig, (Pennycuick), and, I suppose, Cockpen, etc. Cuach (the unaspirated nominative) is derived from the bird's cry."

Throughout western Scotland the Cuckoo deposits its egg chiefly in the nest of the titlark or meadow pipit, especially on the borders of glens and sides of mountains where that species is perhaps the commonest bird to be met with. I have found young cuckoos barely fledged in the islands of Loch Lomond: the last one I saw was on Inchmoin, and was attended by a pipit, which diligently ministered to its wants as it sat weighing down a mass of purple heather bloom, at the roots of which lay the flattened nest of the pipit. On putting up the fat little fellow he boldly turned his head towards the mainland, but had not proceeded fifty yards when he fell plump into the loch. His little foster-mother followed him with an uneasy zig-zag sort of flight, giving vent, for a few minutes, to its grief and surprise at the catastrophe, but finding it could do nothing for him it wisely returned to its island home.

The Rev. Wm. Patrick, in his account of the parish of Hamilton, states that, about two years previous to the date of his report, "many of the inhabitants of Hamilton were attracted to $\mathrm{Mr}$ Fisher's at Claudsburn, in the neighbourhood of the town, to see a robin redbreast feeding a young cuckoo which it had hatched. The little bird had been a pet during the winter, but, leaving its master, and searching out for a mate in the spring, met with this misfortune. The toil of feeding so large a bird as the Cuckoo, which by this time was flying about the orchard, soon compelled robin to apply once more to his former benefactor for assistance; and it was curious to see the fond dupe come and peck worms and 
other viands out of Mr Fisher's hand, and carry them off directly to his great insatiate pseudo-nestling."

Another writer of parish records describes an incident of a young Cuckoo being seen at the head of Monk's burn, in Midlothian, "flying after a titlark, from which it got the signals when to keep out of danger. The titlark was also observed feeding him, when the little nurse, to get at his mouth, generally leapt on his back, and made him turn round his head, which was as big as the other's whole body."

In some parts of Scotland this bird calls during the whole of the summer nights at all hours. I have myself heard its wellknown cry about 11 P.M. on the Loch Lomond hill sides, and $\mathrm{Mr}$ Harvie Brown informs me that in the north of Sutherlandshire he has heard it at half-past 12, and again at 2 and half-past 2 in the morning.

INSESSORES.

MEROPIDE.

FISSIROSTRES.

\section{THE ROLLER.}

\section{CORACIAS GARRULA.}

VERY little, of course, can be said of so rare a species as the Roller is in Britain, except the mere enumeration of the localities in which it has occurred. There are, indeed, but few examples to chronicle: one appears to have been seen on St Kilda about twenty-five years ago, and another was shot at Stevenston, in Ayrshire, as recorded by the late Rev. Dr Landshorough, at one time minister of that parish. A third was shot at Coulter House, near Biggar, in October, 1866. The Roller has likewise been found at Dunkeld, in Perthshire, and in Dumfriesshire in October, 1864, as I have been informed by Sir William Jardine, who communicated a notice of the occurrence to the Dumfries and Galloway Natural History and Antiquarian Society in February, 1865. Mr Shearer, in a communication to the Royal Physical Society of Edinburgh in January, 1862, states that a Roller was seen and watched by himself for two or three days at Ulbster, in Caithness-shire, in 1857; and Mr Harvie Brown has written to inform me that a specimen killed in Sutherlandshire is now in the museum at Dunrobin Castle.

Mr Thomas Edward has sent me word that one was killed at 
Strathbeg, and that another, a female, was obtained at Boyndie, near Banff, in September, 1848, by J. Ker Fraser, Esq. I have likewise been informed by Mr Angus that a fine specimen of this beautiful bird was shot in April, 1847, in the enclosure at Seaton House, Aberdeenshire, by Mr Davidson, gamekeeper there.

In addition to these instances, Mr M'Leay, taxidermist, Inverness, has sent me notice through $\mathrm{Mr}$ Harvie Brown that he preserved a female specimen of the Roller which was killed near Dornoch on 25th September, 1868; and I have also been informed by the Rev. Dr George Gordon of Birnie, that a remarkably fine specimen, which he saw, was shot about a month afterwards at Oakwood, near Elgin, by Mr Nicholson, gamekeeper.*

OBs.-Dr Bree announced in his "Birds of Europe," etc., vol. i., p. 157, published in 1859, that a male specimen of the Abyssinian Roller (Coracias Abyssinica, Latham) was killed at Crookston, near Glasgow, a year or two previously, and sent to Mr Small, birdstuffer, Edinburgh, and that a second bird, a female, was also shot a short time afterwards. Dr Bree justly concludes that these birds had escaped from confinement, and cannot therefore be regarded as even European stragglers. The male specimen is now, I believe, in the collection of the Paisley Museum, Mr Small having presented it to that institution.

\section{THE BEE-EATER。}

MEROPS APIASTER.

I HAVE seen specimens of this bird which were killed in Forfarshire and Aberdeenshire. A fine specimen was exhibited at a meeting of the Natural History Society of Glasgow in 1852 by my friend $\mathrm{Mr}$ Thomas Ferguson; it had been shot a short time previously on his brother's estate, near Peterhead. The Bee-Eater has likewise been observed in Wigtownshire, a specimen having been procured in Logan Garden, parish of Kirkmaiden, in the summer of 1832; but the species, in Scotland, can only be ranked as a rare and accidental straggler.

Mr Edward has informed me that a specimen was obtained some years ago in Banffshire.

\footnotetext{
* I have since visited Elgin and seen this bird.
} 
INSESSORES.

HALCYONIDAE.

FISSIROSTRES.

\section{THE KINGFISHER.}

\section{ALCEDO ISPIDA.}

THE beauty of the plumage of this well-known bird has made it a marked object, and almost every one accustomed to use a gun shoots it when it comes in his way. Hence, in the winter months, when the banks of rivers are naked, and the leafless willows spread their slender wands against the grey sky, the stealthy ornithologist finds but little difficulty in stalking the wished-for prize. Nor can it be said to be much safer, or less easily observed, during the spring and summer months, especially when incubating, as it then plunges more frequently for prey to supply its nestlings. The following description of its habits at this season, taken from an account by the Rev. E. S. Dixon of Norwich, is both pleasing and accurate:-

"The holiday stroller from the confinement of a large town, as he tracks the retired footpath that skirts the margin of some small brook overhung with alders and willows, is startled by a shrill, sharp cry, and sees glancing past him one or two winged emeralds: in a moment they are gone, and he walks on thinking of the brilliant creatures that have just vanished from his gaze. Soon he advances to a spot where the streamlet spreads into an open pool: he sits down to rest, wondering at the beauty of the dragon flies, longing to reach the floating water-lilies, and enjoying the perfume of the mint he has trodden under foot. He hears a short splash; he turns, and sees the spreading circles on the water; he looks up, and behold, on an outstretching branch, a bird whose ruddy bosom alone meets his view. He remains motionless, watching his newly discovered neighbour. Soon the bird dashes into the water, and returns immediately to its seat on the branch: in flight it seems all blue; in repose, all ruddy brown! It is the same bird which he saw before, but has two completely different aspects -like those double masquerade costumes, wherein the front assumes one character, and the back another. Again a plunge is made into the stream, and the bird uprises, bearing a little fish in his beak; this time he returns, not to his branch, but departs straight away like a levelled rocket: perhaps the nest is near at hand." 
Throughout the west of Scotland the Kingfisher occurs in almost every stream south of Sutherlandshire, and in some localities is never absent. It has been found once or twice in Islay, and likewise in Skye, but not, so far as I am aware, in any part of the outer chain of islands, where, looking to the absence of bush-margined streamlets, its presence can scarcely indeed be expected. I have found it breeding in several parts of Lanarkshire and Ayrshire; one nest which I discovered on the banks of the Girvan water was not more than five or six feet above the stream, and was consequently exposed to inundation - a fate which ultimately befel the entire family group, as I afterwards learned.

Mr Harvie Brown writes that the Kingfisher is common along the banks of the Carron, in Stirlingshire, and that it is also well known on the banks of the Endrick and other streams flowing into Loch Lomond. He has taken the nest on several occasions near his residence, and seen young broods following the parent birds after being fledged, creating in the bright sunshine a somewhat unusual bird spectacle.

INSESSORES.

HIRUNDINIDA.

FISSIROSTRES.

\section{THE SWALLOW.}

\section{HIRUNDO RUSTICA.}

Gobhlan-gaoithe.

THIs elegant bird is a well-known summer visitant over the whole of western Scotland, extending to both groups of islands. It does not appear to remain to breed in the Outer Hebrides, but specimens are seen there every year. I have observed it in North Uist, Benbecula, and South Uist, and Captain Feilden informs me that he saw it in Barra on the 8th May, 1870. Mr Harvie Brown also observed it near Lochmaddy on the same day. Its visits to. the remoter islands are generally made early in the season, and can only be looked upon as the results of a restless flight before the birds settle in their breeding quarters. In the Inner Hebrides, its stay extends over the summer: it is common in Mull and Iona, in Skye, Rum, Tyree, Coll, and probably all the smaller isles.

On the mainland it becomes even more numerous, and is found 
distributed throughout every parish from the sea margin to the highest moorlands. I have observed its nest under bridges, and also in the rafters of old and dismantled shielings in the midst of the wildest mountain scenery; and Mr Struthers has informed me that two years ago, when in company with some friends on the top of Ben Cruachan in Argyleshire, the elevation of which is not less than 3,400 feet, he saw several Swallows soaring high above the summit of the topmost peak.

Large flocks of Swallows are observed congregating in Ayrshire and Wigtownshire previous to their final departure from the southwestern districts of Scotland. In the neighbourhood of Girvan the young birds that have been hatched in the uplands assemble on the banks of the Girvan water within two miles of the sea, where they remain until the middle of September. Many hundreds have been seen by $\mathrm{Mr}$ Anderson and myself resting themselves during the day on the branches of trees* and betaking themselves at nightfall to a clump of alder bushes growing on the margin of the river, and overhanging the deepest pools. From these bushes we have repeatedly dislodged the birds after nightfall, and have noticed that their habit of roosting there extends over a period of two or three weeks previous to the general migration.

It is somewhat interesting to notice that as this and the next mentioned species have been gradually drawn from their natural haunts, the chimney swallow has shown less trust in man's protection than its congeners. Hence we see that while the martin swarms in almost every town and village, and the gloomy swift occupies holes in the masonry of fashionable squares, the elegant and dashing Swallow often repairs to rural spots, even in moors, where it passes its brief summer skimming the purple heath and cradling its brood under some rustic bridge. There it will take up its abode, placing its nest-lined with game birds feathers-under the stone arches through which the moorland burn rolls its dark waters-a pleasant lullaby it may be to the first. brood, but too often the requiem of later fledglings.

In East Lothian I have seen Swallows breeding in the funnel of a kiln for drying oats. Two or three nests were built on the wood work, and the birds did not appear to be disturbed while the

* In August, 1870, we observed from 80 to 100 swallows perched on an ash tree in full leaf by the side of the public road between Girvan and Dailly. 
kiln was in use, though the smoke must have been a great annoyance, if not a positive danger. A very curious situation for a nest of this bird is given in Audubon's Orn. Biog., vol. v., on the authority of Mr T. Durham Weir, who states that it was built in the shaft of a coalpit in the parish of Bathgate, "at the astonishing depth of fifteen fathoms."

I have a Swallow in my collection which was shot near Glasgow on 1st June, 1868, with the whole of the under parts of a deep rufous tint, but not quite so intense as the colouring of the African variety Savignyi. The specimen, however, shows that intermediate stage which has prevented some ornithologists regarding the Hirundo cahirica of Lichtenstein as anything more than a mere variety.

\section{THE M A R T N.}

\section{HIRUNDO URBICA.}

THE gentle and familiar Martlet is altogether wanting in the Outer Hebrides. In Skye, Mull, and Iona, however, it is common, building its nest in the eaves of houses, and is, in the two last named islands especially, much more common than the chimneyswallow.

Though the breeding haunts of this bird are now so intimately associated with the habitations of man, there must have been a time when the rude dwellings of pre-historic races forbade its approach. Previous to the erection of houses with suitable windows, indeed, the Martin was chiefly met with in the face of rocky precipices, mostly fronting the sea. In such situations, bleak and solitary, often far removed from cultivated places, and exposed to the roughest storms, it is a highly interesting spectacle to see hundreds of Martins issuing, as it were, from the rock itself-their clay habitations being quite invisible. I have examined many nurseries of this kind in various parts of Scotland, and in several instances have noticed the nests built inside the mouth of a cave, and wholly inaccessible. Among the rocky habitats I have visited, I may mention one in Berwickshire at Cove Bay, which is frequented by a large colony of birds; one in Ayrshire at Currarie Port, near Ballantrae; and a third in Argyleshire, near Oban. In July, 1868, I saw eleven occupied nests of the Martin under the upper pro- 
jecting ledge of the granite column of Portpatrick Lighthouse; but as the structure was not so high as the surrounding cliffs, the Martins wisely chose the lee side of the pillar, and were thus safe from the westerly gales, which often dashed the waves and spray with great violence against it.

It sometimes happens, especially when the weather becomes unsettled, that hirundines generally are obliged to leave our inhospitable climate as early as the beginning of September. I remember, ten years ago, seeing on the last day of August, hundreds of this species, the chimney swallow and the sand-martin, fluttering in an excited state near the Kelvin Bridge, on the Partick Road, Glasgow, having apparently sought refuge in the sheltered bend of the river, where they would be less distressed by the wind and rain, and where also they appeared to find flies and other insects, which they snatched from the surface. Sometimes they would essay to fly higher than the trees, but were driven back by the wet gusts sweeping overhead, and forced to amuse themselves as before by swarming over the filthy watercourse, and threading their way through the arches of the bridge. Their numbers became augmented from the surrounding country; and at last, when the storm was well spent, they congregated one morning on the housetops above the village of Partick, holding a council as to their future plans. It lasted but an hour or two, for before mid-day they rose in a body, and, after a few anxious twitterings, ascended cloudwards, and left our country. This, of course, is the manner of swallows when leaving us for a warmer clime, as every bird-observer knows; but in this case the act being performed so early in the season, we are left room to speculate on their reasons, so to speak, for depriving us of their company.

As I have frequently observed similar early movements of hirundines en masse, it is possible that in almost every case these were attributable to local causes, and that the birds were merely shifting their quarters to a more southerly district of Britain. "One swallow," we are told, "does not make a summer;" and, on the like principle, it would be wrong to refer what may have been but the "first assembly of the season" to the movement of a general migration. 


\title{
THE SAND MARTIN.
}

\author{
HIRUNDO RIPARIA.
}

\section{Gobhlan-gainbhich. Fallag.}

THIs delicate little swallow is widely distributed throughout Scotland, extending to all the remoter islands. It is a regular summer visitant to Lewis, Harris, and North Uist, breeding in sandbanks on the western side of these islands. It also inhabits South Uist and Barra, but I have not seen it on Benbecula, which probably does not furnish suitable banks for a bird of its mining habits.

On the mainland I have met with the Sand Martin in almost every parish, and have noticed it taking up its summer quarters in sequestered places in single pairs, and also in large colonies, both in the vicinity of water, and at a considerable distance from it. The birds, in fact, appear to make their burrows wherever suitable landslips or quarried sections occur. If the cliff be extensive and capable of accommodating two or three hundred pairs, the whole surface is burrowed until it frequently happens that four or five tunnels are made within the compass of a single yard; and when such a breeding haunt is fully occupied, the constant bustle and mechanical labours of the birds, especially for the first week after their arrival, become a sight of no ordinary interest.

This bird is believed to be identical with the Cotyle riparia of American authors. Professor Baird-the most recent general writer on the ornithology of that country-refers to some slight differences observable in specimens from the Sacramento valley, and also from the Upper Missouri, but at the same time admits that "careful comparisons have hitherto failed to exhibit any tangible difference." "It furnishes," continues that writer, "almost a solitary instance among land birds, of the same species inhabiting both continents permanently, and not as an accidental or occasional visitor on either."

Wilson, in his account of the species, alludes to the vast social communities that are found in some parts of North America, comparing the immense multitudes that congregate on the shores of the Ohio to a swarm of bees. He also mentions having "taken notice of the common crow, in parties of four or five, watching at 
the entrance of their breeding holes to seize the first straggling young that should make its appearance." In one respect the American Sand Martin differs from the European, namely, in the selection of materials for nest-building. Wilson's account is that the nests are constructed of fine dry grass, with a few large downy feathers; but in most parts of Scotland, so far as I have observed, the structure is composed of the coarse and hard stems of common grass wrack gathered from the fields, and lined, in many cases, with the curved and stiff wing and tail feathers of the domestic duck or the lapwing. The birds appear to be much infested by fleas, and I have sometimes thought that these hard beds, which often caused me to wonder why the eggs were not frequently broken, were less likely to encourage the unwelcome parasites, than a bed of down.

\section{THE COMMON SWIFT.}

\section{CYPSELUS APUS.}

Gobhlan dubh.

DURING its three months' residence in Scotland, the Swift is very commonly distributed in the western mainland, but is rare on the inner islands, and totally wanting in the Outer Hebrides. $\mathrm{Mr}$ Graham informs me that a pair of these birds have bred for some years in a hole in the ruined tower of Iona Cathedral, but I am unable to give any other instance of their nesting on the inner islands.

This species seems partial to old towers and ruined castles, which are so numerously scattered over the western counties, and I have observed that in many instances where these remains of ancient strongholds are far removed from towns or villages, the Swifts are quite as numerous as they appear to be when located in populous districts.

In the months of July and August, 1868, I observed this bird to be unusually abundant in Wigtownshire. During the prevalent heat of that season, many hundreds, if not thousands, might have been seen hawking for prey above the village of Glenluce, attracting the notice of even unobservant people by their extraordinary numbers.

I have seen Swifts adroitly catching feathers and straws when on wing, and carrying them to their holes under the eaves of a slated house. In some towns they build chiefly in such situations, 
and often have to contend with sparrows for possession of the holes. I have witnessed many tough and noisy fights of this kind, and have caught all the combatants by spreading a net over the entrance.

It sometimes happens that Swifts, obeying their unconquerable instincts, will, at the close of a stormy season, desert their unfledged young and leave them to perish of hunger. Late broods especially are subject to this unnatural desertion. Oftener than once I have seen the little round sooty faces of the young ones peering out of their holes and plaintively crying for food, after which they crept back to die. In these very nests on the return of another season, the same old birds have been known to re-arrange their building materials-a few straws merely being laid over the bones of the abandoned to receive a new family.

The Swift has been seen occasionally in Orkney; it was observed in 1830 and again in 1847 .

INSESSORES. CAPRIMULGIDA. FISSIROSTRES.

\section{THE NIGHTJAR.}

\section{CAPRIMULGUS EUROPQEUS.}

An t' seabhag-oidhche.

THE familiar goatsucker is a common bird in almost every Scottish county from Wigtown to the North of Caithness, extending also to the inner group of islands, but not, so far as I can learn, reaching the Outer Hebrides. It is not uncommon in Islay, Iona, and Mull, and is generally distributed in Skye, in all of which islands eggs have been found.

In the Western Highlands, the haunts of the Nightjar are, for the most part, in retired tracts which are covered with "brackens," or in the vicinity of fir woods where, on still evenings, its strange jarring cry may be heard till an advanced hour. Occasionally, however, it is seen hawking for insects in parks in the low grounds, and at times it approaches even large towns like Glasgow. It is observed annually frequenting the South Side Park of that city, and dexterously pursuing its flight among the trees in quest of night-flying moths. I have seen it also in grass fields cleverly picking ghost moths (Hepialus humuli) off the stems, from the points of which these sluggish insects were temptingly hanging. But as 
a rule, the Nightjar captures its prey while in flight, and several may sometimes be observed at a time hawking in company by the side of a wood of Scotch firs whose dark foliage forms a somewhat treacherous back-ground to the moths. Mr Harvie Brown informs me that at Dunipace, in Stirlingshire, he has seen one of these birds passing and repassing the front door of the house after dusk, and successfully capturing the nightfliers as they flitted past, or were attracted to, the light of the hall lamp.

The monotonous call-note of this bird is uttered about the close of day, and begins just as other bird voices are silenced by the shadows of the deepening twilight. I have often listened to it on the hill sides above Loch Lomond, and also in Ayrshire where the species is comparatively common; and I have observed that the noise is made by the birds while perched either on the summit of a tree, a block of stone, or some slight eminence on the ground. On these occasions it has occurred to me that a single bird may cause the listener to imagine that at least two or three other nightjars are in the neighbourhood, for, as the performer turns his head in the act of jarring, the sound appears to come from all quarters, and in different degrees of loudness.

With regard to the use of the serrated claw of the Nightjar, about which there have been so many opinions expressed, the best theory I have yet seen advanced is one advocated by Mr Sterland in his lately published and very interesting work entitled, "Birds of Sherwood Forest." The following quotation explains Mr Sterland's views, and I may add that I entirely agree with him:- "The larger number of species composing the family of the Caprimulgidce do not perch across a bough, as all other perching birds do, but lengthwise; and it is for this peculiar use that I believe the foot to be specially formed. In the ordinary position of perching birds, the twig or bough is grasped by the foot, and thus a firm hold is obtained, the weight of the body, by tightening the tendons, increasing the stability; but it is evident the Nightjar cannot effect any grasp of the bough as it sits lengthwise, and therefore the necessary firm position is obtained in other ways. It will be seen by any one who will take the trouble to examine it, that the serratures on the centre claws are therefore placed in exactly the best position for preventing the foot from slipping sideways; and this is still further provided against by the hind toe projecting forwards and inwards-so much so, indeed, that it has 
the appearance of being inserted on the inner side of the foot; and the whole organ is thus admirably adapted for its designed use.

"It is worthy of remark, as tending to corroborate my theory, that there are one or two Australian species (Podargus and Egothales), and at least one in South America, which have the middle claw smooth and the hind toe directed backwards. This variation in structure leads, as might be expected, to a corresponding difference in the use of the organ; and we consequently find that they do not perch sideways, but across, and also hop from bough to bough."

This curious bird has been taken in Shetland, and also in Orkney, where, according to Baikie and Heddle, two or three specimens were obtained upwards of forty years ago.

RASORES.

COLUMBIDE.

\section{RINGDOVE OR WOOD PIGEON.}

COLUMBA PALUMBUS.

Smudan. Caluman choille.

The Wood Pigeon is a bird now so widely distributed throughout Scotland, that most persons must be familiar with it, both as an inhabitant of wooded preserves, and a frequenter of farmed lands. But though at the present day it exists in very great numbers in cultivated districts, its first appearance is an event actually within the recollection of old people now living in the county in which the species is most abundant. In East Lothian the Wood Pigeon is perhaps more numerously met with than elsewhere in Great Britain, yet it is not more than 80 years since it was quite unknown. Mr Hepburn, in referring to this fact in a very interesting paper published by him in the proceedings of the Berwickshire Naturalists' Club for 1848, says:- “I am acquainted with a man, now 65 years of age, whose bird-nesting days were spent in the woods near Gifford, and he states that the Wood Pigeons were then so very rare that the discovery of a nest was looked upon as a great feat; and there are several people in the parish of Dirleton who remember having gone to look at a Wood Pigeon feeding in a cottage garden during the long snow storm of 1791." Mr Hepburn also states that "the appearance and subsequent increase of 
the Wood Pigeon has followed the introduction of the clovers and turnip, and the extension of fir plantation, and all parties look upon these birds as the greatest curse to agriculture." It is remarkable that, after a lapse of twenty years, during which interval active measures have been used to keep down its numbers, this bird should still be regarded as a rapidly-increasing pest, and an agricultural scourge of such magnitude as to baffle all attempts to bring about even a partial remedy. As a proof of the enormous flocks still to be found in East Lothian, which occupies but a limited area compared with other Scottish counties, I here give the particulars of the numbers killed during the last eight years, under the auspices of the United East Lothian Agricultural Society, which have been obligingly furnished to me by the Society's secretaries :-

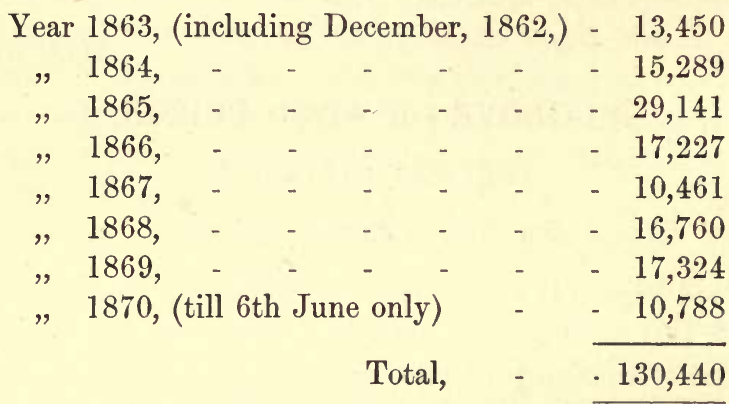

Notwithstanding this extraordinary slaughter, which is almost without a parallel in the history of British birds, no perceptible diminution of the nuisance has yet taken place-a fact which begets a suspicion, to say the least of it, that East Lothian is yearly invaded by large numbers of these birds, which have been reared in other countries; and that so long as the migratory flocks continue to arrive, no amount of persecution, however well timed, can be expected to root out the evil. The Wood Pigeon in Scotland is well known to be of sedentary habits, encouraged no doubt by the abundance of the food it finds, especially in a purely agricultural county like Haddingtonshire; hence the winter visitants from the pine forests of Norway, Denmark, Sweden, and some parts of Russia where the bird is known to migrate, do not return, like the redwings and fieldfares, on the approach of summer, but remain, perfectly satisfied with their new quarters, and thus fill the place 
of home-bred birds, which have fallen a sacrifice to the warfare now urged against them.

Although I cannot find in published records that either Professor Macgillivray or Sir William Jardine-two of our best authorities on Scottish birds-gives place to the idea of Wood Pigeons in this country being augmented in their numbers by the arrival of migratory flocks, I believe that such will be found to be the true reason why farmers have so much difficulty in extirpating them. That a large yearly accession to the winter flocks takes place through migration is, I think, evident from the fact that the eastern counties only are affected by the increase; and that, looking to the destruction of so many thousands in one year, no such increase can reasonably be traced to the results of a single breeding season. Some years ago, indeed, I was informed by Mr Alexander Henderson, an observant bird student resident in East Lothian, that he had repeatedly seen considerable flocks of Wood Pigeons alighting on the coast near his house, evidently in a state of exhaustion. These birds, he remarked, were smaller and darker in plumage than those hatched in the neighbouring woods, and he was convinced, at the time of their appearance, that they were migrants from other countries. Very soon after this information was communicated to me, I witnessed a still more extraordinary instance of foreign invasion on the sea-shore about three miles east of Dunbar. I had gone out about daybreak, and was astonished to see a prodigious cloud of pigeons fully a mile seawards, steering for the nearest land. The entire body of birds alighted on the sandy beach at Catcrag bay, which they completely covered between the rocks near the limestone quarry and the opposite point in the direction of the town. I am satisfied there must have been in the flock twenty or thirty thousand pigeons, at the lowest computation; and, from the fact of their alighting immediately on reaching land without any preliminary survey of the ground, I concluded they had come in from a long journey. Their tameness on my approach confirmed this conjecture, as I was allowed to put them up within twelve or fifteen yards. The cloud slowly ascended, and a line was formed, six or eight birds deep, which gradually drew off the main body, forming a singular spectacle when viewed against the morning sky, and almost realizing the descriptions of Wilson and Audubon, when writing of the passenger pigeon of North America, and its "five mile" processions in the air. 
With the experience, therefore, of such visitations from an acknowledged depredator, the question whether the damage it does is really atoned for by the good it effects in the destruction of the seeds of injurious plants, becomes rather an important one. From a very interesting communication with which I have been favoured by the Earl of Haddington, whose recent observations on the ornithology of East Lothian and Berwickshire possess more than ordinary interest, I find that the result of a series of observations on the food of this bird, extending over a period of some years, conclusively proves that the Wood Pigeon is an agricultural pest of no ordinary kind, and that the late remarkable increase of the species in Haddingtonshire has entailed heavy losses on the farmers of that county. The mischief committed by these birds is indeed almost incredible, especially on newly sown corn fields and fields of young grass, where they devour bushels of the leaf of the white clover. As an example of the bird's extraordinary voracity, Lord Haddington has forwarded to me, in separate cases, the contents of the crops of four Wood Pigeons opened at different times: the first contains 144 field peas and 7 large beans; the second 231 beech nuts; the third 813 grains of barley; and the fourth 874 grains of oats and 55 of barley. Such damage may be better estimated from the fact that the bird is known to feed three times daily, each meal probably involving the consumption of an equal quantity of grain by a single bird. In a grain-producing district, therefore, where from 15,000 to 29,000 pigeons have been destroyed within twelve months, without effecting any apparent decrease in their numbers, the loss to agriculturists must be enormous. The st $x$ tistics furnished me by Lord Haddington also embrace the results of his frequent investigations over a period of nine months, beginning with August, and ending with May; and, after making due allowance for the bird's habit of feeding upon the roots of noxious weeds, (upwards of 700 pigeons having been examined by his Lordship) it has been found that any slight benefit of this nature is more than counterbalanced by the excessive consumpt of grain. In further illustration of the ravages committed by this bird, Lord Haddington refers to its habits of attacking fields of Swede turnip, and remarks that, although it has been accused of breaking into the bulb, he is not of opinion that the bill of the Wood Pigeon can accomplish this. He likewise states that he has been informed by the Earl of Home, who has watched the proceedings of the birds, 
that in severe frosts they seem to feed on little else than turnip bulbs, which they appear to hollow out successfully. In these cases, however, it may be presumed that rooks and partridges, as well as hares, have preceded the pigeons in their work of destruction, though there can be no doubt as to the fact of the pigeons eating the leaves or shaws, and thus checking the growth of the turnip in its earlier stages.*

Throughout the western counties of Scotland, the Wood Pigeon, though very numerous, and apparently on the increase, is by no means so abundant as in the eastern districts. It is plentiful in Islay, where it was introduced by the late $\mathrm{Mr}$ Campbell, proprietor of the island. It is also found in Mull, Skye, Inverness, Ross, and Sutherlandshires, but westward of the inner islands it ranks only as a straggler. A few are occasionally seen in spring and autumn in Benbecula and South Uist, but they do not remain.

During the autumn and winter months, the ringdove, as this beautiful bird is also called, feeds chiefly upon the seeds of wild mustard (Sinapis arvensis), chickweed (Stellaria media), roots of ranunculus or crowfoot, ivyberries, oak "spangle," berries of the hawthorn and holly, and various other fruits and seeds. I remember many years ago shooting great numbers in a garden at Dunbar, where their plundering visits to the gooseberry bushes were a source of constant annoyance. Each pigeon must have consumed a large quantity daily, as I found the crops of those I killed quite distended with gooseberries. Beech-nuts are also a favourite food, judging from the immense quantities devoured. From newspaper paragraphs now before me, I learn that in the crop of one bird shot in East Lothian 272 beech-nuts were found, and that in another shot by Mr Joseph Sadler, at Alyth, in Forfarshire, there were found 1020 grains of corn! Mr James S. Dixon of Glasgow, who has for some years taken notes on the food of this species, informs me that he has many times been interested in watching a flock of Wood Pigeons traversing a grass field, and eagerly picking off the seeds of the common buttercup, which they appeared to swallow with avidity.

I believe that the very great increase in the numbers of the

* As the limits of this volume do not admit of a more lengthened abstract of this interesting communication, I refer my readers with much pleasure to the Proceedings of the Natural History Society of Glasgow, Part III., 1871, in which it has since appeared in extenso. 
Wood Pigeon in Scotland is in the main attributable to the destruction of all kinds of birds of prey, which, if allowed to exist to a moderate extent, would, it is certain, have kept this agricultural pest within reasonable bounds. The hooded, or carrion crows, for example, would destroy vast quantities of eggs - the pigeon's nest being a mere platform of sticks, on which the exposed contents are readily perceived. Partridges and other game birds, on the other hand, do not run the same hazard, as the female bird invariably covers the eggs on leaving her nest.

Though extremely wild when assembled in flocks in the open fields in autumn and winter, this bird becomes comparatively tame in the breeding season, frequently building its nest in trees near mansion-houses, which at other seasons of the year it never frequents. It appears to be easily tamed, but very few instances can be cited of its having bred in captivity. I have several times reared young birds from eggs placed under a common pigeon, and in these instances they maintained a quiet habit, mixing freely and tamely with their domestic neighbours. Only one instance has come under my own observation of the Wood Pigeon breeding in confinement, and that was the case of a female that had been taken in a wood while young, by Mr Alex. Crawford, Cumnock. By kind treatment the bird grew up to be strong and handsome, and having been allowed her liberty, instead of flying back to the woods she betook herself to a neighbouring dovecote, belonging to Mr Hugh Thomson, joiner, in the same town, and mated with one of his bachelor pigeons. The pair had eggs three times, though only one young bird was reared: it was larger than the domestic pigeon, and resembled the female parent in its general markings.

The favourite breeding place of this species in the West of Scotland is in large fir plantations, ${ }^{*}$ some of which afford abundant shelter to Wood Pigeons at all seasons of the year. Viewed from a distance, especially where the eye can rest on the far spreading surface of the green plumed forests adorning some of our larger glens, these solitudes seem impenetrable even to the pigeons, as they flit through the purple mist on a summer's evening, or mount in the air with noisy flap, as their mates sit brooding on

* I have found it breeding in hedgerows of old hawthorn bounding the fields of the farm of Elmscleugh, in Berwickshire, where I observed about a dozen nests some years ago. Mr Anderson has also taken note of several nests situated in tall whin bushes, near Arbroath in Forfarshire. 
the nest. Fair as such scenes outwardly appear, their character changes as one wanders into their pathless recesses, imperfectly lit as they are by the straggling gleams which here and there reach half-way down the trees. Yet in the gloomiest woods I do not know a more pleasing or less wearisome sound of long continuance than that in which

“ Deep toned

The cushat plains; nor is her changeless plaint

Unmusical, when with the general quire

Of woodland harmony it softly blends."-GraHAME.

Tannahill, in his fine song "Thou bonny wood o' Craigielea," also associates the sound with the music of other bird voices:-

\footnotetext{
"Far ben thy dark green planting's shade,

The cushat croodles am'rously.

The mavis down thy bughted glade

Gars echo ring frae every tree."
}

Throughout western Scotland the Ring Dove is best known by the name of Cushat-a name which appears to be used by most poets and song writers, who introduce the bird into many of their sketches of woodland scenery. In less poetical districts, where perhaps fewer bird lines have been penned, its presence is recognised by names unknown, at least to the bards from whom I have quoted. Last summer, under the guidance of a Wigtownshire farmer, I visited a vitrified fort in that county, situated on an extensive moor about ten miles inland from the village of Portwilliam; and while standing on this mound, overlooking a large tract of country, I remarked several flights of wood-pigeons, and drew the attention of my companion to the fact of their ravages in other parts of Scotland having led to the establishment of clubs for their extirpation. "Wood-pigeons," I added, "should be kept down, they are so destructive." "Very true," rejoined my friend, "but that's not the name we gi'e the bird here." "And what name do you give it?" I inquired. "Oh," said he, apparently unconscious of any parody, "we just ca' them Timmer doos!"

Obs.-The Stock Dove (Columba cenas) is catalogued by the late Mr Sinclair, surgeon, Wick, as a very rare species in Caithness, but no date or locality is given. I include it here, however, as the list (already often referred to) has been reproduced in the proceedings of the Royal Physical Society of Edinburgh, with remarks by 
Messrs R. J. Shearer and H. Osborne, whose observations of late years have contributed some valuable information regarding the birds of that county.

This species has also occurred once in Orkney-a specimen having been shot at Deerness on 12th October, 1861, as I have been obligingly informed by $\mathrm{Mr}$ W. Reid, of Pulteneytown, Wick, who had an opportunity of seeing the bird.

\section{THE ROCK DOVE.}

\section{COLUMBA LIVIA.}

Caluman fiadhaich.

THE gentle yet timid Rock Dove is a very abundant species over the whole of the coast line of the West of Scotland, and is nowhere more common than in both groups of islands whose rocky shores are pierced by numerous caverns, many of which are seldom or never visited by man. It is likewise found in the gloomy caves of the Haskar rocks, where large flocks are yearly accumulating. These flocks come daily to the Long Island to feed, and may be seen on the flat cultivated lands of Benbecula, North and South Uist, and Barra. It is probable that the St. Kilda birds also make daily flights to distant places in search of a living, as the scanty subsistence to be found on that desert isle could hardly support them. In these outlying districts parti-coloured birds are almost never observed; but on the mainland, especially in the neighbourhood of cultivated lands and farm houses, the breed is not so pure. I have observed the same fact to prevail at the haunts of the Rock Dove in the east of Scotland, where the bird appears to be even less decided in its markings, although equally wild in its habits. This circumstance is greatly in favour of the opinion that our domestic pigeons, especially those unfed birds living in large dove-cots, have sprung from the Rock Dove. All the caves of Ayrshire and Berwickshire appear to be frequented by a mixed breed; and even in Argyleshire, and some of the wilder parts of the coast, extending as far as the mainland opposite Skye, the usual pigeon haunts are similarly occupied.

On the moist pastures of the western side of the Long Island, especially on South Uist and Benbecula, I have often observed large flocks alighting in the centre of a field or common, and 
diligently clearing the ground of small shells, such as Helix ericetorum, a species which is found in some places in extraordinary abundance. I have always found them very wary when approached on these open pastures-a timidity which is, no doubt, owing to the frequency with which the flocks are fired at;--the Rock Dove, when viewed as an article of food, being one of the most valuable birds frequenting the Outer Hebrides.

The following interesting notes on this bird were sent to me many years ago, by my friend Mr Graham, who was then resident in the island of Iona:- "The granite cliffs in the south of Mull, the basaltic crags of Staffa, and lofty precipices of trap rock upon the adjacent islands, are all perforated by innumerable caverns of every imaginable size and shape; from the well-known majestic hall of Fingal, resounding with the sullen booming of ever-rolling waves, down to the fairy little grotto whose cool white shell-sand is scarce dimpled by the sparking ripples of the sheltered sea.* Some of these caves are grand, and of lofty dimensions, with no floor but the deep blue water which heaves to and fro through their huge frowning portals; others are romantic and picturesque, their rocks covered with many coloured lichens, and their dark apertures fringed with shaggy heather and ivy, amongst which is browsing a wild mountain goat, with huge horns and beard. But many more of these caverns are horribly gloomy and forbidding-deep black dens extending far beyond the reach of the light of day, stretching into the very bowels of the adamantine cliff; the air smells dank and foul, and the walls are dripping with unwholesome slime. Such caves generally have legends attached to them,of fugitive clansmen hiding from the pursuit of the avenger of blood, of wholesale deeds of murder, or of wild scenes of diablerie; and the names of the Cave of Death, the Pit of Slaughter, and the Hobgoblin's Den, are often met with, showing their grim character. These haunts of bygone murderers, smugglers, and outlaws, are now only tenanted by doves, the emblem of innocence. They may be seen perpetually flitting in and out, some parties going off to feed, others returning to rest; a few birds sitting about the entrance, pluming themselves in the

* Mr Struthers informs me that he has noticed that this bird is partial to the caves on the line of raised beaches throughout the coasts of the Inner Hebrides -Islay, Jura, etc., where he has had many opportunities of making careful observations. 
sunshine, or quietly dozing upon a sheltered ledge of rock. Upon a nearer approach the cooing of the old birds may be heard, together with the querulous peep-peeping of the young demanding food, and the occasional stir of wings; but, upon any alarm being given, the voices are immediately silenced, the clang and whirr of wings reverberate from the profundity of the cave, and out pours a long stream of snowy bosoms and silver wings, which swiftly skim along the surface of the sea and disappear round the next headland. In Iona alone (though but a small island) we have as many as nine or ten caves frequented by pigeons, and in nearly every island of the Hebrides there is sure to - be one cave called par excellence - ' Ua' Caloman'- the pigeon cave.

"The Rock Dove's nest is made up of small sticks or heather, or dried sea-weed, and is lined with dried grass: the situation selected is any little ledge or cleft within the sheltering bosom of a rocky cavern. The eggs are two in number, generally producing male and female birds. The time for commencing their nestling seems rather variable. This year I found some young ones already hatched on the 2nd of April, while other pairs were only making their nests. They have several broods in the year, and their eggs may be found unhatched as late as September.

"These birds are easiest shot while feeding abroad in the fields; at the caves a shout will cause them to fly out, but with such suddenness and swiftness, that it requires something of a Battersea pigeon shooter's knack to succeed in hitting them quick enough; an indifferent shot (after knocking over one or two which may be incautiously napping upon the outer ledges), had better conceal himself either in the cave, or in a good position above it; in a short time a bird is sure to come darting swiftly for its accustomed haunts, but upon catching a glimpse of a lurking foe he stops his rapid career, flutters his pinions for a moment, uncertain what to do; that momentary indecision is fatal-down he falls, while a roar of a volcano bellows along the vaulted roof, and the cave is filled with wreaths of sulphureous smoke." 


\section{THE TURTLE DOVE.}

\section{COLUMBA TURTUR.}

Although the 'Turtle Dove has been found in most of the counties in Scotland, it can only be ranked as a straggler. All the specimens that have come under my own observation have been procured in autumn or spring. It has occurred, perhaps, more numerously in Wigtownshire than elsewhere on the west side: it has likewise been met with in Ayrshire* and Dumbartonshire. In the Hebrides, specimens have been shot in Islay and Skye, but in the outer islands, as might be expected, none have yet turned up. A specimen of an allied species-Turtur Egyptiacusevidently an escaped bird, was caught in an exhausted state at Scolpeg, North Uist, on 20th October, 1866, as I have been informed by Mr John M'Donald, Newton.

Dr Saxby mentions three instances of the occurrence of the Turtle Dove in Shetland; and in addition to the specimen recorded in their work, a note in manuscript by Messrs Baikie and Heddle states that one was got on Holm, in Orkney, in 1850.

On the east and north of Scotland, I have myself seen this bird in a wild state in East Lothian, Aberdeenshire, Banffshire, and Morayshire.

\section{THE PASSENGER PIGEON.}

\section{ECTOPISTES MIGRATORIUS.}

The late Dr Fleming mentions in his 'History of British Animals,' that a specimen of this bird was shot at Monymeal, in Fifeshire, on 31st December, 1825, and that the specimen was in his possession. It showed no traces of having been in confinement.

In Yarrell's work it is stated that a second British specimen was obtained in Hertfordshire in July, 1844, and another seen near Tring in the same county by the Rev. Mr Williams. Besides these examples, I learned last year (1869) that another had been shot in Berwickshire by the late Earl of Haddington, regarding

*When visiting the town of Kilmarnock in October, 1870, Mr Faton, birdstuffer there, showed me an Ayrshire specinen, and informed me that almost every season Turtle Doves, shot in the county, are sent to him for preservation. 
which the present Earl informs me that a short time previously a gentleman in that county had turned out several pigeons of this species, so that it is more than likely the specimen in question was one of the birds which had been set at liberty. It is somewhat remarkable, however, as Lord Haddington observes, that none of the others were again seen or heard of in the district.

A most graphic account of the habits of this beautiful pigeon is given by Audubon in the first volume of his "Ornithological Biography," (pages 319 to 326). This author states that in March, 1830, he bought about 350 of these birds in the New York market at four cents a piece, and carried the most of them alive to England, where they were distributed amongst several noblemen. Bearing this fact in mind, it is indeed strange that no other so-called British example of the species has come under the notice of ornithologists.

RASORES.

PHASIANIDA.

\section{THE COMMON PHEASANT.}

\section{PHASIANUS COLCHICUS.}

Is very commonly distributed throughout the western counties, extending from Sutherland to the shores of Wigtown. I have been informed by $\mathrm{Mr}$ Elwes that it is now naturalized in some of the higher grounds of Ross-shire.

In the neighbourhood of Loch Lomond, it may occasionally be noticed on the mountain sides, at a considerable elevation, sometimes as far up as 1200 feet. In Shemore glen, I have seen male birds rise from the heath among the rocks, and wheeling round, direct their flight down the valley with extraordinary speed. Very different indeed is the flight of these strong winged natives of the glen from that of over-fed birds in wooded preserves; and as one bird after another shoots past high in the air, one can hardly resist the impression that, if left to its own selection, the Pheasant would adapt itself wonderfully to the drawbacks of its adopted country. Mr Elwes informs me that he has frequently seen pheasants in Islay get up in the most unlikely places, such as an open moor, miles away from any covert or corn-field, and sometimes in a wet bog, where one would be more likely to find a snipe. On that island, where it was introduced about thirty years ago by $\mathrm{Mr}$ 
Campbell, the Pheasant is now not uncommon, and appears to be on the increase. In the Outer Hebrides it has likewise been introduced into Lewis by Sir James Matheson, who has obligingly informed me that, since its introduction twelve or fifteen years ago, it has become fairly established, although it has not increased to the extent that might have been expected in a more favourable locality. "The deep drains in the peat moss," writes Sir James, "are supposed to be the cause of the death of the young chicks by their falling into them. For some years at first there was a want of cover for pheasants, but they are now better off in this respect, and are increasing gradually. Some of the first brood wandered about sixteen miles to the west side of the island, it is supposed, in quest of cover."

In some parts of Ayrshire and Argyleshire, especially on the lands of Skipness in the latter county, a breed of Pheasants has been established, and is now often met with-namely, a cross between Diard's Pheasant ( $P$. versicolor) and the common species. It is many years since it was first introduced into the last-mentioned district at considerable expense, but it appears now to have become tolerably common, judging from the fact that it is occasionally sent with other game to the poulterers' shops.

In June of the present year (1869), through the kindness of John Fleming, Esq. of London, I had the great pleasure of seeing several beautiful birds of this breed in a state of liberty on the estate of Kilkerran, Ayrshire. Mr Fleming has obligingly informed me that his keeper has at present upwards of forty young birds of this handsome variety under his care, for the purpose of being turned out in the preserves as soon as they are able to shift for themselves. I have also the gratification of being able to state that Mr Fleming has succeeded in obtaining another cross between the common species and Reeves' Pheasant (P. Reevesii) and will probably have from ten to a dozen pairs this season, the produce of five male birds of the last mentioned species imported by himself direct from China. Mr Fleming very kindly afforded me an opportunity, a few weeks ago, of seeing these superb birds in his pheasantry. Besides the growing shrubs and trees, the ground is partially covered with bundles of withered fir branches, so as to provide both shade and concealment for the birds. When lying crouched among these dried sticks, the Pheasants were almost invisible, but the moment they were approached by the keeper, 
the startled creatures-covered with golden stars-wildly flew out from their hiding place, uttering their sharp and anxious cry, and betraying a restless activity which showed off their spangled feathers to great advantage. It is to be hoped that the cross-breed may turn out to be handsome birds. The chicks which I saw in June were almost pure white, indicating a closer resemblance to the male than to the female parent. Mr Fleming informs me that it is his intention, after a time, to turn out these birds also, so that Ayrshire may shortly have the distinguished credit of introducing an entirely new breed into our Scottish preserves.

One or two pairs of the true Phasianus versicolor lately escaped from the pheasantry at Kilkerran, and are at present in a perfectly thriving condition, frequenting a particular cover, and keeping for the most part by themselves. Mr Fleming pointed out to me a cock and hen bird during a recent visit to that place. The cry of this species is much shriller than that of the common bird.

There is a very handsome breed of ring-necked Pheasants on part of Sir James Colquhoun's estates on the banks of Loch Lomond: they are small and beautifully-shaped birds, and very active both when running and on the wing.

Although the Pheasant has been an inhabitant of the British islands for the last six hundred years, it does not appear to have been in early times the same precious subject for preservation as it is at the present day. In the reign of Edward I. it was sold at eightpence a brace. The first mention of the Pheasant in old Scots Acts is in one dated 8th June, 1594, in which year a keen sportsman occupied the Scottish throne. He might almost have been called "James the protector" of all kinds of game. In the aforesaid year he "ordained that quhatsumever person or persones at ony time hereafter sall happen to slay deir, harts, phesants, foulls, partricks, or uther wyld foule quhatsumever, ather with gun, croce bow, dogges, halkes, or girnes, or be uther ingine quhatsumever, or that beis found schutting with ony gun therein," etc., etc., shall pay the usual "hundreth punds," etc.

It is certainly to be regretted that this bird and the partridge should be associated with so much law-breaking and bloodshed. Being in great request as delicacies for the table, they have always been coveted by the lawless poacher, who is never at a loss to find a market for his plunder. In this respect, however, the present generation of sportsmen has, perhaps, less to complain of than the 
game preservers of old. King James the First, whose "Acts" appear to have been but indifferently respected during his reign in Scotland, found himself in no better plight when he tried to govern his poaching subjects in the South, and thus states his own particular grievance to the Lords and Commons of Parliament, at Whitehall, in 1609:-

"Now as to the last point concerning matters of Pleasure, it consists in the preseruing of Game, which is now almost utterly destroyed through all the kingdom. And if you offer not now a better Law for this than was made in the last Session of Parliament, I will neuer thanke you for it. But I pray you, how can the Game be maintained, if Gentlemen that have great Lordships shall breed and preserue them there, and so soone as euer they shall but flie ouer the hedge, and light in a poore fellowe's close, they shall be all destroyed? Surely I know no remedie for preseruing the Game that breedes in my grounds, except I cast a roofe ouer all the ground, or else put veruels to the Partridges feet, with my Armes upon them as my Hawkes haue; otherwise I know not how they shall be knowen to be the King's Partridges, when they light in a Farmour's Close." After some further remarks on the "Stealing of Deer," he then proceeds:- "I know you thinke that I speak partially in this case like a Hunter; but there is neuer a one of you that heares me, that cares the least for the sport for preseruation of the Game, but he would be as glad to haue a pastie of Venison if you might get it as the best Hunter would?"

This appeal, temptingly enough put by his Majesty, did not, however, avert the fate of the next species-another of the royal favourites that ultimately extinguished itself in some "poore fellowe's close."

\section{THE CAPERCAILLIE.}

TETRAO UROGALLUS.

Cabar Coille.

Perthshire and Forfarshire are at present the stronghold in Britain of this fine game bird. In these counties it breeds extensively, and has become so firmly established that proprietors of the forests in which it is found do not now object to its falling to the sportsman's gun. In some places, indeed, it has been 
thought prudent to thin the Capercaillies where they have become numerous. Mr Geike, factor to the Earl of Airlie, lately informed me that he has seen as many as fifteen brace killed in a day by one shooting party. These birds are also abundant on the estate of the Earl of Breadalbane, where of late years they have increased to a great extent. Stray birds are often seen in the counties adjacent to the two just mentioned. Numbers are sent to the Glasgow poulterers, but from the rankness of their flesh they are not much esteemed for the table-a quality which in these degenerate poaching days must materially lessen the chances of their destruction.

Mr Elwes, whose interesting notes are now before me, remarks that as they are not included in the game laws, and can be shot at any time of year, it is a favourite plan in some places to reserve them until January and February, when, with a few roe-deer and woodcocks, they help to make up a very good day's sport. As they keep mostly in high Scotch firwoods, and are very wary, it is necessary to drive them with beaters, and though from their great size very easy to hit, a hard blow and large shot are necessary to bring them down. They are said to drive the black game very much away from the woods they frequent, and in some places are not much liked on this account.

On consulting some of the older records respecting the occurrence of this "chieftain of the grouse tribe," I find that as far back as the early part of the seventeenth century its head-quarters had been almost where they now are, and that it had spread from this centre northwards. * In Inverness-shire it had lingered until 1745.

* As an exception to this rule it may be mentioned that the Rev. J. Headrick, in his "View of Arran," published in 1807, remarks that the Capercaillie "formerly abounded" in that island, but seemed then to be extirpated. I have the satisfaction, however, of stating that the bird has been again introduced into the island, and is now (1870) observed in considerable numbers. From this district eggs have been obtained by parties at a distance, and experiments tried in Dumfriesshire and Wigtown with a view to the re-establishment of the bird in the firwoods of these counties These experiments have been so far successful that several broods have been dispersed throughout the south of Scotland, but from the want of sufficient cover it is extremely doubtful if the species can increase in that direction. Indeed, judging from newspaper records, it would appear that in several instances the birds have wandered from their native woods, and been destroyed by grouse shooters. In December, 1868, a fine male, in beautiful plumage, was shot in Lanarkshire by Henry Lees, Esq., on his moors at Auchengray, near Airdrie ; and in the last week of November, 1869, 
Writing in 1794, the Rev. John Grant says:- "The last seen in Scotland was in the woods of Strathglass about thirty-two years ago;" but the bird must then have been but a rare straggler, as is evident from a note by the minister of Kiltarlity, written about the same period, in which he says:-_" The Caperkaily, or king of the wood, said to be a species of wild turkey, was formerly a native of this parish, and bred in the woods of Strathglass; one of these birds was killed about fifty or sixty years ago in the churchyard of Kiltarlity,"-an ominous haunt, indeed, for the last of his race. Besides these notices, mention is made of the species in the statistical account of Urquhart and Glemoriston, and other parishes -all records agreeing in the fact of the bird being extremely rare between the years 1745 and 1760, when it apparently became extinct.

The following is a copy of a letter written in 1617 by the royal sportsman, mentioned in the account of the preceding species, to the Earl of Tullibardine, ancestor of the Duke of Athole :-

"James R,

"Right trustie and right well beloved cosen and counsellor. We greet you well. Albeit our knowledge of your dutiful affection to the good of our service and your countrie's credite, doeth sufficientlie persuade us that you will earnestlie endeavour yourself to express the same be all meanes in your power; yet there being some things in that behalf requisite, which seem, notwithstanding of so meane moment, as in that regaird both you and others might neglect the same, if our love and care of that, our native kingdom, made Us not the more to trie their nature and necessity, and accordingly to give order for preparation of everything that may in any sort import the honour and credite thereof.

two specimens-both females-were killed in Galloway: one in the neighbourhood of Newton-Stewart, the other at Auchencairn, Kirkcudbrightshire.

Again, writing from Dunipace, in Stirlingshire, Mr Harvie Brown says: "You will, I think, be glad to hear that the Capercaillie may now be considered as fairly established in this part of the country. Last year several birds bred in Torwood, and are now seen not only by the keepers but also by the gentlemen who shoot over the covers. They are also not unfrequently seen in the adjoining cover of Daleswood, both males and females. They are not, of course, as yet in any numbers, but three or four are often seen together. They have doubtless spread in this direction from Tullieallan through Dunmore, where a nest of eggs was found some years ago, though not hatched on account of an accident." 
Which consideration, and the known commoditie yee have to provide, capercaillies and termigantis, have moved $\mathrm{U}_{\mathrm{s}}$ very earnestly to request you to employ both your oune paines and the travelles of your friendis, for provision of each kind of the saidis foules, to be now and then sent to Us be way of present, be means of Our deputy thesaurer, and so as the first sent thereof, may meet us on the 19th of April at Durham, and the rest as we shall happen to meet and rancounter them in other places on our way from thence to Berwick. The raritie of these foules will both make their estimation the more pretious and confirm the good opinion conceaved of the good cheare to be had there. For which respectis, not doubting but that yee will so much the more earnestlie endeavour yourself to give Us good satisfaction anent the premises, as yee will do Us acceptable service, we bid you farewell. At Whitehall, the 14th Marche, 1617."

From this letter it would appear that the capercaillie had been one of the delicacies of the royal table during the reign of James in Scotland; and it is amusing to observe the somewhat impatient directions given to have birds forwarded to Durham to meet him there on a certain day, and others as he should "happen to rancounter them" in his route northwards. Modern taste would hardly seem to confirm the good opinion "conceaved" by his Majesty of these birds, but their "raritie" was perhaps more esteemed than the flavour of their flesh. The species, as we have seen, probably continued scarce for another century, and finally disappeared about the year 1758 .

It is not quite so certain that "termigantis" have ever been in danger of extinction.

\section{THE BLACK GROUSE.}

TETRAO TETRIX.

Colleach dubh (mas.) Liath-cheare (foem.)

THIs fine game bird is common on all the mountain ranges, hilly districts, and patches of upland heath, extending from the north of Sutherlandshire to the Mull of Galloway. It is likewise found plentifully on many of the Inner Hebrides. On Mull it is much commoner than the red grouse, as I have been informed by $\mathrm{Mr}$ Graham; and on Islay, according to Mr Elwes, it is increasing 
rapidly in the north part of the island, although that portion of it is bare of cover. In autumn, it regularly frequents the stubblefields there, morning and evening, to feed. I have observed the same habit of the species on the Loch Lomond range of hills, where it is very abundant. In this district the birds are found from a moderate elevation to the summit of the hills on the west side; but, in the breeding season, the females appear to come nearer the glens, especially those fringed with birch trees, at the root of which the nests are often placed.

Being anxious to know whether black game could be obtained within sight of so large a city as Glasgow, I applied to Mr G. Shirlaw of Motherwell, who has kindly sent me the following note :- "The moorland that I sometimes take a shot over, is in the upper part of the parish of Carluke, from which, in a clear day, St. Rollox is distinctly visible. Black game are scarcer than red grouse, which are plentiful; the former breed sometimes well out in the moors on suitable feeding ground, such as the margin of a water course, where there is plenty of bent grass and rushes; but, for the most part, you find them on half cultivated ground on the outskirts of the moor, and the more readily if there should be a scraggy plantation, high beech and birch hedges, and a meadow close by."

In connection with the food of this species, a curious fact is mentioned by Dr John Walker, at one time professor of natural history in the University of Edinburgh, in his work entitled, "An Economical History of the Hebrides," etc. In vol. i., page 337, the following note occurs:- " The stomach of the Tetrao tetrix Linn, or black cock, after the bird had lived in woods during winter, was several times found stuffed with the foliage of the Polypodium vulgare Linn, or common polypody. This is the only certain instance that has occurred of any animal living upon a plant of the fern kind in this country."

It is certainly a strange feature in the history of this species that it refuses to become naturalized in Ireland. Repeated attempts have been made to introduce it into that country, but all have signally failed. This singular fact is all the more to be wondered at when it is borne in mind that the bird has become of late years tolerably common in the south-west of Scotland. It wanders to the very verge of the rocky headlands, Burrow Head and the Mull of Galloway, and even to the heights above Portpatrick, whence 
it can, by lifting its head above the heather, see the Irish coast, clear and well defined;-but there it stops.

Dr Dewar informs me that while on Ailsa Craig in the summer of 1867 one of the cragsmen found an egg of the black grouse in the nest of a lesser black-backed gull near the summit of the island: it bore evidence of having been carried thither by the vagrant owner of the nest-the colouring matter having been rubbed off the one end, which had apparently been in the gull's mouth.

A nest of this species, containing sixteen eggs, was found in the summer of 1868 on the moors at Daldowie, in Ayrshire; on being visited some time afterwards it was found that two hen birds had divided the number, and were then sitting on eight eggs a-piece within a foot of each other.

The grey hen, as in the case of the hen pheasant, frequently assumes the plumage of the male. Two examples occurred within my observation in November, 1868: one from Argyleshire, belonging to $\mathrm{Mr}$ J. Gilmour, had the head and neck exactly like those of a grey hen-the rest of the plumage resembling that of a young male, and the lateral tail feathers showing a tendency to curve outwards; the other from Ayrshire, a remarkably glossy and beautiful bird, was wholly dark in colour, the tips of most of the feathers being adorned with clear reddish brown pencillings, giving the specimen a most attractive appearance. Both were exhibited at a meeting of the Natural History Society of Glasgow.

\section{THE RED GROUSE.}

\section{LAGOPUS SCOTICUS.}

Coileach ruagh (mas.), Cearc-fhraoich (fom.)

The jealous care with which this beautiful bird is protected appears of late years to have materially affected the well-being of the species. The present work is hardly suited for discussing the influences now at work and threatening to lessen, if not wholly destroy, one of the most popular of sporting pursuits; yet I cannot withhold expressing a fear that the Red Grouse of Scotland, if not soon left to its own resources, may ultimately become a victim to over protection. The great changes that have taken place within the last thirty years in the management of moorland tracts, and 
the excessive rents now derived from such properties, have induced both land-owners and lessees to clear the ground of all kinds of animals that would naturally prey upon those birds which are not strong enough to protect themselves; hence, sickly broods of grouse perpetuate other broods that year by year degenerate until disease ensues, and in some instances almost depopulates an entire district. There can be no doubt that this unwarrantable destruction of hawks and buzzards affects adversely the condition of the birds with which our Scottish mountains are stocked-the number of wounded birds alone which survive the unprecedented annual slaughter, through which the Red Grouse is now obliged to pass, being an argument sufficient to shew that such merciful agents are wanted to prevent the spread of enfeebled life. It is a somewhat significant fact that even healthy-looking grouse, or at least birds shewing no outward signs of disease, are much infested with tapeworms-a condition which is not local, but wide spread, as I have proved by examining specimens from moors remote from each other. Professor J. Young, M.D., of Glasgow University, having made similar observations, informs me that he believes the so-called grouse disease does not in any way depend on the presence of these Entozoa, but that the mortality which has of late years caused so much alarm among sportsmen, is in fact due to malnutrition, "to a cachectic state transmitted from parent to offspring, and predisposing the young to suffer from influences such as severity of seasons or temporary scarcity of food, which, under other circumstances, they would have resisted successfully."* In other sections of the animal kingdom epidemics similar to that affecting grouse have been noticed, and so far as my own observations have enabled me to judge, I am disposed to regard these periodical outbreaks of disease as more or less associated with a derangement of Nature's laws. In almost every case where undue protection is given to certain animals by the rigorous destruction of others, man's interference is followed sooner or later by evils of a graver nature than those which the protective measures were intended to cure; and until some more rational plan is tried for the restoration of the Red Grouse to its original vigour, no one can say what may be the

* See Proceedings of the Natural History Society of Glasgow, Vol. I., Part I., p. 225 (1868), which contains a short abstract of a paper by Dr Young, on "Certain Aspects of the Grouse Disease." 
final issue of the somewhat anomalous position in which, as a species, the bird is now unfortunately placed.

Throughout Western Scotland the Red Grouse is widely distributed, being found on all our moors ranging from the base of the highest mountain peaks, down to the patches of heath that skirt the salt water lochs of the Outer Hebrides. It is found in almost the whole of the islands of both the inner and the outer group, being common in Islay, Mull, Skye, Rum, and Jura, where the species is said to be increasing. It is also tolerably abundant in Lewis, Harris, North and South Uist, and Barra. All the birds I have examined from these wild wastes appeared to be quite free of disease, but as a rule they may be said to be smaller and lighter in colour than those from moors on the mainland, especially the mountain ranges of the north-east of Scotland, which invariably yield, in good seasons, the largest and most beautifully marked grouse. In many districts the native grouse partake of the coloration of the ground in their markings; thus the finest and darkest birds are those frequenting rich heathy tracts; while on broken ground of a rocky character, such as may be seen in the south of Wigtownshire, the grouse are either more or less mottled, or are altogether lighter in colour, and less in size and weight.* Accidental varieties likewise occur. I have seen specimens of grouse that were wholly of a pure buff colour; the last pair of the kind I examined were shot near Forres, in October, 1867, and had for some time previously been marked objects on the moor where they were killed.

I have found the nest of this species at various elevations in localities where the heather grows in luxuriance, from the shoulder of the highest hills to the low slopes, almost touching the margin of some of our sea lochs. I remember finding two nests in the island of Bute in 1867-a year of disease and great mortalityabout ten yards from high-water mark; and some of my correspondents sent me similar records from other parts of the country. The food of the grouse though consisting, as is well known, of young heather shoots and various alpine plants, is often varied by farm produce, especially oats - a grain which is frequently sown on reclaimed patches of land near its haunts. In Wigtownshire, I

* Mr Elwes informs me that in the district of Gairloch, west Ross-shire, grouse vary very much in the breast markings, and that they never pack in that part of Scotland, nor become wild except in bad weather. 
have observed large numbers frequenting even stubble and turnip fields. On 29th September, 1870, when driving from Glenluce to Portwilliam, I noticed upwards of thirty grouse perched on a stone-wall dividing two fields in the immediate neighbourhood of a moor. This was late in the afternoon, just as the dyke was being tipped with the warm hues of approaching sunset, and the birds sat in a line with a curiously regular space between each. None of them appeared to take notice of the conveyance as it went past, and, on looking back and keeping the wall steadily in view for some minutes, I saw eight or ten more birds flying in their direction; so that, in all likelihood, the assemblage would increase as the evening advanced. On mentioning the circumstance to a friend in Portwilliam, I was informed that this habit of settling on stonewalls is not uncommon in that district; and that as many as forty to fifty grouse are frequently seen ranged on such perches. Poachers, who are aware of the habit, take a raking shot at them as they sit, and often in this way secure three or four brace at a single discharge.

Although I have spent many solitary hours on the mountain side watching the varied phases of bird life, I feel that it is impossible in words to convey to others an idea of the impressions to be derived from repeated communings with nature in the secluded haunts of the gorcock or ptarmigan. Those who have been much on the green wastes of heath that clothe our "Scottish Alps," will, I daresay, prefer their own recollection of sights and sounds to anything I might attempt to picture; and any of my readers who have not yet traversed these trackless solitudes, will find a vivid description of a naturalist's night walk in the History of British Birds by the late Professor Macgillivray, where the perils and pleasures of the bird student are gratefully portrayed. Every line of the author's sketch must have been penned when fresh from his lair of heath.

The true ornithologist, whose rambles extend at times far beyond the mountain home of the Red Grouse, looks upon this bird with a peculiar interest. Its history, as we have seen, has now become invested with so many unusual features that it may fairly be questioned whether the species is destined to a much longer existence than it has already enjoyed. Those who have visited its haunts at all seasons of the year, will better understand its loss than the mere sportsman, whose acquaintance with it has begun and ended on the moors during the months devoted to its destruction. It is 
not impossible, therefore, that while treading the brown tracts of deserted heath in after years, the naturalist may be forced to recal, with a melancholy interest, the lively challenge of this feathered highlander as he startled the very hills with his sudden flight, and lament that he cannot now stand-

\section{" And mark}

O'er many a farm house, many a ranked stook, Our pastoral country's upland barrier dark, Where flocks graze numerous, and the sheep dogs bark; Along yon moorland brown with heather bells, There swarm the honey-bees and sings the lark; While grouse, which summer saw burst from their shells, Rough-footed run o'er knowes where moss-bees build their cells."

-Maid of Elvar.

\section{THE PTARMIGAN.}

\section{LAGOPUS VULGARIS.}

Tarmachan.

Av abundant species on all the higher mountains of Scotland extending to the Outer Hebrides, but becoming less frequent and somewhat local as we trace it westwards, especially on the Long Island, where it is wholly confined to the rocky peaks of Harris and Lewis. Sir James Matheson has informed me that on some parts of his estate in Lewis, small flocks are found on the summit of the highest hills, but that the bird can only be regarded as a scarce species there. He has, however, issued orders for their protection, being anxious to see their numbers increase.

In Headrick's time, it was met with "on the granite mountains of Arran,"* and is still a native of Goatfell and Ben Noūsh, but in reduced numbers. Three years ago, Mr Halliday, the Duke of Hamilton's gamekeeper, procured a number from Inverness-shire, in order to strengthen the breed; but it appears doubtful if the mountains of Arran are sufficiently attractive for the future increase or well-being of the species. It would be impossible, I daresay, to imagine a more extraordinary or awe-inspiring scene than that presented to the adventurous climber on gaining the summit of either of these stupendous mountains. Well did my late friend,

* See "View of Arran," etc., by the Rev. James Headrick, Edinburgh, 1807, p. 327 . 


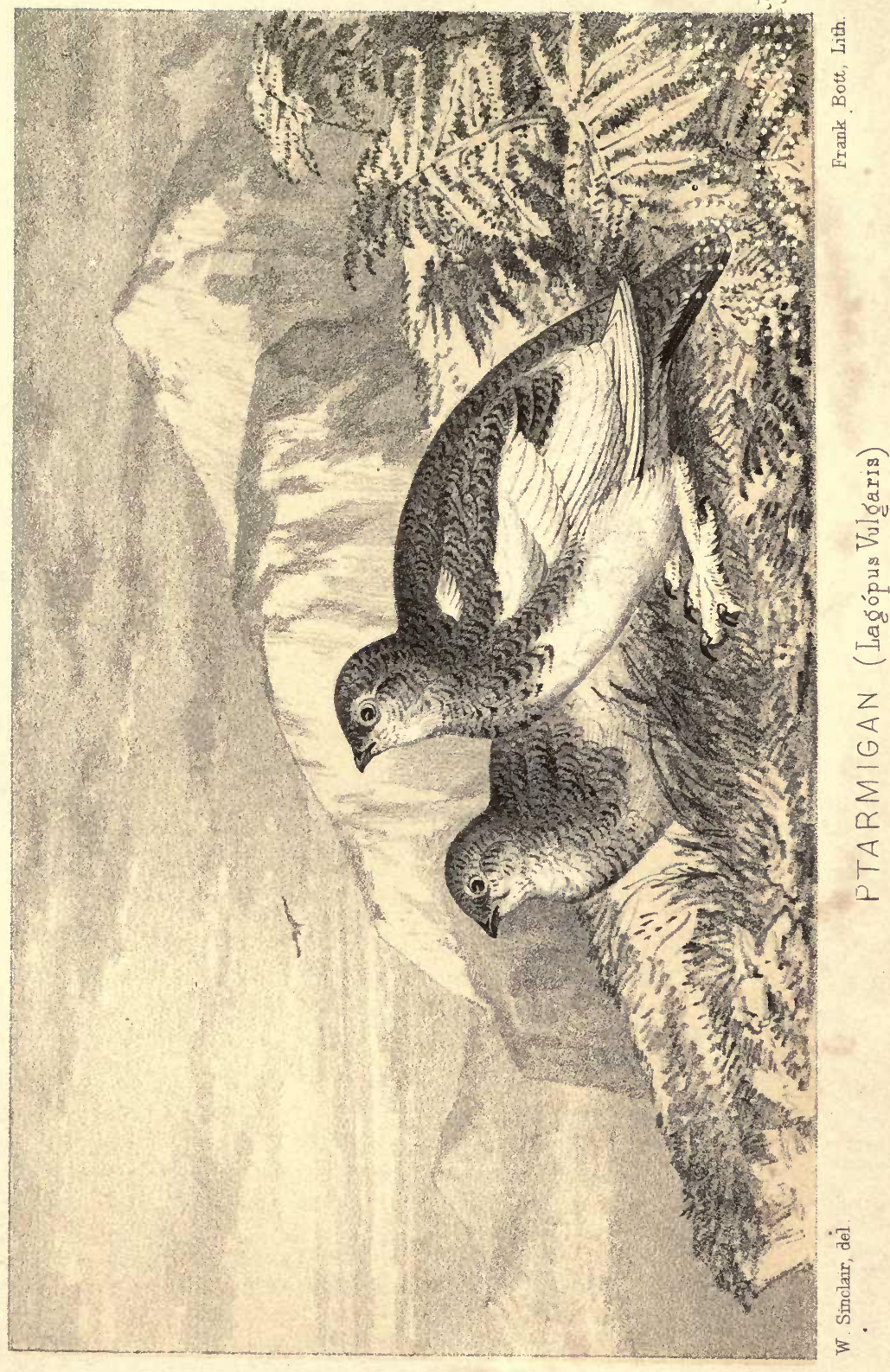


$\because \because$

$\because 00=$

vov ice

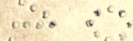

$\because$ o

ios

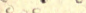

is $c^{c} c_{c}^{c}$

oces ace

cere tee

ice cose 
the lamented Dr Landsborough, describe this wild and savage tract as a

"Vast scene of utter solitude."*

I have been on many mountain ranges, but those of Arran have certainly left with me deeper impressions than all the rest combined.

" In vain you look for hamlet's humble walls;

For curling smoke from peaceful cottage roof ;

For slightest trace of slightest change produced On nature's features by the hand of man.

All, all is still; save when the savage scream Of eagle echoes through the lonely sky.

Where, like dark speck, immovable she hangs

In the blue vault; or when an aged deer-

Sole remnant of the herd-bounds nimbly by,

And turns with look of wonder and reproach

To gaze on the intruder." †

The Ptarmigan is perhaps nowhere more numerous in Scotland that in Ross-shire. On the higher ranges of Ben Wyvis-a region of perpetual snow-it is often obtained in considerable numbers by sportsmen during their autumn excursions. I have been informed by Mr Walter Arras, Fodderty, near Dingwall, that in the course of a day's shooting on Ben Wyvis he has seen ten brace shot; and that, in September, 1868, one shooting party had about fourteen brace within eight days. Mr Elwes writes that on the western mountains of the same county it is "very abundant-so much so, indeed, that Lord Hill's son killed over 100 brace to his own gun in two days in the autumn of 1866."

Writing in May, 1869, Mr Harvie Brown informs me that the Ptarmigan is still a very common species on the mountains of Sutherlandshire, and thus describes his search for the nest of the bird: "Friday, May 21. To-day R. and I, along with the minister's shepherd, went up to the 'region of stones' on the top of Ben Harran in the glebe, and searched diligently for a Ptarmigan's

* Nor are the glens less solemn or impressive. An artist friend lately told me that, on one occasion while sketching in one of the most retired "bits " of Glen Sannox, he was almost appalled by the intense gloom pervading the scene. Overhead the leaden thunder cloud revealed a small break, through which there came a struggling gleam of light penetrating, but not diffusing itself, into the dark ravine. "One glance," said my friend, "was more than enough, and I was glad to shut up my portfolio and run."

+ Arran. A poem, by the Rev. David Landsborough. 
nest. We put up plenty of cock birds; but for a long time failed in finding the nest. At last, well on in the day, and just as we were thinking of returning to the inn, a hen bird rose off her nest about ten yards in front of us. It contained nine very light-coloured eggs; the nest was a deepish cup, scraped, or chosen, in the turf, on the flat top of a rocky slope, and sparingly lined with slender grasses and a few feathers."

Mr Elwes has stated to me that out of nineteen Ptarmigan shot in the district of Gairloch, in the west of Ross-shire, "some were very backward in their winter plumage, and had scarcely a white feather in their backs." The assumption of the full winter dress appears in a great measure to depend on the state of the season, and the same remark applies to that of the spring and autumn.

\section{PALLAS'S SAND GROUSE.}

\section{SYRRHAPTES PARADOXUS.}

EARLY in the summer of 1863 , Scotland shared with other parts of Britain in the extraordinary irruption of this very interesting bird which then took place. Its first occurrence north of the Tweed, of which I have any record, was obligingly communicated to me by my friend Mr Harvie Brown, who examined three specimens killed in Stirlingshire on the 13th May of that year; and the latest instances of its capture, which were from the Outer Hebrides and the Shetland islands in the month of October following, shew that during the five months it remained with us, it had gradually retreated to, or what is more likely, been driven in its wild and excited flight upon less frequented tracts in a vain effort to find that rest which was denied to it on the mainland.

The following records, noted at the time, are all I have been able to glean respecting the appearance of the bird in Scotland. Very many more specimens, were no doubt obtained and probably lost through ignorance of the species; consequently the importance of its occurrence has been in a great measure lost sight of.

1863, May 13th. Three specimens were shot in Stirlingshiretwo of them males, the sex of the other unknown. One of these birds is in Mr Harvie Brown's collection, another in the possession of Dr Brotherston of Alloa, and the third in the Alloa Museum. The three were killed about a mile and a half east of Stirling. 
May 28th. A flock of fifteen seen near Stonehaven: two were shot, and sent for preservation to the curator of the Aberdeen Museum.

May 31st. One, an adult male, killed in Perthshire, and forwarded to a game dealer in Derby. This specimen is now in the Derby Museum.

One specimen, which I have seen, was killed near Elgin, and is now in a private collection there.

June 6th. One specimen killed near Dornoch in Sutherlandshire, and preserved by Mr M'Leay, bird-stuffer, Inverness.

June 8th. A flock of ten or twelve seen on the farm of Wester. seat, near Wick: one of these birds was shot while the flock fed among the young braird of oats, and was afterwards placed in the collection of the late Mr E. S. Sinclair of Wick.

June 10th. Mr Alex. Henderson informs me that a specimen was pursued by a peregrine falcon on the Dunbar Links, East Lothian, and captured by a fisherman from his boat in the creek at the vaults.

Seven or eight were shot in Forfarshire: one of these-a female, killed on Montrose Links-is now in the Montrose Museum, a second in the possession of Dr Howden, Sunnyside Asylum, and a third in the hands of Dr Johnstone, Montrose. For these particulars I am indebted to Mr Don, of Brechin, but I have not been able to learn the fate of the other specimens.

July 10th. A second Sutherlandshire specimen shot at Ulbster, in Caithness, by Captain Bentley Innes.

I am indebted to the Earl of Haddington for the following notes on the species from Haddingtonshire:- "A flock of about twenty was seen in June on the shore near Seacliffe, and one was shot. Others may have been killed in East Lothian, but this is the only one that I heard of. In July, 1865, I was told by Mr Small that a specimen had been caught alive near Paisley. He procured this bird for me immediately, and as they are so rarely met with, a few remarks on him may interest you. I made for him a small wire netting enclosure in the garden, with a miniature shed in one corner, but of this he would never avail himself in the heaviest rain. Part of the enclosure was thickly covered each day with dry sand, and his great delight was to bask and roll in this on a sunny day. He would sometimes lie on his side with one leg extended in full enjoyment of the heat-a position in which you may have 
seen chickens in a hot day. I tried him with all sorts of seeds, but though he liked rape, hemp, and canary seed, there was nothing he was so fond of as chickweed. I was so much absent from home that we never became great friends, but he was quite attached to the gardener, and on seeing him would utter three or four peculiar chirps, running to meet him with his wings touching the ground like a turkey cock, and his tail spread almost in the form of that of a fantail pigeon. He would eat from his hand, and was very partial to a bit of dry bread. On seeing a stranger he would give a grunt, or if much frightened a squeak, and run with wonderful rapidity to the further corner of his enclosure. I kept him for about eighteen months; at last a young dog frightened him, and on flying up, a projecting point of the wire netting entered his skull, killing him instantaneously."

October 13th. One-a solitary specimen-was shot on the island of Benbecula, Outer Hebrides, by C. W. M'Rury, Esq., surgeon, and is now in the collection of Dr Dewar of Glasgow; and finally Dr Saxby writes, that in the same month several appeared in Unst, Shetland, with a steady breeze from the south-east, and that he succeeded in shooting one-a female, in perfect plumage.

Professor Reinhardt found this bird breeding on the west coast of Denmark, and communicated some interesting notes to Professor Newton of Cambridge, a portion of which is given by Mr Stevenson in his 'Birds of Norfolk' - a work in which the reader will find a very full account of the local captures, besides other valuable information on the species. Forty years ago, according to Sir William Jardine, Delanoue "found the nest of the female among some stones, collected under a shrub, containing four eggs of a reddish white, spotted with brown. The nest was perfectly simple, constructed with only a few stalks of grass, and the female exhibited the utmost solicitude for her precious deposit." *

* Nat. Lib. Orn., vol. iv., Game Birds. Edinburgh, 1834. 


\title{
THE COMMON PARTRIDGE.
}

\author{
PERDIX CINEREA.
}

\section{Coleach tomain (mas.) Cearc-thomain.}

THIS well-known game bird is plentiful throughout all the cultivated tracts of Scotland extending from the Mull of Galloway,where several broods are found annually on a patch of enclosed ground belonging to the Lighthouse Commissioners and overlooking the highest cliffs, - to Cape Wrath. On the mainland, it seems to have followed naturally upon the reclamation of waste land and the introduction of husbandry; but it does not appear to have ventured beyond the circle of the Inner Hebrides, where it is probably confined to three islands, viz., Islay, Mull, and Skye. In Buchanan's "Travels in the Western Hebrides" (1795), I find it stated that partridges were introduced into Harris by Mackenzie of Seaforth, about 80 years ago ; and also into Lewis, where I have been informed they have since been re-introduced more than once, but without good results. They do not thrive in these remote islands, and are now said to be extinct, though there are numerous corn and turnip fields at the present day to afford them both feeding and shelter.

Regarding the distribution of the Partridge on the western mainland, I am indebted to various correspondents for recent observations. Mr Harvie Brown writes that "it is very scarce in the west of Sutherlandshire, though a few coveys may be seen near Loch Inver." "I observed," he adds, "one or two pairs at Rosehall, where I imagine they are not uncommon." Mr Elwes informs me that it is common in all the cultivated parts of Islay; and also that, in the district of Gairloch in west Ross-shire, as many as ten brace have been killed in a day. Mr Anderson states that in Ayrshire and Wigtownshire it has of late years increased considerably in numbers, many of the coveys haunting the hill farms at a much higher elevation than had previously been known. During a recent drive from Girvan to Stranraer (September, 1870) I noticed upwards of twenty dead partridges - all in a fresh state, and lying at intervals of less than fifty yards-close to the turnpike road, along the side of which three or four telegraph wires are conducted on poles. These wires are very destructive to passing 
coveys of game, as I have many times proved in different parts of the country.

During the breeding season, the Partridge often courts safety and shelter in places where one lititle expects to find a bird of such wary habits. I have frequently found the nest at the roots of hedges, and even by the side of walls among rank grass, where the sitting birds managed to get safely off with their brood. I have rarely found more than sixteen eggs in a nest, and frequently I have seen fewer than that number. Mr Alston tells me that he knew of a pair of partridges that succeeded in rearing a brood of twenty young ones in the Upper Ward of Lanarkshire. When the young leave the nest, which, according to Dr Fleming, they do in twelve hours, they are led by the old birds to the nearest ant-hills, "the eggs in which," says that writer, "constitute their early nourishment." At a later stage they find their way into turnip fields, where they may be seen picking the aphides from the under side of the leaves-a good service to the farmer. The Earl of Haddington has informed me that in hard weather they attack the bulb of the turnip, and do great injury; and that, in many cases, the wood pigeon is blamed for much mischief of this kind, which may be traced to the Partridge.

Several curious varieties of the Partridge have come under my notice; one, a pure albino, now in the collection of Mr Stewart of Tonderghie, in Wigtownshire, was shot by that gentleman on his property some years ago. I have also seen pale buff-coloured specimens killed in the counties of Moray and Inverness. In the autumn of 1868 , I saw in the hands of a Dundee birdstuffer a pair of partridges that had been shot on the higher grounds of Forfarshire a short time previously. They were strikingly handsome birds, and agreed precisely with the partridge figured by Sir William Jardine as perdix cinerea var montana, in his volume on game birds (Naí. Lib. Orn., vol. iv., pl. 2. Edinburgh, 1834). The keeper who shot them seemed to distinguish them as hill partridges, and I was then informed that small numbers were occasionally seen, in the lower grounds, mixing with coveys of the common species.

The following suggestive paragraph is taken from Thompson's 'Birds of Ireland':- "There is a singular difference in habit between the partridge of the north of Ireland and that of the opposite portion of Scotland, as is well known to sportsmen who have 
shot in both countries: I have myself remarked it with some interest. The Irish covey generally springs without uttering a call, but the Scotch covey shrieks with all its might when sprung. The Scotch birds, too, even where very little molested, more knowingly take care of themselves than the Irish; their watchfulness is extraordinary. Their sense of hearing as well as of sight must be remarkably acute. One day, in the month of October, an experienced sportsman and myself sprang either twenty-four or twenty-six coveys (nearly all double, or containing about two dozen birds) in the neighbourhood of Ballantrae, Ayrshire, when they all not only forbade a near approach, but, though we advanced as silently as possible, never admitted us into the same field with them. A sporting friend, who has had much experience in both countries, remarks that he has more than once seen every bird of a moderatesized covey shoi in Ireland, but never saw this done in Scotland. He has bagged as many birds from a certain number of individuals in the former island as he has from the same number of coveys in Scotland."* As this quotation refers only to the partridges of the north of Ireland, it is not certain that those of the south would have stond fire so callously: the "coveys" of Cork might therefore fail to substantiate the parallel. So far as the Scotch birds are concerned, it may safely be said that the national trait is not confined to pariridges.

\section{THE RED-LEGGED PARTRIDGE.}

\section{PERDIX RUFA.}

Mr W. C. Angus informs me that Mr James Mearns shot a specimen of this bird within two miles of Aberdeen, in the last week of January, 1867. This specimen, which is in beautiful preservation, was in a flock of common partridges, and unaccompanied by any outhers of its own species. Messrs Baikie and Heddle mention that the Red-Legged Partridge was incroduced into Orkney at the same time as the common bird, but were, at the time they wrote, unable to say with what measure of success. It is not likely to have maintained its ground there for twenty years. This Aberdeenshire specimen, thereiore, must have been a migratory visitor from the south.

* Nat. Hist. of Ireland-Birds-by Wm. Thompson, vol. ii., p. 65. 


\section{THE VIRGINIAN COLIN.}

\section{ORTYX VIRGINIANA.}

This beautiful quail, which is so well known in North America under the name of "Bob White," was introduced into East Lothian in 1857 , by Dr W. P. Turnbull of Philadelphia, who sent four brace of birds to Mr William Paterson, North Berwick Mains. They were turned out and appeared to thrive well for a time, but Mr Paterson informs me that they have since disappeared. A similar fate appears to have befallen a number of pairs which were introduced into the county of Norfolk by the late Earl of Leicester, early in the present century.* I feel sure that if any proprietor desires to renew the experiment, my friend will gladly forward others.

An interesting account of this species will be found in the first volume of Audubon's 'Ornithological Biography.' The author adds a word in praise of the quality of its flesh. Besides being juicy and tender, it is white and extremely agreeable to the palate, and therefore in much request. In alluding, however, to the introduction of the bird into various parts of Europe, Audubon says "it is not much liked there, being of such pugnacious habits as to drive off the common grey partridge, which is considered a better bird for the table."

Professor Baird, whose work will be found both interesting and useful to the British ornithologist, mentions that "this species is subject to considerable variations, both of size and colour, the more northern being considerably the larger. Southern specimens are darker, with more black about the head, on the wings, and the middle of the back. There is also a more appreciable mottling on the wings, and the feathers of the back are streaked with black." Instances of other variations are given by $\mathrm{Mr}$ Baird, the most notable of which is a large "and redder coloured" individual from the Devil's river,- - the differences in this case being supposed to indicate something more than mere variety; but in valuing these it should not be overlooked that in even the common partridge of this country a much greater variety of plumage is known to exist.

* 'Birds of Norfolk,' by Henry Stevenson, F.I.S., vol. i., p. 436. 


\section{THE COMMON QUAIL.}

COTURNIX VULGARIS.

Gearradh-gort.

The Quail, which is a common bird in Ireland, is also a well-known visitor to the western counties of Scotland. It breeds with us in limited numbers, and in the autumn months it is a familiar bird in Ayrshire, extending over the whole of the county. In many places it is called weet-my-feet, on account of its call-note resembling these words, and which may often be heard on dewy evenings in fields of grass or stubble, where grass has been sown. I have often listened to its soft chatterings on still summer nights, in situations like these near Girvan, where the Quail is by no means uncommon. In the adjoining county of Wigtown, quails appear to have been abundant about the end of last century.*

This bird appears to be very rare in the Long Island. There is a specimen, which I have seen, in the collection of Sir James Matheson, Bart., at Stornoway; it was shot in Lewis, where, I have since learned, one pair, at least, bred in 1868. When in the island of North Uist in the beginning of August, 1870, Mr John Macdonald, Newton, showed me a nest of twelve eggs which had been taken near his residence about ten days previously. These are now in the collection of Captain Orde. On the east of Scotland it is by no means so common as on the west; still it is met with in nearly all the counties ranging from Berwick to Orkney. In the midland counties it is sparingly distributed, but is rare in the north. The nest of the species is not often found. I have procured eggs from Lanarkshire, Ayrshire, Wigtownshire, and Kirkcudbrightshire. The nest has also been found in Mid-Lothian. Mr J. H. Dunn has informed me that, on 4th October, 1851, he got eleven eggs of the Quail that were found by a woman when cutting grain near his house.

Quails are sent in some numbers from Ireland to the Glasgow market during the early part of spring, and appear to be readily disposed of. As an article for the table, it would seem to be regarded with special favour by some epicures. A recent writer in "All the Year Round" thus sounds its praises:-_"The

* See Old Statistical Account of the parish of Buittle. 
Quail, humbly supine on his little mattress of transparent bacon, is an object agreeable to three senses. Enveloped in lard, or clothed with a vine-leaf, the plump little creature is equally delectable. A good roast of quails, even in Paris, costs more than two fat fowls, (and this is no joke, for there are places where one fat capon can cost as much as twelve shillings). Of the French quails, the best are those of Montredon, near Marseilles. There are a thousand ways of disguising them; with beef marrow, truffles, herbs, and mushrooms; they are good à la braise, à la poêle, au gratin (with crumbs), with cabbages, or with lentils coulis. In the lark season it is not uncommon at hotels to disguise larks as quails, but an epicure, even though blind, could tell the difference; for though the lark is much in esteem with poets, and is indeed decidedly a quiet, amiable, well-disposed, and even respectiable bird, he is only a tooth-pick, a mere pastime, in comparison with the exquisite bird that fed the Israelites in the desert."

OBs.-It may not be out of place here to nocice in a few sentences a paper which was read in January, 1870, at a meeting of the Natural History Society of Glasgow, "On the introduction of the WiLd Turkey (Meleagris Gallopavo) into Argyleshire," by Mr John Gilmour. The author of this paper mentioned having received three specimens of this beautiful bird-a male and two femalesfrom the southern extremity of Lake Huron in Canada, in the summer of 1866, since which time various broods had been successfully reared in the neighbourhood of Ardlamont, where the birds had been allowed their full liberty in the woods. At first it was found necessary to establish a brood by hatching the eggs under common barn door fowls, but the young birds at once exhibited their thoroughly wild nature by refusing the shelter of a roof and preferring to roost on trees. One of the birds of this flock (reared in 1867) - a young male-Mr Gilmour described as a very handsome bird of beautiful plumage, his magnificent bronzed feathers shewing to great advantage in the sunlight. In the summer of 1868 , one of the hens selected a site for its nest in a dense thicket of ivy clothing the summit of a high and precipitous rock, where it managed to remain unobserved until the young ones were hatched. After making the discovery of this nest, $\mathrm{Mr}$ Gilmour was interested by observing the manner in which the parent bird approached her secret treasure. Taking advantage of an overhanging tree, the wary creature invariably perched there 
first, and after walking cautiously along a branch, dropped upon the nest on which she sat without the faintest trace of her form being seen. In 1869, the hen birds disappeared for a considerable time in the woods, and nothing was seen of them until each appeared with a brood of about a dozen healthy chicks, feeding in the small grass paddocks at the edges of the coverts, and enjoying the sunshine. While the young ones were busily engaged in feeding on insects, etc., the old birds were standing on the alert, with outstretched necks, ready to give the alarm on any approaching danger. On being suddenly surprised, these quick-sighted sentinels at once crouched close to the ground with a warning cry, and remained motionless in this atititude, the young ones meanwhile disappearing as if by magic in the surrounding tufts of grass. At a later stage of their existence these broods, which spread themselves in the neighbouring moors and in the woods adjoining, were killed by shooting parties, the beaters having disturbed them along with ordinary game. Mr Gilmour also mentioned that they in some cases squatted so close to the ground as to be quite invisible among the withered twigs and ferns, and that in one instance he had actually in firing at a rabbit in the covert, shot a young wild turkey which had been lying concealed in the course taken by the rabbit. Mr Gilmour concluded his interesting paper with a description of the wild bird as compared with those of the domestic breeds, remarking that it possessed greater symmetry, and altogether a more compact form, standing higher on its legs, and exhibiting other characters more like those of a game bird than one of the gallinaceous order. The plumage of the male especially was described as of the most perfect bronze colour, gleaming in the sunshine like a splendid coat of mail. The number of eggs was stated to be from sixteen to twenty, and the time of incubation lasts thirty-one days.

RASORES.

STRUTHIONIDA.

\section{THE GREAT BUSTARD.}

\section{OTIS TARDA.}

THIS remarkable bird has been long extinct in Scotland. As a resident species, it appears to have been entirely confined to Berwickshire, and is thus referred to by Hector Boece, who 
flourished about 350 years ago*:- " Beside these, we have another foule in Mers, more strange and uncouth than all these aforementioned, called a Gustard, fullie so great as a swan, but in colour of feathers and tast of flesh little differing from a partridge. Howbeit, these birds are not verie common, neither to be seene in all places, such also is their qualitie, that if they perceive their egs to have been touched in their absence by man's hand (which lie commonly on the bare earth) they forsake those nests and lie in other places." +

The occurrence of probably the last Scottish straggler is briefly recorded in Fleming's British Animals in these words:- "One was shot in 1803 in Murrayshire, by William Young, Esq., of Borough Head."

For a history of the species in the south of England, the reader is referred to Stevenson's "Birds of Norfolk," and Yarrell's "British Birds." In the account given by the last named author it is stated, on the authority of Mr Nicholson of Balrathkells, who had hunted Bustards in the neighbourhood of Saville, that all the birds he shot "had their stomachs perfectly crammed with barley, both stalks and ears, the leaves of a large-leaved green weed, and a kind of black beetle." A bird captured on Salisbury Plain in 1801, and kept in confinement by Mr Bartley, fed principally upon birds-chiefly sparrows-which it swallowed entire, with the feathers; it likewise ate mice with the same avidity. The following extract from Sir Everard Home's Comparative Anatomy, vol. i., p. 277 , is interesting as bearing on this sulject:- "Understanding that the Bustard in India is a favourite bird for the table, and that all Bustards are there considered to be granivorous birds, I was unable to reconcile this circumstance with the structure of its digestive organs; but this difficulty is solved by the following account of the mode of feeding of this bird, which is taken from Mr Hunter's notes upon this subject, who kept a cock-bustard a whole summer in his garden. It died in November, apparently

* Born 1465. Died 1536. His principal work was a History of Scotland, published in the reign of James $\mathrm{V}$.

+In a communication to the 'Field' newspaper, I find it stated that a Great Bustard was shot in the first week of January, 1871, by Mr Wm. Harvey, at Fenham Marshes, near Berwick-on-Tweed, and preserved by $\mathrm{Mr}$ Reed, birdstuffer in that town. Mr Reed informs me that another was seen ten days afterwards. 
from the cold of the winter. He killed mice and sparrows with his bill by pinching their heads, and then swallowed them whole, even when of considerable size. It was easy to observe a large mouse going down his throat, making a moving tumour till it came to the turn of the neck; it then moved backwards, and although out of sight, yet its progress was traced by the feathers between the shoulders separating and closing again as soon as it passed into the gizzard. It was fond of worms, and while the gardener was digging, stood by him and looked out for them. It ate the buds of flowers, and particularly of roses, also the substance of cucumbers, but not the outside."

The Rev. A. C. Smith, in a highly interesting paper on the "Birds of Portugal," published in the Ibis for October, 1868, vol. iv., No. 16, N.S., thus speaks of the Great Bustard:- "Wild boar and Great Bustards are the lordly species of game, ground and feathered, after which the more ambitious Portuguese sportsmen hunt, and both are found of goodly size and in tolerable abundance in certain districts, more especially in the southern provinces of Alemtejo and Algarve. I was fortunate in procuring a magnificent male bird in the flesh, which was most liberally given me by an English friend, and whose body, after I had taken off the skin, for several days formed a large item in the bill of fare of the Hotel Braganza at Lisbon, the guests of every degree at the table d'hôte, and in private apartments, partaking of the dish, from the British Minister and his family on the first floor to the cook-boys in the area. The bird weighed $30 \frac{1}{2}$ pounds, and is the finest example of $0 . \operatorname{tarda}$ I have ever seen."

\section{THE LITTLE BUSTARD.}

OTIS TETRAX.

There is a specimen of this bird in the Montrose Museum, which was shot near that town in December, 1833. In April, 1868, I had an opportunity of examining this specimen, which is still in good preservation. Another was shot, near St. Andrews on 6th March, 1840, and is now preserved in the Literary and Philosophical Society's Museum there.* A third-a female-was obtained

\footnotetext{
* Captain Feilden informs me that this bird was shot by Dr Adamson of St. Andrews.
} 
in Morayshire on 8th February, 1861: it was shot at Westfield, about four or five miles from Elgin, and when first seen was along with a flock of wood pigeons in a turnip field picking the tops of the plants. This bird, which is a very fine specimen, now belongs to the collection of the Elgin Museum, where I have seen and examined it. A fourth Lititle Bustard was seen in the same county a few days after the last mentioned bird was killed. It was observed on three or four different occasions, but was so shy that it would not admit of a nearer approach than 200 yards.

This species is catalogued by Mr E. S. Sinclair in his Birds of Caithness, and referred to by Mr Shearer, who states in a paper communicated to the Royal Physical Society of Edinburgh, that it has been only once observed in that county, but gives no particulars. I am not aware of the occurrence of the Little Bustard in any of the western counties.

GRALLATORES.

CHARADRIIDA.

\section{THE CREAM-COLOURED COURSER.}

\section{CURSORIUS EUROPEUS.}

A MALE specimen of this very rare bird was shot in a grass field near Lanark by Charles Walker, Esq., of Braxfield House, on the 7th October, 1868. It was alone, and on rising, $\mathrm{Mr}$ Walker remarked its flight to be somewhat dull and heavy, not unlike the common plover when newly disturbed.

Mr J. H. Gurney, Jun., to whom the body of the bird was forwarded, has obligingly furnished me, through my friend Mr Harvie Brown, with the following notes taken by himself on its dissection: - " In the throat was a small fly undigested; the tongue is narrow, with the appearance of bristles at its base, acute, and seven-eighths of an inch in length; the osophagus three-and-a-half inches long, its width inconsiderable, the proventriculus three-quarters of an inch long. The stomach is of the ordinary shape, compressed, an inch long, and seven-eighths in breadth; inner coat full of wrinkles. The intestine only fourteen inches long; it varies in width. The cœec, which arise at a short distance from the end, are about twoand-a-quarter inches in length. The sternum closely resembles that of a redshank." 
It may not be out of place to record here the following notice taken from the proceedings of the Berwickshire Naturalists' Club for 1847, which I have not seen quoted elsewhere:- "Cursorius Isabellinus - a young male bird of this species was killed near Cheswick on the 9th of November, 1846, by Mr David Rowtin (in the preventive service), who shot it during a strong gale from the south, being chased by gulls."

\section{THE GREAT PLOVER.}

\section{EDICNEMUS CREPITANS.}

ONLY one specimen of this bird has occurred in Scotland, namely, a male shot near St. Andrews on 27th January, 1858, as recorded in Turnbull's "Birds of East Lothian." I had an opportunity of seeing the specimen in the University Museum there. A very good account of this curious plover and its head-quarters in Great Britain will be found in Stevenson's "Birds of Norfolk" -an excellent work which should be in the library of every ornithologist.

\section{THE COLLARED PRATINCOLE.}

GLAREOLA TORQUATA.

IN Bullock's Museum Catalogue, dated 1812, there is the following brief record of the only specinien of this bird that has ever been found in Scotland: "Austrian Pratencole (Glareola Ausiriaca). We killed this extremely rare British bird in September, 1812, in the island of Unst, within three miles of the northern extremity of Great Britain." Seven years afterwards, at the dispersion of this celebrated collection, the specimen was sold for eight guineas, and placed in the British Museum. This may be considered a large price for a bird, but it falls greatly short of what was obtained for the first British killed specimen of the cream-coloured courser, which became the property of Donovan at eighty-three guineas:* it also is in the national collection.

* See "Ornithology of Charnwood Forest," p. 69. 


\section{THE GOLDEN PLOVER.}

CHARADRIUS PLUVIALIS.

Feadag.

THIs beautiful plover is extremely abundant over the whole of the western counties of Scotland, where it breeds on all the hills of moderate elevation. It is likewise found throughout the Outer Hebrides at all seasons of the year, being scattered during the breeding season in small companies in suitable localities, and afterwards collected into very large flocks, which are seen frequenting the machirs on the sea shore as the tides happen to regulate their movements. On the inner islands-Rum, Skye, Mull, Islay, Jura, Colonsay, etc.-it may be observed as a constant resident under similiar conditions. I have procured beautiful specimens of both sexes in full breeding dress from many of these localities, and I find they present no differences apart from those obtained from inland and eastern districts, with the exception of the under parts having numerous pure white feathers mixed with the black-a state of plumage which Mr Selby supposes to be peculiar to the female. After the strictest scrutiny, I have failed to detect the American form, Charadrius virginicus, even as an accidental visitant. Professor Baird states that it has been found occasionally in Europe, but gives no particulars; and as it is well known in Greenland, we should naturally expect stray visitors to travel southwards, via Iceland and the Faroe islands, where, however, it appears to be quite unknown, though our British bird is found in abundance. The distinction between the two species is easily made out by the ash-coloured axillary feathers of the American bird, those of the British Golden Plover being white. It is rather remarkable that Audubon in the third volume of his Ornithological Biography describes the axillaries as white, while in the fifth volume of the same work he refers to a second American Golden Plover-the Ch. marmoratus, of Wagler-with black axillaries. This mistake is all the more curious when we consider that none of the recent writers on American ornithology make mention of Charadrius pluvialis, and that it is now even doubtful if it is to be found out of Europe.

Where groups of plovers are met with on the moors in the nesting time, their plaintive and somewhat melancholy note is one 
of the sounds sure to catch the ear of the wandering naturalist, and make him hesitate in prolonging the intrusion of his presence on their solitudes. The birds themselves seem bewildered as they turn round inquiringly on some little eminence to watch his movements. Sometimes, especially in little frequented tracts, they admit of a very near approach. On some of the Hebridean moors I have frequently seen small numbers of male birds quietly occupying heathery knolls near the main road, at a short distance from their sitting mates, and trying, when put up, to allure me from their haunts by running along the road in front of the conveyance I was travelling in. On the hill ranges of the mainland, their usual breeding haunts are bare platforms about midway between the base and the highest shoulder, but in some instances they choose even the summit of the range. There is a plover haunt in the vicinity of the Eaglesham moors, which partly overlooks the city of Glasgow. From this range of hills a varied and extensive prospect may in clear weather be obtained-the densely crowded city, and adjoining towns and villages on the one hand, and the firth of Clyde, including Arran, Ailsa Craig, and the Irish coast on the other. On this heath-covered eminence small companies hatch every year, and in severe winters I have seen moderately large flocks descend from their moorland haunts, and alight on the fallow grounds in the immediate neighbourhood of Glasgow. Mr Harvie Brown informs me that in Sutherlandshire they never breed among the heather, but seem to prefer places, at no great elevation, which have been cleared by burning, especially the dry and stony spots. It would almost seem as if this Plover selects lower breeding stations as we proceed northwards. In Iceland, according to the Rev. G. Landt, it "frequents chiefly the uncultivated fields, where it lays its eggs among the grass," while the nearly allied American bird, as we are informed by Sir John Richardson, takes up its breeding quarters on the "barren grounds, coasts, and islands of the Arctic Sea."*

* In connection with the breeding haunts of this bird, it may not be unworthy of note that the late Mr Yarrell fell into a mistake while quoting from Don's "List of the Fauna and Flora of Forfarshire," in supposing that it formed an appendix to Lightfoot's Flora Scotica. The last-named work was published in 1777, and the "Caledonian Zoology" prefixed to it was, as is mentioned by the author in his preface, written by Mr Pennant. Don's list was appended to Headrick's "View of the Agriculture of Forfarshire," published in 1813-a work which is now eagerly sought after by local faunists. 
In autumn, sometimes as early as the last week of July, immense flocks of Golden Plovers congregate on the Ayrshire coast, and alight on the stony parts of the beach near Girvan, and also on the shores of Loch Ryan in Wigtownshire. It is, indeed, impossible to estimate their numbers, as they literally cover many acres of ground. They seem partial at these times to the wet rocks and sandy patches exposed at low tide, and particularly the flat ridges covered with yellow seaweed, which assimilaties so closely to the dorsal plumage of the birds as to render their detection, when at rest, almost impossible. Similar, or even larger, flocks of Plovers are well known to coast shooters in all parts of Britain, who profit largely by their habit of packing. Mr Thompson, in his work on the Birds of Ireland, speaks of eighteen having been killed at one shot out of a flock of seventy or eighty; and further, that one hundred and eight Golden Plovers were bagged on 22d January, 1848, at one discharge. The late Professor Wilson, in his "Recreations of Christopher North," would assuredly have classed such a gun with the farnous flint weapon of his boyhood, which he so graphically describes as an "awfu' scatterer."

\section{THE DOTTEREL.}

\section{CHARADRIUS MORINELLUS.}

\section{Amadan mointich.}

WhATEVER may have been the numbers of Dotterel that visited North Britain in by-gone years, it is now certain that comparatively few frequent the well-known resting places occupied by the migratory flocks thirty years ago. On consulting the old parish records published towards the close of last century, I find that most of the compilers had to some extent a personal knowledge of the bird. In 1792, the minister of Carmylie, in Forfarshire, wrote as follows:- "The Dotterels, birds of passage, alight on the rising grounds about the beginning of April, continue here about three weeks, remove to the Grampian Hills, about twelve miles to the nortliward, and revisit this parish about the beginning of August. After abiding here about three weeks, they fly off to the southward, and are not seen till the first of April following." Two 
years previously, the Rev. Thomas Somerville, of Jedburgh, recorded that "Dotterel abounded in the south and hilly parts of the parish." In 1794, Mr John Renton, of Chesterbank, who wrote the statistical account of the parish of Coldingham, in Berwickshire, mentions that "Dotterel appear in vast numbers on the heights." About the same period, the Rev. Mr Stewart, of Luss, in Dumbartonshire, in one of the most scientific lists that these voluminous records contain, also writes of the Dotterel, and distinguishes it by a Gaelic name, showing his acquaintance with the species. Various other writers in East Lothian, Fife, Kincardine, Perth, and Aberdeenshires, likewise refer to the migratory movements of this bird, and all these records tend to show that it had then been sufficiently common to attract attention. At the present day, however, though the Dotterel may be said to be still regular in its visits to some of the localities just named, it is absolutely necessary for observers to be careful in watching for its appearance. In some parts of Berwickshire, for example, the flocks, besides being much reduced in numbers, never remain longer than three days in their old haunts, which in the early part of the present century they frequented during as many weeks. Indeed, in other parts of the same county it would almost seem to have discontinued its short visits. The Earl of Haddington informs me that it "was formerly very common in Berwickshire; and on Boon Hill, near Lauder, large flocks were to be seen at certain seasons. It is now, however, rarely, if ever, seen in this county." From recent investigations, I am disposed to think that a similar scarcity has been observed for some years past in East Lothian, where, it is to be feared, only a few stragglers now occur. Mr Harvie Brown has sent me word that a specimen was shot on Gullane Links in that couniy in the first week of May, 1869, and sent to Mr Small, of Edinburgh, for preservation. This bird, which was a female, contained ova the size of grains of barley. The same correspondent, in a paper communicated in January, 1871, to the Natural History Society of Glasgow on the "Birds found breeding on Sutherlandshire," has the following remarks:-_"Mr St. John mentions the Dotterel as breeding on Ben Clybric,* but by no means numerously. There are specimens in the Dunrobin

\footnotetext{
* Ben Clybric, the highest mountain in Sutherlandshire on the skirts of the parishes of Lairg and Farr. It is of a conical form, and is about 3,200 feet in height.
} 
Museum. Mr Crawford, landlord of Lairg Inn, and at one time a gamekeeper in the district of Ben Clybric and eastward, writes me that they are seen on that mountain, but his informant could never find the nests. The shepherd used to tell him of getting the nests frequently twenty years ago, but he never preserved the eggs."

The late Professor Macgillivray (B. B., vol. iv., 1852) states that "it arrives about the middle of May in the upland tracts of the counties of Forfar, Kincardine, Aberdeen, Banff, and Moray, and resides there until the end of September, when it migrates southwards." $\mathrm{He}$ also gives the names of several observers who had met with the bird in the moors of these counties. The same author relates that on 10th September, 1821, he observed in the parish of Towie, Aberdeenshire, "a very large flock on a low hill, and was assured by a gentleman residing at its foot that they bred on the elevated moors every year;" while thirty years laternamely, on 8th August, 1851-he speaks of seeing a single specimen at Loch Ranza. "I came upon a Dotterel," he writes, "which flew from among the stones, pretending lameness, and hovered around, manifesting great anxiety. I shouted for two of my companions who had advanced, to come and see it, which they did. Although it was evident the bird had a nest and young ones, as it fluttered and limped when chased, we failed in discovering its charge, and therefore left it."

Regarding the occurrence of this bird in the southern counties, Sir William Jardine has lately written to me as follows:- "The Common Dotterel (Ch. morinellus) used to appear regularly in spring and the fall in some moors near this [Jardine Hall, Dumfriesshire], and I have reason to suppose that one or two pairs bred here. I did not discover the locality until too late, and they have left now, but I have specimens shot during their spring visit. The locality is about five miles from this." Sir William has mentioned in his work on British Birds that the chief food of the Dotterel "seems to consist of insects, particularly Coleoptera, many species of which are extremely abundant on the coasts, and come abroad in numbers during the heat of the day"-an observation which I have on several occasions corroborated during their spring migration. No one seems to have recorded what they live upon during the time they are located on our mountain ranges at a great distance from the coast. 
In the western counties, I have been quite unable to trace the occurrence of the Dotterel except as a mere straggler. $\mathrm{Mr}$ Struthers, of Larkhall, has mentioned to me that two specimens were shot some years ago by Mr Graham on the farm of High Possil, near Glasgow, and preserved by a bird-stuffer in that city.

Bearing in mind what has been said on the now comparative scarcity of this bird in its accustomed halting places during its migratory movements, it is not to be expected that the few breeding localities from the heights of Dumfries to Inverness-shire will be otherwise than scantily occupied. I am doubtful, indeed, if more than a dozen pairs are to be found nesting together in any part of Scotland. Passing by the stations said to exist on the Grampians where no recent observations appear to have been made, the northern limits of Perthshire, and the confines of Invernessshire, may be said to be the only breeding localities from which collectors have had really authentic information up to the season of 1870 . In the case of a species which has of late years admittedly become scarce in Scotland, I hope the reader will excuse any reticence on my part with regard to what I know of its present habitats. It would hardly be fair, indeed, to record the precise locality where at most a few pairs return yearly to their breeding places. I shall, therefore, content myself by giving the following quotation from Dr M'Culloch, which includes at least one of the stations, and which I think sufficient almost to prevent the risk of inroad by the most adventurous egg collector or death-dealing naturalist:- "At the southern extremity, Loch Ericht terminates in flat meadows, vanishing by degrees in the river of Rannoch, and in that wild and hideous country which extends to Glen Spean along the eastern side of Ben Nevis. This is, indeed, the wilderness of all Scotland. The wildest wilds of Ross-shire and Sutherlandshire are accessible and lively compared to this; they might, at least, contain people, though they do not, which this tract never could have done, and never will, nor can. I know not where else one can travel for two days without seeing a human trace! a trace, a recollection of animal life, and with the dreary conviction that such a thing is impossible. It is, indeed, an inconceivable solitude; a dreary and joyless land of bogs, a land of desolation and grey darkness, of fogs ever hanging on Auster's drizzly beard - a land of winter, and death, and oblivion." Living in such a country, it is well, perhaps, that Dotterels are not subject 
to any of the ills that beset the genus homo, or we should know still less of their nesting habits at a time when the breeding stations are so sparingly inhabited.

I may here mention that in Mr Dunn's copy of Messrs Baikie and Heddle's Fauna Orcadensis there is the following manuscript note:- "Delete, 'remains during winter, and leaves in spring for more northern regions." The same note states that the Dotterel breeds in the Orkneys.

\section{THE RINGED PLOVER.}

\section{CHARADRIUS HIATICULA.}

Bodhag. Trileachan traighe.

IN its spring plumage, the little "sandy laverock," as this species is called, is perhaps the most pleasing and attractive object to be seen by the naturalist in his shore rambles. Its sprightly movements, and clear contrasting colours, as it runs hurriedly along the smooth golden strand, at once arrest the eye, and few persons fail to discover in this beautiful creature the plaintive piper that had so often in the previous autumn charmed them with its mellow call-note. I have nowhere been more interested with it than in the Outer Hebrides-a district throughout which it abounds at all seasons of the year. Towards evening, in the month of September, when walking along the sandy bays of Benbecula, I have been startled with its cry, even after the sun had gone down and left all in comparative darkness. This note fell upon the ear with a strange effect as the flowing waves came seething up on the dry sand and disturbed the sleeping birds. That part of the coast being but little visited, the little Plovers were exceedingly tame and fearless, allowing me to walk within a few feet of them. Often I imagined that they met me in my walks and alighted in wonderment near their extraordinary visitor. On several occasions, indeed, I observed them halt in their flight, and sit down on the sandy expanse right in front, saluting me with a gentle whistle. But in such places man is not their worst enemy. Writing from Iona, Mr Graham mentions regarding Ringed Plovers that they are regularly hunted and captured by the ermine. "They seem," says Mr Graham, "to be a good deal persecuted by the stoat, whose tiny foot-marks I have frequently observed imprinted on the 
wet sands which these birds frequent both by day and night whenever the tide is out; and when rummaging out a stoat's nest, a number of ringed dotterels' wings are invariably found among the bones, feathers, and other refuse forming the little hunter's spoils of the chase. I have seen the stoat hunting in such localities, and if he happens to be in his ermine dress, he forms a very pretty and interesting object, running backwards and forwards, stealthily but swiftly beating over every inch of the ground, winding in and out among the rocks, turning the corners sharply with a snake-like action of his long elastic backbone, and so intently occupied in his pursuit as to allow you to approach near enough to stop his career for ever."

The largest flocks of Ringed Plovers I have ever seen in Scotland are to be found on the eastern shores of the Mull of Galloway. Many parts of the beach between Sandhead and Drumore are covered with rolled stones, round and polished, each about the size of a bird. On ground of this nature, hundreds, if not thousands, of these birds congregate, forming into flocks greatly exceeding those I have seen elsewhere. The beach is, of course, well-adapted for concealing the birds when assembled; and as it is very unlikely they could have been bred in the neighbourhood, these extraordinary congregations, which never appear until the close of autumn, may be looked upon as migratory flocks on the march.

I have found this beautiful bird breeding on the banks of many of our inland lakes, such as Loch Lomond, Loch Awe, etc., where it occupies promontories spread over with grey stones and round white pebbles of spar to which the plumage of the birds closely assimilates. In these situations, when running away from disturbance or pursuit, along the margins of the lake, they linger or stand perfectly still only on the stony places, and hurry across any green patch of grass, should such come in their way. On sea beaches, the nest is found just a little beyond high-water mark, and is merely a saucer-like hollow, lined occasionally with broken bivalve shells, which, in several instances, I have known to have been carried a yard or two from where they were left by the tide. The eggs are by no means easy to find, as on leaving the nest the old bird runs to some distance from it before telling the intruder of her presence by her remonstrative but mellow pipe.

On very warm evenings in autumn, I have frequently been very 
much interested in watching the Ringed Plovers on the Girvan shore feeding on sandhoppers. The numbers of these brisk little creatures living in the dry sand, and keeping up an animated dance for hours along some miles of the beach between Girvan and Turnberry must have been immense-the line of high-water mark appearing as if covered with a dense smoke. On walking, indeed, into the midst of these countless myriads of jumping crustaceans, the noise is like that of a pelting hail shower. Here the little Plovers soon finish their evening meal, and it is extremely amusing to see them catching their restless prey, and swallowing them hurriedly as they touch the ground. At other times of the day, when there is not a sandhopper to be seen, I have lain concealed behind a rock and noticed the birds running up to a stranded shell of a sea-urchin, which they knew to be full of them, and, by tapping it, warning out the occupants, who jumped through the hole on the top in the most comical state of alarm, scampering sideways and zig-zag, making the hollow shell clatter as the last of them cleared the premises. The bodies of crabs are appropriated in the same way by the sandhoppers, the little cannibals revelling on the remains of a big brother crustacean with as much relish as if it were a stranded cod-fish.

I recollect meeting with a beautiful male of this species one clear morning about day-break on the Dunbar shore under very peculiar circumstances. The frost was intense, and had frozen many of the salt-water pools on the beach. By the side of one of these I saw a fluttering object, on nearing which I found to my surprise a ringed dotterel with its foot in a hair noose attached to three pieces of string united at the two ends by bits of wood-a trap such as boys in country places use for catching small birds. The little Plover had been in some field at a distance and had become entangled; but, being stronger than the usual kind of juvenile game, had drawn out the pegs by which the gin was fastened and carried off the entire device. More at home on his native strand, he had sat down to rest himself, when part of the trap which was in the water had become frozen, and held the poor bird a prisoner. I was glad to release him after thawing his little frozen legs for half-an-hour in my pocket.

The variation in the size of this species has been a source of much perplexity to me. In the spring time, I have shot many specimens so much smaller than the Ringed Plover which breeds 
with us that I have long thought, seeing they only appear in spring, that they must belong to a southern race. I have never yet been able to trace the little Ringed Plover (Ch. minor) in any part of Scotland.

\section{THE SANDERLING.}

\section{CALIDRIS ARENARIA.}

A VERY common shore bird on the west of Scotland, especially on its arrival from its breeding haunts in the north. On the outer islands it is plentiful on the sands at low tide between Benlecula and North Uist towards the end of August, by which time it has completely assumed the winter garb. It is never, so far as I am aware, seen at this season with even the remains of its summer dress - a contrast to the dunlin and turnstone, both of which occur in the same place with Sanderlings, clad in nearly as brilliant plumage as at the height of the breeding season. It is a common species in autumn on the Ayrshire coast, but disappears from these shores after a few weeks' residence. In early spring it returns to our estuaries and salt-water lochs, and has then changed its colour. Stray birds are seen occasionally so late as the beginning of June, but this depends altogether on the state of the season.

Mr Harvie Brown, who has for some years taken notes on the arrival of those birds on the banks of the Forth, informs me that he meets with flocks of Sanderlings about the last week of August mixing with ringed dotterels and dunlins. I have now before me several beautifully marked specimens obtained there by Mr Harvie Brown, to whom I have been much indebted for an opportunity of examining, by dissection and otherwise, a variety of wading birds sent to me in the flesh.

The flesh of this species is well-flavoured, and in some request for table use. The birds, on their arrival in autumn, are loaded with fat, and are then at their best. 


\section{THE GREY PLOVER.}

SQUATAROLA CINEREA.

Fheadag-ghlas.

The Grey Plover is nowhere a common bird with us, and, so far as my observation extends, it is found in greater numbers on the east than on the west coast. It frequents the Firth of Clyde in winter in limited numbers, and has also been observed on the shores of the inner group of islands. In the Outer Hebrides, it occurs but sparingly. I have obtained occasional specimens from Benbecula.

On the eastern shores of Scotland it frequents yearly, in the winter season, the estuary of the Tyne near Dunbar, and the mouth of the Eden near St. Andrews. It is likewise distributed along the rocky parts of the coast, both in Fifeshire and East Lothian, where I have seen from three to five birds in company. I recollect noticing, many winters ago, several grey-backed birds in the large flocks of golden plovers frequenting the Dunbar shore, and mistaking them for this species. Happening, however, to fire into one of these flocks as it rose close to me one morning before daybreak, I was soon undeceived, for on picking up two of the shot birds they turned out to be golden plovers that had previously been wounded and become coated with hoar frost.

Mr Harvie Brown informs me that he has seen as many as four or five of these birds killed in one day on the banks of the Forth near Grangemouth. In November, 1869, and same month in the year following, he observed small flocks repeatedly when out shooting along the coast there, and I have myself watched these birds with great interest when rambling in his company.

I have the pleasure of introducing here a view from the sketch book of my friend, Mr J. R. Prentice, of Howard Place, Edinburgh, in whose company I have frequently travelled in search of the picturesque: the scene represents a wild part of the coast at Whitbury Point, in East Lothian, where I have often met with Grey Plovers; and where many a hapless vessel has been dashed to pieces on the rocks. 


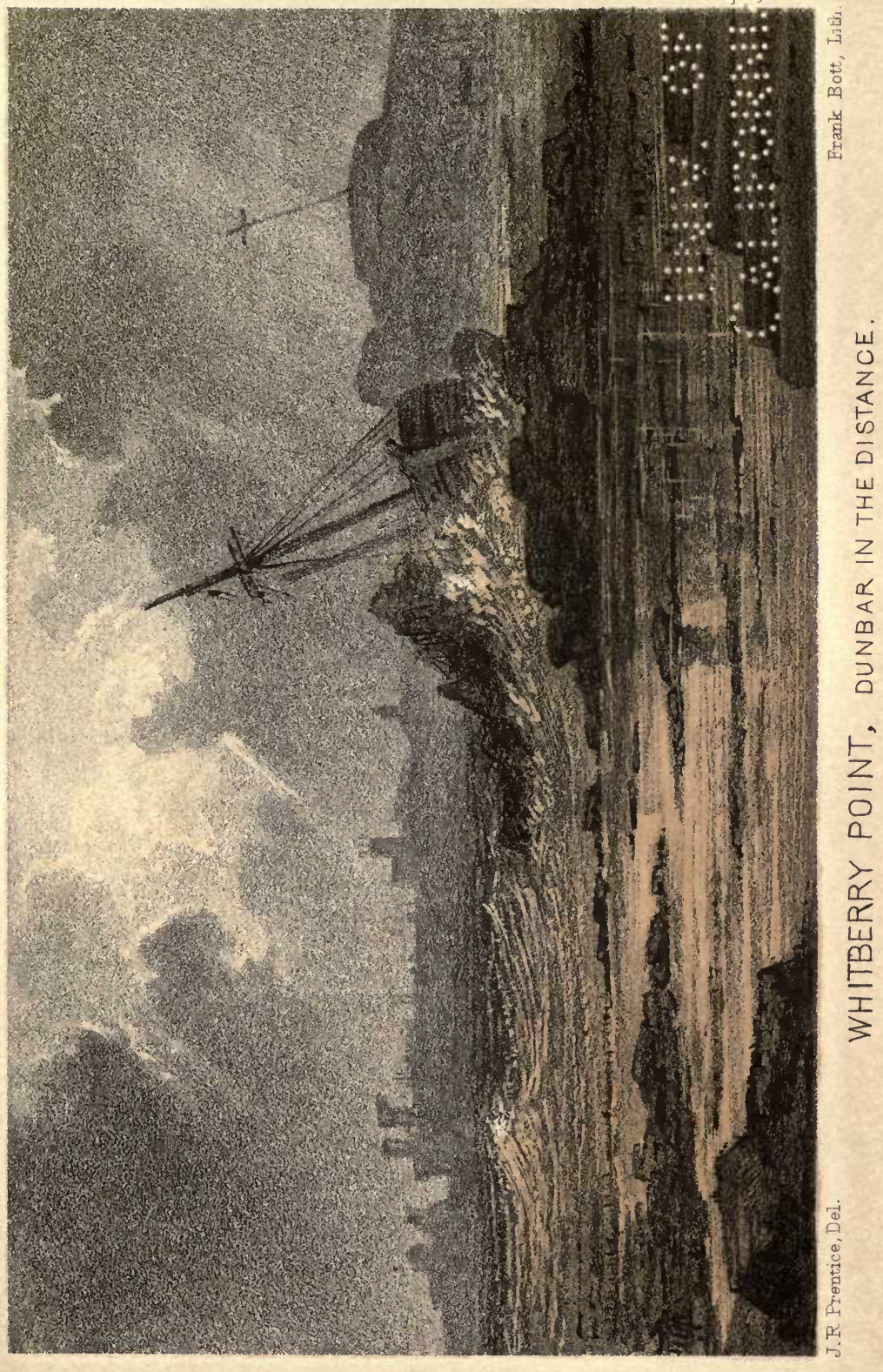





\title{
THE LAPWING OR PEEWIT.
}

\author{
VANELLUS CRISTATUS.
}

Curcag, adharcan-luachrach. Pibhinn.

THIs beautiful bird is very abundant throughout the western counties of Scotland, and, indeed, over the whole of north Britain, with the exception of some parts of Sutherland and Caithness. It is very generally distributed, in the breeding season, on many of the cultivated uplands, and is found, in suitable places, in great numbers, extending to the inner islands, but becoming much scarcer westward of that group. In Iona and Mull, Mr Graham states that it is common at all times of the year, frequenting moors and the sea shore alternately, and breeding on almost all the neighbouring islands, even the very smallest, especially if there is a patch of wet boggy ground somewhere on its surface.

The well-known cry of the Lapwing has rendered it in almost every country district one of the most familiar birds of spring, and has given rise to a variety of names bearing more or less a resemblance to it. Hence the French name dix huit, and the Gaelic one pibhinn (pronounced peeveen); and also the more common names of Peewit and peeseweep, appealing, as they do, to one's recollections of upland country life, and many pleasant sights and sounds with which the summer haunts of the bird are associated.

In the wildest tracts of moorland, the Lapwing is often found breeding at a considerable distance from any homestead or shieling, away in the barren wastes abandoned to Highland sheep and black game. There, in the bare patches that meet the eye-green spots in the midst of the brown and flowerless heath-small companies congregate and occupy their encampments with watchful care. At this season the vigilant creatures are easily alarmed, and become restless and clamorous on the appearance of any object, whether man or dog, keeping up a constant and wailing outcry so long as the cause of their disturbance remains in sight. In some parts of the south of Scotland the Lapwing is on this account looked upon with great dislike, the behaviour of one of these colonies calling to memory the betrayal of persecuted Covenanters, whose movements on the hill side were in constant danger of detection by their enemies being so guided to their places of con- 
cealment. The following original lines, taken from the "poets' corner" of a country newspaper, though somewhat invective in their style, fairly express the feeling still prevalent in the minds of some of the shepherds and others now living near the scenes of by-gone persecution and bloodshed:-

\section{TO THE PEESWEEP.}

Thou idle, ill-conditioned bird, At sight o' men most strangely stirr'd !

Was ever passion as absurd

Yet hatch'd in breast?

Can body g'ye a pleasant word?

Thou waur than beast!

What though ye're ruff' $d$ wi' bonny black, Wi' glancing grey out owre your back, And wame and wings soft linings tak'

The hues o' snaw,-

Your idle, endless, senseless clack, Just mars it a'.

'Tween herds and you there's deadly feud; He breaks your eggs and skails your brood, And-waur than yrudging ye a rood O' skrunty heather-

He'd pook ye bare, frae tail to hood, To the last feather.

He minds what Scotland greets for yet, When helpless Hill Folk, hard beset, Could naewhere but in muirlands get A night's safe quarters, -

Ye brocht the troopers on them het, And made them martyrs.

O sorra on your wicked din, And shame on a' your kith and kin!

And though there's naething 'neath the skin That's fit for pot, Wad ony body ca't a sin To wuss ye shot? 
After the breeding season is over, the young broods gather into very large flocks, frequenting pasture lands in the vicinity of the coast, and repairing to shores and estuaries at low tide. ${ }^{*}$ I have observed such flocks resting in conscious security on rough beaches below water mark near Girvan, and also at Dunbar, where the ground is spread over with numerous pools and wet stones resembling the lights and shadows of the birds' plumage, and making their detection almost impossible to an unpractised eye. An observer may walk up to these sitting birds within shooting distance unaware of their near presence, the company breaking up quite leisurely by flying off in small detachments, and causing him to wonder how so many invisible birds could have been there. Immense numbers of Lapwings are bred in the neighbourhood of Loch Lomond, in which district I have seen the autumn flocks, numbering thousands of birds, collected on the gravelly shores of Inch Moin, one of the islands. The young ones occasionally take to the water voluntarily, or at least on the slightest appearance of danger, even when but a few days old. I have observed them crossing a sheltered bay from one stony promontory to another to join their fellows when they happened to become separated.

In the neighbourhood of Glasgow, a pair or two are still seen in spring revisiting their old haunts. Within the last four or five years they have bred in some fields at Dowanhill, not far from the site of the new University. They are still very numerous on some of the hilly farms in the direction of Eaglesham and Mearns Moor, where their nests are plundered apparently to good advantage, judging from the numbers of eggs sent as luxuries to the Glasgow market There appears to be a strange and unreasonable prejudice against the use of this bird as an article of food in Scotland. Its flesh is certainly not much inferior to that of a golden plover, which is allowed to be of a very delicate nature. The doings of Claverhouse and his troopers may have, to some extent, fostered this prejudice.

I find a very curious note on the destruction of Lapwings by the

* In some seasons, I have observed Lapwings in very large flocks about the middle of July, and in 1869, these flocks had congregated in Ayrshire early in the month. I found, however, on the sandy pastures of Warren Farm, near Turnberry Castle, on the sea coast, several young broods not more than ten days' old, on the 24th July. Most of the Lapwings had commenced laying in April, so that these late broods must be regarded as unusual. 
Rev. James Headrick in his Agricultural View of Forfarshire, published in 1813. Under the heading, "Winged Fauna," in section xi. of this work, he says:- "The green plover, or peeseweep, appears early in spring and goes off in autumn. As they only come north for the purpose of incubation, and are very lean, none of them are liked for food. They return to the fenny districts of England, where they get very fat, and are killed in great numbers. In consequence of the inveteracy excited by the ambitious pretensions of Edward I. to the Scottish crown, an old Scottish Parliament passed an Act ordering all the peeseweeps' nests to be demolished and their eggs to be broken; assigning as a reason, that these birds might not go south and become a delicious repast to our unnatural enemies the English." A similar law, but without any fixed time of enactment, is alluded to in Burt's "Letters from the North of Scotland," and has also been referred to by Bishop Stanley in his "Familiar History of Birds," but I have altogether failed in my endeavours to get any authenticated copy of it entire. Dr Barclay, of Perth, has obligingly aided me in this search, and Professor Cosmo Innes, of Edinburgh-than whom there could, perhaps, be no better authority-has expressed to me his conviction that no such law was ever passed.

\section{THE TURNSTONE.}

\section{STREPSILAS INTERPRES.}

Comyonly distributed over all the Scottish coasts, remaining in some of the western counties until the second week of June, and reappearing in the outer islands about the middle of August. Mr Graham mentions that he has shot the Turnstone in its nuptial dress in Iona in early summer-a few pairs being usually found lingering on the shores of that island till the end of May - and that he also shot the species on the island of Staffa in the end of June. The birds were going in pairs, and were in full summer plumage, from which my correspondent inferred they might have been breeding on the island.

In August, 1867, when travelling in the Outer Hebrides, I observed, for several days in succession, flocks of Turnstones, all clad in their beautiful tortoise-shell dress, frequenting the sound of Benbecula, where they had been seen late in June 
previously; they kept by themselves, even when grouped on the sands beside flocks of dunlins, also in breeding plumage, and formed an agreeable and attractive sight as they wheeled in their flight after rising, and dashed rapidly past within a few feet of where I stood. These flocks are seen every year in the same haunts, and are absent only about five or six weeks. It is difficult to trace their movements after quitting the Hebrides. Professor Newton, in his account of the birds of Iceland, states that they arrive in that country in April and May; Sir John Richardson gives June as the date of their arrival at their breeding quarters on the shores of Hudson's Bay; and Mr Hewitson says that on the coast of Norway they incubate about the middle of that month. But, looking to the lateness of their departure from the Outer Hebrides, and the early date of their return, I incline now to the belief that limited numbers will yet be found nesting on the Haskar rocks, the St. Kilda group, and probably the Monach isles, localities somewhat difficult of access, but well worth the attention of ornithologists desirous of clearing up some features in the history of our shore birds that are at present imperfectly known.

Mr Elwes informs me that the Turnstone is very common in Islay in the winter season-as many as forty or fifty birds being seen in a flock there. Coming nearer the mainland it is found in equal numbers congregated on the shores of many of the islands in the Firth of Clyde. On some parts of Bute it was seen in flocks in the second week of May, 1868, still in the winter plumage; and on the 1st June of the same year a specimen, only slightly marked with red spots, was shot by a correspondent in North Uist, showing a tardiness to complete the summer dress somewhat unusual. Very beautifully marked Turnstones have been shot on a rocky skerry near Ardrossan as late as the middle of May regularly for some years past by Mr Oliver Eaton, bird-stuffer, Kilmarnock, in whose collection I lately saw some very fine specimens. I have often discovered small flocks of this interesting bird on the sandy bays of the shores of East Lothian and Berwickshire beside stranded fish and other dead animals, which I imagined they had managed to turn over with the object of feeding on the sandhoppers and other crustaceans lying in concealment beneath the carcase. I have, however, never seen the birds in the act of undermining or pushing over these objects. I cannot recollect an instance of meeting with the Turnstone away from the beach; but $\mathrm{Mr}$ 
Graham, I find, mentions in his very interesting notes that in very stormy weather he has seen large flocks in Iona feeding in the ploughed fields.

It was suggested by the late Dr Fleming that this species might breed in Shetland, as he had observed it at all seasons of the year; and $I$ find it mentioned in a manuscript note by one of the authors of the Fauna Orcadensis, that it breeds in the Orkney Islands. No authentic record, however, has yet been published of the nest or eggs having been found in either group of islands: it is, indeed, possible that on account of the bird having been seen every month of the year except July, these writers may have been misled.

\section{THE OYSTER-CATCHER.}

\section{HAMATOPUS OSTRALEGUS.}

Gille Brideun.

THIs beautiful and lively bird is a familiar resident in all the outer islands, and is also found throughout the whole year over the shores of the west of Scotland generally, its breeding stations being numerously scattered from north to south. It is likewise found on the Haskar rocks and St. Kilda, in both of which places its nest has been found by Mr John M'Donald, Newton.

The Oyster-Catcher pairs early in the season, and in some parts of Scotland is known to travel long distances inland. When travelling from Perth to Inverness in April, 1870, I observed several pairs on the banks of the Tay evidently mated. Near Dalguise, I saw others frequenting ploughed fields at some distance from the river; and at Ballinluig two or three pairs were observed near a farm steading feeding not more than twenty yards from the pigeons and poultry. On reaching Pitlochry, I found five or six pairs, all apparently mated; and finally, as we passed Blair Athole and proceeded northwards towards Struan, I counted about a dozen more, showing that these birds follow the windings of such a river as the Tay, and take up their summer quarters on its banks at the commencement of the breeding season. About a week afterwards, while travelling along the side of the Spey from Rothes to Abernethy, I took notice of the fact that pairs of this bird were located in the same way on the banks of the river from 
the Moray Firth to the confines of Inverness-shire, where they would almost meet those coming from the Firth of Tay. In like manner these birds ascend the Findhorn as far as its source in the Monadhliadh mountains, and also penetrate to Lochness and Loch Oich, where they are met by others which have entered by the south at Loch Linnhe. The same remark applies to the whole of the Western Coasts, where the many streams and sea-lochs that characterize that side of Scotland attract the Oyster-Catcher and other birds of like habits, and lead them gradually inland, so that during the breeding season they turn up before the tourist almost everywhere.

Towards the end of August the families congregate into large flocks, numbering sometimes a hundred birds or more, when seen feeding together; but when these are disturbed it seems natural to the birds to break up into two or three companies, each having a leader, who appears to guide them when on wing. I have often, indeed, admired the regularity of their flight, and been led to compare their movements with those of a flight of wild geese steering steadily in a straight line, and uttering at times a whistling note of assurance. These flocks are very attractive to the ornithologist, forming a fine variegated line of black and white glancing in the light as it relieves the dark brown of some rocky cliffs, deep blue of the sea, or heavy cloud of neutral tint hanging over the distant horizon.

Mr Graham mentions in his notes that more than once he has seen a whole flock of Oyster-Catchers alight upon the surface of the sea a long way from land. "On these occasions," says Mr Graham, "the water was perfectly smooth and calm, and I supposed them to be attracted by the large shoals of herring-fry which were swimming near the surface. Small fish as well as molluscs form a part of their diet, and the birds that we have occasionally kept in confinement would devour fish greedily." Mr Graham has also seen them frequenting ploughed fields in Iona.

I have many times studied the habits of this shy bird when lying concealed on the shore waiting a shot at passing wild ducks, or other birds I was in quest of. I recollect seeing about thirty in a flock pitch upon a shelving rock from which the waves had just receded and commence an attack upon the limpets, which were very numerous. Being within three or four yards of them, I could distinctly perceive their movements, and could not help being 
struck with their dexterity in overturning the shells, and scooping out their contents. Sometimes a bird would run forward to a limpet and bend down its head sideways, as if in a listening attitude; then it passed to another and another, repeating the scrutiny, apparently to see if the shell was at all raised from the rock, until it found one ready for treatment, which it immediately put in force, by thrusting its thin pointed bill suddenly between the edge of the limpet and its point of attachment, and turning it neatly over. One foot was then placed on the object, and the animal taken out as cleanly as if done with a knife or other sharp instrument. Another favourite feeding ground is some sheltered sandy bay, where a pair or two will often station themselves for a few hours, boring the wet sand for annelids, which I have seen them pull out of their burrows, and carry to the water for a slight rinsing before being swallowed.

GRALLATORES.

GRUIDA.

\section{THE COMMON CRANE.}

\section{GRUS CINEREA.}

Chorra-mhonaidh. (Synonyne for Heron).

THE Crane is one of the rarer birds of Scotland, and has been met with but in two instances in any of the western counties. A young bird, which I have seen and examined, was shot on Dundonnell Estate, near the head of Loch Broom, West Ross-shire, in September, 1869. Another was seen in March, 1870, at Torridon, in the same county, by a keeper, who shot at the bird, but it made its escape. I obtained these particulars in the neighbourhood personally, about a month afterwards. It has, perhaps, occurred more frequently in Orkney and Shetland than elsewhere in Britain. The years $1807,1832-33$, may be mentioned in connection with its appearance. In Mr Dunn's copy of Baikie and Heddle's work, a note in MS. by one of the authors states that a specimen was killed in Shetland in 1848. I examined a very fine bird of this species, which was shot near Hawick, in May, 1863: the specimen is still in the possession of Mr Forrest, gunmaker, Jedburgh.

Dr Saxby mentions that two were shot in Shetland in 1865: one in July by himself; the other at Haroldswick, a few weeks 
previously; and also that he obtained a male in the island of Unst, in the end of May, 1869, where a pair had been seen on the 11th of the same month. One-an immature specimen-was killed on the banks of the Dee, in Aberdeenshire, in the end of May, 1851, by Mr Francis Anderson, and is still in that gentleman's possession. This bird, as I have been informed by Mr Angus, frequented a field contiguous to the river, for several days. It was wounded in the evening about dusk, and in the darkness escaped by flying into a neighbouring wood. It was, however, shot dead next morning, while roosting in a tree. The specimen was preserved by $\mathrm{Mr}$ Mitchell, and shown by him to the late Professor Macgillivray shortly before his death: it was the only example of the species ever seen with flesh by that excellent ornithologist, and is now invested with a somewhat melancholy interest, as being the very last bird he examined.

An old Scots Act, passed in 1551, provides that the price of a Crane shall not exceed five shillings, thus ranking it with the swan in value. No act of the present day would prevent collectors giving, at least, ten times that amount for a British killed specimen.

\section{THE NUMIDIAN CRANE.}

\section{GRUS VIRGO.}

A FINE male bird of this elegant species was shot at Deerness, near Kirkwall, on the 14th May, 1863. Two were seen there for some days, and having attracted the attention of sportsmen in the locality, at once became subjects of close persecution, which resulted in the death of one of the birds. The survivor, not liking this Orcadian welcome, flew off to the adjoining island of Copinshay, and ultimately disappeared. The elegance of their figures and gracefulness of their movements were greatly admiredan enjoyment, however, of brief duration, which the early death of the one and banishment of the other but too soon proved. The specimen procured was in good condition, although the stomach contained nothing but a handful of oats. Both birds were much persecuted during their short stay by the gulls and lapwings, which continually buffeted the poor strangers, in spite of the screams of remonstrance which they were ofttimes heard to utter. Looking, therefore, to their inhospitable reception, both amongst 
birds and bird hunters, we may probably have to wait a few years ere we can again chronicle the demoiselle crane as a straggler to our shores.

The reader will find a well-executed coloured portrait of this beautiful bird in Dr Bree's "Birds of Europe," and also a pleasing account of its habits, taken from M. Nordmann.

The following account of the plumage is taken from $\mathrm{E}$. T. Bennett's "Gardens and Menagerie of the Zoological Society":"The elegant species to which the French Academicians have given the name of demoiselle, is remarkable for the graceful symmetry of its form, the tasteful disposition of its plumage, and the agreeable contrast of its lighter and darker shades of colour. In an upright position, it measures, when fully grown, about three feet six inches to the top of the head; and its length, from the point of the bill to the tip of the tail, is about three feet. Of these measurements the neck and legs form a very considerable proportion. A patch of light grey occupies the whole of the upper surface of the head, the sides of which, together with the neck, including the long slender pointed feathers which depend from its lower part over the breast, are of a uniform, but not very intense shade of black. Every part of the head and neck is fully plumed. Behind each eye there passes off, in a backward direction, a tuft of pure white feathers three or four inches in length. These crests, as they are improperly termed, are extremely light and flexible, and have their bulbs so loose as to float in graceful undulations on the slightest motion of the bird. The rest of the plumage, with the exception of the outer halves of the quill feathers of the wings and tail, is of a uniform slaty grey. The secondary quill feathers are considerably longer than the primary; and, when the wings are folded, form on either side of the body a tuft of dependent plumes, curving downwards towards their extremities. All the quill feathers have their outer halves of a dusty black. The bill is yellowish or flesh coloured; the iris reddish-brown; and the legs and claws approaching to black."

Since the above was written, I have been informed by $\mathrm{Mr} \mathrm{J}$. H. Gurney, Jun., that the Orkney specimen is now in the collection of W. Christy Horsfall, Esq., of Horsforth Low Hall, near Leeds. 


\section{THE COMMON HERON.}

\section{ARDEA CINEREA.}

\section{Chorra-riathach. Chorra-ghlas.}

THIs well-known bird is abundant in all the western counties, and also throughout the Long Island, or Outer Hebrides. It is equally distributed over the inner group of islands where there are several heronries. On the mainland, these interesting nurseries occur at intervals, from the north-west of Sutherland to Wigtownshire. In many of the wilder districts, where trees are either of stunted growth, or entirely absent, the sites selected are very different from those one is accustomed to see in cultivated localities. ${ }^{*} \mathrm{Mr}$

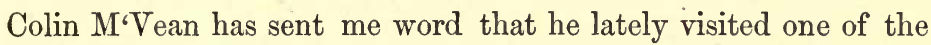
largest heronries he ever saw; it was on the point of Ardnamurchan, where the rocks are tolerably steep, and covered with ivy and shrubs, among which the herons had built their nests. It was an extraordinary sight, when pulling along shore, to find hundreds of young birds sitting on the ledges, and stretching their long necks to look down at the party in the boat. After the families are reared, they appear to keep very much together, flying in company even to distant places on their fishing expeditions. On some of the west country lochs, I have seen, in September, as many as nineteen of these birds together in a group, and Mrs Blackburn, in her beautiful book on "British Birds drawn from Nature," mentions having counted twenty-three herons at once on the shores of Loch Aylort; one of the plates in the work referred to represents a group of eighteen observed at Lochiel side.

According to Pennant, heronries in woods had, in his time, been much more crowded than similar settlements of the present day. One, in particular, deserves mention, as showing how birds will take the fullest advantage of strict protection when it is given them. Writing of Lincolnshire and its ornithology, he thus proceeds:- "But the greatest curiosity in these parts is the vast heronry at Cressi Hall, six miles from Spalding. The Herons resort there in February to repair their nests, settle there in the

* Dr Dewar informs me that a selitary nest was observed on the face of a cliff, in the island of Rum, in 1869. 
spring to breed, and quit the place during winter. They are numerous as rooks, and their nests so crowded together that myself and the company that was with me counted not fewer than eighty in one tree. The family who owned this place was of the same name with these birds, which seems to be the principal inducement for preserving them." Let us hope they were not disciples of Isaac Walton. Each of these nests would contain four or five eggs, so that this remarkable tree would send nearly four hundred feathered poachers into the nearest streams and fish ponds.

Mr Graham has furnished me with a very interesting account of the habits of the Heron as observed by himself in the island of Iona during his residence there, and I have much pleasure in giving the following selection from his letters:-

"Except during the breeding season, the heron is a never wanting accessory to our coast scenery, forming a conspicuous feature in every rocky bay and lonely wave-margined sand-flat, standing immovable watching its own inverted image in the clear pools left by the ebbing tide, or roosting in sluggish attitude on some high bare rock. When fishing in the pools left among rocks, these birds are extremely wary against surprise; but, when wading in open sandy bays, they are much less jealous of a moderately near approach, and a party of six or seven together may then be watched following their employment of fishing. For a while the heron stands motionless, as if he were a bundle of withered sticks cast up by the waves and left stranded in the ooze, when an almost imperceptible motion of the head, a levelling of the bill for aim, and a moment of extreme tension and suspense precedes a lightning dart of head and bill under water, which emerge again holding some small writhing object. This is quickly swallowed by the gaunt grey extended throat, and then the heron shakes his head and bill, gives himself a comfortable shrug all over, steps a little deeper into the receding tide, and again becomes a model of patience and vigilance.

"The gamekeeper at Inverlussa, in the island of Jura, assures me that they make their nests on the ground on the top of a high steep bank, not far from the house. In this place they no doubt feel themselves safe against human enemies; and, as to rats and vermin, they know too much of the heron's sharp eye, and sharper bill, to venture near her nursery. Having no trees to roost ·pon 
when with us, the herons roost on secluded rocky islets, on certain of which, if visited at high water, and approached noiselessly, a party of a dozen or so may sometimes be surprised dozing together under the shelter of a high rock. Standing on one long rigid leg, the other drawn up to the body and concealed among the feathers all puffed up in a great ball, with only the tip of the bill protruding, the party looks like a circle of great grey mops stuck in the ground. When waking to the fact of an intruder, a man with a gun, being in the midst of them, away they go flapping and floundering, with every mark of extreme consternation, but in perfect silence, till, having got some little distance, and fairly on the wing, they come wheeling round to examine the cause of their terror, and then scold him with braying screams for the shock their nerves had sustained. When winged, a heron walks away, cowering down among the inequalities of the rocks, her neck extended horizontally, near to the ground, trying to conceal her tall form as much as possible, her bright yellow eye fixed vigilantly and anxiously upon her adversary. When brought to bay, she defends herself valiantly, lunging out wickedly with her long rapier-like bill, quickly recovering herself again, and putting herself in guard like a master of fence, and uttering all the time such dreadfully discordant outcries that, on one such occasion when picking up a wounded heron near a little fishing village, I was afraid that the women would come out, alarmed that a child was being killed."

Regarding the absence of heronries on the Outer Hebrides, $\mathrm{Mr}$ Elwes has sent me the following remarks:- "This bird, though common at all other times of the year, does not breed, so far as I am aware, in the Long island. I am at a loss to find a reason for this, as the country is in every way very suitable to its habits; and, though there are no trees on which to make its nest, there are many small islets in excluded lochs which, in Ross and Sutherland, are often used as breeding places. In Islay there is a ruined castle on an islet in Loch-a-Gurim, the walls of which, though not more than five or six feet high, have several Herons' nests on them every year; and Thompson, in his Birds of Ireland, gives an account of a heronry on a bare hill-side in the same island. In the Highlands, the Heron is the earliest breeder we have, except the raven and cross-bill, as I have found their young ones hatched by the middle of April. In the south they are nearly a month earlier." 
A wounded Heron will sometimes swim out of reach to evade capture. I recollect shooting one, which fell with a broken wing into a deep weal in the water of Girvan, from which it did not appear very anxious to make its escape. It swam from one end of the pool to the other and back again with surprising vigour-a somewhat unusual and astonishing feat, considering the structure of its paddles. Being on the embankment above the wounded bird, I noticed that it struck out behind with well-timed strokes of its feet, and could readily have escaped had the water been that of a deep loch instead of a river. On landing the bird, and turning it adrift on the banks, it attempted to regain the water, but was immediately assailed by a Scotch terrier I had with me, who ran open-mouthed at the Heron. The attack was instantly met with a defiant look, such as a Heron's eye can assume. The panting terrier stood a second or two irresolute; then, fearing mischief, it suddenly turned round, the wounded bird meanwhile darting its long neck and wedge-shaped bill, and pinning the unfortunate dog with a force both awkward and severe.

I have been nowhere more struck with the figure of this "grey watcher of the waters" than on the time-stained rocks bordering the lakes of the Outer Hebrides. Having been storm-bound in the island of North Uist for nearly a fortnight in the autumn of 1867, I had many opportunities of seeing these watchful creatures "brooding gloomily" on the margins of the salt water creeks near Loch Maddy. On the banks of a nameless lake, which forms the subject of the frontispiece to this volume, I saw one every morning occupying the same stone for twelve successive days. There was no great depth of water at the place, but it was doubtless a lucky perch to the bird and a dangerous rock to many a poor fish.

\section{THE PURPLE HERON.}

\section{ARDEA PURPUREA.}

- A specimen of the Purple Heron, killed in Caithness, is mentioned by the late $\mathrm{Mr}$ Wilson as being in the collection of Mr E. S. Sinclair, surgeon, Wick. This occurrence had previously been published by the Rev. Charles Thomson in his statistical account of that parish, dated March, 1841.

Another example of this rare bird was shot in the parish of 
Monquhitter, Aberdeenshire, in March, 1847, as recorded in Macgillivray's British Birds, on the authority of the Rev. James Smith, who furnished Dr Macgillivray with the full particulars of its capture.

\section{THE GREAT WHITE HERON.}

\section{$A R D E A A L B A$}

In the works of Dr Macgillivray and Mr Yarrell, mention is made of the occurrence of this noble-looking Heron in Haddingtonshire, on 9th June, 1840; and I have been informed by the Earl of Haddington that the bird, which is in magnificent plumage, is still preserved in the collection at Tyninghame House, East Lothian. This appears to be the only instance of the occurrence of this splendid bird on the mainland of Scotland; but I find, on referring to $\mathrm{Mr}$ Dunn's copy of the Historia Naturalis Orcadensis, that one of the authors has stated, in manuscript, that two specimens were met with on the island of Damsay, in Orkney. No other particulars, however, are given.

A full description of the Haddingtonshire specimen, which was mistaken by Macgillivray for a new species, and named by him Erodius Victorice, will be found in Part II. of the 'Manual of British Ornithology' published by that author in 1842; but, in the fourth volume of his larger work, published ten years later, he has withdrawn the name Victorice, and doubtfully referred the specimen to the Egretta Nigrirostris of Bonaparte's "Comparative List," page 47 , No. 329, European species.

Sir William Jardine, in referring to the same specimen, remarks that, during the winter of 1840-41, several "White Herons" were "seen and killed both in England and Scotland which, it is little doubt, were egrets of one species or other." " Notices of these appeared chiefly in the newspapers - the peculiar colour and appearance of the birds having drawn upon them general attention. The season was remarkable for the intensity of the cold. This author also states that, in the same winter, a 'White Heron' was seen several times upon the shores of the Solway, on the English side, above Port Carlisle, and that it may have been identical with the great egret. There is always more or less uncertainty

* Birds of Great Britain and Ireland, vol. iii., 1842, p. 135. 
attending the value of newspaper paragraphs, especially when specimens are only seen. I have myself, on more than one occasion, been told by country people living near estuaries in various parts of Scotland, of large White Herons having made their appearance on the mud-flats at low tide. These of course may have been albinoes of the common heron, or storks, or spoon-bills-the name ' heron' being applied indiscriminately by such informants to any wader above an average size.

\section{THE LITTLE BITTERN.}

\section{BOTAURUS MINUTUS.}

IN the transactions of the Wernerian Society of Edinburgh mention is made of a Little Bittern having been shot in the Tyne estuary in 1836, and exhibited at one of the society's meetings, by Sir Patrick Walker. Since that time no other Scottish specimen had occurred until 1866, one having been caught on board a vessel entering the harbour of Aberdeen, on the 21st of October, as I have been informed by Mr G. Sim of that city. Mr Angus, in referring to this specimen in one of his letters, states that a second Aberdeenshire specimen of this rare British bird was shot by Mr A. Bowie, on the 28th May, 1868, at the junction of the Don and the Ury below Keith Hall, the residence of the Earl of Kintore. "This bird," writes Mr Angus, "which is now in my collection, was in the water when observed, and on being disturbed, alighted on the branch of a tree, along which it ran with great speed. It flew like a grey heron, but with a quicker motion of its wings. The specimen is an adult female, deep in the moult, incubation having almost bared the lowest parts of the feathers. The stomach contained a solitary minnow." A third specimen killed in this county has been notified to me by the same gentleman:- "An immature male was shot on the marsh, near Fintry House, on the 23d September, 1868. Its manner of flight is described as resembling that of a heron; the stomach, which is remarkably large, contained small worms, a stickleback, and the legs of a common frog. The bird was sent by Sir William Forbes, Bart., to Mr Mitchell, for preservation, and has been added to that gentleman's valuable collection." 
In addition to these Aberdeenshire specimens, I am enabled, through the kindness of the Earl of Haddington, to record the occurrence of a very perfect male bird, at Luffness, in East Lothian, on 23d June, 1867. This specimen, which was exhibited at a meeting of the Natural History Society of Glasgow shortly afterwards, is now in the Mellerstain Collection.

Dr Edmonston has noticed the species in Shetland, and it is also mentioned by Messrs Baikie and Heddle, in the Orkney Fauna-one having been shot by Mr Strang, on Sanday, in 1806 .

\section{THE COMMON BITTERN.}

\section{BOTA URUS STELLARIS.}

\section{Ghràineig.}

Is not a common species anywhere, though I have seen examples from almost every county. The Bittern has, once or twice of late years, been killed at Possil Marsh, and also at Hogganfield, both places being within a few miles of Glasgow. It has likewise been shot in Arran, Islay, and Mull, but not, so far as I am aware, on any of the other inner islands, except Skye, on which island one was shot in May, 1867. On the Outer Hebrides it appears to be a rare bird; one was shot in North Uist a few years ago, but I am not able to quote any other authentic instance of the occurrence of the Bittern in the Long island.

In the east of Scotland the distribution of the Bittern extends from Berwick to Caithness - the number of specimens obtained being about equal to that met with in the west.

It is many years since this bird bred in any part of Scotland. In the old statistical account of Galston, in Ayrshire, dated 1792, the Rev. George Smith, then minister of the parish, recorded that a pair of Bitterns had their nest on an island in Bruntwood Loch, near Mauchline, in 1782 , but as the birds made a loud roaring noise, some superstitious people in the district banished them in the belief that their uncommon cries foreboded no good. The chance of banishing rare birds like the Bittern, however, does not now fall to the lot of timid people. The rapid progress made of late years in the cultivation of districts once attractive to birds of 
the waste has operated in a very marked degree against their accustomed visits. Graham, in his "British Georgics," has well expressed the change:-

\footnotetext{
"No more the heath fowl there her nestling brood

Fosters; no more the dreary plover plains;

And when, from frozen regions of the pole,

The wintry bittern to his wonted haunt,

On weary wing, returns, he finds the marsh

Into a joyless stubble ridge transformed,

And mounts again to seek some watery wild."
}

\section{THE AMERICAN BITTERN.}

\section{BOTAURUS LENTIGINOSUS.}

A specimen of this bird was shot in Dumfriesshire near the residence of Sir William Jardine, Bart., in October, 1844. The occurrence of this specimen is noticed in Yarrell's 'British Birds.'

In addition to the subject of this notice, a second was obtained in Aberdeenshire about ten years later, as I have been informed by $\mathrm{Mr}$ Angus, to whom I am indebted for the following particulars. It was shot by Colonel William Fraser in November, 1854, near the toll-bar at the Bridge of Don, on the property of his cousin, H. D. Forbes, Esq., of Balgownie. This gentleman, having often shot the species during his residence in America, at once identified it. The specimen, after being stuffed by Mr Mitchell, was presented to the King's College Museum, but at the union of the universities was afterwards removed to the Aberdeen University Museum, where it now remains. Previous to being skinned, the bird was examined by the late John Longmuir, Esq., whose excellent notes Colonel Fraser has kindly permitted me to make use of here:-

"The American Bittern is easily distinguished from the other two species which have occurred in this country by having the upper parts of a chocolate brown, with brown and grey variegations and a purplish gloss-the under parts of a more yellow hue, with various chestnut and brown streaks on the neck, breast, and belly. The length varies from twenty-three to twenty-seven inchesColonel Fraser's specimen being somewhat more than twenty-four inches. The bird obtained here was a female, and remains of small fishes were found in its stomach. It is found in various parts of North America, extending from a high latitude to the Southern 
States. Whether it extends its range beyond the American continent, except as an occasional straggler in Europe, has not yet been accurately determined. It is naturally of a timid and solitary disposition, frequenting marshy ground and willow thickets. It has a curious habit of standing on one foot for hours with its eye fixed on the sun-a custom which has earned for it among the inhabitants of Lower Louisiana the name of 'Garde soleil.' Though usually sluggish and inert, when wounded its courage is aroused, and with its neck plumage raised, and the feathers of its body ruffled, it defends itself by means of its powerful beak, with which it strikes furiously at its adversary. When seized, it frequently bites and scratches, inflicting, at times, considerable injury. It booms like the common species, nestles in swamps, and lays four greyish green eggs. Colonel Fraser's specimen is in admirable preservation, and forms an addition of great interest to the fauna of Aberdeenshire."

After an interval of eight years, a third specimen of the American Bittern was obtained in Caithness, as I have been informed by Dr Smith, secretary to the Royal Physical Society of Edinburgh. It was shot at Latheron-wheel by F. S. Bently Innes, Esq., of Thrumster, in the autumn of 1862 , and a notice of the occurrence was communicated to that society in April, 1864.

While this sheet was passing through the press, Mr Harvie Brown has drawn my attention to the following paragraph taken from the Field newspaper of 4th March, 1871:-

"American Bittern in Mid-Lothian.-A remarkably fine specimen, killed by John Kinkell, gamekeeper to Charles Cowan, Esq., of Logan House, about ten years ago, near the Compensation Pond in the Pentland Hills, Mid-Lothian, . . . . still forms one of the most interesting ornaments in $\mathrm{Mr}$ Cowan's hall, in a case of rare birds and animals killed on the estate."

\section{THE NIGHT HERON.}

\section{NYCTICORAX GARDENI.}

So far as I am aware, this species has occurred but in one instance in the West of Scotland-a specimen having been shot many years ago within a mile of Kilmarnock, as I have been informed by $\mathrm{Mr}$ Oliver Eaton, bird stuffer in that town. 
With regard to the occurrence of the Night Heron in other parts of Scotland, the reader will find, on referring to the works of Yarrell and Macgillivray, that the former author speaks of two specimens having been obtained north of the Tweed, and that the latter-apparently describing one of these-states that it was shot by the Earl of Home, near Coldstream, in 1823. Sir William Jardine, however, remarks that two birds were obtained by that nobleman, and mentions another in his own collection which was killed on the banks of the Cluden, in Dumfriesshire, in 1825. The late Dr R. D. Thomson, who was for many years resident in Glasgow, and personally known to me, mentions the species as a "rare visitor" in his statistical account of the parish of Eccles, in Berwickshire, but without giving examples of its occurrence. He had no doubt, however, good reason for introducing the species when he drew up the list.

To these instances, all of which are probably of thirty years' standing, I have much pleasure in adding another of recent date, which has been communicated to me by $\mathrm{Mr}$ Angus, of Aberdeen. This specimen, which is in immature plumage, was shot on the 9th January, 1866, at Menie, about eight miles north of Aberdeen. It was seen in the dusk of the evening flying across a pond, and killed by the keeper, who thought "it was an out of the way owl;" and, as such, entitled to a place in his museum, the coach-house door. In this precious repository, it was found suspended by the lower mandible, and attracted the notice of James Buchan, Esq., of Auchmacoy, who obtained possession of it, and sent it to Mr Mitchell, of the Aberdeen Museum, for preservation. The following description of this bird, written by $\mathrm{Mr}$ Angus when it was in the flesh, has been kindly forwarded to me by that gentleman, who expresses himself indebted to Mr Mitchell for an opportunity of identifying the species :-

"Weight of specimen, one pound, fourteen and a half ounces; length, two feet, three inches and a half; extent, three feet, eleven inches; upper mandible, from the gape, four inches and a quarter; wing, from flexure, thirteen inches and a quarter; first primary half an inch shorter than the third, which is the largest of the wing; second and fourth equal. Bare space round the eye, which extends to the beak, greenish yellow. Iris, crimson vermillion; pupil, brownish black. The bill robust and 
of considerable length, with a deep notch near the tip of the upper mandible, which is dark-horn colour above, with three ridges on each side extending to within half an inch of the tip, which is narrow and acute. A stripe of yellow co-extensive with the ridges, and a parallel stripe of dark-horn colour along the cutting edges, which are remarkably sharp, as are also those of the lower mandible, the latter having the corresponding lines of dark and yellow, and being feathered to within half an inch of the point. Nostril straight, widening a little toward the centre, but the aperture is by no means so large as it is represented in Macgillivray's figure, which, being taken from a dried specimen, shows an exaggeration of the orifice. Head bushy; neck behind with soft flowing feathers; crown of the head dark brown, which is the predominating colour on the whole of the upper parts. The larger feathers streaked on each side of the shafts with reddish white; the outer feathers on the shoulder of the wing with diagonal streaks of dirty white. Space between the wings without the spots or streaks. The outer web of the first primary margined with white for three-fourths of its length, and tipped with the same colour; the white on the points of the inner primaries increasing to spots of a triangular shape, and on the secondaries to large round spots. The greater wing coverts also terminate in white spots, which form a straight dotted line when the wing is extended, and an angle when it is closed. Lower parts brownish white, streaked with darker. Tail rounded, dark grey, tinged with reddish-brown. Feet, dirty greenish yellow; toes slender, the fourth the largest, connected by a large membrane; claws bluish, arched, much worn, the middle claw pectinated on the inside. On dissection, the bird proved to be a male. The stomach, which is oblong, contained sand, a quantity of viscous matter, and a perch about six inches long."

Wilson gives a very graphic account of the breeding habits of this Heron, which is very abundant in some parts of North America. This author states that the birds congregate early in April, taking possession of solitary and deeply shaded groves of swamp oak and cedar, and that the best known nurseries have been occupied from time immemorial by as many as one hundred pairs. The nests are described as being built entirely of sticks, in considerable bulky quantities; the eggs, four in number, are of a very pale blue colour. "On entering the swamp in the neighbourhood of 
one of these breeding places," says Wilson, "the noise of the old and the young would almost induce one to suppose that two or three hundred Indians were choking or throttling each other. The instant an intruder is discovered, the whole rise in the air in silence, and remove to the tops of the trees in another part of the woods, while parties of from eight to ten make occasional circuits over the spot to see what is going on. When the young are able, they climb to the highest part of the trees; but, knowing their inability, do not attempt to fly. Though it is probable that these nocturnal birds do not see well during the day, yet their faculty of hearing must be exquisite, as it is almost impossible, with all the precautions one can use, to penetrate near their residence without being discovered. Several species of hawks hover around, making an occasional sweep among the young; and the bald eagle himself has been seen reconnoitring near the spot, probably with the same design."

I am reminded by Mr Angus that Mr Gould (vide "Birds of Europe"), considers Nycticorax Europous to be distinct from Ardea Nycticorax of American authors. "If the difference be specific," writes Mr Angus, "which I much doubt, the specimen killed in this country is the larger bird." On consulting Professor Baird's valuable work on the "Birds of North America" (Philadelphia, 1860), I find it stated, under the head Nyctiardea Gardeni, that "the American Night Heron is similar to the European N. Grisea, but is larger, the bill stouter. The young birds have the quills with an apical white spot not found in the European." If the latter distinction, therefore, holds good, the specimen which my excellent correspondent so carefully describes, is in reality the American bird, and consequently new to Britain, if not to Europe.

\section{THE WHITE STORK.}

CICONIA ALBA.

Chorra-bhàn.

THIs handsome and interesting bird has never, so far as I can learn, appeared in any part of the western mainland.

In the statistical account of the parish of Craig, in Forfarshire, prepared by the late $\mathrm{Mr}$ Thomas Mollison, Montrose, and published 
in 1835 , it is stated that a Stork had been seen a short time previously near that town, and was afterwards shot at Ethie House. Dr Macgillivray, in referring to this specimen, mentions that the occurrence of another in Aberdeenshire in the winter of 1837-38 was communicated to him by the Rev. James Smith, Monquhitter, and likewise describes one in his work that had been shot in Mainland, Shetland, and presented to the University Museum, Edinburgh. In Yarrell's work on British Birds mention is made of two specimens having been obtained in Shetland, and of another Scotch specimen communicated to him by Mr Grant, without, however, specifying either date or locality. Messrs Baikie and Heddle also include the species in their catalogue-a specimen having been killed on South Ronaldshay, Orkney, in 1840.

In addition to these instances, I have to record the occurrence of a very fine specimen which was shot near St. Abb's Head, Berwickshire, in 1848, by a fisherman, who gave it to Mr William Paterson of North Berwick. This bird is still carefully preserved in that gentleman's collection. I saw it shortly after its capture, and have since seen it when visiting Mr Paterson in company with Dr Turnbull, who takes notice of the specimen in his little work on the Birds of East Lothian.

All the foregoing examples had evidently been stragglers, driven to our shores probably by the severity of the weather. Looking, indeed, to the circumstance of the Stork being abundant in Holland and France, and also a well-known visitant in Sweden, and some of the northern parts of Russia, it appears strange that the eastern coasts of Scotland especially are not visited by the species when pursuing its migratory flights to and from these countries. In referring to this peculiarity, Selby speaks of it as "a remarkable instance of the laws which direct the migrations of birds, and confine them within certain limits," probably overlooking the fact that the instincts of the bird may take it where its natural food (consisting chiefly of frogs and other reptiles) is most plentiful. It is said, however, that in some towns in Holland and Flanders the species is of great use in devouring all kinds of garbage that might accumulate and putrify on the streets; and bearing in mind this convenient habit, it might not be an unwelcome invasion were a few hundred Storks to diverge from their line of flight, and pass an hour or two in some of our coast towns and villages. 


\section{THE WHITE SPOONBILL.}

\section{PLATALEA LEUCORODIA.}

IT is not unlikely that the Spoonbill will be found to be an occasional visitant to the western islands. I am informed by Mr H. D. Graham that this bird has been accurately described by several residents on the Outer Hebrides to $\mathrm{Mr}$ Colin $\mathrm{M} \cdot \mathrm{V}$ ean. At Barra, especially, the species has occurred oftener than once; on one occasion five were seen together in a flock. I am unable, however, to say anything from personal observation. The species has also been seen on the east coast, in Tyne estuary;* and has been shot in Shetland, where, however, it is extremely rare.

In October, 1859, a flock of ten was seen flying across the Bay of Kirkwall, in Orkney, by some work people, who soon spread the information, which led to the destruction of half their number. A week afterwards, three more were seen, one of which was killed, thus making the sixth "martyr to the cause of science," as subjects of this kind are now mildly termed. All these specimens were young birds without the crest.

\section{THE GLOSSY IBIS.}

\section{IBIS FALCINELLUS.}

THIs straggler has never, to my knowledge, been met with in the West of Scotland, except in the single instance mentioned by Macgillivray - a specimen having, according to that writer, who saw it, been shot in Ayrshire. No date is given.

On the east coast, one of these birds was shot in September, 1842, in Fifeshire, by Mr Hepburn, who communicated the circumstance to $\mathrm{Mr}$ Yarrell. A third specimen appears to have been obtained near Banchory, in Kincardineshire, on the property of Sir James Burnett, Bart., about the year 1844. This bird, as I have been informed by Mr Angus, was presented to the late Professor Macgillivray, in whose work, however, no particulars are given, although the simple occurrence is noticed.

To these instances may be added the occurrence of an immature

* See Turnbull's Birds of East Lothian, page 43. 
bird, which was shot in a corn-yard, at Balta Sound, Shetland, in October, 1862, and whose demise is recorded by Dr Saxby, in the "Naturalist," for October, 1865. Mr J. H. Dunn informs me that a specimen was shot near Kirkwall, in October, 1857.

GRALLATORES.

SCOLOPACIDA.

\section{THE COMMON CURLEW.}

NUMENIUS ARQUATA.

Guilbneach.

The Curlew is an abundant bird everywhere in suitable localities, extending to all the outer islands; it does not, however, breed, so far as I know, on the moors of that group. In the nesting season, indeed, it is perhaps more numerous in the hilly districts of the southern and western counties below Perthshire and Argyleshire, than elsewhere in Scotland. I have, at various times, wandered over many miles of their moorland solitudes, where the only other bird within hearing was the familiar meadow pipit, whose feeble note served but to deepen the impression produced by the wild cry of the Curlew. This call is most bewildering when the watchful male birds are disturbed on the hill-side at the time the females are on their nests. One after another rises from the brown heath, till the seemingly lifeless moor rings with their pertinacious outcries. Soon the alarm spreads, and, away in the distance, these wary creatures, scarcely seen against the grey side of the mountain, rise into the air above their mates, hovering uneasily until the cause of the disturbance disappears. Then as the traveller gets to a distance, just out of their sight, they settle beside them again with a strange musical utterance of satisfaction-a long gurgling and quavering note, exceedingly wild, yet not unpleasing, when we think of the faithful bird assuring his mate that all danger is past. When the young are hatched, the note of the curlew is even more vociferous, as both birds then join in these wailing remonstrances. I have often caught the chicks when about two or three days' old; they squat so close to the ground that it is nearly impossible to find them among rough heath; but, on a bare spot, a practised eye may discover the little puff-balls cowering to avoid capture. When taken up, however, and set down again, they become quite 
regardless, standing high on their ungainly legs, and looking about with apparent surprise and wonderment.

Besides breeding on the higher ranges of mountains, the Curlew nests on islands in fresh water lakes, especially in places which are solitary and undisturbed. I have repeatedly found its nest on Inch Moin, a low flat island in Loch Lomond, which is not more than twenty or thirty feet above the sea level. Mr Elwes informs me that it does not breed in Islay, though it is found there in great numbers during most of the year.

From Mr Harvie Brown's journals, I learn that in Sutherlandshire, where the Curlew is local, though common in the districts it frequents, four eggs are almost invariably found in the nest, three being the usual number taken in nests throughout the midland and southern counties. In one nest in Sutherlandshire, a shepherd took as many as five eggs, which are now in $\mathrm{Mr}$ Harvie Brown's collection.

\section{THE WHIMBREL.}

\section{NUMENIUS PHEOPUS.}

Eun-bealltuin.

THIs species is known to breed in various parts of Scotland; perhaps more numerously in Orkney and Shetland than elsewhere. In the outer islands, it is found in considerable numbers throughout the month of May, in Benbecula and North Uist, from both of which localities I have obtained specimens now in my collection. In these islands it is known, as in other parts of Britain, by the name of May bird-the bulk of the migratory flocks moving onwards during that month to higher latitudes. Some of my Hebridean correspondents tell me that the Whimbrel comes regularly about the first of the month; at first only a few are seen, but as the season progresses the flocks become very large.* They are then seen daily feeding on the pasture lands near the sea, chiefly on the west side of Benbecula and North Uist. These pastures, as I have myself observed, are covered with a small land shell (Helix ericetorum), which is so abundant that I have

* Captain Feilden informs me, that he saw a flock of fifty Whimbrels in the Sound of Wiay, on the $3 \mathrm{~d}$ June, 1870. 


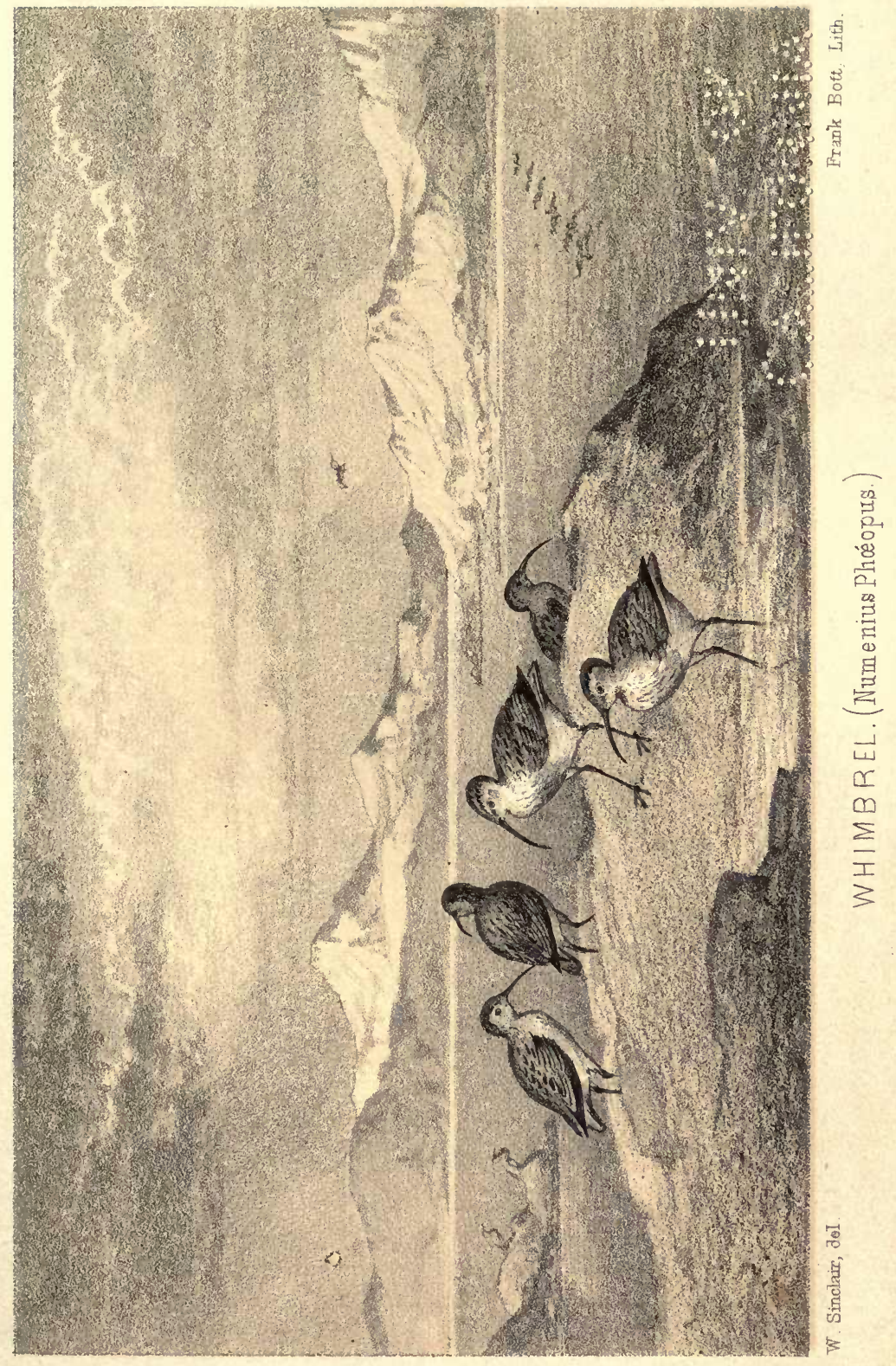



gathered hundreds in a few minutes, and this shell constitutes the chief food of the Whimbrel during its stay on the islands, extending over a period of three or four weeks-sometimes longer, as I have procured birds that were killed in June. The flocks, as a rule, depart after their temporary sojourn about the last of the month, and do not return, except as very rare stragglers, until the first of May following. Writing from Iona, Mr Graham states that the Whimbrel only visits that island in May, arriving in very large flocks about the first, and remaining until the very last of the month, after which they entirely disappear, and are seen no more for the rest of the year, except as single stragglers. They are then very tame and unsuspicious. My friend thus describes its arrival:- "When the wintry storms have at last done roaring, and the sea has subsided into peaceful calm, when the air is genial, and the sky is blue, then the unusual and peculiar cry of the Whimbrel announces the fact that summer is nigh. Its call consists of several rapidly repeated, short and clear whistles, uttered about seven times in rapid succession; whence its name of seven whistler has been derived. This cry is heard as the flocks are flying to and fro high in the air, before alighting on the grasscovered sandy levels which skirt a considerable portion of the shores of Iona, and are at this time of the year enamelled with wild hyacinths, purple orchis, and other wild flowers. Here a flock of some fifty of these long-legged birds, scattered over the bright green turf, forms a very alluring sight, and their comparative heedlessness makes them an easy prey to one accustomed to circumvent the timid and cunning curlew. They do not touch here on their autumnal migration."

The total absence of these birds in many of the outer islands, at a time when one would expect to see them on their return, has been a frequent subject of remark. On the island of Islay, however, as I have been informed by Mr Elwes, they are found in flocks about Loch Indall during the winter and spring, which shows that a few, at least, come south by the same route. I have seen one or two stray Whimbrels in the Clyde estuary early in August, along with small troops of dunlins, back at that season from their breeding haunts on the moors.

The plate represents a small group of these birds at one of their well-known haunts in the Sound of Harris-the view including the islands of Pabbay and Berneray in the distance. 


\section{ESQUIMAUX CURLEW.}

\section{NUMENIUS BOREALIS.}

ONLY one specimen of this rare bird has, as yet, been detected in Scotland; it was shot at Durris, near Aberdeen, on 6th September, 1855, by $\mathrm{Mr}$ R. Cusack Smith, Esq., and preserved by $\mathrm{Mr}$ Mitchell, of Aberdeen, who has sent me word that it was in fine plumage, and in excellent condition. Mr Angus informs me that the species was identified by the late Mr J. Longmuir, who wrote to Mr Yarrell informing him of its occurrence. No other example of this species appears to have been since obtained in any part of the British islands.

\section{THE SPOTTED REDSHANK.}

\section{TOTANUS FUSCUS.}

HAS not yet been traced to any of the western districts, but on the east coast of Scotland it has frequently been obtained in localities ranging from Haddingtonshire to Caithness. It has been taken in Banffshire by $\mathrm{Mr}$ Edward, and in Aberdeenshire by $\mathrm{Mr}$ Angus, who has obligingly supplied me with the following notes:- " An immature specimen was shot on the Old Town Links on the 19th September, 1867, and presented to Mr Mitchell, to whom I am indebted for the opportunity of making a description of the bird, which I now give you in a condensed form. Basal half of the lower mandible, light orange, dusky towards the point: on each side of the mandible, a distinct groove, which is co-extensive with the orange colour; legs and feet, orange; claws, black. Iris, hazel; crown of the head, greyish brown, and slightly spotted. Lores, dark brown, a white line extending from behind the eye to the base of the upper mandible; chin, whitish. Belly, vent, and under tail coverts, dirty white, barred with dusky - the bars more distinct on the vent and under tail coverts. The feathers on the breast resembling those of the common gull in its first plumage. The first quill the longest of the wing, having the shaft white; the primaries, as also the scapulars and the space between the shoulders, purplish; the smaller wing feathers, whitish, and lightest on the edges. Space between the wings, white. Tail beautifully barred 
with white, each feather having sixteen bars; the middle feathers rather the longest. Tibial feathers long and downy. The stomach contained the remains of small crustacea, and I found a small fish in the gullet."

In the Orkneys, as I find from a manuscript note in Messrs Baikie and Heddle's work, "one was shot by Mr Strang in Sanday, in September, 1849."

\section{THE COMMON REDSHANK.}

TOTANUS CALIDRIS.

Cam-glas. Clabhais feach.

A very abundant species. It breeds plentifully in many inland districts of the West of Scotland, usually at a considerable distance from the sea, and sometimes in marshy places as much as a thousand or twelve hundred feet above the sea level. I have found its nest on the higher grounds of Renfrewshire within ten miles of Glasgow. It also breeds at Ardlamont, in Argyleshire, from which locality several specimens of both sexes, in summer plumage, as well as young birds a few days old, have been obligingly obtained for me by Mr J. Gilmour of Glasgow. On the banks of Loch Lomond about fifteen or twenty pairs annually take up their summer quarters in a grass park on the farm of Mid-Ross, where I have seen their nests. In this locality the birds generally select a tuft of ragweed, or other plant, under the shade of which the eggs are deposited without much preparation in the way of nestmaking - the few straws on which they are placed looking more like an accidental lining than one designed by the owners. These nests are exceedingly difficult to find. In very dry seasons, when the loch is low, the Redshanks sometimes choose the line of highwater mark for a breeding place, the nests, if they may be called so, being placed on the mass of sticks and straws which are blown on shore by the wind, and huddled together by the action of the little waves. On the east coast of Scotland, I have obtained the eggs of the Redshank in Forfarshire and Aberdeenshire.

The habits of this vigilant and noisy shore bird have been so often described, that it is hardly necessary to repeat them here. Every sportsman accustomed to shore shooting knows the impossibility of stalking either geese or wild ducks, should there happen 
to be a Redshank in the way. The moment the troublesome fellow catches a glimpse of an intruder, he is up in the air uttering his shrill warning cry, which he persistently keeps up until every bird within hearing has taken the friendly hint and decamped. Frequently have I banged at these tell-tales, out of pure revenge, in my early shooting experiences. On one occasion, having fired at the leader of a flock passing me, the bird dropped into deep water, and, to my surprise, was immediately surrounded by his companions, who, with piercing outcries, hovered within a few inches of his head, as if trying to get him lifted from the sea. What they might have done it is now impossible to say-the fluttering crowd proving such a temptation as to cause me to discharge the other barrel into the midst of them. My perch had been a slippery one, for without a moment's warning, I went down head foremost into the heaving waves, and my exertions to recover the gun, after coming to the surface myself, were too arduous to admit of any further bird observations for that day.

During my shore rambles at Dunbar in the winter of 1846 , my attention was repeatedly attracted by the movements of a pair of Redshanks, which I observed every morning flying together about the same part of the coast. I noticed that when they alighted anywhere, one remained sitting on a stone while the other foraged among the surrounding pools for small marine animals, which it carried to the stone. Seeing these movements so often repeated, I was naturally curious to know why the two kept so constantly together, and why the one always remained still while the other was running about; but, on examining both birds after they were shot, I found, to my great sorrow, that the sitting bird-a female -plump and fat as it was, had only one mandible - the lower one having been, apparently a considerable time before, completely shot away. Thus the faithful mate of the previous summer had ministered to the wants of his unfortunate companion. I have never shot a Redshank since. 


\section{THE GREEN SANDPIPER.}

\section{TOTANUS OCHROPUS.}

WITH the exception of a single specimen shot on 10th November, 1868, on the Pollok estate, near Glasgow, and another seen in its company by Mr W. Cox, keeper there, this beautiful species has never, so far as I am aware, occurred on any part of the western mainland, or its island dependencies. From north to south, however, in the eastern counties, various specimens have been obtained. It is mentioned in Mr Sinclair's Caithness catalogue, and has been found in East Lothian on the banks of the Tyne and other streams by Dr Turnbull. In Dumfriesshire, the earliest record of its occurrence is in 1829, by Mr Selby; and Sir William Jardine informs me that he has frequently procured it in the same county since 1836. I have likewise been informed by Mr W. Smellie Watson, of Edinburgh, that he has shot this species near Carlinwark House, Castle-Douglas, and Mr Harvie Brown sent me a fine specimen in the flesh which he shot on the banks of the Carron, in Stirlingshire, in the last week of August, 1870.

Mr Angus, of Aberdeen, has obligingly furnished me with the following notes on this species:- "The Green Sandpiper has frequently been found in the county of Aberdeen. A beautiful specimen came under my observation lately; it was shot by a lad named Smith on the old Town Links, on the 12th September, 1867, and sold to Mr Mitchell, of the Museum. I believe that this species occasionally breeds in Aberdeenshire. A male and female were killed by the side of a hill burn in July, 1865, and preserved by Mr William Beveridge, of Craigh-a gentleman well known for his talent in stuffing game birds. I have also undoubted evidence of its occurrence in summer in other parts of the county."

As naturalists hitherto have had but an imperfect knowledge of the nidification of this bird, the following quotation from "Ten Years in Sweden," by Mr Wheelwright, better known as "the old bushman," may not be considered out of place:"Although it is easy enough to know whereabout the bird is breeding, a man may look till doomsday for the eggs if he followed the stereotyped description of, I believe, all our naturalists, and sought for the nest where they tell us, 'in sand, on a bank, or among grass by the side of a stream.' The fact is, I don't believe 
any naturalist had seen the really authentic eggs of this bird until I discovered its breeding haunts some years since. In Sweden, the Green Sandpiper never makes a nest upon the ground like the rest of its congeners, but invariably lays four pyriform large eggs of a very light colour, spotted all over sparingly towards the small end (at the top the spots are much larger, darker, and crowded together), with two shades of purple, and amber brown-in an old nest of a squirrel, jay, or crow. I once, however, saw them in a new common thrush's nest in the forest, often far from the water, always in a fir tree, sometimes forty feet from the ground."

A very interesting paper by Professor Newton on the nidification of this species will be found in the proceedings of the Zoological Society, 8th December, 1863.

\section{THE WOOD SANDPIPER.}

\section{TOTANUS GLAREOLA.}

THE only specimen of this Sandpiper which I have seen on the west coast is one in my own collection; it was shot on the Renfrewshire banks of the Clyde, opposite Bowling, in the autumn of 1853 .

In the eastern counties it has occurred several times. The late Mr Sinclair, surgeon, Wick, had one in his collection, which was procured in Caithness many years ago, and I have been informed by $\mathrm{Mr}$ Angus that a specimen was shot near Aberdeen, on 1st September, 1866. I have had an opportunity of seeing this bird, and also another Aberdeenshire specimen, which was shown to me when in Aberdeen, in May, 1869, by Mr G. Sim, bird-stuffer, King Street. Mr Sim stated that it was shot by himself, on 8th July, 1867.

Mr A. G. More has recorded in the Ibis, that a nest of the Wood Sandpiper was taken near Elgin, in Morayshire, the eggs of which are in the possession of $\mathrm{Mr} \mathrm{F}$. Bond. In addition to these examples, I may mention that I have recently been informed by $\mathrm{Dr}$ J. A. Smith, of Edinburgh, that a specimen was shot near the village of Heriot, Mid-Lothian, on 14th August, 1856, by Richard Bell, Esq., who sent him the bird for exhibition, at a meeting of the Royal Physical Society. The stomach of this bird, 
which was a male, was filled with the remains of insects (Gyrinus, Hydroporus, Donacia micans, Colymbetes Sturmii, etc).

There can be no doubt that future observant naturalists will yet find the Wood Sandpiper occurring in limited numbers on our shores.

\section{THE GREEN-RUMP TATLER, OR SOLITARY SANDPIPER.}

\section{TOTANUS CHLOROPYGIUS. (VIEILLOT).}

A SINGLE specimen of this bird having been obtained in Lanarkshire, I have ventured to give the species a place in the present work, believing that as the numbers of ornithological observers increase, it may yet be found to make occasional visits to this country. Though nowhere numerous, it is widely diffused throughout the temperate regions of North America; being the well-known solitary Sandpiper described by Wilson, Audubon, and other authors. The following description of the bird's habits is taken from the third volume of Audubon's 'Ornithological Biography': — "The flight of the solitary Sandpiper is swift and protracted. It moves in a zig-zag manner, and at times makes its way through the woods with surprising ease, seldom leaving the starting place without uttering a clear and pleasant tweet. In realighting, it pitches downwards, like the common snipe. On the ground they are very active, and at times so indifferent to the approach of man, that they will merely fly across, or around a small pond for a considerable time, and if shot at and not touched, they will be sure to be found in the same place a few hours after. Its alighting on trees has often appeared to me as singular as that of Bartram's snipe and the semipalmated species. The solitary snipe is, however, the most expert at catching insects on the wing, especially the smaller kinds of dragon flies, which it chases from the sticks on which they alight, and generally seizes before they have flown across the little ponds, which are the favourite place of resort of this species. I have found their stomachs filled with aquatic insects, caterpillers of various kinds, and black spiders of considerable size." The same author found a single nest of this bird in the woods near Bayou Sara, by the side of a small pond; it was carelessly formed of grass and withered leaves, and contained three eggs. 
Wilson, on the other hand, who gives a brief, though vivid account, of the habits of the species, states that after many long and close searches, he was never able to discover the nest. He also remarks that it breeds regularly in Pennyslvania - a tract of country in which it was afterwards found nesting, on the gravelly banks of rivers, by Sir John Richardson.

The only specimen of this Sandpiper that has yet occurred, so far as I am aware, in Britain, was shot some years ago, by the late William Gordon of Airdrie, somewhere on the banks of the Clyde, on the higher grounds of Lanarkshire. This bird remained in $\mathrm{Mr}$ Gordon's hands until his death, in August, 1869, when his collection was brought to Glasgow, and submitted to me about a month afterwards. The owner of the collection had often referred to the specimen as one which he could not make out, but had never shown it to any one qualified to give an opinion; and as he left no notes attached to any of the specimens, the exact date of its occurrence, with other particulars which might have been of interest, cannot now be ascertained.

The two British species which this bird most resembles are the green sandpiper and the wood sandpiper. It differs from both in having the two central tail feathers of the same hue as the dorsal plumage. Compared with $T$. ochropus, it may be said to be smaller, besides having the upper tail coverts greenish brown instead of white; and contrasted with $T$. glareola, it wants the white shaft of the first quill which distinguishes that species.

\section{THE COMMON SANDPIPER.}

\section{TOTANUS HYPOLEUCOS.}

THis elegant little summer visitant is everywhere common, penetrating to the Outer Hebrides, where a few pairs are seen frequenting the streams of Harris, and also the moorland lochs of Lewis, and other districts lying to the south. On the inner islands it is likewise a well-known object, as it skims the surface of the quiet lochs with arched and almost motionless wings, or stands on some isolated stone, vibrating its body as it salutes the rambling intruder on its haunts. I have seen it in the islands of Rum, Mull, Canna, Tyree, Eigg, Colonsay, Iona, Islay, and Jura, restlessly flitting along their shores, and uttering, when several are on wing 
together, a series of shrill, though not unpleasant, pipings, which on calm and sultry days are indeed the only bird voices to be heard. Throughout the western Highlands, it is known by the name of the "little fiddler," and is always welcomed by the natives as a glad messenger from the sunny south. In some places it is called killileepie - a name evidently derived from its oft-repeated cry.

On the mainland it is still more common, being found on the banks of every stream and inland loch from Sutherland to Wigtown. It breeds in considerable numbers on the sandy and pebbly margins of Loch Lomond, from which it frequently ascends the mountain streams, and encamps on their banks at an elevation of twelve or fourteen hundred feet above the level of the loch. In spring time small parties are seen following the course of the river Clyde from the sea to the Upper Ward of Lanarkshire, where numerous pairs take up their summer quarters. I have seen it occasionally in gardens and orchards on the banks of the Clyde near the town of Lanark, forming its nest under bushes in flower plots and among growing plants. Mr Alston informs me of having taken similar notes on its nesting habits near Lesmahagow; but in such cases it is invariably found in the immediate vicinity of water. Frequently I have seen pairs select a turnip field contiguous to the water of Girvan, and lay their eggs under the leaves of the growing plants -a habit acquired from experience of previous floods which had for one or two seasons in succession swept away their nests from the banks of shingle on which most persons, as well as birds, would have thought them safe against such a mishap. The fact of these Sandpipers transferring their nursery to the fields on the other side of the embankment, and persistently remaining in their new quarters, shows that the same pairs frequented the river on their return to this country, and had a wise recollection of their bygone misfortunes. On the banks of Loch Eck in Argyleshire, I have seen this bird in early summer flying among the big grey boulders on the mountain side at some distance from the water, and alighting at times among the rank heather, as if their nests or young were there. In the immediate neighbourhood of Glasgow it also appears regularly in spring in places surrounded with buildings, but is generally found by the side of rain pools or old quarries, where it seems as much at home as when skimming the clearest loch or river, crossing and re-crossing the stagnant water, 
and whistling all the while to its own shadow, when there is light enough in the sky overhead to make it visible.

In the summer of 1867 , when walking one day in company with Mr Sinclair, along the public road skirting the shore near Inverkip in Renfrewshire, I was arrested by the movements of a Sandpiper as it rose from the beach and flew high into the air above the adjoining wood, where it made several wide circles, uttering during its flight a constant outcry varied by an occasional long-drawn note. It was watched for some minutes by $\mathrm{Mr}$ Sinclair and myself, until it disappeared on the other side of the wood. On the following day we again saw the bird at the same place, but on this occasion it rose from the wood, and not from the beach. It then repeated its flight as before, above the trees, and finally perched on one of the top branches of a Scotch fir about twenty feet from the ground. The wood was, unfortunately, strictly protected, and we were consequently obliged to continue our observations from the road. We both distinctly saw the bird descend to a lower perch, and run along the horizontal branch to its extremity, where it disappeared among the green tufts. This bird appeared to be somewhat larger than the Common Sandpiper, and its note was louder-differences which certainly suggest the possibility of its having been a green sandpiper. We both regarded our exclusion from the wood as a great drawback, as a close scrutiny might have at least enabled us to find out whether there was an old nest in the tree which the sandpiper had appropriated. There have been no sandpipers in the wood since that year, but measures have now been taken to institute an effective search should the perching bird again make its appearance.

In several instances I have taken the nest of this Sandpiper in grass fields near Loch Lomond, where several pairs of redshanks were also found breeding. The nests were always placed beside a tuft of growing plants, and frequently had a most picturesque appearance when the plants were in flower. 


\section{THE SPOTTED SANDPIPER.}

\section{TOTANUS MACULARIUS.}

THE only authentic instance of this rare bird having been found in Scotland was lately communicated to me by my obliging correspondent, $\mathrm{Mr}$ Angus, of Aberdeen, who states that two specimens - a male and a female-were left at the Aberdeen Museum in August, 1867, in the absence of Mr Mitchell, who up to the present moment does not know by whom the birds were presented, or where they were shot. Both were in the flesh, and had not been long dead: they were very prettily marked and somewhat dissimilar in size-the male being the larger. The female is now in Mr Angus' cabinet; the other specimen has been kindly presented to me by Mr Mitchell, and is now in my own collection.

This species has been catalogued as a Caithness bird by $\mathrm{Mr}$ Sinclair, of Wick, but no information is given as to the locality or time of capture.* It is likewise in a Forfarshire list of birds, drawn up by Mr Mollison, of Montrose, for the statistical account of the parish of Craig in that county; but, in this case, a mistake may have been committed.

According to Audubon, who writes in a very interesting manner of its habits from his own observation and that of his friends, the Spotted Sandpiper, like its congener, often traces the streams some distance into the interior, and betakes itself during the summer months to gardens, and other enclosures near dwellinghouses. It differs, however, from the common bird in the construction of its nest, which is bulky, and raised from the ground to the height of from six to nine inches. The structure is well finished, and lined with slender grasses and Eider duck's feathers. Wilson also mentions its habit of resorting to cornfields to breed. A nest found by him consisted "wholly of short pieces of dry straw." The following incident is related by that agreeable writer in his account of the species:- "My venerable friend, Mr William Bartram, informs me that he saw one of these birds defend her young for a considerable time from the repeated attacks of a ground squirrel. The scene of action was on the

* I have since learned from J. H. Gurney, Jun., that Mr Sinclair had mistaken some other bird for the Spotted Sandpiper. 
river shore. The parent had thrown herself, with her two young behind her, between them and the land; and, at every attempt of the squirrel to seize them by a circuitous sweep, raised both her wings in an almost perpendicular position, assuming the most formidable appearance she was capable of, and rushed forward on the squirrel, who, intimidated by her boldness and manner, instantly retreated; but presently returning, was met as before, in front and on flank, by the daring and affectionate bird, who, with her wings and whole plumage bristling up, seemed swelled to twice her usual size. The young crowded together behind her, apparently sensible of their perilous position, moving backwards and forwards as she advanced or retreated. This interesting scene lasted for at least ten minutes; the strength of the poor parent began evidently to flag, and the attacks of the squirrel became more daring and frequent, when my good friend, like one of those celestial agents who, in Homer's time, so often decided the palm of victory, stepped forward from his retreat, drove the assailant back to his hole, and rescued the innocent from destruction."

\section{THE GREENSHANK.}

\section{TOTANUS GLOTTIS.}

Deoch Bhingh.

THIs handsome wader, which is a bird of wide distribution, may be said to be somewhat common throughout the western counties, and is in some districts permanently resident both on the outer islands and on the mainland. During winter I have met with it in small flocks, but more frequently stray birds, in suitable localities, ranging from the Mull of Galloway to Cape Wrath. When the breeding season is past, the old birds, with their families, appear to shift southwards, but are replaced by others, probably from more northern latitudes; the number bred in this country being comparatively small. Even at that time of the year, the Greenshank is often found at some distance from the coast, frequenting the shingly banks of rivers and smaller streams, and also inland lochs and mill-dams. Four beautiful specimens are now before me: two of these were shot in the bed of the Girvan water, by Dr Anderson; the others were killed beside a large dam of water, 
on Mearns moor, within eight miles of Glasgow. These last mentioned birds had probably been arrested in their migratory flight, as they are frequently seen there again in spring, about the time of their return journey. Last year (1870) I was surprised to see one rise from the neighbourhood of one of the water dams, while I was looking for dunlins' nests; it appeared to be alone, but it persisted in circling round my head, making all the while a chiding outcry, as if its mate had been sitting. A pair of redshanks had their nest on the spot, and one of the birds joined the Greenshank in its clamorous lament at the intrusion. I have also observed the Greenshank in pairs frequenting the river Cart, near Paisley, from the 14th of April till the end of the month. It is therefore possible that Mearns moor, which is not more than four miles from the Cart, may be a breeding station.

I have the eggs of this bird from Sutherlandshire and Argyleshire. A few pairs breed near the Black Mount, in the latter county. There are also four or five other breeding stations in the western counties, occupied by at most eight or ten pairs. In the Inner Hebrides, the Greenshank is not uncommon in Islay and Jura, especially about Loch Indall, and the shores of some fresh water lakes. I have, however, hitherto failed to discover any breeding station on either of these islands. There is one near Sligachan, in Skye, frequented by two or three pairs; while, in the outer group, Lewis and Harris may be said to be the only localities where eggs have of late years been actually taken.

Three male specimens of this bird were shot by Audubon on Sand Key, in Florida, on 28th May, 1832, and the species has therefore been allowed a place in the avi-fauna of North America. The late Prince Lucien Bonaparte, in the belief that this single specimen, which has been preserved, differed in some particulars from the common European species, named it Glottis Floridanusa name which it now retains in the works of American authors. Professor Baird, who has described Audubon's specimen, states that it appears to be "smaller in all its parts" than any of the numerous specimens from the Old World in the museum of the Philadelphia Academy. At the same time it is but right to say that he acknowledges his hesitation in admitting its specific distinction. Not having seen the bird, of course I cannot judge as to its appearance; but, from the description, minute and accurate as it is, both as to coloration and measurements, I would certainly 
infer that it is but a small specimen of the Greenshank of this country. As far as my observations have extended-and I have examined upwards of fifty specimens-the adult Greenshank is subject to great variation in size, whether we take into account the bill, wings, or tarsi; so that, on this ground alone, $\mathrm{Mr}$ Audubon's specimen has been invested with an importance to which it was clearly never entitled. It is certainly not a little remarkable that no other American specimen has yet turned up.

\section{THE AVOCET.}

\section{RECURVIROSTRA A VOCETTA.}

Not found on the west coast. Dr Edmonston has mentioned that it is an occasional visitant in Orkney; and I have been informed by Professor Dickie of Aberdeen that a specimen was shot on the Old Links near that city in 1841 by Mr Mitchell, who presented the bird to the late Dr Fleming.* Of late years the only specimen that has occurred to my knowledge is one that was shot on the sands of Kirkcaldy in Fifeshire, by Mr John Wilson of that town, in the second week of August, 1862. The Avocet may occasionally stray into our estuaries-especially on the east coast; and a careful watching in such localities would doubtless be the means of recording other examples. At present it can only be catalogued as an extremely rare bird in Scotland.

This beautiful bird has now become rare even in the south, where up to the commencement of the present century it existed in considerable flocks. In the Fens of Lincoln, "opposite to Fossdyke wash, during summer," writes Pennant, "are great numbers of Avosettas, called there yelpers, from their cry: they hover over the sportsman's head like the lapwing, and fly with their necks and legs extended."

Modern records in the death catalogue of London magazines are now confined to simple notices of the bird's destruction.

* Dr Fleming, in his work on 'British Animals,' states that the Avoset is "a straggler in Scotland," and as this book was published in 1827, we are led to infer that Mr Mitchell's specimen was not the only one he had passed through his hands. 



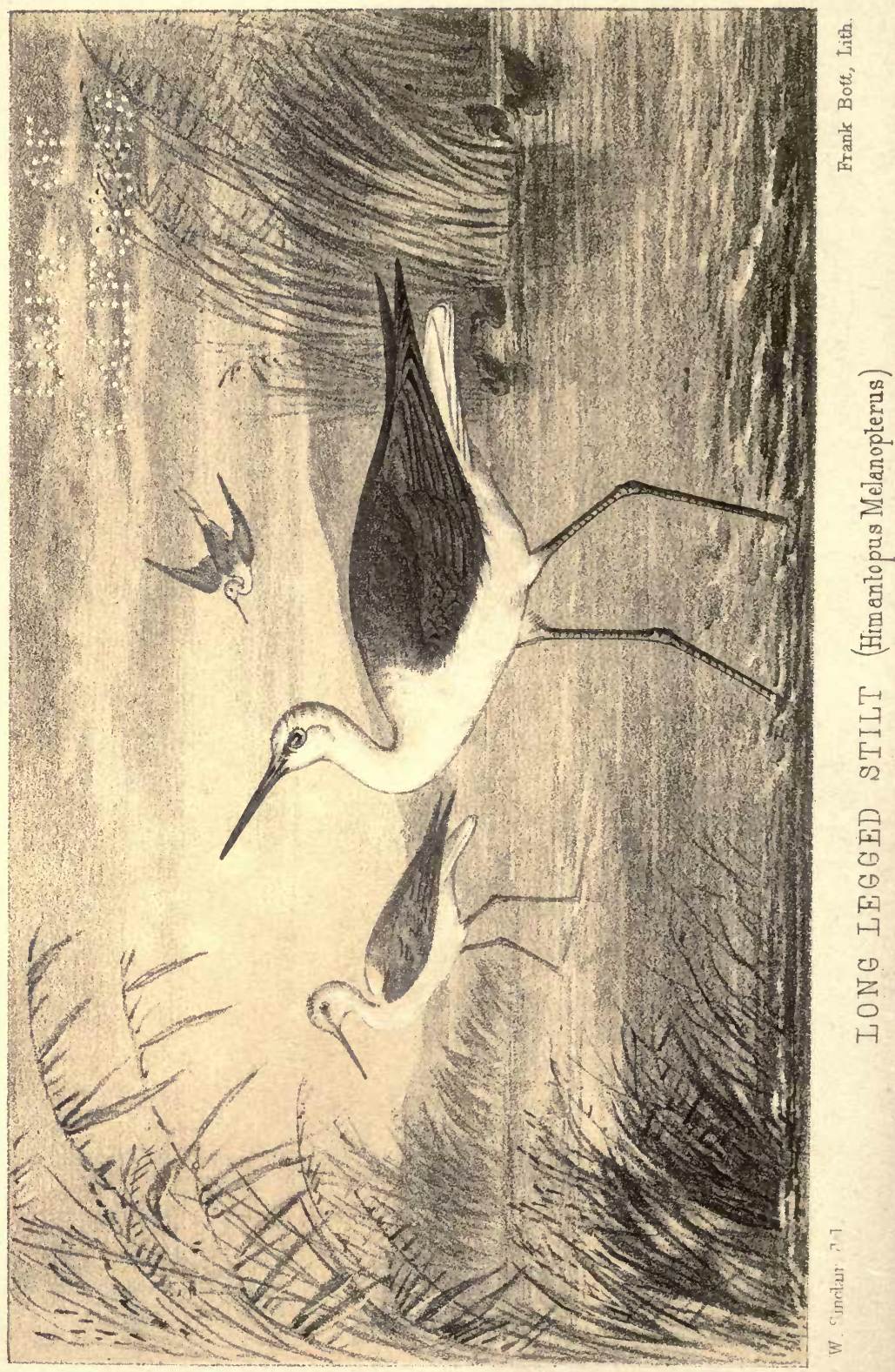




\section{THE BLACK-WINGED STILT.}

\section{HIMANTOPUS MELANOPTERUS.}

ThIs curious bird is figured in Pennant's "Caledonian Zoology," Plate IV., and simply catalogued as a Scottish species on page 35 of that work - the author's authority for its introduction being apparently Sir Robert Sibbald, who states, in the work referred to by Pennant, (Hist. Scot. lib. iii., 18 tab. xi. xiii.,) that two specimens had been obtained at a lake near Dumfries; one of these had been examined by the author.

The next occurrence of the Black-winged Stilt is thus alluded to by Don in his Forfarshire list, published in 1812:- "I once saw one bird of this species on the mountains of Clova: I have never observed but another, which was on Ben Lawers, in Perthshire, in August, 1793: it is a rare bird, and, I believe, but few naturalists have seen it alive." Two specimens were also killed at Lopness, in Orkney, in 1814. Later still it is mentioned as a rare species found in the parish of Glenshiel, in Ross-shire, by the Rev. John M'Rae, who published his statistical account in November, 1836. I can find no other record of its appearance in any part of Scotland until 1850, when a specimen, killed on the banks of the Clyde, near Port-Glasgow, was exhibited at a meeting of the Royal Physical Society of Edinburgh, by Dr J. A. Smith, the society's secretary. After a lapse of nearly twenty years, it reappeared in 1867 , and, from the several records communicated to me, I am inclined to believe that a small flock had visited Britain in that year. The first information I received was from my indefatigable correspondent, Mr Angus, of Aberdeen, in the following note:- "15th September, 1867.-I observed a bird in the Tile Burn, near Don mouth, which, on close inspection, I recognised as the stilt plover. It stood at an angle across the water, with its head to the wind, which at the time was blowing hard from the south-west. It appeared to be a bird of the year; certainly the plumage was not that of the adult. The under surface of the body was dirty white; head dusky, with dark streaks; the upper parts dusky brown, or appeared to be so, viewed with a binocular glass under a clear sun, at a distance of one hundred and thirty yards; the legs orange; iris, beautiful red. Not having seen this species before, I was particularly struck with 
its comportment. It would now and then thrust its head and a great part of its neck into the water, as if catching something that swam or floated up with the rising tide; or it would suddenly snap at some object in the manner of a dog catching flies. For half an hour the bird was thus engaged without moving a foot, until the flowing water caused it to remove to a place of safety. It then flew a considerable way up the burn, and alighted on the bank, where it walked and ran, in the most lively manner, in search of insects. Its flight was slow, regular, and graceful. When on wing the neck was considerably arched, the wings remarkably convex, and the legs thrust out behind. All its movements, whether on wing or on foot, were characterized by comeliness and agility.

"The author of the charming history of Selborne thought it would be 'a matter of great curiosity to see the stilt plover move.' At best it could be but a 'bad walker.' It wanted the back toe'that steady prop to support its steps;' would perpetually vacillate, and 'seldom be able to preserve the true centre of gravity.' Such was the speculation of one of our best observers regarding this peculiar bird. I note the passage as showing the futility of attempting to throw any light on the habits of our feathered favourites, except by actual observation."

In the month of October following, a Black-winged Stilt was seen at Possil marsh, within four miles of Glasgow. It frequented the place three or four days, and was distinctly observed by different persons. Notwithstanding repeated attempts on its life, the bird luckily escaped.

Writing from Dumfriess-shire, on 25th December, of the same year, Sir William Jardine has sent me the following note:- " $\mathrm{My}$ gamekeeper gave me the description of a bird he saw about six weeks ago, that I could make out to be nothing but a Black-winged Stilt, and I heard of it being killed about eight miles off, but it had been thrown out, and not a feather was to be got."

The figure in the accompanying plate has been drawn by $\mathrm{Mr}$ Sinclair, from a specimen in his own collection. 


\section{THE BLACK-TAILED GODWIT.}

\section{LIMOSA MELANURA.}

So far as I can learn, the Black-tailed Godwit, which is still believed to breed in limited numbers in the south of England, is strictly a winter visitant, and is only of occasional occurrence in any part of Scotland. I have very rarely indeed seen west country specimens: one which I examined was shot near Dumbarton on 25th November, 1867; another, the sex of which was not noted, was taken in the flesh to $\mathrm{Mr} \mathrm{M}^{\prime} \mathrm{Culloch}$, bird-stuffer, Glasgow, on the last week of August, 1869; it was killed on the Castle Semple estate, Renfrewshire. The Earl of Haddington informs me that early in the same month in which the Dumbarton specimen occurred, another was procured on the shore near Leith. I recollect being informed by my lamented friends, the late John Nelson, Esq., Broomhouse, Dunbar, and his brother the late Dr Nelson, Pitcox, that they had occasionally shot this species in the Tyne estuary, in East Lothian; but I took down no dates of its occurrence, and am now unable to trace any records of the fact in letters I received from these gentlemen. Writing from Northumberland, which is not far distant from that county, Mr Selby (Ill. Br. Orn., vol. ii., p. 96) speaks of the Black-tailed Godwit as being widely dispersed at the period of its annual movements, and as frequently visiting the Northumberland coast and other northern districts. To that statement he adds in a foot-note that while writing his account (March, 1831) four Godwits were brought to him for sale, "three of which were of the black-tailed species, and just beginning to acquire the summer plumage."

Elsewhere on the east coast specimens of this bird have been obtained; on at least two occasions in Forfarshire, and also in Aberdeenshire. Respecting its occurrence in the last named county, Mr Angus writes to me as follows:- “ Black-tailed Godwit - on the 2nd September, 1867, I shot two immature birds, out of a very large flock, as they passed southwards by the coast line, near Aberdeen. Their stomachs contained sand and broken shells. The bar-tailed godwit has been procured every autumn for the last seven years, between the Dee and the Ythan, along the coast; but Mr Mitchell, who has been collecting and stuffing during the last 
thirty years, informs me that he has never had this species through his hands."

The authors of the 'Natural History of Orkney,' state that this Godwit is "rather a rare winter visitant, during which season it appears in small flocks." Professor Newton is of opinion that it breeds in Iceland: he obtained a fine pair in the flesh at Reykjavik, towards the end of June. Professor Baird, in his 'Birds of North America,' states that this bird is allied to the Hudsonian godwit (Limosa Hudsonica, Lath), but " differs in having the axillars, and under coverts dark brown instead of white; the neck brownish grey instead of chestnut."

\section{THE BAR-TAILED GODWIT.}

LIMOSA RUFA.

Rhuid Ghuilbnach.

I BELIEVE this Godwit will yet be found nesting in the Outer Hebrides, although I am not, in the meantime, aware of the eggs having been found. In 1858, Dr Dewar shot five specimens on the 26th June on Bernera, an island in the Sound of Harris, three of which I had an opportunity of seeing about a month afterwards. They were in full breeding plumage, and Dr Dewar informs me that all the birds he saw had apparently paired, and seemed from their habits to have their nests at no great distance.

The Bar-tailed Godwit is widely distributed in the winter season, but is only found in flocks in estuaries, where the oozy shores attract them by the profusion of small marine animals, chiefly annelides and crustacea, which live in the mud. Where these shores are very soft and yielding, the birds content themselves by dabbling in the ooze, much in the same manner as a duck; but where there is a mixture of mud and sand of tolerable consistency, I have seen them ploughing it with a curious zig-zag motion, and at other times inserting their bills about an inch or so, and running round till they almost described a circle. I have observed the habits of this Godwit in the Firths of Forth and Tay, the estuary of the Eden in Fifeshire, and the Bay of Cromarty from the Ross-shire side. The last named locality, which offers at low tide perhaps one of the most attractive mud flats in Scotland, is frequented by considerable numbers. Mr Harvie Brown informs 
me that he finds it common in autumn on the shores of the Forth, near Grangemouth. In November, 1870, when visiting that part of the coast in his company, I observed about a dozen resting themselves on the muddy expanse. The tide had already begun to flow, and the bird repast was over; a thick haze rested on the water, and partially obscured that part of the bank nearest to it. With a good glass, however, we made out the waders with ease, and were much interested in observing their varied attitudes. Several grey plovers were also close at hand, and a small troop of sanderlings, ringed dotterel, and golden plover, the whole forming as pleasant a group for out-door study as one could wish for in a day's ramble. As the haze wore off, and the blue sky appeared, the curtain seemed raised all round, till at length the sun shone forth in his subdued strength and warmed the distant perspective into a splendid view of the northern mountain peaks of the Ochills. A broken foreground of rough stones, the middle distance a sweep of mud and sand, and the blue Forth, on the other side of which glimmered the white pillar of a river beacon, all combined to make an agreeable picture, while the eye took in the far-off hills and peaks, and rested there as if the composition of the landscape were perfect.

This bird appears to be a very common species in some parts of Ireland, where, according to Mr Thompson, from two to three hundred have been seen in a flock. I am not aware of such numbers having been seen in any part of Scotland. From Argyleshire to the west coast of Sutherland, where there are numerous sea-lochs stretching inland for considerable distances, the spring and autumnal flocks are comparatively small. At these seasons their food appears to consist of small annelides and crustaceans, such as burrow in mud and sand, or a mixture of both. The female of this species is larger than the male.

\section{THE RUFF.}

\section{MACHETES PUGNAX.}

EXCEPT in a very few instances, and these chiefly in Ayrshire and Renfrewshire, I have never met with the Ruff in the western counties. It appears to affect the east coast principally, extending from Berwickshire to Orkney and Shetland. The trending of the Solway Firth seems to check its progress northward on the west; 
or, more correctly speaking, it leads it eastward from its line of flight. One or two occasionally cross and penetrate as far as the Clyde, but these are mere stragglers. The last one I examineda plain and unobtrusive female shot near Bowling in October, 1869-was brought to Glasgow, as a great curiosity, by a keeper who had long been accustomed to shore shooting in the estuary, but had never seen one before. Eastwards it occurs more frequently, and in greater numbers in Aberdeenshire than elsewhere. Mr Harvie Brown has seen and shot various specimens on the Forth at Grangemouth. Writing in September, he informs me that he had shot two specimens there in a forenoon. The occurrence of this remarkable bird in Aberdeenshire so frequently in autumn, after the breeding season is over, is a circumstance which need excite but little surprise when it is borne in mind that large numbers breed in Scandinavia, and that the flocks there congregating for the autumnal journey would naturally touch first of all on the outlying shoulder of that county as the nearest land on their way southwards. On the other hand, in returning, the flocks appear on both the eastern and western shores of England; * though, as we have seen, they shorten their route by following the course of the rivers running into the Solway, and speeding eastwards into Berwick and East Lothian, whence they advance by easy stages to the estuaries of Aberdeenshire, their last halting place before crossing the North Sea.

Nothing new appears to have been written on the breeding habits of the Ruff by British authors since the time of Montagu, and, indeed, that accurate and painstaking naturalist has left but little for others to say on the subject.

\section{THE WOODCOCK.}

\section{SCOLOPAX RUSTICOLA.}

Coilleach-coille. Crom-nan-duilleag.

IN the winter time, the Woodcock may be said to be plentiful in North and South Uist, and in Benbecula, as well as other parts of the Long island, but it does not, so far as I can learn, remain in these districts to breed. It has, however, been ascertained beyond

* I have seen considerable numbers in full-breeding plumage killed on the banks of the Ribble, in Lancashire, in the first week of May. 
a doubt that it breeds occasionally in Mull. Mr Graham informs me that a party of peat-cutters found a young brood on that island, opposite Iona, and caught one of the chicks, which he had an opportunity of examining. Nearer the southern mainland it becomes more plentiful, and is found in Islay in considerable numbers, ${ }^{*}$ although, as I am informed by Mr Elwes, comparatively few remain there during the breeding season; but in Dumbartonshire the nest is frequently met with, especially in the neighbourhood of Loch Lomond, and on some of the islands of the loch itself, where it may be seen on summer nights soaring in circles above its nursery haunts, and occasionally carrying its young tucked between its legs when removing to another feeding ground. + It is probable that it could be traced from north to south in summer, breeding here and there between the counties of Sutherland and Wigtown. Captain Cash of Dingwall has informed me that he has undoubted evidence of its nesting in Ross-shire; the nest has been obtained in the woods at Brahan Castle, and also on the estate of Castle Leod, both properties being within a few miles of

* The late Mr Thompson, in his 'Birds of Ireland,' mentions that on two properties in Islay-Ardimersy and Islay House-one thousand Woodcocks were killed in the season of 1846-47.

+ The Rev. J. E. Somerville has kindly communicated to me the following note on this habit of the Woodcock, and I have much pleasure in giving it here as the direct evidence of an eye-witness:-About the middle of July, this year (1869), I was passing in company with a younger brother, through the woods which surround Brodick Castle, in the Island of Arran. The day being oppressively hot, we left the path, and struck down among the spruce firs, in that portion of the wood which lies at the entrance to Glenrosa. On reaching a cleared space beneath some large trees, I was startled by the sudden rise of a Wondcock from within two or three yards of my feet. My attention was immediately arrested, not so much by the appearance of such a bird at that season of the year, as by its very remarkable mode of flight, which was slow, heavy, and apparently sustained with difficulty. A few moments' observation revealed the cause. The legs of the bird were seen hanging downwards, and between them was clasped a little mass of feathers. It was one of its own young, which maternal instinct had prompted the parent to rescue in this most curious manner. The Woodcock flew forwards about thirty yards, and then dropped down into the dense growth of fern. During its flight it uttered a peculiar rapid note, between a scream and a croak, which was continued for some minutes after alighting, but in more subdued tone. Believing other young ones to be in the neighbourhood, we made a careful search, but without result, and then retired into concealment, to await the return of the parent bird. After a few minutes it appeared creeping cautiously up among the ferns. On catching sight of us, it squatted down on the ground for some time, then rose, and flew away to a short distance. 
Dingwall. It has also bred regularly for the last thirty years at Tarbat, in the same county, information to that effect having been obligingly sent to me, through Mr Dickinson, the head keeper there. I have also been informed that Woodcocks have always bred at Beaufort, near the Beauly Firth. In the winter of 1868-1869, the birds were very scarce on these two propertiesa circumstance probably owing to the heat and want of rain in the month of July, the young birds having been nearly all killed. In many parts of Morayshire, especially in the neighbourhood of Darnaway forest, considerable numbers remain to breed.

About the time of the autumnal migration, our preserves derive a large accession of Woodcocks from other countries. These flights reach the coasts during the night, and are well known to lighthouse-keepers, who capture the bewildered travellers in considerable numbers. Some of these men have informed me that for seven or eight nights in succession the birds continue to arrive, and hundreds perish by striking themselves against the lantern.

The food of this species consists chiefly of small worms and the larvæ of insects. I recollect, however, finding a large quantity of heather shoots in the stomach of a Woodcock shot on the Lammermoor hills, Haddingtonshire.

Judging from an old Scots Act, fixing the prices of wild fowl, and passed in the reign of Queen Mary (dated 1st January, 1551), the Woodcock appears to have been valued at a much lower standard than at present. The following list shows the estimation in which the various birds were held:- "The cran, five shillings; the swan, five shillings; the wild guse, five shillings; the claik, quink, and rute, the price of the peece auchteene pennies; item the quhaip, six pennies; the woodde cocke, four pennies, the dousane of laverocks, and utheris small birdes, four pennies; the snipe and quailzie, price of the peece twa pennies."

\section{THE GREAT SNIPE.}

\section{SCOLOPAX MAJOR.}

HAS occurred in several instances in the western counties: one was shot near Ardrishaig in the autumn of 1864, and exhibited by $\mathrm{Dr}$ Dewar at a meeting of the Natural History Society of Glasgow. It has also been killed in Renfrewshire. More recently, this species 
has been taken in Ayrshire by Mr William Boyd of Greenock, who informs me that he killed a specimen on 15th September, 1868, on the lands of Corsehouse, in the parish of Stewarton. "I had just broken up a covey of partridges," writes Mr Boyd, "and marked two of them into the middle of a large patch of heather and rushes; my dog had also marked them, and was creeping anxiously up to them when he made one of those undecided points which dogs make at game they are not accustomed to. I was quite sure from his attitude that he had not found the partridges, and expected every moment to see either a hare or a fox. I was surprised, therefore, when the Snipe rose, and did not then fire, as I did not wish to disturb the partridges;- - after shooting these, however, and making another search, the dog found it again in the middle of a stubble field; it again flew off before I got up, but at length dropped near a ditch, where I observed it running, just keeping before the dog's nose. I then shot it as it dashed off, and I remarked that while flying it looked very much like a golden plover. I had seen the same bird three days before, as we were coming home in the evening: it rose from our feet as we were walking through a patch of potatoes, and flew slowly away, looking in the dusk like a very young partridge. I may remark that the bird was very fat."

On the eastern coast it has occurred, perhaps, more frequently. The Earl of Haddington has obligingly sent me word of one which was shot at Mellerstain, in Roxburghshire, by his father, the late earl, in the autumn of 1865, and states that he himself, about that time, observed a very large Snipe at Earlston, which he was certain belonged to this species. In the winter of the same year one was shot in Forfarshire, and is now in the Museum at St Andrews; and Mr Harvie Brown has informed me of another, which he lately saw, having been killed in Fifeshire. Mr Wardlaw Ramsay writes that two others were shot near St Andrews by a gardener named Hutcheson in the service of Mr Craigie of Halkett. The species is also mentioned by Mr St. John, in his 'Tour in Sutherland,' as one of the Snipes said to breed in one or two localities in that county, but he gives no other particulars. It is catalogued as a Caithness bird by Mr Sinclair of Wick, in whose collection there is a local specimen.

According to Messrs Baikie and Heddle, the Great Snipe had several times occurred in marshy ground on Sanday in September, 1815. In other parts of the country it affects dry pasture lands, 
and from this habit its presence may have been overlooked. From the records given, it will be seen that, in the meantime at least, it can only be ranked in Scotland as a rare autumnal visitant.

\section{THE COMMON SNIPE.}

\section{SCOLOPAX GALLINAGO.}

Eun-ghabrag. Croman loin. Mennan aidheir. Naosg.

AN abundant species all over the western counties and both groups of islands. Its ordinary haunts-the trackless moors and mosses which characterize much of our western scenery-are but seldom invaded, save by the sportsman who halts but a short time as he passes in quest of larger game; hence in the absence of merlins and peregrines, now so systematically killed, snipes have multiplied to a great extent. On some of the lower grounds, especially on the mainland where drainage is now carried on beneficially, the species is not quite so numerous, two or three pairs at most being found where formerly as many hundreds were reared. These chiefly frequent drains and ditches, which in very warm seasons are nearly dried up, and consequently a poor haunt indeed for a soft-billed wader. In the hot summer of 1863 , great numbers of stupified Snipes might have been seen located on the banks of the river Kelvin, near Glasgow, having, no doubt, been driven from their usual haunts which, in many places, had become an expanse of hardened clay.

On the Outer Hebrides, where the moist heaths are many miles in extent, Snipes are extremely numerous, and appear to be resident the whole year. In some parts of Benbecula, North Uist, and Harris, they frequent in severe winters exposed places in their anxiety for a meal, and on these occasions they may be seen probing the bare ooze in large companies like a flock of dunlins. I have nowhere else seen similar multitudes of Snipes exposed in a body to a raking shot. On these islands the Snipe breeds on the margins of the fresh water lakes, as well as on the highest mountains, their nests being found in patches of marshy ground at an elevation of upwards of 1800 feet.

In East Lothian, I noticed, many years ago, that large numbers of Snipes frequented the sea shore, near Dunbar, at ebb tide, 
resorting invariably to places covered with large stones, below which they could take shelter in case of being disturbed. I have watched them in such situations, almost daily, for two or three months, and have often been amused on seeing them hurrying with anxious jerks to get out of sight under the boulders when any one approached their feeding ground. As might be expected, this species is abundant in Orkney.

Of late years accounts have been published by Mr E. H. Rodd of Penzance, and Mr J. Gatcombe of Plymouth, respecting a British Snipe presenting some characters differing from those of the common species, the chief of which are a uniform ruddiness of plumage and a shortness of the tarsi when compared with the body. Mr Gould, in his work on British Birds now in course of publication, proposes to name this bird the Russet Snipe (Gallinago russata), assuming that these characters may be found to be permanent. I have never myself met with this snipe in my shooting experiences; but when in Inverness in February, 1869, Mr W. MacLeay showed me a fine specimen which had been killed some time before, near Tain, by Dr Bryden, and it is not improbable that it may yet be found in some numbers in other parts of Scotland.

\section{THE JACK SNIPE.}

\section{SCOLOPAX GALLINULA.}

BEING a migratory species, and only a winter visitant to this country, the Jack Snipe is much less numerous than its congener, the common snipe. It is, however, found in nearly the same localities both in the Hebrides and on the mainland, but is never seen congregating in numbers at any season. In Skye, Islay, Jura, Iona, and Mull, and in nearly all the islands of minor extent, it is found in small groups in the marshes; and even in districts thickly populated it regularly appears-small-parties being observed every winter on the shootings in the immediate neighbourhood of Glasgow. I find the Jack Snipe nowhere more common than in Forfarshire. From some of the marshes in the neighbourhood of the county town I have obtained six or seven brace in the course of a short turn with the dogs.

On the west coast these birds arrive early in October, and are nearly all gone about the beginning of April; but, in the island of 
North Uist, single birds have been flushed and shot as late as the second week in June. The resident keeper on that island persists in saying that Jack Snipes breed there, but I have never had an opportunity of examining a bird shot off the nest, which appears to be the only true way of settling all doubt on the subject.

Mr Hewitson mentions in his British Oology that he has seen the Jack Snipe at Prestwick Carr, near Newcastle, after the common snipe had begun to lay its eggs. "I have very little doubt," he adds, "that some of them remain to breed on the extensive moors and morasses of Scotland and Ireland. Such places are frequented only by the cutters of peat, and are very rarely trodden either by the ornithologist or any one interested in his favourite subject; neither is it the time of year for the pursuits of the sportsman."

Mr Thompson, in his 'Birds of Ireland,' gives what he considers a well-authenticated instance of the Jack Snipe breeding in Ireland, near the town of Ballyhannis, (Co. Mayo,) on the property of Lord Dillon; and I have been informed by Mr Angus that, in one instance, at least, a nest was discovered in Aberdeenshire by J. W. Stuart Burnett, of Keithhall. Writing on the birds found breeding in Sutherlandshire, Mr Harvie Brown has the following remarks:- "On different occasions I have been assured that the Jack Snipe breeds in the county, and that the young have been shot in August, etc. These accounts were frequently from persons who must have been perfectly acquainted with the bird. In vain, however, have I attempted to obtain a nest of eggs, along with the old bird, by offering a large reward, and the fact still remains, I believe, that no collection yet contains thoroughly identified and well-authenticated British specimens."

\section{THE BROWN SNIPE.}

\section{MACRORHAMPHUS GRISEUS.}

Through the kindness of Dr J. A. Smith of Edinburgh, I am enabled to record this North American species as a rare straggler to our Scottish shores. A specimen, the sex of which has not been noted, was shot at Dumbarnie Links, near Largo, in September, 1867, by Mr Hutcheson, gamekeeper to Robert Rintoul, Esq., of Lawhill, and exhibited at a meeting of the Royal Physical Society. 
Wilson, in his account of this bird, observes that it arrives on the sea coast early in April, in great numbers, flying in flocks, sometimes at a great height, and uttering a loud and shrill whistle. It feeds upon "small snail shells, which lie in millions on the salt marshes;" and as its flesh appears to be eagerly sought after as a delicacy for the table, immense numbers are shot down and sent to the markets. From its habit of huddling close when alighting on the sand bars and mud flats, a good shot is easily obtained. Eighty-five have been killed at one discharge.

Sir John Richardson, in his fauna of North America, states that the specimens killed by his party on the Saskatchewan plains, had their crops "filled with leeches and fragments of beetles."

Professor Baird, in his 'Birds of North America,' remarks that this species is very "variable in plumage, scarcely any two being exactly alike except in very mature plumage." In the same work, (page 712), he introduces another bird-Macrorhamphus scolopaceus -(Say), giving a description of its specific characters, which may be said to be almost identical with those of $M$. griseus, and concluding with the following remarks:- "The only characters which appear to be reliable are those pointed out by Mr Lawrence, which are the greater length of the bill and tarsi in the present species. It is, however, nearly related to that immediately preceding ( $M$. grisens,) and, for the present, with numerous specimens of both before us, we consider it but of doubtful validity as a species; and its study is further complicated by the fact that it bears a striking resemblance to the rare European species, supposed to be identical with the common bird of America, as will be seen in Gould's beautiful figure in 'Birds of Europe,' vol. iv., pl. 323, the latter seems to be a little larger than our common species." Mr Baird adds that this variety, if it be nothing more, is found throughout " the temperate regions of North America."

Believing that a description of the Scottish specimen will be acceptable to the ornithologist, I have much pleasure in giving the following particulars with which Dr Smith has most obligingly furnished me:- "Top of the head is dark brown, mottled with a few lighter spots; lores, dark brown; over eye to bill, a light or pale fawn streak. Upper parts of body brown; middle of back and scapulars, dark brown, many feathers edged and spotted with yellowish brown; rump, white, slightly spotted with brown; upper tail coverts white, barred with brown; tail nearly even, 
and barred diagonally white and brown, outer feathers tipped with white. Wing coverts brown; primaries dark brown, shaft of first white; secondaries edged with white; tertiaries brown, and much elongated; axillaries white, diagonally barred with brown. Below-chin and neck, breast and flanks, fawn colour or light reddish brown, spotted on the neck and breast, and barred on the flanks with darker brown; middle of abdomen and vent, white; under tail coverts white, spotted and barred with brown. The bill is $2 \frac{1}{4}$ inches in length, of a greenish brown with the tip darker. Wing, from flexure to point of first primary, which is the longest, 6 inches. Tibia bare at the lower part; tarsi scutellate, and feet greenish brown; first and second toes short and slender; two outer toes connected at the base by a broad web or membrane."

Since the above was written, I have ascertained that a specimen, in winter plumage, was killed some years ago in Lanarkshire, by the late William Gordon of Airdrie, and is now in the possession of Mr Francis M'Culloch, taxidermist, Glasgow. This specimen was exhibited at a meeting of the Natural History Society of Glasgow, held on 28th December, 1869.

\section{THE CURLEW SANDPIPER.}

TRINGA SUBARQUATA.

IT is difficult to state with certainty the comparative numbers of this bird, when contrasted with the large flocks of dunlins, or other species, frequenting the sounds and sea beaches of our western shores. It appears to be a much less common sandpiper than the dunlin, and in my repeated searches after it, when birds of all kinds were abundant, I have been oftener disappointed than gratified.

In September, 1867, when driving across the sand ford at low tide between North Uist and Benbecula, I saw a number of Curlew Sandpipers mixed with dunlins and ringed dotterels feeding on the muddy sands near the latter island. There were hundreds of birds of these three species collected together, and they were so tame and confiding that as the wheels sped noiselessly along the smooth ford, I was several times afraid they would crush some of the little creatures boring in the ooze. Oftener than once, on coming up to 
a large group, the birds merely gave way in the centre, running to each side and allowing the machine to pass, after which they drew together again. I struck at several family groups with the whip, and it was then I saw the white-rumped birds as they rose. The call-note of the Curlew-billed Sandpiper is a chattering sort of whistle, which at once arrests attention as something different from the disturbed cry of the dunlin.

$\mathrm{Mr}$ Graham states that this species is found "occasionally in Iona and Mull; and it is likewise sparingly distributed along the shores of Argyle and Ayr, being especially noticeable in early autumn, when the migratory flocks return from their breeding quarters. Small flocks have also been seen, and specimens obtained, on the banks of the Forth, near Grangemouth, by Mr Harvie Brown. In East Lothian the Curlew-billed Sandpiper is met with in small numbers on the banks of the Tyne. Many years ago, when rambling along the sands at the mouth of the river, I noticed a man and a boy, with a horse and cart, stalking dunlins and other small shore birds. The pony had been trained to walk slowly towards a group of birds, while the owner lay concealed in the cart ready to fire his long-barrelled gun over the side; and after waiting until I had seen him literally mow down a flock, I had an opportunity of turning over the contents of his bag, in which I found a fair proportion of this species of sandpiper. On the 9th of May, 1870, I observed on the shore at the 'Vaults' near Dunbar a large flock of Curlew Sandpipers flying in circles, as if disturbed, just above the sea margin at low tide. I was at once attracted by their musical twitterings, uttered while the flock was on the wing, and sounding like a concert of tiny whistles. The birds were evidently migrants from the south, and were resting probably for an hour or two in the course of their journey northwards.

Mr Mitchell of Aberdeen has sent me in the flesh the Curlewbilled Sandpiper from near the mouth of the Don, where it appears to be a well-known visitant; and in connection with the same county, I have been assured by Mr Stuart Burnett of Keith Hall that he has met with the bird in a marshy spot in the parish of Kinellar (long since drained) on 30th May, 1852. " At the time," writes Mr Burnett, "it seemed to have young near, as it fluttered along the ground in a decoying way, dragging its wings. The same year I saw one or two others in some wet localities near 
Kintore and Echt, but have not met with the species since in these parts."

Mr Burnett has also sent me word that he discovered a nest of this Sandpiper in a tract of sedgy bog round the Loch of Spynie, near Elgin, on 8th June, 1853: it was placed in a tuft of marsh grass, from which the bird fluttered out at his feet, "rolling, tumbling, and uttering strange cries." The eggs were four in number, and in course of being hatched, the shells being chipped by the bill of the young bird.

\section{THE KNOT.}

\section{TRINGA CANUTUS.}

JUDGING from my own observations, I should be inclined to regard this bird as a somewhat uncommon species in the western counties of Scotland. I have met with occasional specimens from Sutherlandshire to the Mull of Galloway, but have never seen such flocks on our shores as are to be seen on those of the eastern counties. It has occurred in Islay, as I have been informed by Mr Elwes, but not, so far as I am aware, on any of the other islands, except in a single instance, namely, that of a specimen in full summer plumage, which was shot on the 30th July, 1870, by Captain MacRae in the Strand of Vallay, in North Uist, and shown to me by that gentleman three days afterwards when I visited the island. This specimen is now in the collection of Captain Orde. In September, 1866, when on a visit to the Mull of Galloway Lighthouse, I saw a fine specimen taken on the lantern, against which it fell stunned; but Mr M'Donald, one of the keepers there, informed me that he had never observed one before.

On the east coast the Knot is usually found in small flocks on all the shores extending from Caithness to Berwick. At some places, and in particular seasons, these flocks are much larger than at other times, especially in the month of September, about the time of their arrival, when they are seen in hundreds. On Tyne Sands, East Lothian, and also on some parts of the shore southeast of Dunbar, many specimens may be obtained even by stoning the birds when the migratory flocks arrive, as for some days after alighting they are exceedingly tame, but whether from fatigue or stupidity, I am unable to say. After a time, however, they 
become rather wary, and present a less tempting shot to the shore shooter, the flocks being smaller and sometimes found mingling with other sandpipers, in whose company they appear to acquire a better idea of how to take care of themselves.

It is not easy to name with certainty the breeding haunts whence these flights of knots have come. Mr Dunn has suggested Finland as the likely nursery for the species, as no birds are seen in Scandinavia except in spring and autumn, and he has further started the question whether we are indebted to Europe, Iceland, or North America, for the vast numbers that appear on the English coasts in autumn. As regards Iceland, however, this question may now be considered settled by Professor Newton, who states that on the south-west coast the species is very well known as a bird of passage. "One morning," says this very accurate writer, "at the end of May, 1858, I found the shore at Kyrkjuvogr literally alive with a large flock of knots, all in their beautiful red plumage. There had been none there the day before. They stayed about a week, their numbers gradually diminishing, until at last only two or three were to be seen. This is one of the birds possessing great interest to the oologist, for I believe no collection has well authenticated specimens of its eggs." *

According to Dr Saxby, Knots are tolerably numerous in Shetland, where they have been seen by himself at all seasons. In summer he has obtained adult birds in brilliant chestnut plumage, as well as young ones barely fledged. He has likewise obtained eggs which he has good reasons for believing are those of this species.

\section{THE BUFF-BREASTED SANDPIPER.}

\section{TRINGA RUFESCENS.}

A SPECIMEN of this rare British bird is mentioned in a catalogue of species found in Caithness, by the late Mr Sinclair of Wick, and published in the statistical account of that parish in 1835 . This specimen is still preserved in the collection which belonged to Mr Sinclair, and has of late years been referred to by Mr Shearer, in a paper which was published on the proceedings of the Royal Physical Society of Edinburgh.

\footnotetext{
412.

* See Baring Gould's "Iceland: its Scenes and Sagas," Appendix A, page
} 
The Buff-breasted Sandpiper is a bird which is not likely to be mistaken for any other species, the singular and beautiful markings on the under surface of the wings being sufficient to enable any one readily to distinguish it.

\section{THE LITTLE STINT.}

TRINGA MINUTA.

I AM not yet able to include this bird as a western species. It appears to be sparingly distributed on the eastern coasts of Scotland, from Berwickshire to the Shetland Islands, where, according to Dr Saxby, it is a regular winter visitor in small numbers. I have observed it in East Lothian, Fifeshire, and Forfarshire, and so far as my own observations enable me to judge, it is somewhat solitary in its habits. On two or three occasions I have met with single specimens not mixing with other sandpiners. It has likewise been found in the north of Caithness; and I find that a note in MS. by Messrs Baikie and Heddle, states its occurrence at Sanday in 1848. Specimens were procured in Banffshire, in 1855, and at Fraserburgh, in Aberdeenshire, in September, 1854; Macgillivray mentions the occurrence of several flocks in that county in 1841, but only one specimen was obtained. Of late years numerous specimens have been obtained near Aberdeen, by Mr Alexander Mitchell, who informs me that he procures them regularly every winter. Mr Angus here also met with the species repeatedly, and has killed as many as four at one shot. A specimen in my collection was forwarded to me in the flesh, in August, 1869, by $\mathrm{Mr}$ Angus, who states that the Little Stint may be looked upon as a regular winter visitant. Writing again on 1st October, 1870, he says:- "The Little Stint has occurred in unusually large numbers this winter, on the sandy portion of the coast, near Aberdeen. Last month, at the 'Black Dog,' I saw as many as thirty in one flock, and on several occasions I have seen flocks of six to twelve at low tide, between the bridge of Don and the mouth of the river; while stragglers were to be seen here and there during the second and third weeks of the month. A correspondent sent me eighteen specimens, the result of a right and left into a flock at Charlie's Pot, near the mouth of the Ythan. At Don mouth I killed a number, mostly young birds." Mr Harvie Brown has also met 
with this bird, on the shores of the Forth, near Grangemouth; an adult specimen shot by him was sent me for examination in October, 1870. I may also state that in the Elgin museum, there is a specimen which was shot in Morayshire, and presented, along with many other valuable birds, to that institution by J. Gatherer, Esq.

A very perfect specimen now before me was shot a few years ago on the sands at Kirkcaldy, and preserved by Mr John Wilson, taxidermist, there. Three others in my collection are from Aberdeenshire, and were presented to me by Mr Mitchell, who shot them near the mouth of the Don, in the winter of 1870-71.

\section{TEMMINCK'S STINT.}

\section{TRINGA TEMMINCKII.}

THE only instance of the occurrence of this species in Scotland that I have been able to trace, is a solitary specimen shot in Caithness-shire, many years ago, and now in the collection of the late Mr E. S. Sinclair of Wick.

\section{THE PECTORAL SANDPIPER.}

\section{TRINGA PECTORALIS.}

I AM indebted to my correspondent Mr Angus for an opportunity of introducing this rare British bird into the Scottish fauna, and have much pleasure in inserting here a description of a specimen shot in Aberdeenshire, and examined by that gentleman immediately afterwards.

"The specimen," writes Mr Angus, "is an immature bird, and was shot by Mr Mitchell, at Don mouth, on the $2 \mathrm{~d}$ October, 1867. Having examined it while it was in the flesh, I carefully noted the following description in my note book:-Plumage compact, more so than that of other sandpipers. Weight, $2 \frac{1}{4} \mathrm{oz}$. Bill, olivaceous, duller at the point; upper mandible, from the gape, $1 \frac{1}{2}$ inches. Wing, from carpus, $5 \frac{3}{4}$ inches; extent, 18 inches. Bare part of the tibia, five-eighths of an inch. Feathers of the head, blackish brown, edged with reddish brown. From the eye to the lower edge of the upper mandible, a dark line; a lighter line above. Chin, white. Neck and breast reddish grey, with dark longitudinal 
streaks; belly, vent, and under tail coverts, white, the latter having a faint dusky line along the shafts. Wing feathers, dusky, first quill white, edged and tipped with dull white; the margin broader on the inner feathers. The coverts on the larger wing feathers, dark and glossy, those innermost being tipped with white. Rump and upper tail coverts, black, the latter tipped with reddish. Tail feathers grey, edged with white; the central feathers longest, darkest, and edged with reddish. Space between the shoulders, blackish brown, edged with reddish, the outer edges of the large feathers white. Scapulars with broad reddish brown edges; some of the wing coverts broadly tipped with white. Legs and feet greenish yellow; claws black; inner edge of the greater toe serrated. Iris, dark brown. Contents of stomach, coarse sand and the softened remains of small crustacea."

\section{THE DUNLIN.}

TRINGA VARIABILIS.

Pollaireun. Gille Feadaig.

The Gaelic name of Pollaireun, given to the Dunlin in the Long island, signifying "bird of the mud pits," expresses in a single word its habits better than any English or Scottish synonyme. The Dunlin, in fact, is nearly always found, except during the breeding season, in places where it can bore into the muddy sand for its living. Here it may at all hours be heard prefacing its repast with a shrill cry, as it alights by day or by night, in flocks, on some tempting place left bare by the receding tide. The flocks which are seen on our coasts in autumn and winter are occasionally very large, though not, perhaps, so extraordinary as those that have been observed in other parts of Britain. Mr Thompson, in his work on the Birds of Ireland, speaks of having, in 1847, seen a flock of not less than two thousand five hundred Dunlins in Belfast Bay, and another of about one thousand five hundred, three hundred yards distant from it. Again, he mentions a still larger flock, in which there could not have been less than five thousand birds. "A few days afterwards," he continues, "a friend being out shooting early in the morning, on the down shore of the bay, saw a flock of several thousands. He described their appearance, as the sun rose, to 
have been one of the most beautiful sights he ever witnessed. The great body first appeared glancing in the sun; then it broke up into a dozen flocks, which rose and fell in the air like molten silver, or, as his companion observed, like showers of new shillings -a most apt image.* One of the finest effects is when the back ground is so dark that the birds are only seen in silvery whiteness flashing their under plumage upon us. The uncertainty as to where they may next appear-like that of lightning from an extensive mass of thundercloud-adds much to the effect." It is sad to think of these fair creatures, whose silver-lined wings are so agreeably pictured, being destined to a pitiless fate the moment they descend to the shore. In the very next paragraph, $\mathrm{Mr}$ Thompson states, in his usually circumstantial way, that on 16 th October, 1843, two hundred and sixteen were picked up at one discharge, and on the 9th of December, 1845, upwards of three hundred!

In the West of Scotland the Dunlin is found breeding in almost every moorland and marshy tract where the snipe or golden plover is met with. It is extremely abundant in North Uist, Benbecula, and South Uist, and indeed over the whole of the Outer Hebrides. It also breeds on St. Kilda and the Monach isles. On the inner islands it is equally plentiful, while on many parts of the mainland it is never absent. Mr Alston has found it breeding in the Upper Ward of Lanarkshire, at an elevation of one thousand feet above the sea level, and I have taken the bird and eggs on several occasions on the Renfrewshire hills, within eight or ten miles of Glasgow, and within full view of the city.

The variations to which this species is subject appear to be much greater than those occurring in any other wading bird of its size. It would almost seem as if there were several races to be found throughout Scotland. In some districts of the Outer Hebrides, for example, the Dunlin is smaller than that of the mainland -a remark which applies to the entire bird, and not to any particular feature. The bill is at least one-half shorter; the tarsi and toes more slender and diminutive; the dorsal plumage redder and more streaked; and the black abdominal patch not so large. When comparing extreme specimens from this part of Scotland

* Oyster shells might be deemed equally apt as an illustration. We can well imagine, however, that in at least some districts of Ireland, not to speak of other places, showers of shillings would produce a really good effect. 
and the eastern counties - that is to say, taking the smallest from the west, and the largest from the east, the Hebridean bird may safely be said to be not much over half the weight of the other. Some of the Dunlins on the western mainland have the bill considerably depressed towards the base; indeed, in a few specimens which I have handled, this feature was so marked as almost to justify a novice in mistaking them for the broad-billed sandpiper. I have also obtained very characteristic examples of this smaller race, with very short and straight bills, in some of the inner islands. In 1870, I had several specimens in full breeding dress from Gigha and Tyree. This tendency in the Dunlin to excessive variation has long been noticed, and has been referred to by various British and continental ornithologists. Sir William Jardine appears to have met with a breed frequenting some of the lochs in Sutherlandshire, which presented marked differences in size and coloration from the ordinary type; and Macgillivray (B. B. iv., p. 214) makes the remark, that "the birds that visit the eastern coasts of Scotland seem in general much larger." To this I may add, that during many years' careful examination of the species in the county of East Lothian, it was remarked by Mr Sinclair and myself, that the greater number of Dunlins shot by us were birds fully as large as the curlew sandpiper, and had bills of equal length and curvature.

The late Mr Cassin, of Philadelphia, in Professor Baird's work, has the following remarks, which I think have some bearing on this subject:- "Tringa alpina var Americana. We have not a sufficient number of European specimens of the true T. alpina of that continent for satisfactory comparison, especially as ornithologists mention differences in size at the same localities; but of eight specimens from Europe and Asia, now before ns, not one ought to be considered as specifically the same as the American bird. The size is invariably smaller, and the bill disproportionately shorter. In fact, we have little doubt that the bird inhabiting both the Atlantic and Pacific coasts of the republic, is quite distinct and may be easily recognised." It would not be difficult, I think, to match this American Dunlin precisely with hundreds of specimens from the eastern coasts of Scotland, and I have long entertained the opinion that these larger birds are not bred on our moors, but are migrants from other countries. 


\section{THE PURPLE SANDPIPER.}

\section{TRINGA MARITIMA.}

WHEREVER the shore is rocky, but not shut in by precipitous cliffs, the Purple Sandpiper is met with in small flocks. Generally these restless groups may be seen close to the water's edge trying to find a footing on some little boulder, as if the perch were not large enough to hold them all. The birds, therefore, may always be identified by their curious crowding movements, even at a considerable distance, either when the tide is flowing or recedingthe rockpipers, as they may with propriety be called, always exhibiting a fear of wetting their feet by fluttering upwards as the waves momentarily cover the stone. I recollect one evening meeting with a considerable flock of Purple Sandpipers near Dunbar, in somewhat interesting circumstances; and the following extract from one of my note books will perhaps better illustrate their habits, as observed by myself, than if put in another form:"November $3 \mathrm{~d}$-while lying crouched behind the skerries this evening about twilight, waiting a shot at some scaup ducks, there suddenly arose a confused though not unmusical babbling within a few yards of where I lay concealed. On looking cautiously over the ledge which inclined seawards, I found a flock of Purple Sandpipers had pitched on a half-submerged boulder, the lower part of which the back-going tide was gradually exposing. As soon as the birds could safely get at the base of the stone, they flew down to a part of the skerry, and then waded quickly to it as if eager to get at the small animals, on which they soon began to regale themselves. Shortly afterwards the stone was left nearly dry; still the Sandpipers diligently pursued their pecking until the supply was exhausted, when they came running back to the flat rocks in my direction. They then halted a little, uncertain apparently what to do, and stood within two ramrod lengths of the rock on which I sat. Beginning again, they proceeded to search the small crevices in the rock, running hither and thither with amusing eagerness, and sometimes coming right up the slope to within a few inches of my face. There were, as near as I could compute, sixty-five or seventy birds altogether; and, as I had never seen so large a flock of Purple Sandpipers before, I looked upon them with great interest. Not wishing to disturb the ducks, which were now pushing landwards 
with rapid strokes from the sea, I took off my cap and sent it spinning with great force among the Sandpipers. Two of the birds lay stunned, and on picking them up I found the plumage to be dingy, and the legs inclining only to an ochre colour, from which I inferred they were both young ones of the year. The probability is that most of the specimens in the flock were birds of similar plumage. As my two captives were not much hurt, I let them off with an admonition to be more careful on the next skerry they visited, so, with a feeble note of thanks they darted seawards, and at once disappeared in the haze." I may here remark that I had previously taken notice of little parties of Purple Sandpipers at another part of the coast where there is a considerable extent of shelving rocks, on which, in moderately rough weather, the surf is constantly breaking. Here their habits were very different-many of the little fellows showing an actual contempt for the spray as it sometimes dashed over them in a heavy shower. I have even seen them face the broken masses of water as the threatening waves came rolling in upon their feeding ground, and nimbly resume their search as soon as the danger was past. No one, indeed, in looking at the bird, can have failed to remark the comparative shortness of its tarsi, general stoutness of form, and greater apparent strength to withstand its rough experiences among the rocks, which distinguish it from other sandpipers.

Throughout the West of Scotland the Purple Sandpiper is found from September till the end of April and beginning of May, but in some of the inner islands, as well as those of the outer group, many specimens are observed even a month later in the season. Dr Dewar observed several flocks on the Ascrib islands in Loch Snizort, in the north-west of Skye, on 6th May, 1870. Single birds, indeed, were found lingering on the mainland about the same time, two specimens having been sent to me from the shores of Loch Ridden in the Kyles of Bute. Captain Feilden shot two specimens near Barra Head, on the island of Berneray, on 27th May of the same year, and two others on Mingalay. On dissection, they all proved to be females, and one of them showed some abrasion of the belly and breast feathers, from which it was inferred that it had been sitting on eggs. The ovaries of all the birds were found to be much distended, but no mature eggs were found in them. Two of these specimens are now before 
me, and appear to be in full breeding plumage. Captain Feilden has suggested to me that when the four birds were shot the males had been sitting on the nests. Single birds have also been seen in Harris late in May, and I have myself observed solitary birds on the island of Scalpa at the entrance to Loch Tarbert. Mr Graham has met with various specimens in complete summer dress on the islands of Iona and Staffa, where a few pairs appear to linger every year.

On the east coast the Purple Sandpiper is also met with in summer in equal numbers-ranging from Berwickshire to the Shetland islands. Small parties were observed in the last-named district by Mr Hewitson about thirty years ago. Mr Selby found the young more than once on the Farne islands in the month of June, when they were scarcely able to fly, and I met with, and shot stray specimens, fully fledged, near Dunbar, in the end of July, 1851. Sir William Jardine also saw a pair on the Bass Rock at a time when all the other birds had young, and Macgillivray mentions having seen one on the same rock on 20 th May, 1831.

Dr Saxby remarks that the Purple Sandpiper is very abundant in Shetland during winter, remaining till late in spring, and that he has three eggs taken on the island of Hunie which he suspects belong to this species.

\section{THE GREY PHALAROPE.}

\section{PHALAROPUS LOBATUS.}

IN its summer plumage, the Grey Phalarope is totally unknown in western Scotland-all the specimens that have occurred being in the plain garb of winter. Even at that season, the species is of rare occurrence, single specimens only being met with. I have seen examples from Dunstaffnage Bay near Oban, the banks of Loch Fyne, and the Frith of Clyde: one was obtained as far up the estuary as Port-Glasgow in the winter of 1866. I have also examined specimens from the shores of Loch Etive and the coast near Helensburgh, where they were shot in December, 1868.

On the east coast of Scotland it is much oftener seen, and appears to visit all the shores from Berwick to Orkney, sometimes arriving 
in small flocks, but generally in scattered groups. It has been frequently shot in East Lothian on the banks of the Tyne estuary, and also in Berwickshire at the mouth of the Tweed, as I have been obligingly informed by the Earl of Haddington. I watched a pair of Grey Phalaropes sitting in a shallow pool among the rocks near Dunbar, in February, 1864; they allowed me to approach within a few feet of the water, and I could almost have touched them with an ordinary cane. On putting them up, they both flew a little distance, and alighted in another rock-encircled pool, where the depth of water obliged them to swim, which they did with extreme grace. After seeing them picking off some of the smaller marine animals which they found adhering to the sea weed on the sides of the rock, I again disturbed them, after which they took out to sea, and were soon lost to sight.

In the Fauna of Orkney, published by Messrs Baikie and Heddle, it is stated that "this species was first observed in Orkney by $\mathrm{Dr}$ Neill in 1804, who killed several in Papa Westray. It is found in Sanday, and some other islands, in most of which it breeds;" but on referring to Dr Neill's 'Tour,' I find he says [Aug. 6th]:"On the margins of the lakes and marshes in this island we saw many birds of the Phalarope genus, which the inhabitants very appropriately name 'half-webs.' We shot the Tringa lobata, or Grey Phalarope." It is possible that this writer saw and shot the red-necked phalarope, as that species would then be congregating before quitting the island; and it is nearly certain that in stating the bird breeds in several of the islands Messrs Baikie and Heddle committed a mistake. It is proper to mention, however, that Pennant, in his 'Caledonian Zoology' (1777), says that the Grey Phalarope was then supposed to breed in Orkney, the species having been shot there in summer. In 1768 his information regarding this and the following species must have been very meagre, as may be seen on consulting his 'British Zoology' first 8 vo edition, published in that year. His tour in Scotland resulted in the accumulation of ample materials for subsequent editions of his general work. 


\section{THE RED-NECKED PHALAROPE.}

\section{PHALAROPUS HYPERBOREUS.}

Dearganallt.

Though met with at irregular intervals over the whole of the western coasts of Scotland, this interesting species is only found breeding in the Long island or the Outer Hebrides. There are four or five stations there-the most numerously frequented of which is Benbecula, where from ten to twenty pairs are annually found haunting the little lakes that abound in that island. There are also several nurseries in the islands of North and South Uist frequented by, at least, other twenty pairs, so that the entire Dearganallt population on these three islands may be reckoned at something less than fifty pairs. The time of their appearance varies a little according to the season; generally, however, the stations are occupied in the last week of May, and the nests found in the first week of June. About the middle of July the families gather together preparatory to their departure, which is also to some extent regulated by the state of the weather; but as soon as August sets in, young and old have entirely disappeared. The season of 1867 was an exceptional one in Benbecula, and I presume at the other stations also-the Phalaropes being as late as the second week of June in arriving, while their departure took place rather before than after the usual time. In that year there were at least twenty-five pairs on a shallow lake on the west side of the island between Nunton and Castle Borve. I visited the island on 4th August, 1870, but did not see a single straggler either at this lake or the picturesque sheets of water on the farm of Milton, in South Uist, which I visited three days afterwards-all the Phalaropes having disappeared three weeks previously. ${ }^{*}$ At both stations the birds on their arrival at once take up their quarters on these lakes, where they may be seen swimming on the calm surface, and moving in circles with great elegance. Any one who chooses to wade near enough, and make up his mind to stand knee deep in very cold water, may sketch the beautiful creatures as they paddle

* My friends Captain Feilden and Mr Harvie Brown found the first phalaropes of the season, and took their eggs on the shores of one of the South Uist lakes, on 29th May of the same year. 
about like so many miniature ducks, and write down a pleasint chapter on their habits in his note book. They seem to have no fear, but come right forward as if curious to know what the intruder is about, uttering all the time a feeble note with every motion of their head, not unlike the ticking of a clock. The little half-clad boys of Benbecula, who of late years have heard of the esteem in which their familiar visitor is held, often attempt to catch the Phalaropes by wading through their haunts; and the sight of halfa-dozen such young rascals in full pursuit, and getting soused occasionally, through a false step in the eagerness of their clutch, is very diverting.

From a comparison of seven specimens now before me, I find that the female is larger than the male, and is brighter in colour. Both sexes share in the duties of incubation, if one may judge from the bare spot being present in the male as well as the female. The nests are mere depressions in the tufts of grass, with a few withered straws moulded into shape by the sitting birds, and are placed on tolerably firm ground near the water's edge. The eggs, four in number, appear to be subject to but little variety; they resemble some of the darker specimens of the dunlin's egg, but are much smaller, and, speaking from my own experience, are never met with of the light green shade which is so conspicuous among those of the dunlin.

I have a specimen of this Phalarope in my collection in full summer plumage, from the island of Skye, but I have failed to discover any breeding place there. It has also been found there in winter, by Captain Cameron, but in other localities on the mainland it is a mere straggler. On the east coast it occurs at irregular intervals from Berwick to Orkney. I have myself met with it in East Lothian and Fifeshire. Two specimens were shot in the Old Links, Aberdeen, by Mr Alex. Mitchell-one on the 15 th, the other on the 18th September, 1870. One of these, kindly forwarded to me by Mr Mitchell, is apparently a young bird of the year, and has a white forehead, the upper part of the head being very dark in colour. 


\title{
THE LANDRAIL, OR CORNCRAKE.
}

\author{
CREX PRATENSIS.
}

\section{Treun-re-Treun. Treunna.}

There is, perhaps, no Scottish bird more generally distributed than the familiar Corncrake; it is found in every district, cultivated and uncultivated, on the western mainland, from the Mull of Galloway to Cape Wrath, and also over the whole extent of both groups of islands, and all the rocky islets on the west coast, extending to Heisker rocks, the Monach islands, and St. Kilda. It will, in fact, take up its abode and rear its young on such places as are almost exclusively frequented by birds dependent on the sea for their daily subsistence: all that can be looked upon as an attraction being but an occasional patch of grass, and a moist hollow to remind it of the distant meadow where perchance it had its haunts the previous summer. I have observed it in the uninhabited islands of the Hebridean seas, and have heard it near the summit of Ailsa Craig rasping its eerie cry after nightfall, as a rude lullaby to the gulls hatching on the grassy verge of a precipice. In such places, as well as on the mainland, I have noticed that the Corncrake utters its cry during the whole of the night, from the time of its arrival until the end of July, with the exception of a three weeks' lull while the first brood is being hatched. There appears to be a second brood about the middle of July. The species unally arrives early in May, and disappears early in September. The latest date which I am able to record for its occurrence, in any part of Scotland, is the 30th October. A specimen, which I saw in the flesh, was shot near Glasgow on that date, in 1867.*

Many persons imagine that it is a very difficult matter to procure Corncrakes, and strange faculties have been curiously attributed to the species, such as its ventriloquial talents and powers of con-

* Macgillivray mentions that Corncrakes are sometimes known to winter in this country, and that a case of this kind had been reported to him from Elgin. The late $\mathrm{Mr}$ James Wilson of Woodville, also chronicles the finding of a Corncrake in mid-winter, but, with characteristic humour, he qualifies his statement by the admission that the specimen had passed the time in confine. ment in an Edinburgh garret 
cealment. Like all other skulking birds, it makes rapid progress through a field of standing grain or rank grass, and in this way it will traverse a great extent of ground in a very few minutes, uttering its note at short intervals, and causing the person watching it to wonder how the sound could emanate from so many points of the compass in so short a space. I have frequently spent an idle hour in observing its motions in a field of clover or rye grass, and have almost invariably seen the bird, when in the act of craking, standing quietly with its head slightly elevated, and occasionally turning it to the right and to the left, as if directing the sound in its full strength to all parts of the field. The cry is uttered by the male; as I have ascertained fur myself, and may be presumed to be uttered as a note of attraction to the female. The serenade is certainly a harsh one.

Knowing the Corncrake's partiality for water, I have often obtained specimens of the bird by going to a particular part of a stream, about the middle of the day, during very hot weather. They may be then seen frequently leaving their grassy haunts, and crossing public roads, or leisurely tracking their way along some hedgerow to the nearest pools among the stones which pave the bed of the now shallow stream. I have even seen the poor creatures'mount a high stone wall, from the top of which they could get a view of the surroundings, and run anxiously along the ledge as if in search of more agreeable quarters. A useful instrument for securing these birds may be made of a horse's rib notched like a saw, across which another sharp bone is smartly drawn, so as to produce an exact imitation of the cry. I remember being led into a boyish adventure with a set of such instruments, under a strong desire to possess my first Curncrake. I knew of the existence of a verdant clover field, frequented by two or three pairs, on the other side of a walled garden - the scene of many of my early shooting exploits; and after climbing up the spread arms of a pear tree, I plied the bones with commendable diligence, until a landrail's uplifted head invited me to stop. Lifting my gun from the top of the wall, I took a steady aim, but forgot in my eagerness that my support was but a feeble one; so at the moment of firing the branch gave way, and I went down backwards with an awkward suddenness, which made that wall at least a somewhat unpleasant element in my after recollections of the species.

The food of the Corncrake, so far as I have remarked, consists 
of small fresh water shells, larvæ of beetles, and thick-bodied moths, which seek refuge in the day time among the grass.

According to Professor Baird, this species is a constant summer visitor to Greenland, and has of late years been found on several occasions on the eastern coast of the United States.

\section{THE SPOTTED CRAKE.}

\section{CREX PORZANA.}

So far as I have observed, the Spotted Crake is a very uncommon species in the western counties; it is, however, more numerously distributed throughout the eastern counties, extending from Orkney to Berwickshire. In Aberdeenshire and Forfarshire, according to Macgillivray, it can scarcely be called very rare. "In Scotland," says Mr More, in the Ibis, "the nest has been found only in Perth, Aberdeen, and at Loch Spynie, in Elgin;" but, as the birds have been repeatedly taken in the breeding season in Banffshire, Fife, East Lothian, and Berwick, it is not unreasonable to infer that the species nests in these counties also.

In the West of Scotland the Spotted Crake has been taken in Wigtownshire, Ayrshire, and Renfrewshire; but I have no authentic instance to give of its occurrence north of the lastnamed district. In its habits this bird closely resembles its congener, the water rail, and like it, is not easily flushed from its haunts.

Although a migratory species, the Spotted Crake appears to come early, specimens being occasionally taken about the beginning of April: as a rule, it also lingers much later than other migratory birds, stray examples having been shot in November, December, and even January, so that it is absent not more than two or three months. It may, indeed, be yet found to be, in some of the southern districts, permanently resident. From its shy and unobtrusive habits, and its life of seclusion and silence in marshy places, from which it but rarely issues, it is much less frequently seen than birds which try to escape by flight when disturbed. Rather than take wing, it will thrust itself, when molested, into any hole or tuft of grass, and remain concealed until quiet is restored; and on this account the comparative numbers of the species cannot readily be ascertained. 


\section{THE LITTLE CRAKE.}

\section{CREX PUSILLA.}

A SINGLE specimen only of this modestly coloured species appears to have been met with in Scotland, and I record the circumstance here on the authority of Mr Thomas Edward of Banff, who has informed me that the bird was found dead in a plantation on the banks of the Isla at Thornton, in the parish of Grange, Banffshire, on the 12th March, 1852. This is probably the same Banffshire specimen which is alluded to by Mr Yarrell in the last edition of his work on British Birds, published in 1856, though neither date nor precise locality is given.

\section{BAILLON'S CRAKE.}

CREX BAILLONII.

SiR William Jardine appears to be the only writer on British birds who has found this bird in Scotland. In his excellent manual, published in 1842, he describes a specimen that was shot on a moss near Lockerbie. This is probably the only one obtained north of the Tweed, with the exception of that referred to by the late $\mathrm{Mr}$ James Wilson in his voyage round Scotland, as having been procured in Caithness-shire by Mr Sinclair of Wick, and preserved in that gentleman's collection.

\section{THE WATER RAIL.}

\section{RALLUS AQUATICUS.}

The Water Rail is commonly distributed over the whole of Scotland, including the Outer Hebrides and the Orkney and Shetland islands. I have obtained specimens from the counties of Argyle, Ayr, Inverness, Perth, Moray, Banff, Aberdeen, Forfar, Fife, East Lothian, Berwick, and Wigtown; also from the islands of Harris, North Uist, Lewis (where it is plentiful), Skye, Mull, and Iona. It is also met with in Ross and Sutherlandshires. In some of the midland and eastern counties it appears to be resident all the year, and the same, indeed, may be said of it in some of the inner islands, where, from the want of vegetation or brushwood 
near its haunts, it is often, when frozen out, seen running about in a half-bewildered state seeking protection. At such times it may easily be captured, as it seems reluctant to take flight for its own safety, even when pursued. When caught, it soon becomes reconciled to a life of captivity. Mr Graham mentions having had one at Iona which he kept in the house, allowing it full liberty to run about the rooms. It was very amusing to see it unconcernedly stalking through the apartments, picking its steps enquiringly among the dogs and cats basking on the hearthrug, and with as much apparent freedom as if it were merely reconnoitring the banks of a duck pond.

According to Sir William Jardine, white varieties of this bird sometimes occur. I have observed remarkable differences in the size of specimens-some measuring within a fraction of twelve inches in length, while others were little more than nine inches and a-half.

\section{THE MOOR-HEN.}

\section{GALLINULA CHLOROPUS.}

Cearc uisge.

The familiar Moor-hen is abundant everywhere on the western mainland, and also throughout both groups of islands. In the Outer Hebrides, and, indeed, in many of the less frequented parts of the mainland, it is much more tame than in other places where sportsmen are in the habit of shooting wild fowl, and is sometimes found associating freely with barn-door fowls, feeding and even roosting with them. I recollect seeing in the island of Benbecula one of these birds perched on a rope in one of the native huts. It came to the hut every night and took up its position among the cackling poultry, preferring, however, this curious perch where it sat alone and swung itself to rest. In the morning it left for the lakes, a short way off, where it spent the day in pursuit of shells and water beetles. For ease and dexterity, the most proficient ropewalker could not have excelled the performances of this feathered Blondin.

Mr Graham, writing from the island of Iona, says: "Two pairs came regularly to breed upon a little marshy lake among the hills of Iona. I suppose the natives are not very familiar with it, for 
on showing a specimen, which I had shot, to some of our islanders, they could not decide what it was, although a serious old Celt hazarded the conjecture that it might be the devil in feathers; for, having the feet and legs of a common hen, was it not running in the face of all nature's laws to dive and swim? The pairs referred to had evidently been migratory visitors from the mainland, as even in this out of the way mountain tarn, which was so small as to be walked round in a few minutes, and had no more cover than a handful of thinly growing reeds, it was nearly impossible to get a shot at them. They invariably disappeared whenever anybody approached, and continued invisible so long as the cause of alarm remained." I had often observed Moor-hens practising the same ingenuity at concealment in other places, and on several occasions had seen them holding with their long toes the stems of plants under water, in order to keep their bodies submerged. I remember surprising a young family of full fledged Moor-hens in Inch Moin, on Loch Lomond. In their wild alarm they all took to the water and dived beneath the surface. Having sprung into the boat to watch their movements, I was astonished to see two or three of them at the bottom trying to push their heads under a half submerged boulder lying on a bed of shingle, just as crabs would have done on being disturbed. They were very soon, however, obliged to abandon their apparently suicidal intention and come to the surface, after which they paddled quickly away from the shore. An hour afterwards I found one of them floating helplessly on the lake about half a mile distant; it was quite stiff, and incapable of motion.

Mr Harvie Brown informs me that the Moor-hen is found breeding in the north of Caithness, and that he has eggs in his collection which were taken in the summer of 1869 near Thurso.

I have a number of eggs of this species now before me, from the banks of Loch Leven, where they were obtained by Mr Sinclair. These present considerable variation, both in shape and colouring, from the common type; they are much more obtuse at the ends, and are of a darker shade; the ground colour is in fact only a shade lighter than the spots. 


\section{THE PURPLE GALLINULE.}

\section{PORPHYRIO HYACINTHINUS.}

A SPECIMEN of this bird, the sex of which was not noted, was shot near Campbeltown, in Argyleshire, in the first week of December, 1863 , and sent in the flesh to $\mathrm{Mr} \mathrm{M}^{\prime}$ Culloch, bird stuffer, Glasgow, in whọse hands I saw it. The specimen was afterwards exhibited by Dr Dewar at a meeting of the Natural History Society of Glasgow.

This splendid species appears to be found abundantly in the southern parts of Europe, and is a native of Italy, Sicily, the Ionian Islands, Sardinia, and France. It has, in fact, a somewhat extensive geographical range, being well known over a great portion of Africa, as well as India. In these countries the bird delights the ornithologist as it rises from its sedgy haunts, its blue plumage flashing in the sunlight with a peculiar lustre.

Quoting from Degland, Dr Bree, in his 'History of the Birds of Europe,' etc., states that "this beautiful water-hen is by nature gentle and timorous, and does not leave its solitude unless driven from it by hunger or danger. Its simplicity is such that it will allow itself to be taken alive by the boatmen as it plunges to escape from them. It is also, according to the same authority, easily tamed, and is brought up in some countries in the poultry yards among the fowls, and is contented with the same food that they have." Its habits as observed by other writers, however, can hardly be reconciled with these remarks. Writing from Eastern Africa, Mr Salvin (Ibis, vol. i., p. 361) says it keeps very much out of sight among weeds, quietly devouring the contents of ducks' nests ; while Mr Tristram, who had observed it in abundance on the northern lakes of the same continent (Ibis, vol. ii., p. 80) mentions that he had seen one seize a young duckling in its huge foot and crush its head with its bill, after which it ate the brains and left the rest of the carcase untouched. Such a carnivorous appetite but ill accords with the fine purple clothing of the bird, and certainly lessens the regret one must feel at the inhospitable reception this "foreign ambassador" met with on reaching our shores. Our duck and snipe preserves can well dispense with so dangerous a visitor.

Having observed the same, or at least a nearly allied species in 
private aviaries in various parts of the West of Scotland, there is a possibility of the Campbeltown bird having escaped from confinement. After a careful scrutiny of the specimen, however, I can find nothing in its appearance to lead to this conjecture; and as the species is so abundant in many parts of Europe, the idea is not untenable that it may have been driven to our coasts in some of the gales at that time prevalent, or come of its own accord to select fitting quarters for a fat living.

A good figure of the Purple Gallinule is given in the fourth volume of Dr Bree's work, to which, and the accompanying description of the species, I have much pleasure in referring my readers.

GRA LLATORES.

LOBIPEDIDAE.

\section{THE COMMON COOT.}

FULICA ATRA.

Lacha-bhlar.

The Common Coot, although much less numerous as a species than the Moor-hen, appears to have an equally wide distribution, being found from north to south over the whole of Scotland, and from east to west extending to the Long island or Outer Hebrides. It is common throughout the inner islands, breeding in suitable places where the two species are found in company. Islay, Skye, and Mull, are frequented by considerable numbers. In a few of these localities it is migratory, leaving its breeding haunts about the commencement of winter; numbers, however, remain all the year. A single pair only has been observed in Benbecula, but it is more common in North and South Uist, as well as Harris and Lewis. One of the Benbecula birds was killed some years ago, but the survivor, after a short absence, returned with another mate, probably from one of the neighbouring islands.

The Coot is common near Glasgow, and is found nesting every year in Possil marsh, and similar places within easy reach of the city. In some districts of the western mainland it migrates on the approach of winter, and repairs to lochs which are but seldom frozen, being more dependent on water than its congener the gallinule. In severe winters, indeed, I have observed it quit its usual haunts, and betake itself to the sea coast; and on such 
occasions have mistaken it at sea for a black duck, especially in the uncertain light of daybreak. Fishermen, and others who have catered for my collection, have also at different times brought me Coots as "foreigners," which they had obtained at a considerable distance from the shore. I attribute their appearance there to their impatience of snow and ice. The gallinule, on the contrary, when frozen out, mixes freely with the poultry or ornamental water fowl, and feeds with them in grateful silence on the good things provided. Pennant says in his 'British Zoology,' (vol. ii., 8vo ed. 1768, p. 393), that he has seen the channel near Southampton covered with Coots, and that in his time they were often taken to market, "where they were exposed for sale without their feathers, and scalded like pigs." It would, no doubt, require skilful treatment to divest the bodies of the black down, which must certainly mar the appearance of a featherless Coot.

The nest of this species is, in some places, especially marshes subject to sudden overflow, a large and compact pillar-like structure, composed chiefly of the stems of water plants. I have seen examples built entirely of a species of Equisetum, and raised fully two feet above the surrounding vegetation. The work of building must be quickly performed, as one which I examined last year on a bit of marshy ground, near the banks of Loch Lomond, and which was remarkably well put together, was constructed of Equisetum stems as fresh as if they had been gathered but a few hours previously.

Dr Saxby states that the Coot is occasionally met with during the winter season in Shetland, but in Orkney it appears to be resident all the year.

NATATORES.

ANATIDE.

THE GREY-LAG GOOSE.

ANSER FERUS.

Geadh-glas.

BeIng a permanent resident in the Long island, this species is perhaps the best known of all the wild geese which frequent that extensive district. At one time it had been one of the commonest birds in the marshy tracts of the south of England; but since 
drainage and cultivation have done so much to banish the more conspicuous wild fowl from their former haunts, it has gradually withdrawn itself from the moorland lochs of the mainland, and is now almost wholly confined during the breeding season to some of the bleakest bird nurseries of the Outer Hebrides. There it leads a comparatively quiet life, being but seldom molested, save at the season when the slender crops are being gathered, and even then the native farmers prefer the practice of driving it off by lighting fires, to the extreme measure of powder and shot. For the last hundred years, indeed, the flocks of wild geese that collect about that season-and a very important one it is to these isolated husbandmen-have been kept at bay by fires alone. As soon as the breeding season is over the geese gather into large flocks, and are then very destructive to farm produce of all kinds; indeed, it requires the utmost watchfulness on the part of the crofters to keep them in check. Several fires are male in the fields, and kept burning night and day; by this means the crops are to a great extent saved; but the moment any of the fires are allowed to fail, the geese, which are continually shifting about on wing, suddenly pitch on the unprotected spot, and often do much mischief before they are discovered.

The Grey-lag breeds in nearly all the islands of the outer group. It is common in North Uist, Benbecula, and South Uist, and is found occupying the breeding stations early in May. Mr Harvie Brown took a nest of eggs which were hard sat upon, on 2d May, 1870; but Mr Elwes, who visited the Long island in 1868, saw flocks of as many as thirty together later in the season. The nest, which resembles that of a great black-backed gull when found breeding on heath clad islands, with the exception of being lined with down and feathers, is generally placed in a tuft of coarse grass, or among rank heather, and contains from four to six eggs. When the young are fully fledged, they keep together in family groups for some weeks, and are often seen shifting their quarters from one side of the island to the other. I have noticed small flocks of seven or eight birds in the beginning of August, and a month later I have observed as many as from forty to fifty; but about the middle of October the various families collect into still larger flocks, and continue together until the month of April following, when they break up for the season. During a visit to the Long island in 1867, I was much interested with a flock of 
semi-domesticated Grey-lag Geese on the farm of Mr John Macdonald, Newton. There were about thirty birds in this flock, and they had all been hatched from eggs taken on the moors. On walking towards them I found they would not permit a near approach, but flew off at once, getting readily into a strong flight, and uttering loud cries as they wheeled in a wide circle before alighting again. Mr Macdonald informs me that these birds betake themselves regularly to the hills to breed, and come back to the farm as soon as the hatching season is past. My most recent experiences [August, 1870] in the Outer Hebrides, remind me of a curious effect which I noted in connection with the call note of this bird in these quiet solitudes. I had reached South Uist, and taken up my quarters under the hospitable roof of Mr Birnie, at Grogary, whose very great kindness I shall not soon forget, and in the stillness of the Sabbath morning following my arrival, was aroused from sleep by the cries of the Grey-lags as they flew past the house.' Their voices, softened by distance, sounded not unpleasantly, reminding one of the clanging of church bells in the heart of a large town.

Nothing can be more desolate looking than some of the haunts of the Grey-lag in the Outer Hebrides. In North Uist especially, where it breeds away from the cultivated tracts on the west side of the island, the nests are usually found on the most barren part of the moor, out of sight and hearing of all that tells of civilized life. In Benbecula and South Uist there is perhaps less of that feeling of desolation to picture; in one or two spots, indeed, such as the neighbourhood of Nunton in the one island, and Howmore and Grogary in the other, the nursery scenes are comparatively bright and fair; still the very cries of the birds as they cross the path of the wearied traveller on the Hebridean highways are so full of lament and disquietude that when, at the close of day especially, the disturbed groups rise one after another in alarm from their dreary repose, the blending of voices becomes, perhaps, one of the most memorable sounds that the ornithologist can listen to. Such, at least, has been my own feeling when traversing these lonely wastes, though it must be admitted that in listening to such "voices of the night" much depends on the circumstances in which the traveller is placed, for these same moors are capable of yielding impressions varied according to the time of day, the season of the year, the state of the weather, to say nothing of the temper of the 
tourist. I have, it need not be denied, experienced the force of all these considerations, having journeyed from north to south, and from one side to the other of the entire group; in the dead of night, against a westerly gale and floods of rain, and under the burning blaze of a July sun; in the full enjoyment of the calm delights of autumn, when the blue lakes were studded with a thousand water lilies, and in less pleasurable moments, about which the least said would certainly be soonest mended. I recollect some years ago experiencing a somewhat rough passage of three days and nights to Lochmaddy, during which but little bodily rest could be obtained, and finding on my arrival that in order to save a delay of some hours I should be compelled, instead of enjoying a night's sleep at the inn, to face the darkness and travel twenty miles southwards. On the road I found myself exposed to a succession of showers of rain like split peas, which even at this distance of time force the conviction upon me that the most amiable temper could not long survive the full blast of a Hebridean storm. "Does it always rain in this furious fashion?" I asked of the guide who accompanied me. "Oh no, sir," he promptly answered, "it was warse yesterday."* On we travelled, and as we neared the ford-three miles in breadthwhich separated the islands of North Uist and Benbecula, we found a comparatively clear track indicated by stone beacons, just becoming visible in the morning light. About half way across, where the sand was dry and firm, we came upon a large flock of Grey-lags resting themselves. There were altogether from eighty to a hundred birds, and they took but little notice of us as we wheeled round a rocky point in full view of the assemblage. Wishing to know how near we could approach without exciting their suspicions, we diverged from our course, and bore noiselessly down upon them, the little Highland pony pricking his ears in wonderment at the apparent obstruction of stones in the way; and when at last the gander in chief sounded his warning and rose, followed by the entire gang, we were near enough to tempt me to take from my pocket a lump of granite, which I had picked up as a cabinet specimen, and hurl it into their midst. "Did you

* Dry humour like this deserved full recompense at the nearest licensed house of shelter, but in reply to my inquiries, Allan, to his credit, assured me it was thirteen miles distant. Many gillies would have declared it to be but wanl 
observe," I remarked to my companion, after recovering my specimen, "how the pony pricked his ears at the geese?" "Deed aye, sir," rejoined Allan, "I saw his lugs whyles pointed backwards."

Mr Harvie Brown informs me that the Grey-lag still breeds in some numbers in Sutherlandshire, and from Mr Elwes I have learned that it is found in small flocks during the greater part of the winter in various parts of Islay, where it is less plentiful than the white-fronted goose. It is later in arriving than that species, and leaves about the middle of April. Considerable numbers are known to breed in the counties of Ross and Caithness, especially on the islets on Loch Maree.

\section{THE BEAN GOOSE.}

\section{ANSER SEGETUM.}

In the Outer Hebrides the Bean Goose is a common winter visitant, remaining on the outlying rocks and islets, especially in the neighbourhood of Harris, as late as the beginning of June. Its nest has never to my knowledge been discovered in any part of the Long island, although it is stated by Macgillivray that it frequents the Hebrides in summer. There can be no doubt that his observations ou this bird apply to the preceding species. According to $\mathrm{Mr}$ Selby, the Bean Goose had been found breeding in several of the Sutherlandshire lakes, but recent observers have failed to corroborate his records. There may have been a mistake in the species here also-a circumstance hardly to be wondered at when it is borne in mind that the grey-lag was then supposed to be a comparatively rare bird, whereas it now turns out to be the only native species inhabiting the north and north-western districts of Scotland.

Mr Elwes informs me that the Bean Goose is not uncommon in some parts of Islay, but that it does not arrive there till January or February. The flocks are not large, and the birds are very wary. These are probably from some of the outer islands, where they have exhausted their feeding grounds. The movements of geese, indeed, are greatly influenced by this consideration.

Throughout the winter months very large flocks of this species frequent Montrose Basin at ebb tide, and the adjoining fields when the vast stretch of mud and sand is covered. I have seen 
many hundreds there, and have recognised them readily from a passing train at Dubton Junction. On one occasion, the birds, although feeding within thirty yards of the railway embankment, merely ran together with raised heads, and stood on the alert until the train had gone past, after which they lowered their necks and resumed feeding.

The Bean Goose is also common in Haddingtonshire, where it frequents wheat fields, doing considerable damage sometimes to the sprouting grain. Large and noisy companies resort at nightfall to the open sands near the Tyne estuary, and retire at daybreak to the Lammermuirs. In Fifeshire its habits are similar. When travelling through that county in the winter time, I never fail to observe small flocks coming from the higher grounds in the afternoon, and steering for the mouth of the Eden, near St. Andrews. Mr Harvie Brown, writing from Stirlingshire, says: "It is our commonest goose on the east coast, punishing the farmers' newly sown beans in early spring, through the day; and, as one of the fraternity informed me, 'paidling aboot i' the mud at nicht,- - deil tak' them.' " The Carseland, west of Stirling, is also visited by them in great numbers. It is somewhat strange that this species, which is so very common on all parts of the east coast of Scotland, should only be an uncertain winter visitant in Orkney.

In my earlier recollections of these "cloud cleaving" birds, I well remember the long lines of geese steering in their $>$ shaped flight across the town of Dunbar in a westerly direction to the Tyne mud flats. Almost daily as many as six or eight of these flights could have been observed flying scarcely out of gunshot, and making a loud and confused cackling noise. Sometimes in misty weather the birds lost their way. I recollect being surrounded one evening after dusk by some hundreds, judging from their prodigious outcries. I was walking on the public road, and was surprised to find the benighted geese fluttering against the bare hedge, the prickles of which certainly did not diminish their consternation. A similar incident is narrated in the new Statistical Account of Scotland by the minister of Borthwick, who thus describes the occurrence:-

"Flights of wild geese regularly pass over us to the moors, where they have their favourite feeding grounds. These birds are proverbial for leading men on a perplexed and fruitless search; but I 
once witnessed a puzzled and diverting condition of their own phalanx. The day had suddenly become foggy to an uncommon degree. As I was amusing myself in my garden, I heard the wild geese advancing at some distance. When they had come almost directly over the spot where I was, they seemed to have become seized with an immediate panic, from an apprehension that they had either lost their way, or could no longer proceed in safety through the mist. The noise they made in consequence was like the twanging of a thousand instruments of brass. Sometimes they seemed to descend in a body so near the earth that a stone thrown vigorously from the hand might, as it seemed, have brought some of them to the ground. Again they mounted to a much greater height-and the noise and the perplexity continued for about twenty minutes-the birds still hovering over nearly the same spot of ground. No person who heard the noise could doubt that their fear and perplexity were extreme. At length they found some way of escape; but whether a breeze had opened up to them the distant prospect which they sought for, or whether they had ascended to a higher region above the fog, or whether some goose more sagacious and possessed of greater authority than the rest, had undertaken to pilot them through the mist, I was not able to determine. The impression, however, on my mind at the time was, they were a very fit emblem of some popular assemblies which I have seen, [let us hope the reverend writer does not refer to meetings of presbytery] when, like the wild geese, they too are at a stand about some puzzling question, and know not how to proceed. The noise and the dissonance were very much of the same kind."

\section{THE PINK-FOOTED GOOSE.}

\section{ANSER BRACHYRHYNCHUS.}

The late Mr John Macgillivray announced many years ago that he had found the Pink-footed Goose breeding in considerable numbers on the islands in the Sound of Harris, and also on the lakes of North Uist; but subsequent observations have proved that he had mistaken the grey-lag for that species. The Pinkfooted Goose is, in fact, only found in the winter months in any part of Scotland; and, with the exception of the western islands, no locality can boast of it in any numbers. In Montrose basin 
it appears to be a regular visitant in very small flocks, consisting of at most four or five birds. I have seen and carefully examined specimens in the flesh which had been shot there. On the western mainland it is even less common, occurring for the most part singly or in pairs, and mixing with other wild geese. In this way it is taken by the lessees of the west country shootings, and sent to the Glasgow poulterers. One or two were killed in the winter of 1867-68 in the Clyde estuary.

Writing from Newton, in North Uist, Mr John Macdonald states that the habits of this bird differ from those of the grey-lag, and that he has no difficulty in distinguishing flocks of both species when shifting their quarters. "They arrive here," says Mr Macdonald, "in October and November, in small flocks which seldom contain more than thirty birds; when watching their movements on the wing, it often occurred to me that they were very undecided, and seemed not sure of their course. I have known them go more than a mile, then turn back and afterwards take the same course, and this when not disturbed. When they alight they seem to want the faculty of knowing, as the grey-lag does, the most dangerous places. I have seen them in parks and enclosures near houses-localities generally avoided by the grey-lag, except when tempted by corn or young clover. I have never noticed any Pinkfooted Geese after the month of January; in fact, they then appear to rest here only for about two months, and retire regularly to some other attractive habitation. Their call is so very different from any other geese, that there can be no mistake in distinguishing them. They do not associate with the grey-lag, but I obtained a single specimen which was shot in the midst of a flock of Bernicle geese."

\section{THE WHITE-FRONTED GOOSE.}

ANSER ALBIFRONS.

AFTER much patient research, I have come to the conclusion that this species is the most local of all the British wild geese. It seems to be plentiful in Islay, from which island I have seen fine examples of the bird sent to the Glasgow bird stuffers; but in nearly all the other islands, including the whole of the outer group, it can only be ranked as a straggler. Mr Graham has met 
with it on one or two occasions in Iona and Mull-the specimens which he obtained having been attracted by tame geese in the poultry yard, with which they remained for some time. Mr John Macdonald, Newton, has also informed me that it is rare in North Uist: one was seen on his farm in 1856, and another was shot there in the winter of 1868. This last specimen attracted Mr Macdonald's attention by its peculiar cry: it remained for several days beside his semi-domesticated grey-lags, and seemed to prefer their company to that of the domestic geese. Similar records have been sent me from other islands, and also from some districts on the mainland, all of which tend to shew that when single individuals stray from the main body they readily take refuge, after a time, among domestic poultry. In the West of Scotland its head quarters are in the island of Islay, and I am indebted to Mr Elwes for the following interesting notes which are the result of his own observations on the species:- "This is the common grey goose of Islay. It arrives usually in the first week of October, and stays till the second week in April. On their first arrival they keep a good deal about the lochs, and feed in the marshy places around them; but later in the year they go regularly to the stubble and grass fields to feed, shewing a great partiality for particular fields. They go in flocks of from three or four to one hundred or more, and are not very difficult of approach to a good stalker when on the fields, as there is nearly always some wall or ditch within shot of them. The old birds sometimes have the breast entirely black, but usually the black is in irregular bars. Neither the whitefronted nor any of the geese except the brent, settle on the water often, unless driven to do so, as they seem to prefer the land." From this island, as has been remarked, stragglers appear to leave the main body occasionally, and make their appearance here and there as solitary visitors at farm steadings. The last deserter I had an opportunity of examining - a very beautiful male birdwas shot on the Clyde, near Dumbarton, on 15th January, 1868.

In the eastern counties of Scotland the principal flock of Whitefronted Geese seems to attach itself to the county of Elgin or Moray, where the species appears to have attracted the notice of the late Mr St. John many years ago. Southwards it is found wandering in exactly the same way as has been observed in the west. I have seen stray specimens killed in Forfarshire and Aberdeenshire, and the Earl of Haddington informs me that a 
very fine specimen in adult plumage, now in his collection, was shot in a meadow at the mouth of the Tyne in East Lothian, on 11th February, 1867.

Sir John Richardson, in the Fauna Boreali Americana, remarks, with regard to this species, that it is not uncommon on the coast of Hudson's Bay. The Indians imitate its call by patting the mouth with their hand while they repeat the syllable wah. The same writer, on the authority of Mr Murray, has the following notes on its breeding habits in his 'Journal of a Boat Voyage,' etc., published in 1851, which I have not yet seen quoted in any ornithological work:- "With respect to the breeding quarters of the laughing geese (Anser albifrons) I am able to inform you correctly, having myself seen a few of their nests; and, since the receipt of your letter, made further inquiry among the northern Indians. Their nests are built on the edges of swamps and lakes throughout most of the country north of the Porcupine where the ground is marshy. It is only near the most northerly bends of the river that they are seen in the breeding season, and these are male birds. They pass to their breeding places in the beginning of June, and make their nests among long grass or small bushes, where they are not easily seen. They are shy birds when hatching; and, when any one comes near the nest, manage to escape unperceived, and then show themselves at a distance, and manœuvre like grouse to lead the intruder away from the place. Notwithstanding our ruthless habit of collecting eggs of all kinds to vary our diet, I have often felt for a laughing goose, whose anxiety for the safety of its eggs was frequently the means of revealing to us the situation of its nest. When the bird was swimming some hundred of yards off, immediately that any person in walking round the lake came near its treasure, the poor bird began to make short impatient turns in the water, resuming her calm demeanour if the intruder passed the nest without seeing it. As soon as the eggs are taken, the goose rises out of the water and flies close to the head of the captor, uttering a frightened and pitiful cry. These geese are more numerous in the Valley of the Yukon than any other kind; and the numbers that pass northwards there are perhaps equal to that of all the other species together."*

Audubon speaks of the flight of this species as very similar to * 'Arctic Searching Expedition,' etc., vol. ii., page 110. 
that of the Canada goose, being firm and well sustained, and that when travelling the flock passes at a considerable height, arranged in the same angular order, and apparently guided by one of the older ganders. Later writers, in the belief that a greater size of bill entitles the American bird to specific distinction, have changed the name to $A$. Gambelli. Professor Baird even hints the possibility of there being two species of White-fronted Goose on that continent. Age, sex, difference of feeding, to say nothing of the too prevalent desire to establish new species, should not be lost sight of in the consideration of this subject. As regards the bills of all our British wild geese, there could not, I fear, be a more inconstant feature on which to found a specific character.

Professor Newton mentions having seen several freshly killed examples of this goose in May, 1858, at Reykjavik, in Iceland, where all the Icelanders who saw the birds recognised them by a local name.

\section{THE BERNICLE GOOSE.}

ANSER LEUCOPSIS.

Cathan.

The Bernicle Goose is a very common bird in the West of Scotland, and especially abundant in the Outer Hebrides, where it arrives early in October. Being a strictly migratory species, it takes its departure about the end of April or beginning of May, by which time the grey-lag goose has commenced laying.* Previous to leaving, the Bernicle Geese assemble in immense flocks on the open sands, at low tide, in the Sounds of Benbecula and South Uist; and as soon as one detachment is on the wing it is seen to be guided by a leader, who points the way with a strong flight northwards, maintaining a noisy bearing until he gets the flock into the right course. After an hour's interval, he is seen returning with noisy gabble alone southwards to the main body and taking off another detachment as before, until the whole are

* Mr Harvie Brown informs me, that in the first week of May, 1870, he saw and fired at large flocks of Bernicles in North Uist, and that on the 12th of the month he picked up a dead male, quite fresh and fat, on an island near Lochmaddy. It had been wounded two days previously by $\mathrm{Mr}$ J. M'Dunald, who saw large flocks passing northwards at a great height. 
gone. A notice of this singular habit was first communicated to me by $\mathrm{Mr}$ Alexander A. Carmichael, and has since been corroborated by Mr Norman M'Donald, who informs me that the inhabitants of the Long island have been long familiar with it.

Throughout the Inner Hebrides the Bernicle is also a wellknown winter visitant to localities where there is suitable feeding ground. I have been informed by $\mathrm{Mr}$ Elwes that it frequents Islay in very large flocks every year, where it seems to attach itself to an island near Ardnave. Being but little disturbed there, and finding plenty of grass on the island, and on the sand-hills of Ardnave, these flocks remain the whole winter. At low water they often betake themselves to the open sands at the mouth of Loch Grhuinard, but make the island their head-quarters, and go but seldom to feed on the shore until they have eaten up all the grass of the island. They are not so shy as the grey geese, and, when feeding busily, may be approached with ease under cover of the sand hills.* They keep up a constant cackling both when feeding and when on the wing, being in this respect unlike the grey geese, which usually feed in silence. The Bernicle Goose seems essentially a land bird, and is never known to settle on the water unless constantly shot at. It feeds entirely on grass and the roots of the bents which grow on the sand hills. Gastronomically considered, the Bernicle is by no means equal to the brent goose.

The following curious record of the habits of this bird appears in "A Memoriall of the most rare and woonderfull things in Scotland as they were Anno Domini 1597," the authorship of which has been ascribed to one J. Monipennie:-

"At Dumbartan, directly under the castle at the mouth of the river of Clyde, as it enters into the sea, there are a number of claik-geese, blacke of colour, which in the night time do gather great quantitie of the crops of the grasse growing vpon the land, and carry the same to the sea. Then they assemble in a round, and, with a wondrous curiositie, do offer euery one his owne portion to the sea floud, and there attend vpon the flowing of the tide, till the grasse be purified from the fresh taste and turned to the salt; and lest any part thereof should escape, they labour to

* By watching a favourable opportunity, a good raking shot may be obtained. I have known as many as eighteen to have been killed in the Sound of Harris at one discharge from an ordinary fowling-piece. 
hold it in with labour of their nebhes. Thereafter orderly euery fowle eates his portion. And this custom they obserue perpetually. They are verie fatte, and very delicious to bee eaten."

It is not a little strange that these birds, notwithstanding the extraordinary changes that have taken place, and the continual passing and repassing of large ships and steamboats, should still visit the locality in considerable numbers. I have been informed by Mr J. Watson that he has of late years seen large flocks near Cardross, and heard their noisy outcries after nightfall.

\section{THE BRENT GOOSE.}

\section{ANSER TORQUATUS.}

\section{Guirenan.}

Throughout western Scotland the Brent Goose is much less common than the preceding species-a circumstance arising probably from a comparative want of suitable feeding ground. It is therefore more local in its habits with us than on the eastern shores, where such places as the Firths of Beauly and Cromarty prove so great an attraction. Though it occurs in the Outer Hebrides, one can never calculate with certainty on seeing it, as in the case of the bernicle. A few are known to frequent the west side of Loch Bee, in South Uist, where the water is occasionally brackish, and small flocks have sometimes been met with in Benbecula and North Uist. Its visits are, of course, strictly confined to the winter months. In the circle of the inner islands, the best known haunt of the Brent is in Islay. A very large flock is annually observed at Loch Indaal-a locality much better suited to the habits of the bird than most Highland sea lochs, on account of the abundance of grass which grows on the muddy sands, and which forms the principal food of the species. Mr Elwes, who has observed this flock, informs me that the Brent Geese remain at Loch Indaal during the entire winter, and that at low water they sit a good deal on the sands, and seem to feed principally by day, being very little disturbed and sometimes tame enough to let a boat approach within seventy or eighty yards before rising. Their cry is a deep metallic note something like craunk, craunk, repeated several times, but they do not utter it much, except when they 
have been disturbed by boats or otherwise. Brent geese afford excellent eating, their favourite food being a sweet grass which grows on the flats in shallow water.

On the east coast of Scotland the Brent Goose is particularly abundant in certain firths or estuaries, and is found throughout the winter months in tolerably large flocks from Berwick to Orkney. Selby speaks of having been informed that twentytwo were killed at one shot near Holy Island; and a writer in the 'Edinburgh Journal of Natural History' for May, 1837probably Mr Macgillivray, the editor-states that he had seen a flock of ten thousand Brent Geese in the Cromarty Firth between Invergordon and Cromarty ferry. He does not, however, say what means he took to count them.

\section{THE RED-BREASTED GOOSE.}

\section{ANSER RUFICOLLIS.}

The late Dr Fleming, in his meritorious work on British Animals, thus announces the occurrence of a specimen of this rare straggler in Scotland:- "One was shot near Berwick-on-Tweed by $\mathrm{Mr}$ Burney, gunsmith, and sent to $\mathrm{Mr}$ Bulloch, in whose possession I saw it in May, 1818." Another, said to have been killed in the county of Caithness, is alluded to by Mr Wilson, but the date and precise locality are not given: the specimen is still preserved in the collection which belonged to the late Mr Sinclair of Wick. A third appears to have been seen for several days in the immediate vicinity of the loch of Strathbeg many years ago-a notice of which was sent to Professor Macgillivray by the Rev. Mr Smith of Monquhitter, who stated that the species had been "recognised by more than one individual well conversant with ornithology."

\section{THE EGYPTIAN GOOSE.}

\section{ANSER EGYPTIACUS.}

THIs species appears to be of irregular occurrence both in the eastern and western coasts of Scotland. It is generally met with in flocks during winter, and although these exhibit all the wariness of ordinary wild fowl, it is very doubtful whether they can be 
regarded in any other light than escaped birds from private ponds where large numbers of ornamental water-fowl are kept. Being a southern species, it is hardly probable that its range extends to Great Britain; yet it is somewhat curious that in some particular years it should be more restless than in others. Thus in 1832 unusual numbers appear to have been roaming over the southern districts of Scotland ranging from the Tweed to the Forth, thence across to Loch Lomond. A small flock was seen on the Tweed in February of that year, and in the month of November following a flock of nineteen was observed in East Lothian flying southwards during a storm. The leader was shot, and examined by the late Dr Macgillivray. About the same time, three were shot near Campsie, in Stirlingshire, and one or two birds alighted on Loch Lomond, where the species has been procured on two or three subsequent occasions. Three were shot out of a flock of five on this loch in the winter of 1861 , one of which was exhibited by $\mathrm{Dr}$ Dewar at a meeting of the Natural History Society of Glasgow; and in January, 1867, other two were shot from a small flock which had been observed to alight there some time previously. Another was killed on the Forth at the same time, and is now in the collection of Dr Dewar.

Five of these birds were observed in Montrose Basin in the winter of 1865 , and a similar flock appeared there in 1867 . In addition to the East Lothian flight already mentioned, I may refer to another flight of about a dozen, out of which a beautiful male bird fell to the gun of a friend, who sent me the specimen when fresh. This occurred at Tyne Sands in 1846, and the Earl of Haddington has obligingly informed me that he shot a fine male near the same place in the winter of 1862 .

\section{THE SPUR-WINGED GOOSE.}

\section{A NSER GAMBENSIS.}

THE only Scottish specimen of this rare bird which I have seen recorded, is one which was shot near Banff in February, 1855, and preserved by Mr Thomas Edward.

A nearly allied species-Plectropterus Rueppelli-which has been described by $\mathrm{Mr}$ Sclater in the proceedings of the Zoological Society for 1859, has been held as identical by Professor Schlegel 
in his catalogue of the Leyden Museum, 1866. This has induced the editor of the 'Ibis,' who is assured of their being specifically distinct, to enquire to which of these species the specimens killed in Great Britain should be referred.

\section{THE CANADA GOOSE.}

\section{ANSER CANADENSIS.}

IN writing of the vernal flight of this species, Wilson, the American ornithologist, says:- "It is highly probable that they extend their migration under the very pole itself, amid the silent desolation of unknown countries, shut out since Creation from the prying eye of man by everlasting and insuperable barriers of ice. That such places abound with their suitable food, we cannot for a moment doubt, while the absence of their great destroyer, man, and the splendours of a perpetual day, may render such regions the most suitable for their purpose." This restlessness of the species becomes apparent in April, and continues till the middle of May, when the great body has passed northwards for the purposes of incubation. There can be no doubt that on their return southwards many birds are driven out of their reckoning, and find their way to the shores of Great Britain. Single birds and small flocks have at various times occurred in the West of Scotlandon Loch Lomond repeatedly, on the river Clyde, and in Ayrshire. A specimen was shot in the estuary of the Clyde on 29th March, 1863; another on a loch at Tarbolton on 11th March, 1865; while on Dongalston Loch, near Glasgow, a flock of six or seven birds was observed in March, 1867, three of which were shot. A few specimens have likewise come under my notice in April, in which month they apparently collect and steer northwards as they do "at home." Mr J. H. Dunn of Stromness, Orkney, has informed me that on 8th May, 1843, he saw a flock of Canada Geese flying overhead on their way homewards, probably en route for Greenland via the Faroes and Iceland. According to the late Sir John Richardson, this species occasionally breeds in trees on the banks of the Saskatchewan, taking possession of, and depositing its eggs in the deserted nests of ravens or fishing eagles. A raven's nest is no doubt a bulky enough structure, but after having been sat upon by a fat goose during the period of incubation, it 
must have greatly perplexed the original proprietor on revisiting it in the following spring when trying to identify its own property.

Mr Harvie Brown informs me that a female Canada Goose, now in his collection, was shot out of a flock of four at Carron dams, near Falkirk, on 8th June, 1869.

\section{THE HOOPER OR WHISTLING SWAN.}

\section{CYGNUS FERUS.}

Eala.

The Common Wild Swan, as this species is called, generally arrives in the Outer Hebrides in November, although in some years earlier, especially during the prevalence of northerly winds. Four or five birds, and occasionally a dozen or so, come together in a flock; they fly low, and are often shot as they pass overhead, coming in from the sea. These flocks appear to be families, judging from their arrival in groups of young and old. They always fly in a line, calling to one another frequently with loud trumpeting cries. On Loch Bee, in South Uist, which is never known to be frozen over, they are especially numerous in severe weather, as many as four hundred having been seen there in one flock. This lake is quite shallow at the north-western extremity, and affords the birds ample feeding ground, so that it becomes a general rendezvous for many weeks. They are not much molested as, unless the birds are very near the shore when fired at, it is almost impossible to capture any that may be wounded, the lake being several miles in circumference, and deep and cold enough to deter any ordinary human retriever, even after getting fairly under weigh. Ten minutes experience in Loch Bee would convince the bravest man or dog that a wounded swan there might as well be in the Minch. About the middle of April the noble congregation breaks up into detachments, as the bernicle geese are known to do, and after much sounding of bugles summoning the feathered hosts into the air, they soon get into their line of flight, and are afterwards seen at a great height steering for their northern home.

On the other numerous lakes of the Long island, similar observations on winter flocks of swans may be made. In Lewis they 
are occasionally known to alight on Loch Langabhat, and also in Harris in a lake of the same name. Benbecula and North Uist are likewise frequented, but all these haunts are much inferior in interest to Loch Bee. Sometimes a straggling pair remain behind the main body, as if inclined to make Loch Bee their summer quarters, but when they have had time to ponder over their prospects, they wisely take their departure. Mr Harvie Brown, writing from the Outer Hebrides on 17th May, 1870, informed me that two wild swans were seen about a week previously on a lake in the west side of North Uist.* In the Inner Hebrides the Hooper occasionally visits Skye, Iona, and Mull, and is also found in small flocks every winter in Islay, where it is much more numerous in hard weather. One which was caught and pinioned, has lived on Loch Guirm in that island for thirty years, but is said to be still rather wild. On the mainland flocks occur regularly in various districts from Sutherlandshire to Wigtownshire. Numbers appear in Loch Lomond, especially in severe winters, and it is still more common in Lochwinnoch, in Renfrewshire, where about fifty tame swans are kept. In the summer months, the sight of this splendid fleet proudly sailing on the blue expanse of water is very striking, and, even in winter when the loch is clear of ice, they may be seen at all hours feeding in the shallow parts. Attracted by these birds, the wild swans often alight in parties of six or eight, and are soon recognised by their alertness and inferior size, besides the darker colour of their plumage, many of them being young birds. Several were shot there in January and February, 1871, and $\mathrm{Mr}$ Harvie Brown has informed me that three or four were observed on the Forth, in Stirlingshire, about the same time.

In other parts of Scotland the Wild Swan is frequently met with, but its appearance is, in a great measure, regulated by the state of the weather. In mild winters it is not often observed, but during seasons of unusual severity it is still a marked object in our principal lochs and estuaries which are frequented by other

* A few years ago, a wounded swan remained throughout the summer on Loch Bee, and attracted much attention by the loud and melancholy cries to which it gave utterance. An old crone, in telling me about this bird, reiterated her conviction that it was the ghost of her grandmother, who had met with a violent death about sixty years previously. It was a bold image, though I cannot but think that a black swan would have been more appropriate. 
kinds of wild fowl.* In October, 1844, the late Mr St. John, in writing to Professor Innes, mentions having seen nearly three hundred swans in the bay of Findhorn, in Morayshire. The birds allowed him to stand at one hundred and fifty yards distance, and count up to one hundred and ninety, when they all rose in a cloud, and presented a magnificent sight while on wing. The following notes by that pleasant writer show a practical acquaintance with the bird which few naturalists have now an opportunity of acquiring:- "A large flight of these noble birds as they circle round the fresh water lakes on their first arrival, is one of the most beautiful sights imaginable. There is, too, a wild harmony in their bugle-like cry as they wheel round and round, now separating into small companies, as each family of five or six seems inclined to alight, and now all joining again in a long undulating line, waiting for the word of command from some old leader whose long acquaintance with the country and its dangers constitutes him a swan of note among the common herd. At last this leader makes up his mind to alight, and in a few moments the whole flock are gradually sinking down on the calm loch. After a brief moment or two spent in looking round them, with straight and erect necks they commence sipping the water, and turning their flexible necks into a thousand graceful curves and attitudes." The Rev. Alexander Stewart of Ballachulish, who has observed the bird in Loch Shiel, in Moidart, and elsewhere in Invernessshire, speaks of its "loud and melodious note, which has a sort of clang and semi-metallic ring about it not unlike that caused by the sudden snapping of the overtightened string of a bass violin." Much, no doubt, depends upon the situation of the listener. I once heard a flight of swans after nightfall in the Outer Hebrides giving utterance in the distance to a series of what I thought pleasant enough sounds; but, on another occasion, as ten of these birds passed within shooting range, and vented their music on me as I suddenly stood up to blaze both barrels (charged only with No. 4) at their leader, I fancied a strong resemblance in their cries to the discord of a German street band. My disappointment on seeing the birds rise higher into the air unscathed, may have induced the unfriendly comparison.

* Mr R. Scot-Skirving has of late years observed wild swans in Aberlady Roads, at the mouth of the Forth, in East Lothian. In 1867, two specimens were seen there by that gentleman as early as the 26th August. 
On 16th April, 1860, a flock of thirty wild swans visited the loch of Strathbeg, in Aberdeenshire. The resident swans (Cygnus olor), although not half so numerous, would not allow them to rest, and ultimately drove them off. Similar notices have reached me from the districts in the east of Scotland, where there are lochs and ponds of sufficient size to attract birds of their habits. In old records I find frequent mention made of wild swans appearing in various districts, counties, and parishes, and alighting chiefly in lakes which are, for the most part, now drained. Thus in 1823, during very rough weather, about twenty pitched upon Kilconquhar Loch, in Fifeshire, a favourite resort of wild fowl, and remained there until the storm abated;" other flocks of a like extent were seen on Loch Spynie, in Morayshire, and also on some of the Ross-shire and Sutherlandshire lakes; and even so far south as Loch Inch, in Wigtownshire, flocks were seen every winter. About one hundred years ago, according to Mr Low, a few pairs bred in the Loch of Stenness, in Orkney, but even there they were so much disturbed by the country people that their early disappearance as summer residents was considered inevitable. The late Dr Patrick Neill-a good authority - has the following note in his 'Tour in Orkney,' which was published in 1806:-“Large flocks of swans annually arrive in Orkney and Shetland in the month of October, and spend the winter about the numerous fresh water lakes in the islands. Early in the spring they take their departure for the peaceful Arctic regions, where they may incubate and rear their young without molestation. Till within these twenty years (as I was told in Orkney) a few pairs regularly remained during the summer in the islets of the great lake of Stenness, and there produced their broods; but, about that time, having been much harassed, this little colony finally abandoned this Orkney-breeding place." Pennant, in his 'Tour in Scotland,' also speaks of great flocks of swans migrating in winter to Loch Spynie (now drained), and mentions having been told of some remaining there to breed.

* In the 'Witches of Pittenweem,' allusion is made to these birds being in this loch at the drowning of a famous hag, in the following graceless and ungallant record:-

" They took her to Kinniuchar Loch,

And threw the limmer in,

And a' the swans took to the hills

Scared with the unhaely din." 


\section{BEWICK'S SWAN.}

\section{CYGNUS BEWICKII.}

IN the Outer Hebrides this, the smallest of our British swans, is well recognised; it frequents the same lakes as the Hooper, and is easily distinguished from that species, even at a distance. Sometimes a flock is seen to remain together in a compact body, and continue for some time feeding on the shallower parts of the loch, thus affording a good "family shot" to the watchful sportsman. Mr Dugald M'Donald has informed me that he killed three of these birds at one shot on a loch in Benbecula in 1859. The flock, on being fired at, rose steadily into the air, leaving two of their number on the water, one killed outright, and the other winged so as to be unable to rise; and after attaining a considerable height, they directed their flight northwards in the direction of the Sound, and were speedily out of sight. In the meantime my friend, having secured his two birds, was preparing for a homeward march, when, to his great surprise, the same flock, after an absence of half-an-hour, returned to the loch they had left, and began circling in their course before alighting. In a few minutes he observed one of their number turn over and fall lifeless with a splash into the water. A shot like this can seldom now-a-days be recorded in connection with any British locality.

On Loch Lomond, Bewick's Swan has been once or twice obtained, and it has also occurred on Hogganfield Loch, near Glasgow. In January and February, 1871, four specimens were shot on Castle Semple estate, Renfrewshire, and early in the latter month other two were killed at Barnashalag, in Argyleshire. All these birds were preserved by $\mathrm{Mr} \mathrm{M}^{\circ} \mathrm{Culloch}$, bird stuffer, Glasgow, in whose hands I saw them. Mr George Kirkpatrick informs me that five specimens were shot in Wigtownshire in January, 1871, and sent to $\mathrm{Mr}$ Hastings, bird stuffer, Dumfries, for preservation. In the east of Scotland it has likewise been noticed from Berwickshire to the Shetlands, where it is known as a regular winter visitant, appearing at the same season as the hooper. At Dunbar, and other places in East Lothian, it has been met with occasionally, but chiefly in immature plumage. 


\section{AMERICAN SWAN.}

CYGNUS AMERICANUS.

The late Professor Macgillivray, in his 'British Water Birds,' vol. i., pp. 675,682 , mentions having found a specimen of this bird in a poulterer's shop in Edinburgh in February, 1841. It had been shot in the South of Scotland. I can find no other record of its occurrence anywhere in Britain. From its general resemblance, however, to the preceding species, its presence in our western lakes and estuaries may have been overlooked. It would be well, therefore, for those who have time and opportunities at their command, to make a careful examination of all the smaller swans captured during the winter months, especially in the Outer Hebrides-a district to which the larger migratory flocks are now almost entirely restricted, since so many changes have been effected through drainage on the mainland.

The specimen described by Mr Macgillivray is probably now in the British Museum, as I find, on referring to Mr G. R. Gray's catalogue of British birds, in that collection (London, 1863) the locality given for the specimen is "Edinburgh."

\section{THE POLISH SWAN.}

\section{CYGNUS IMMUTABILIS.}

I INTRODUCE this swan as a Scottish species, as it has been recorded by Messrs Yarrell and Macgillivray, and also by Sir William Jardine, in their respective works on British birds. The late Mr Yarrell appears to have been the first naturalist to distinguish its characters; and in his account of the species, published originally in the proceedings of the Zoological Society of London, he mentions that "during the severe weather of January, 1838, several flocks were seen pursuing a southern course along the line of our north-east coast from Scotland to the mouth of the Thames," and that "several specimens were obtained." From that time to the present, however, I can find no trace of other specimens having been procured; nor can any of my numerous correspondents state with certainty that they have ever seen the species. 


\section{THE BLACK SWAN.}

\section{CYGNUS ATRATUS.}

DURING the very severe winter of 1828-29, some black swans appeared on Loch Lomond, and one was shot. In 1863, one was seen on the Firth of Clyde near Innellan, and after being watched upwards of a day and a half, it was at length shot. This specimen is now in the Hunterian Museum, Glasgow. Another was killed out of a flock by Mr Clift, bird stuffer, Brechin, in December, 1865. Mr Clift informs me that the swans passed overhead within easy range, as he lay in a field near Montrose Basin after nightfall watching for ducks and wild geese; they were strong on wing and travelling in silence, and he had no idea of the species until the bird fell. A third was shot near Coupar-Angus in November, 1867. In addition to these, Mr Graham has informed me that one was seen on Loch Gilp two or three years ago. On being told of the circumstance, he kept a look out, and at length encountered the bird one day when rowing in his punt. "On after inquiries," says Mr Graham, "I learned that no such bird had ever been kept by any one in our part of the country, and so it must have come from a long way off. I therefore regretted not having shot it, as it was probably lost to its owner."

There can, of course, be no doubt that all these swans had escaped from private ponds, and that their occurrence in a state of liberty merely shows the same restlessness in the bird that occasionally affects other ornamental water-fowl. They seem, however, to be able to forage well enough on their own account when acting the part of deserters; but objects so marked as these rarce aves of old, will never be allowed to give ornithologists any idea how long they could survive in this country if left to themselves.

\section{THE RUDDY SHIELDRAKE.}

\section{TADORNA RUTILA.}

THis rare species, which appears to have occurred but in two or three instances in England, and once in Ireland, has been met with twice within Scottish limits. One of these specimens was 
shot in the island of Sanday, in Orkney, by Mr Strang, in October, 1831, as noticed by Messrs Baikie and Heddle at page 74 of their Natural History of Orkney; the other was shot in Caithness-shire, and is still preserved in the collection of the late Mr Sinclair of Wick. 'The first named seems to have been overlooked by $\mathrm{Mr}$ Yarrell, but is referred to by Mr Macgillivray (B. B., vol. v., p. 21).

\section{THE COMMON SHELLDRAKE.}

\section{TADORNA VULPANSER.}

Cradh-gheadh.

The Strand Goose, or Cradh-gheadh of the Hebrideans, is a very common species, though only a summer visitant, over the whole of the Long island. It is also numerous in Skye, Mull, Islay, Jura, Colonsay, Muck, Tyree, and Coll, and indeed on nearly all the smaller islands of any consequence in the inner group, where it is found breeding. In North Uist it is often domesticated, and becomes an ornamental addition to the poultry yard. I saw several pairs in the autumn of 1867 on the farm of $\mathrm{Mr} \mathrm{J}$. Macdonald, at Newton, mixing freely with the common ducks and other poultry.* Mr Macdonald had also in his possession at the time of my visit one or two hybrids between this bird and the domestic duck, which were at once distinguishable by their curious shape, long legs, and smarter movements. Its principal haunts are on the west side of the outer islands, where there are large tracts of sand and low pasture lands; but, even with these attractions, the Shelldrake is sometimes not satisfied, as it has been known to betake itself to inland haunts, and settle in burrows on the open heath. In such situations, however, it is never far from water-the Long island being literally covered with lakes.

* About two years ago, a beautiful male visited the farm of Woodland, near Girvan, in Ayrshire, and voluntarily took up its quarters in the poultry yard. Mr Cunningham, through whose courtesy I had an opportunity of seeing and examining the bird, informs me that it came during a westerly gale, and immediately joined the other ducks about the farm as if it had been accustomed to their society. It daily goes to the beach, which is quite close to the farmsteading, and frequently indulges in a short flight seawards, during which its beautiful plumage is seen to great advantage. 
A few pairs also breed on the east side of North Uist. Mr Harvie Brown took a nest on an island in a lake near Lochmaddy, on 10th May, 1870; the burrow described nearly a circle, and the eggs - ten in number, which had been sat upon-were found nine feet from the entrance.

Mr Graham has favoured me with the following notes on the species, as observed by himself at Iona:- "This handsome and showy bird is common at all times. Its nest is frequently found on the smaller islets in rocky holes, or holes scooped in the sand, and the young broods are often met swimming a little way from the land, convoyed by one or two of the old birds, who show their uneasiness by flying about, rising and alighting just out of shot of the approaching boat. But their anxiety for their little ones is groundless, as the little downy creatures are quite able to take care of themselves. They disperse in all directions, and dive and double under water with surprising agility and cunning, so as to make catching them impossible. Being mud-feeders, we never cared to shoot the Shelldrakes for the pot, for in spite of their fine feathers they are but foul feeding."

On the mainland the Shelldrake is, in many localities, very numerous in the breeding seasons, frequenting sandy pasture lands near the shore, where it generally takes possession of rabbit-holes. Its principal haunts are often wet sands, on which it is not easy to stalk a bird so watchful; but during the time the females are sitting, the usual shyness is not so noticeable. I have seen beautiful groups of male birds on the sea off Ardlamont Point, in Argyleshire, and have traced it all along the south-western shores as far as the southern extremity of Wigtownshire. On the eastern coasts of Scotland it is resilent all the year, usually remaining on the sandy shores of the larger estuaries where there is a broad expanse, on which an enemy is easily detected. I have seen large flocks in January and February at the mouth of the Tyne in East Lothian, and Mr Harvie Brown informs me that on the banks of the Forth, at Grangemouth, he has at various times seen flocks of twenty and thirty Shelldrakes in the months of October and January.

The food of the Shelldrake consists, at least in the winter season, of very minute shells, bivalve and univalve, such as are found in muddy estuaries. The late Mr Thompson, who took the trouble to examine the stomachs of ten different birds shot in Belfast Bay, found in one of them nine thousand specimens of 
Skenea depressa and Montacuta purpurea, and about eleven thousand others, making a total of twenty thousand shells in the crop and stomach of a single Shelldrake! Mr St. John, on the other hand, in writing from Morayshire, speaks of these birds feeding during the summer season on cockles and other bivalves, which they swallow whole-a habit probably acquired through the necessity of feeding in great haste during a short absence from their nests at low tide.

\section{THE SHOVELER.}

\section{ANAS CLYPEATA.}

The blue-winged Shoveler, or broad-bill, as this beautiful bird is sometimes called, has repeatedly occurred in the West of Scotland: one-a fine male, which I had an opportunity of examining-was shot in a small stream near Girvan, in May, 1860; another-also a male-was shot in Possil Marsh, near Glasgow, on 24th May, 1869 ; a third - the male bird of a pair-was killed on the Gryfe, near Inchinnan, Renfrewshire, in the first week of June, 1870. The Shoveler has likewise been met with several times on Loch Lomond, chiefly in severe winters; and a pair-male and femalewere shot on the Cree, in Wigtownshire, in the spring of 1865. Several were killed on the Nith, in Dumfriesshire, in 1850, 1851, and were preserved by Mr Hastings, bird stuffer, Dumfries.

Some of my Hebridean correspondents have, at various times, sent me word of ducks with broad-bills, but I have never obtained a specimen from the outer islands, nor have I been able to get the species sufficiently authenticated there. Mr Elwes informs me that it is a rare winter visitor in Islay.

Having seen numbers of Shovelers shot on the Ribble, in Lancashire, early in May, and traced the migratory flight of the species northwards to the Solway Firth, thence in an easterly direction through the counties of Berwick, East Lothian, Fife, Forfar, and Kincardine, to Aberdeen, I conclude that the breeding haunts of the species must lie somewhere to the north-east of the British Islands, and that in migrating northwards along the west coast of England, the flocks are tempted to diverge from their course by the trending of the Solway. A few of the Shovelers which cross the firth probably remain to breed; indeed, in one 
instance Sir George Leith shot a female, and found the nest in Dumbartonshire, and it is not unlikely that the pair seen at Inchinnan in June were breeding when the male was shot. A few straggling pairs may also remain in the eastern counties. Sir William Jardine mentions in his History of British Birds that he saw a nest and eggs, with the female bird, that had been brought from Gullane Links, in East Lothian.*

Regarding the occurrence of the bird itself on the east coast, the Earl of Haddington informs me that he shot a beautiful male at Tyninghame, in February, 1861, and Dr J. A. Smith of Edinburgh has sent me word of a pair-male and female-which he examined, having been shot at Kincardine-on-the-Forth, on the 1st April, 1859. In December of the same year, a young male was obtained near Aberdour, in Fifeshire. Mr Harvie Brown has also informed me that Mr Samuel Singer of Kincardine, has, on two occasions, shot the Shoveler on the Firth of Forth. The species is included in Don's Fauna of Forfarshire-a county in which it is still found. The last specimen that came under my observation was shot in 1867, in the loch of Forfar by one of the Earl of Strathmore's keepers. In Aberdeenshire it has several times been procured, as I am informed by $\mathrm{Mr}$ Angus, who has given the following account illustrating how much may be done sometimes by earnest perseverance in tracing species correctly:-

"In the spring of 1856, Mr Davidson, gamekeeper, Seaton House, shot an adult female Shoveler in the dam near the toll-bar at the Bridge of Don. It is now in Mr Mitchell's museum. I shot an adult male at the same place on 21st April, 1866. The tinting of the plumage was almost perfect; the stomach contained seeds, insects, and a large quantity of gravel. On the 4th of May of the following year I learned that two "wigeons with braid nebs" had been shot at the dam, but on calling at the house of the person who killed the birds, I was told they had been cooked and eaten. I fortunately found, however, the heads, which had been thrown out, and recognised them as female Shovelers. On the 6 th, I visited the dam by 4 A.M., and had the good luck to find three Shovelers-two males and a female-busy diving and feeding. By crawling behind the embankment on the south side

* Mr St. John found the nest of the Shoveler on the banks of Loch Spynie, in Morayshire. Several pairs bred there in 1852. 
of the water, I got quite close to them, and waited to get the birds in a line, but they were either too far apart, or not on the surface at the same time. I killed one of the males with my first barrel, and wounded the female with my second, but she managed to escape seawards. The other male rose within ten yards; his flight was much slower than that of the mallard, and he did not rise to the same height. Though killed fourteen days later than the specimen shot in 1866, the male I secured on this occasion was not so far advanced in its breeding plumage. Its stomach contained sand, mud, and fresh water molluses. The irides of both birds were bright yellow. On the morning of the $23 \mathrm{~d}$ I again visited the dam in company with my friend, Mr Proctor, and fired two unsuccessful shots at the other male, which I was informed had regularly frequented the place, arriving at night; but after this he did not return. Mr John Wilson, Methlic, who is an enthusiastic ornithologist, and who possesses a very select and neatly mounted collection of our local birds, informs me that he once observed this species on the lake at Haddo House; and I may add that an Aberdeenshire male Shoveler, formerly in the collection of the Rev. Mr Leslie of Coul, is now in the University Museum here."

Messrs Baikie and Heddle mention that a Shoveler was killed in Orkney by Mr Strang in 1833; but there appears to be no other trace of its appearance there, or in any of the Shetland islands.

\section{THE GADWALL.}

\section{ANAS STREPERA.}

Although but a few instances of the occurrence of this species in Scotland have been recorded in the writings of British authors, the Gadwall has been frequently met with both on the east and west coasts. It is included in Mr Don's list of the Birds of Forfarshire, where it had been seen by that accurate observer on the lakes of Rescobie and Balgavies, showing that for nearly half a century it must have been greatly overlooked; and the species was also recorded by the late Mr Sinclair of Wick, in his list of Caithness birds published upwards of thirty years ago. In the West of Scotland, the Gadwall is probably not unfrequent, as it is occasionally sent, among other wild fowl, to the poulterers' shops in 
Glasgow from west country shootings. Mr Elwes has informed me that it is a rare winter visitor in Islay. In the outer islands it has also occurred several times: one, a male, was shot at Barra in the autumn of 1863; and two specimens-male and female-were shot by Dr Macrury in Benbecula, in March, 1864, within fourteen days of each other. Besides these, Dr Macrury has informed me that he saw a flock of twelve Gadwalls on a loch in the island of Barra in 1868.

On the east coast it has been killed on the Tay, and likewise on the Forth; in Aberdeenshire, Forfarshire, Perthshire, and East Lothian. The Earl of Haddington has informed me that in the last named county he shot a specimen in immature plumage at Tyninghame, and that about the same time a pair, male and female, were shot in the river Spey, and taken to $\mathrm{Mr}$ Small, bird stuffer, Edinburgh, for preservation. In Orkney, according to Messrs Baikie and Heddle, it has at times been killed in Sanday, but is not a regular visitant.

Although of unobtrusive appearance, the Gadwall is a beautifully marked bird. It appears to be a very abundant species in some parts of Europe, and common in North America, where its habits have been well described by Audubon. It is not a little strange that Wilson, who travelled over as much of that great country as his successor, was altogether unacquainted "with its particular manners or breeding place."

\section{THE PINTAIL DUCK.}

ANAS ACUTA.

Although nowhere a common species in Scotland, the Pintail has occurred in almost every county. It is now many years since I made my first acquaintance with it in East Lothian, where I happened to shoot a brace out of a flock one winter evening as I sat under shelter of a rock on the sea coast near Dunbar. The birds were flying noiselessly in a line, and about to pitch down on a fresh-water stream at its junction with the sea, where I had seen them two nights before: the two I shot were females.

In the western counties the Pintail is a scarce species, some winters passing without a single specimen being seen or obtained 
by any of the shore shooters. A young male, which I examined, was shot on the river Cart, near Glasgow, in January, 1864, and in several other instances stray specimens have come into my hands. In only one case, however, have I been able to trace it in the Outer Hebrides-a specimen having been shot on the farm of Milton, in the island of South Uist, by Mr A. Carmichael, in the winter of 1869-70. As a rule, therefore, this bird is found mostly on the east coasts ranging from Berwickshire and East Lothian to the Shetland Islands, where it is found in spring, and again in autumn. In many parts of Orkney it is said to be pretty abundant, especially in Sanday, where it occurs both in the sea and in fresh water. Mr Angus has informed me that a pair of Pintail ducks were seen in the loch of Slains, in Aberdeenshire, on 4th May, 1866, and that he shot at a pair (probably the same birds) three days afterwards as they flew up the Ythan, nearly opposite Waterside. Mr Angus also states that he examined an immature male in the collection of Mr John Wilson at Methlic, which had been shot by that gentleman on the loch at Haddo House, on 10th March, 1867.

The movements of this beautiful duck, which is distributed over the whole of Europe, are described by various writers as quiet and graceful, which indeed any one in looking at the elegant figure of the bird would naturally expect. Audubon, in speaking of its soft and pleasant notes, says that "there seems to be a kind of natural modesty in it which you do not find in other ducks." Both this writer and Wilson give an interesting account of its habits on American waters, where it appears to be very abundant.*

Although the Pintail is a scarce bird north of the Tay, in Scotland, it would appear to be a native of Iceland. Professor Newton, in his account of the ornithology of that country, appended to Mr S. Baring Gould's 'Scenes and Sagas,' etc., states that according to Faber it arrives on the coast at the end of April, and reaches Myvatn the beginning of May, where it breeds pretty commonly; that it is probably of general distribution throughout the country; and that it disappears at the beginning of September.

* Wilson, in his 'American Ornithology,' remarks that “ great flocks of them are sometimes spread along the isles and shores of Scotland and Ireland, and on the interior lakes of both these countries," but does not say on whose authority he makes the statement. It could not have been from personal observation. 


\section{THE WILD DUCK.}

\section{ANAS BOSCHAS.}

Lacha-chinn-naine. Lacha-rhiach.

IN almost every flock of wild fowl attractive to the sportsman in our western counties, the mallard is by far the commonest species of duck to be met with. It is very abundant on all the islands of both the inner and outer group, and also on the whole of the western mainland from north to south. On the larger sheets of water-such as Loch Lomond and Loch Awe, Loch Shiel, Loch Maree, and Loch Assynt_-vast numbers breed and collect together after the broods are able to fly, until their principal haunts become overcrowded, when they break up into scattered groups, betaking themselves in open weather to moorland marshes, or to the seashore when the snow and ice compel them to seek a change. Immense numbers also congregate on the retired parts of some rivers where, especially in protected grounds, they find a safe refuge. In walking through the policies at Duff House, in Banffshire, I was much struck with the extraordinary flights of mallards at a particular pool in the Deveron. There must have been many hundreds together in the pool, and on being approached, they merely swam or flew to the other side of the river. I have seen similar flocks on the lake of Ochtertyre, in Perthshire, and other secluded lochs within private policies throughout both the eastern and western counties of Scotland. The most remarkable assemblage of mallards I ever saw was on the pond at Douglas Castle, Lanarkshire, in the spring of 1870 . The birds were so tame as to allow even strangers to approach within six or eight yards of the bank where they sat pruning their feathers, before plunging into the water. Mr Dugald Macdonald has informed me that he has seen hundreds of mallards on a mill-dam near Monymusk, in Aberdeenshire, which were so tame as to come at the call of a miller who fed them. This man no sooner made his appearance, and uttered the peculiar whistle which they were accustomed to hear, than the ducks came flying in from all parts of the pond and surrounding marshes, aud alighted within a few yards of where he stood throwing out handfuls of corn. No stranger, however, could ever prevail on them to approach. A very curious instance of this kind of confiding tameness is given 
by a writer in the 'Field Naturalist' (London, 1833, vol. i., p. 507), who states that a gentleman in Forfarshire, whose property was bounded on one side by the river North Esk, was accustomed to amuse himself by laying down a quantity of grain, and watching the Wild Ducks regaling themselves on it. After continuing the practice for some time, he brought such crowds of ducks around him that it seemed as if the entire mallard population of that part of the country were present. With his pockets full of loose grain, this old gentleman went out regularly on his sporting expeditions, and returned with a brace or two of mallards without ever firing a shot, for, in their eagerness to gobble up the corn, the birds waddled up to his feet, and all he had to do was to stoop down and quietly seize a victim, which was easily transferred to his capacious pockets.

The food of the mallard appears to be varied both in kind and in quality. Every farmer knows its partiality for grain of all sorts, and sportsmen who shoot along the sea-coast are familiar with its visits to the shallow pools at low tide. On some of the Ayrshire farms where the use of a gun is prohibited, great damage is sometimes committed by the Wild Ducks in the potato pits. I have seen as many as forty or fifty mallards at one pit. It is only, of course, a small potato that can be swallowed by these birds, but in their hasty pilferings a mistake is occasionally made. I recollect seeing a male mallard shot by the late Dr Nelson with a potato sticking in its gullet. The bird rose from the field uttering a wheezing sound, and in this way attracted our attention as we were preparing to pitch our camp for a night's shooting. $\mathrm{Mr}$ Macgillivray, on the authority of one of his correspondents, says that this bird devours great quantities of frogs, while Mr Thompson speaks of it eating slugs and horse leeches. The last named author, in his well known work on the Birds of Ireland, gives the following as the contents of the stomach of what he calls an 'omnivorous mallard' killed at Larne Lough, in October, 1848 :An eel, four inches in length; a crab (Carcinas monas) an inch broad across the carapace, or shell, and perfect; of marine univalve and bivalve shell-fish, one Lacuna quadrifasciata, two Rissoa interrupta, four Rissoa albella, five Modiola discrepans (fry), about twenty of the young of Littorina vulgaris and $L$. retusa, forty Montacuta purpurea, three hundred and ninety-one Bulla obtusa, and four hundred and seventy-five Rissoa alba: it contained also above four 
thousand five hundred of the handsomely sculptured seeds of the grass wrack, Zostera marina; nor was this all, as fully one-tenth of the matter-that which adhered to the coats of the stomachwas not taken into account."

Notwithstanding such omnivorous tastes, the mallard is acknowledged to be one of the best of all ducks for the table; and it may please the consumer to be here reminded of the following excellent relish, which will at least obliterate any flavour imparted to the bird by the long list of organisms just quoted. The recipe appears to be that of an epicure who does not agree with the French cooks when they allow that this inimitable and venerated bird is best eaten plain roasted, with a few tears of lemon dropped upon his brown smoking breast:- "The finest sauce we know for duck, or any wild fowl, is one that Dr Kitchener derived from Major Hawker, the celebrated sporting writer. It is perfect. Man wants but little here below, but this sauce he must have. A celebrated cook of 1816 used to charge a fee of a guinea for disclosing it. It would make even a politician who had ratted swallow all his early speeches. Here it is for nothing. 'One glass of port wine, one spoonful of caviare, one ditto of catsup, one ditto of lemon juice, one slice of lemon peel, one large shalot sliced, four grains of dark cayenne pepper (not venetian red and brick dust), and two blades of mace. Scald and strain this, and add it to the pure gravy of the bird. Serve the duck (if it be a duck) in a silver dish, with a lamp under it, and let this sauce gently simmer round it.' The duck who spends his useful life in flitting from lake to brook in search of rush buds and olive-brown water-cresses, would, if he could but taste this sauce, rejoice in being so embalmed, and exult in being so honoured." Dr Kitchener, however, might not care to have the duck's opinion on the subject.

\section{THE GARGANEY.}

\section{ANAS QUERQUEDULA.}

Is of very rare occurrence in the West of Scotland-nearly all the specimens killed north of the Tweed having been obtained on the east coast, and chiefly on the river Forth. The Garganey, however, is a species which has probably been overlooked as a Scottish bird. The earliest record of it is that given by Dr Barry in his Natural 
History of Orkney, in which it is stated that it " is frequently seen in the lochs of that group of islands in mild weather:" it is next mentioned in Mr G. Don's Fauna of Forfarshire as having been seen by that excellent naturalist in the lake of Forfar about the beginning of the present century. More recently a specimen was obtained in Banffshire by the Rev. James Smith, who recorded the circumstance in 1836. We next hear of it in Yarrell's 'British Birds,' six specimens, according to that author, having been shot in Stirlingshire in 1841. Macgillivray states that four specimens, said to have been shot near Stirling in the same month and year, were exposed for sale in the Edinburgh Market; and also mentions that it had been seen in small numbers in Montrose Basin. A specimen of the Garganey, shot near Stirling in May, 1857, was exhibited by Dr Hugh Colquhoun at a meeting of the Natural History Society of Glasgow, held on the 26th of that month; and $\mathrm{Mr}$ Harvie Brown informs me that one was shot also on the Forth by $\mathrm{Mr}$ Singer of Kincardine. Mr William Hamilton has obligingly informed me that a pair of these birds were seen in spring on a small moorland loch by his brother, in the district of Upper Loch Fyne-the only instance I have it in my power to give of its occurrence west of Stirling, with the exception of a specimen which was shot in the Bay of Luce, Wigtownshire, in 1867. For this additional instance I am indebted to the Rev. George Wilson of Glenluce, to whom the bird was sent for identification. Messrs Baikie and Heddle state that it is a rare spring visitant in Orkney. In Shetland it has been obtained by Mr Joseph Dunn, and likewise by Dr Saxby, who remarks that he has shot it in September, but that the species is very uncommon there.

From the dates given in connection with the foregoing instances, it will be seen that the Garganey is entirely absent from Scotland during the breeding months.

\section{THE TEAL.}

\section{ANAS CRECCA.}

Crann-lacha.

In the outer islands the Teal is somewhat rare compared with other species: it is found occasionally in Lewis, and is also met with sparingly on various lakes in North Uist, and on one or two 
islands in the Sound of Harris. Mr John Macdonald, Newton, informs me that he has frequently seen the bird in these localities. I cannot, however, find any trace of its breeding there. It is also met with on the lakes in Skye, and in many of the other islands lying to the south. Dr Dewar informs me that it breeds in Rum. Although not abundant in Mull and Iona, it is commonly distributed there. Mr Graham writes that one or two pairs may often be found breeding in the neighbourhood of the moorland lochans, and that in winter they are found there in small flights, as well as on the sea-shore in hard weather, among the mallards and wigeon, when it is usually very tame and easy of approach.

I have found a number of pairs breeding on Inch Moin, Loch Lomond; the nests are invariably placed on the higher tufts of heath, growing on a comparatively firm and dry spot in the marsh, and are formed of the leaves of water plants, and lined with a profusion of down and feathers. The young, on being left by the old bird when suddenly surprised, remain huddled in a compact variegated ball, but if an attempt be made to touch them, they break up in a moment, and rush headlong into the nearest pool. There they dive, and, by some mysterious means, never show their bodies on the surface, but appear to get to the side and thrust up their little heads merely to breathe until the alarm is past. I have seen this done by broods less than a week old.

In the north and east of Scotland the breeding haunts of this beautiful little duck are extensively distributed, reaching even to the Shetland islands. In the winter season I have observed small parties on the sea-shore at Dunbar frequenting the mouth of freshwater streamlets, where they often remain all night. I may mention that some of the west country specimens have the under parts of their plumage coloured brick red, and are otherwise a shade darker in general markings.

\section{THE BLUE-WINGED TEAL.}

QUERQUEDULA DISCORS. (STEPH.)

A SPECIMEN of this North American Teal was shot by the late Mr Shaw of Drumlanrig, on the Nith, in Dumfriesshire, in January, 1863. Sir William Jardine, in whose collection the bird is now 
preserved, informs me that he happened to be at Drumlanrig, and called to see Mr Shaw shortly before his death, when he was told by him that he had shot the duck and sent it to Mr Hastings, bird stuffer, Dumfries. " On returning home," writes Sir William, "I went to Mr Hastings and got the bird from him, and it is now before me." I believe this to be the first occurrence of the species in any part of Europe.

Wilson, in his account of this Teal, states that it is met with along the shores of the Deleware sitting in crowds on the mud close to the edge of the water, where the gunners often kill great numbers at a single discharge. The birds fly rapidly, and in alighting drop down suddenly, like the snipe or wood-cock, among the reeds, or on the mud. Being vegetable feeders, their flesh is excellent, and they rarely visit the sea-shore. Audubon likewise dwells with enthusiasm on their appearance during flight, and compares the blue on their wings to the glistening of polished steel, or "the dancing light of a piece of glass suddenly reflected on a distant object." He then tells his readers of the soft lisping note which they emit during their flight and also on the ground, when under apprehension of danger, and finishes his paragraph by saying that he saw a friend of his kill eighty-four by pulling together the triggers of his double-barrelled gun!

As this bird may occur again, I here give Wilson's description of both sexes, which is as follows:- "Length, about fourteen inches; extent, twenty-two inches; the bill is long in proportion, and of a dark dusky slate; the front and upper part of the head are black, from the eye to the chin is a large crescent of white, the rest of the head and half the neck are of a dark slate richly glossed with green and violet, remainder of the neck and breast is black or dusky, thickly marked with semi-circles of brownish white elegantly intersecting each other; belly, pale brown barred with dusky in narrow lines; sides and vent the same tint, spotted with oval marks of dusky; flanks elegantly waved with large semi-circles of pale brown; sides of the vent pure white; under tail coverts black; back, deep brownish black, each feather waved with large semiovals of brownish white; lesser wing coverts a bright light blue; primaries dusky brown; secondaries black; speculum or beauty spot rich green; tertials, edged with black or light blue, and streaked down their middle with white; the tail, which is pointed, extends two inches beyond the wings; legs and feet 
yellow, the latter very small; the two crescents of white before the eyes meet on the throat.

"The female differs in having the head and neck of a dull dusky slate, instead of the rich violet of the male; the hind head is also whitish. The wavings on the back and lower parts more indistinct; wing nearly the same in both."

\section{THE WIGEON.}

\section{ANAS PENELOPE.}

Glas-lacha.

Although I have never taken the nest of the Wigeon in the Outer Hebrides, I have little doubt of, at least, a few pairs nesting there regularly. Some of my correspondents who are resident in these islands meet with Wigeon in pairs at the season when all other water fowl are breeding. Dr Dewar of Glasgow, who spent two months in North Uist in 1858, observed a pair on a lake near the Sound of Harris in the last week of June, and shot the male bird, which I afterwards saw. In the winter season the species is abundant over the whole of the Long island, crowding many of the shallower lakes of South Uist and Benbecula, and it is likewise a very common bird in almost every district on the western mainland.

In other parts of Scotland the Wigeon is known to breed in Ross-shire and Sutherlandshire, where it is found in considerable numbers. Sir William Jardine and Mr Selby took the nest in 1834 upon a low island in Loch Laighal, and Mr Harvie Brown has informed me that the Wigeon is distributed in the breeding season over the central and northern parts of the county of Sutherland. He also states that several pairs are frequently observed on some marshy ground between Tongue and Loch Eriboll. Mr A. G. More (Ibis, 1865) remarks that Mr R. Danford describes the Wigeon as breeding regularly in Ross-shire, and that the nest has been found in Caithness. Mr Harvie Brown once took a nest on a large loch in the county of Cromarty: it was placed on a tuft of old heather, and contained eight eggs. Col. Drummond Hay has found the nest in Orkney; and Dr Saxby, writing from Shetland, says:- " In cold backward seasons I have several times procured the eggs." 
The following quotation from Mr Graham's correspondence relates to the habits of this duck on the western shores of Argyleshire:- "The Wigeon is more numerous than the mallard in winter, but more local, congregating in large flocks in every suitable bay. Loch Gilp, and other inlets of Loch Fyne, Loch Tarbert, Jura, Loch Sweyn, Feochain, Caolisport, and many other lochs on the mainland and islands of Argyle, are famed for the quantities of Wigeon frequenting them, in spite of the constantly increasing number of guns which are brought to bear upon them. The birds are shy when they expect to be molested; but the same birds, in another place where they consider themselves safe from molestation, are quite free of shyness. I have often proved this by putting up a flock in Loch Gilp, which would rise wildly at the punt's approach two hundred yards off, then following them to the retired inlets at the junction of Loch Fyne and Loch Gilp would find them sitting till within forty or fifty yards of them. In certain bays they cannot be approached, while in others they let themselves be easily stalked. The wounded birds are troublesome to capture. I have seen them holding on to the weed at the bottom in shallow water, and have had to dislodge them with the boat-hook, or reach them with my arm, if not ton deep. In March, when they break up into pairs, but have not yet finally quitted our shores, I have sometimes, while coasting, come upon a pair in full breeding plumage, enjoying their honeymoon, in some out of the way little creek. The duck, trusting to the unobtrusive nature of her plumage, will remain floating among the long fronds of brown sea weed, but the drake, who shines like a star, gets fidgetty and flies about, calling in vain to his capricious mate, who will not take the hint to follow, and at last forces him to pitch on the.water a little way off. The duck at last rises when the boat is within thirty yards, flies a short distance, and alights again, where she is immediately joined by her faithful spouse. The same performance may be gone through again and again, till very often, if you are in want of a full-plumaged male, he falls a victim to the caprice of his partner and his own gallantry."

The Wigeon is also a very common duck on the eastern shores of Scotland, especially in those estuaries where it can get good grazing and other feeding when the tide is out. In the winter of 1864, I spent some hours daily for about a week near the mouth of the Tyne in East Lothian, in company with my friend, $\mathrm{Mr}$ 
David Robertson of Glasgow, and had various opportunities of conversing with a party of shore-shooters who were watching for wild ducks, and who appeared to be killing large numbers of this species. On enquiry, we were told that each of these men earned as much as $£ 2$ per week by disposing of the birds they killed with ordinary fowling pieces. They were intelligent men in their way, and seemed tolerably well acquainted with the habits of wild fowl, as no doubt they might, seeing the abundance of material before them for study. The bay was literally full of birds. At a moderate computation, there would be about eight hundred or one thousand Wigeon alone in a single flock within three hundred yards of where we stood. Flocks of fifteen or twenty were constantly rising from the water and steering eastwards to the various feeding grounds exposed by the receding tide along the coast. At these flocks the watchers, who lay concealed behind the sand-hills, fired many random shots, yet the disturbance caused no diminution of their numbers. The mere pot-hunter will not spend a shot upon any bird that is not marketable; hence his ordinary spoil has little or no interest to the ornithologist. When these men, however, learned that we collected birds, they brought us during our stay a daily supply which utterly astonished us, besides affording a pretty sure guide to the numbers of the various species frequenting that part of the coast. The Wigeon and mallard were by far the most numerous, the teal plentiful, and the golden eye, merganser, and shelldrake, far from rare. A brace of Wigeon now before me vividly recall their fate in the estuary I am now speaking of. I had been for some time in the company of the duck shooters, when it was found that the tide was sufficiently far out to admit of the river being forded. One of the men had already crossed the sands, and was nearly thigh deep on his way to the other side, being anxious for a first chance. The sun was setting in a blaze of crimson and gold, throwing a deeply impressive shade over the stretch of sand and water. The man paused, as we imagined, for a little reflection on the singular sublimity of the scene, and stood nearly waist deep gazing cloudward a few seconds with no other apparent intention. In another second, however, we were undeceived; there was a sudden upward movement of his arms, and, after a momentary flash of light, we heard a report such as a duck shooter's gun alone can make, and the two poor wanderers, part of a small flock we had not observed, fell into the river not far 
from where he stood. One of them-in my left hand as I write-is the most perfect male I have ever seen, but even now, on looking at the pair, I cannot help thinking that the glories of that sunset were dimmed by their death.

\section{THE EIDER DUCK.}

\section{SOMATERIA MOLLISSIMA.}

\section{Lacha lòch lannach. Lach mhor. Colcach. Lach Cholonsa.}

The extraordinary number of Eider Ducks found on the island of Colonsay has gained for this bird the local name of Lach Cholonsa over a considerable portion of the western districts of Scotland. I am told by my friend $\mathrm{Mr}$ Graham that in spring and summer it is very abundant there, surrounding the smaller islets, where they hatch and multiply to a great extent, being strictly protected by the proprietor; it is likewise very numerous around Mull and Iona, where it may be met with at all times of the year, along shore or half-way out to Tyree, ten or fifteen miles from land. "The male birds," writes Mr Graham, "shine like stars upon the deep blue, long-heaving swell which comes in from the Atlantic Ocean. They are not very shy when sailed down upon, and are less suspicious of a large boat than of a smaller. We considered them better eating than most other maritime ducks; they seem to feed entirely on seaweed, browsing at the bottom in deep water. When startled, they take flight at once, without having recourse to diving as a means of escape. We sometimes find the nest upon the unfrequented islets, among the rocks a little above the sea level. The young, when hatched, are black, and about the size of goslings." I have seen family groups of Eiders in September off the western shores of Benbecula and North and South Uist and Lewis riding at their ease on the troubled sea that almost constantly breaks upon that side of the Long island. Numbers breed upon the islands in the Sound of Harris; and sometimes when a nesting-place is selected on the moors of North Uist, the old birds are met leading their young ones by the nearest route to the water. On these occasions they will at times linger at a fresh water loch, remaining there a few days, as I have been informed by Mr MacDonald of Newton, who has noticed them, and has shot the old birds. Mr MacDonald 
has also informed me that he has frequently placed the eggs under a domestic duck, and had the satisfaction of seeing Eiders brought up safely in the barn yard. The experiment has repeatedly been tried in other parts of the Outer Hebrides, and proved equally successful. The nest of this bird is a somewhat bulky structure of matted heather, sea-weed, and grass, and is lined with a profusion of down and feathers. The eggs are from five to seven, or sometimes eight in number, and appear to vary in size. I have seen quantities of eggs sent to Glasgow poulterers from Islay, where Eiders are found numerously all the year, especially at Ardnave and Sanaig, on the north-west side of the island. Similar consiguments are occasionally sent to market from the islands of Tyree and Coll. Southwards of Islay the Eider Duck is but a winter straggler. Mr St. John ('Tour in Sutherland,' vol. i., p. 140) states that it breeds on some islands at the entrance of the Kyle of Tongue, on the north coast of Sutherlandshire, and it probably still breeds on the islands of Suleskeir and North Rona, as it did 300 years ago in the time of Dean Monro, who gives a very quaint account of its habits, under the name of Colk, in his 'Description of the Hybrides,' published in 1594. Martin ('Descr. West Islands of Scot.,' London, $2 \mathrm{~d}$ ed., 1716) also mentions the bird, which he distinguishes by the same name (the Gaelic one still in use), and gives a most glowing and exaggerated description of its plumage, which he compares to that of a peacock! His account was probably copied from previous writers, as he repeats what is stated by Dean Monro, viz., that the bird "lived mostly in the remotest islands, as Heisker and Rona." At the close of his ornithological records, however, he makes the following highly curious remark, which may, to some extent, account for his magnified description:"The Air is here moist and moderately cold; the Natives qualify it sometimes by drinking a Glass of Vsquebaugh. The Moisture of this Place is such that a Loaf of Sugar is in danger to be dissolved." The precise nature of the humidity is not explained, nor yet the cure, though the melting of the sugar is rather suggestive.

In the east of Scotland, where this bird is called St. Cuthbert's Duck, considerable flocks make their appearance off the coasts of East Lothian and Berwickshire. These are probably natives of the Fern islands, the numbers which breed on the islands in the Firth of Forth being now much reduced. 


\section{THE KING DUCK.}

\section{SOMATERIA SPECTABILIS.}

UPWARDS of fifty years ago, Mr Bullock communicated to Col. Montagu, the author of a 'Dictionary of British Birds,' that he had found a nest of this rare bird containing six eggs, in Papa Westray, one of the Orkney islands. In that district the species is now but very rarely seen-only one specimen being mentioned by Messrs Baikie and Heddle in their little work on the Natural History of Orkney. It was obtained in one of the islands of that group, and exhibited at a meeting of the Zoological Society of London by Mr Gould, in November, 1832 ; but a manuscript note by one of the authors states that the species had been found by Mr Dunn in Shetland. Mr St. John, in his "Tour in Sutherlandshire,' (vol. i., p. 140) remarks that the King Duck is seen at the entrance of the Kyle of Tongue, but only rarely. The late Dr Nelson of Pitcox, East Lothian, informed me that he saw one in the winter of 1847 at the mouth of the river Tyne in that county, and that he was quite sure of the species. I have also been informed by E. S. Hargitt, Esq. of London, that he shot a female King Duck in Orkney in May, 1868.

These records, it must be confessed, are somewhat imperfect, but the species, being strictly oceanic in its habits, may occur much more frequently off our coasts than has been supposed. It rests indeed with some hardy ornithologist to give his fellows a better idea of what is really to be met with at sea, within the prescribed limits, than has yet been advanced.

According to northern voyagers, the King Duck is very common in the Arctic seas, resorting in vast numbers annually to the shores and islands of these regions during the breeding season; and it is not unreasonable to suppose that at the breaking up of these numerous families, small flocks may take their course to Britain, especially when it is known that they gather into flocks, and feed together at very great distances from land after they have left their breeding quarters. Regarding its value in an economic sense, Sir James C. Ross has stated that the crews of Arctic ships have on many occasions used the King Duck as food in considerable quantities; and a friend of the late Mr Thompson did not scruple to use a few baked in pies when nothing better could be had. 


\section{THE VELVET SCOTER.}

\section{OIDEMIA FUSCA.}

I AM more familiar with this conspicuous bird as an east coast species than as a visitor to the west. "Black ducks," which are so very abundant in the Firth of Forth, are almost never seen on the Firth of Clyde; and although the Velvet Scoter is said to breed on the Faroes and Iceland, the flocks reaching our western shores are very much smaller than those visiting the estuaries of Aberdeenshire, Fifeshire, and East Lothian. Several small flocks were seen by Mr Elwes on Loch Indaal, in Islay, in November, 1867, and Mr Graham has sent me word that he has seen the species at Ardrishaig. A very fine male, which I had an opportunity of seeing, was also shot on Gareloch in the first week of January, 1869.

I have never been at a loss to identify this from the next species, even when assembled together, the white patch on the wings being sufficient to distinguish the birds at a little distance. Off Dunbar, where they appear from the end of August till the middle of April, I have seen hundreds of both sitting on the water within one hundred and fifty or two hundred yards of the shore, and remaining there nearly a whole day. Occasionally they approach the rocks within shooting range in their eager search for sandy spots where they may find their favourite shell-fish, which I have invariably found to be bivalves; and I have a beautiful male bird now before me which was procured in this way. From this specimen, and others which I have dissected, I have taken quantities of a species of Donax, with a very strong shell, which had been broken into fragments. The food of this species consists solely of shell-fish, and, generally speaking, the contents of its gizzard are much bruised, so that it is not easy to make out the species which it prefers. Only the thicker-shelled molluscs are distinguishable, and even these are smashed into small pieces. Living on such diet, it is not to be expected that the flesh of this bird can be much esteemed. Some persons seem to think that fresh earth will effectually remove the strongest flavour natural to a fisheating bird. I would therefore recommend any one desirous of trying the edible qualities of a Velvet Scoter to bury it in a convenient place, and leave it there. 


\section{THE COMMON SCOTER.}

OIDEMIA NIGRA.

\section{Tunnag dubh.}

This bird, like the preceding species, is much commoner on the eastern than on the western shores of Scotland. It is a very marked object in all states of the weather, keeping well off the land, and shifting constantly from one place to another in search of good feeding ground. I have many times seen large flocks of Scoters riding at their ease outside the line of breakers-the heaving blue waves lifting long lines of birds momentarily on their crest, and showing their numbers to the watchful naturalist. They appear to feed much more quietly than the long-tailed ducks, with whom they often associate, more perhaps by accident than design, and contrast strangely with these lively fellows as much in deportment as in dress. Again, on rough days, when the waves are rolling wildly in huge white masses on the sandy shores, the black plumage of these birds, as they fly along the broken water, comes out in fine relief, and with an effect almost as pieturesque as the snow-white gulls against a thunder cloud.

Quoting from Mr William Dunbar, Mr A. G. More, whose excellent contribution to the 'Ibis' on the birds breeding in Scotland is a model of its kind, states that this Scoter "breeds every year in many parts of the moors of Caithness, making its nest in the boggy swamps around the lakes. He has known the eggs taken more than once." Mr More likewise notices that a "black duck" is well known as breeding in one or two lakes in the Thurso district. Mr Elwes has written to me expressing his belief that a few pairs nest every year on some of the hill lochs, and has furnished me with the following notes:- "The late Ronaleyn Gordon Cumming told me that he had two or three times shot the bird off the nest in Inverness-shire, and I saw a forester this year who said that a bird which he described as tunnag dubh-evidently the Scoter-bred in the upper parts of Strathglass. I saw a young bird, half grown, killed there in the beginning of September. Caithness is also a very likely county for this bird to breed; and if it is proved to do so, I think this will account for the small parties of Scoters seen every year in May and June on Windermere, and for those which I have seen myself in July on the coast of Sussex." 


\section{THE SURF SCOTER.}

\section{OIDEMIA PERSPICILLATA.}

THE only specimen of this unmistakable species which I have seen in the West of Scotland is one now in the collection of Sir James Matheson, Baronet, of Lewis: it was shot in the winter of 1865 at Holm, near Stornoway, by Mr Macgillivray of Stornoway. The species is included in a list of Caithness birds by Mr E. S. Sinclair of Wick, but neither date nor locality is given. An adult male was shot at Swanbister, parish of Orphir, in Orkney, in March, 1866, as I have been obligingly informed by Mr J. H. Dunn; and in June, 1847, the same gentleman states that in one of his boating excursions after other birds in Rona's Voe, Shetland, he saw an adult male of this species several times, but was unable to procure it.

Messrs Baikie and Heddle's statement, that "small flocks are seen in our sounds every winter," is an obvious mistake.

The Surf Scoter has been shot in the Firth of Forth, a specimen having been procured off Musselburgh in 1851, as recorded in Turnbull's 'Birds of East Lothian,' etc.

\section{THE RED-CRESTED WHISTLING DUCK.}

\section{FULIGULA RUFINA.}

IN a communication made in January, 1863, to the Natural History Society of Glasgow by Henry D. Graham, Esq., one of its corresponding members, it is stated that a specimen of this bird was shot on a fresh water loch on Craignish, in January of the previous year, and sent to him by Captain M'Dougall of Luing. The specimen was for some time in Mr Graham's possession, but was afterwards given by him to Captain J. P. Orde of Kilmory, in whose collection it has been placed.

This appears to be the only record of the occurrence of the Redcrested Pochard in any part of Scotland. The species is known to have a tolerably wide geographical range, though not extending so far westward as the British islands. It can only, therefore, turn up as an accidental visitor. 


\section{THE POCHARD OR DUN BIRD.}

\section{FULIGULA FERINA.}

Lacha mhasach.

Over the whole of the West of Scotland the Dun bird is a very familiar species. In some districts it appears in very large flocks, and offers a temptation to sportsmen to try a raking shot. On Loch Lomond many hundreds congregate together and feed in shallow water over the borders of some of the low lying islands, such as Inchmoin, where half a dozen or more could easily be obtained by firing into their midst.

On many of the Inner Hebrides this species is also common, being found in the fresh-water lochs of Islay and Mull, where they are frequently shot. Unusual numbers were sent from the west coast shootings in the winter of 1866-67. I have not been able satisfactorily to make out the proportion of Pochards among the vast flights of wild duck that frequent the lakes of the outer islands, as I have not been there in the winter season. Limited numbers at least fly in company with wigeon and tufted ducks; and those who practise shooting on these lochs for the table, readily distinguish it from the next species.

On the eastern shores of Scotland, where fresh-water lochs are of less frequent occurrence than on the west, I have seen great numbers of this bird frequenting estuaries after nightfall. In Fifeshire and East Lothian it may be called abundant. I recollect being on Tyne Sands on a moonlight night many years ago in company with the late Mr Nelson of Kirklandhill, and seeing a constant stream of Pochards coming in from the sea and flying up to the muddy parts of the estuary. We bagged seven brace in little more than half-an-hour, and every flock we saw passing overhead appeared to be of the same species. All the wigeon and mallards were up the stream fully an hour before! We therefore inferred that the Dun birds had been far out at sea, where they had probably been feeding all day like their allies the scaups. That they were addicted to eating shell-fish, sea urchins, etc., we indeed abundantly verified on dissecting some of the specimens. It is worthy of note that while in western Scotland the Pochard is useful as a bird for the table, it is on the east coast in poor 
request, being considered rank and unpalatable, owing, doubtless, to the difference of diet in the two districts.

The Pocharl has been killed in Orkney so late as the 28th of June.

\section{THE FERRUGINOUS DUCK.}

\section{FULIGULA NYROCA.}

I kNow of but one instance of the occurrence of this bird in any part of Scotland, viz., a specimen which was shot near Musselburgh in 1855, and exhibited at a meeting of the Royal Physical Society, Edinburgh, on the 26th December, by Dr J. A. Smith, the Society's Secretary, to whom I am indebted for a notice of the circumstance.

The following measurements of the specimen are taken from vol. i., p. 52, of the published proceedings:- "The bird, an adult male, measured $16 \frac{3}{4}$ inches from the point of the bill to the tip of the tail; and $27 \frac{1}{2}$ inches in breadth from point to point of its extended wings. The first primary is the longest, others gradually decreasing in length. From flexure of wing to point of first primary measures $7 \frac{3}{4}$ inches; inside of wings and axillaries white. Its weight was seventeen ounces. The trachea (which was exhibited), $5 \frac{1}{2}$ inches long, is peculiar, the upper part being rather more than a quarter of an inch in diameter, gradually expanding to half an inch, and again contracting to less than a quarter of an inch towards the lower part, where it terminates in a bony and membraneous labyrinth about $1 \frac{1}{2}$ inch in length. The œesophagus was about $7 \frac{3}{4}$ inches in length; the stomach, a strong and muscular gizzard, was filled with seeds of the oat mixed with small pieces of quartz and gravel. The intestines, from pylorus to anus, were three feet nine inches in length; two coeca, one $4 \frac{3}{4}$ inches, the other $4 \frac{1}{4}$ inches long, enter the gut about $2 \frac{1}{2}$ inches from its lower extremity."

\section{THE SCAUP DUCK.}

\section{FULIGULA MARILA.}

THIs duck is perhaps the least common among the ordinary seaducks that frequent the western shores of Scotland. Being partial to mud flats, it is found chiefly near estuaries, remaining for the most part out at sea in the day time, where it dives like the scoters 
in quest of molluscs and crustacea, and coming shorewards in the evening for a change of diet. I have observed that it will often prefer swimming instead of flying to its night quarters; and, after repeatedly noticing this habit, I have lain in wait on an outlying rocky skerry at the river's mouth, knowing I was sure of a shot. Sometimes in very hard winters the flocks of Scaup Ducks are large, but usually the birds live in small groups, occasionally mixing with golden eyes and scoters. On the Outer Hebrides a few frequent the oozy shores between North Uist and Benbecula, on both sides, from the isle of Gremsay on the east to Baleshare on the west. Late in autumn these small parties are seen there at nightfall dabbling in the mud left bare by the tide; and they usually remain in the neighbourhood of this well known ford throughout the winter. In very stormy weather they appear to seek shelter in the Sound of Harris, where a stray bird occasionally falls to the gun by accident, the species being notorious for the rankness of its flesh, and consequently not in request. Mr J. Macdonald informs me that in the dusk of the evening, when one kind of duck is hardly distinguishable from another, he knocks over a Scaup at times instead of a mallard, but that its numbers are comparatively small, the birds only coming in his way when continued bad weather forces them into the Sound.

$\mathrm{Mr}$ Graham states that this species is a regular winter visitant to Iona and the shores of Mull, and that it is often killed near the coast in fresh water. It is likewise seen occasionally on the shores of Islay.

Scaup Ducks appear to linger through the summer in some parts of Scotland. One instance is given by Sir William Jardine, who shot a female bird near Loch Erribol, in Sutherlandshire; and Dr Saxby states that it is occasionally observed in summer in the Shetlands.

\section{THE TUFTED DUCK.}

\section{FULIGULA CRISTATA.}

IN very severe winters the Tufted Duck is much more frequently obtained than in open seasons. This may arise from its habit of keeping out at sea, or well off shore in the firths and estuaries in moderate weather, and coming into our rivers to feed when it is too 
rough outside. On the Clyde, numbers are killed every week throughout the winter and sent to the Glasgow market; and limited numbers are also shot on some of the inland lochs and ponds from October to March. I have seen small flocks of this bird, on two or three different occasions, flying at great speed up the river Clyde, a few feet above the surface of the water, and reaching even the Glasgow Bridge at the Broomielaw. On one occasion a beautiful male, accompanied by two females, came up in this way, and pitched down on the river close to the bridge, where they swam about in a half-bewildered state among the broken water caused by a steamer leaving the quay. The male went twice under the paddles of another steamer close at hand, and was at last shot, while his two more soberly dressed companions were allowed to escape. At another time I observed six or eight Tufted Ducks, headed by a splendid male, flying in a string up to the same place; but not liking the appearance of so many revolving wheels in the water, they turned round just as they neared the arches of the bridge, and, after performing a beautiful curve, shot down the river with their usual rapidity. In the winter of 1866-67 great numbers were shot, in company with female golden-eyes, opposite Dumbarton Castle.

In the Outer Hebrides it occurs but sparingly. I have seen it as early as September, and have likewise procured it from Benbecula, later in the season, in the plumage of the first year. In the autumn of 1867, when at Hougharry Point, North Uist, I observed a pair of early visitors on the sea near the shore attending a blackthroated diver which still retained its brilliant summer dress: the weather, which had for some days been rather stormy, was on the afternoon I saw the birds suspiciously serene, the sea having calmed down like a smooth lake, and wrapped itself to sleep in a golden sheet. The diver, as if disinclined for the company of the ducks, pushed himself forward with such force at two or three strokes that he soon left them behind; but for a few seconds the group struck me as being rather interesting and remarkable, and in the accompanying plate ${ }^{*} \mathrm{Mr}$ Sinclair has well expressed the movement

* Mr Bott, in reproducing Mr Sinclair's drawing, has attached Macgillivray's name of Tufted Scaup - a name which, in the first proof submitted to me, was inadvertently printed Scamp Duck. Though the origin of the word Scaup has long been questioned, I did not consider the substitution of the other word an improvement, and therefore had it altered. 
of this Highland chief and his two unusual followers. Ten days afterwards, when crossing the Minch, in a vain attempt to reach Dunvegan with a rent mainsail, I thought, and not without a certain feeling of bitterness, of the utter impossibility of making any such ornithological observations. I have been on rough seas on many occasions, but a more tumultuous body of water than the Minch presented on that occasion could hardly be conceived. It was certainly a mistake to leave Lochmaddy and the crews of a dozen wind-bound vessels wondering at our temerity. The sea was too rough for even the Manx shearwater, several of which I saw steering for the narrow entrance to the loch as we left it. Three hours afterwards, on returning crippled to our starting point, I saw the wise birds enjoying their shelter, and a host of plunging gannets playing at their old game of "follow my leader." "Everything comes in here when it's coorse," said the skipper; and on getting into the snug inn I had left in the morning, with a feeling of relief at my escape, I thought Lochmaddy not such a bad place after all.

\section{THE LONG-TAILED DUCK.}

\section{FULIGULA GLACIALIS.}

Eun buchuinn.

THE Long-tailed Duck, or Northern Hareld of British authors is, to the greater number of their readers, one of the rarer species, whose habits and history appear to have received less consideration than they merit. Since the time of Willughby these have been but lightly treated, one writer having handed down what another had written before him, without adding a word from personal observation. Hence, this most interesting and beautiful bird holds a place among the feathered tribes of our country as an uncommon visitor, its occurrence on our coasts being merely records of where the bird was found and by whom it was shot. Yet in many parts of Scotland the species is tolerably well known, as it returns regularly each season to its accustomed haunts, where food and other causes make the locality attractive. In the winter season, from October till March, it is very common in the Sound of Harris in the Outer Hebrides, and is likewise met with in considerable numbers off the coasts of Skye, Mull, and Islay, but southwards of 


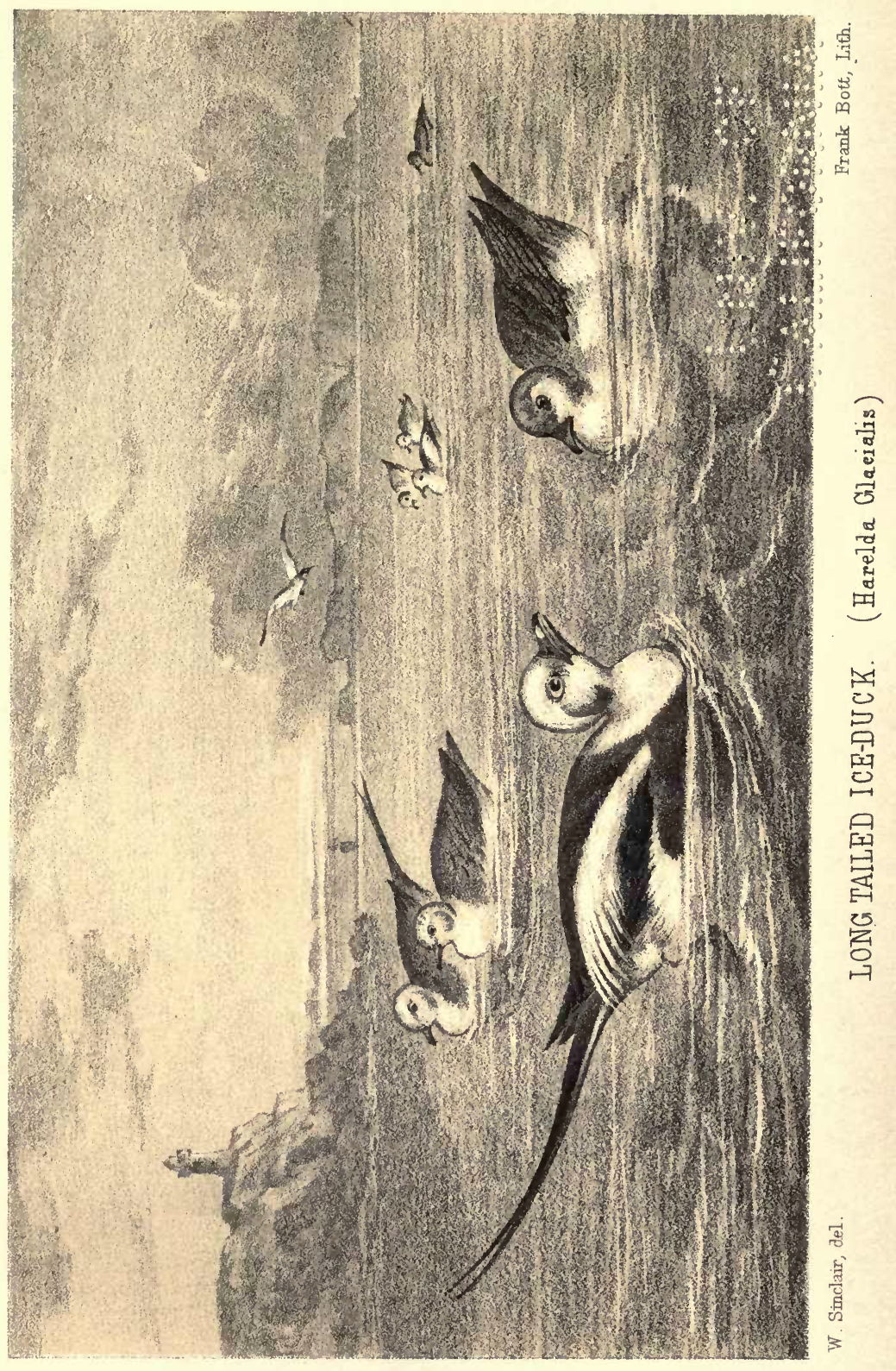



the last-named island its occurrence is extremely irregular and uncertain.

Twenty years ago, Mr Graham, then resident in Iona, favoured me with some highly interesting letters descriptive of the birds of that island, and from one of these I have much pleasure in selecting the following notes, believing that even at this distance of time they have lost none of their original vigour or freshness:- "The Long-tailed Duck comes to Iona in the early part of November, when there appears a small flock of a dozen or so which takes up its station off the northern coast of the island. These are generally reinforced during the frosts and severe weather of December and January by fresh arrivals which are driven in from the sea, and from their more unsheltered haunts, till at last very great numbers are assembled in the bay. Towards the end of March this large flock begins to break up into pairs and small parties; many go away; and when the weather keeps fine they make long excursions, and for days the bay is quite deserted. A change of weather, however, will still bring them back, and a smart gale would assemble a considerable flock of them, and this as late as the second week in April; but after this time you see them no more. Thus we have them with us about four months: they arrive with the first frown of winter, and depart with the earliest blink of summer sun. The Northern Hareld brings ice and snow and storms upon its wings; but as soon as winter, with his tempestuous rage, rolls unwillingly back before the smile of advancing spring to his Polar dominions, the bird follows in his train; for no creature revels more amidst the gloom and rage and horrors of winter than the ice duck. The cry of this bird is very remarkable, and has obtained for it the Gaelic name of Lach Bhinn, or the musical duck, which is most appropriate; for when the voices of a number are heard in concert, rising and falling, borne along upon the breeze between the rollings of the surf, the effect is musical, wild, and startling. The united cry of a large flock sounds very like bagpipes at a distance, but the note of a single bird when heard very near is certainly not so agreeable. On one occasion I took great pains to learn the note, and the following words are the nearest approach that can be given of it in writing: it articulates them very distinctly, though in a musical bugle-like tone:- 'Our, o, u, ah! our, o, u, ah!' Sometimes the note seems to break down in the middle, and the bird gets no further than our, or ower, which it runs over several 
times, but then, as with an effort, the whole cry is completed loud and clear, and repeated several times, as if in triumph. At this time they were busily feeding, diving in very deep water on a sand bottom, and calling to one another when they rose to the surface. I never saw these ducks come very near the shore; perhaps this is partly owing to the bay which they frequent having shores which they could not approach easily, as there is usually a heavy surf breaking upon them. I have frequently watched them at night, to see if they would come into any of the creeks, but they never did; on the contrary, after dusk they would often leave the bay; the whole of them would fly off simultaneously in the direction of the mainland of Mull, as if they were bound for some well-known feeding ground. I have often seen them actively feeding in the day time, though more generally they are floating about at rest or diverting themselves. They are of a very lively and restless disposition, continually rising on the wing, flying round and round in circles, chasing one another, liurrying along the surface, half-flying, half-swimming, and accompanying all these gambols with their curious cries. When the storms are at their loudest, and the waves running mountains high, then their glee seems to reach its highest pitch, and they appear thoroughly to enjoy the confusion. When watching them on one of these occasions, I had to take shelter under a rock from a dreadful blast, accompanied by very heavy snow, which in a moment blotted out the whole landscape; everything was enveloped in a shroud of mist and driving sleet; but from the midst of the intense gloom there arose the triumphant song of these wild creatures rising above the uproar of the elements; and when the mist lifted, I beheld the whole flock careering about the bay as if mad with delight."

On the eastern and northern coasts of Scotland, the Long-tailed Duck may be called a familiar winter visitor, being distributed in small flocks off shore from Berwickshire to Caithness. It is plentiful in some seasons in the Firth of Forth, where it never fails to arrest the attention of persons living near the beach-its singularly wild and musical cry being an agreeable break in the continual murmur of the waters. When gathered into still larger flocks, their restlessness seems to increase as the barometer indicates a change, and the birds are sometimes heard, when hurrying seawards towards nightfall, sounding their curious melodies in unison with the waders piping on the shore. At other times I 
have seen as many as thirty approaching the land like unquiet spirits, flitting past again and again, and calling in clear bugle-like strains, as if telling of the coming storm. Many years ago, during my ornithological studies at Dunbar, in East Lothian, these lively birds were my daily delight as I stood on the ruined heights of the old castle watching their playful movements on the water. On many occasions, when the waves were not actually breaking on the rocky foundations, the ducks would come right up to the ruins and pitch down on the heaving volumes of water, where, after diving, they could be distinctly seen browsing on the small shells adhering to the long ribbon-shaped seaweed growing at the bottom. Another favourite feeding place of the same flock, which on some days numbered as many as twenty-two, was at the back of the harbour pier, about one hundred and fifty yards distant from the castle. One day, when stationed in a convenient look-out behind the parapet, I noticed eighteen Long-tailed Ducks feeding quite close to the mason work of the pier, and was somewhat surprised to see one of their number, a male, always on the surface. As I had previously considered that, in the event of sudden intrusion or appearance of danger, it would be difficult indeed for the sentry to communicate with his submerged comrades, I kept a strict watch until the whole flock were under water except himself. Immediately on showing myself and making a noise-I was only about thirty feet above him - the bird, instead of flying off, as another duck would probably have done, instantly dived. What he did or said could not of course be observed; but in a few moments the entire flock came up and flew squattering along the surface until they got on wing, after which they alighted abruptly about a hundred yards out, each bird turning round to have a look at the cause of the disturbance. They then joined in a general chorus of their famous song, which in this instance might be interpreted as a congratulatory chuckle over their escape. Next time I went to this post of observation I found my feathered friends again riding at their ease on some heavy breakers outside the battery. They soon commenced feeding, and remained a considerable time under water. Being anxious to make some further notes on the nature of their food, I waited for a shot at a fine male which is now before me, and knowing the ground to be rocky and covered with seaweed, I was prepared to find the bird's stomach filled with shells. All the stomachs of the Long-tailed 
Ducks I have skinned, indeed, contained nearly the same species -Lacuna vincta and Patella pellucida. These, with young specimens of Mytilus edulis, mixed with some fragments of pebbles, seem to constitute their chief food in this particular locality. The birds must search deliberately (as indeed I have seen them doing when the surface of the water was unruffled) at the bottom for these shells, and go from one mass of seaweed to another, picking them off the fronds to which they adhere. From the stomach of one specimen I took upwards of 100 shells, all in the most perfect state, being clean and free from sand. Of six beautiful specimens now on the table as I write-four males and two females-only one was found to have been feeding on small crustacea, its stomach being filled with entire as well as mutilated specimens of Idotea tricuspidata. In clear frosty weather, these birds often collect into very large flocks, and remain far out from the land over some well known sandbank, where they appear to find their favourite food in abundance. On exceptionally quiet evenings their singular cries are heard by persons on shore, though the birds themselves are not in sight. This strange music is heard at all hours of the day, and reaches the shore from very great distances, especially when a flock is acting in concert. The cry is not uttered on one key, but is modulated, and though not so loud, it in some measure resembles the note of the swan. I believe the male to be the chief performer, although it has been said on apparently good authority that both sexes are alike in that respect. The trachea of the male, as is well known, presents a peculiar conformation - the end near the kidney-shaped protuberance being flattened and divided into five oblong spaces, covered with a membrane resembling the panes of a window. Some authors think that this curious mechanism is in some way connected with the extraordinary sounds emitted by the bird, but others say that the female utters the same note, while her windpipe has no such peculiarity of construction. My impression, from what I have repeatedly observed, is that the female utters but one note, or syllable, while the male runs over five. When a flock consists of males only, as is often the case, the cries are always clear, distinct, aud unbroken: on the other hand, where a proportion of females is seen, the notes are $o g h$, $a g h$, or $u g h$, breaking upon the more intelligible voice of the male, and destroying in some measure its full effect. It is a difficult matter to decide; one thing, however, 
is certain, that a troop of Long-tailed Ducks, when in high glee, is responsible for a great outcry, which has given rise to an idea now prevalent on the east coast among the fishermen, that it is a derisive shout addressed to themselves as they are returning homewards in a half-frozen state at the close of a poor day's work. The last time I had an opportunity of hearing their bagpipe-like music was at my old post on Dunbar Battery, in the winter of 1869. After watching a lively group of fifteen males and five females diving and diverting themselves, I drew the attention of a fisher lad with a gun to their movements. After waiting until they all re-appeared on the surface within range, he made ready for a raking shot over the parapet, but in his impatience he somewhat miscalculated the result, for while his legs and feet wriggled for a convenient prop he slipped backwards at the moment of firing, and the shot, which was intended for the ice ducks, took an almost opposite direction. I expected the birds would have taken wing, but they only paddled out of danger, and when sufficiently beyond range, turned round facing the disappointed lad, and raising such a chorus as to provoke a shout of laughter from the people on the pier. At this time I carefully noted the cry, and was able to appreciate fully the origin of the whimsical name given to the bird in many parts of Scotland-viz., Coal and Candle Light, or more correctly, Coal an' Can'le Licht, for it speaks with a good Scotch accent. The resemblance of the cry to these words, when heard within a short distance, is quite remarkable.

I may remark that in skinning this bird I have been struck with the smallness of the ear aperture. The irides are said by $\mathrm{Mr}$ Yarrell to be hazel, while Macgillivray says they are red. I have invariably found them to be of a bright yellow. The length of the central tail-feathers varies-some measuring six inches, and others seven and eight. Mr David Robertson has a specimen in his collection with these feathers measuring fully nine inches.

In the east of Scotland, Dunbar appears to be the boundary line of the migratory flight of this duck. In November, 1862, I counted forty in a flock off that town; and in the beginning of April, 1865, a flock of between fifty and sixty was observed by $\mathrm{Mr}$ Sinclair and myself off the farm of Thorntonloch, on the confines of Berwickshire: the birds were idly floating just outside the line of breakers, and enjoying the bright sunshine in tolerably smooth water. 


\section{THE HARLEQUIN DUCK.}

\section{FULIGULA HISTRIONICA.}

THE first notice of this beautiful bird as a British species appeared in Montagu's Ornithological Dictionary, published in 1802. Both sexes are described by that author from a pair that had been shot a few years previously in Scotland, and presented by Lord Seaforth, in whose property they were taken, to $\mathrm{Mr}$ Sowerby of London. Coloured figures of these two specimens afterwards appeared in 'Sowerby's British Miscellany,' published in 1806.

The Harlequin Duck has since been included in a catalogue of the Birds of Caithness, prepared by Mr E. S. Sinclair, surgeon, Wick, and published in the statistical account of that parish by the Rev. Charles Thomson, in March, 1841. The specimen is still in that gentleman's private museum. More recently a single specimen appears to have occurred in Banffshire-a circumstance alluded to by Mr Yarrell, who remarks that he saw the bird, which was a young one, and was killed in the autumn of $1851 . *$ In addition to these examples, Major W. Ross King, author of "The Sportsman and Naturalist in Canada,' mentions in his beautiful work that he had a specimen of this rare duck which had been killed in Aberdeenshire; and on communicating with that gentleman I have been obligingly informed that the bird was a male in very fine plumage, and was shot in 1858. It was apparently a solitary specimen. Messrs Baikie and Heddle, in their catalogue of Orkney Birds, allude to a young female bird of this species which was shot in their district by Mr Simmons, and sent by that gentleman to $\mathrm{Mr}$ Sowerby.

The male Harlequin, from the singularity of its markings, is an unmistakable bird; but the female, especially in its immature plumage, is apt to be confounded with the female of the long-tailed duck, and no doubt has occasionally been mistaken for it. As, however, the species breeds in Greenland, and likewise in Iceland, it is somewhat surprising that it does not oftener occur on our shores, especially as it frequents deep water, and is frequently seen at considerable distances from land.

\footnotetext{
* Since this was written, Mr Elwes has informed me that it has been now ascertained beyond a doubt that Mr Yarrell had, in this instance, mistaken a female long-tailed duck for the harlequin.
} 


\section{THE GOLDEN-EYE.}

\section{FULIGULA CLANGULA.}

THE handsome and conspicuous Golden-eye is commonly distributed over the whole of western Scotland, being a regular winter visitant to all the sea lochs of the mainland from Wigtownshire to Cape Wrath, and also the sounds and lakes of both groups of islands. Most of the specimens obtained are females and young birds, very few adult males being seen in their company on their arrival. In severe winters, as the season advances, they ascend our rivers and take up their quarters in quiet places where they find plenty of feeding consisting of fresh water shells, small crustacea, and larvæ of insects. I have seen them on the river Cart, near Paisley, in the beginning of April. Being a day-feeder and a splendid diver, the Golden eye often assembles in large flocks out at sea over some favourite bank of sand or mud, where they remain from morning until nightfall, after which they usually betake themselves, with a rapid and vigorous flight, to moorland lochs, or follow the course of the larger rivers till they meet with a safe refuge. On the east coast, near Dunbar, I have seen hundreds of males mingling with other ducks, such as dun birds, tufted and common scaups, and presenting a very showy appearance outside the line of shore waves as they floated lightly on the water. At other times, on a clear breezy day, with just enough of wind to ruffle the blue sea, I have seen large flocks of these bachelor Golden-eyes by themselves, and looking as if ranged in a line when a broad-backed wave lifted them into full view as I stood upon the beach. I have sometimes sailed down upon such assemblies: at first the ducks sat high on the water, looking really handsome when at their ease, but as the boat sailed nearer they commenced sinking their bodies and finally dived, reappearing at a distance, and then rising almost in a body. Mr Harvie Brown informs me that he finds the Golden-eye to be common on the Forth at Grangemouth, and also on the Carron, in all stages of plumage, and of both sexes.

The Golden-eye probably breeds occasionally in Sutherlandshire, as specimens have been seen and obtained in that county as late as the end of May. Mr A. G. More has stated in the 'Ibis' for 1865 that a pair of Golden-eyes bred in the hollow of an old larch tree at Loch Assynt. The nest, with the young birds, was found 
by a shepherd. Macgillivray states that he has seen pairs on fresh water lochs in Harris in the beginning of May, and stray specimens sometimes linger in Benbecula and North Uist till about the same time.

This duck, in some districts of Scandinavia and elsewhere, invariably breeds in holes of trees, and has probably done so since it became a duck. Persistence in this habit does not appear to have altered its aquatic tastes, for although the nests are often placed at a distance of twelve or fifteen feet from the ground the young ones are no sooner hatched than they are carried to the nearest water-parent and offspring rejoicing alike, no doubt, that they were free to descend from their exalted station. Most persons, indeed, would think them right in leaving the perch above and turning their thoughts to the perch below.

For many years I have carefully watched for the appearance of an allied species-Clangula islandica, (Gmel.) - in the Outer Hebrides, but without success. It may probably yet reach our shores in some winters, especially during the prevalence of northwesterly gales, and collectors would do well to turn their attention to the subject.

\section{BUFFEL-HEADED DUCK.}

FULIGULA ALBEOLA.

The late Mr Yarrell in his 'History of British Birds' mentions that Mr Mummery, curator of the Museum of Natural History at Margate, sent him word of a specimen of this duck having been obtained in Orkney by himself in 1841. I had long looked upon this record as the only instance of the bird's occurrence north of the Tweed, until Mr Angus showed me a beautiful male which was shot on the Loch of Loriston, Aberdeenshire, in January, 1865. A few days later, Mr Edwards of Banff showed me a specimen-also a male-which had been shot many years ago in the Loch of Strathbeg, and placed in the Banff Museum by the late Mr Smith, minister of Monquhitter. This handsome little duck, which is called in some parts of America the Spirit Duck and Conjuror, from the quickness of its movements when diving, is very shy in its habits and difficult to procure: it may therefore be much more common in our rivers, 
lakes, and estuaries than has been hitherto supposed, and may have escaped detection by its dexterity in avoiding danger.

Wilson states that this bird is usually known by the name of the Butter Box, or Butter Ball, from the fat condition in which it is often found. The following is his description of the plumage of both sexes:- "The male Buffel-headed Duck, or rather, as it has originally been called, the Buffalo-headed Duck, from the disproportionate size of its head, is fourteen inches long and twenty-three inches in extent; the bill is short, and of a light blue or leaden colour; the plumage of the head and half of the neck is thick, long, and velvety, projecting greatly over the lower part of the neck; this plumage on the forehead and nape is rich glossy green, changing into a shining purple on the crown and sides of the neck; from the eyes backward passes a broad band of pure white; iris of the eye, dark; back, wings, and part of the scapulars, black; rest of the scapulars, lateral band along the wing, and whole breast, snowy white; belly, vent, and tail coverts, dusky white; tail, pointed, and of a hoary colour.

The female is considerably less than the male, and entirely destitute of the tumid plumage of the head; the head, neck, and upper parts of the body, and wings, are sooty black, darkest on the crown; side of the head marked with a small oblong spot of white; bill, dusky; lower part of the neck, ash, tipt with white; belly, dull white; vent, cinereous; outer edges of six of the secondaries and their incumbent coverts, white, except the tips of the latter, which are black; legs and feet a livid blue; tail, hoary brown; length of the intestines three feet six inches; stomach filled with small shell-fish.

\section{THE SMEW.}

\section{MERGUS ALBELLUS.}

THE Smew is a winter straggler to western Scotland, and is found only at irregular intervals. It has been shot repeatedly on Loch Lomond, and Mr Elwes informs me that in Islay it is a very rare winter visitor. In the southern counties it has occurred in Kirkcudbrightshire, Dumfriesshire, and Wigtownshire. A male was killed on Castle Kennedy Loch, near Stranraer, in March, 1855, as I have been informed by the Rev. G. Wilson, Glenluce. It may 
be remarked that in every case the specimens were procured either on rivers or fresh water lochs.

The most recently killed examples of this handsome species which I have examined were obtained in the winter of 1868 ; one, a female, on Loch Lomond, on 10th January; the other, a fine male, in Islay, in February last.

On the east of Scotland the Smew has been much oftener observed, and has been met with more frequently, perhaps, in East Lothian than in other counties. Nearly all the specimens I have seen or heard of as visitants to that district have been shot in the Tyne estuary, where many years ago I first had an opportunity of examining a newly-killed specimen: it fell to the gun of my lamented friend the late John Nelson, Esq., whose interesting collection contained many valuable specimens of East Lothian birds. In connection with the same locality, the Earl of Haddington has obligingly sent me the following note:- " A very perfect male was shot by me on the Tyne at Tyninghame in January, 1861; it is now in my own collection. Another specimen was shot on the Tyne by Mr Hope in February, 1865; and I saw a female about the same time which had been shot on the shore near Tyninghame."

So far as my own observations lead me to judge, this bird is partial to estuaries where it feeds, like the Mergansers, on marine worms. Dr Dewar informs me that during the Crimean war he observed very large flocks of Smews frequenting the shores of the Black Sea. At Varna they came in great numbers to a marsh close to the walls of the town, and he remarked that very few males were to be seen, the females being in the proportion of twenty to one. It was supposed they fed upon leeches which swarmed in the marsh. In Messrs Baikie and Heddle's work, a manuscript note by one of the authors states that the Smew breeds in Orkney, but no particulars are given.

\section{THE HOODED MERGANSER.}

\section{MERGUS CUCULLATUS.}

I INSERT this species on the authority of the late Mr Sinclair's catalogue of the Birds of Caithness, originally published in the statistical account of the parish of Wick in 1841, and afterwards 
reprinted with remarks by $\mathrm{Mr}$ Shearer and the late $\mathrm{Mr} \mathrm{H}$. Osborne; in the proceedings of the Royal Physical Society of Edinburgh. The specimen obtained is still in the collection, which I believe has not yet been dispersed. Mr Shearer, in his joint contribution, which was read at a meeting held on 22d January, 1862 , merely observes, in connection with the species, that it is "very rare."*

In the Ibis for 1867 (vol. iii., N. S., p. 239) the editor, Professor Newton, in noticing a little work entitled "Sporting Days," by John Colquhoun, states that he had been informed by the author that he had seen three Hooded Mergansers in the Firth of Forth on the 5th May, 1853. On referring to the book itself, I find that Mr Colquhoun, after telling of his triumph in having secured four Eider ducks, gives the following particulars:- "Could I have foreseen that ere the day closed another of these much admired Eiders would have deprived me of a shot at the rarest sea bird I ever detected in the Firth, I might not have regarded them so complacently. Having landed to search one of the homeward islands, a male Eider was asleep on a promontory which flanked a tiny bay. A ledge of rocks parallel to both made the stalk after fowl, either in this creek or on the promontory, very easy. Neglecting (contrary to my wont) to examine the bay, I gave my whole notice to the unsuspecting drake, struck him badly at the sitting shot, and brought him down dead with the other. Before I could rise from my hiding, three little sea-fowl swam rapidly into view from the bay. They never saw me, and seeming more surprised than frightened, never attempted to fly. The leader had a hood like a hoopoe, and in the centre of the hood a white star, the Hooded Merganser! It was a tempting and mortifying moment to watch the little trio, within such fair distance at first, quickly paddle out of reach long before I was "shotted." Leaving the Eider where he fell, we were soon in full chase; but the American strangers had, on second thoughts, betaken themselves to their wings when I ran to warn the men to bring the boat, and I have never fallen in with this rare mergus before or since. When we returned to pick up the dead drake, the fishermen, far from sympathising with my chagrin at losing such a prize, were firmly convinced that the

* Proc. Royal Phys. Soc. of Ed., vol. ii., 1863, p. 340. 
Eider ought to be ample consolation, and was by far the most valuable "fule" of the two."*

\section{THE RED-BREASTED MERGANSER.}

\section{MERGUS SERRATOR.}

\section{Siolta-dhearg.}

Although in the summer season this beautiful bird is shy and unobtrusive, it is well known as a native of nearly all the lakes of any importance north of Loch Lomond. It is likewise numerously distributed throughout the Long island, where it appears to be permanently resident, breeding in South Uist, North Uist, Benbecula, the islands in the Sound of Harris, and Lewis. Within the circle of the Inner islands it is found breeding on rocky islets off Skye, Islay, Jura, Colonsay, and Tyree. I have seen large companies about the close of autumn swimming in the salt-water creeks which intersect the eastern side of North Uist, especially in the neighbourhood of Lochmaddy, where these creeks decoy many an inexperienced Merganser to an early doom. In September, 1867, while waiting there for a change of weather, in the hope of making for Dunvegan, in Skye, I noticed that the Mergansers were uncommonly numerous. Every day for at least a week from forty to fifty young birds, attended by two or three old ones, were seen regularly in these winding sea reaches; but being at length discovered by the owner of one of the few punt guns in the island, my observations on their habits were hastily put an end to. I had been in the habit of concealing myself among the rocks near one of their favourite pools, and had gone out as usual to watch the confiding creatures fishing within a few feet of my hiding place, when a bellowing outburst from the other side of the creek was followed by a rush of buck shot into the midst of the unoffending birds, and three of their number were left floating lifeless on the water. Ah, Roderick! it was poor consolation to hear you betray your disappointed longings when you discovered they were but "them fishy sawbills;" and as their sad requiem rolled mournfully along the sides of Ben Eval, I could almost have wished that shot to be your last. 
The nest of this speeies, which I have often had an opportunity of examining, is generally placed among heath on unfrequented islands. It is like that of an Eider duck, but not so much flattened, being tidier and more compact. The materials are straws, dried moss, and bits of heather, and the whole lined with a profusion of feathers. I have repeatedly seen the nest on the island of Inchmoin, in Loch Lomond, which is frequented by a large colony of the lesser black-backed gull, and about a dozen pairs of the great black-backed gull, who appear to be somewhat dangerous neighbours. In the breeding season of 1864 , I put a female off her nest on that island, and left it untouched after having carefully noted the structure and its contents in my pocket journal. About an hour afterwards, on passing the place, I observed one of the larger gulls had discovered the treasure, and was in the act of breaking the last of the ten eggs which it contained.

On the east coast I have never discovered any breeding place. I have frequently shot the bird on the rocky parts of Dunbar shore, in East Lothian, chiefly at the mouth of some fresh water stream, while feeding on nereids and other sea worms, which had been dislodged by the fresh-water, and were rolling seawards with the current. On one occasion I watched eight Mergansers diving repeatedly at this place about daybreak. From their eagerness in remaining over the same spot, I knew they were finding plenty to satisfy their hunger, and though not in want of a specimen, I selected a male, and shot him as he emerged from below, within range of my hiding place. Finding the stomach full of small black eels, I went back to the burn mouth next morning, and on carefully tracing the rivulet landwards, I at length discovered a swarm of eels on the march. Their progress had been arrested by a barrier of stonework across the stream, over which the rivulet poured in noisy volume, and effectually prevented them reaching the pond on the other side of the wall by swimming. The little creatures, however, had instinctively quitted the water, and were at the moment I saw them wriggling their way up the sides of the stonework in thousands, and clinging to the damp moss, which seemed a great help to them in their efforts to get over the barrier. Many hundreds were already at the top and finding their way to the pond through the grass-avoiding the short rush of water between the reservoir and the fall. 
Dr Macgillivray states (B.B., vol. v., p. 220) that very considerable differences as to size occur in both sexes. I have seven specimens, all killed in winter, from the Outer Hebrides and the mainland of Argyll, now on the table before me, but can discern no appreciable difference either in size or coloration; nor do any of my notes on the bird found in other parts of Scotland furnish a corroboration of that author's statement. I have specimens in breeding plumage from the counties of Perth, Sutherland, and Ross, and have at various times carefully examined others taken in September and October in the eastern counties ranging from Berwick to Caithness, and all may be said to show an unusual uniformity with respect to colour and measurements.

Writing from the west of Argyllshire, Mr Graham says:-_"The Red-breasted Merganser is the more abundant of the two species, being in fact our common goosander. A very pretty sight they make in some rock-embosomed creek a party of some half-dozen, including one splendid male. At one time they float upon their own reflections imaged in the dark-blue water; then, as if by word of command, they all leap down together into the depths below. After a minute's interval, up they pop to the surface, emerging with great buoyancy. They are now a little scattered, so they converge upon their gallant admiral, whose bright parti-coloured plumage is further set off by the rich soft shades of chesnut which forms their own colouring. They advance with great swiftness through the water, without any visible effort or motion of any part of the body. The long slender neck is kept erect and motionless, except to turn the head and long coral bill gracefully round as the bird looks about, suspicious of lurking danger."

As young males resemble the female bird in plumage, the sex can always be readily ascertained without dissection by passing the fingers along the windpipe. That of the male has an enlargement at the end where it enters the body, while the trachea of the female is of a uniform thickness throughout its entire length. 


\section{THE GOOSANDER.}

\section{MERGUS MERGANSER.}

\section{Siolta bheag.}

As a winter visitant, this handsome species occurs in the western counties in even greater numbers than the merganser. It is very common in Renfrewshire, frequenting the river Cart and other sluggish streams, and is at no time difficult to procure. I have examined a number of beautiful male and female birds obtained in that county, and in Argyllshire, in the winter of 1869-70. As many as ten or twelve are sometimes seen together on streams within a few miles of Glasgow. In some of our west coast lochs, as well as those in one or two districts of Perthshire, it lingers till the month of April, but then disappears. Dr Dewar found the Goosander breeding in North Uist in 1858, and shot a female off the nest. One of the eggs taken at that time is in my possession: it is larger than a merganser's egg, cream-coloured, slightly darker in shade, and easily recognised when placed in a group of eggs belonging to the common species. In 1862, I had four or five of these eggs from South Uist, but on these I cannot place implicit reliance, as the bird was not obtained. The fact, however, of the Goosander having bred in North Uist can scarcely be called in question: there were at least two separate stations for it; one near Lochmaddy, the other on the north-west side of the island, where both the Goosander and Merganser are well known. I visited both localities in 1867, and was informed by Mr John M'Donald that he had taken notice of the two species since Dr Dewar's visit.

It may be here stated that Pennant, in his Tour in Scotland, mentions having seen a Goosander in the hands of Dr Walker of Moffat (afterwards Professor of Natural History in Edinburgh University), which had been obtained during the summer in the western islands. As additional testimony to the fact of the Goosander remaining with us during the summer, I have much pleasure in inserting bere the following note from Mr Graham's correspondence. Writing from Iona, he says:- "The Goosander is very plentiful along our shores, I may say all the year round, for though I have never found it actually breeding, it cannot be very far off, as the young broods make their appearance at a very early age, diving and fishing as actively as the old birds. Goosanders 
are not difficult to shoot, as they can be stalked when diving near the land, where they come in very close, sometimes to catch small flounders and other little fish. One I shot had just bolted a mussel, shell and all unbroken. Their flesh is not fit to eat, so we only killed them when wanting specimens."

Since the above was written, I think it right to state that $\mathrm{Mr}$ Elwes, who traversed the greater part of the Outer Hebrides in the summer of 1868, has informed me that he could find no trace whatever of the Goosander in North Uist, nor indeed in any of the other islands, and has expressed his opinion that both $\mathrm{Dr}$ Dewar and Mr M'Donald have been labouring under a mistake in supposing they had seen either the bird or its nest.* While, however, I am quite aware of the painstaking nature of the search made by Mr Elwes, I do not look upon his want of success as setting aside the statements and observations of other naturalists. The late Professor Macgillivray has stated in his work on British Birds that he several times met with Goosanders on the lakes of the Long island in summer; and that his son, Mr John Macgillivray, "found it pretty common, breeding by the larger lakes and occasionally by the sea, as near Lochmaddy, in North Uist." $†$

Like the cormorant, this bird is very destructive to fish in rivers and in fresh-water lakes. Macgillivray mentions that eighteen trout were found in the gullet of one killed on the Tweed in 1838 .

It is only within the last twenty years that the American form of this species has been held to be distinct from that found in Europe, and the following remarks from Professor Baird on this subject may suggest the propriety of a closer scrutiny of specimens

* A still later testimony has come to me through Captain Feilden and Mr J. A. Harvie Brown, who traversed a considerable portion of the Long island in the summer of 1870. Neither of these gentlemen could find a single trace of the bird; and I may add, that while in North Uist in August of the same year, I was myself equally unfortunate. From a long experience in connection with the Outer Hebrides, I have ascertained, however, that some birds do not regularly visit the same spot, so that the Goosander may possibly turn up after a time in some of the lakes that have been hitherto but little visited. Any one who has experienced the extraordinary difficulties which beset the explorer of these lakes, must know that a question like this requires much patient observation.

+ Dr Fleming remarks in his ' History of British Animals,' that the Goosander breeds in the Hebrides, and Mr Selby mentions having seen two or three birds in the Sutherlandshire lakes in June, 1834. 
found in the Outer Hebrides:- "According to Mr Cassin, the American "sheldrake" or goosander differs from the European in having the prolonged feathers of the head almost restricted to the occiput and neck behind, while in the other species they begin almost at the base of the bill, and are erectile and crest like. On the greater wing coverts of the American bird there is always an exposed and conspicuous bar of black, which in the European is entirely concealed by the lesser coverts. Bonaparte says that the bill of the American species is shorter and thicker." It may be added that the last mentioned author in describing the bird calls it only a variety (Mergus castor Var. Americanus), and in this I think he is right.

NATATORES.

COLYMBIDA.

\section{THE GREAT CRESTED GREBE.}

PODICEPS CRISTATUS.

The Great Crested Grebe has come less frequently under my notice in the West of Scotland than any of the other grebes. I have, indeed, seen but one recent specimen for some years. Mr Elwes informs me that he has observed it once or twice on Loch Indaal, Islay. It has been more frequently obtained on the east coast, and may be said to be a well known visitor in the winter season to the larger estuaries. On the Forth it has been repeatedly captured: one was taken as far inland as Stirling. At Dunbar it has also occurred; and on the river Tyne, near that town, specimens have been several times procured. Some of our bird stuffers seem not to be able to distinguish between this and the next-mentioned species. During the past winter two or three red-necked grebes were shown to me both in Edinburgh and Glasgow as specimens of the Great Crested Grebe: the latter, however, may always be easily recognised by its more slender bill, and having the base of the under mandible of a carmine colour; in the former species the colour is yellow.

The habits of this bird are well described by Audubon in the third volume of his 'Ornithological Biography:' it appears to make a much more frequent use of its wings than other grebes, and is described as migrating in flocks of seven or eight to fifty or more, passing swiftly in the air at about a hundred yards from the ground, 
and continuing its flight at all hours of the day. In this country, like the rest of its family, it moves about on wing chiefly during the night.

In the first octavo edition of Pennant's 'British Zoology' (1768), I find the following note in his description of this bird in its winter plumage:- " This species is scarce in England, but common in the winter time in the lake of Geneva. They appear there in flocks of ten or twelve, and are killed for the sake of their beautiful skins. The under sides of them being dressed with the feathers on, are made into muffets and tippets; each bird sells for about fourteen shillings." Hence, no doubt, the name satin grebe and tippet grebe applied to this bird.

Selby states that the Crested Grebe breeds " on a few of the northern Scottish lakes," but gives no locality, and subsequent observers do not appear to have been able to confirm the statement. It breeds in some numbers on Lough Neagh in Ireland, as recorded by the late Mr Thompson in his birds of that country. Bearing this fact in mind, it is somewhat singular that the species does not occur more frequently in the Inner Hebrides or the western mainland of Scotland.

\section{THE RED-NECKED GREBE.}

\section{PODICEPS RUBRICOLLIS.}

ALthough occasionally shot in the western counties in full summer plumage, the Red-necked Grebe does not breed in any part of Scotland; it leaves us in April, returning in autumn, and is sparingly distributed in the winter season. So far as I can judge, it is much more common in the eastern counties. In East Lothian it is frequently obtained, and from that county northward it cannot be called uncommon. Mr Angus states that he shot a specimen in breeding dress on the $2 \mathrm{~d}$ May, 1867, in Aberdeenshire.

I find from my note books that this species is oftener obtained in our rivers at a distance from the sea than either the greatcrested or Sclavonian grebes. Mr George Brown of Glasgow, showed me one in the flesh which he had shot in the river Cart, near Paisley; and I have also examined specimens killed on the Clyde: one, in beautiful summer plumage, having 
been obtained as far inland as the neighbourhood of Lanark. In Haddingtonshire, on the other hand, it is almost wholly confined during the winter time to the estuary of the Tyne, leaving it, however, in calm weather, and travelling along the coast, coming within shooting distance of the rocks to feed. Those I have examined at this season had the ruff and occipital tufts well defined.

The Red-necked Grebe is now and again obtained in the creeks of the inner group of islands, but no specimen has ever yet reached me from the Outer Hebrides. It appears to be not uncommon in Orkney, as one might indeed expect, seeing that the species has been found breeding in some numbers in countries lying to the north-east of Scotland.

\section{THE SCLAVONIAN GREBE.}

\section{PODICEPS CORNUTUS.}

THE suggestive names of "Water Witch" and "Hell Diver" applied to this bird in various parts of America, would lead us to suppose that collectors have some difficulty in securing specimens for their cabinets. Ordinarily, it must be confessed, these names are not misapplied, and may with reason be extended to the whole family of grebes, as it would be difficult to name a more expert class of birds at practising self-concealment. No sooner do they perceive that they are observed and watched, than they are instantly out of sight, sometimes by a rat-like turn of their bodies in the act of diving, but more frequently by a mysterious and almost imperceptible submergence, without occasioning the slightest ripple, or again breaking the smooth surface on which they had previously floated.

The habits of this lively species may be best studied in spring, just about the time when it collects in pairs before migrating. In many of our western sea-lochs it is very conspicuous at this season; and on calm evenings, when the water is motionless and burnished by the slanting sunlight, delighting the eye with a series of coloured cloud pictures as the daylight recedes, the ear at once catches the comical call-notes of these interesting birds holding their Punch and Judy conferences. Far off, at almost a mile's distance, the little specks may be distinctly traced on the unruffled 
loch shifting in circles and chasing each other, accompanying all their gambols with their shrill intercourse about their future movements. Writing from Ardrishaig, Mr Graham says :- " Last year I observed this bird here in March. A considerable number remained in the loch during the last week of the month, bad weather having retarder their progress. Although going in small parties, they had evidently paired, the couples keeping close together, so close indeed that I got two specimens at one shot. They were in full summer dress, and a very striking and beautiful combination it is of buff, black, and white, the largely developed horns of orange plumes being a very attractive feature, and adding very much to the quaint appearance of the birds. The iris is of a rich ruby red, with an extremely fine exterior thread of white running round it." Sometimes their appearance in Loch Fyne is delayed two or three weeks, according to the weather. They remain generally until the last week of April.*

A somewhat remarkable feature in connection with this species is given by $\mathrm{Mr}$ Yarrell, quoting from Mr Proctor of the Durharn Museum, namely, its habit of diving with its unfledged young ones under its wings. "One day during my sojourn in Iceland," says Mr Proctor, "having observed one of these birds dive from its nest, I placed myself with my gun at my shoulder waiting its reappearance. As soon as it emerged, I fired, and killed it, and was surprised to see two young ones, which it seems had been concealed beneath the wings of the parent bird, drop upon the water. I afterwards shot several other birls of this species, all of which dived with their young ones under their wings. The young were placed with their heads towards the tail and their bills resting on the back of the parent bird."

I have had this species sent to me from North Uist by my very obliging friend, $\mathrm{Mr}$ Alexander A. Carmichael, who procured it near Lochmaddy in the month of March.

* Since this account was written, I have been informed by Dr J. A. Smith of Edinburgh, that a pair of Sclavonian Grebes, male and female, were shot on the loch of Killisport, Argyllshire, on 20th June, 1860, and exhibited at a meeting of the Royal Physical Society. "From the season of the year," Dr Smith adds, "and from the locality to which they seemed attached, they were considered as probably rearing a brood of young, although the species has not yet been known to breed in Scotland." 


\section{THE EARED GREBE.}

\section{PODICEPS AURITUS.}

NoT of common occurrence in the western counties, where it is but sparingly distributed. A very fine specimen in full breeding plumage, shot on Loch Sunart, and now in my own collection, was sent in the flesh to Mr Bell, gunsmith, Glasgow, in the spring of 1866. It has likewise been found in the Outer Hebrides, a specimen having been sent to Mr Macgillivray from North Uist.

I have known this bird as a visitant to the shores of East Lothian since 1846. It is a species well known to the fishermen and shore shooters by the form of its bill, and I have several times obtained specimens by giving directions to the gunners of that coast to bring them for the purpose of supplying a friend's cabinet. In the winter of $1864 \mathrm{I}$ examined five specimens obtained in this way near Dunbar.

The Eared Grebe has been shot on the Nith in Dumfriesshire; it is also mentioned as a Mid-Lothian bird in the 'List of Animals,' etc., given by the late Mr Patrick Neill in a life of Allan Ramsay, with illustrations of scenery, etc., published in Edinburgh in 1808; and in a manuscript note appended to Baikie and Heddle's work by one of the authors, I find that a specimen was killed at Kirkwall by Mr J. H. Baikie in October, 1852.

\section{THE LITTLE GREBE, OR DABCHICK.}

\section{PODICEPS MINOR.}

Spagaire tuinne. Goblachan uisge.

ThIs curious and unobtrusive bird is permanently resident, and very generally distributed throughout Scotland, extending also over the whole of the Long island or Outer Hebrides. Among the inner group of islands it is well known in Skye, Rum, Mull, Islay, and Jura, as well as those of minor extent, embracing the islands of Gigha, Colonsay, Tyree, Coll, and Iona, etc. It is frequently found breeding at a great elevation on our western mountains. Mr Sinclair procured a specimen in a little loch near the summit of Ben Eadden, one of the hills of Morvern in Argyllshire, at an elevation of perhaps 2000 feet; and I have been informed by $\mathrm{Mr}$ 
William Hamilton of London that his brother met with the bird in the neighbourhood of Scuir Ouran in Inverness-shire at even a greater height above the sea level. In the neighbourhood of Glasgow it is found nesting in Possil Marsh, and also at Hogganfield Loch. Sixteen nests were found in the first-mentioned locality in the breeding season of 1868-many of them by my friends Messrs W. Lorrain and J. S. Dixon, whose persevering skill has been the means of revealing the comparative numbers of birds breeding in that now rapidly-decreasing marsh. A number of eggs taken by these gentlemen is now before me: they are all much stained, though they were quite fresh when blown-a circumstance arising from the bird's habit of covering its eggs with damp weeds on leaving the nest. Out of the sixteen nests I have mentioned, only one was found with its contents uncovered, all the others being heaped over with wet plants, which had apparently been pulled out of the water by the grebes only a short time before they were discovered.*

I have many times found the Little Grebe frequenting salt water pools among the rocks by the sea shore. I recollect meeting with one on the coast near Dunbar in a little sheet of water surrounded by rocks which were profusely fringed with Corallina officinalis, and seeing the bird make repeated, though ineffectual, attempts to conceal itself in a tuft of coralline. It made no effort to escape by flight, but seemed rather to trust to its instinctive powers of deception. Even when fired at, instead of rising on wing, it merely shifted from one side of the pool to the other till it became exhausted, and could not dive with the same rapidity. In ordinary circumstances, when fairly awakened to a sense of its danger, the Little Grebe, like all its family relations, will defy the quickest shot in the water.

In one or two of the outer islands, such as North Uist and Benbecula, the Little Grebe disappears for a time in winter from the inland lakes, and is then found in the vicinity of the islets in the sounds which separate these islands. It is curious to speculate on the probability of these birds remaining constantly in such haunts as the mountain tarns on the summit of hills within the

* The plant used by these birds in nest-building, and also for covering the eggs, in Possil Marsh, is one which has of late years become very abundant there, namely, Anacharis Canadensis. It is also spreading to a great extent in some of our canals and private ponds, where it is looked upon as a nuisance. 
natural range of the eagle and ptarmigan. The late Mr Yarrell imagined that this grebe in particular was possessed of but limited powers of flight, and would have no doubt been surprised to learn that it haunted the lochans of some of our highest mountains. Few persons have an opportunity of making constant observations at so great an altitude, and we shall probably never know how the grebes make the ascent, if indeed they ever come down for a change.

\section{THE GREAT NORTHERN DIVER.}

\section{COLYMBUS GLACIALIS.}

Bun-bhuachaill. Mur-bhuachaille.

THIS splendid diver is a very common species in the west of Scotland, being widely distributed from the Mull of Galloway to Cape Wrath in the north of Sutherlandshire. In the Outer Hebrides it is also very abundant, and, as a rule, is found there at all seasons of the year, except the month of July. Early in summer they begin to collect round the shores of Lewis, Harris, North Uist, Benbecula, and indeed the whole of the Long island, where they linger until the beginning of June, some remaining even as late as the middle of the month.* A few remain in Benbecula all the summer; the nest, however, has never been found. They return some time in August, and are seen in groups of fifteen to twenty birds, swimming near the shore immediately on their arrival. I observed a gathering of this kind on the west side of Benbecula on the 29th of August, 1867, and was told by a friend residing there that he had seen them fully a fortnight before. All the birds were in brilliant summer plumage, and, as a group, formed a spectacle which is not often looked upon by even the most fortunate ornithologist. In many of the Sounds and salt-water reaches of the inner islands, similar companies have been observed at the beginning of the season. Dr Scouler has informed me, that in the course of a yachting cruise among these islands, he has seen from fifty to sixty Great Northern Divers, all in groups of six or eight birds, preparing to quit the coasts for

* I have in my collection a beautiful male in full breeding plumage, which was shot near Nunton, on the west side of Benbecula, on 24th June, 1866. 
their breeding stations. Where these may be, I am at a loss to conjecture. The absence of the birds extends through so short an interval as to preclude the idea of the journey being a lengthened one. In six weeks at most many of them are back to their old haunts, even as far south as the coasts of Ayrshire, where I have seen adult birds in August, accompanied by their young ones little larger than a mallard. As the species is much later in spreading along the eastern shores of Scotland, it may be presumed that the Great Northern Divers of the western islands are hatched either in Iceland or the north-eastern shores of Greenland. It is possible that Greenland birds may leave sooner than those bred in Iceland, as on referring to Professor Newton's very interesting list of the birds of the latter country, it will be seen that mention is made of this Diver forming into parties on the sea in the end of August, and remaining off that coast during the winter. Although it has been at various times hinted that the species may have bred in this country, positive proof is yet wanting to set the question at rest. Mr A. G. More states (Ibis, 1865) that Mr W. Dunbar informed him of having seen, when he was a boy, a pair of Great Northern Divers, with one young one, in Loch Endorb(?) On the same loch were two or three pairs of the black-throated diver, so that the two species were easily distinguished by the great disparity of size. Mr More likewise mentions that Dr Saxby had procured from Yell, in Shetland, some eggs which he considered to belong to the Great Northern Diver; but I may here repeat what I communicated to $\mathrm{Mr}$ More during the preparation of his paper, that eggs alone can scarcely be relied upon, as I had seen some specimens about as large as those of Colymbus glucialis, and very like them in shape, which had been taken from a blackthroated diver shot on the nest. Mr Harvie Brown has informed me that he is nearly certain of having seen the Great Northern Diver for two successive years in a loch in Sutherlandshire during the height of the breeding season. He has described to me the different cry and general deportment of the birds as contrasted with those of the black-throated diver, with which he is perfectly familiar. I have therefore a hope of yet hearing that the species has bred in that county.

According to the Rev. J. L. Buchanan, who published a book of travels in the Western Hebrides in 1793, this bird was then called the Bishop Carara in the Long island. The bishop, says this 
writer, "was never known to fly, the wings being too short to carry a weight seldom under, but often above, sixteen pounds."* In spite of its weight, however, the bird flies with great speed. I have frequently seen it at the close of day rise from the extremity of sea-lochs at a distance of many miles from the open sea, and after getting fairly on wing, direct its flight seawards with tremendous swiftness, as if impelled by a gale of wind. On these occasions it follows herrings and other fishes into the lochs, which it penetrates to their narrowest recesses until satisfied, after which it seems to realize the danger of remaining there during the night, and takes the safer course of returning to its 'home on the rolling deep.' At various times I have seen Great Northern Divers caught in salmon nets: two very fine specimens, in full breeding dress, were captured in this way at Girvan in the second week of May, 1869. In its submarine flights, this bird is not proof against accident from contact with the legitimate inhabitants below. In November, 1860, some fishermen belonging to Ackergill, while pursuing their ordinary avocations in Sinclair Bay, Caithness, had their attention directed to a large fish struggling on the surface of the water at no great distance from their boat. On rowing towards it they found to their surprise that it was a large sea-devil or angler (Lophins piscatorius) which had closed its capacious jaws on a Great Northern Diver, but had been unable to swallow more than the head and neck. With its willely extended wings the bird was frantically thrashing the water, and effectually resisting the equally frantic efforts of the 'Devil' to get him under the surface. By the use of a boat-hook, the "whole affair," as one of the fishermen described it, was hauled in triumph over the gunwale, and the bird, which was still alive, at once released. The probability is that the Diver, in descending to the floor of the sea in quest of crustacea and other marine animals on which it feeds, had accidentally thrust its head into the open jaws of the fish, which, as is well known, conceals itself at the bottom by stirring up the mud and sand with its abdominal fins, and keeps its huge mouth prepared to receive any inquiring fishes that may happen to swim to the spot to find out the cause of the disturbance.

* The largest and heaviest Great Northern Diver I have seen was killed in Stornoway Bay, island of Lewis, in the spring of 1866. It weighed twelve pounds, and another killed at the same time and place, which I also saw, weighed eleven pounds and a-half. 


\title{
THE BLACK-THROATED DIVER.
}

\author{
COLYMBUS ARCTICUS.
}

\section{Learga.}

WHEN seen decked in its beautiful summer plumage, it may fairly be questioned if there is a finer or more striking bird in the entire range of British ornithology than the Black-throated Diver. There is something in its appearance which at once captivates the most careless, and when caught alive by the fishermen, who sometimes find a stray specimen on their lines, and in salmon or herring nets, it is taken home in triumph as an object of beauty, and carefully bargained into the hands of the nearest collector. Many times I have seen these lovely captives carried about for disposal at fishing towns on both the eastern and western coasts of Scotland. They seem to come shorewards in May, and remain a short distance from land, travelling northwards, especially ou the west coast, until they slip off unperceived about the same time as their ally the great northern diver. A number of pairs take up their summer quarters on various lochs on the mainland, in Argyllshire, Perthshire, Inverness-shire, Ross-shire, and Sutherlandshire; and on almost every loch in the Outer Hebrides there are to be found one or two pairs breeding. In Lewis they may be seen on Loch Langhabat, and similar sheets of water, and in North Uist I know of at least five different lakes where they breed. Benbecula can likewise boast of several hreeding stations. I have seen both old and young birds there in September. The spots selected for nidification on these solitary patches of water are generally small rocky islets, and occasionally a spit of land or stony promontory stretching some distance into the lake. There is no nest-the eggs being merely placed on the ground, and near the water, often not eighteen or twenty inches from it. When the young are hatched, the parent birds lead them away almost directly, especially if in the slightest way molested, and throughout the entire breeding season, indeed, this species is remarkably shy. Sometimes, by close and careful watching, and keeping strictly concealed, one may get near enough to distinguish a family group as they are fishing together on the lakes about sunset. I have myself managed to come upon them unperceived when so engaged, and a more beautiful group of birds could not be inragined. Immediately on 


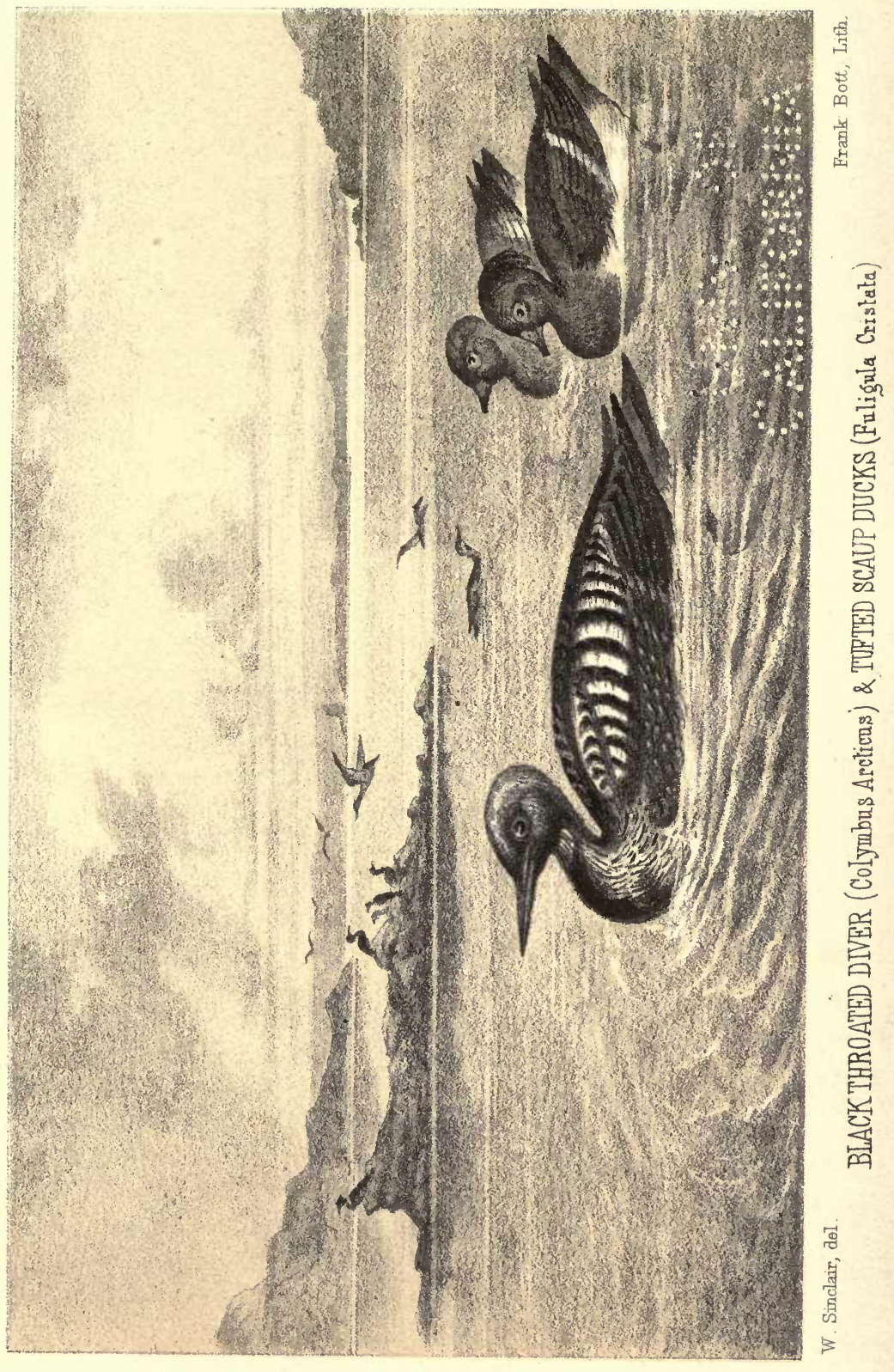


?o

Deco oc

oos ${ }^{\circ} \mathrm{C}$

Doc 0 o

है

हce

ci o

ceco ocas

c cice

ctec cies

cco ocos

st $c$

5,5 
being noticed, however, their bodies were lowered, and their heads turned to the other side of the lake; then their swimming powers were seen to great advantage as they hastened out of danger. In dry seasons, especially, their extraordinary cry frequently startles the lonely traveller as he passes their haunts, making the still waters resound with strange echoes from their rocky embankments. The natives of Benbecula and North Uist compare it to "Deoch! deoch! deoch! tha'n loch a traoghadh," which may be interpreted by the words, "Drink! drink! drink! the lake is nearly dried up."

Apart from these Hebridean summer haunts of the Blackthroated Diver, the most interesting breeding places are unquestionably the lochs of Sutherlandshire, where Sir William Jardine and the late Mr Selby discovered the nest in 1834. Mr Selby's notes having been communicated to Mr Yarrell, and published in that author's 'History of British Birds,' it is unnecessary to repeat them here; but as allusion is made to Mr James Wilson's discovery of a nest and two young ones on Loch Craggie, near Lairg, the following particulars by that pleasing writer, which I have not seen quoted in any ornithological work, may not be unacceptable to general readers:- “The Black-throated Diver (Colymbus arcticus) is a bird of large size and singular beauty. It almost invariably builds on the small low islands of inland lakes, preferring those with flat or somewhat open shores to such as are precipitous or rock-bound. The first time we ever encountered the species in its natural state was while examining the shores of Loch Craggie, a famous angling loch of Mr Matheson's of Lewis, lying in the upland north-east of Ben Doula, near Lairg. A small stony point (an island when the waters are full), not unadorned by tufts of grass and rushes projected from the lower end of the loch; and seeing the parent birds swimming somewhat anxiously near it, and not, as usual, seeking to escape by diving, we made our enquiring way by wading across the water, and soon discovered two little cowering existences covered with black down. They lay in a shallow trampled hollow which seemed to serve as, though it could scarcely be called, a nest. We took them up, treating them very tenderly, and then placed them close to the water's edge, where they waddled a little for the first time in their lives, and then striking out with both feet and winglets, were instantly joined by their parents, who met them more than half way-the whole forming a family group of great beauty. 
"Next morning, having occasion to angle in the loch, we paid it another visit, accompanied by two ornithological friends, who alas! in addition to their rods, were each armed with an unfailing fowling piece; but being ourselves in a minority, there was no help for it. We approached the 'beaked promontory,' and soon saw the fair creatures, full of parental fondness, also bearing gallantly towards it, uttering a warning cry. They were met by their sooty little offspring, who seemed to have improved upon the lesson in swimming which we had given them the preceding day, and then wheeling round with many serpent-like motions of the head and neck, were making rapid way into the deeper portion of the loch, when a couple of almost simultaneous shots laid both parents, and a single young one, dead upon the waves. The wind soon drifted them within our reach. The other young one could be nowhere seen. When the lifeless bodies, 'beautiful exceedingly,' were laid upon the bank, we (the angling minority) could not help thinking mournfully of the many lustrous days and peaceful nights during which they had fearlessly breasted those wild waters, or reposed along their barren shores in undisturbed tranquillity. How many calm sunsets had gilded that sedgy home - how many bright moonlights had thrown a cloudless radiance over the mirror of that lonely lake-and how often the summits of Ben Doula had reddened as if rejoicing in the morning rays, since the 'unoffending creatures' had first looked upon these waters as their own! But as Mr St. John averred of the osprey, 'their skins were wanted;' and such ornithologists as Sir William Jardine and $\mathrm{Mr}$ Selby were made of sterner stuff than to bewail their own success."*

Mr Harvie Brown, who has paid regular visits to Sutherlandshire for some years, informs me that a number of pairs still breed on the lochs of that county, and that one pair at least is now known to breed on the loch near Pitlochry, in Perthshire. The same gentleman found two pairs in 1870 on Loch Howna, at the base of Unavall, in North Uist, one of which had a young one hatched as early as the 14th of May. The following notes, written by $\mathrm{Mr}$ Elwes, relate chiefly to his experience in the Outer Hebrides, and are corroborative of what has been observed by Mr Harvie Brown and myself in the same district and elsewhere:- "The Blackthroated Diver sometimes lays its eggs as early as May 9th, though 
I have found them fresh six weeks later; and if the first pair are taken, it always lays again in the vicinity of the first nest. I have even heard of a fifth egg having been laid after the second pair were taken. They are not found on the small lochs to which the redthroated diver retires to lay, but on large pieces of water containing several islands. In one of these islands where the shore is soft and shelving, the bird creeps up about a yard from the water and lays two eggs on a bare round spot as large as a dinner plate, sometimes placing a few bits of grass or rush round them, and always making a visible track to the water by the pressure of her breast. When disturbed by the approach of any one, she dives quietly off the eggs and comes up at a little distance, but is very unwilling to leave the place altogether. They are found in scattered pairs nearly all over the West Highlands, though I do not think they breed in Skye, Mull, or Islay. In winter they are not often seen, and are difficult to distinguish from the great northern diver."

Dr Dewar, who has also had considerable experience in observing the habits of this bird, found several nests in the island of North Uist in the breeding season of 1858, and has also obtained both birds and eggs from one or two stations in Argyllshire.

\section{THE RED-THROATED DIVER.}

COLYMBUS SEPTENTRIONALIS.

The Red-throated Diver is a very common bird in the West of Scotland, and is found at all seasons of the year. It breeds in some numbers on many of the islands in fresh-water lakes, and is permanently resident throughout the Hebrides, where I have had frequent opportunities of studying its habits. The nest, if nest it can be called, is like that of its congener the black-throated diver placed very near the water, so as to allow the sitting bird to make its escape readily in case of danger. I have never seen more than two eggs in a nest, which is one short of the number usually laid by the same species in North America. According to Audubon, three eggs are as often found in a nest as two. It sometimes happens with us, however, that the rearing of a pair in safety is even more than the old birds are able to accomplish. On 
two occasions at least I have noticed them with only a single young one-the other having probably, in spite of their assiduous care, fallen a victim to some passing raven or peregrine. On these Hebridean lakes the Red-throated Diver is extremely suspicious and vigilant, never allowing a very near approach unless the eggs have been for some time sat upon, when the female, and even the male, who is her constant attendant, remains at hand, swimming anxiously within gunshot, and betraying the utmost concern for the safety of their treasure. Should the eggs be taken, the poor creatures seem to feel the deprivation with unusual keenness, and give expression to their grief-for sorrow I really believe it to be -in loud lamentations. These cries are so full of melancholy meaning, when heard echoing in the midst of the rock-bound lakes of that barren district, that few persons hearing them once would ever desire their repetition. Many of the natives, indeed, would never think of robbing the birds on that account alone. I once asked a man living near their haunts on Loch-an-Astrom to get me the contents of a nest on the point of a small islet where I had watched the birds for some days, "Ah, maister," said he, "I could soon do that, but I don't like to hear the birds cry." When I afterwards saw the proud parents giving their two little black downy things their first swimming lesson at early dawn, I could not help thinking that the loch looked much fairer on account of their presence, and that it would have been almost a shame to have invested such a scene with the story of even a bird's despairing cries.

Among rustic people, the ordinary note of the Red-throated Diver is said to portend rain; in some districts, indeed, the bird is known by the name of rain goose. I have oftener than once had an opportunity of hearing the birds calling at nightfall in the Outer Hebrides. On the 1st of August, 1870, I witnessed a curious scene at Lochmaddy, in the island of North Uist, about nine o'clock in the evening. The air was remarkably still and sultry, and frequent peals of thunder in the distance were the only sounds that for a time broke upon the irksome quiet that otherwise prevailed. At length the thunder, on becoming louder, seemed to waken up the Divers on various lochs within sight of where I stood, and first one pair, then another, rose high into the air, and flew round in circles, until there must have been twenty or thirty in all. After a time, they settled in one of the salt creeks about half a mile to the east- 
ward, and then there arose a wild and unearthly noise from the birds, which I cannot describe. It is, in fact, a. sound which no one can ever forget after once hearing it, especially in these Hebridean solitudes, where it acquires its full emphasis. Next morning, about four o'clock, while bowling along towards the Sound of Benbecula in the face of a rain-cloud such as I wish never to see again, several of the birds passed us overhead at a considerable height, uttering the same cries, which might be likened to a person in despair making a last shout for help when no help is near. Once or twice we pulled up and listened to the distressing sounds, but at last, with an impatient lunge of the whip, Allen could stand it no longer. "Let's oot o' this, sir," he said; "I don't like it at all, and 'deed I wonder hoo ye can pit up wi' them brutes, when there are so mony bonnie jukes where we're going to." So when the next Diver rose and wheeled eastwards with the customary wail of anguish, Allen, whose face was now tears all over with the wild blast of rain, seemed more deeply convinced than before that the "nasty wretches," as he called them, were the sole cause of it all.

In the winter season, the Red-throated Diver loses every vestige of the rich cochineal patch on the throat and neck, and is then a less attractive "loon," frequenting sandy bays by the sea shore, and occasionally appearing inland at some distance from the coast. I have seen specimens taken in fresh water ponds within two miles of Glasgow. In the southern counties, where there are no breeding places, single birds are sometimes met with in full nuptial plumage. A beautiful specimen was shot off the pier at Troon, in Ayrshire, in May, 1870, and sent to Mr Eaton, bird stuffer, Kilmarnock, for preservation. On the east coast, the Redthroated Diver is a common species in winter, frequenting friths and estuaries, and feeding on young herrings and sand eels, in pursuit of which, over the sandbanks, it often comes very near the shore. I have on many occasions, during my early experiences, lain in wait for it behind various boulders on the sea shore at Dunbar, in East Lothian, and been rewarded by the acquisition of specimens. These were chiefly young birds of the year, which appear to be much more common than adult birds, especially at the close of the breeding season, when the broods, perhaps through dislike of a northern climate, shift rapidly southwards. 
NATATORES.

ALCADA.

\section{THE COMMON GUILLEMOT.}

URIA TROILE.

Gearadh-breac. Eun-dubh-a'-Chrùllain. Langaidh. Eun an t' a Sgadan.

This Guillemot, as the last of its Gaelic names implies, is the "Herring-bird" of the Hebrides, and is the most abundant of the Alcadce to be found in the West of Scotland. Immense numbers of Guillemots frequent the coasts of the mainland, as well as the inner and outer group of islands, and wherever suitable cliffs occur, they take up their quarters during summer, forming colonies numbering, in some particular places, two or three hundred thousand birds. In the vicinity of these breeding haunts they literally blacken the surface of the sea, creating a sight interesting alike to the bird student and ordinary tourist.

On Ailsa Craig these birds breed on the narrow ledges of rock, and occupy the entire face of the highest precipices-presenting, when viewed from the sea, a very remarkable and orderly appearance. They make no nests, but lay their single egg upon the bare ledge, which is seldom more than six inches in breadth, so that each bird is obliged to sit erect while incubating. I have frequently climbed to a height of four or five hundred feet to see the most thickly-populated breeding-place; and having hurled down a few stones to frighten the birds, have seen them all take wing, leaving a most extraordinary collection of eggs behind them. The Guillemot's egg, which is very large, and of a handsome shape, is extremely variable in colour, and is found of all shades, from a pure white to a deep green-many being spotted with fantastic characters, and intricate lines, which baffle description or portraiture; the sight of so many, therefore, lying exposed on the bare rock, is one of no common interest. On such occasions many hundreds - I may almost say thousands-may be seen, all nearly touching one another; and when the birds afterwards come pouring in towards the ledges, each flying directly to its own egg, the infinite variety of colouring, or private marks, so to speak, may be looked upon as an all-wise arrangement for keeping up the harmony of the settlement. 
I recollect climbing with a friend one evening in June to the top of the cliffs to take some notes of the birds generally, and approaching the perpendicular walls of basaltic rock facing the south, on which the Guillemots, razor-bills, solan geese, and kittiwakes were sitting in congregations which could scarcely be over-estimated. There was a party shooting from a boat close to the base of the Craig, and I noticed that the birds on the upper shelves, when disturbed by successive shots, resembled a heavy fall of large snow-flakes, the lower stratum of kittiwakes appearing from above as a flickering shower of white particles. Having crept cautiously to the verge of the precipice, and thrust my chin over the edge of a pillar-my heels being meanwhile held by my companion behind-I had a satisfactory view. Looking down about four hundred and fifty feet, I saw that the gulls and other birds floating on wing near the water had no particular form, on account of the distance; but there could be no doubt as to the specific identity of the black imps just under my face. These were young Guillemots and razor-bills-the old birds being beside them, anxiously poking out their necks, and looking upwards with an eye of fear that fairly put me out of countenance. It was evident from their expression that they divined nothing good from my head being between them and the sky, and their mingled look of terror and perplexity, on seeing the apparition, conveyed to me anything but a compliment. Under the perch of these odoriferous "children of the mist" other families came in view, lower and still lower, their untidy habits being modified by distance, till the eye lost sight of the species, and sea-fowl in general became responsible for the smell and uproar.

While on the rock, I learned from the keeper, whose accuracy of observation I have never had any reason to doubt, that when the young Guillemots are half-fledged, he has seen the parent birds daily taking them down on their backs to the sea, and unceremoniously pitching them off when within a few feet of the water. He has also observed them seize their young ones by the hind neck, as a cat would do its kittens, and, after a moment's hesitation, launch from their high perches, and descend with an unsteady flutter till they could drop them with safety. At this season I have seen-as no doubt every other visitor to Ailsa must have observed-great numbers of down-covered Guillemots swimming in the sea, and plaintively calling during the submergence of 
the old birds on their behalf. From their tender age, it was evident that they could not have got down from their perches without having been carried; and it appears strange that the habit of lifting their young ones should prevail among this kind of sea-fowl. It is just possible that the labour of carrying their food nearly five hundred feet into the air is too great; or perhaps the employment of carrying fish at all may be distasteful to a bird of high descent.

Towards the end of autumn, or beginning of winter, large flocks of Guillemots betake themselves to salt water lochs, and occasionally to fresh water lakes a little way inland. They have been seen in mid-winter on Loch Leven in the east, and several places of a like nature in the west; but their stay appears to be entirely influenced by the weather.

At Barra, in the Outer Hebrides, where there is an extensive nursery of these birds, great numbers died on the ledges in the breeding season of 1867, as I have been informed by Mr Alexander A. Carmichael, Lochmaddy. Incubation had been delayed till the middle of August, on account of the severity of the weather, which seems to have caused the mortality. In more favourable situations, the young birds had, by that time, all left their perches.

Albinoes sometimes occur on the west coast. The last variety of this kind that came under my observation was shot in the Firth of Clyde, near Rothesay, and is now in the collection of Dr Dewar of Glasgow.

\section{BRUNNICH'S GUILLEMOT.}

\section{URIA BRUNNICHII.}

THough this species has been said to be a native of St. Kilda, I can find no reliable information on the subject of its breeding there. None of my correspondents who have visited St. Kilda appear to have recognised the bird at all. It is, therefore, extremely doubtful if it can be regarded in any other light than as a very rare straggler in any part of Scotland. The late Mr Wilson of Woodville, in his 'Voyage,' mentions having seen a specimen in the collection of Mr E. S. Sinclair of Wick: it had been shot in Caithness, and was preserved by Mr Sinclair, who was unable to name the species (although its peculiarities were observed) until $\mathrm{Mr}$ Wilson identified it. In Macgillivray's work on 'British 
Birds' it is stated that Sir J. C. Ross found the species at Unst, in Shetland, as well as "in several parts of Scotland," but no other localities are given. Mr Macgillivray likewise states that he found a specimen among some skins from Orkney belonging to $\mathrm{Mr}$ Wilson, janitor of the Edinburgh University. Mr A. G. More mentions (Ibis, 1865) that a specimen was obtained by the late Sir William Milner in Sutherlandshire; and Messrs Baikie and Heddle state that it has occurred once or twice in Orkney.

I have a specimen of this bird now before me, which was preserved by a bird stuffer at Hamilton, and said to have been obtained on the west coast of Scotland, and from the smooth appearance of the webs of the toes, I should imagine it must have been set up when in a fresh state, relaxed skins being readily distinguished by the shrunk appearance of the membranes.

The following curious circumstance in connection with the breeding quarters of this guillemot is narrated in 'Nature' for April 27, 1871:- “The western gull (Larus occidentalis) is very abundant on the whole coast of California, especially on the Farrallone islands, where it is a serious hindrance to the men employed in collecting the eggs of the murre (Uria Brunnichii) which breeds there in countless numbers. The traffic in their eggs between these islands and San Francisco alone reaches annually the sum of between one and two thousand dollars. The egg-hunters meet at one o'clock every day during the season (from May to July) with the exception of Sundays and Thursdays, and at a given signal, so that each may have an equal chance in gathering the spoil, start off for the most productive egging grounds. The gulls understanding, it would seem, what is to occur, hover overhead, awaiting the advance of the men, who rush eagerly into the rookeries. The affrighted murres have scarcely risen from their nests, before the gull, with remarkable instinct, flying but a few paces ahead of the hunter, alights on the ground, tapping such eggs as the short time will allow before the egger comes up with him. The broken eggs are passed by the men, who remove only those which are sound. The gull, then returning to the field of its exploits, procures a plentiful supply of its favourite food. Dr Heermann says that he once saw three gulls scientifically approach a single murre sitting on her egg. Two of them feigning an attack in front, the murre raised herself to repel them; instantly the third, advancing from the rear, seized her solitary egg from be- 
neath her, and flew off with the booty, the two first immediately following to claim their share. The egg was dropped and broken on the rocks, when a general scramble ensued between the three robbers for the valued prize."

This bird is the Uria (Cepphus) arra of Pallas (Zoog. RossoAsiat, ii., 1811), and is said by Mr Cassin to be "the most frequent species of this group on the coast of the middle and northern states on the Atlantic, occurring nearly every winter as far south as the coast of New Jersey."

\section{THE RINGED GUILLEMOT.}

\section{URIA LACRYMANS.}

Although the Bridled Guillemot, as this bird has also been called, is very abundant in some districts of the West of Scotland, while it is of rare occurrence on the east coasts, and may be said therefore to have a special geographical range, it is, I think, extremely doubtful if it can lay claim to specific distinction. Selected specimens might, no doubt, be evidenced as possessing a shade of colouring and slenderness of bill slightly different from characteristic examples of the common guillemot; yet, after carefully examining a very large series of ringed or bridled birds, I can perceive no distinction in any one specimen entitling it to rank as a separate species. Some of the common guillemots have the rich brown upper plumage, while many of the bridled birds have the same parts of the precise hue which is said to prevail with the common one, thus reversing the supposed distinctions of colour. The same may be said of the differences in the size and shape of the bill-the one bird having as stout or as slender a bill as the other. Sir William Jardine is inclined to think that this Guillemot is one of those closely allied species which we so frequently meet with in particular genera, and appears to found his opinion on the bird having a weaker and more slender bill than the common guillemot, the dark olive brown of the head and neck being intermediate in shade between that of the common and Brunnich's, and the eye being surrounded with a ring of white, which is prolonged in a narrow line below the separation of the auriculars. The colour of plumage, and the dimensions of the bill, are, as we have seen, characters which become blended in the two birds, so that the mere 
possession of a white ring round the eye, and extending backwards over the ear, is all that would seem to distinguish the one from the other. Mr Cassin, in Professor Baird's work on the Birds of North America, says, that the white line is not always present,* although in the specific characters which he defines, this feature is referred to as a ready means of distinguishing it from the common species. In the same work Uria troile is catalogued on the assumption that it must have occurred in the northern regions of that continent, though Mr Cassin admits that he had never seen an American specimen. The Ringed Guillemot, on the other hand, is described as "one of the most common birds of the higher northern latitudes on both sides of the continent," and this leads to the conclusion that North America is the head-quarters from which it has gradually spread eastwards to the British islands. On the western coasts of Scotland it occurs in all localities frequented by the common guillemot. In my own collection I have several specimens from Ailsa Craig, Loch Sunart, and various places on the Firth of Clyde. It has been procured as far up the Firth as Greenock-a specimen having been shot there in April, 1861. Mr John Gilmour of Glasgow informs me that on 10th April, 1868, he shot three guillemots when boating in Kilbrannan Sound, two of which were ringed birds. These, although in winter plumage, show the white line round the eye very distinctly. It is only of late years that the variety has been recognised by the fowlers at Ailsa and elsewhere. "Weeping guillemot," "silver-eyed scout," and "bridled marrot," are instances of local distinction among the fishermen, but these names have evidently been acquired through intercourse with collectors.

On Ailsa Craig specimens occur every year, and during the time the tacksman and his assistants were in the habit of snaring the sea fowl previous to the passing of the Sea Birds Preservation Bill, they took on an average three specimens in a week. I have seen two and even three taken in one day, and on the occasion of my last visit to the rock in company with $\mathrm{Mr}$ Anderson, I counted over one thousand five hundred dead guillemots, and found only two bridled birds in that number. One of the men, however,

* The exact words are:- "The white line behind the eye frequently wanting, and different in length in specimens"-a description which shows that even the character on which the name is founded wavers and disappears. If $\mathrm{Mr}$ Cassin really examined specimens without this white line, it seems strange that he should say that he never saw an American specimen of Uria troile. 
informed us that he had that morning found another in the nets, but having tethered it to a stone until his work was finished, he could not again find it. From repeated observation on Ailsa Craig I have computed that not more than one ringed bird in five hundred of the common ones can be recorded from that locality. From Mr Harvie Brown's journals, I learn that on the island of Handa, on the west of Sutherlandshire, the proportion is one in a hundred. Again, at Barra Head, I have been assured by the lighthouse keeper, the number may be reckoned at one in fifty; but Mr Elwes, who spent four days there in the summer of 1868, and was at some pains to ascertain the exact proportion, states that he counted the guillemots as they flew past the cliff on which he sat, and found one in ten or twelve. A later and more painstaking investigation has been made both at Barra and on the comparatively little known and seldom visited Stack of Lianamull, off the island of Mingalay, by Captain Feilden and Mr Harvie Brown, whose full and most interesting journals have been obligingly placed at my service, and I have the pleasure of inserting here the following result of their observations:- "On Barra we came to the conclusion, after the most careful scrutiny, that the proportion of bridled birds is one in five. We examined seven ledges on Barra and one in Mingalay, and after we had both in turn counted and recounted, the particulars now furnished may be accepted as accurate notes taken on the spot:-

1st Ledge - 28 birds in all, of which five were bridled; two bridled birds were paired, and were trimming each other's feathers; and another pair, a male of the common guillemot and a female ringed bird, were observed in copulâ.

2 d $\quad 29$ birds, of which five again were bridled.

3d " 12 birds, of which three were bridled.

4 th " 16 birds, of which four were bridled.

5 th " 10 birds, of which only one was bridled.

6 th " 21 birds, of which four were bridled.

7 th " 4 birds, of which two were bridled; of these two we obtained the eggs identified.

8th „ 4 birds, of which one was bridled, and we again obtained the egg (this ledge was on Mingalay).

Total, 124 birds, of which twenty-five were bridled. 
"We saw other two bridled birds rise from their eggs and adjust them with their bills and thighs. Like the others, they are ordinarily marked eggs, and quite as much blotched as streaked. We examined many other ledges, and in nearly every case found the average to agree with the details given. We may add that the weather was calm and oppressively hot, and consequently we had no opportunity of counting the birds as they flew past, which can only be done during wind or a prevailing mist."

\section{THE BLACK GUILLEMOT.}

\section{URIA GRYLLE.}

\section{Caileag.}

THE Black Guillemot, which is permanently resident; may be called a common species on the whole of the western coasts, including both groups of islands. In the outer chain, or Long island, the breeding places are not so numerous as those occurring on the same extent of "coast line on the mainland. It is found nesting on Berneray (Barra Head) and Mingalay, and also on various rocky islets northwards of these localities as far as the extremity of Lewis. There are breeding places on the Shiant isles in the Minch, Ascrib islands in Loch Snizort in the north of Skye, and similar groups of rocks on the western coast of that island; in the islands of Canna, Rum, and Eigg; in Coll, Tyree, the Treshinish islands, Iona, Staffa, and Mull; at Lanaig in Islay, and finally on Arran, south of which I have not been able satisfactorily to trace any breeding place. On the mainland it has been found nesting in a number of places ranging from the island of Gigha, off the coast of Cantyre, to Handa, on the west coast of Sutherlandshire. On 31st May, 1869, Mr Harvie Brown took nine nests of the Black Guillemot on Meal Mhor rocks, at the entrance to Kyle Sku; each bird was sitting on two eggs, which is the usual number, though it is stated by Audubon that many of the nests which he found during his researches in America contained three. That writer, indeed, has ventured the statement (Orn. Biog., vol. iii., p. 149) that "our species," as he calls the bird, always deposits three eggs. "No true student of nature," he continues, "ought ever to be satisfied without personal observation when it can be obtained. It is the 'American woodsman' 
that tells you so; and to satisfy yourself (good reader) as to the correctness of the statements which he here lays before you, go to the desolate shores of Labrador."*

The same author, in referring to the bare spots on the lower parts of the sitting birds, remarks, that in the specimens which he caught he found the feathers and down plucked off quite across the breast so as to admit of the three eggs being covered. $\mathrm{Mr}$ Thompson, in his 'Birds of Ireland,' speaks of a correspondent having captured a male bird with two bare patches, one for each of the eggs on which it sat. Out of four birds taken off their nests in Sutherlandshire by Mr Harvie Brown, three were also males: one of these, kindly sent me for examination, is much spotted in the white on the belly and vent. None of the four appeared to have more than one bare spot on the under parts.

I have seen flocks of this bird in full summer plumage off the west coast of Inverness-shire, especially in Loch-na-nuagh and Loch Aylort, where considerable numbers appear to breed on the rocky islets which abound in that district. I have also observed parties of three and four birds flying about in the north Minch about the same time. A few pairs are seen in the Firth of Clyde, and occasionally a stray bird is detected in the vicinity of Ailsa Craig. I have hitherto failed, however, to ascertain that it breeds there. Frequently I have observed a pair or two in the height of the breeding season as far south as Luce Bay, in Wigtownshire, when cruising in the neighbourhood of the Scaur rocks, where it probably breeds. Limited numbers have also been noticed by myself and Mr Anderson near the mouth of Loch Ryan, in the same county.

The favourite food of this beautiful little bird consists of fishes, generally the fry of the coal-fish and the herring, and small shells and crustacea. In procuring these, it has often to encounter heavy shore waves-its principal haunts being in the neighbourhood of rocky islets, among which the sea boils in broken masses. The bird shows great activity in diving, and rides buoyantly on the surface even in the severest storms. It flies with rapid strokes of the wing, and in mounting higher to avoid the crest of a wave, it may be seen to alter its position by inclining sideways. A good

* The inimitable wag "Artemus Ward" was in the habit of saying, when commencing his lecture in the Egyptian Hall some years ago, "If you should he dissatisfied with anything here, I will admit you all free in New Zealand, if you will come to me there for the orders." 
figure of this guillemot on wing will be found on plate 14 of vol. iv. of Sir William Jardine's 'British Birds,'-a great contrast to the figure on the plate immediately preceding it, which is that of a common guillemot flying as languidly as a gorged sea-gull. The breeding places are always situated in rocky crevices, and the eggs are frequently laid on what I have supposed to be rough shingle thrown into these cracks by heavy winter seas. I have never found more than two eggs in a nest, and the young ones appear to remain in the fissure until fully fledged, as I have never seen them on the water in the downy state, like the young of the common guillemot. After leaving the nest, indeed, the old ones appear to leave them to forage for themselves.

The following notes on the habits of the Black Guillemot as observed at Iona and Mull, have been sent to me by Mr Graham:"Though the common guillemot rears but one young one and this bird rears three, yet it is infinitely less numerous, nor is it a gregarious bird, though to a certain extent it is migratory. It is usually found solitary, or swimming in pairs, on the wildest and most rocky parts of our coast, utterly regardless of the dreadful surf tumbling in white cascades off the jagged rocks when the heavy swell of ocean heaves downwards. The Black Guillemot is a very pretty and interesting little bird, quite tame, allowing a close approach by boat. Its plumage undergoes an extraordinary seasonal change, so that in spring and autumn two birds will not be found exactly alike, its colours ranging through every shade of grey, from white speckled piebald to jet black with a shining green lustre. In its nearly pure winter dress the name of Black Guillemot is an evident misnomer, and that of doveky or Greenland dove is much more applicable. It is remarkable that at such seasons birds should be found both in complete summer and perfect winter plumage. I should imagine that the former had been wintering in the south and had never assumed the winter garb. In intensely severe weather in the depth of winter the whitest specimens are to be procured.* The Black Guillemot breeds on all the smaller uninhabited islands, in holes under the rocks very little above the water mark, whence I have often extracted the little black downy young ones, and have reared them on small fry, for which they are

* In the first volume of the 'American Naturalist' (p. 53), Mr G. A. Boardman records having found specimens of this guillemot in full black plumage all the winter on the coast of Maine. 
very clamorous, uttering a querulous impatient cry, unlike the adults, which are mute. When fledged, the young are dingy black above and dirty white underneath; the white speculum on the wing is clouded with black specks; and the legs, which in the old birds are a vivid coral red, are a dull reddish brown."

The following incidents in the life of a pet tysté, detailed as the "sorrows of an ornithologist," are taken from a chapter in Mr Wilson's voyage round the coasts of Scotland and the isles-a book which, though now out of print, is well worthy of a place on a naturalist's book-shelves:- "We might here [Quendal Bay, Shetland] have obtained an addition to our live stock in the shape of a tame cormorant which we found perched contentedly upon the roof of a fisher's hut. But our heart was too full from the recent loss of an ornithological pet of great promise to admit of our running the risk of a second sorrow. We may now mention that while at Lerwick we took on board a live specimen of the tysté, or Black Guillemot (Uria grylle). As it could not feed itself, we kept it at first in a fishing basket, and several times a day pushed various small pieces of fresh fish down its little throat. It soon came to comprehend what we were doing, and as speedily began to do something for itself-that is, so soon as it found a morsel between its mandibles, it no longer required a ramrod, but gobbled it down like a voluntary. Thus matters throve for several days, and when we put him one fine morning into a basket-ful of sea-water, he dived, and splashed, and swam, and filled the air around with sparkling gems, and when taken from his translucent bath, he preened, and dried, and beducked himself, and became a beautiful bird to look upon. Ere long, he ate out of any one's hand, or dabbled up portions of juicy herring when thrown towards him on the deck. He never became a very alert walker, and this was characteristic of his kind, but he would get upon a good man's knee and stretch himself up upon his hind legs, and flap his little wings, like a penguin, and was the friend and favourite of all the human race. When he desired to leave his basket, he would raise himself upon his hinder end till he was almost as tall as a little spruce tree, and then he would waddle on to the palm of a person's hand, and sit there flapping his wings as if he was flying at the rate of fifty miles an hour, and then he would rest himself on his abdomen, and shut one eye and wink with the other at the sun, and anon rouse himself to eat a hearty dinner, and finally retire to his fishing basket to be out of 
harm's way for the night. But the cabin boy said from the beginning that 'he was too good to live,' and we felt it so ourselves. As he lived happy, he died lamented. On opening the basket one morning to give him his usual meal, he was found lying much in his usual attitude upon his breast-but dead. So when we were offered the cormorant of Quendal Bay, a large magnificent bird, with dark, yet lustrous plumage, who would almost have swallowed a fishwoman, haddocks and creel together, we remembered the premature fate of the tysté, and forbore."

\section{THE LITTLE AUK.}

\section{MERGULUS MELANOLEUCOS.}

THIs interesting little bird is of irregular and uncertain occurrence only in the West of Scotland. So far as I can learn, not more than three or four specimens have, at any time, been met with in the Outer Hebrides. Mr M'Donald procured two in North Uist in the winter of 1868-69. They were both found dead on the beach, having been cast up by the waves during a storm from the west, but were quite fresh, showing they had been in life a few hours previously. Similar waifs have been picked up at other places in rough weather; and many living, though exhausted little Auks, have been scattered broadcast over the western mainland in the same accidental way. Thus in the winters of 1866-67 and 68, several were captured near Oban, and southwards, as far as the Firth of Clyde, other examples were obtained. The species has also been shot at Millport, in the Isle of Cumbrae, and on the banks of Loch Fyne, as I have been informed by Mr William Hamilton, Jun. Specimens of the bird have even been found as far inland as Kilmarnock, in Ayrshire, on the west coast, and in the heart of Lauderdale on the east.

It is not a little singular that in migrating southwards this species should keep almost entirely to the east coast. In East Lothian, where for many years I had ample opportunities of watching its appearance, it is observed regularly every winter; coming near the shore, however, only in stormy weather. Some of my earliest records of the Little Auk, written as far back as 1846 , notify sudden and unusual flights of the bird landwards, and the capture of numerous specimens almost daily so long as the 
storm lasted. I recollect getting as many as thirty or forty Little Auks in one week; they were nearly all captured alive, but in an exhausted state, many of them being found in fields and ditches several miles inland. The idea of these birds having come to Britain from Arctic seas within a few hours is hardly tenable; and I venture to suggest that it is a mistake to suppose that the simultaneous occurrence. of birds and storms can at all be closely associated-I mean so far as regards the migration of any species out of its ordinary flight. The Little Auk, which is looked upon as an uncommon bird, is a good illustration of this, being often literally blown on shore in great numbers in a violent gale of not more than a day's duration. On these occasions, its sudden appearance can only be accounted for on the supposition of its being a regular winter migrant to the shores of Scotland, and the experience of the last twenty years has fully confirmed this impression. Coming in annual flocks of many hundreds, these birds keep well off the land-probably from twenty to thirty miles -and, of course, when a gale blows persistently for twelve or fourteen hours, it obliges them to rise on wing, when they get bewildered, flying, however, before the wind, until they are driven, it may be, a mile or two over field and forest half stupid with fatigne.

Many of the seafaring people, living on the shores of East Lothian and Fifeshire, are quite familiar with this little bird, meeting with it almost daily when out at sea. They call it the rotchie, or sea dove, and are always able to acquaint local collectors of its appearance. Acting on their information, I have myself repeatedly obtained specimens by inducing a boat's crew to take a gun out with them, with which they could procure winter visitors in calm weather; and it frequently happened that throughout an entire season not a single specimen was seen near the shore, all those obtained having been shot far out at sea. The appearance of the Little Auk in moderate weather within a reasonable distance of the shore, is, in fact, unusual, and for that reason the bird has been reckoned among the rarer species, while in reality it is as common as the guillemot or razor-bill. Joined to these flocks there are sometimes numerous parties of young puffins-birds of the first year-who share a like fate with the rotches when a sudden storm from the east drives them out of their reckoning.

Similar observations confirmatory of these views have reached 
me through various correspondents. Writing from Brigus, Newfoundland, on 8th November, 1869, my friend, Dr William Anderson, says:- " Our harbour, and, in fact, the whole bay, were visited by a great number of Little Auks last week. Men went out in boats shooting them for three successive days, and I think some thousands were killed. Some might have been shot on the water from the balcony of my house. They were thought to indicate rough weather out at sea, and the specimens I handled were in poor condition."

In Macgillivray's British Birds it is stated that the Little Auk breeds at St. Abb's Head, but I have never seen the species there, although I have undertaken several journeys expressly for the purpose of looking for it. I have, however, seen at least two specimens in the month of June on the Bass Rock, where they were probably breeding. Mr Macgillivray himself observed two on the same rock, ${ }^{*}$ so that it is likely a few pairs may remain with us during the nesting season. As collateral evidence on this point, it may be mentioned that Pennant, in his 'Tour in Scotland,' records having seen the species on the Farne islands on 15th July, 1769 ; and also that the late $\mathrm{Mr}$ Thompson, in his 'Birds of Ireland,' narrates that "on 19th May, 1849, Mr Darragh, of the Belfast Museum, saw four Little Auks on Ailsa Craig: one of them remained on the water at the base of the Craig until approached by the boat within about eighty yards, when it flew off in the direction which its three companions had taken a minute before."

\section{THE PUFFIN.}

\section{FRATERCULA ARCTICA.}

\section{Fachach. Seumas ruadh. (Barra.)}

THIS very interesting bird is perhaps the most abundant species of sea-fowl to be met with in the West of Scotland, some of the breeding-places being literally over-stocked with it. Its haunts are numerously distributed from Barra Head to the Butt of Lewis on the one hand, and from Cape Wrath to the Scaur Rocks, in the Bay of Luce, on the other. Westwards of the Long island, it is 
found on the Flannan isles, the Haskeir Rocks, and St. Kilda, the last mentioned locality being frequented by countless numbers during the height of the breeding season. In the Minch, the chief breeding-place is on the Shiant isles, and considerable numbers also incubate on the Ascrib islands and other rocky islets off the coast of Skye. Another important station is at the Mull of $\mathrm{Oe}$, in Islay, but, in point of interest, it falls greatly short of Ailsa Craig, which may be said to rank next to Mingalay, Berneray, (Barra Head), and St. Kilda, as a crowded bird-hive. The most favourable time for seeing the greatest numbers on the rock is when the young have left their burrows and joined the flights of old birds which then congregate on the upper slopes, about the end of July. I have on various occasions seen flights of Puffins that out-numbered all calculation. Some years ago, I went to the cliffs alone, one evening about sunset, and saw, as I believed, the entire bird population at one view. All the Puffins, young and old, were fast coming in from fishing, and taking up their position on the broken masses of rock and the surrounding patches of grass, within a hundred feet of the summit. Waiting until the last flock arrived, I had time to notice that the whole extent of available perching ground within view was occupied, and that the birds were so closely packed that it would have been almost impossible to insert one's hand anywhere amongst them. On rising from my place of concealment, and running towards them, the entire mass of birds at once got on wing and flew seawards, returning in a few minutes and surrounding me completely, without the slightest regard for the presence of an enemy. For a time their numbers seemed so great as to cause a bewildering darkness, and as they approached near enough to be touched by an outstretched arm, I was not sorry when they came to their senses, and began to settle on the ground. I could scarcely have believed, indeed, in the existence of so many Puffins in any locality so near the mainland.

In the Firth of Clyde, and indeed in many parts of the West of Scotland, the Puffin arrives in February. It is sometimes seen in the vicinity of Ailsa Craig as early as the last week of January.* Its appearance on the rock itself is very regular,

* On the east coast of Scotland, especially in the Firth of Forth, the Puffin is never absent-the place of the local birds, which go southward, being supplied by flocks from more northern localities. 
and the same may be said of its time of leaving. Its favourite abode there is a mass of fallen rocks, lying at the base of the cliffs, on the south-west side of the island. These rough and angular blocks, which are being constantly added to by masses falling from the upper ridges, form a highly curious nursery, and one may imagine the singular spectacle afforded by a legion of Puffins pouring out of their holes when a few tons of trap happen to fall upon their territories. On the upper slopes of the Craig very large numbers are also found breeding in burrows of their own making, which resemble rabbit-holes. From these strongholds it is almost impossible to dislodge them, except by a dog trained for the work. On one occasion, many years ago, I accompanied the keeper, who owned a dog of this kind, to a Puffin warren, near the summit of the island, and I was greatly diverted at seeing the little fellow, after having pushed his way along the dark passages, shuffle out of a burrow with half a dozen Puffins dangling from various parts of his body. Like a bull-dog, an angry Puffin never thinks of quitting its hold-a habit which makes the shaggy coat of a Skye-terrier extremely serviceable as a bait. The single egg laid by the bird is generally placed at the farthest extremity of the passage, so that it is difficult to extract it. I have often taken the eggs by the help of a crooked stick, and not unfrequently I have drawn out the bird itself by the same instrument, when it happened to be seized hold of by the vicious little occupant. When newly laid the egg is pure white, and marked with faint ashy spots, but after a time it becomes very much soiled by the sitting bird, and before the young one is hatched the shell has become as dark as the brown earth can make it. The young Puffin remains in the burrow for some weeks, during which time it is plentifully supplied by both parents with sprats and sand-eels. I have seen old birds knocked down in the vicinity of the breeding holes while carrying each as many as eleven small fishes, all held by the head, with the bodies dangling free, five being ranged on one side of the bill and six on the other. It seems a mystery how these birds can catch so many such slippery creatures consecutively without mutilating any other part but the head, or how they manage to hold fast the fish first caught without risk of losing it when the bill is opened to secure the second; yet no one who knows the habits of the Puffin can fail to see the necessity for such an arrangement, when he considers the distances 
to which it travels in search of food-twenty and even thirty miles being a common journey.

Vast numbers of Puffins were killed on Ailsa Craig previous to the passing of the Sea Birds Preservation Act. The tacksman and his assistants captured the birds chiefly with nets, which they spread at nightfall over the rocks under which the poor creatures were sitting on their eggs or beside their callow young. In the morning, about an hour after sunrise, the men returned for their spoil; and, after twisting the necks of the fluttering captives, threw the bodies into the sea, where they were picked up by one of the fowlers who attended in a boat for the purpose. Several hundreds have been taken in this manner in one day. I have, on more than one occasion, counted from four to five hundred brokennecked Puffins laid out in rows in the hut, waiting removal to the mainland. Towards the close of the season, when the birds had assembled near the summit of the rock, in the manner I have already described, one of the more expert fowlers took his stand in a convenient place, with a pole for striking the birds as they flew past, and, by a dexterous use of this weapon, would sometimes kill upwards of a hundred before quitting the spot. David Bodan, who was tacksman of Ailsa Craig in 1826, undertook for a wager to kill eighty dozen Puffins with a pole in one day, and actually accomplished the feat. This fact was well known at the time, and was lately communicated to me by $\mathrm{Mr}$ Anderson of Girvan, to whom Bodan frequently spoke of the circumstance. ${ }^{*}$ Considerable differences are observable in the

* This extraordinary feat admits of easy explanation when it is borne in mind that Bodan was a very powerful man. Two very good stories are told of him, shewing his great strength and self-determination:-On one occasion, during a smuggling raid on the coast between $\mathrm{Ayr}$ and Dunure, he was beset by six armed men of the coast-guard, and called upon to surrender. Bodan, however, put his back to a rock, and, taking bis assailants one by one as they approached, forcibly seized their guns, hurled the men back, and, after breaking the weapons across his knee, threw the fragments down the cliffs. At another time, during his tenure of the Craig, Lord — went there for a few days' shooting at the goats, which abound on the island. On his return with Bodan and his two favourite dogs, one of the animals was, for some slight offence, unmercifully struck on the head with the butt-end of a gun by his lordship-an act of cruelty which Bodan instantly resented by seizing his companion by the neck of his coat and the loose part of his nether garments and sousing him over the boat's side into the sea. A second dip was threatened unless an apology were immediately tendered, but there was no occasion to put the threat in force 
size of the bill of this species-the depth varying from one inch to one inch and a half. In July, 1867, four specimens were examined on Ailsa Craig by $\mathrm{Mr}$ Anderson and myself, which at first sight resembled a nearly allied speciesFratercula glacialis (Leach.) The bills of these birds at once arrested our attention on account of their superior strength and size, as we glanced over the rows of dead Puffins lying in the hut. Some of the fowlers believed them to be males, and seemed anxious to impress upon us the fact that as only four were found in five hundred that had been taken in the nets, the female must alone undertake the duties of incubation. Differences in the birds themselves have been observed elsewhere. In a very interesting paper by $\mathrm{Mr}$ Elwes, published in the Ibis for 1869, mention is made of considerable variation in the size of the Puffins seen by that gentleman at Barra Head, and of one of the largest having a bill greatly beyond the average size. There can be no doubt that these large billed British examples are merely varieties, as they fail to stand comparison with specimens of the true Fratercula glacialis from Spitzbergen, which appears to be the head-quarters of that species. A very beautiful figure of the bird, by Mr Wolf, is given in the Ibis for 1865, to illustrate an excellent paper on the birds of Spitzbergen, by Professor Newton of Cambridge.

The following quotation from a History of St. Kilda, published in 1764 by the Rev. Kenneth Macaulay, minister of Ardnamurchan, would seem to point to a second species being a native of that island in his day:- "The Bougir of Hirta is by some called the Coulterneb, and by others the Puffin. This is a very fine sprightly bird in size, much like a pigeon; it seems to be conscious of its own beauty, cocking its head very smartly, and assuming great airs of majesty. Its colour is black on the outer parts, and about the breast red and white; the legs are red, and the beak fashioned like a coulter, edged above and most charmingly painted with red and yellow. Incredible flights of these Puffins flutter during the, whole summer season round about St. Kilda and the two isles pertaining to it. Sometimes they cover whole plots of ground, and sometimes, while on wing, involve everything below them in darkness, like a small cloud of locusts in another country. There are two species of them, the one larger and the other smaller, with some other marks of diversity scarce worthy of being pointed out. Their feathers are the softest produced 
here. Their eggs are white, and of much the same bigness with those of a hen. The people of this isle live mostly all the summer on the two kinds of this fowl, together with eggs of various sorts; and I shall make no difficulty of affirming that the place could easily afford enough of these different articles to support two thousand persons more during that season."

Young birds with half-formed bills are frequently cast on shore on the east coast of Scotland during winter storms. These are probably migrants from higher latitudes, as they are always associated with little auks, which suffer a like fate.

\section{THE RAZORBILL.}

\section{ALCA TORDA.}

\section{Coltraiche. Dui' Eunach.}

The Razorbill is a much less common species than the puffin or the guillemot at all the breeding-stations in the West of Scotland. Barra Head and Ailsa Craig may be regarded as its chief haunts, though it is found in limited numbers at the Mull of Oe, in Islay, and other places of minor extent, both in the Outer Hebrides and on the western mainland. In its habits it resembles the guillemot, and arrives at the breeding ledges about the same time, taking up its position in small companies, which are arranged in orderly rows, from almost the base of the cliffs to the summit. I have observed a number of pairs incubating beside the kittiwakes, on the rocky platforms and crevices near the base of Ailsa Craig, and almost within arm's-length of the rough pathway which extends about a third of the distance round that island.* Here it often may be seen dozing, and waiting an opportunity of attacking the puffin and the guillemot as they come in from the sea

* Audubon mentions having found hundreds breeding in a rocky fissure on a rugged island in the Gulf of st. Laurence, and also states that he found several birds sitting upon two eggs, a circumstance which he turns to account by saying that the Razorbill lays one or two eggs, according to the nature of the place. In this fissure, however, which he describes as being "about two feet in height, and thirty or forty yards in depth," and thus forming a kind of trap for the poor birds, when he and his boat's crew entered it, the Razorbills were found to be closely packed together, so that it is possible that the birds which were sitting upon two eggs had more than their own share. 
with a supply of fishes for their young. I have seen several at a time sallying from the ledges and buffeting these birds until they dropped the fish, which were afterwards picked up by the aggressor, as they momentarily floated on the surface. On one occasion, a friend, in cruising past the Craig, saw a Razorbill and puffin strike each other dead, by coming into sudden and forcible collision, the one bird while hurrying towards the rock and the other in launching from it; a calamity which, as his skipper declared, might have been averted, had they taken the precaution to "port their helms."

The egg of this bird is subject to wonderful variety, both in size and colour, some being very light, and besprinkled with small spots, while others are darkly clouded with mahogany-coloured blotches, which give the egg a very peculiar appearance. A series of fifty, now before me, shows these varieties in a very marked degree; of twenty from Barra, taken in 1869, only three have the usual ground colour, the others being curiously marked with irregular blotches, so thickly distributed over the surface as to present a uniform hue; other thirty from Ailsa Craig, taken in 1870, are uniformly small, one or two being little over half the size of those from Barra, and every specimen is light in colour and minutely spotted. I am inclined to think that these smaller and lighter coloured eggs are of a second laying, though it would entail patient observation on the spot to satisfy one's self of the correctness of this surmise. The same rule as to size would not apply to the eggs of the common guillemot, many of the smaller specimens being of a very deep green, while some of the largest eggs are cream-coloured and spotted with light brown.

At the close of the breeding season, which is usually the last week in July, the Razorbill assembles in large flocks off shore, in the vicinity of the rock stations, where it appears to feed chiefly upon sand-eels. When these become scarce, the birds disperse along the coasts, and, sometimes in favourable seasons, are known to congregate in large companies, and remain for some time over the sandbanks at a considerable distance from land. I have, on various occasions, seen such companies, when every bird was distinctly visible on the smooth sea, and on rowing towards the place, could always judge of the duration of the assembly by the quantity of feathers floating about. At this season, also, the Razorbill may be distinguished on calm days flying in small 
parties, in single file, close to the surface of the water-a habit which I have not been able to trace in the common guillemot, which, at a little distance, this bird so much resembles in flight. The two species do not mix together while fishing out at sea, though they appear to prey upon the same kinds of fish. Numbers of Razorbills are often captured in the nets of the Girvan fishermen, when these happen to be set near the Craig; but I have never seen guillemots captured in this way.

'I may here refer to a very extraordinary mortality which occurred among the sea-fowl of the Firth of Clyde in September, 1859 , and which at the time attracted considerable attention from local naturalists. The principal victims to this epidemic, if such it may be called, were the puffin, guillemot, razorbill, and common gull (Larus canus). The Razorbill perished in extraordinary numbers, being found in the proportion of ten to one of the other species. From information communicated to the Natural History Society of Glasgow by one or two of the members, it would appear that the mortality had set in about the time of the birds leaving Ailsa Craig and the breeding places off the coast of Ireland, and that during the few intervening weeks they had probably, from a diminution or entire absence of their usual food, fallen into a low condition favourable to the development of disease to which they ultimately succumbed. They were all found much farther up the firth than usual, as if in search of food, many birds being obtained even at Renfrew and other places, in waters at a distance from the sea. In these situations they darted eagerly at any food which came in their way, rushing at baited hooks on a hand line, and otherwise exhibiting a tameness more like the result of starvation than actual disease. They were all in a wasted condition, being reduced almost to skin and feathers, and were found dead or dying in thousands over a wide extent of sea, from the mouth of the river Clyde to the Irish coasts, the master of one of the mail steam packets having reported that he sailed his ship through miles of floating carcases. At a meeting of the same Society, held on 29th November following, my friend Mr David Robertson read a report on this mortality, in which he gave an apparently satisfactory explanation of the mystery. In this communication it was shown that nothing unusual was observed among the birds until a few days after the storms in the early part of the month of September; and that they were then 
in a state bordering upon starvation may be proved from the fact of so many hundreds-even thousands, resorting to estuaries, heedless of danger and contrary to their usual shyness. The testimony of the fishermen at various places shewed that the common dog-fish was unusually abundant, while the small herring fry and other fishes constituting the food of sea-birds had entirely disappeared. Favouring the hypothesis of death by starvation, Mr Robertson observed that no trace of organic disease could be found on examination, and that, moreover, an epidemic does not attack indefinitely, but is confined to one species-the prominent symptoms of which, viz., disturbance of organic functions, loss of appetite, etc., being opposed to what had been observable in the birds-an empty stomach, keen appetite, heedlessness of danger to secure food, tameness, feebleness, and death occurring at the extreme point of emaciation-in other words, the universal symptoms of hunger. The mortality, therefore, not being confined to one species as is constantly the case in epidemic diseases, and which have been known to occur in other sections of the animal kingdom, the author of the report stated his belief that it was attributable to the extreme scarcity of food, causing an emaciation resulting in death.* While it is borne in mind that the solan goose and the larger species of gull-birds of vagrant habits and possessing strong powers of flight-were exempt, there need be little hesitation in accepting Mr Robertson's solution of what was at the time regarded as a remarkable and mysterious visitation.

\section{THE GREAT AUK.}

\section{ALCA IMPENNIS.}

\section{An Gearbhul.}

No bird has received so much attention of late years as the now extinct Garefowl or Great Auk. Every item of information, however meagre, from the brief records of Sir George M'Kenzie of Tarbat, and Sir Robert Sibbald, published in, and previous to 1684 , to the equally brief announcement of the discovery of the remains of two Garefowls in a kitchen midden on the coast of

* See Proceedings of the Natural History Society of Glasgow, vol. i., p. 4, from which this abstract of Mr Robertson's remarks has been reprinted. 
Caithness, in 1864, has been carefully treasured, in the full conviction that too much importance cannot be attached to a subject in which naturalists of every country are now so deeply interested.

The first intelligible account of this extraordinary bird as a British species is unquestionably that given by M. Martin, in a curious little work, entitled 'A voyage to St. Kilda, the remotest of all the Hebrides,' which was published in 1698. This author who, as he tells us in his preface, "was prompted by a generous Curiosity to undertake a Voyage through several Isles to St. Kilda, and that in an open Boat, to the almost manifest hazard of his life," thus speaks of the bird :- "The Sea Fowls are first Gairfowl, being the stateliest, as well as the Largest, of all the Fowls here, and above the Size of a Solan Groose, of a Black Colour, Red about the Eyes, a large White Spot under each Eye, a long broad Bill; stands stately, his whole Body erected, his Wings short; he Flyeth not at all, lays his egg upon the bare Rock, which if taken away, he lays no more for that Year; he is Palmipes, or WholeFooted, and has the Hatching-Spot upon his Breast, i.e., a bare Spot from which the Feathers have fallen off with the heat in Hatching; his Egg is twice as big as that of a Solan Goose, and is variously spotted Black, Green, and Dark; he comes without regard to any Wind, appears the first of May, and goes away about the middle of June." It is, I think, doubtful whether Martin ever saw the bird, as in another and larger work, entitled ' $A$ description of the Western Islands of Scotland,' published five years afterwards, and in which he gives a full account of St. Kilda and its birds, he does not even mention it - an omission he would scarcely have made had he been favoured, and consequently impressed, with a sight of its "Whole body erected." His account, however, considering the time when he wrote, is sufficiently accurate to show that the description, if from hearsay, must have been supplied by persons who were accustomed to see the bird regularly. Sixty years' later, viz., in 1758, the Rev. Kenneth Macaulay landed on St. Kilda on the 6 th of June, and remained a month there; after which he wrote a history of the island, which appeared in 1764 . In this work he says, "I had not an opportunity of knowing a very curious fowl, sometimes seen upon this coast, and an absolute stranger, I am apt to believe, in every other part of Scotland. The men of Hirta call it the Garefowl, corruptly, perhaps, instead of Rarefowl, 
a name probably given it by some one of those foreigners, whom either choice or necessity drew into this secure region. This bird is above four feet in length, from the bill to the extremities of its feet; its wings are, in proportion to its size, very short, so that they can hardly poise or support the weight of its very large body. His legs, neck, and bill are extremely long; it lays the egg, which, according to the account given me, exceeds that of a goose, no less than the latter exceeds the egg of a hen, close by the sea mark, being incapable, on account of its bulk, to soar up to the cliffs. It makes its appearance in the month of July. The St. Kildians do not receive an annual visit from this strange bird as from all the rest in the list, and from many more. It keeps at a distance from them, they know not where, for a course of years. From what land or ocean it makes its uncertain voyages to their isle is perhaps a mystery. A gentleman who had been in the West Indies informed me that, according to the description given of him, he must be the penguin of that clime, a fowl that points out the proper soundings to seafaring people." Another work, entitled 'A Description of St. Kilda, by the Rev. Alexander Buchan, late minister there,' was published in 1773 by his daughter, who states in her preface that her "deceased father thought fit to write the description which he gathered partly by good informations and partly by his own observations, he having been their first settled minister, and lived amongst them twenty-four years till his death." We also learn from her that he was sent by the Church of Scotland to St. Kilda in 1705, and that he died there of fever in 1730. During that interval he appears to have amused himself by copying out with his own hand 'A Description of St. Kilda, alias Hirta,' every word of which seems to have been pirated from Martin's two volumes. Like Sir Robert Sibbald when condensing what Sir George M'Kenzie had previously written of the bird, Mr Buchan thus treats Martin:"The sea fowls are first, Gairfowl, the stateliest and largest of all the fowls here." And so the ornithological world is now left lamenting his incapacity to make a better use of his lengthened residence.

Following these older records of non-scientific writers, the first mention of the Great Auk in any work on British natural history seems to occur in Pennant's 'British Zoology, which was published a few years later than Macaulay's work. The 
information given, however, is merely a repetition of what that writer and Martin had previously recorded. In a still later publication, viz., Lightfoot's Flora Scotica (1777), to which is prefixed a sketch of Caledonian Zoology by Pennant, the following brief account is given:- "Great Auk-Sometimes visits St. Kilda, and breeds there; not a regular migrant; called there Gairfowl, from Geyr-fugl, the name it is known by in Iceland, where they are common; from whence or from Norway they may probably wander."

In 1793 another of the Church of Scotland missionaries, the Rev. John Lane Buchanan, published a book of 'Travels in the Western Hebrides, from 1782 to 1790 ,' in which (pp. 118-146) he professes to give a full account of St. Kilda and its birds. "The Garefowl," he writes, "is four feet long, and supposed to be the pigeon (?) of South America. Its egg is said to exceed that of a goose as much as the latter exceeds that of a hen, which it lays close by the seaside, being incapable from its bulk of soaring up to the clifts. It appears in July, and even then but rarely, for it does not visit St. Kilda yearly." It is extremely doubtful, I think, whether this writer was ever on St. Kilda, and his brief account of the Great Auk is evidently borrowed from Macaulay. A better notice of it appears in the appendix to a 'General View of the Agriculture of the Hebrides, by James MacDonald, A.M.,' published in 1811 - "a work," as he himself tells us, "drawn up by a native, and the result of seven voyages and journeys at different periods since 1793 among these isles, and particularly of a journey of more than 2900 miles through them in the months of May, June, July, August, and September, 1808." In his account of St. Kilda he gives a list of the birds, the commencement of which is as follows:- "I. Bunnabhuachäille, or Great Auk, is the largest bird met with in the neighbourhood of St. Kilda. It is larger than the common goose, of a black colour, the irides red, having a long white spot under each eye ; the bill is long and broad at the base. It cannot fly, by reason of the shortness of its wings ; lays only one egg, and, if robbed of it, lays no more that season. It arrives in St. Kilda early in May, and departs towards the latter end of June." It is worth noticing here that Mr MacDonald, if he did not see the Great Auk alive, must have supposed that Martin, in speaking of the bird being "red about the eyes," referred to the irides. 
The next record of any consequence as to the occurrence of the species in Britain appears in the supplement to Montagu's Ornithological Dictionary, published in 1813, in which it is stated that Mr Bullock, who visited the Orkney islands about a year previously, had been told by the natives that one male only had made its appearance for many years; it had regularly visited the island of Papa Westra. The female had been killed just before Mr Bullock's arrival, but the male was seen by him and unsuccessfully chased for several hours by a six-oared boat, the speed of which, in the water, was as nothing compared to that of the bird. Dr Latham, in his 'General History of Birds,' Vol. X., in referring to this incident, narrates that as soon as Mr Bullock had left, the poor bird, confiding in the native boatmen, suffered them to approach so near as to knock it down with an oar,-a lucky stroke which secured for the British Museum its finest Garefowl, the specimen (which realized $£ 155 \mathrm{~s} 6 \mathrm{~d}$ at Bullock's sale) being now preserved in the National Collection. To these particulars Professor Newton (Nat. Hist. Review, 1865) adds:-_"Another account, furnished us by a relative of the lady who transmitted the bird to Mr Bullock, states that one of the two which about this time frequented the 'Auk Craig,' on Papa Westra, was killed by some boys or lads with stones, and that it was not got at the time, but sometime afterwards washed on shore. The excellent condition of the specimen now in the 'British Gallery' of the British Museum leads us to suppose, independently of Latham's testimony, that if this story be correct it refers to the female bird."

About ten years after Bullock's experience in Orkney, namely, in 1821 or 1822, the late Professor Fleming had an opportunity of seeing and describing a live specimen of the Great Auk, while visiting the island of Scalpa, at the entrance to East Loch Tarbert, in Harris. This bird had been captured by Mr M'Lellan, tacksman of Scalpa, sometime before, off St. Kilda. It was presented to $\mathrm{Mr}$. Robert Stevenson, civil engineer, and taken on board the lighthouse yacht, but afterwards, while being indulged by its considerate owner with a swim in the sea, restrained by a cord fastened to one leg, it made its escape. One of Dr Fleming's personal friends, the late Mr James Wilson of Woodville, who was much interested in the history of the Garefowl, writes as follows, in a highly graphic and interesting contribution to the North British Review for May, 1853:- "So unfrequent has this great sea-bird become of late years 
that many considerate people begin to question the continuance of its existence upon earth. It has not been known to breed along any of the shores of Continental Europe for towards a hundred years, and although as recently as Landt's time it was still seen in Iceland, Graba informs us that it is now unknown there, and has not been observed or heard of, either in Greenland or the Faroe Islands, for many a day. None of our own assiduous northern voyagers ever met with it, and although known in St. Kilda by the name of Gairfowl (Geirfugl of the Icelanders), it has now ceased to frequent that lonely isle. Martin says, "he flyeth not at all."'

The most recent authentic instances of its occurrence may be briefly mentioned. The late Mr Bullock, while visiting the Orkneys in 1813, discovered a male bird, called by the natives King of the Auks, off Papa Westra, and pursued it unremittingly for many hours in a six-oared boat, but such were the rapidity and perseverance of its courses under water that he was completely foiled, and finally gave up the chase. This individual was, however, obtained after his departure, and is now in the British Museum. A female, the supposed mate of the preceding, had been procured in Orkney a few weeks before Mr Bullock's arrival, but her remains were not preserved. Dr Fleming, while taking a cruise in the autumn of 1821 with the late Mr Robert Stevenson in the lighthouse yacht, obtained a live specimen of the Great Auk at Scalpa (Isle of Glass), which had been captured sometime before off St Kilda. It was emaciated and sickly, but improved in condition in a few days, in consequence of being well supplied with fresh fish, and permitted to sport occasionally in the water, being secured by a cord attached to one leg. Even in this trammelled state, its natural movements while swimming or diving under water were so rapid as to have set all pursuit at defiance had the bird been free.* As it was, its love of liberty eventually proved stronger than the cord by which that liberty was restrained, for during a subsequent washing, with which it was considerately favoured, off the island of Pladda, to the south of Arran, it burst its bonds, and was seen no more for ever. Many years afterwards a dead specimen was found floating in the sea off the isle of Lundy, on the coast of South Devon. Some have fondly fancied that this may have been Dr Fleming's

\footnotetext{
* 'Edinburgh Philosophical Journal, Vol. X., p. 96.
} 
individual, but it would have been difficult to prove it so, and we believe that under the circumstances no claim was made. From the presumed and almost proven inability of this species to fly, and its nearly equal inaptitude for progress on the ground, we do not set much store by Mr Bullock's statement that an example was found in a pond in Buckinghamshire two miles from the Thames. There are many large geese in the world, and one would suffice either to make or occasion the mistake."*

To return to Dr Fleming's specimen, the following description of the species taken from that author's 'History of British Animals,' becomes of great interest when we reflect that it is the only description given by any British writer from the living bird:- "Length, 3 feet; bill—dorsally 3 , in front of the nostrils $2 \frac{1}{4}$, in the gape $4 \frac{1}{2}$, depth $1 \frac{5}{8}$ inches; 7 ridges in the upper, and 11 in the lower mandible; legs black; irides, chesnut; margin of the eyelid, black; inside of the mouth, orange; head, back, and neck, black-the latter with a brownish tinge; quills, dusky; secondaries, tipped with white; breast and belly, white. In winter the brownish black of the throat and foreneck is replaced by white, as I had an opportunity of observing in a living bird brought from St. Kilda in 1822. When fed in confinement it holds up its head expressing its anxiety by shaking the head and neck and uttering a gurgling noise. It dives and swims under water, even with a long cord attached to its foot, with incredible swiftness."

In a series of papers on the Outer Hebrides, contributed by the late Professor Macgillivray, to the Edinburgh Journal of Natural and Geographical Science, in 1830, the following note occurs in a

* In a manuscript list of the "Birds of Renfrewshire," now before me, prepared many years ago by various members of the Philosophical Society of Paisley, I find the Great Auk included, on the authority of a $\mathbf{M r}$ Small who, as I have been informed, died in 1860 . On making inquiry at one of his personal friends, I find that some vague recollections of the bird, which was washed ashore dead near Gourock about fifty years ago, are yet entertained by the surviving compilers of the list. Mr Small could not have mistaken any other bird for the Great Auk, as the list includes the Great Northern Divera species which is sometimes confused with it in districts where Gaelic names only are in use. If, therefore, Mr Small's record be correct, and I have no reason to doubt it, may it not account for the ultimate fate of Dr Fleming's specimen, Gourock being situated at a part of the Firth of Clyde likely to be visited by a bewildered bird from the coast of Arran, where this half-emaciated garefowl regained its freedom? 
long and apparently very complete list of the birds, forming the concluding section:- "Alca impennis, the Great Auk-An Gearbhul-An individual of this very rare species, I was informed by Mr Adam, was sent to him in Lewis. The late $\mathrm{Mr}$ M'Neill, who was long tacksman of St. Kilda, informed me that it occurred there at irregular intervals of two or three years; but I have not heard of its having been seen on the coast of the Outer Hebrides." It is somewhat singular that Dr Macgillivray has not inserted these particulars in his work on British Water Birds, published in 1852. It may be said, indeed, that he has shown considerable carelessness in his account of the Great Auk, as is evidenced by his statement that a second specimen was obtained at St. Kilda by Mr Murdo M'Lellan, in 1829-a record which obviously applies to the bird mentioned in the preceding paragraph of his work, the names of the individuals, and the fate of the bird being identical with those associated with Dr Fleming's specimen captured in 1822. In his 'Manual of British Ornithology,' Part II., p. 217 (1842), he alludes to the last-mentioned bird only.

No recent visitor to the island of St. Kilda appears to have received any satisfactory information regarding the existence of the Great Auk there. There is not even the bare mention of it in the 'Journal of an Excursion to St. Kilda,' published in Glasgow in 1838, by L. Maclean-a writer who furnishes an interesting account of the birds on the authority of the then resident clergyman, the Rev. Neil Mackenzie, who had been there eight years; and $\mathrm{Mr}$ John Macgillivray, who visited the island in 1840, was informed that though the bird was by no means of uncommon occurrence about St. Kilda, none had been known to breed there for many years past, and that the "oldest inhabitant" only recollected the procuring of three or four examples. Mr Elwes, who visited the island in H.M.S. "Harpy," on $22 \mathrm{~d}$ May, 1868 , has the following remarks in a valuable paper on the 'Bird Stations of the Outer Hebrides,' contributed to the Ibis for 1869:- "On landing, we were met by the minister, $\mathrm{Mr}$ Mackay, who appeared very glad to see any one, as may well be imagined. Strange to say, he did not seem to take any interest in, or to know much about the birds, though he has been two years among people whose thoughts are more occupied by birds than anything else, and who depend principally on them for their 
living. I showed a picture of the Great Auk, which $\mathrm{Mr}$ J. H. Gurney, jun., had kindly sent me, to the people, some of whom appeared to recognise it, and said that it had not been seen for many years; but they were so excited by the arrival of strangers, that it was impossible to get them to say more about it, and though Mr Mackay promised to take down any stories or information about the bird that he could collect, when they had leisure to think about it, he has not as yet sent me any. I do not think, however, that more than two or three examples are at all likely to have been seen in the last forty years, as $\mathrm{Mr}$ Atkinson of Newcastle, who went there in 1831 , does not say a word about it in his paper* beyond mentioning the name; and neither John Macgillivray, who visited the place in 1840, nor Sir W. Milner, says that any specimens had been recently procured. I believe that Bullock was also there about 1818; and as he had not long before met with the species in Orkney, there is little doubt he would have mentioned it to somebody if he had heard of any having been recently procured at St. Kilda. I made every inquiry about this bird on the north and west coasts of Lewis, and showed pictures of it to the fishermen; but all agreed that nothing of the sort had been seen since they could remember." Writing in 1861, Professor Newton, in a paper contributed by him to the Ibis for that year, on Mr Wolley's researches in Iceland respecting the Garefowl, states that Sir William Milner had informed him that within the last few years he had become possessed of a fine Great Auk, which he had reason to believe had been killed in the Hebrides. This specimen was found to have been stuffed with turf. The Great Auk is not mentioned by Dr Patrick Neill in his 'Tour through the Orkney and Shetland Islands,' printed in 1806 - a work which contains a full list of the birds known to inhabit that district; nor is it alluded to by Dr John Barry in his 'History of the Orkney Islands,' which appeared in the following year. Negative evidence like this, however, may not carry much weight. Low, who died in 1795, but whose natural history manuscript was not published till 1813, remarks as follows:- "I have often inquired about the Great Auk especially, but cannot find it is ever seen here;" + yet nearly twenty years later, it was found by Mr Bullock, who was but a casual

* Trans. Nat. Hist. Soc., Newcastle-upon-Tyne. 1832.

+ Fauna Orcadensis, page 107. 
visitor. The following remarks from an interesting little work entitled 'The Ornithologist's Guide to the Islands of Orkney and Shetland,' published in 1837 by Robert Dunn, the father of $\mathrm{Mr}$ Joseph H. Dunn, now of Stromness, may not be out of place:"I have never seen a living specimen of this bird, nor do I believe it ever visits Shetland. I made inquiries at every place I visited, but no one knew it: had such a remarkable bird been seen there I must have heard of it. During my stay in Orkney, and while on a visit at Papa Westra, I was informed by Mr Trail, whom I had the pleasure of seeing two or three times, that a pair of these birds were constantly seen there for several years, and were christened by the people the King and Queen of the Auks. Mr Bullock, on his tour through these islands, made several attempts to obtain one, but was unsuccessful. About a fortnight after his departure one was shot and sent to him, and the other then forsook the place. Mr Trail supposed they had a nest on the island, but on account of its exposed situation the surf must have washed the eggs from the rocks, and thus prevented any farther increase." Ten years later another little work on the Natural History of Orkney was issued by Dr W. B. Baikie and Mr Robert Heddle, who thus speak of the Great Auk:- "This bird has not visited Orkney for many years. One was seen off Fair Isle in June, 1798. A pair appeared in Papa Westra for several years."

With the exception of Otho Fabricius, no author whom I have consulted appears to have had an opportunity of ascertaining from personal observation the nature of the food of this bird. In his Fauna Gronlandica, that writer states that it consisted of Cottus scorpius, Cyclopterus lumpus, and other fishes of the same size.* He likewise mentions that he had seen the young bird covered with grey down taken in the month of August, from which he concluded that it was but a few days old: its stomach contained littoral plants-he mentions rose-root (Rhodiola rosea)-and no fishes. In the same work Fabricius remarks that the young bird has not the white patch in front of the eye. In his day the adult bird appears to have been very rare, and was known among the Esquimaux by the name of Isarokitsok, which means "little wings."

A figure of the Great Auk, drawn by W. B. Hawkins, from

* Latham and Selby repeat this in their respective works, but have omitted to state their authority. 
Bullock's specimen, now in the British Museum, is given on plate 35 of a folio volume, entitled 'Illustrations of Zoology', etc. (Edinburgh, 1831), by James Wilson, F.R.S.E., the writer from whom I have already quoted. In this work the following remarks occur bearing on the bird's incapacity for flight, which was doubtless one of the chief causes which led to its extinction:- "From the total inability of these birds to fly, and their inaptitude at walking, they are seldom observed out of the water. Neither are they often seen beyond soundings. This probably arises from the necessity under which they labour of drying their plumage occasionally by mounting upon a rock or stone, as their feathers can derive no advantage from the usual effects of flight. This motion of swimming, also, being so much less rapid than that of flying, they are comparatively restricted in their acquatic excursions." Of the various portraits of this bird illustrating the works of British authors, that by Stewart, forming plate 16 of the fourth volume of Sir William .Jardine's British birds, and the woodcut in Yarrell's third volume, may be instanced as both pleasing and accurate. Donovan's figure, published in 1819, was, as he informs us, taken from a specimen formerly in the Leverian Museum, and purchased by him, at the dispersion of that collection, for ten guineas-a price which has risen at least tenfold within the last thirty years. Nor are the eggs less valuable in proportion. Four were sold in London by public auction in 1865 , and realised in separate lots $£ 33, £ 31 \mathrm{10}$ s, and two at $£ 29$ each. As time deepens the conviction of the utter disappearance of the species, the value of both skins and eggs will to a certainty increase. In a recent communication to the Ibis, "on existing remains of the Garefowl," by Professor Newton of Cambridge, a copy of which, corrected to May, 1871, has been obligingly forwarded to me by the author, I find the following summary given:-

Skins.

Germany..............20

Denmark.............. 2

France ......... (or 8 ?)

Holland

Italy.......

Germany

France
Norway

Sweden

United K............

Russia .............. 1

Switzerland.
Belgium

Portugal

United States.......... 3

Total 71 (or 72 ?)

Skeletons.

Italy ............... 1 
Detached Bones.

Denmark......10 (or 11 ?) individuals Norway .........8 (or 10 ?)

United Kingdom.....13

"6

United States 7 individuals

Total 38 (or 41 ?)

EGGS.

Germany 8

Belgium 2

Denmark 1 .

Switzerland United States......... 2

Total .65

"Therefore," concludes Professor Newton, "the existence is recorded of 71 or 72 skins, 9 skeletons, detached bones of 38 or 41 different birds, and 65 eggs." A summary which shews that Britain possesses the largest share of these interesting relics of a by-gone species.

I cannot conclude this very imperfect history of the Garefowl as a Scottish species, without referring to the highly important services rendered to the cause of ornithology by Professor Newton, through the publication of various papers, during the last ten years, on the past history of the species. The first of these, entitled 'An abstract of $\mathrm{Mr}$ J. Wolley's researches in Iceland, respecting the Garefowl or Great Auk,' was published in the Ibis for 1861; a second, being 'Remarks on the exhibition of a natural mummy of Alca impennis,' appeared in the proceedings of the Zoological Society of London for 1863 ; a third, also a contribution to the Ibis, appeared in that magazine for April, 1870, and contains a full record of all existing remains of the bird so far as could be ascertained; while a fourth, and perhaps the most interesting of all, on 'The Garefowl and its historians,' reviewing five different publications on the subject, was published in the 'Natural History Review' for 1865 (pp. 467, 488). It is impossible to praise too highly the scientific ability shewn in these ornithological contributions; and it is to be hoped that their distinguished author may shortly publish the entire history in a collected form. Year after year is passing away without the slightest intelligence being received which can excite even a hope of the bird being yet alive; and a subject so significant as the death of a species within the recollection of naturalists whose cabinets contain the remains of all that future zoologists can hope to investigate, is too important to be treated by other than the ablest hands. In one of the papers enumerated, the last gleam of hope is thus tenderly alluded to:"In former days, when 'penguins' were abundant about Newfound- 
land, they seem to have passed southward along the coast in winter, and thus we find Catesby, in the early part of last century (Hist. Carol, App. p. xxxvi.), including the species as an occasional visitor at that season to the shores of Carolina; but we can well imagine a settlement of, at most, some few hundreds existing for years on such spots as the Geirfugladranger, or the Virgin Rocks, without even a straggler coming across the path of the few sea-faring men who would appreciate the value of the meeting. This belief we confess to fondly cherishing; - we cannot yet bring ourselves to address our old friend the Great Auk in the tender words of Milton:-

\footnotetext{
'Aye me! whilst thee the shores and sounding seas

Wash far away, where'er thy bones are hurl'd, Whether beyond the stormy Hebrides, Where thou, perhaps, under the whelming tide, Visit'st the bottom of the monstrous world.'
}

Whether, however, the species be extinct or not, the fate of the Garefowl has still much interest. If it still exists, its doom will probably be sealed by its re-discovery. For all practical purposes, therefore, we may speak of it as a thing of the past; and, regarded in this light, the subject becomes even more than interesting, because, owing to the recent date of the bird's extirpation (whether completed or not), we possess much more information respecting the exterminating process, than we do in the case of any other extinct species. Without drawing any over-strained inferences, we see how the merciless hand of man, armed perhaps only with the rudest of weapons, has driven the Garefowl, first from the shores of Denmark, and then from those of Scotland. At a later period it has been successively banished from the Orkneys, the Faroes, and St. Kilda. Then, too, a casual but natural event has accelerated its fate. The eruption of a submarine volcano on the coast of Iceland, by laying low one of its chief abodes, has contributed effectually to its destruction. But worse than all this has been the blow which, on the discovery of America, came upon the portion of the race inhabiting the Newfoundland islets, when it was brought suddenly face to face with a powerful and hitherto unknown enemy, and where the result has been what invariably happens when a simple tribe of savages, used only to the primeval customs of its forefathers, is all at once confronted with invaders of the highest type of civilization-' the place thereof knoweth it no more."” 
NATATORES.

\section{THE COMMON CORMORANT.}

\section{PHALACROCORAX CARBO.}

\section{Bailliare-bodhain. Sgarbh-buill.}

THE well-known figure of this conspicuous bird is a never-failing accessory to the coast scenery of many districts of the mainland of Scotland, especially the south-western counties. In Ayrshire and Wigtownshire it is much more common than its ally, the green cormorant, and in these counties is found breeding on rocky precipices overhanging the sea, where it occupies separate ledges, as well as on islands in inland lakes, at a distance of many miles from the coast. There is a large breeding colony every year on Loch Moan, in Ayrshire-a place but little visited, and distinguished for nothing but these Cormorants and the sterile scenery by which they are surrounded. In the breeding season of 1867 this loch was visited by a fishing party who, finding nothing in the loch itself-every fish having been devoured by the birds-launched a boat they had brought across the hills, and proceeded to the island, where they built a pyramid of Cormorant's eggs, which they had no difficulty in gathering, to a height of two or three feet, and smashed the entire lot with heavy stones. One of the party -an officer in the 33d Regiment-informed me that though the eggs were not counted, he was certain of more than a thousand having been destroyed. A similar colony existed a few years ago on the lochs of Mochrum and Drumwalt, in Wigtownshire. In 1867, when visiting these lochs, I found the numbers of the Cormorants greatly diminished, and I have since been informed that only a few pairs are now to be found nesting there. Their unwelcome presence had been too much for the resident keeper's good nature; and, indeed, it would be a strong liking for Cormorants that would tolerate even the temporary visits of several hundreds of these feathered poachers where the fishing is supposed to be "preserved." In the autumn of 1870 , after the young birds had left the district, I counted nearly fifty groups of these gaunt creatures on the coast between the point below Sinniness and the village of Port-William, a distance of eight or ten miles; there were from fifteen to twenty in each company, and 
in some instances the birds were sitting drying their wings within thirty yards of the public road. I saw no green cormorants among them; nor could I discern a single bird of either species on the water-all being in a state of rest. A very large proportion of these Cormorants appeared to be birds of the year; but I could not learn with certainty where they had been bred. From their extraordinary numbers within a comparatively limited space, it was evident that they had located themselves in a good fishing ground. Several times I observed two or three birds rise together as I drove along the road which skirts the shore, and after attaining to a considerable height, steer in a straight line across the hills, and I concluded they were flying to some favourite inland roosting place. On the Ayrshire coast there are several breeding stations on the line of rocks overhanging the sea between Ballantrae and the entrance to Loch Ryan. The colonies which occupy these nesting places are very conspicuous when viewed from the sea. When cruising past I have been amused with their odd gestures, as they turned their heads from side to side in evident wonderment. On the whitewashed and comparatively flat surface of the rock, every bird stood out in bold relief; some were half raised from the nests, and others, apparently males, were in rows behind, stretching out their necks and balancing themselves on their tails and awkward splay feet. On these occasions, indeed, they display so much fear, mingled with curiosity, that it quite upsets one's gravity to look at them. Our skipper uttered more than his own sentiments one day when he turned round and said: "I'd give a shilling to hear them beggars speak."* When the wind is blowing off shore, it is by no means pleasant to be assailed by the offensive odours which are wafted on board; the abomination is only exceeded when on a hot day you venture within the precincts of the nursery itself. In such a place one can almost understand the aversion with which the bird is regarded by many persons who have given it a bad character. Various poets have done what they could to foster this prejudice by describing it as unclean, while Milton goes a

* The minister of Ardnamurchan is reported to have said the same of the St. Kilda puffins, but on inquiring at the skipper whether he had read that gentleman's writings, he said he was only partly familiar with his Lies of Ancient Rome, from which I inferred that he had but a confused knowledge of the two Macaulays. 
step further by comparing it to Satan, or rather, he supposes the arch-fiend to have entered its form before assuming that of a serpent to betray man :-

" Thence up he flew, and on the tree of life,

The middle tree, and highest there that grew, Sat like a Cormorant."

From living exclusively upon fish, its flesh, as I have been informed by those who have had the courage to taste it, is peculiarly rank and unpleasant. An old friend of mine told me lately that he had cooked one and eaten part of it about forty years ago, and that the terribly fishy flavour was in his mouth still. Perhaps Milton had some such gastronomic recollections of the bird.

In the Outer Hebrides the Common Cormorant is much less numerous than on the south-western mainland, its place there being to a great extent occupied by the next species. It frequents various caves on the east side of the Long island from Barra to Lewis, and is also found on the Haskeir rocks. Within the circle of the inner islands it is found breeding on some parts of the coasts of Skye, Mull, and Islay, likewise in Rum, Eigg, and Canna. Mr Graham informs me that it is frequently met with in Iona and Staffa, though it is by no means so common as the green cormorant. On all these islands it breeds apart from its ally, and invariably perches at a higher elevation on the rocks.

Some of the old writers whom I have consulted would appear to recommend this bird with all its imperfections as an article of food. Martin, in his quaint description of the Isle of Skye, thus refers to the subject: "The Sea-Fowls are Malls of all kinds, Coulterneb, Guillamot; Sea Cormorant, etc. The Natives observe that the latter, if perfectly black, makes no good Broth, nor is its Flesh worth eating; but that a Cormorant which has any white Feathers or Down, makes good Broth and the Flesh of it is good Food, and the Broth is usually drunk by Nurses to increase their Milk." He does not, however, ascribe any unusual rapacity to the natives who were so unfortunate as to have been brought up under this peculiar treatment. 


\title{
THE SHAG OR GREEN CORMORANT.
}

\author{
PHALACROCORAX GRACULUS.
}

\section{Sgarbh.}

THE Green Cormorant, though less numerous on the western shores of the Scottish mainland than the preceding species, is abundant in the Outer Hebrides, where it is permanently resident and to a great extent gregarious. It is found breeding in great numbers in all the caves which intersect the precipitous coasts of Harris and Barra, and also on the uninhabited rocks, such as the Haskeir group and other islands lying to the west of North Uist. Very large companies frequent the sounds which separate the islands; and in these stations they are seen daily, at certain states of the tide, fishing in congregations which, in extent, remind one of a dense colony of guillemots. Late in the afternoon they rise on wing in detachments and betake themselves to the caves, in which they generally pass the night. One of these caves named Liuir, on the west side of Harris, is perhaps the best known throughout the Long island. There cannot be less than two or three hundred Green Cormorants in it during the breeding season, and at other times of the year it gives ample shelter to the poor birds when the fury of the winter storms prevents a seaward flight. In the Inner Hebrides this Cormorant is equally common, frequenting similar caves. Dr Dewar found a large breeding colony in the island of Rum: the nests were chiefly on broken boulders not far from the water's edge, and the birds were so tame as to allow themselves to be seized with the hand before quitting the nest. Nearer the mainland it is found in Skye, Mull, Iona, and Staffa, as well as upon Islay, Jura, and Gigha; a few pairs frequent Ailsa Craig, and I have observed considerable numbers in the caves along the rocky shores of Ayrshire and Wigtownshire. It is frequent at the Mull of Galloway, and at Burrow Head; thence northward as far as Garliestown. I have seen from forty to fifty in one day while driving between these two places.

The nest of the Green Cormorant is usually built of heather and sea-weed, and is at best a very clumsy structure. At the end of the season it is so much trampled and besmeared with dung and the remains of putrid fish that it is not easy to recognise 
the materials of which it has been originally composed; nor is it by any means an agreeable task to examine such an offensive mass. The eggs, in most cases four in number, are at first pleasant to look upon, but soon become soiled. Of their quality as an article of food I am unable to speak from personal experience; but Dr Edmonston - a correspondent of the late Dr Macgillivray-who seems to have tried them, says they "deserve all the execration which even the Esquimaux bestow on them." Yet the bird itself, which must even be worse, is eaten and relished by the Hebrideans, who prefer it when young, as its flesh is then said to be more tender. As regards the flavour, however, both young and old must be equally offensive; and it would certainly baffle the cleverest cook to disguise or keep down the aroma of such a dish. When subjected to a temporary burial in fresh earth the odious taste is said to be much ameliorated; but I hope that none of my readers may ever require through necessity to put a scart's edible properties to the test.

The obliteration of the nostrils of this bird takes place about the time when the young ones are ready to fly. It is very extraordinary that the possession of this feature should be retained only during the stay of the bird in the nest-a cradle acknowledged by every observer to be almost insufferable to the sense of smell. Many persons would think that the want of nostrils at this period of their lives would be a much better arrangement.

The late Professor Macgillivray, whose account of the species is, I think, the best given by any British author, was informed by Dr Edmonston that in the Shetland Islands it is subject to epidemics, which occasionally greatly reduce its numbers-a remark which has evidently been founded on partial observation.

\section{THE GANNET OR SOLAN GOOSE.}

\section{SULA ALBA.}

Sùlaire.

DURING the summer months this well-known bird is an abundant species over the whole coast line of the West of Scotland. From Ailsa Craig vast numbers distribute themselves in the day time from the south of Wigtownshire to the northern shores of Argyle; while from St. Kilda even larger flocks become dispersed through- 
out the Hebridean Sounds, extending even to the lochs of Skye, and the still more distant shores of western Ross-shire. Again, the coasts of Lewis, the North Minch, and the shores of Sutherland and Caithness, are frequented by wandering Gannets from Suleskeir, or North Barra, as it is sometimes called-a small island lying about ten miles west of Rona, the most north-westerly land in Europe. This island of Suleskeir has been apparently confused with another rock of a similar name (the Suliskerry of British authors), as no reference has been made to it as a breeding place of the Gannet in any of the numerous works on British Ornithology. Mr Elwes (Ibis, 1869) states that though now uninhabited, it is still visited annually by a boat from Ness, which goes in September for the sake of the down and feathers of the young Gannets, several thousands of which are usually killed. There are therefore five different breeding stations for the Gannet in Scotland, viz.: Ailsa Craig, St. Kilda, Suleskeir (marked in most maps as North Barra), Stack of Suleskerry, about forty miles west of Stromness in Orkney, and the Bass Rock in the Firth of Forth. From these localities, as has been shewn, the birds make long excursions in search of prey. The flight performed by the St. Kilda Gannets indeed cannot be much short of 200 miles in one day, without taking into account the distance gone over while they are engaged in fishing. I have observed them regularly returning across the Minch from the shores of Skye, and passing through the Sound of Harris on their way home about an hour before sunset; and in the height of the breeding season I have also seen Gannets from Suleskeir winging their way back to their distant nursery as we passed Cape Wrath. I am inclined to think that the poor birds sometimes become inert through fatigue, and find themselves unable to continue their flight. In August, 1870, when rounding the Mull of Cantyre about 10 P.M., I saw strings of solan geese, seven and eight at a time, flying homewards in the direction of Ailsa Craig, and keeping close together as if wearied. Next morning on going on deck about four o'clock I observed numbers of these birds apparently asleep on the water in the Sound of Jura: they were all floating helplessly with the tide, with their heads buried in their plumage. In sailing northwards the same facts were observed, until after rounding the point of Ardnamurchan, when it was found that the Gannets all took a north-westerly course towards evening, from 
which, I inferred, that they belonged to St. Kilda. During another cruise in the autumn of 1870 , I saw, as we were leaving Castle Bay one morning about six o'clock, several hundred Gannets plunging for prey on the west side of the island of Muldoanich, which lies about three miles east of Vatersay, one of the isles of Barra. There must have been a large shoal of fish at the place, as the birds were diving with extraordinary rapidity, their movements, when seen against the dark shade of the island, reminding one of a shower of snow. As this happened in the first week of August, and about ten days before the St. Kilda geese are known to have their young ones fledged, the birds which I saw were probably providing a family breakfast to carry back to the rocka distance of fully eighty miles.

At both Ailsa Craig and the Bass Rock-the two breeding stations with which I am most familiar-the Gannet is very abundant. It is believed that at a moderate calculation the number on the Bass Rock may be set down at 20,000, and I feel sure that the number frequenting Ailsa cannot be reckoned less. Since the time of Martin, who describes with amusing quaintness the habits of the Gannet as observed by himself at St. Kilda, nearly two hundred years ago, very little change has taken place in the remoter strongholds of the species; but on the Bass Rock, where, in former years, a large colony had possession of part of the grassy slopes, on which they built their nests, the intrusion of visitors has driven the birds entirely to the precipitous ledges on the west side of the island. The interest in this famous breeding place has therefore become greatly diminished; and notwithstanding the protection now afforded this bird in common with other seafowl, it is extremely doubtful if the colony I speak of will ever resume the occupancy of that part of the rock. Twenty years ago, about one hundred and fifty nests could have been examined without the slightest difficulty, and the birds were then so tame as to allow a person to walk among them and lift and examine both young birds and eggs without much remonstrance-a sight which well repaid the trouble of a long journey. In 1859, before they finally quitted the spot, I visited the rock and found their habits considerably changed. The old birds were dreadfully vociferous, and in some cases showed fight. Professor Macgillivray well described their cry in comparing the torrent of crackling sounds to the words 
Varroch, Varroch, Kirra, Kirra, Cree, Cree, Krak, Krak-an address which they utter with great rapidity; but ultimately, finding that it makes no impression, they change it to a loud call for Grog. While standing surrounded by an excited multitude of open bills I noticed my guide, one of the Cantabay boatmen, apparently absorded in thought. "Is there any risk of them biting?" I ventured to inquire. "Oh, no, sir!" he rejoined; "I was only thinking how like they are to oursels."

With regard to Dr Macgillivray's statement as to this bird occasionally laying two eggs, it may be presumed that the fourteen nests which he was informed had been seen to contain that number were situated on the accessible slope already referred to. In the height of the breeding season excursionists were almost daily on the rock, and I have seen persons out of wanton mischief exchange the contents of some of the nests, which were very close to each other, and even leave two and three eggs for one bird to sit upon. That nests have been tampered with in this way regularly there can be no doubt; indeed, one of the boatmen confessed to me on one occasion that the nesting habits of the Solan Goose could be made to suit the fancy of any particular visitor! The nest is built of pieces of turf and masses of sea-weed, which become so much shrivelled by the heat as to necessitate constant repairs. The old birds, therefore, are continually carrying materials which they find floating on the sea. I have occasionally seen small branches of trees introduced. Martin, in his description of the Western Islands, mentions that the steward of St. Kilda told him of having found a red coat in one nest, and a brass sun dial, an arrow, and some Molucca beans in another.

The principal food of this bird consists of fishes of moderate size, such as whiting, haddock, and sethe. It is also partial to herrings; and I have seen numbers in the sheltered bay of Millport, in Cumbrae, plunging in pursuit of the Poor Cod (Morrhua minuta), which in certain seasons frequents the bay in shoals. The prey is generally, if not always, secured when swimming above a sandbank - a fact which any observer may test for himself by taking up his position for an hour or two at any part of the coast where he can from a height look down upon the floor of the sea on a clear day. The spots of sand are easily perceived in contrast to other parts which are covered with rocks and sea-weed. I have many times watched the Gannets flying to 
and fro near the coast line between Girvan and Lendalfoot, where I had an opportunity of looking down upon even the flying birds, and have invariably observed them plunging over these banks of sand. I do not think that they are successful at every plunge, unless the fish happen to be numerous; and I imagine they must pursue their prey while under water, as single birds have frequently been discovered drowned in the salmon nets which are placed in the various localities along the Ayrshire coast. I have seen Gannets fishing very near the beach and quite within gunshot. In August last I observed one diving in the line of broken waves where the water was probably not of a greater depth than $2 \frac{1}{2}$ or 3 feet; the bird seemed for a moment or two averse to run the risk of securing his fish by a hazardous plunge in shallow water, and it was interesting to notice the dexterity with which he dashed diagonally into the frothing waves, emerging again on wing with the fish he had coveted. The Ailsa Gannets usually continue their shore fishing near Girvan until sunset, when they suddenly stop and fly steadily seawards in the direction of the rock. At various times I have discovered dead birds at the base of the cliffs there, with gurnards firmly wedged in their throats, and have been obliged to use a knife for cutting the spines before the fish could be taken out. Individuals have also been picked up on the water similarly situated.

The Solan Goose usually makes its appearance on the Ayrshire coast in February, and leaves sometime in October ; and on the east coast some hundreds have been known to remain all winter in the vicinity of the Bass Rock for three or four years in succession. In these years it was noticed that herrings were at the same time plentiful : it may be said, indeed, that the movements of the bird are, to a great extent, influenced by those of the various kinds of fish on which it is known to feed. On leaving the Bass Rock in September, vast flocks occasionally proceed northwards, visiting the bays and firths which, at that season, are frequented by shoals of fish. Writing on 23rd August, 1770, Pennant, who seems to have discovered this habit, thus speaks of what he observed:"On my way between Thrumster and Dunbeth, again saw numbers of flocks of Gannets keeping due north, and the weather being very calm they flew high. It has not been observed that they ever return this way in spring, but seem to make a circuit of the island till they again arrived at the Bass Rock, their only 
breeding place on the eastern coast." Early in February several thousands at a time have been observed off the village of Ballantrae, in Ayrshire, attacking shoals of fish with extraordinary voracity as if they had for some months been on short allowance. I have seen a like assernblage, though in the summer months, in Belhaven Bay, near Dunbar, and also at the Tyne estuary, where their rapid movements form a sight of great interest.* With the exception of the Caon Sands on the north-west side of the island of Benbecula, in the Outer Hebrides, I do not know a finer expanse on the entire coast line of Scotland than that extending for some miles between the Tyninghame Woods and the village of Belhaven. In the strong heat of summer which is there tempered by the easterly haur setting in about mid-day, one may sit for hours in pure delight while he watches the airy figures of the Gannets and Terns sweeping athwart the soft azure,-

"Blue the soft heavens, and blue the far ocean,

Gently their shores the hoarse waters sweep,

Hushed the dark forest, no quickening motion

Save in the breast of the tremulous deep.

Here on the pinnacle stand $I$ and treasure

The musical notes of the deep booming sea,

As they strike on the air with unvarying measure,

And murmur their drowsy but sweet melody."

- Netherton,' by C. Gulland, Jun.

After the breaking up of a winter storm when the clear bracing air becomes enjoyable with the accompaniment of bright sunshine, one cannot but stand in admiration of the breakers which come rolling in sparkling white masses into the bay from the blue water outside. It is not easy to do justice to the scene through any mere description. The sands which stretch some miles from east to west, and seawards more than a mile when the tide is out, present a vast yellow expanse on which the waves, like a great white wall,

* In speaking of the destruction among fish, committed by these birds during their residence on our coasts, a writer in the 'Quarterly Review' makes the following calculation:- “The Solan Goose can swallow and digest, at least, six full sized herrings per day. It has been calculated that in the island of St. Kilda, assuming it to be inhabited by 200,000 of these birds, feeding for seven months in the year, and with an allowance of five herrings each per day, the number of fish for the summer subsistence of a single species of birds cannot be under $214,000,000$. Compared with the enormous consumption of fish by birds, and by each other, the draughts made upon the population of the sea by man, with all his ingenious fishing devices, seem to dwindle into absolute insignificance." 
press onwards and cover their allotted space. Unlike the same waters at the heads between Belhaven and the town of Dunbar, the breakers, instead of dashing themselves on precipitous battlements of rock, come landwards in a long curling line of foam, inexpressibly fine when seen in clear sunlight against the blue background, and conveying the same idea of power as when

" On iron coast in angry waves

You seem to hear them climb and fall And roar, rock thwarted."

I have at various times had Solan Geese in my keeping as pets, but I am sorry I cannot say much in their favour. The last lot I had -about half-a-dozen-behaved very badly. They kept up an incessant clamour for fish, quantities of which they ravenously, and I may say, thanklessly devoured; for I no sooner presented myself within the enclosure where they were confined than I was furiously met by the whole gang, launching their wedge-shaped bills wherever they could effectively strike a blow, and uttering all the while the most discordant cries it was possible for birds to give vent to. With such experience, it would be folly to recommend the Gannet as a proper subject for the Aviary: it does not requite one for his trouble; and, besides, it is not the most gentle occupation of a morning to be visiting one's pets armed with a cudgel.

Though there are now, as has been already said, but five breeding stations for the Gannet in Scotland, it appears from the writings of old travellers in the Hebrides that colonies existed in various other places within the circle of the inner islands. Dean Munro, who visited nearly the whole of the islands between 1540 and 1549 , and has left a very quaint account of what he saw, says, in his description of Rum, "Many Solane Geese are in this isle ;" and again in speaking of Eigg he proceeds:- "North from Ellan Muchd be foure myles, lyes ane iyle called iyle of Egga, foure myle lange and twa myle braid, guid maine land with a Paroch Kirk in it and maney Solane Geese," though one cannot see exactly how the two things should in this curt way be associated. J. Monipennie, who wrote in 1597, thus refers to Rum and its productions:"Then Ruma sixteene miles in length and sixe in bredth, rising high in strait hilles full of woods and scrogges, and for that cause it is inhabited in very fewe places. The sea fowles laie their egges heere and there on the ground thereof. In the middest of the 
spring time, when the egges are laide, any man that pleaseth may take of them. In the high rockes thereof, the sea guse, whereof we spake before [Solayne geese], are taken in abundance." This writer, however, does not give the information from personal observation, but acknowledges in his preface that he "will follow Donald Munro, a man both godly and diligent, who trauelled all these isles vpon his feet, and saw them perfectly with his eies"a character and example which it would be well, perhaps, for some modern naturalists to imitate.

NATATORES.

LARIDA.

\section{THE SANDWICH TERN.}

\section{STERNA BOYSII.}

IN bygone years it was no uncommon thing to see flocks of this fine species fishing in shallow water on many parts of the coast. Serious inroads, however, have been made upon its breeding haunts on both the east and west coasts, and in places where formerly their eggs could be seen in hundreds it is now a rare occurrence to find more than the contents of one or two nests. Some of the best known haunts, indeed, including the rocky islets near the Bass Rock on the east, and some of the islands on the Frith of Clyde on the west, have become entirely deserted; and it is questionable whether there is any breeding station in Scotland at present equal to those of twenty years ago.

There is a small colony of Sandwich Terns on Inchmoin, a low flat island on Loch Lomond where they have been found breeding along with other species, and where they will probably increase if unmolested. In the time of Pennant this species seems to have bred on the isles of Loch Leven, in Fifeshire. Speaking of the birds in his 'Tour in Scotland,' he calls them Great Terns-the same name he gives those he saw on the Farne Islands where the Sandwich Tern still retains its ground, although in greatly reduced numbers.

I have of late years observed stray birds of this species frequent. ing the shores of East Lothian and Fifeshire: and it is to be hoped that the recent Act for the preservation of sea birds will be the means of reinstating both it and the next mentioned species in localities which have for years been wholly abandoned. 


\section{THE ROSEATE TERN. \\ STERNA DOUGALLII.}

Since the discovery of the Roseate Tern in the Cumbrae Islands by $\mathrm{Dr} M \cdot D o u g a l l$, in 1812 , it has been known to frequent a number of localities throughout Scotland; and although many years have elapsed since it totally disappeared from 'The Allans,' where it was originally met with, it is still found in considerable numbers in many parts of the western counties. The principal breeding place within easy reach is situated in Kilbrannan Sound, separating Arran from Kintyre. Two or three years ago I got a basketful of eggs from this station, gathered in a few minutes; but I afterwards regretted having taken so many, as I found on leaving the place that a number of pairs of the common tern were hovering overhead, mixed with the rarer species, from which I inferred that some of the eggs at least in my basket were not those of the Roseate Tern. The whole of them were blown, and about thirty specimens are now before me. They appear somewhat longer, of a lighter colour, and more minutely marked than those of the arctic or common terns.

A few pairs of this very elegant bird have located themselves on Inchmoin, in Loch Lomond, where they breed in company with the two birds just named and the lesser and sandwich terns. The island is the property of Sir James Colquhoun, Bart., and is strictly protected, as it certainly ought to be.

The Roseate Tern still frequents the Culbin Sands, in Morayshire, and has also been found in East Lothian by Mr Turnbull, who states that it is not uncommon, and that it breeds on the isle of May.*

\section{THE COMMON TERN.}

STERNA HIRUNDO.

\section{Stearnan.}

Although called the Common Tern this bird is in reality much less numerous than the species which follows: it is, however, not a scarce bird, being in most cases found in some numbers mixing

\footnotetext{
* ' Birds of East Lothian,' page 34.
} 


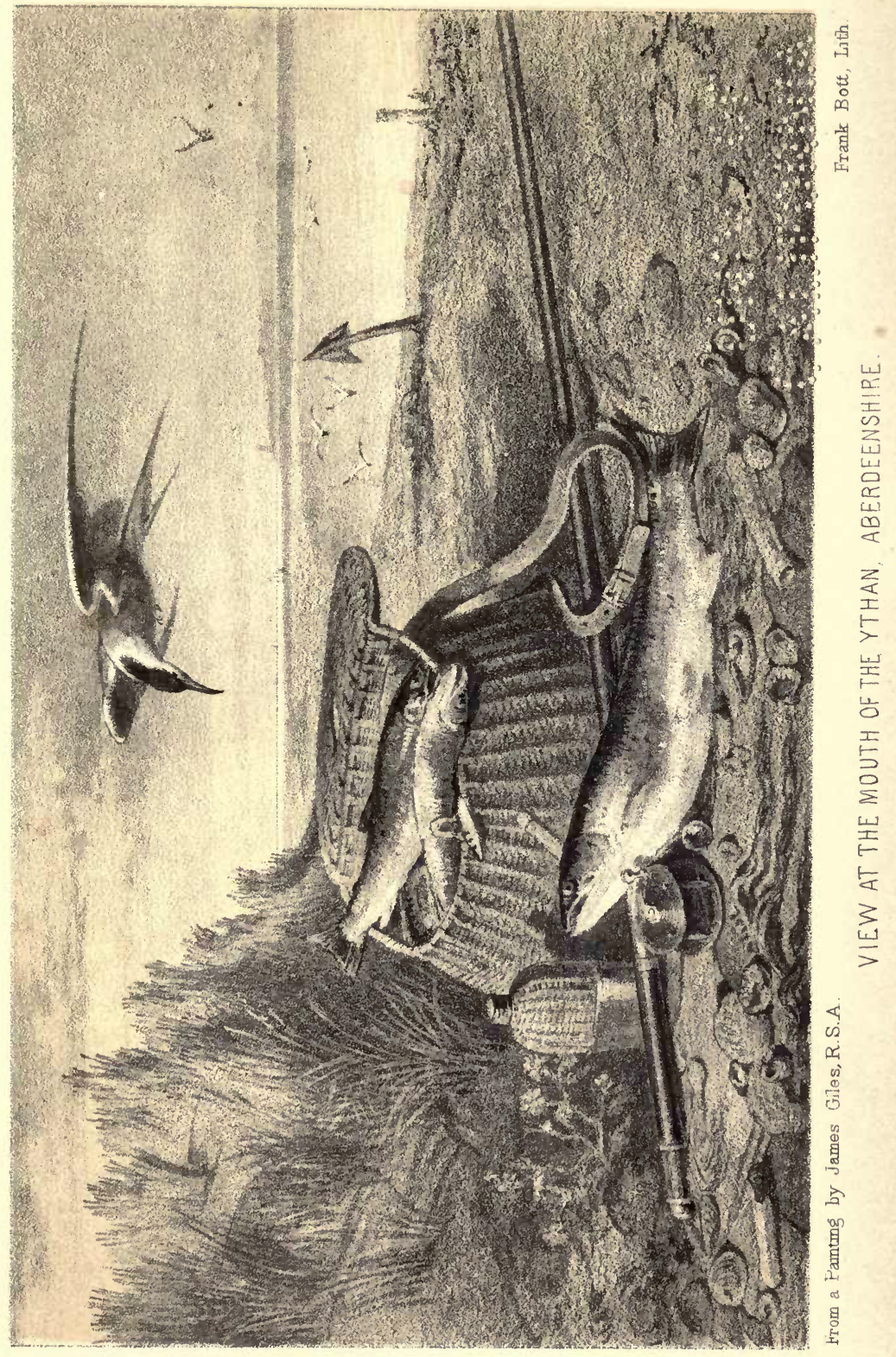



with the more plentiful species, although the arctic tern does not appear to travel inland to breed as the Common Tern is known to do. In the Outer Hebrides this tern breeds on various islands in the Sound of Harris, and also on the rocky islets lying west of the principal group-many of them being uninhabited. It is likewise tolerably common in some of the sea reaches in Ross-shire, and occurs on all the known breeding stations for terns from that county southwards. I have found several pairs breeding for many years past on Inchmoin, an island in Loch Lomond. On this island there is a large nursery of black-headed gulls, but the terns keep by themselves, occupying a stony promontory at one end of the island. During the breeding season, after the young are hatched, the old birds may be seen high in the air above the Loch Lomond hills, steering across to the Firth of Clyde for fish to feed their nestlings. I have stood near their nests and seen them arrive with these sea fish, which they sometimes carried by the middle of the body. From this habit, which is very noticeable, it would appear that the terns there prefer salt water fish to those nearer at hand; and there can be no doubt that in thus gratifying their partiality they are fulfilling an arrangement in which those who practice the "gentle art" on the loch must fully concur.

In that beautiful piece of Scottish scenery-Loch Sunart-there are several populous breeding places of this graceful and interesting bird. These haunts are singularly enticing to an ornithologist who, withont seeking to molest the busy multitudes, contents himself by watching their elegant flight as they whirl and glide above their summer encampment. About the end of June, or sometimes the middle of July, the congregations break up and disperse, small flocks betaking themselves to the sheltered bays of our western shores, travelling southwards as the season advances until they altogether disappear. In April and May these flocks return and frequently congregate in particular estuaries and rivers at no great distance from the sea, especially in rough weather. I have often at this season observed many hundreds at a time of both the common and arctic tern on the Clyde opposite Dumbarton Castle, and have remarked that their presence there always indicated an approaching storm.

The accompanying plate, in which an inquisitive sea-swallow evidently betrays an acquiescence with the title of " Too many for 
the basket," is from the accomplished pencil of the late James Giles, Esq., R.S.A., and contains a view of the mouth of the Ythan in Aberdeenshire-a locality where Mr Angus has been fortunate in procuring many rare and interesting British birds.

\section{THE ARCTIC TERN.}

\section{STERNA ARCTICA.}

\section{Stearnal.}

THE Arctic Tern is a much more common bird than the preceding species, frequenting rocky islets in almost all the lochs of the west coast, and also extending to the whole of the western islands, including the outer group and the rocks beyond. It is extremely numerous in some places there, taking precedence of the other terns in almost every breeding haunt; and is nowhere more abundant than in the Sound of Harris, where there are so many islets to afford it a safe encampment. It frequents Borreray, Bernera, Pabbay, Ensay, Killigray, and a number of nameless rocks forming so many stepping-stones from North Uist to Harris; and in the summer months these and the smaller islets which are uninhabited are literally covered with terns and their nests.

On the western shores of Ross, Inverness, and Argyleshires, there are numerous breeding places for this bird, especially on rocky islands in the sea lochs stretching inland, such as Loch Sunart, Loch Alsh, Loch-na-Nuagh, and Loch Etive. These nurseries are equally numerous off the coast of Mull, and others of the larger islands forming the Inner Hebrides. Having asked Mr Graham as to the comparative numbers of the two commonest terns, I was furnished with a very interesting account of their habits, which may not inappropriately be inserted here:-

"The name of sea swallow is the most applicable to these ocean martlets, not only on account of their long sharp pointed wings and forked tails, but because they are also harbingers of summer to the inhabitants of the coast, as the land swallow is to those of the fields and groves; and so sure as I hear their shrill screams, and see the long-stroked flight of their sharp wings, so sure do I know that the 12th of May has come or gone, for their arrival is punctual to a day. I have no doubt that there are, among the clouds of terns which then arrive, representatives of the many 
other less frequent species; but I am obliged to acknowledge that I never took much pains to search them out. Indeed, when our tardy and short-lived summer does arrive, we have so many occupations, amusements, and engagements to be entered upon, that the fast fleeting fine weather months always glide by, leaving many things unperformed. The two species which are abundant are the Arctic and the Common Tern, in the proportion of about ten of the former to one of the latter. Almost inimediately on arrival the process of incubation is commenced. The spots they select are the numerous steep rocky islets-stucks, as they are called-which in winter are almost continually submerged by the awful seas rolling in from the Atlantic, but which now are completely covered by the nests of these 'halcyons of the ocean.' When these rocks are visited, the white winged birds rise up in clouds, filling the air with their shrill angry clamour, hovering, wheeling, and darting at the invaders of their nests-almost striking them with their wings, exhibiting every sign of rage both in voice and action, and so daring in their approach as to let us knock them down with a stick or boat-hook."

In the first week of August, 1870, when travelling from North Uist to Benbecula, I witnessed a very interesting habit of this tern in crossing the fords which separate the two islands. I had previously been told by a friend to look out for the birds, which, he said, I should find waiting for me on the sands. On coming within sight of the first ford, I observed between twenty and thirty terns quietly sitting on the banks of the salt water stream; but the moment they saw us approaching they rose on wing to meet us, and then hovered gracefully above our heads as the pony stepped into the water. As soon as the wheels of the conveyance were fairly into the stream, the terns poised their wings for a moment, then precipitated themselves with a splash exactly above the wheel tracks, and at once rose, each with a wriggling sand eel in its bill. Some held their prey by the middle of the body, others by the head; the latter being able to swallow the fish as soon as they rose. The other birds, however, allowed their fish to drop out of their bills free, and caught them properly by the head before they reached the water, after which they flew to the sands where their fledged young were patiently sitting and fed them with the spoil. At the next ford, a similar scene was repeated by another group of Arctic Terns which we found there waiting the arrival of 
some friendly travellers. In both these cases the birds showed no fear, but dexterously caught their prey though repeatedly struck at with the whip. Twice over, by stretching out my arm, I nearly caught one of them as it poised itself for a plunge. On making particular inquiry, I was told by many of the inhabitants of both islands, that this habit of the tern is a constant entertainment to those who cross the fords in wheeled conveyances. The pressure of the wheels must bring the burrowing sand-eels momentarily to the surface, and the quick eye of the tern at once enables the bird to transfix them on the spot.

I observed large flocks of this species on the Clyde opposite Dumbarton Castle, on 21st May, 1868. The weather was rough at the time and had apparently caused them to seek shelter over smooth water. In situations where two or three species of terns are found breeding in company, it is sometimes difficult to distinguish the eggs of the Arctic from those of the common tern. In my experience, however, I have seen that the Arctic Tern's eggs are slightly smaller, and marked with fewer blotches-these being also larger than the markings of the common tern. I have also observed that Sterna arctica often lays but two eggs, whereas the other bird has usually, if not always, three; so that in visiting their haunts about the time the birds are beginning to sit, the collector may almost rely on this difference as a ready means of detection. Mr Elwes, when visiting the Haskeir Rocks in the breeding season of 1868 , found this bird hatching in great numbers, and noticed that none of the nests contained more than two eggs. Macgillivray, on the other hand, states in his 'British Birds' that the number varies from two to four.

\section{THE LESSER TERN.}

STERNA MINUTA.

THIS graceful little bird, although not numerous in any part of Scotland, is generally distributed over both the east and west coasts. Its breeding haunts are usually on retired stony promontories or mounds of shingle, over which the tides in summer do not flow. In many of the localities extending from the Solway to the shores of Inverness, these colonies are tolerably safe against intrusion, and for the most part occupy a spot by themselves without 
the companionship of other birds, although sometimes they take up their quarters beside the common tern and black-headed gulls. On Loch Lomond there are a few pairs usually found breeding on Inchmoin - a low, flat, and marshy island, where birds of many species are exceedingly numerous; but a situation like this is entirely exceptional. Like its allies, the Lesser Tern does not trouble itself about the construction of a nest, but deposits its eggs, which are two, and occasionally three in number, in a shallow cavity in the sand or shingle, to which they closely assimilate in colour, and are in consequence very difficult to find.

In the autumn season small numbers of these elegant little creatures frequent the estuary of the Clyde; and stray specimens are occasionally obtained at a distance of one or two miles from the sea in some parts of Argyleshire and Ayrshire. On the east coast-the breeding colonies being larger and more numerousthis tern is often seen in fishing groups frequenting Belhaven Sands in Haddingtonshire; the sands at the mouth of the Eden, near St. Andrews, in Fifeshire; Barrie Sands in Forfarshire; and similar localities in Aberdeenshire. In its habits it resembles other terns; but is even a more interesting study to the ornithologist, being so much smaller than the common or arctic terns. During the breeding time it shows considerable impatience on its haunts being invaded, and meets the intruder with shrill cries, which it persistently utters so long as he remains in the neighbourhood. On the dispersion of these breeding colonies it travels by slow degrees southwards, and finally quits our shores in September, arriving again in the following spring.

Wilson in his description of the habits of this bird, gives an account of its breeding places on the beach of Cape May, and narrates the following incident:- "During my whole stay these birds flew in crowds around me, and often within a few yards of my head, squeaking like so many young pigs, which their voice strikingly resembles. A humming bird that had accidentally strayed to the place appeared suddenly among this outrageous group, several of whom darted angrily at him ; but he shot like an arrow from them, directing his flight straight towards the ocean. I have no doubt but the distressing cries of the terns had drawn this little creature to the scene, having frequently witnessed his anxious curiosity on similar occasions in the woods." 
Messrs Baikie and Heddle state that this species is often observed on Sanday, one of the Orkney islands, "where it usually arrives about the middle of May and departs towards the end of August"-from which account we may infer that it breeds there.

\section{THE BLACK TERN.}

\section{STERNA FISSIPES.}

AвOUT the end of last century Mr Don, of Forfar, catalogued this species as a common one on the sands of Barrie; but as subsequent writers have looked upon it as an extremely rare visitant to our Scottish waters, it may fairly be doubted whether the birds seen by him were resident. The likelihood is that a troop of stragglers had visited the sands referred to, and were noted as common, because there happened to be a flock. Of late years Black Terns have been observed in the spring time and autumn in many Scottish counties; but these, generally speaking, have been stray birds. In Haddington, Berwick, Aberdeen, Fife, and Dumfries shires many specimens have from time to time been shot and preserved. In the West of Scotland small flocks occasionally appear at Loch Fyne and other sea reaches. Mr George Hamilton informs me that he and his brother observed five specimens near Minard in September, 1860; and I have myself seen the species on Loch Lomond, flapping round the boat in which I was rowing, within a distance of eight or ten yards. I may add that one-an adult bird-was shot near Stranraer on the 29th August, 1868, and preserved by $\mathrm{Mr} \mathrm{M}$ 'Comish, birdstuffer, in that town; and about the same time, in the year following, a young bird of the year was seen by myself at Girvan, in Ayrshire. Mr Angus informs me that a specimen of the Black Tern was shot near Aberdeen by Mr Giles, a well-known artist, residing in that city;* and that another-in summer plumagewas shot by himself at Don Mouth on 30th April, 1867. The specimen on Loch Lomond was seen on the 25th May following. A young bird of the year was shot by Mr Harvie Brown on the banks of the Forth, near Grangemouth, on 10th September, 1870.

When Pennant visited the Lincolnshire Fens, in 1771, he found this bird in such "vast flocks as almost to deafen one with

* Died October, 1870. 
their clamours;" but the species has for many years past been on the decrease, and would now appear to occur in very limited numbers in localities where formerly it abounded.

\section{BONAPARTIAN GULL.}

\section{LARUS BONAPARTII.}

I HAVE not been able satisfactorily to trace the occurrence of this bird anywhere in Scotland since 1851, in which year a single specimen was obtained on Loch Lomond by Sir George Leith, Bart., as recorded by that gentleman in the 'Zoologist' for that year. I have on several occasions, when boating on Loch Lomond, seen black-headed gulls, which I knew were not the common species; but evidence of this nature is, of course, inadmissible when speaking of a bird which can only with certainty be identified in the hand. Yet I have no doubt that a prudent and skilful sportsman might, if so inclined, discover this species and the little gull to be at least occasional visitors to the lake referred to. It contains, among its numerous attractions, a safe asylum for feathered wanderers-Inchmoin; and it is not unlikely that the extent of feeding ground afforded by this beautiful sheet of water may yet prove an attraction to birds of this family, which can only in the meantime be regarded as occasional and uncertain stragglers.

Obs.-The Cuneate-tailed Gull (Larus Rossi) may be included in this list, on the authority of Dr Saxby, who states that in Shetland, in the summer of 1854, he shot a gull, which, although unknown to him at the time, and unfortunately lost, was without doubt an example of this very rare species. Its description and measurements are still in the note-book which he carried at the time.*

Sabine's Gull (Larus Sabini) may be included on the same authority, Dr Saxby having communicated to the 'Naturalist,' for 1865, a note of the occurrence of two examples in Shetland. The following note, from Sir John Richardson's 'Journal of a Boat Voyage,' gives later information than is furnished by Mr Yarrell

* In the Ibis for 1865 the editor, Professor Newton, has expressed his belief that there are not more than five specimens of this bird existing in scientitic collections. 
regarding the distribution of this species during the breeding season:- "1848, August 7.- The island on which we encamped is a breeding place of Xema Sabini, the handsomest of all the gulls. Many of the parents were flying about, accompanied by their spotted young, also on the wing. This is the most easterly ascertained breeding station of the species, which has been found at Spitzbergen, Greenland, and Melville Peninsula. Mr Rae shot some fine male specimens, whose plumage and dimensions agreed exactly with the description in the Fauna Boreali-Americana. The eggs are deposited in hollows of the short and scanty mossy turf which clothes the ground."*

\section{THE LITTLE GULL.}

\section{LARUS MINUTUS.}

According to $\mathrm{Mr}$ Selby, this species has been obtained in the Firth of Clyde, but no date is given. Since the publication of his work on British ornithology, in which the Clyde bird was figured, the Little Gull has been observed in several Scottish districts; but only, so far as I can learn, in two other western localities, viz.: the island of Skye, where a specimen was killed in 1865 by Captain Cameron, of Glenbrittle, and Loch Lomond, where another was seen by myself.

In 1840 I saw seven or eight specimens flying in the old harbour at Dunbar in East Lothian; they were very tame, and seemed intent on picking up floating garbage on the water. The birds at length attracted the notice of idle fishermen and boys who were lounging on the pier, and owing to their tameness (whether arising from hunger or other causes, I am not able to say) three of them were literally pelted to death with stones.

The late Mr James Wilson, in his interesting voyage already referred to in this work, mentions having seen a specimen which was killed in Caithness, in the collection of Mr Sinclair, surgeon, Wick; and I have seen a very perfect adult bird in the Elgin Museum which was shot near Fraserburgh on 28th June, 1854. The species had previously occurred in Morayshire, a specimen having been procured near Loch Spynie, in April, 1847, as recorded by the late Charles St. John. Mr Edward of Banff

* Vol. i., p. 262. 
informs me that in 1854 two specimens came under his observation; and in the same year I examined a fine adult specimen, in the summer plumage, which had been shot by Mr William Paterson, near North Berwick, in East Lothian. In 1852 the Little Gull was procured at Orkney, and in the following year it occurred in Shetland.

This beautiful little gull appears to occur on the eastern side of Britain occasionally in some numbers. I have been informed by Mr J. H. Gurney, jun., that he procured no less than fourteen of these birds from the Yorkshire coast at intervals between the 13th of July and the 21st November, 1868;* several of these were in winter plumage, and one was in adult summer dress. $\mathrm{Mr}$ Gurney further states that he heard of a few others that had passed into private hands. A specimen in my own collection-a young male - shot on the sands near Don Mouth, Aberdeenshire, on 29th March, 1869, was presented to me by Mr Alexander Mitchell of the museum in Castle Street, Aberdeen, who has since informed me that he shot other two specimens, adult and immature, at Aberdeen on the 28th September, 1870. I have had the opportunity of seeing another-a female-which was shot at Coldingham Harbour, Berwickshire, on December of the same year. Mr Angus informs me that several were obtained on the Aberdeenshire coast about the same time. It would appear, indeed, that during its migratory journey southwards this species keeps strictly by the east coast.

Nothing appears to have been known of the nidification of the Little Gull until 1869, in which year Mr H. E. Dresser exhibited five eggs, with the bird itself in summer plumage, from Lake Ladoga, in Russia, at a meeting of the Zoological Society of London, held on 25th November. These had been collected by Mr A. Mewes, a well-known Swedish ornithologist. The eggs resembled those of Sterna arctica, especially the dark varieties. Out of twenty-five specimens Mr Dresser did not observe much variation, and none of them had a light ground colour.

* In the following year the species was met with in even greater numbers, as many as thirty specimens having been procured off the Yorkshire coast in a few weeks. 


\section{THE BLACK-HEADED GULL.}

\section{LARUS RIDIBUNDUS.}

Ceann-Dhuban.

THIs beautiful gull is very abundant in the West of Scotland, extending to all the outer islands. Its breeding haunts are also numerous throughout those districts, in which it meets with encouragement. I have visited many of these on the mainland, and on both groups of islands, and find a great similarity in choice of situation, construction of nests, time of breeding, and general habits of the birds in localities widely apart. The two best known to myself are both within easy reach of Glasgow. One of these interesting nurseries is on a small marshy islet in Hairlaw Loch - a patch of water, partly artificial, situated near Neilston Pad, which is within full view of the city. There are perhaps from 500 to 800 pairs to be found breeding there every year. The islet is not safe against intrusion, adventurous boys being able in very dry seasons to wade across to it at a point where the water is comparatively shallow even when the loch is full. The gulls, nevertheless, maintain their ground, and manage to rear several hundred young ones yearly. At the time when this colony is in the state of greatest activity the old birds are constantly flying about the neighbouring fields, especially those from which potatoes have been lifted, and picking up worms and beetles, the remains of these being found at almost every nest. I look upon this bird, indeed, as a useful friend to the farmer, in clearing his ground of injurious insects, etc., on which it may generally be seen feeding. At a later stage of the breeding season the old birds fly much longer distances in search of food, until at length the young ones are induced to accompany them either to the sea-shore or the vicinity of the river Clyde, where they are still attended and fed, as in the case of the terns. I have seen numbers of fully-fledged young birds perched on stones in the middle of the river Kelvin, and patiently waiting till the old ones brought them what they could find in the water. During the whole of the month of July this river, where it flows through the West End Park of Glasgow, is constantly frequented by these birds, the pure white of their plumage contrasting pleasantly with the foliage of the trees. 
They are also abundant at the same season on the river Clyde, in the very heart of the city.

Another numerous colony of Black-Headed Gulls has for many years frequented the island of Inchmoin, on Loch Lomond. This island, which is about two miles in circumference, is quite flat, and stands but little above the level of the water. In wet seasons, therefore, it is to a great extent converted into a wet marsh. About the centre, where the ground is firmer, the Gulls construct their nests, which in some cases measure about eight inches in height, so that the contents are always safe against damp. Here, as well as at Hairlaw, many of the nests contain four eggs, though three is the usual number. Great variety also exists in the markings-some being pale blue and slightly spotted, others entirely of a dark colour, like some varieties of the egg of Richardson's skua. In one nest on Inchmoin I found a nest with two eggs-one of which was much elongated, pale green in colour, and spotless; while the other was much shorter, nearly twice the thickness, and almost as black as a piece of bog oak.

In February, 1870, I examined eight specimens of this gull, which were shot at Girvan. Two were adults, in full winter plumage, with coral-red bill and legs ; two were apparently of the third year, with the bill and feet orange, inclining to red; the remainder being of various ages, from the first year to the end of the second, legs and bill of a dull, yellowish tint. There were not two alike, either in the quill markings, colour of feet and bill, or in the dimensions of the bill. The orbits in two of them were red; but in another, which was just assuming the black cap, and had the rest of the plumage identical, the orbits were black. . The general measurements of all the specimens also differed considerably. There seems to be considerable variation in the space occupied by the dark brown feathers on the head of this bird. The variety known as the Masked Gull (Larus capistratus) has several times occurred in Aberdeenshire, as I have been informed by $\mathrm{Mr}$ Angus. I examined a fine specimen in Mr Mitchell's collection, which had been shot near Don Mouth in 1867, and also one in Mr Angus's collection, killed about the same time and place. The white spot near the eye of Mr Mitchell's specimen appeared to me to be larger than that seen on L. ridibundus; but in other respects as regards the measurements and general markings, excepting of course the masked form of the black cap, the two 
birds are alike. I may mention that $\mathrm{Mr}$ Mitchell also showed me several specimens of the Black-Headed Gull, which were tinged with a beautiful rose colour on the breast, suffused through the feathers, as if they had been dyed. These specimens retained the colour for some weeks; but, as is known to occur with specimens of the sandwich and roseate terns, they finally lost it. I have never seen the rose tint so strong in west coast specimens.

\section{THE KITTIWAKE GULL.}

\section{LARUS TRIDACTYLUS.}

Seagir.

THE familiar Kittiwake is extremely common on the west coast, where there are many breeding stations ranging from the Scaur Rocks, in the bay of Luce, to the Island of Handa, off the coast of Sutherlandshire on the one hand, and from Barra Head to Suleskeir and Rona on the other. It is abundant during the summer months on Ailsa Craig, and the Mull of Oe in Islay, the Island of Rum, where there is an extensive breeding colony, the Shiant Isles, Haskeir Rocks, and St. Kilda. I have nowhere seen greater numbers than in the North Minch, at the close of the season, when the breeding ledges are deserted. Very large flocks then assemble and remain congregated until the weather becomes unseasonable, when they migrate southwards. On the shores of the western mainland, however, considerable numbers of Kittiwakes are seen from time to time throughout the winter season frequenting harbours and sheltered bays, and feeding upon garbage which they find floating upon the water. I observed such flocks constantly during the winters of 1866-67-68-69 and 70 in the Firth of Clyde and along the coast of Ayrshire. Mr Alston informs me that he has been aware of the occurrence of Kittiwakes in Ayrshire in the winter time for some years. Several adult specimens in my own collection were shot near Helensburgh, in Dumbartonshire, in January and February, 1867.

Throughout the summer months the Kittiwake is the commonest species of gull to be met with at sea, especially within a mile or two of the breeding haunts; and a crowd of them fishing about sunset affords a very interesting sight, illustrating the manner in which a bird so slight and airy-looking can capture its 
prey in a rough sea. I have frequently observed multitudes of these beautiful creatures assembled over a migratory shoal of fish, and been suprised as well as delighted with the quickness of their movements. I remember one clear breezy evening in June, about nine o'clock, seeing an unruly pack of several hundreds congregated in this manner off Ailsa Craig. They had discovered a shoal on the march, and were, at the moment I observed them, in full pursuit just over the brilliant streak thrown aross the sea by the sinking sun. The strong glare upon the water was exceedingly beautiful, and the green waves showed a wonderful transparency as they stood a second or two against the sky; and as each billow, unbroken at the top, rose and rolled onwards, the gulls dashed at it with extraordinary uproar. On this narrow and burnished pathway every bird was distinctly visible; and during the time I kept watch they travelled many miles, keeping up the same excited outcry until they were out of sight.

On Ailsa Craig itself the Kittiwakes are among the first birds to arrive, and for a day or two during the time of nest-building they are seen tearing up the loose turf-the clamour of the birds while at this employment being almost as bewildering as when they are pursuing their prey. Some of the nests, the foundations of which are laid with turf with the loose earth adhering to it, are placed at the upper ledges at the elevation of 500 or 600 feet; while others are quite within reach of the visitor as he passes along the rough road at the foot of the cliffs. In course of time the bottom of the nest, through rain and spray, becomes trampled into a kind of clay which looks as if the nest had originally been built of mud, and hence the inaccurate report of some observers. While incubating, these gentle birds are tame and confiding, seldom taking wing if fired at or otherwise disturbed; but should one or two be shot and fall back dead on the nest, the neighbours will then rise on wing and flit about, making pitiable lamentations, and crying all the while Kittawee, Kittawee! Ah, get away, get away! I hope that no true ornithologist or sportsman will find fault with me for saying that to practise this kind of shooting is a shame. On the southern coast of Ayrshire, which, between Girvan and the entrance to Loch Ryan, presents a series of bold rocky headlands, there are many sheltered nooks caused by the wearing down of the softer rocks, and in these coves I have seen great numbers of Kittiwakes dozing on the grey barnacle-covered stones laid bare 
at low tide. I once looked down from a considerable height upon a quiet congregation of this kind resting themselves in the middle of the day at a part of the cliffs which is but seldom visited. There were several hundreds altogether, and after watching them for some time I broke off a few bits of rock and threw them down into the centre of the flock. They, however, paid no attention to the warning missiles until I increased their volume by hurling down two small boulders, which made a grand leap from a projecting rock and dashed with a tremendous plunge into the sea close to a stone on which about fifty birds were sitting. They then all rose at once, and after pursuing a soft flight for about one hundred yards, alighted on the water.

In some of the older works on the Natural History of Scotland, I find the Kittiwake spoken of as a favourite article of food. Sir Robert Sibbald, in noticing its edible qualities, states that the "Kittiweak is as good meat as a partridge;" but as this opinion has now been before the world rather more than 150 years without prejudice to the species, it may reasonably be inferred that Sir Robert was not a gourmand. Yet even in later times its value in this respect has been acknowledged by the writers of the statistical accounts of the coast parishes, from which it would appear that it was largely made use of as an article of food about the close of last century, especially, among fishermen and others living in the neighbourhood of its summer haunts. When visiting the Bullers of Buchan, in Aberdeenshire, in 1771, Pennant-evidently referring to Dunbuy - took notice of a great insulated rock covered with multitudes of Kittiwakes - a sight which induced him to make some inquiries about the bird. "The young are a favourite dish," he writes, "in North Britain, being served up a little before dinner as a whet for the appetite; but from the rank smell and taste, seemed as if they were more likely to have the contrary effect. I was told of an honest gentleman who was set down for the first time to this kind of whet, as he supposed; and after demolishing half-a-dozen with much impatience, declared that he had eaten sax and did not find himself a bit more hungry than before he began!" 


\section{IVORY GULL.}

\section{LARUS EBURNEUS.}

OF occasional and uncertain occurrence only. Since the first recorded British example of this beautiful sea gull was procured in Shetland, in 1822, by Mr. Edmonston, various specimens have occurred in Scotland, three of which were shot in Orkney. One of these was killed in 1848; but from that time to the present year I find no other trace of its occurrence in these islands, with the exception of a specimen killed at Melsetter, in May, 1867, making the fourth Orkney specimen, as I am informed by Mr J. H. Dunn. Sir William Jardine has informed me that he has an Ivory Gull in his collection which was shot at Thrumster, in Caithness, in November, 1854. The species had previously been taken in that county-a local specimen having come into the possession of Mr Sinclair, of Wick, upwards of twenty years ago. Mr Thomas Edward also includes this species in his list of Banffshire birds-one having been shot at Gardenstown in December, 1860.

On the West of Scotland where, according to Mr Selby, a specimen in immature plumage was obtained in the Firth of Clyde, the Ivory Gull has come under my observation on various occasions. A fine adult bird was shot near Greenock in the winter of 1858; another on the shores of Arran in September, 1866, by Mr Dunlop, of Glasgow; and a third-a very perfect specimen, which I had an opportunity of examining-was killed near Campbeltown in February, 1867. About the same time one was killed in Islay (where it had previously occurred on one or two occasions), and another came on shore at Ardchattan, Loch Etive, in a state of exhaustion, and is now in the possession of $\mathrm{Mr}$ M'Calman there. The species has also been observed on the upper shores of Loch Fyne-the late Mr James Hamilton having informed me that he procured one near Minard, and saw others in 1863.

In addition to these instances of the Ivory Gull's appearance on our coasts, I may state that Mr Sinclair saw what he believed to be a bird of this species on Ailsa Craig in June, 1854. He was attracted by the pure white figure as it sat on a rock, jutting from the water at the base of the cliffs. This was about 
sunrise-my friend being at the time a resident on the island for the express object of taking notes on its ornithology - and the sea was unusually quiet. The bird was surrounded by kittiwakes, lesser black-backed and common gulls, and presented a marked contrast to the rest of the group. Mr Sinclair allowed his boat to drift within twenty-five yards of its perch, and he, as well as the two cragsmen who were with him, had an excellent opportunity of seeing the stranger. I have since learned that pure white gulls have oftener than once been noticed of late years in the same place.

Unlike its congener the kittiwake, which preys upon living fishes, the Ivory Gull, in its native haunts, feeds upon whale blubber and other garbage, generally associated with the fulmar petrel-the entertainment and the company but ill harmonising with the spotless plumage of the bird.

OBs.-A specimen of a variety of this gull, which is known as the SHORT-LEGGED Ivory GULL (Pagophila brachytarsus (Holböll), was shot at Thrumster, near Wick, by Mr R. Shearer, and sent to Sir William Jardine, who thus alludes to the bird in a paper read by him before the Royal Physical Society of Edinburgh, 26th January, 1859, and published in vol. ii. of the Proceedings, page 57:- "In regard to the northern gulls, it was remarked that there were two birds supposed to be confounded under the common name of Larus eburneus or Ivory Gull, and it is uncertain to which of these the few specimens recorded as killed in Great Britain belong. These gulls are very closely allied, and yet require careful comparison. The one is Pagophila eburnea (Phipps), (Voyages to North Pole, 1773); the other Pagophila brachytarsus (Holböll), (in Bruch's paper, Cab. Journ. fur Ornith., 1855, p. 287). The latter is distinguished by its smaller size, greater comparative length of wing, short tarsi, and darker bill, tipped with bronze. My principal reason for alluding to these is that a beautiful specimen of the latter form was shot a few years since in Caithness by Mr Shearer, and is now in my possession (vide Proceedings Royal Physical Soc., vol. i., p. 4). At the time I considered it as the old $P$. eburnea, but I find it now belonging to the long-winged form, and as such the first recorded in this country."

I find from my note-books that I had several times noticed a disparity of size in British-killed examples of the Ivory Gull, and it is possible that this longer-winged and shorter-legged bird has 
occurred in Scotland oftener than once. Ornithologists would do well, therefore, to write down a full description, and accurate measurements, of all such gulls while in a fresh state which may come under their observation in future.

This variety, which was first described by Bruch (see Cab. Journ., 1855, p. 287) is stated by that writer to resemble $P$. eburnea in all its parts, but to be somewhat smaller, besides having the wings longer and reaching two times beyond the tail. Bonaparte, on the other hand, as pointed out in Professor Baird's work on the Birds of North America, "makes it identical with $L$. niveus of Brehm, to which he gives precedence, and describes it as similar to $P$. eburnea, but whiter and handsomer; as being larger than that species, and having a shorter bill, which is yellow, with the point orange."*

\section{THE COMMON,GULL.}

\section{LARUS CANUS.}

THE breeding places of the Common Gull are similar to those selected by the lesser black-backed gull: they are found alike on the grassy summits of precipitous rocks in or near the sea, and on moorland lochs at some distance inland, sometimes even on the highest mountain ranges. Mr Sinclair has seen a large colony on Ben Eadden, about 1800 feet above the level of the sea, and its nurseries are often found on desolate moors, especially in the central islands of the Outer Hebrides, where there are no suitable cliffs to occupy. The islets in the Sound of Harris are also frequented during the breeding season by this bird; and on Islay and Mull it often resorts to islets in fresh water lakes for nesting purposes. The same remark applies to the species in many parts of Sutherlandshire and Argyleshire.

In some of the midland counties this species is frequently observed in great numbers crossing the country from east to west, and often flying at a considerable height in the air; but they have never, so far as I am aware, been seen going in a contrary direction. Occasionally large flocks travel inland in stormy weather

* Sir William Jardine writes (of date 18th December, 1869) that he has again looked at the bird in his collection, and that he certainly thinks it distinct from L. niveus. 
and alight in ploughed fields, where they appear to content themselves for a time with what they can pick up in the way of subsistence. I have seen many hundreds at a time resting themselves during a snow storm, and dozing on one leg for nearly a whole day, huddled together in a mass, and looking very subdued. On being put to flight on such occasions, they would merely flap lazily in circles above the intruder, and return to their roosting quarters, drawing closely together as before where the snow had been trampled down on their first assemblage.

In the beginning of November, 1868, I observed about 150 of these gulls late in the afternoon rising from the land and flying seawards across the links of Dunbar. The birds were quite near enough to be recognised, and I distinctly saw that the feet of some of them were covered with clay, which had adhered to them when on the ploughed fields, and apparently baffled all their efforts to remove. As they flew over my head, I could see them vainly trying to shake the dust off their feet; and as they directed their flight seawards, I could not help thinking they might visit some earth-covered rock, and there leave any grain or seeds, which happened to be in the clay, to take root and grow for the future edification or wonderment of some wandering botanist.

\section{THE ICELAND GULL.}

\section{LARUS ICELA NDICUS.}

THE Iceland Gull, or lesser white-winged gull of Yarrell, may be distinguished from all the other British gulls by the absence of the black tips to the wings at any age. This feature, no doubt, also belongs to the glaucous gull, but the dissimilarity in size between the two birds prevents them being confounded. The only species closely resembling it at first sight is the herring gull, from which, however, it can always be distinguished by the quill feathers being all white. One of the English names, therefore, given to the species by Mr Yarrell, while serving to recognise it from the herring gull, at the same time distinguishes it from the glaucous, which may be called the greater white-winged gull-a nomenclature which has been found useful in describing the two gulls with a "black back" since Pennant first noticed the difference in their size. 
Although the Iceland Gull is by no means a common bird on our Scottish coasts, it has been frequently met with on both the eastern and western shores. From Shetland to Berwickshire immature birds are seen or killed almost every winter, and the same may be said of its appearance from the coast of Skye to the south of Ayrshire. The late Mr Thomson mentions in his 'Birds of Ireland' that he had procured two specimens from Ballantrae on the borders of Wigtownshire, where they are seen every winter, and that his friend Mr Sinclair had also seen six or eight of these birds in the island of Arran. The species, indeed, appears to be a regular visitor to the Clyde and the shores of Ayrshire, as I have observed it for years in succession near Girvan. The keeper on Ailsa Craig has seen three or four at a time frequenting that rock; they were of indolent habits, in the day time especially, but late in the afternoon they set out seawards, returning to their quarters unseen after dusk. This was at a time before all the other seafowl had congregated; consequently the keeper was attracted to them as strangers, and as having no black tips to their wings. Frequently at the gloaming I have seen what I have believed to be a pair of these birds hovering over the water of Girvan about a mile from the sea, and dipping their bills into the river as if picking up small fry.

Mr Elwes informs me that the Iceland Gull is a rare winter visitor in Islay, but I have not heard of its occurrence at any time on the outer islands.

\section{THE LESSER BLACK-BACKED GULL.}

\section{LARUS FUSCUS.}

\section{Faolig-bhig.}

IN inland situations particularly, this beautiful sea-gull is, next to the black-headed gull, the best known species. During the autumn months it betakes itself at nightfall, especially in broken weather, to grass parks at some distance from the coast, remaining in companies numbering sometimes as many as a hundred birds till daybreak, when they wing their flight back to the sea shore. About the same season of the year it follows the course of large rivers, and travels twenty or even thirty miles inland in small flocks, picking 
up morsels of food which it finds floating on the stream. I have seen numbers of these splendid birds every year on the Clyde in the heart of the city of Glasgow, circling in their beautiful flight above the river between the bridges, and also in the most bustling part of the harbour crowded with ships and steam vessels. Undisturbed by the noise and busy tumult surrounding their haunts, these gulls soared gracefully over the shipping, descending at times to the water as they found a clear space, and tapping the surface with their feet for an instant, as if afraid to touch the polluted river. After picking up any bit of floating garbage which had attracted their attention, they rose at once to the same height, performing their evolutions as before.

The Lesser Black-backed Gull of the west coast inhabits all the breeding places frequented by the great black-backed gull and the next species, but it is likewise found in equal, if not greater, numbers in fresh water lakes occupying low-lying and heath-clad islets, where it frequently associates with terns and tarrocks, although the nests are all by themselves on rougher ground than that selected by the birds of lesser size. On Inchmoin in Loch Lomond I have studied their habits for many years in succession, and have repeatedly visited their nests during the breeding season. The nests there are almost invariably placed in thick bushes of heather, although an occasional one is found in a tuft of rushes or coarse herbage; the structure is somewhat bulky and is formed of grass and mosses; and the eggs, three in number, are very variable both in form and colouring.

In the Outer Hebrides this gull is very common, and breeds on many of the islands there. In autumn there is a considerable accession to its numbers by arrivals from St. Kilda and other outlying stations. It also abounds on some of the inner group of islands, and on Ailsa Craig, where it makes itself obnoxious to the other birds by destroying immense quantities of their eggs. I have picked up great numbers of guillemots' and razor bills' eggs at the foot of the cliffs, with holes pierced in the side and wholly emptied of their contents. Some of these were so little injured as to serve for tolerably fair cabinet specimens when laid with the hole downwards. 


\section{THE HERRING GULL.}

LARUS ARGENTATUS.

From Ailsa Craig northwards to the Shiant isles and the cliffs of Cape Wrath, the silvery gull, as this species has been called, has numerous breeding places. For the most part it prefers nesting on the turf near the summit of its sea-beaten haunts, and is therefore found at times in colonies, not mixing with, but sitting alongside groups of lesser black-backs as well as the great blackback, forming a large but harmonious family of gulls, conspicuous at a great distance when viewed from the sea, and looking like large white flowers among the grass. It is very abundant on all the shores, including those of the outward islands, where I have observed it to be very tame. Those bred at St. Kilda and Haskeir Rocks betake themselves in autumn to the western side of the islands of Harris, North Uist, Benbecula, and South Uist, and are easily approached. I have shot very interesting specimens there shewing the last remains of the immature plumage, sprinkled in brown spots over the back of the birds and the wing coverts, giving them a marbled appearance, the rest of the plumage being complete.

On the eastern shores this bird is nowhere more common in early spring than in Fifeshire. On Leven sands they assemble in companies numbering thirty or forty birds, and show so much tameness, that $I$ have at times walked up to a group at rest within twenty-five yards without causing the birds to take wing. On the shores of East Lothian, and the adjoining county of Berwick, Herring Gulls are also very numerous. A few pairs breed on the Bass Rock; but the principal station for the species in the district is that part of the Berwickshire coast between St. Abb's Head and Fast Castle, where there are numerous pointed stacks of rock standing apart from the headland, and affording the gulls a safe refuge. The nests are placed at various elevations on these isolated rocks, from the topmost peak to within a few feet of high-water mark, so that should a storm arise during the breeding season, the nests are occasionally in danger of being swept away.

When driving one day along the shore between Stranraer and the Mull of Galloway, I observed numbers of Herring Gulls lifting mussels from the beach, and, after carrying them some distance in 
the air, letting them fall among the stones so as to break the shells and enable them to get at the contents. I had previously seen rooks at this ingenious employment, but I never before saw or heard of gulls exercising their instincts in this manner. Mr Watson, of Stranraer, informs me that he has frequently observed Herring Gulls breaking mussels in the same way. The sarne gentleman showed me a specimen which he had killed by a rifle shot at a distance of 150 yards. The ball had entered the forehead of the bird as it sat on the water, and drilled a tolerably neat hole through the cranium. Mr Watson had previously shot gulls at greater distances in different parts of the body with the same rifle.

\section{THE GREAT BLACK-BACKED GULL.}

\section{LARUS MARINUS.}

Farspach.

THIs large and powerful bird is much more common in the remote northern districts than in the southern counties. There are several breeding stations within a few hours' journey of Glasgow. Two of these are very dissimilar in their character, one being situated near the summit of Ailsa Craig, and the other on the island of Inchmoin in Loch Lomond. In the former locality the nests are on the grassy slopes of the rock, and are mere hollows formed in the turf with a very scanty lining; but in the inland nursery they are formed of materials similar to those used by the lesser black-backed gull, and are generally found among coarse grass and bushes of heath. Twelve or fourteen pairs annually take up their quarters on Loch Lomond, in the island just named, but seem to keep aloof from the other species frequenting the place, repairing in the daytime to the upland glens, where they occasionally fall in with dead sheep and other animals, on which they surfeit themselves. In the evenings they may be seen returning to the loch sailing majestically over the tree tops, or hovering a minute or two above the banks of the brawling torrent to pick up some stranded object.

In the Outer Hebrides there are breeding colonies on nearly all the islands. There are several in Lewis, which occupy small grass- 
covered islets on the fresh water lakes there, and also one or two in North Uist. Mr Harvie Brown found about twenty-five pairs nesting, with the eggs hard sat upon, on an island in a loch near Lochmaddy, on 14th May, 1870. There are likewise important stations on some of the Inner Hebrides, one of these being the island of Rum, where the birds are seen occupying isolated rocks round the coast, safe from molestation. On St. Kilda, where several hundred pairs are found breeding, they are very much disliked by the natives, in consequence of the depredations which they commit among the nests of the other birds. Mr Elwes (Ibis, 1869), while visiting the island of Dun, one of the St. Kilda group, thus speaks of their manner of thieving: "After searching for some time I looked over a cliff and saw, far below me, a broad flat ledge on which hundreds of Fulmars were sitting among the stones. I descended with a rope we had brought from the 'Harpy,' as none of those the natives had were long enough. Two of the young men followed me, coming down hand over hand at a tremendous pace. As soon as the Fulmars were disturbed from their eggs, the black-backed gulls came swooping down and carried them off in their beaks, much to the indignation of my companions who hate the 'Farspach' (as they call Larus marinus) with a deadly hatred, and practise all sorts of barbarities on them whenever they catch them, as they are terrible robbers of eggs."

In the East of Scotland this species is also very common. During the months of January and February I have seen as many as twenty of these gigantic gulls in view at one time at Dunbar, in East Lothian: they usually continued their stately flight in a south-easterly direction until they reached the first of the fish-curing stations along the coast. On being attracted to these places by a plentiful supply of offal, they gather like a flight of ravens, and I have known as many as six killed at one shot from the door of one of the smoking houses.

In various parts of Orkney and Shetland this gull, as might be expected, occurs in great numbers. The following notes relating to the last mentioned locality have been sent me by Captain Feilden, who visited these islands in 1869:- "The most interesting sight at Noss Head is a vast colony of Larus marinus that has taken possession of the Holm, a detached stack or rock with a flat surface about two acres in extent. A tremendous chasm separates 
the Holm from the island of Noss. Formerly the gulf was crossed by a cradle or box strung on two parallel ropes which conveyed the shepherd and one sheep across at a time; but the gentleman who farms the island, deeming the crossing in the cradle too hazardous both for man and beast, has taken away the entire apparatus within the last few years. Immediately on this being done, the Great Black-backed Gulls, recognising the impregnability of the Holm, collected on it in great numbers for breeding. When I visited Noss Head in the end of May, 1869, the surface of the Holm was covered with them and their nests. Many hundreds of pairs were incubating on these two acres, and it was interesting to see these usually wily birds seated on their nests, walking about or lying down within gun shot perfectly unconcerned. They seemed fully alive to the impossibility of any one molesting them since the removal of the cradle, and though I fired off my gun, they took little notice of the report."

As a proof of the extraordinary strength of this gull, I may mention that about four years ago J. H. Trotter, light-keeper at the Fern islands, shot one while on the rocks at some distance from the water, and found on examination that it had swallowed a piece of fish about four inches long, to which had been fastened two hooks and a strong line thirty-seven feet in length. At the end of the line there was a stone seven pounds in weight, which the bird had evidently drawn from the water after swallowing the bait. It was afterwards learned that the line had been set by some French fishermen whose vessel was anchored at some distance from the islands.

\section{THE GLAUCOUS GULL.}

\section{LARUS GLAUCUS.}

\section{Burgomaster.}

Throughout the western counties of Scotland this large sea-gull is in general less plentiful than on the eastern shores. It is seldom, indeed, found roaming within the circle of the inner islands, but for the most part remains in the vicinity of the Outer Hebrides. Nor is it even there a regular winter visitor in flocks - some seasons passing with only a stray bird or two to represent the migratory companies that at other times visit these islands. 
In the winter of $1862-63$, considerable numbers were seen in North Uist, frequenting chiefly the west side of the island, and the Sound of Harris. In this district-distinguished for large tracts of sand and mud at low tides-these flocks generally take up their quarters, feeding on stranded fish, and other garbage left by the sea. They seldom or never go inland, but when rough northern storms are blowing the masses of foam over the sands, their usual restingplace, they get on wing and travel along the shore, visiting the sands of Benbecula and South Uist, and returning to their headquarters when the weather moderates.

The Glaucous Gull is perhaps more numerous in the Shetland islands than elsewhere in Scotland. In some seasons, indeed, it may be said to be abundant there, appearing in very large flocks. Dr Saxby states that shortly after their arrival the greater number of the old birds entirely disappear. The species likewise occurs in Orkney; and southwards of these two groups of islands old birds are generally met with, although I have at various times seen and shot young birds on the Haddingtonshire coast. It is not uncommon as a winter visitant to the Cromarty Firth, and from that locality to the coast of Northumberland it cannot be said to be very rare.

Regarding its occurrence in Aberdeenshire, Mr Angus writes:"I have never been out in the bay in winter without seeing this bird, which is a very conspicuous object, being more oceanic in its habits than any of its congeners. Along the coast its advent is heralded by the screaming of the other gulls whom it torments and tyrannizes over like the skuas. Even the great black-backed gull must give place to the Burgomaster. In the stomach of one I obtained an immature puffin in a mutilated state but perfectly recognisable, the tail and wings being almost entire. Another, on being wounded, disgorged a large pellet, composed principally of feathers and bones."

From the same county Mr Alexander Mitchell has very kindly sent me two beautiful specimens of the Glaucous Gull in the flesh: one of these is a splendid male in full adult winter plumage, the other apparently a young bird of the second year. The former measures in length 32 . inches, extent of wing 5 feet 6 inches; the latter 27 inches in length, and extent of wing $61 \frac{1}{2}$ inches. Both birds were shot on the coast near Aberdeen in the last week of December, 1870 . 
I have frequently seen single birds, and sometimes a pair, on the most rocky and retired parts of the coast between Dunbar and Cove Bay, feeding on dead fish which had been cast up by the tide. On these occasions they would remain tugging at the heavy fish, and even drag it a little out of its place until put up by a near approach; before, however, getting fairly on wing they were obliged to run with a hobbling kind of motion eight or ten paces until their bodies were inflated and their wings fully expanded. Then as they rose, widening in their eircles as they ascended, their motions in the air seemed to me to be the perfection of ease and freedom.

During the breeding season their habits would appear to be much less sedate. In Captain J. Ross's 'Voyage of Discovery in the ships Isabella and Alexander,' it is said: "They build on high cliffs, and they destroy and eat the smaller aquatic birds. We did not absolutely see them attack other birds; but when our parties were out shooting the little auk, these gulls, hovering over our heads, would pounce upon the wounded birds and carry them off. A female bird that was shot disgorged a whole bird; and being brought on board, it smelled so offensively that it was immediately examined, and in its stomach was found another bird quite whole; the stomach was distended and in a state of mortification as well as the small bird." See Appendix No. 2, p. 55 .

This bird is associated in my mind with at least one vivid picture of a wild sea. On the iron-bound coasts of Berwickshire -fatal to many a gallant ship-I witnessed some years ago a terrible tempest raging, spreading destruction and death: sea and sky were mingled in one dark, drizzling mass, and all else blotted out save a foreground of rocks on which the broken waves were crashing with the noise of artillery, and from which clouds of spray were rolling landwards like wreaths of smoke from a battlefield. Against the background of sea and cloud there appeared a burgomaster gull and a small band of kinsmen-the snow white parts of their plumage appearing like specks on the pitch-like neutral tint-best understood by those who paint the "war of elements." With a free sweep the splendid birds seemed to rejoice in the tumult beneath, calling to one another in loud, hoarse shouts as, after a moment's suspense, they dashed across the gloom. From a peaceful-looking gull they had each become 
like a storm demon, hovering at times in the dark cloud, and presiding over the troubled sea, their very presence forming an essential element in the picture. Such is their life!

\section{THE COMMON SKUA.}

\section{LESTRIS CATARACTES.}

THE fact of the breeding haunts of this skua being strictly confined to the Shetland Islands, has of late years led to so much destructive intrusion by collectors that it is now only by the most careful protection that the birds are enabled to maintain a footing there. Thirty years ago there were three separate nesting localities, viz., the outlying islands of Foula and Uist, and Rona's hill on the main island. The last-named haunt is now entirely deserted, and in the two others the number of skuas which yearly resort thither for nesting purposes is comparatively small. From these haunts a few usually find their way southwards along the coasts of the eastern counties; but the bird is of rare occurrence in the west. I have not indeed seen more than three or four examples during the last twenty years: one was obtained on Loch Nell, near Oban, in the autumn of 1867 , and another was found alive in a corn-field near Aberfoyle, on the banks of the Forth, in September, 1862.

During the breeding season the Common Skua becomes quite fearless, attacking any intruder in its haunts with so much spirit as occasionally to drive both man and dogs off the ground. Its habits at other seasons can seldom be observed, as it does not often come near the shore. I have at times recognised its bulky figure some distance out at sea on the east coast; and Mr R. ScotSkirving has informed me that he shot one some years ago on the Haddingtonshire coast after it had struck down a herring gull, and while it was in the act of worrying it like a dog.

Interesting details regarding its nesting habits have been published by Captain Vetch in the fourth volume of the Wernerian Society's memoirs, and also by Mr Robert Dunn, in his Ornithologist's Guide to the Orkney and Shetland Islands, but as these have already appeared in various other works it is unnecessary to repeat them here. The following account, however, from Bullock's Guide to his museum relating to the personal adventures of that 
indefatigable collector in Foula in 1812, has not, so far as I am aware, been copied into any subsequent publication:- " The principal breeding place in Great Britain of the larger brown species, called the Skua Gull, is on the top of a mountain in the secluded isle of Foula, distant about eighteen leagues from the Orkneys. We visited this romantic spot early in the month of July, and received a hearty welcome from the poor but hospitable inhabitants, to whom the sight of a stranger is an unusual occurrence. On learning the object of our visit, the person who acts as schoolmaster and minister, for they have no resident clergyman, offered to attend us to the top of the hill where the Bonxies (the Shetland name of the Skua) were then hatching their young. We had scarcely arrived at the place before we were attacked in the most furious manner by these enraged and formidable birds, who flew with the utmost violence in the direction of our eyes, and were not at all intimidated by the report of our guns, or the numbers that we killed. A large dog that we took with us was so roughly treated that it was obliged to come to us for assistance, and my son received a violent blow on the back of his head whilst stooping to secure a bird he had wounded. They lay their eggs, four in number, of a dull olive colour with large dusky spots, on the ground, among the short heath and grass, and it was with difficulty we could find them; the young were covered with a fine cinnamoncöloured down, exceedingly soft and beautiful. We brought some of them alive to England; they were very tame and affectionate, but were much longer in getting their first feathers than the young of any of the other gulls. Their voice was very remarkable, strongly resembling the horns used by the guards of the mail coaches."

\section{THE POMERINE SKUA.}

\section{LESTRIS POMARINUS.}

THIS is another of the numerous birds of Scotland which are met with more frequently on the eastern than on the western shores. In the Firth of Forth it has been frequently seen in autumn and spring chasing the smaller gulls. I have often observed it off Dunbar at this piratical work, and when two of them unite in pestering a flock of these birds, it is amazing to see the pertinacity 
with which they keep up the attack, following the distressed gulls through their many turnings in the air, and buffeting them all the while into a state of the greatest terror. When storms are frequent, however, they seem unable to meet the blast with the same ease as the gulls, and consequently they try to cross the country to the other side-that is, from east to west-in quest of both shelter and objects of attack. A very fine specimen, now before me, was caught in a disabled state on the public road near Larkhall, in Lanarkshire, one stormy evening a few winters ago, by a female hawker, who put it into her basket, thinking it was a curious duck that had strayed from a neighbouring farm. Joyful in the prospect of a dinner on the morrow, she declined parting with the windfall to an inquiring bird collector, who had a better knowledge of its character, and unwisely took the bird home. Speedily, however, the "duck" dispelled the woman's belief in its anatine descent by inflicting one or two severe bites which, as she pathetically remarked, "werena' like the bite o' a braid neb at a';" so it was reserved for a better fate, as in all likelihood the aroma given off in the process of cooking a skua would have entailed its total loss. While looking at it, I am reminded of an incident lately communicated to me by a medical friend in Glasgow who presented an old woman in the Highlands with the body of a sea eagle he had just flayed as a veritable turkey. Sometime afterwards the doctor, happening to meet the recipient, expressed a hope that the "fowl" had been acceptable. "Ou, aye," said the old lady, "it was a gude turkey, but oh it was teuch!"

This species of skua does not entirely depend upon its piratical exertions for subsistence, but contents itself occasionally with a diet of putrid fish or small dead animals which it happens to meet with in its flights along the shore. It has even been known to devour rats and birds.

Mr Graham has sent me word that his friend Mr Colin M'Vean, who has a very accurate knowledge of British birds, has found this skua breeding in the Outer Hebrides. I have not myself seen it there, nor have I ever obtained a specimen from any part of the Long island. It has occurred in the Firth of Clyde and on the Ayrshire coast; in Wigtownshire, Kirkcudbright, and Dumfriesshires, but only, so far as I am aware, in the winter season. 


\section{RICHARDSON'S SKUA.}

\section{LESTRIS RICHARDSONII.}

Fàsgadair.

THIs is perhaps the most common species of pirate-bird throughout Scotland. Its breeding places, however, are mostly confined to the Outer Hebrides. The nurseries on some of the islands are frequented by forty or fifty pairs; there are several stations on South Uist; on Stuala island, Wiay, Benbecula, and North Uist. There are also one or two breeding places in Lewis. These haunts are generally the most uninviting spots in appearance, being dark peat bogs, with patches of heather growing where the ground is firm. The nest is similar to that of the black-headed gull, and the structure is placed often on a tuft of heath to keep it dry in case of inundation, which frequently happens in very wet seasons, though the nature of the ground at any time makes it somewhat difficult to take the eggs without wading. There is the same variety in the eggs (which are two in number) as in those of the gull referred to-many of the nests containing a dark and a lightcoloured one.

These birds are very courageous in defending their eggs and young, and will strike an intruder pretty smartly if care is not taken to ward off the blow. Dogs meet with even a worse reception, and frequently beat a retreat rather than face the angry bird. Their cry at these times is harsh and grating, not unlike that of a peregrine falcon. The following remarks, extracted from a paper on the island of Foula - the most western of the Shetland groupby Captain Vetch of the Royal Engineers, show the force of the bird's attack:- "In approaching the nest of the Arctic gull, an attack still more fierce than that of the skua commences. The intruder receives constant flaps with the wings of the bird. Judging from the rapidity of the dart, and their just grazing the head of the person, I imagined if any hard substance was suddenly elevated above the head a few inches at the moment previous to the graze, the animal would probably terminate its existence against it. I accordingly elevated the muzzle of a fowling-piece a few inches above my head, and after a few trials, in which the bird showed a most extraordinary power of altering its course when almost touching the gun, the experiment ended by its death; and 
so great was the force with which it struck the gun that its brains were forced out and the death was instantaneous; and I have no doubt that an adroit person might kill numbers in this way."

In the islands I have mentioned the skuas are very destructive to the nests of other birds, especially the black-throated and redthroated divers, the eggs of which they break and carry off. With such fare, and the remains of fish which are disgorged by the terns, kittiwakes, and other gulls, against whom it wages a constant warfare, it manages to pass the few weeks of incubation pleasantly enough. But after quitting its breeding haunts, when there are no nests to plunder, it follows its piratical pursuits entirely at sea or along the shore, dashing with great ease and power into the midst of a flock of terns or gentle kittiwakes, and attacking one after another until its hunger is satisfied. In speed of flight its victims are no match for it; and the dexterity with which it picks up the falling plunder dropped by the buffeted gull reminds one of a hawk or falcon more than the action of a sea-bird.

In coloration of plumage this species seems to vary very much even from the downy state to maturity. I have seen very handsome specimens with all the lower parts, from the chin to the under tail coverts, of a clear yellowish-white, giving the bird at first sight a strong resemblance to the next species; others again, apparently about the same age, are almost wholly dark, with but faint traces of light grey on the neck and throat, in which state they are often found breeding with what may be termed adult birds. The full adult plumage, as in the case of many of the seagulls, is not acquired for some time; and as the species is often found nesting in its second year, it would appear that no definite description of the breeding plumage can be given. On referring to Captain Vetch's account, from which I have already quoted, I find he says that "the old birds are generally of a blackish colour all over, with the exception of the belly, which is of a rusty or tarnished appearance. Considerable numbers, however, appear with white bellies, and a few variously speckled on the breast, forming a gradation between those with black and those with white bellies. These varieties of colour, I imagine, are the effect of different ages, having observed pairs belonging to the same nest associated in every possible mode of combining the colours, as two whites, two blacks, a white and black, a white and speckled, and a blackspeckled, and two speckled." 
I may mention that an unusually dark specimen in the precise plumage figured by Swainson in the 'Fauna Boreali-Americana,' was sent to me for exhibition at a meeting of the Natural History Society of Glasgow, by William Boyd, Esq., Greenock: it had been shot in the Outer Hebrides some time previously.

Mr Harvie Brown informs me that he found a quantity of zoophytes (Actinice) in the stomach of one of these birds, which he shot in Sutherlandshire last year.

\section{BUFFON'S SKUA.}

\section{LESTRIS BUFFONII.}

ON the mainland of the West of Scotland this Skua is only a straggler; but it is probably a regular summer visitant to the outer islands. A specimen was shot in Skye, in the antumn of 1855, and exhibited at a meeting of the Royal Physical Society of Edinburgh; and in the summer of 1863 I examined a pair that were shot on the island of Wiay by Colin M'Rury, Esq., surgeon, as they hovered over a marsh where there were nests of Richardson's Skua and other birds. The likelihood is they had a nest on the spot. Wiay is a small island lying to the south-east of Benbecula, and distant from it about a quarter of a mile: it is two miles in length, and in breadth about a mile and a half. The ground is chiefly heath and peat moss, and there is a small fresh water loch on it frequented by the usual wading birds of the adjoining islands. At the south-east end there is a range of high and nearly perpendicular rocky cliffs, the principal elevation of which is called the Eagle's Crag, and is about 300 feet in height. On this cliff a sea eagle had a nest for many years, but is supposed to have deserted the place in 1849. The snowy owl has also been observed frequenting the island. This remote spot has only one house upon it, inhabited by a shepherd and his family: the island supports about a hundred cattle besides a few sheep; and it is a likely. place, from its unfrequented aspect, to attract such birds as may have been disturbed, or driven from other places. About the centre of the island the ground rises to some height, forming a hill, conspicuous at a considerable distance. Here, as elsewhere in the Hebrides, there are no trees, the entire surface being covered with grass and heather. 
Buffon's Skua has been found breeding in Oaithness-shire, though not for some years past; and also in Shetland, as I have been informed by Mr Dunn, who procured the eggs from one of three nests in the island of Hoy, fifteen years ago.

In the autumn season stray birds are found flying along the coasts, but not in any numbers. Two specimens were seen in the autumn of 1866, on the river Kirtle, Dumfriesshire; one of them was shot, and exhibited by Dr J. A. Smith, at a meeting of the Royal Physical Society, Edinburgh. Another specimen of this skua, which I had an opportunity of seeing, was shot on the Cree, near Newton-Stewart, in 1863. According to a note in MS. by Messrs Baikie and Heddle, a single specimen of Buffon's Skua was shot in Sanday in 1849 .

\section{THE FULMAR PETREL.}

\section{PROCELLARIA GLACIALIS.}

Am Fulmaire.

The head-quarters of the Fulmar are St. Kilda, Borrera, and Soa, from which group of rocks it is but a straggler in the summer season to the Outer Hebrides. It formerly bred in the south isles of Barra, but has now entirely abandoned that locality, none having been seen there in the breeding season since 1844. I was lately informed, however, by Captain Cameron of Glenbrittle, that he has had the eggs of this species obtained in Skye, where it breeds in at least one locality—a "stack" off the farm of Tallisker, halfway between Stack na Maidaidh and Breshal Beg. The nests are in holes in a very steep grassy slope, extremely difficult of access. The country people say there are many more breeding places of this bird in Skye.

The Fulmar would almost appear to have at one time bred in the island of Mull. Pennant, in his account of the species, copies the following paragraph from one of the newspapers of the day. - the General Advertiser for June, 1761:- "Isle of Mull.-A gentleman of the name of Campbell, being fowling among the rocks, and having mounted a ladder to take some birds out of their holes, was so surprized by one of this species spurting a quantity of oyl in his face that he quitted his hold, fell down and perished." 
On three or four different occasions this bird has been met with in Iona, and Dr Dewar has a specimen in his collection which he captured in summer off the coast of Skye: it is also found occassionally on the west side of the Long island, but it is worthy of remark that in nearly every case these stragglers from the distant rocks referred to are in an emaciated state.

On the eastern shores of Scotland the Fulmar ranks only as a straggling winter visitant. In East Lothian it is occasionally found in December and January. I have seen specimens that were cast up dead on the beach near Dunbar. Northwards, stray examples have been recorded from Caithness-shire, and nearly all the intervening counties. These individuals probably come from breeding haunts situated to the north-east of Scotland, although I cannot find any mention of such having yet been discovered.

Writing from Shetland, Dr Saxby states that he has never seen the Fulmar in a living state. "When in want of specimens," he continues, "I send a gun out with the fishermen when they go to the 'haaf.' The birds seem to be met with in great abundance about thirty miles north of Uist, but it is singular that none appear before the men begin to throw the offal overboard." In Messrs Baikie and Heddle's MS. notes inserted in a copy of their work, it is stated that one specimen was obtained at Scalpa in 1849 .

The late Mr John Macgillivray, who visited St. Kilda in June, 1840, and afterwards published an account of his visit in the 'Edinburgh New Philosophical Journal,' has remarked that the eggs of the Fulmar are much esteemed by the natives, who gratify their partiality by robbing all the nests in the month of May, and apparently trust to the bird laying a second time.

The following account from another source, judging from the dates given, obviously refers to a second raid on its haunts, more exciting in the details than mere egg taking:- "The young Fulmer is valued by the natives more than all the other tribes of birds taken together: it may be said to be their staff of life; they therefore never meddle with the egg. The 12th day of August, if a notable day in the moors, is more so in the rocks of St. Kilda: a day or two before every rope is tested, every oil-dish cleaned, every barrel emptied. Some of these ropes are older than their owners, and are chiefly made of thongs from cow-hide, salted, and twisted into a cable. The 12 th arrives, the rope is made fast 
round the waists of the heavier party, whilst the other and lighter party are let down the perpendicular rock several hundred feet. Here the work of destruction goes on night and day for a given space; the St. Kilda man has nothing to do but take the young Fulmer, wring his neck, and then suspend him by a girth which he wears round his loins; his neighbour looks on with unconcern, and allows the same experiment upon his neck. When the person of the man is overloaded he forms a parcel, which he lays to a side, and resumes. This is the harvest of the people of St. Kilda. They are aware it is to last only eight days, and therefore sleep itself is banished for this space, seeing that the millions that may be left to see the eighth day after the 12th, are sure to be off to their own fairy world for a season. The number killed in this one week may be from eighteen to twenty thousand. They are from two to three pounds weight; about two hundred will go to fill a herring-barrel; yet each family, after serving the poor, shall have from four to five barrels salted for winter use." *

At page 11 of the same curious work the difficulties encountered by the more adventurous of the Hirta climbers while attacking the Fulmar in its strongest fortress are thus alluded to: "The staca-biorrach, or pointed, or pyramidical rock, lying betwixt So'a and St. Kilda, is the test of a St. Kilda hero. As for fighting or striking, not a single instance of the kind has occurred for eight years. On the summit of this rock, which is flattish, the Fulmer reigns secure. The rope here is of little avail. The people, however, climb it occasionally, as sweeps do St. Paul's in London, by way of a feat. The man who cannot perform it, never gets a wife in St. Kilda. It is from 400 to 500 feet high. There were just two individuals up since $\mathrm{Mr} \mathrm{M} \cdot$ Kenzie (the resident clergyman) went to the island eight years ago. They did it to shew their dexterity to an Englishman, and for a quid of tobacco (?). Mr M'Kenzie, who was present, says that the attempt was fearful. When they got up, however, they committed tremendous havoc among the secure Fulmer, etc.; these they tied in immense bundles which they flung down into the sea: the parcels rebounded several fathoms, as if threatening to regain the summit, creating at the same time a cloud of blood which, when it fell, crimsoned the sea as if the 'second angel' had sounded."-A very alarming

* Sketches of St. Kilda, and journal of excursion thither. By L. MacLean, author of Adam and Eve, etc. Glasgow: 1838. 
account, certainly. The author of the book, it may be mentioned, had previously published a work in which he endeavours to prove that our first parents, Adam and Eve, spoke Gaelic: he does not, however, hazard even a conjecture as to the language spoken by the serpent of that period.

The oil which this bird yields by vomiting when caught is highly valued by the natives of St. Kilda as a cure for all diseases. Its virtues, indeed, have been extolled by all the older writers from Martin downwards; but no one, so far as I am aware, has ever given the slightest information as to its chemical properties. I have therefore much pleasure in inserting here, with other details on the subject, the following note which has been obligingly furnished me by Mr Edward C. C. Stanford, F.C.S.:-

"The method of catching these birds is peculiar to St. Kilda; the men may well call themselves bird-catchers, for assuredly there are none like them. The process seems simple enough, but the awful danger must be seen to be appreciated; indeed, the climbing propensities of these men would astonish any member of the Alpine Club.

"Hanging on a rope (often made of heather) the bird-catcher descends the fearful precipices, armed with a sort of fishing-rod, having a slip noose at the end. This he dexterously throws over the head of the bird, which is sitting on a ledge of the rock beneath him, and hauls him up. He then dips the bird's beak into a small leather bag suspended to his waist, and there the oil is vomited. The bird is then killed and eaten as food, the feathers and the oil forming the two articles of export. Beds made of the feathers are said never to harbour insects, but it is alleged also that they are difficult to keep dry.

"The oil is a good deal mixed with a rougher sort from solan geese, and realises a poor price as an ordinary rough fish-oil. When genuine, it is of a clear, dark, slightly reddish sherry-colour, and has a powerful and peculiar odour-an odour of which the whole island and all the inhabitants smell. It is certainly a fishoil, and it possesses nearly all the properties of cod-liver oil.

"Its specific gravity is midway between cod-liver and sperm.

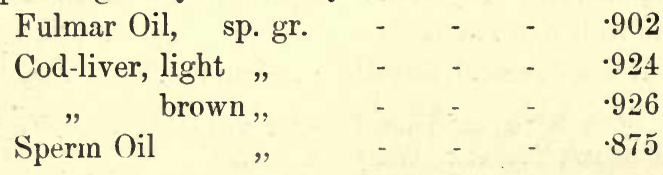


It is soluble in ether. Cold alcohol dissolves less than 1 per cent. and hot alcohol 3 per cent.

"Treated with a drop of oil of vitriol, it produces precisely the same coloured re-actions as cod-liver oil, which, if the generallyreceived views be correct, would show it to be a liver-oil.

"It contains a very faint trace of iodine.

"Heated with oil of vitriol and excess of potash, it gives off a strong odour of oil of rue.

"Saponified with soda, the soap retains the peculiar odour, and yields a tolerably fluid fatty acid on acidifying the solution.

"I shall be glad if this short notice of Fulmar oil will induce any one to experiment with it for medicinal purposes. I have no doubt a good deal might be obtained, and a good market would be a boon to that isolated people."

\section{THE MANX SHEARWATER.}

\section{PUFFINUS ANGLORUM.}

Scraib.

There are numerous breeding haunts of this Shearwater throughout the West of Scotland, and the bird itself may be called abundant within the circle of the Inner Hebrides. Westward of that group, the only breeding localities with which I am acquainted are Pabbay - one of the isles of Barra, and St. Kilda. Some years ago, the lighthouse keeper at Barra Head informed me that the shearwaters had entirely deserted the island of Bernera, on which the lighthouse is built, none having been seen nesting there since 1843; and Mr Elwes (Ibis, 1869) has the following remarks bearing on the same locality:- " This bird was formerly very common, and the young ones, which were called "Fachach," were so highly esteemed that a barrel of them formed part of the rent paid by each crofter in Mingalay, to the Macneills of Barra. About a hundred years ago, however, the puffins, which before were not numerous, began to increase very much, and drove the shearwaters from the holes which they occupied in the cliffs; and now they have completely supplanted them, so that only a few pairs of shearwaters are left in the island of Pabbay, which is next to Mingalay. The Shearwater seems to be on the 
decrease in most of its other breeding places, though I never heard any reason assigned for the circumstance." In the same paper, Mr Elwes remarks that on Soay, one of the St. Kilda group, where it was formerly very common, the Shearwater is now by no means plentiful-a change probably arising in this case also from the increase of the puffin. One of the most extensive breeding places frequented by this species at present is on the island of Rum: this nursery-haunt is situated on the face of a hill among broken boulders, and is about a mile distant from the sea. In early times the breeding place was on the coast, and the birds were then collected at the close of the season, as at Barra, and salted for winter use. There is another nesting haunt on the island of Eigg, and the Treshinish isles, Staffa, Iona, and various rocky islets of limited extent are also frequented during the breeding season. The shearwaters appear in April, sometimes as early as the 10th of the month, and continue until October, when flocks are sometimes seen off the north coast of Islay. I have seen small numbers pursuing their swallow-like flight near the entrance to Lochmaddy, in the Outer Hebrides, and have also noticed them at mid-day in the Firth of Clyde. On 25th June, 1868, I saw three or four specimens when midway between Ardrossan and the island of Arran. Mr Graham informs me that the species is common in Iona and Mull, and that on the 12th of May, during very calm weather, as he was sailing to Staffa with a party in a boat, he saw a number of very large flocks of shearwaters swimming upon the water. They were very tame, and he procured a considerable number.

While cruising among the western islands I have often been arrested by the elegant flight of this petrel as it suddenly rose above the waves. About day-break the numbers are greatest, especially during a fresh breeze, but on undeniably stormy days, I have seen them in extensive flocks, even at mid-day. Towards sunset, should a look-out be kept in the neighbourhood of their breeding places, the observer will be surprised at the numbers which issue from these haunts and fly seawards. I recollect one evening as we lay becalmed near the island of Coll, seeing many hundreds mysteriously flitting past the vessel, and disappearing in the darkness before we could well make out their forms. On this occasion I counted upwards of forty flocks, each numbering from twenty to thirty shearwaters-all of which came from the 
rocky slopes of the island, and passed eastwards in the direction of Ardnamurchan. In the early dawn I have also seen large numbers hovering like swallows over a turbulent sea off that headland, and have invariably regarded their flight with feelings of admiration. There is something truly elegant in their aerial movements as they soar a moment or two above a huge wave, and then sweep down into the hollow, rising with the curling mass of water until it breaks, when they dart high into the air with a rocket-like flight; and no one who has really watched them with pleasure will, I think, deny that this is one of the most interesting sights a yachting naturalist can enjoy.

Obs.-I find the Cinereous Shearwater (Puffinus cinereus) recorded by Messrs Baikie and Heddle, in a manuscript note, as having occurred in Shetland; and the species also catalogued by the late Mr Sinclair of Wick, as a rare visitant to the county of Caithness.

\section{THE FORK-TAILED PETREL.}

\section{THALASSIDROMA LEACHII.}

Gobhlan-goidhe (Barra).

THIS species, which was originally discovered about fifty years ago on the island of St. Kilda by Mr Bullock, has since been found breeding there in a colony which has established itself on Dunan isolated stack-under the loose rocks near the summit, and is also known to frequent the island of Mingalay in Barra, where a few pairs incubate every year in company with the next species. The eggs in the last-mentioned locality are, according to Mr Elwes, found principally in holes and cracks in the dry peat on the top of the cliffs. There is a more extensive breeding place in the island of Rum situated on rough stony ground at the north-west side at a place called Braedinach. Having repeatedly obtained specimens within the parish of the "small isles," I some years ago instituted inquiries which resulted in the discovery of this additional nursery. Though a strictly western species in Scotland, it appears to be gradually extending its habitats, and is likely to spread in the direction of the mainland as the Hebridean haunts become overpopulated. I look upon it, indeed, as equal in numbers to the storm petrel. 
The following remarks from Mr Elwes' paper on the bird stations of the Outer Hebrides (Ibis, 1869) gives the latest intelligence regarding the St. Kilda breeding place of this bird:- " Some of the man-of-war's men had been collecting eggs on shore; and this excited the indignation of the older men, who considered it in the light of stealing their property. After we had pacified them with some small presents of tobacco and sugar, I showed them the pictures in my 'Yarrell,' among others pointing out the Fork-tailed Petrel. This, however, they did not seem to distinguish, by any peculiar name, from the storm petrel which is common enough and is here called 'Assilag.' The petrels are too small to be of any use for food, and are probably not much seen by the natives, especially as they only come out at night; but the pictures of all the other birds, which are found here, were at once recognized, and the Gaelic names given." Having landed on Dun, the same writer proceeds:- "I expected to find the petrels breeding near the top of the cliff; but none were at present visible, and I think it must have been too early in the year for eggs. There is no doubt, however, that the Fork-tailed Petrel does breed here, as I have seen eggs from St. Kilda, and Sir W. Milner procured the birds, though John Macgillivray, like myself, was disappointed in finding them."

I have obtained specimens of the Fork-tailed Petrel from Benbecula, Barra, Skye, Rum, Eigg, and Canna; also from various districts on the Firth of Clyde, and as far up as Dunoon and Roseneath. Numerous specimens occurred on the west coast in the winters of $1863,64,65,67$, and 68 . They are met with, in fact, almost every season, and chiefly in the months of November and December. I only know of two specimens that have occurred in the east of Scotland: one of these, obtained in Caithness-shire, is now in the collection of the late Mr Sinclair of Wick; the other, which is now before me, was found in an exhausted state on the Loch of Forfar in the winter of 1868.

Like the Shearwater and Storm Petrel, this bird is often during storms found in an exhausted state both on the beach and at considerable distances inland. On such occasions it seems unable to withstand the force of the blasts which frequently occur in the vicinity of our western mountain ranges. 


\section{THE STORM PETREL.}

\section{THALASSIDROMA PELAGICA.}

\section{Asilag. Lucha fairge.}

THIS very interesting little bird is a common species in the Hebrides, and its breeding places may be said to be numerous around most of the larger islands, such as Skye, Mull, and Islay. Colonies have long existed near Dunvegan, on the Ascrib islands, Canna, Rum, and Eigg, besides numerous other rocks and islands off the mainland from Cape Wrath to Ardnamurchan, and from that to the Mull of Cantyre. The most southernly breeding station in the West of Scotland is perhaps Ailsa Craig, where an old bird was caught, and a single egg obtained, by the tacksman in the breeding season of 1842 ; but though I have repeatedly visited the rock within the last twenty years, and seen the birds on several occasions, I found it impossible to procure the eggs on account of the size of the basaltic blocks under which the birds were sitting. In some other places, such as the island of Soay, near Iona, the petrels have their holes in soft mud, the entrance halls of which are about as large as rabbit burrows. From these other smaller galleries branch off, so that one external aperture serves as a kind of lobby for a number of pairs.

Although to a great extent nocturnal in its habits, the Storm Petrel is not unfrequently met with throughout the summer and autumn in dull and uncertain weather within a few miles of the shore. Should a gale spring up, they may be seen flitting restlessly above the broken water until they make out some belaboured boat or larger vessel, which they at once fly to and follow, apparently in expectation of finding morsels of food, just as many larger birdssea-gulls, for example-pertinaciously flap in the wake of steam vessels for even twenty and thirty miles. I well recollect my first introduction to the Storm Petrel. I had set sail early one morning towards the end of May from one of the Clyde ports for Ailsa Craig, in company with one or two friends and three experienced fishermen. The weather, as it turned out, was too fine, and before we reached our destination at mid-day the sky betokened a change. About half a mile from the rock I observed a petrel; but knowing the superstitious fear with which the bird is regarded, it did not 
appear necessary to acquaint the boatmen of the circumstance. We had not been on the Craig more than twenty minutes until the sea and clouds excited our apprehensions, and we left immediately after reefing our sail and taking on board some additional ballast. We had, of course, every confidence in our boatmen, but I must confess to a strong misgiving about the boat itself, especially when we arrived at that part of the programme when it became necessary for each man to convert his hat into a baling bucket. Some of our party soon began to show signs of weakness; nor were these lessened when it was announced that the mainsail was giving unmistakable symptoms of the same malady; and as the boat shivered in the angry sea, it was hardly possible for even the greatest enthusiast to think of anything but the impending danger. It was, however, with great satisfaction I hailed at this juncture the appearance of three or four Storm Petrels following in our wake. There they were, pattering the top of each wave, the broken crest of which they barely touched as it rose and threatened our bulwarks. Several times they seemed as if they might have been touched with the hand; and as by this time we were nearly all, by the fishermen's orders, so as to trim the craft, lying flat among the ballast, I saw and admired their little querulous black eyes as they peered into the boat in wonderment at the cargo of queer black fish lying in the bottom. The birds did not appear to pick up anything, but untiringly followed the rising and falling of the water-now going down into a hollow, and now rising with the wave until the edge broke and curled over, when the little feet were let down with a gentle tripping movement as if trying to get a footing on the treacherous deep. Sometimes, as one of them remained in the trough of the sea, until the wave seemed ready to engulph the little creature, it mounted sideways to let it pass, and down it went on the other side with "contemptuous celerity." This little party of petrels kept us company till we were within a mile of the shore, when they disappeared, leaving us to find our way home as best we could. This was found not to be an easy matter. The gale had increased and angered the sea into a state of commotion very much beyond the calculations of our boatmen; and as we neared the shore it was evident we were drifting to certain destruction, unless we could manage to guide the boat into a small sandy creek, to which our attention was directed by the shouts 
and gestures of a crowd of people on shore. Luckily, this was accomplished, and we had the satisfaction of landing up to the armpits in a mass of rotten seaweed which had accumulated in this narrow inlet, and through which we dragged ourselves and the boat to the beach. We were glad to leave it there, six miles from the harbour we should have returned to. A more seaworthy boat than our own was detained at Ailsa nearly three days during the same storm; and the gale which had thrown us so unceremoniously among the seaweed stranded a sloop within a mile of the spot and dashed it to pieces.

Twenty years ago my valued correspondent, Mr Graham, of whom I now take leave in these pages, communicated some very interesting notes on the Stormy Petrel, the insertion of the substance of which may not inappropriately bring my labours to a close. Mr Graham became acquainted with the bird through a mere accident. He had, while residing at Iona, made frequent excursions to the famous isle of Staffa in a small boat of his own named "The Ornithologist," and on one of these occasions had been compelled, through a sudden storm, to remain alone all night on this isolated roosting place under shelter of his boat, which he drew up on the landing and turned bottom upwards for the purpose. Of course, in the circumstances, sleep was impossible; and during the night he heard the most curious buzzing sounds emanating from the rough stony ground he was lying upon. They were not continuous, but broken every ten seconds or so by a sharp click. Waiting until daylight, he found the strange music issuing from beneath his feet; guided by the sound, he commenced removing the heavy stones; and being encouraged in his labours by hearing the sounds nearer and more distinct-sometimes ceasing, then recommencing-he worked away till the noise and rolling of the rocks seemed to provoke the subterranean musician to renewed efforts, until with a vigorous exertion the last great stone was rooted out and the mystery laid bare. He saw a little black object shuffling off, leaving its small white egg lying on a few blades of dry grass which protected it from the hard rock. It made no attempt to escape, as if dazzled by the glare of daylight, or stunned by the depth of its misfortune, but lay passively in his hand when he took it up, uttering only a faint squeak of surprise at the outrage. From this romantic island Mr Graham afterwards procured several young birds, which he kept in confine- 
ment until they became fledged. He reared them solely upon cod liver oil, which they sucked from a feather dipped into it, clattering their beaks and shaking their heads with evident satisfaction. Towards nightfall they became exceedingly restless and active; and on being taken out of their box they sat on the table and set their wings in motion so rapidly that they ceased to be discernible. Their eyes being closed during this exercise, the whirring of their wings apparently fanned the little fellows into the notion that they were far out at sea, travelling at the rate of forty miles an hour; and as their bodies became buoyant by the action of the wings, their little feet could retain no hold of the slippery mahogany; so the exhibition generally ended by the poor petrels falling backwards and disappearing suddenly over the edge of the table. Two of these pets died, and were sent to me through the post, accompanied by a note from my friend, informing me that they had both departed this life during the roaring of an equinoctial storm.

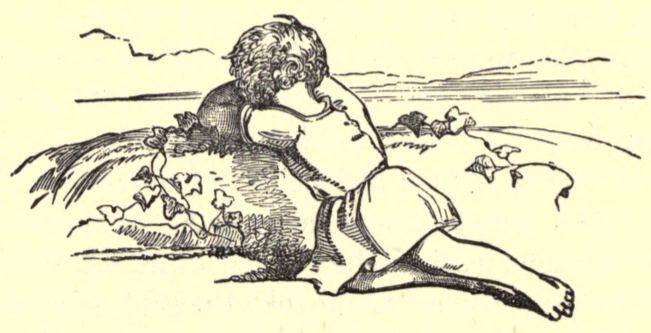




\title{
APPENDIX.
}

\section{THE AMERICAN GOSHAWK.}

\author{
ASTUR ATRICAPILLUS.
}

Page 39.

Having ventured the surmise that this species might occur a second and even a third time in Britain, I may here state that such has actually happened since this work was sent to press. The second example was shot on the Galtee mountains in Tipperary in 1870, and is now in the collection of Sir Victor Brooke; and the third was killed at Parsontown, in the King's county, by Mr Basil Brooke in 1870.

\section{THE HONEY BUZZARD.}

\section{PERNIS APIVORUS.}

Page 48.

Mr Harvie Brown has informed me that a nest of eggs of this species has been procured this year (1871) by himself and Captain Feilden in Ross-shire. The nest was placed in the fork of a tree, and lined with wasps' nests: it was about the size of a rook's, and both birds were seen flying overhead. This pair of birds, it appears, bred regularly in the district for the last six years, and they have usually taken their departure about the middle of September.

\section{THE HEN HARRIER. \\ CIRCUS CYANEUS. \\ Page 52.}

Mr James Thomson of the Kelvingrove Museum, Glasgow, has shown me a pair (m. and f.) of this species from Sutherlandshire which have just begun the assumption of the adult plumage. 
Both birds have a curiously mottled appearance: they were shot at their nest containing young birds, and $\mathrm{Mr}$ Thomson's informant - Mr Crawford of Lairg-assures him that during an experience of eighteen years in the same county he has frequently seen male birls in immature plumage mated, and that he has killed them while at the nest.

Mr W. A. M'Leay, Inverness, informs me that he preserved a female Hen Harrier which was pure white and remarkably beautiful when compared with ordinary albinoes: it was shot at Courthill, Lochcarron, Ross-shire, in the beginning of May, 1870 .

\section{THE GOLDEN ORIOLE.}

ORIOLUS GALBULA.

Page 80.

A specimen of this bird was shot on the estate of Reith, near Kirkcaldy, on 22d April, 1870, and preserved by Mr J. Wilson of that town. Another was killed in the last week of March at Loch Torridon in Ross-shire, and stuffed by Mr W. A. M'Leay, Inverness, to whom I am indebted for a notice of the circumstance.

\section{THE SNOW BUNTING.}

\section{PLECTROPHANES NIVALIS.}

Page 125.

I have been informed by Mr R. G. Wardlaw-Ramsay that Colonel Drummond Hay observed a pair of Snow Buntings in full summer plumage on 21st June, 1870, on Ben-muick-dhui; and Mr Harvie Brown states that in the breeding season of the present year (1871) young birds were again seen on Lochnagar. The nest, however, could not be found.

\section{THE TREE SPARROW.}

\section{PASSER MONTANUS.}

$$
\text { Page } 140 .
$$

This species has been found breeding near Ardrossan in Ayrshire: one-a young bird-was procured from the nest by Mr John 
Jameson, who has since presented me with the specimen. The nest was situated in a hole in a wall.

\section{THE HAWFINCH.}

COCCOTHRA USTES VULGARIS.

Page 144.

Mr George Kirkpatrick has informed me that a Hawfinch was shot near Newton-Stewart in Wigtownshire in January, 1871, and preserved by Mr Hastings, bird-stuffer, Dumfries, in whose hands he saw the specimen.

THE BEE EATER.

MEROPS APIASTER.

Page 203.

I have been informed by Mr J. Bell of Paisley, that about the time the swallows were congregating in the neighbourhood of that town, at the close of August, 1869, Mr W. Scott, keeper on the Walkinshaw estate, observed a Bee Eater flying in their company on the banks of the river Black Cart. On communicating a notice of the circumstance to $\mathrm{Mr}$ Bell, he described the stranger as a bright green and yellow bird, with a forked tail, and stated that he had repeatedly seen it passing and repassing along with the swallows, and hawking for flies in the same manner. Mr Bell afterwards shewed the keeper the collection of British birds in the Paisley Museum, and was gratified on finding that he at once recognized the Bee Eater as the bird which he had seen.

\section{THE COMMON SWIFT.}

CYPSELUS APUS.

Page 210.

A single Swift was seen on 27th May, 1870, in the Long island, or Outer Hebrides, by Captain Feilden and Mr Harvie Brown. 


\section{TEMMINCK'S STINT.}

\section{TRINGA TEMMINCKII.}

Page 321.

A specimen of this rare stint was shot near Aberdeen by $\mathrm{Mr}$ Alexander Mitchell, on 28th August, 1871, and examined by $\mathrm{Mr}$ Angus, to whom I am indebted for a notice of the occurrence. Mr Mitchell has since informed me that he shot a second specimen on 4th September, and has obligingly forwarded it for exhibition at a meeting of the Natural History Society of Glasgow while these pages are passing through the press.

\section{THE LITTLE CRAKE.}

\section{CREX PUSILLA.}

\section{Page 334.}

Mr J. H. Gurney, jun., informs me (August, 1871), that his father has in his collection a Scottish specimen of this bird; but up to the moment of going to press no further particulars of its capture have reached me.

\section{THE GOOSANDER.}

MERGUS MERGANSER.

\section{Page 403.}

Mr Harvie Brown writes to me (August 30, 1871) that he is now in a position to state authoritatively that this bird breeds in Scotland-a nest of eggs having been sent to him from the north of Perthshire: the nest was placed in the hollow of an old tree, and the eggs were taken about the 20th of May. They agree precisely with authenticated eggs of the Goosander already in his collection.

\section{THE GANNET OR SOLAN GOOSE.}

SULA ALBA.

$$
\text { Page } 458 .
$$

Gannets with black tails have been observed at St. Kilda. These I suspect to be birds with the last of their immature plumage not yet effaced. 


\section{IN DEX.}

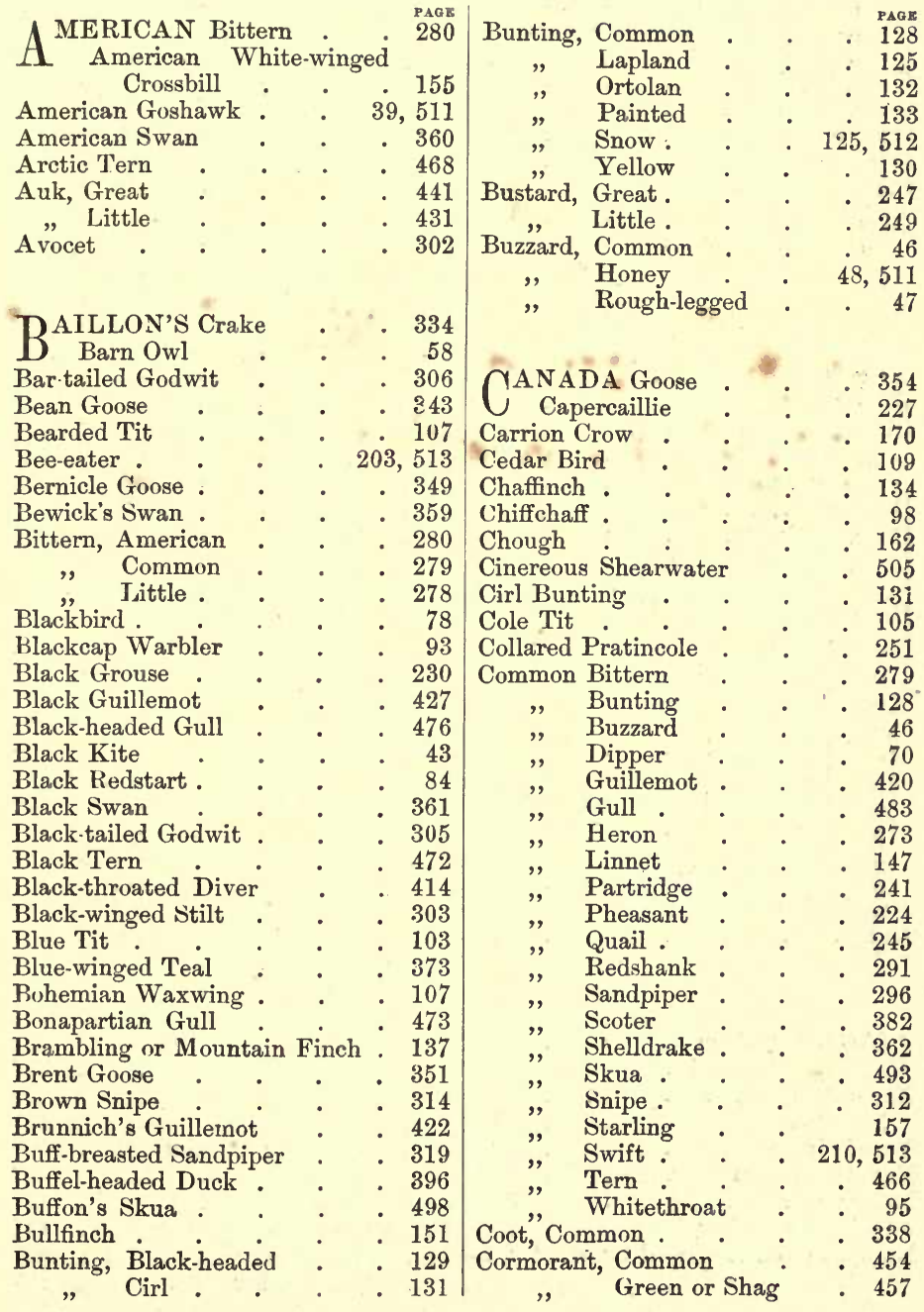




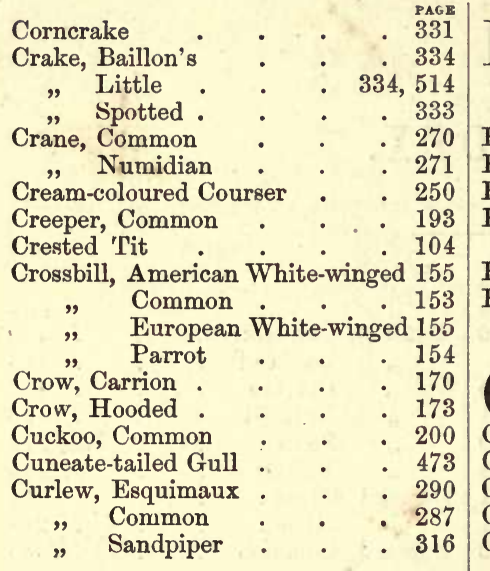

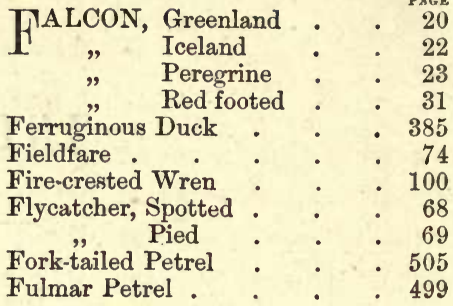

ABCHICK, or Little Grebe 409

CADWALL . . . . 366

G Gallinule, Purple $\quad$. $\quad 337$

Gannet or Solan Goose $\quad$. 458, 514

Garden Warbler . . . 94

Garganey . . . . . 371

Glossy Ibis . . . . 286

Godwit, Bar-tailed . . . 306

, Black tailed . . . 305

Golden-crested Wren $\quad$ • 99

Golden-eye, . . . . 395

Golden Eagle . . . . 1

" Oriole : $: \quad 80,512$

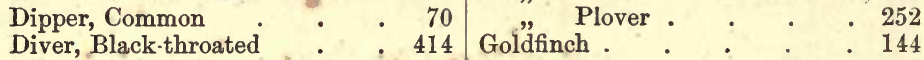

"Great Northern : : 411 Goose, Bean : : . . 343

”. Red-throated . . . 417 " Bernicle . . . 349

Dotterel • . . . . 254

Dove, Rock . . . . 220

Dove, Stock $\quad$. $\quad$. $\quad$. 219

, Turtle . . . . 223

Duck, Buffel-headed . . . 396

" Eider . . . $\div 378$

" Ferruginous : $\quad . \quad$. 385

", Harlequin . . . 394

" King . . . . . 380

", Long-tailed . . $\quad 388$

" Pintail . . . . 367

" Red-crested Whistling . 383

" Scaup . . . . 385

" Tufted . . . . $\quad 386$

" Wild, or Mallard . . 369

Dun Bird or Pochard . . 384

Dunlin . . . . . 322

TAGLE, Golden . . . 1

11 1

Eagle, White-tailed * $\quad \cdot \quad \cdot \quad 9$

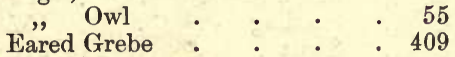

Egyptian Goose . . . 352

Eider Duck . . . . 378

Esquimaux Curlew . . . 290

" Brent . : $: \quad 351$

, Canada . . . . 354

, Egyptain . . . 352

, Greylag. . . . 339

" Pink-footed . . . 345

" Red-breasted. . . 352

" Spur-winged . . . 353

, White fronted . . 346

Goosander. . . . 403,514

Goshawk, European . . . 36

39,511

Grasshopper Warbler ․ 89

Great Auk . . . . 441

, Black Woodpecker . . 191

, Bustard . . . 247

, Grey Shrike . . . 65

"Northern Diver . . 411

" Plover . . : : 251

" Snipe . . . . 310

, Spotted Woodpecker $\quad 190$

"Tit. . . 102

" White Heron . . . 277

Grebe, Eared . . . . . 409

" Great-crested . : $\quad 405$

\# Little, or Dabchick . 409

" Red-necked . . . 406

" Sclavonian . . . 407

Green Cormorant or Shag . . 457

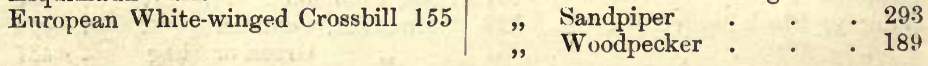




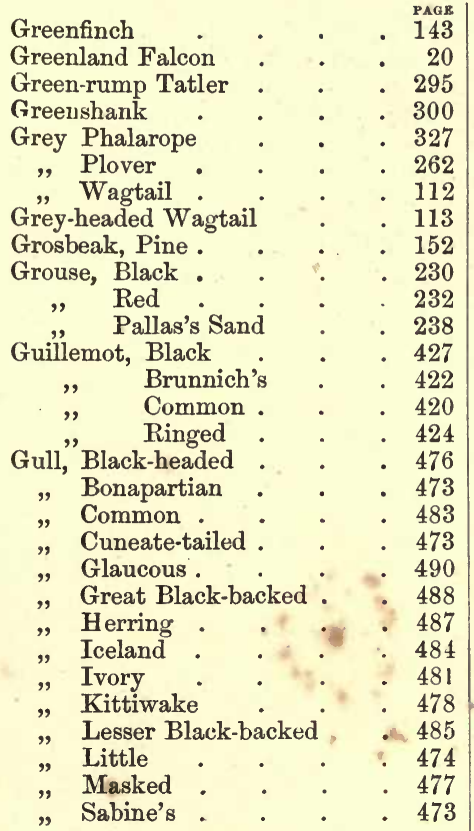

\section{HARLEQUIN Duck \\ H Harrier, Hen}

Harrier Marsh

Hawfinch .

$$
\text { Montagu's }
$$

Hawk Owl

, Red-shouldered

" Sparrow

Hedge Accentor

Herring Gull

Hobby

Honey Buzzard

Hooded Crow

Hooper or Whistling Swan

Hoopoe

House Sparrow

Heron, Common

$$
\begin{array}{ll}
\text { " } & \text { Great White : } \\
\text { Night . } & \text { Purple . }
\end{array}
$$

$\mathrm{I}^{\mathrm{B}}$

BIS, Glossy

Iceland Falcon

Iceland Gull

Ivory Gull

. 49

- 41

- 81

. 487

48, 511

173

398

355

198

141

273

277

281

276
TACKDAW

Jack Snipe . . . 313

Jay . . . . 187

KESTREL . . . . 35

I Kingfisher. . . . 204

King, Duck . . . . 380

Kite, Black . . . . 43

" Common . . . . 42

„ Swallow-tailed . . . 44

Kittiwake Gull • • • 478

Knot . . . . . 318

T ANDRAIL, or Corncrake . 331

4 Lapland Bunting . . 125

Lapwing or Peewit . . . 263

Lark, Shore . . . . 118

"Sky . . . . 120

, Wood . . . . 123

Lesser Black-backed Gull . . 485

, Redpole . . . 149

, Spotted Woodpecker . 191

" Tern". . . . 470

, Whitethroat . . . 95

Linnet, Common . . . J47

, Mountain, or Twite .. 149

Little Auk : . . . 431

, Bittern .. . . . 278

" Bistard . . . . 249

" Crake : $\quad . \quad 334,514$

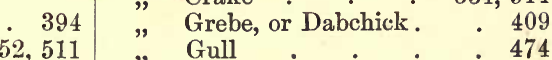

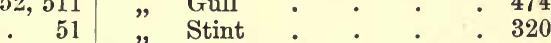

Long-eared Owl $\quad$. $\quad . \quad$. 56

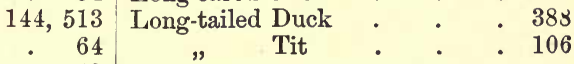

MAgPIE • • . . 18.

1 Mallard . . . . 369

Manx Shearwater . . . 503

Marsh Harrier . . . . 51

"Tit . . . . 105

Martin . . . . . 207

, Sand . . . . 209

Masked Gull : . . . 477

Meadow Pipit . . . . 115

Mealy Redpole . . . . 148

Merganser, Hooded . . 398

, Red-breasted . . 400

Merlin . . . . . 31

Missel Thrush . . . . 73

Moor-Hen . . . . 335

Montagu's Harrier . . . 54

\begin{tabular}{c|cc}
484 & Mountain Finch, or Brambling . & 137 \\
481 & \# Linnet, or Twite & 149
\end{tabular} 


\begin{tabular}{|c|c|c|c|c|c|c|c|}
\hline $\mathbf{Y}$ & & & $\begin{array}{r}\text { PAGE } \\
\text { - } 92\end{array}$ & Pratincole, Collared & & & $\begin{array}{l}\text { PAGE } \\
251\end{array}$ \\
\hline Nightjar & & . & . 211 & Ptarmigan & . & . & 236 \\
\hline Night Heron . & .. & . & . 281 & Puffin . & & & 433 \\
\hline Numidian Crane & . & . & 271 & Purple Gallinule & . & . & 337 \\
\hline Nutcracker . & - & - & - 188 & ", Heron . & . & . & 276 \\
\hline Nuthatch . & .. & - & - 199 & Sandpiper & . & & 325 \\
\hline RIOLE, Golden & & - & 80,512 & UAIL, Common & . & . & 245 \\
\hline $\begin{array}{l}\text { Ortolan Buntin } \\
\text { Osprey }\end{array}$ & & - & . 132 & & & & \\
\hline Osprey • • & . & . & - 18 & & & & \\
\hline Owl, Eagle & . & & 55 & & & & \\
\hline " Hawk & - & . & 64 & R AIL, Water & - & - & 334 \\
\hline " Long-eared & - & - & 56 & Il Raven . & . & & 167 \\
\hline ", scops-eared & - & - & 56 & Razorbill • & & - & 438 \\
\hline " Short-eared & . & . & 57 & Ray's Wagtail . & & & . 114 \\
\hline " Snowy . & . & . & 62 & Redbreast : & & & . 82 \\
\hline " Tawny , & . & - & 61 & Red-backed Shrike & & . & 67 \\
\hline „, Tengmalm's & - & . & 64 & Red-breasted Goose & & . & 352 \\
\hline " White or Barn & & . & 58 & , Mergar & unser & & 400 \\
\hline Oyster Catcher . & . & . & 268 & Red-crested Whistlin & & ack & . 383 \\
\hline & & & & oted Falcon & & & 31 \\
\hline AINTED Bunt & & & & Red-legged Partridge & & & 243 \\
\hline Pallas' Sand & $\lg$ & - & 133 & Red-necked Grebe & & & · 406 \\
\hline Parrot Crossbill & ro & & 238 & ", Phalarop & & & - 329 \\
\hline $\begin{array}{l}\text { Parrot Crossbill } \\
\text { Partridge, Commo }\end{array}$ & - & - & 154 & Red-shouldered Haw & & & 49 \\
\hline Partridge, Common & & - & 241 & Red-throated Diver & & & 417 \\
\hline , $\quad$ Red-legge & & - & 243 & Red-winged Starling & & & 156 \\
\hline Passenger Pigeon & & - & 223 & Reed & - & & 91 \\
\hline Pastor, Rose-coloure & & . & 160 & Reeves' Pheasant & - & & 225 \\
\hline Pectoral Sandpiper & . & . & 321 & Red Grouse & . & - & 232 \\
\hline Peewit or Lapwing & . & . & . 263 & Red Pole, Lesser & . & . & 149 \\
\hline Pennsylvanian Pipit & & d. & 116 & , Mealy & . & . & 148 \\
\hline Peregrine Falcon & -. & - & 23 & Redshank, Common & . & & 291 \\
\hline Petrel, Fulmar. & . & . & 499 & , Spotted & . & - & 290 \\
\hline „ For & . & . & 505 & Redstart, Black & . & . & 84 \\
\hline " Storm . & - & - & 506 & ". Common & & & 84 \\
\hline Phalarope, Grey. & & . & 327 & Redw & . & - & 77 \\
\hline , Red-neck & & . & 329 & Richardson's Skua & & & 496 \\
\hline Pheasant, Common & . & . & 224 & Ringed Guillemot & & & 424 \\
\hline , Diards' & . & . & 225 & $"$ Plover. & & - & 258 \\
\hline , Reeves' & • & & 225 & Ringdove or Wood $\mathrm{F}$ & Pige & & 213 \\
\hline Pied Flycatcher & . & . & 69 & Ring Ouzel : & . & & 79 \\
\hline „ Raven . & . & . & 168 & Rock Dove & . & . & 220 \\
\hline ," Wagtail . & - & - & 110 & , Pipit & . & & 117 \\
\hline Pine Grosbeak . & . & & 152 & Roller . & . & & 202 \\
\hline Pink-footed Goose & & . & 345 & Rook & - & - & 179 \\
\hline Pintail Duck . & - & . & 367 & Roseate Tern & & & 466 \\
\hline Pipit, Tree & • & • & 114 & Rose-coloured Pastor & & & 160 \\
\hline ", Meadow. & & . & 115 & h-legged Buzzar & & . & 47 \\
\hline , Pennsylvanian & & 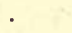 & 11 & Ruby Crowned Wrer & & & 100 \\
\hline , Rock . & - & • & 117 & Ruddy Shieldrake & & & 361 \\
\hline Plover, Golden . & & - & 252 & Ruff . • • & - & - & - 307 \\
\hline , Great . & & • & 251 & & & & \\
\hline Gre & & & 262 & & & & \\
\hline ," Ringed . & & . & - 258 & SABI & - & & 473 \\
\hline Pochard or Dun Birc & & . & 384 & rling & & & 261 \\
\hline Pomerine Skua . & & & 49 & Sand Martin & & & 209 \\
\hline Polish Swan . & & - & 360 & Sandpiper, Buff-breas & sted & & 319 \\
\hline
\end{tabular}




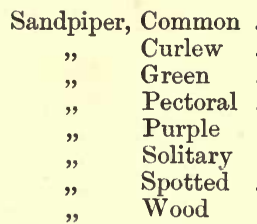

Sandwich Tern .

Scaup Duck

Sclavonian Grebe

Scops-eared Owl

Scoter, Common

,$\quad$ Surf

Sedge Warbler

Shag, or Green Cormorant

Shearwater, Cinereous

Shieldrake, Common $\quad$ Manx $\quad$. 503

" Ruddy . . . 361

Shore Lark . . . . . 118

Short-eared Owl . . . . 57

Shoveler . . . . . 364

Shrike, Great Grey

" Red-backed :
Siskin Woodchat :
Skua, Buffon's :
" Common :
" Pomerine :
Sky Lark.

Smew

Snipe, Brown

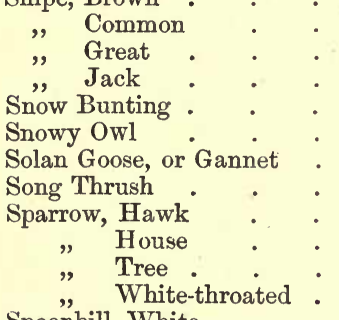

Spoonbill, White

Spotted Crake .

$\begin{array}{ll}" & \text { Eagle } \\ " & \text { Flycatcher } \\ \text { " Redshank } & \text { Sandpiper }\end{array}$

Spur-winged Goose

Starling, Common

" Red-winged

Stilt, Black-winged

Stint, Little

Stock Dove

316

293

325

295

299

294

465

407

56

382

383

381

89

457

68

146

498

493

494

496

120

397

310

313

125,512

41

. 141

68
PAGE

05

Ten

Tern, Arctic

" Black

, Common .

" Lesser

" Roseate.

" Sandwich

. . 191

314

312

. 62

458, 514

75

140, 512

138

286

333

8

290

299

353

- 157

156

303

320

321,514

.

Song

„Blue.

" Cole.

", Crested

" Great

$\cdot \quad \cdot 102$

" Long-tailed . • . 106

, Marsh . . . . 105

Tree Pipit . . . . 114

"Sparrow . . . 140,512

Tufted Duck . . . . . 386

Turkey Wild . . . . . 246

Turnstone . . . . . 266

Turtle Dove . . . . . 223

Twite or Mountain Linnet 149

TELVET Scoter . . . 381

244

WAGTAIL, Grey • 112

Wagtail, Grey-headed 113

Wagtail, Pied . . . . 110

, Ray's . • . . 114

Warbler, Blackcap . $\quad \cdot \quad \cdot \quad 111$

, Garden : • : 94

Grasshopper : $\quad$. 89

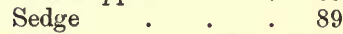

Reed . : : : 91

219 ." Willow . . . 97 
INDEX.

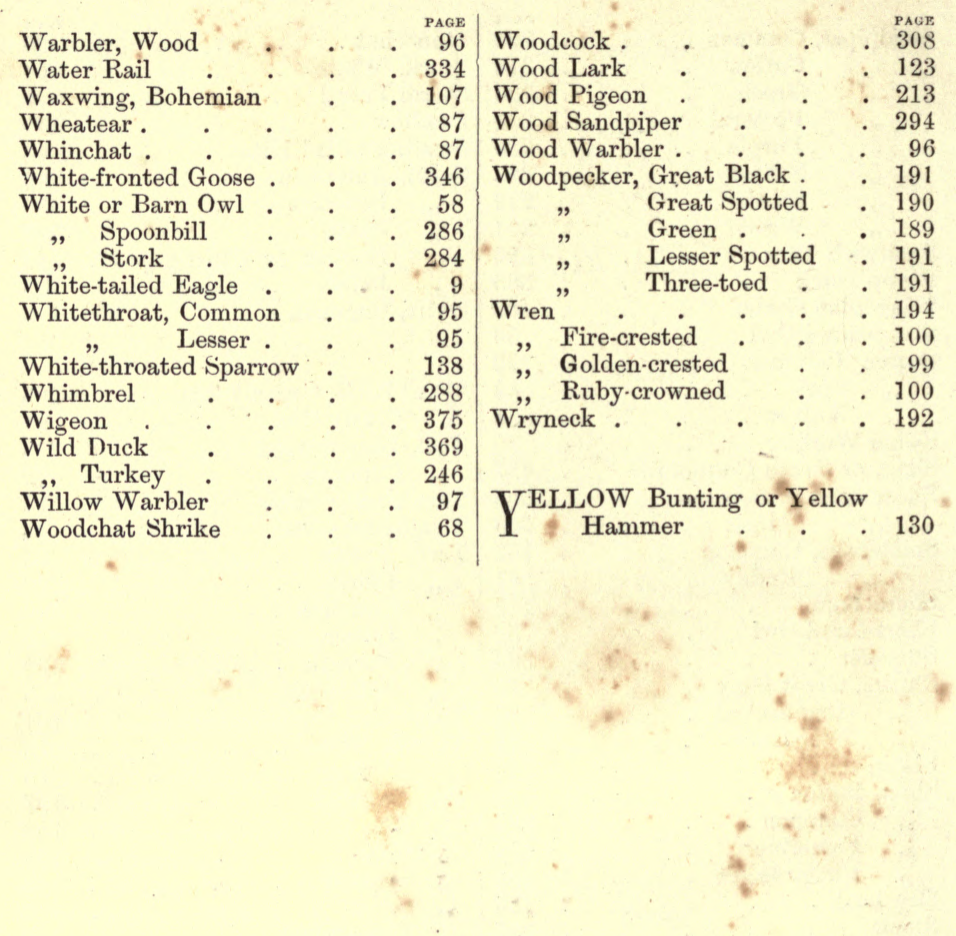


collated nerpect H. Bounind 2anitelH. B.

$\int 1^{0}$ 
THIS BOOK IS DUE ON THE IAST DATE STAMPED BELOW

AN INITIAL FINE OF 25 CENTS WILL BE ASSESSED FOR FAILURE TO RETURN THIS BOOK ON THE DATE DUE. THE PENALTY WILL INCREASE TO 50 CENTS ON THE FOURTH DAY AND TO \$1.00 ON THE SEVENTH DAY OVERDUE.

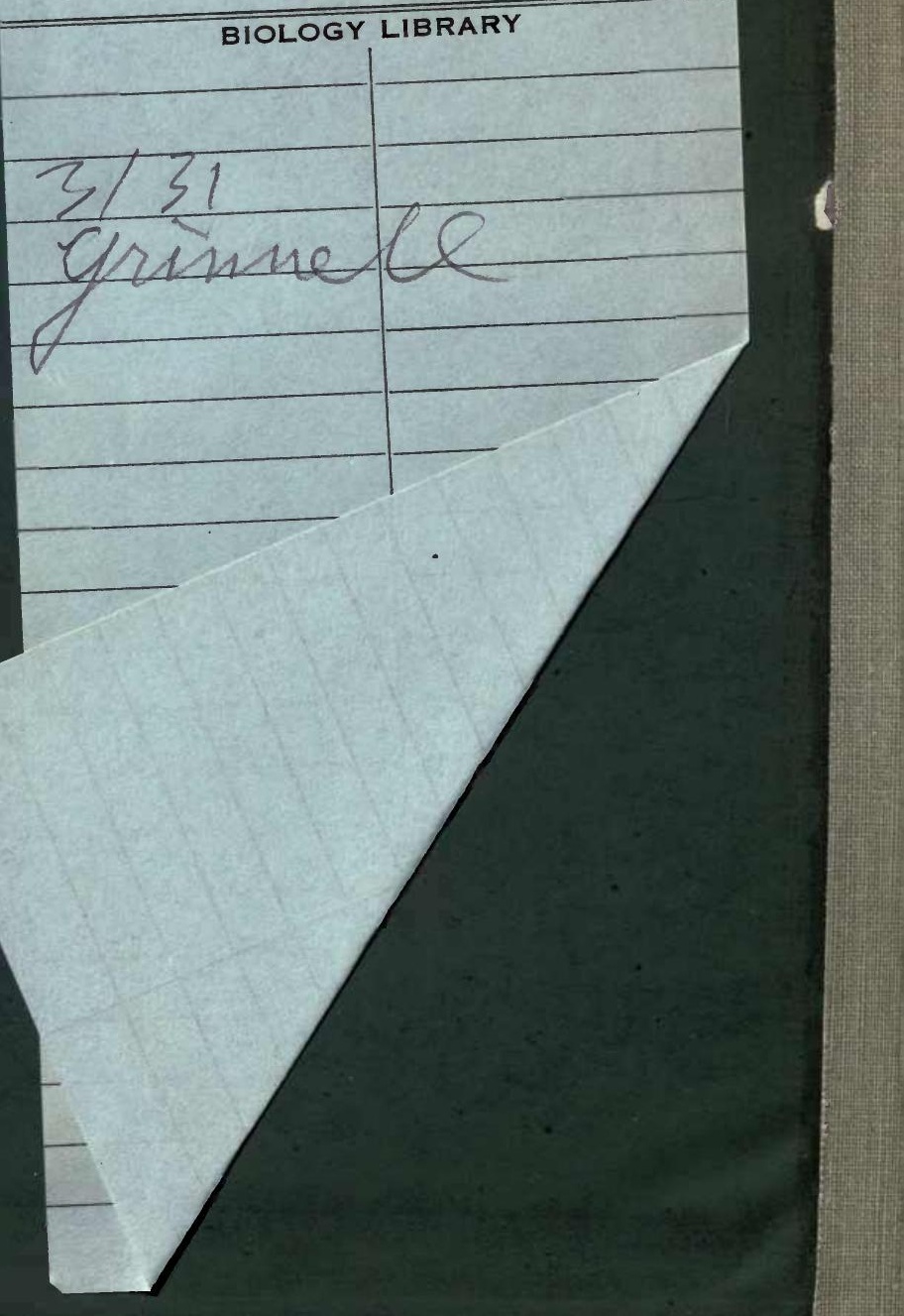




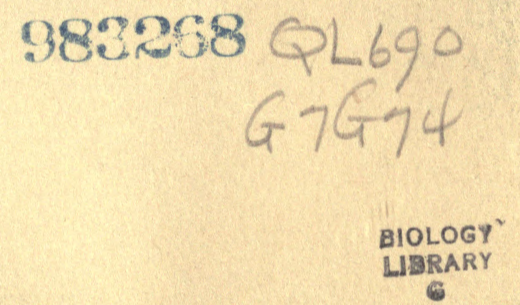

THE UNIVERSITY OF CALIFORNIA LIBRARY 
